\title{
TÓPICOS EM GESTÃO DA PRODUÇÃO VOLUME 4
}

Hélcio Martins Tristão

(organizador)
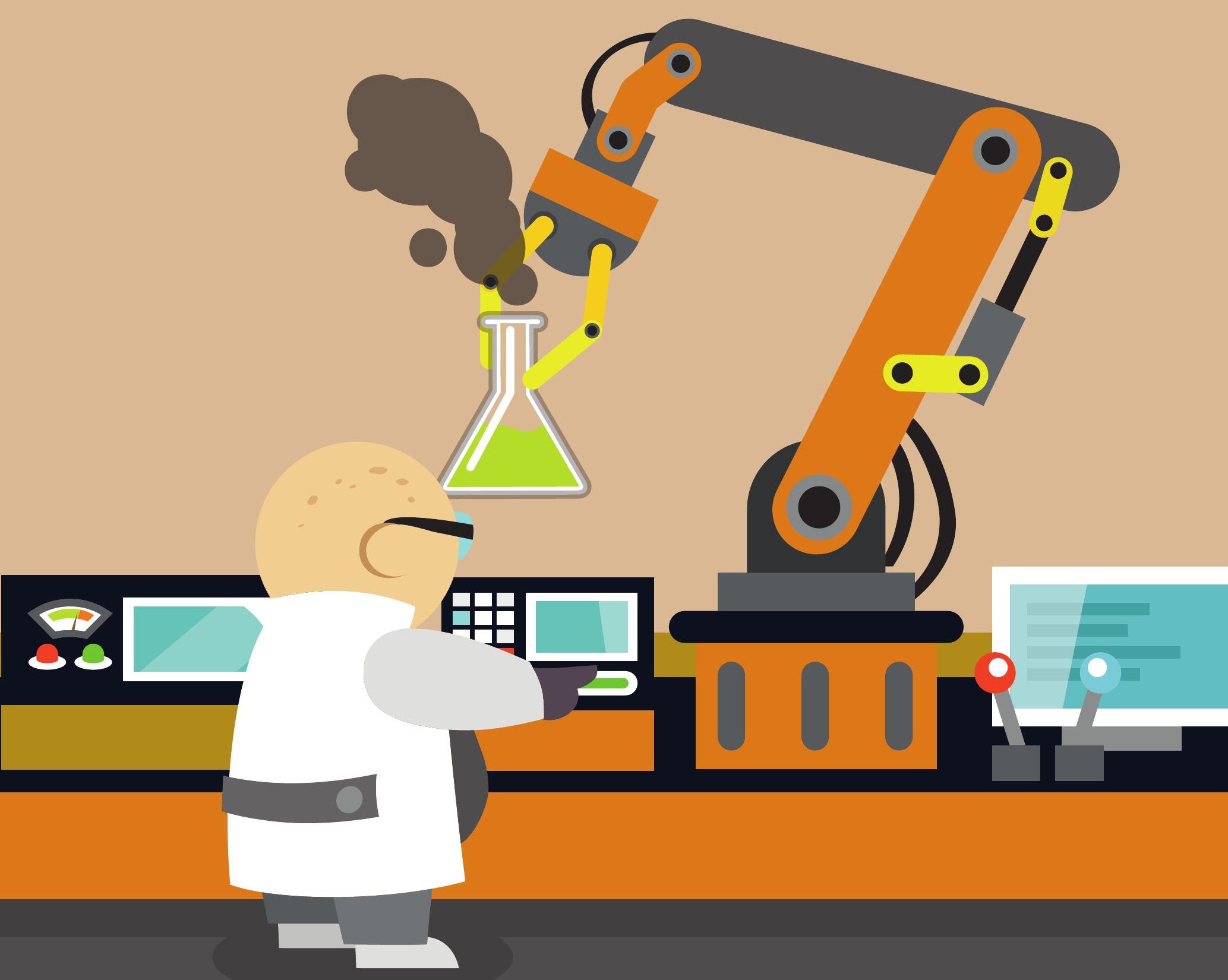

1) Editora Poisson 
Hélcio Martins Tristão

(organizador)

\title{
Tópicos em Gestão da Produção Volume 4
}

\author{
1르 Edição
}

Belo Horizonte

Poisson

2017 


\section{Conselho Editorial}

Dr. Antônio Artur de Souza - Universidade Federal de Minas Gerais Dra. Cacilda Nacur Lorentz - Universidade do Estado de Minas Gerais Dr. José Eduardo Ferreira Lopes - Universidade Federal de Uberlândia Dr. Otaviano Francisco Neves - Pontifícia Universidade Católica de Minas Gerais

Dr. Luiz Cláudio de Lima - Universidade FUMEC

Dr. Nelson Ferreira Filho - Faculdades Kennedy

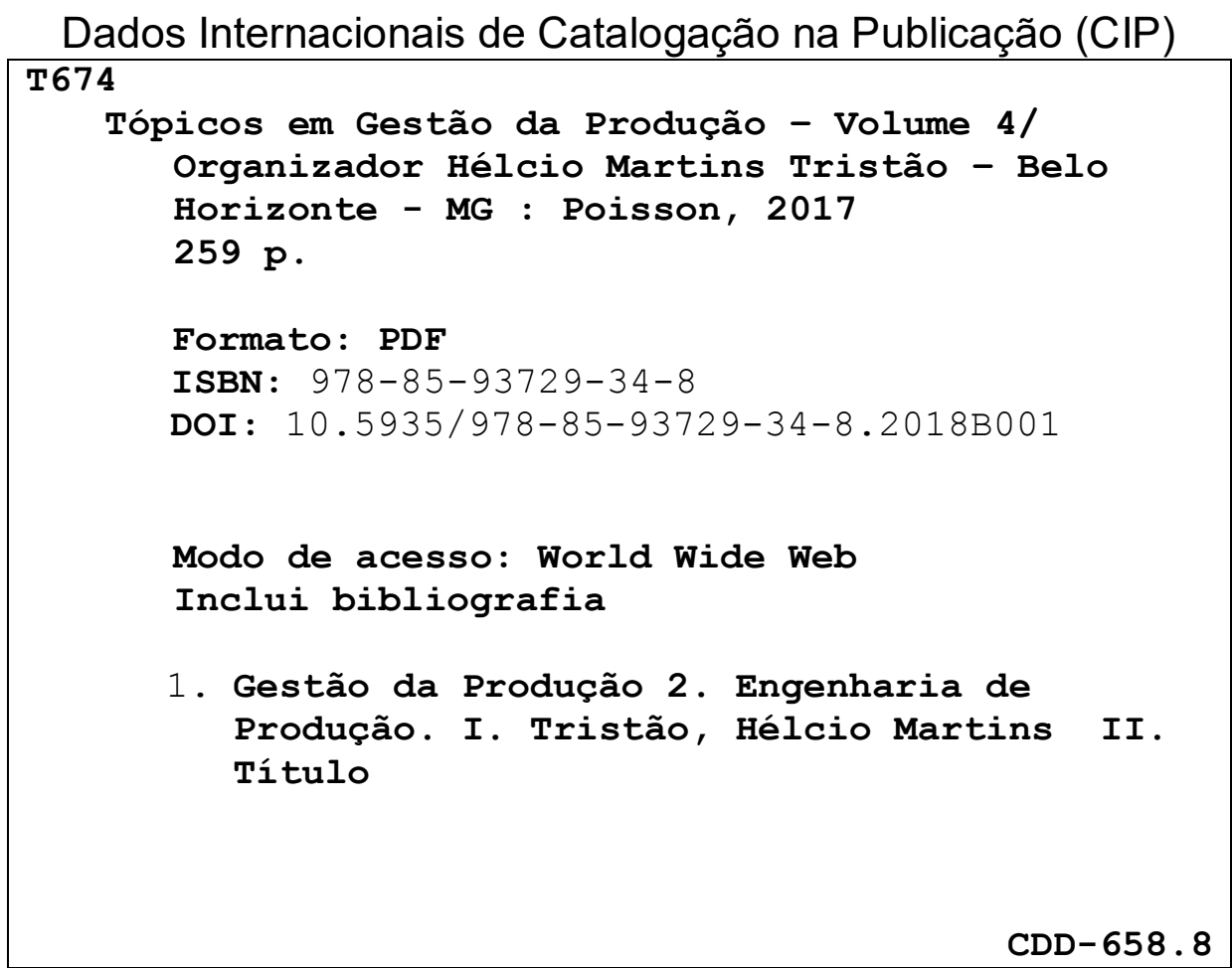

O conteúdo dos artigos e seus dados em sua forma, correção e confiabilidade são de responsabilidade exclusiva dos seus respectivos autores.

www.poisson.com.br

contato@poisson.com.br 
Apresentação

Na dinâmica da competitividade e efetividade da "Gestão da Produção" destacam- se cada vez mais tópicos inerentes à busca pela excelência em resultados econômicos e financeiros das organizações privadas e públicas.

Nesse escopo, este e-book apresenta contribuições da academia por meio de autores dedicados e com conhecimentos específicos que investigam, analisam métodos e aplicações, propõem soluções, desenvolvem formulações e abordam temas sobre: levantamento de estudos, análises e comparações de meios utilizados pelas organizações para o alcance de níveis de desempenho competitivos; da elaboração de propostas de soluções para problemas e melhoria do processo de gestão da produção, sejam eles voltados para a otimização dos recursos utilizados - tempo, recursos físicos e materiais, ou na formulação de instrumentos que permitam controle efetivo sobre - vendas, demandas e eliminação de fatores desnecessários para a produção de produtos e serviços.

Não obstante, ainda traz ampla abordagem de métodos, técnicas, modelos e impactos das novas tecnologias sobre as organizações e que permitem ao leitor ter um contato pragmático com resultados obtidos a partir do uso desses conhecimentos.

Assim, as contribuições inseridas nesse conjunto de abordagens corroboram tanto para acadêmicos quanto para profissionais dos setores privados e públicos, uma vez que não se limitam aos aspectos teóricos e conceituais, mas apresentam formas de integrar conhecimentos específicos dos "Tópicos Modernos da Gestão da Produção" com objetivos de melhoria dos resultados operacionais e da otimização na preservação e uso dos recursos produtivos.

Aos colegas acadêmicos, parceiros profissionais, editores, agradecimentos respeitosos e aos leitores desejo ótimas e profícuas leituras.
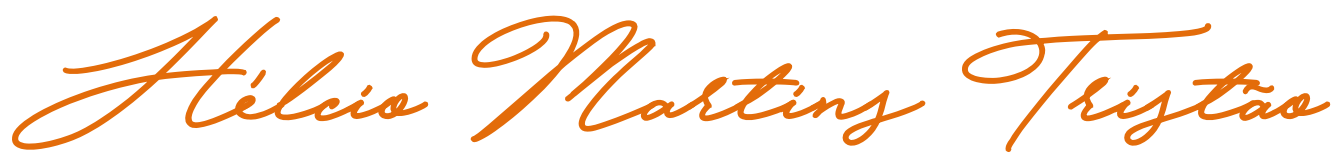


\section{SUMÁRIO}

Capítulo 1 - As Formas de descarte do lixo eletrônico: Estudo com universitários da Universidade Estadual da Paraíba, Campus VII, Patos-PB

(Amanda Almeida de Araújo, Glycia de Araújo Izidro, Thágyda Pryscilla Gonçalves do Rêgo,

Samila Valdegleycia de Oliveira Costa, Lucyanno Moreira Cardoso de Holanda )

Capítulo 2 - Arranjos de condomínio industrial e consórcio modular na indústria automobilística brasileira: Uma análise de múltiplos casos.

(Délvio Venanzi, Orlando Roque da Silva)

Capítulo 3 - Produção mais limpa: Estudo de caso em uma indústria alimentícia (Jordana Dorca dos Santos, Thaís Helena Leite Nogueira, Vanio Faquin, Luani Back)

Capítulo 4 - Estudo para alteração no processo de um conjunto soldado para um conjunto fundido: Um estudo de caso.

(Mario Fernando Mello, Alexandre Possa, Marcelo Rosseto Ludwig)

Capítulo 5 - Proposta para sistematização do processo de remanufatura de produtos rejeitados no centro de distribuição de uma empresa importadora de eletrodomésticos

(Luiz Carlos da Silva Junior, Marcos Francisco letka, Renato Cristofolini, Claiton Emilio do Amaral,

Gilson João dos Santos)

Capítulo 6 - Incorporação dos princípios LEAN nos ambientes make-to-stock (MTS) e make-to-order (MTO) - Um estudo comparativo em uma empresa metalúrgica

(André Luís Almeida Bastos, Guilherme César Silva Mendes)

Capítulo 7 - Aplicação da reengenharia de processos: Estudo de caso em uma indústria de chapas de papelão ondulado

(Everaldo Veres Zahaikevitch, Itamar Braga Lemes, Andréia Gura, Antônio Cecílio Silvério, Juliana Vitória Messias Bittencourt)

Capítulo 8 - Uso de diagramas de causa e efeito para planejamento da síntese de um pigmento polimérico à base de. polianilina.

(Robson Couto da Silva, Sergio Mazurek Tebcherani, Evaldo Toniolo Kubaski, Thiago Sequinel, João Luiz Kovaleski )

Capítulo 9 - Avaliação dos níveis de calor do forno de queima de produtos cerâmicos em uma empresa em Cacoal -.. RO

(Alessandro Aguilera Silva, Leandro Valkinir Kester, Juander Antônio de Oliveira Souza, André Grecco Carvalho, Graziela Luiz Franco Martinez)

Capítulo 10 - Doação de órgãos: Um enfoque logístico no conjunto hospitalar de Sorocaba. 
Capítulo 11 - Avaliação dos níveis de vibração e ruído nas operações de roçada e desgalhamento com motopodas

(Vitor Hugo Breda Barbosa, Stanley Schettino, Luciano José Minette, Amaury Paulo de Souza,

Maria Cristina Martins)

Capítulo 12 - Inovação Tecnológica: Análise do sistema produtivo em uma empresa (Everaldo Veres Zahaikevitch, Ricardo Santin, Andréia Gura, Antônio Cecílio Silvério, Augusto Faber Flores)

Capítulo 13 - Análise das perdas em processos produtivos em empresas de transformação localizadas no perímetro da Zona Industrial de Suape/PE

(Juliana Valença de Sousa, Taciana de Barros Jerônimo, Fagner José Coutinho de Melo, Joás Tomaz de Aquino)

Capítulo 14 - A logística do transporte de carga indivisível superdimensionada: o trajeto de rotor da turbina de hidrelétrica entre Araraquara (SP) e Belo Monte (PA).

(Carolina Carvalhaes Cauduro Orlandi, Natália Fr.an.cisc.a Madi, Bruno. Ricioli. de Andrade, Julio . Cesar. Raymundo, Mauricio Dutra)

Capítulo 15 - Cadeia logística de fármacos: Uma análise do perfil técnico gestor. (Marcelo Gorri Mazzali, leda Kanashiro Makiya, Francisco Ignácio Giocondo Cesar)

Capítulo 16 - Gestão de estoque: Uma análise dos estoques em uma unidade fabril de esquadrias de alumínio

(Michele Domingos Schneider, Renan Cittadin Perito, Julio Cesar Zilli, Adriana Carvalho Pinto Vieira)

Capítulo 17 - Melhorias no fornecimento de peças de reposição após a implementação do processo S\&OP em uma montadora. (Rafael Bonades da Silva, Nilson José Fernandes, Rogério Santana Peruchi, Naiara Faiad Sebba Calife)

Capítulo 18 - Gestão de estoque: Análise da literatura para identificação de oportunidade de pesquisas.

(Rayane Carla Scheffer, Claudilaine Caldas de Oliveira, Rony Peterson da Rocha,

Rosimeire E. dos Santos Sehaber, Ederaldo Luiz Beline)

Capítulo 19 - Análise do sistema de filas da estação Trensurb em Novo Hamburgo (RS), utilizando a ferramenta Arena (Andrey Eduardo Gomes, Guilherme Mendes Fernandes, Yan Henning, Christiane Wenck Nogueira Fernandes, Silvia Lopes de Sena Taglialenha )

Capítulo 20 - Estratégia Relax-and-fix na solução de um problema de roteamento periódico em arcos capacitados (PCARP) (Jailson Domingos de Oliveira, Cassius Tadeu Scarpin)

Capítulo 21 - O uso de ferramentas tecnológicas na gestão do conhecimento

(Danieli Pinto, Gisele Caroline Urbano Lourenço, Flávio Bortolozzi, Mariana Santos de Oliveira, Nelson Tenório) 


\section{CAPÍTULO 1}

\section{AS FORMAS DE DESCARTE DO LIXO ELETRÔNICO: ESTUDO COM UNIVERSITÁRIOS DA UNIVERSIDADE ESTADUAL DA PARAÍBA, CAMPUS VII, PATOS-PB}

Amanda Almeida de Araújo

Glycia de Araújo Izidro

Thágyda Pryscilla Gonçalves do Rêgo

Samila Valdegleycia de Oliveira Costa

Lucyanno Moreira Cardoso de Holanda

Resumo: 0 presente artigo busca investigar investigar qual(is) a(s) forma(s) de descarte do lixo eletrónico realizados pelos alunos do curso de Administração do Campus VII da Universidade Estatual da Paraíba (UEPB).Para auxiliak o problema da pesquisa, foi necessário observar os seguintes pontos: avaliar os problemas encontrados no descarte e discutir a importância da consicentização e do acesso a informação. A pesquisa é caracterizada como aplicada, qualitativa e quantitativa, exploratoria e descritiva, bibliografica e em forma de levantamento. O questionário foi elaborado pelos autores, realizado o piloto e retirado as incongruências dos tópicos abordados. A amostra e probabilística, do tipo casual simples, e responderam cento e cinquenta e oito alunos matriculados. Como resultado foi possível alcançar os objetivos traçados. Portanto, na análise foi observado que, mesmo em uma Instituição de Ensino Superior, o nível de conhecimento da maioria dos alunos, sobre o tema, ainda é parcial, revelando a necessidade de açoes por parte das empresas e do poder público no sentido de informar os riscos e os prejuizos que o descarte incorreto do lixo eletrônico pode acarretar.

Palavras chave: descarte, lixo eletrônico, estudantes universitários. 


\section{INTRODUÇÃO}

O presente trabalho buscou investigar qual(is) a(s) forma(s) do descarte do lixo eletrônico realizados pelos alunos do curso de Administração do Campus VII da Universidade Estatual da Paraíba (UEPB).

Além do objetivo principal foi necessário complementar com os seguintes objetivosespecíficos: avaliar os problemas encontrados no descarte e discutir a importância da consicentização e do acesso a informação.

A pesquisa é justificada pelo trabalho realizado na Associação de Empresas da Indústria Móvel (GSMA) em parceria com a Universidade das Nações Unidas (2015), que apresenta o Brasil como produtor de 36\% do lixo eletrônico da América Latina, contabilizando do 1,4 milhões de toneladas deste resíduo. E o mais preocupante é a previsão do aumento entre 5\% e 7\% por ano de e-lixo até 2018.

O presente artigo contribui no sentido de promover ações informativas e de conscientização sobre a forma de descarte do lixo eletrônico, da importância da educação e dos impactos negativos ao meio ambiente e para a saúde humana.

O diferencial do mesmo é cobrir o déficit de informações educativas na Universidade Estadual da Paraíba, Campus VII, a respeito do tema, e expor ao conhecimento do público as formas corretas de descarte de resíduos eletrônicos. Logo, é de grande importância a pesquisa realizada, onde as informações coletadas contribuem para ações futuras na comunidade acadêmica, também tem o propósito de direcionar os futuros administradores a conscientização ambiental.

Servirá como referência e pode orientar gestores públicos na formulação de políticas públicas que abordem, de maneira específica, as formas corretas de tratamento deste material.

\section{FUNDAMENTAÇÃO TEÓRICA}

\subsection{DESENVOLVIMENTO SUSTENTÁVEL}

A rapidez com que as mudanças estão acontecendo no mundo, favorecem o aumento dos problemas ambientais. A preocupação é antiga, mas, somente nas últimas décadas houve um aprofundamento do interesse com meio ambiente, deste período em diante, eventos promovidos por grupos ligados a diversos segmentos da sociedade intensificaram o debate sobre o tema (CARVALHO, 2010). Segundo o autor, ocorreram os seguintes eventos cronologicamente:

- 1972: Foi publicada a obra intitulada Limites do Crescimento, produzido por um grupo colegiado denominado Clube de Roma, o qual projetava uma catástrofe ambiental no prazo de 100 anos, caso o mundo mantivesse o mesmo ritmo de produção e consumo que estavam vivendo naquele momento (PEREIRA, apud CARVALHO, 2010); ainda, nesse ano, a Organização das Nações Unidas promoveu a primeira conferência cuja pauta foi o meio ambiente: a Conferência das Nações Unidas para o Meio Ambiente (CMMAD), em Estocolmo, na Suécia.

- 1987: O conceito de Desenvolvimento Sustentável (DS) passou a ser difundido, a partir do relatório Brundtland "Nosso Futuro Comum", o DS é aquele que atende as necessidades do presente sem comprometer a capacidade das gerações futuras de atenderem as suas necessidades.

- 1992: Ocorreu a ECO-92, realizado no Rio de Janeiro, visando a celebração das diretrizes dominantes sobre a questão ambiental sobe o manto da ideologia do DS. (OLIVEIRA, 2012)

- 1998: Ocorreu, em Kyoto, no Japão, outro evento mundialmente marcante, com foco na emissão de gases poluentes na atmosfera e na necessidade de empenho para combater o aquecimento global.

-2012: Sucedeu o evento conhecido com RIO+20, cujo objetivo, foi a renovação do compromisso político com o desenvolvimento sustentável, por meio da avaliação do progresso e das lacunas na implementação das decisões adotadas pelas principais cúpulas sobre o assunto e do tratamento de temas novos e emergentes.

Seiffert (2011, pág.4), apresenta que: 
A partir do surgimento do conceito de desenvolvimento sustentável, passou a existir um discurso cada vez mais articulado que procura condicionar a busca de um novo modelo de desenvolvimento aliado à noção de conservação do meio ambiente. Entretanto, foi Ignacy Sachs quem amadureceu o conceito do desenvolvimento, o qual só poderia ser alcançado através do equilíbrio integrado entre cinco dimensões: econômica, ecológica, social, geográfica ou espacial e cultural.

Outro fator preocupante nos dias atuais é o lixo eletrônico, fruto do descarte de produtos eletrônicos, o próximo tópico aborda com maior detalhamento a temática formas de descarte.

\subsection{LIXO ELETRÔNICO}

Com a evolução da tecnologia, os aparelhos eletrônicos passaram a ser obsoletos mais rapidamente. O consumo em grandes proporções desse produto juntamente com a busca constante por novidades tecnológicas faz acelerar a substituição dos aparelhos eletrônicos, ocasionando assim o descarte desses resíduos na natureza. (OLIVEIRA et al, 2013).

Segundo Vieira et al (2009) resíduo eletrônico é conceituado, como todo ou qualquer produto que possua origem tecnológica, tornando-se obsoleto ou inservível, sendo descartado ou jogado ao lixo.

Neste sentido, é possível considerar os telefones celulares, televisores, eletrodomésticos portáteis, rádios, todos os equipamentos de microinformática, filmadoras, vídeos, ferramentas elétricas, DVDs, brinquedos eletrônicos, lâmpadas fluorescentes, e milhares de outros produtos que facilitam a vida da sociedade moderna, e apresentamse, atualmente, como produtos descartáveis, sendo estes exemplos de resíduos eletrônicos (LINHARES, 2012).

Os Resíduos de Equipamentos Eletroeletrônicos (REE) descartados de maneira incorreta se tornam um problema de ordem tecnológica, social e ambiental, com proporções incalculáveis. (SEHNEM et al., 2013). Os resíduos dos mesmos oferecem grande risco ao meio ambiente pois em sua composição há uso de metais pesados altamente tóxicos, tanto ao meio ambiente, a exemplo lençol freático e poluição do ar, como desencadeamento de vários problemas danosos a saúde humana. No lixo eletrônico são encontrados elementos como chumbo, mercúrio, cádmio, arsênio e berílio, os quais podem causar danos ao sistema nervoso, cerebral, sanguíneo, fígado, ossos, rins, pulmões, doenças de pele, câncer de pulmão, desordens hormonais e reprodutivas e ainda problemas respiratórios (MOREIRA apud SEHNEM et al., 2007)

Estimativas do Greenpeace indicam
que 50 milhões de toneladas de lixo
eletrônico são geradas anualmente
no nosso planeta. Já o Programa das
Nações Unidas para o Meio Ambiente
(PNUMA) calcula que a geração de lixo
eletrônico global cresce a uma taxa de
cerca de 40 milhões de toneladas por
ano. No âmbito nacional, o cálculo é
de 96,8 mil toneladas de computadores
descartados anualmente. Em média,
cada brasileiro descarta 0,5 kg de lixo
eletrônico por ano, considerando apenas
computadores. (SIQUEIRA e MACHADO,
2013, pág. 18)

Segundo o Ministério do Meio Ambiente (2016), a Lei no 12.305/10, que institui a Política Nacional de Resíduos Sólidos (PNRS), prevê a prevenção e a redução na geração de resíduos, tendo como proposta a prática de hábitos de consumo sustentável e um conjunto de instrumentos para propiciar o aumento da reciclagem e da reutilização dos desses resíduos, além destinação ambientalmente adequada. Institui a responsabilidade compartilhada dos 
geradores de resíduos: dos fabricantes, importadores, distribuidores, comerciantes, o cidadão e titulares de serviços de manejo dos resíduos sólidos urbanos na Logística Reversa dos resíduos e embalagens pré e pós-consumo.

Com isso, são necessárias medidas para reduzir o descarte incorreto do REEE, como o TI Verde que alia a evolução da Tecnologia da Informação (TI) à preservação do meio ambiente, visando o aumento da vida útil dos computadores, redução e reciclagem de lixo eletrônico, equipamentos ligados somente enquanto estão sendo utilizados, virtualização e diminuição do consumo de papel em impressões desnecessárias. (SIQUEIRA e MACHADO, 2013). Além da chamada Logística Reversa que corresponde ao retorno dos bens de pós-venda e de pós consumo ao ciclo de negócios ou ciclo produtivos, por meio dos canais de distribuição reversos. (LEITE, 2009).

O próximo tópico trata das ferramentas metodológicas que auxiliaram na consecução dos objetivos. Será apresentada a classificação da pesquisa, população e amostra e o instrumento de coleta e a análise.

\section{3 . ASPECTOS METODOLÓGICOS}

\subsection{CLASSIFICAÇÃO DA PESQUISA}

Quanto à natureza da pesquisa, ela é classificada como aplicada, pois objetiva gerar conhecimentos para aplicação prática e dirigidos à solução de problemas específicos. Envolve verdades e interesses locais. (SILVA e MENEZES, 2005, p.20). A pesquisa sobre lixo eletrônico, envolvendo estudantes universitários, irá gerar relevantes conhecimentos para entender como acontece as formas de descarte e discutir a importância da consicentização e do acesso a informação.

Do ponto de vista da forma de abordagem do problema é classificada como qualitativa e quantitativa. A primeira considera a interpretação dos fenômenos e a atribuição de significados é básica no processo de pesquisa qualitativa, não requer o uso de métodos e técnicas estatísticas. (SILVA e MENEZES, 2005, p.20). Portanto, permitiu relacionar as questões não quantificáveis sobre: logística reversa, lixo eletrônico e descarte.

A quantitativa considera que tudo pode ser quantificável, o que significa traduzir em números opiniões e informações para classificá-las e analisálas, requer o uso de recursos e de técnicas estatísticas (SILVA e MENEZES, 2005, p.20). Foi utilizada a abordagem quantitativa, no sentido de gerar dados precisos, que serão analisados e, apartir daí, construir informações que irão dar auxilio no direcionamento do descarte correto e da importância da consicentização.

Do ponto de vista de seus objetivos (GIL, 1991) é classificada como:

Pesquisa exploratória, pois visa
proporcionar maior familiaridade com o
problema com vistas a torná-lo explícito
ou a construir hipóteses. Envolve
levantamento bibliográfico; entrevistas
com pessoas que tiveram experiências
práticas com o problema pesquisado;
análise de exemplos que estimulem a
compreensão. Assume, em geral, as
formas de Pesquisas Bibliográficas e
Estudos de Caso. (SILVA e MENEZES,
2005, pág. 21).

Portando, esta pesquisa visa explorar a temática lixo eletrônico com intenção de discutir problemas encontrados no descarte destes resíduos com base nas informações obtidas dos estudantes de Administração da UEPB, Campus VII, Patos-PB.

Além disso, envolveu estudo bibliográfico que serviu para clarear e aprofundar o assunto abordado.

Pesquisa bibliográfica, quando elaborada a partir de material já publicado, constituído principalmente de livros, artigos de periódicos e atualmente com material disponibilizado na Internet. (SILVA e MENEZES, 2005. p.21) A utilização deste foi feita através de livros, sites da Internet, revistas, artigos 
e dissertações que serviram de alicerce para este novo estudo.

A pesquisa é classificada como descritiva, uma vez que visa descrever as características de determinada população ou fenômeno ou o estabelecimento de relações entre variáveis. Assume, em geral, a forma de levantamento. (SILVA e MENEZES, 2005, p.21). Portanto, a utilização desse método visa descrever, através das opiniões dos alunos, as formas de descarte do lixo eletrônico e determinar os efeitos resultantes do manejo incorreto no meio ambiente.

É do tipo levantamento, quando a pesquisa envolve a interrogação direta das pessoas cujo comportamento se deseja conhecer (SILVA e MENEZES, 2005, p.21). Haverá questionamento direto aos alunos do curso de administração com a finalidade de identificar as formas de descarte do lixo eletrônico, utilizadas pelos mesmos.

\subsection{POPULAÇÃO E AMOSTRA}

População é a totalidade de indivíduos que possuem as mesmas características definidas para determinado estudo. Amostra é a parte da população selecionada de acordo com uma regra ou plano, pode ser probabilística e não-probabilística. (SILVA e MENEZES, 2005, p. 32)

A população é representada pelos alunos do curso de Administração do Campus VII da Universidade Estadual da Paraíba, que totalizam 440, já a amostra é de 158, cujo cálculo amostral utilizou a seguinte formula:

$$
n=\frac{N \cdot Z^{2} \cdot p \cdot(1-p)}{Z^{2} \cdot p \cdot(1-p)+e^{2} \cdot(N-1)}
$$

Onde:

$\mathrm{n}$ - amostra calculada $\mathrm{N}$ - população

Z - variável normal padronizada associada ao nível de confiança $\mathrm{p}$ - verdadeira probabilidade do evento e - erro amostral (SANTOS, 2016)
O erro amostral é de 5\%, o nível de confiança é de $95 \%$, e a distribuição populacional é homogênea $(80 / 20)$.

A amostra é probabilística, do tipo casual simples, onde cada elemento da população tem oportunidade igual de ser incluído na amostra (SILVA e MENEZES, 2005). Pois, cada aluno tem a mesma chance de ser inserido na amostra da pesquisa.

\subsection{INSTRUMENTOS DE COLETA DE DADOS}

A definição do instrumento de coleta de dados dependerá dos objetivos que se pretende alcançar com a pesquisa e do universo a ser investigado (SILVA e MENEZES, 2005, p.33). O instrumento de coleta de dados utilizado foi o questionário que é uma série ordenada de perguntas que devem ser respondidas por escrito pelo informante (SILVA e MENEZES, 2005, p.33).

O questionário de múltiplas escolhas, ou seja, questões fechadas com uma série de respostas possíveis (SILVA e MENEZES, 2005). Ele é composto por sete (7) questionamentos sobre as formas de descarte do lixo eletrônico.

\section{RESULTADOS}

Como já mencionado anteriormente o instrumento de coleta de dados utilizado foi o questionário, este foi aplicado a cento e cinquenta e oito (158) alunos, no mês de Maio de 2016, escolhidos aleatoriamente. Com intuito de obter informações fidedignas nenhum respondente foi obrigado a se identificar nem apresentar documentos de comprovação. Os dados colhidos foram dispostos em sete (7) quadros que serão apresentados a seguir. O quadro 1 trata do nível de conhecimento sobre do que se trata o lixo eletrônico. 
Quadro 1 - Nível de conhecimento do lixo eletrônico

\begin{tabular}{|c|c|}
\hline 01. Nível de conhecimento sobre lixo eletrônico? & \% \\
\hline $\begin{array}{l}\text { 1.1 Conheço parcialmente, no entanto não sei bem } \\
\text { do que se trata. }\end{array}$ & 66 \\
\hline $\begin{array}{l}1.2 \text { Conheço totalmente, e procuro sempre a } \\
\text { melhor maneira de descartar. }\end{array}$ & 27 \\
\hline $\begin{array}{l}\text { 1.3 Nenhum conhecimento, ainda não conheço } \\
\text { este termo. }\end{array}$ & 1 \\
\hline 1.4 Indiferente. Não quero responder. & 6 \\
\hline TOTAL & 100 \\
\hline
\end{tabular}

Fonte: Pesquisa de Campo (2016)

O primeiro questionamento da pesquisa abordou o nível de conhecimento sobre o lixo eletrônico. Como apresentado no quadro 1, a maioria dos alunos detém informação parcial sobre o tema, seja por desinteresse ou falta de conscientização. A falta de conhecimento leva ao descarte incorreto desse material, como mostra o estudo desenvolvido pelo Programa das Nações Unidas para o Meio Ambiente (PNUMA/ONU), que apresenta o Brasil como maior produtor per capita de lixo eletrônico entre países emergentes e em desenvolvimento, resultando em 96,8 mil toneladas de lixo eletrônico ao ano (BRASIL, 2016). O segundo ponto pesquisado trata dos motivos que levou o descarte, o quadro 2 apresenta os dados.

Quadro 2 - Motivos que levaram a descartar produtos e transformá-los em lixo eletrônico

\begin{tabular}{|l|l|}
$\begin{array}{l}\text { 02. O que levou a descartar produtos e } \\
\text { transformá-los em lixo eletrônico? }\end{array}$ & $\%$ \\
\hline 2.1 Defeito. & 37 \\
\hline 2.2 Funções adicionais de aparelhos novos. & 10 \\
\hline 2.3 Fim da vida útil & 43 \\
\hline 2.4 Novos modelos & 15 \\
\hline 2.5 Não opinou & 10 \\
\hline
\end{tabular}

Fonte: Pesquisa de Campo (2016)

* Pergunta de múltipla escolha

O segundo quadro retrata os principais motivos do descarte, diante dessas informações é possível inferir que os produtos eletrônicos produzidos atualmente tem sua vida útil limitada, quebram e/ou danificam com mais facilidade, e o custo para concerto é elevado, ocasionando substituição por aparelhos novos e consequentemente o descarte do mesmo.

Além disso, o consumismo e inovações tecnológicas tornam produtos obsoletos em pouco tempo. A inovação tecnológica e o aumento nos padrões de consumo da sociedade contemporânea têm gerado crescimento constante na produção de equipamentos elétricos e principalmente eletrônicos (SEHNEM, 2013 , p.5). Aliado a isso, há um aumento expressivo na geração de resíduos sólidos, relacionada à rápida obsolescência dos equipamentos eletrônicos (GIARETTA, 2010 apud, SHENEM, 2013 p.5). O quadro 3 apresenta o destino dado aos resíduos eletrônicos.

Quadro 3 - Caso já tenha descartado, qual destino dado ao lixo eletrônico

\begin{tabular}{|c|c|}
\hline $\begin{array}{l}\text { 03. Caso já tenha descartado, qual } \\
\text { destino dado? }\end{array}$ & $\%$ \\
\hline 3.1 Não lembro. & 16 \\
\hline 3.2 Lixo comum. & 56 \\
\hline $\begin{array}{l}\text { 3.3 Empresa onde comprou o } \\
\text { eletroeletrônico ou eletrodoméstico. }\end{array}$ & 6 \\
\hline 3.4 Lixo especializado. & 10 \\
\hline 3.5 Outro. & 5 \\
\hline 3.6 Não opinou. & 7 \\
\hline TOTAL & 100 \\
\hline
\end{tabular}

Fonte: Pesquisa de Campo (2016)

O terceiro questionamento refere-se ao destino dado ao lixo eletrônico, como apresentado no quadro 3, $56 \%$ descartaram no lixo comum, $16 \%$ não lembram do destino, $10 \%$ em local especializado, $5 \%$ na empresa onde adquiriram o produto e 5,1\% responderam que fizeram esse descarte de outras maneiras, como a venda do mesmo a terceiros, doações, ou ainda, aqueles que mantêm guardado em casa. Pode-se inferir que a maioria das pessoas ainda têm o hábito do descarte no lixo comum, o que é prejudicial tanto ao meio ambiente como também a 
saúde humana, devido a uma grande quantidade de substâncias prejudiciais que esses materiais contêm.

Eles devem ser descartados de forma correta, pois possuem aproximadamente quarenta e três

(43) elementos químicos, incluindo cobre, lítio, chumbo e cromo, causadores de danos tanto para o meio ambiente quanto para a saúde. (SEHNEM, 2013 p.7).

O resultado desta pesquisa converge com os estudos realizados por Weiler et al (2013), que diz que dos $71 \%$, que já descartou algum eletrônico ou eletrodoméstico de maneira incorreta, $46 \%$ encaminhou ao lixo comum, $11 \%$ devolveu a empresas em que adquiriu o aparelho, $19 \%$ vendeu a terceiros, $12 \%$ descartou em qualquer lugar e os demais deram outro destino. O quadro 4 evidencia os dados sobre o nível de conhecimento que o descarte incorreto proprociona.

Quadro 4 - Nível de conhecimento sobre os danos causados pelo descarte incorreto

\begin{tabular}{|c|c|}
\hline $\begin{array}{l}\text { 04. Qual seu conhecimento a respeito dos } \\
\text { danos causados pelo descarte incorreto do lixo } \\
\text { eletrônico? }\end{array}$ & $\%$ \\
\hline 4.1 Nenhum & 5 \\
\hline $\begin{array}{l}\text { 4.2 Parcial, tenho ciência de que o descarte incorreto } \\
\text { afeta o meio ambiente, mas não sei quais os danos. }\end{array}$ & 53 \\
\hline $\begin{array}{l}\text { 4.3 Completo, tenho conhecimento da necessidade } \\
\text { do descarte correto, pois feito de maneira incorreta } \\
\text { pode contaminar o solo, o ar e o lençol freático. }\end{array}$ & 35 \\
\hline 4.4 Indiferente & 1 \\
\hline 4.5 Não opinou & 6 \\
\hline TOTAL & 100 \\
\hline
\end{tabular}

Fonte: Pesquisa de Campo (2016)

A maioria dos alunos sabem o impacto negativo que o descarte incorreto do lixo eletrônico pode causar no meio ambiente, porém continuam descartando em locais impróprios, devido a ausência de informações sobre coleta especializada e de locais específicos.

Os danos gerados pela contaminação de substâncias químicas existentes no lixo eletrônico causam problemas no solo, nos lençóis freáticos e no ar. As conseqüências vão desde simples dor de cabeça e vômito até complicações mais sérias, como comprometimento do sistema nervoso e surgimento de cânceres (GUARITÁ aput CARPANEZ, 2007). Em relação a responsabilidade do lixo eletrônico o quadro 5 apresenta as opiniões dos respondentes, existindo uma concentração de resposta no item 5.4.

\section{Quadro 5 - Sobre a responsabilidade do descarte do lixo} eletrônico

\begin{tabular}{|c|c|}
\hline $\begin{array}{l}\text { 05. Sobre a responsabilidade do descarte do lixo } \\
\text { eletrônico }\end{array}$ & $\%$ \\
\hline 5.1 A responsabilidade é de quem possui o mesmo. & 26 \\
\hline $\begin{array}{l}5.2 \text { É da loja que você o comprou, visto que a } \\
\text { responsabilidade cabe aos revendedores e a } \\
\text { indústria de fazer o descarte adequado (praticar a } \\
\text { logística reversa). }\end{array}$ & 11 \\
\hline $\begin{array}{l}5.3 \text { É do governo, pois o mesmo tem que ter } \\
\text { políticas voltadas para esse assunto. }\end{array}$ & 9 \\
\hline $\begin{array}{l}\text { 5.4 É do município, em cada cidade deve ser criado } \\
\text { uma empresa ou órgão encarregado pelo descartes } \\
\text { destes materiais. }\end{array}$ & 44 \\
\hline 5.5 Não sei opinar & 4 \\
\hline 5.6 Não opinou & 6 \\
\hline TOTAL & 100 \\
\hline
\end{tabular}

Fonte: Pesquisa de Campo (2016)

O quinto questionamento refere-se a responsabilidade do descarte do lixo eletrônico, diante dos resultados obtidos, pode-se inferir que, devido ao conhecimento limitado da temática, as pessoas não sabem de quem é a responsabilidade do material a ser descartado, atribuindo até mesmo, ao próprio cliente. No entanto, nota-se a necessidade de ações conjuntas do Município, Governo Federal e Estadual e das empresas privadas.

Contudo, a Política Nacional de Resíduos Sólidos (PNRS), n 12.305/2010, delibera no Art. 33 que: "São obrigados a estruturar e implementar sistemas de logística reversa, mediante retorno dos produtos após o uso pelo consumidor, de forma independente do serviço público de limpeza urbana e de manejo dos resíduos sólidos, os fabricantes, importadores, 
distribuidores e comerciantes (...) VI - produtos eletroeletronico e seus componentes."

Pelo levantamento de 2015 do Sistema Nacional de Informações sobre Saneamento, só 724 das mais de 5.500 cidades brasileiras têm algum tipo de coleta de lixo eletrônico, E não é por falta de Lei, a PNRS foi lançada há cinco anos e prevê a implantação ações eficientes como a logística reversa. O penúltimo quadro questiona o aluno sobre locais de coleta na cidade onde reside.

Quadro 6 - Na cidade que reside tem locais para coleta de eletrônico

\begin{tabular}{|l|c|}
\begin{tabular}{|l|l|} 
06. Na cidade que reside tem locais para coleta de \\
eletrônico?
\end{tabular} & $\begin{array}{l}\text { \% } \\
\text { 6.1 Não. }\end{array}$ \\
\hline 6.2 Caso tenha, desconheço. & $33,5 \%$ \\
\hline 6.3 Sim. & $3,8 \%$ \\
\hline 6.4 Não opinou. & $5,7 \%$ \\
\hline
\end{tabular}

Fonte: Pesquisa de Campo (2016)

Em relação aos locais de coleta do lixo eletrônico, os respondentes afirmara que: $57 \%$ deles não sabem se existem locais em sua cidade, 33,5\% desconhecem a existência desses ambientes, 5,7\% não opinaram e $3,8 \%$ afirmam que nas suas cidades os pontos estão principalmente nos locais expresso no quadro 7.

Quadro 7 - Locais específicos para coleta de eletrônico

\begin{tabular}{|c|}
\hline Locais de coleta \\
\hline Secretaria do Meio Ambiente \\
\hline Empresa de Energia pública (Energisa) \\
\hline Ministério Público Federal \\
\hline Empresa Privada \\
\hline Praças e outros locais públicos \\
\hline
\end{tabular}

Fonte: Pesquisa de Campo (2016)

Todos afirmaram que existe interesse em descartar corretamente o material, porém cabe aos órgãos públicos ou privados disponibilizar locais destinados para esse fim. O último ponto investigado foi sobre a necessidade de conscientização, quase a totalidade dos respondentes concordam que esse é o primeiro passo para eliminar todas as incongruência das formas de descarte.

Quadro 8 - Julga ser necessário a conscientização sobre o descarte correto do lixo eletrônico

07. Julga ser necessário a conscientização sobre o descarte correto do lixo eletrônico?

7.1Sim, é de suma importância que todos saibam sobre este tema.

7.2 Em partes, não vejo tamanha relevância sobre o tema.

7.3 Indiferente.

7.4 Não opinou.

TOTAL

Fonte: Pesquisa de Campo (2016)

O último questionamento foi sobre a necessidade de conscientização do descarte correto do lixo eletrônico, como apresentado quadro 8 , a grande maioria (93\%) afirmou sobre a importância da necessidade ao acesso conhecimento, 5\% não opinaram, 1\% não observa importância sobre esse tema e 1\% é indiferente.

A partir desses dados, pode-se inferir que grande parte dos alunos reconhece essa temática como sendo de vasta relevância para todos, como é reiterado na pesquisa realizada no Rio Grande do Sul por Weiler et al (2013), que apresenta as seguintes informações: vê-se o interesse em pelo menos $96 \%$ dos entrevistados em trabalhar o tema, seja através de folders (32\%), projetos escolares e propagandas nas rádios e Tvs (29\%) ou a partir de palestras (8\%).

A população conscientizada passará a rever suas ações, tendo em vista as graves consequências que o lixo eletrônico proporciona ao meio ambiente e a própria saúde humana. 


\section{CONSIDERAÇÕES FINAIS}

No âmbito do problema abordado, realizou-se pesquisa com finalidade de identificar as formas de descarte do lixo eletrônico, através da experiência dos alunos que cursam Administração do Campus VII da Universidade Estatual da Paraíba, além de avaliar os problemas encontrados no descarte incorreto e discutir a importância da consicentização e do acesso a informação.

Diante dos dados obtidos na pesquisa, foi analisado que, mesmo em uma Instituição de Ensino Superior, o nível de conhecimento da maioria dos alunos, sobre o tema, ainda é parcial, revelando a necessidade de ações por parte das empresas e do poder público no sentido de informar os riscos e os prejuízos que o descarte incorreto do lixo eletrônico pode acarretar.

Também foi identificado que a falta de conhecimento e de locais adequados leva ao descarte incorreto desse materiais, pois a maioria dos alunos descartam em lixo comum, que pode ocasionar a contaminação e poluição do meio ambiente e também gerar doenças nas pessoas.

Diante desta situação, o correto é fazer o descarte em locais apropriados como por exemplo: empresas e cooperativas que atuam na área de reciclagem. As baterias dos celulares podem ser encaminhadas para as empresas fabricantes.

Portanto, o trabalho não tem a pretenção de encerrar o debate e sim instigar estudos futuros a respeito do assunto, elucidando pontos importantes em relação ao destino correto e da seriedade sobre o conhecimento deste.

Deste modo, o descarte depende não só da educação ambiental, que deve fazer parte da nossa cultura, mas também de políticas públicas e ações de empresas privadas.

\section{REFERÊNCIAS}

[1] BRASIL. Lei no 12.305, 2 de agosto de 2010; Institui a Política Nacional de Resíduos Sólidos; altera a Lei no 9.605, de 12 de fevereiro de 1998; e dá outras providências. Disponível em:

<http://www.planalto.gov.br/ccivil_03/_ato2007-2010/2010/ lei/l12305.htm> acesso em 13/05/16, às $11 \mathrm{~h}$

[2] BRASIL. MINISTÉRIO DO MEIO AMBIENTE. Legislação Ambiental CONAMA. Disponível em <http://www.mma.gov.br.> Acesso em 13/05/2016, às 08h00

[3] CARVALHO, Pedro Pereira de. Descarte de equipamentos de informática (reee) nas prefeituras do abc sob a perspectiva socioambiental. 2010. Dissertação de Mestrado em Administração da Universidade Municipal de São Caetano do Sul.

[4] GIL, Antonio Carlos. Como elaborar projetos de pesquisa. São Paulo: Atlas, 1991.

[5] LEITE, P. R. Logística Reversa: Meio ambiente e competitividade. 2 ${ }^{\underline{a}}$ Ed. São Paulo: Prentice Hall, 2009.

[6] LINHARES, S. N.; NOBRE M. F,; MOSCARDI J. P,. Os resíduos eletroeletrônicos: uma análise comparativa acercada percepção ambiental dos consumidores da cidade de Mossoró - RN. III Congresso Brasileiro de Gestão Ambiental. Goiânia, GO - 19 - 22 nov. 2012.

[7] OLIVEIRA, E. L. ; KIST, Daniel ; PALUDO, J. C. ; SILVA, N. Y. F. ; SEHNEM, S. . Logística reversa: uma análise do descarte de baterias e celulares nos pontos de coleta da claro em chapecó SC. Amazônia, Organizações e Sustentabilidade, v. 2, p. 79-95, 2013.

[8] OLIVEIRA, Leandro Dias de. A Conferência do Rio de Janeiro - 1992 (Eco-92): Reflexões sobre a Geopolítica do Desenvolvimento Sustentável. In: VI ENANPPAS - Encontro Nacional da Associação Nacional de Pós- Graduação e Pesquisa em Ambiente e Sociedade, 2012, Belém. VI ENANPPAS - Encontro Nacional da Associação Nacional de Pós-Graduação e Pesquisa em Ambiente e Sociedade. Belém: ANPPAS / UFPA, 2012.

v. 1.

[9] SANTOS, Glauber Eduardo de Oliveira. Cálculo amostral: calculadora on-line. Disponível em: $<$ http://www.calculoamostral.vai.la>. Acesso em: [13/05/2016].

[10] SILVA, Edna Lúcia da; MENEZES, Estera Muszkat. Metodologia da pesquisa e elaboração de dissertação. - 4. ed. rev. atual. - Florianópolis: UFSC, 2005.

[11] SEIFFERT, Mari Elizabete Bernardini. ISSO 14001 Sistemas de gestão ambiental: implantação objetiva e econômica. 4a Edição. São Paulo: Atlas, 2011. 
[12] SIQUEIRA M. L.; MACHADO C. M. C. Atividade extensionista e TI Verde: conectando instituição e comunidade. Revista Brasileira de Computação Aplicada (ISSN 2176-6649), Passo Fundo, v. 5, n. 2, p. 18-27, out. 2013

[13] VIEIRA, K. N.; SOARES, T. O. R.; SOARES, L. R.. A logística reversa do lixo tecnológico: um estudo sobre o projeto de coleta de lâmpadas, pilha e baterias da BRASKEM. Revista de Gestão Social e Ambiental. v.3, n 3, p.120-136. Set. - Dez. 2009. Disponível em: <www. gestaosocioambiental.net> Acessado em: 04 de janeiro de 2012.
[14] WEILER, E; HEDLUND, K. F S; LAMBRECHT, F. R; SILVA,T C N; D'AVILA, M; TORRES, O. Lixo

eletrônico: avaliação e conscientização nos municípios de Frederico Westphalen e Taquaruçu do Sul. Revista do Centro do Ciências Naturais e Exatas - UFSM, Santa Maria, Revista Eletronica em Gestão, Educação e Tecnologia Ambiental REGET (e-ISSN 2236 1170) - v. 17n. 17 Dez 2013, p. 3401 $-3406$ 


\section{CAPÍTULO 2}

ARRANJOS DE CONDOMÍNIO INDUSTRIAL E CONSÓRCIO MODULAR NA INDÚSTRIA AUTOMOBILÍSTICA BRASILEIRA: UMA ANÁLISE DE MÚLTIPLOS CASOS

\section{Délvio Venanzi}

Orlando Roque da Silva

Resumo: Em decorrênclia do aumento da competitividade entre empresas que atuam no setor automobilístico, faz-se necessário organizar as plantas produtivas em arranjos mais competitivos como o condomínio industrial e o consórcio modular. O objetivo desta pesquisa é estudar esses arranjos procurando identificar os fatores que contribuem para facilitar a adoção de práticas que podem impactar na estratégia de produção. A pesquisa utilizada é caracterizada como exploratória e descritiva com estudo de múltiplos casos e como método de analise de dados, a abordagem qualitativa. A pesquisa analisou as diferenças mais relevantes entre os arranjos e suas implicações para a gestão de operações.

Palavras chave: Consórcio Modular, Condomínio Industrial, JIT, JIT Seqüenciado

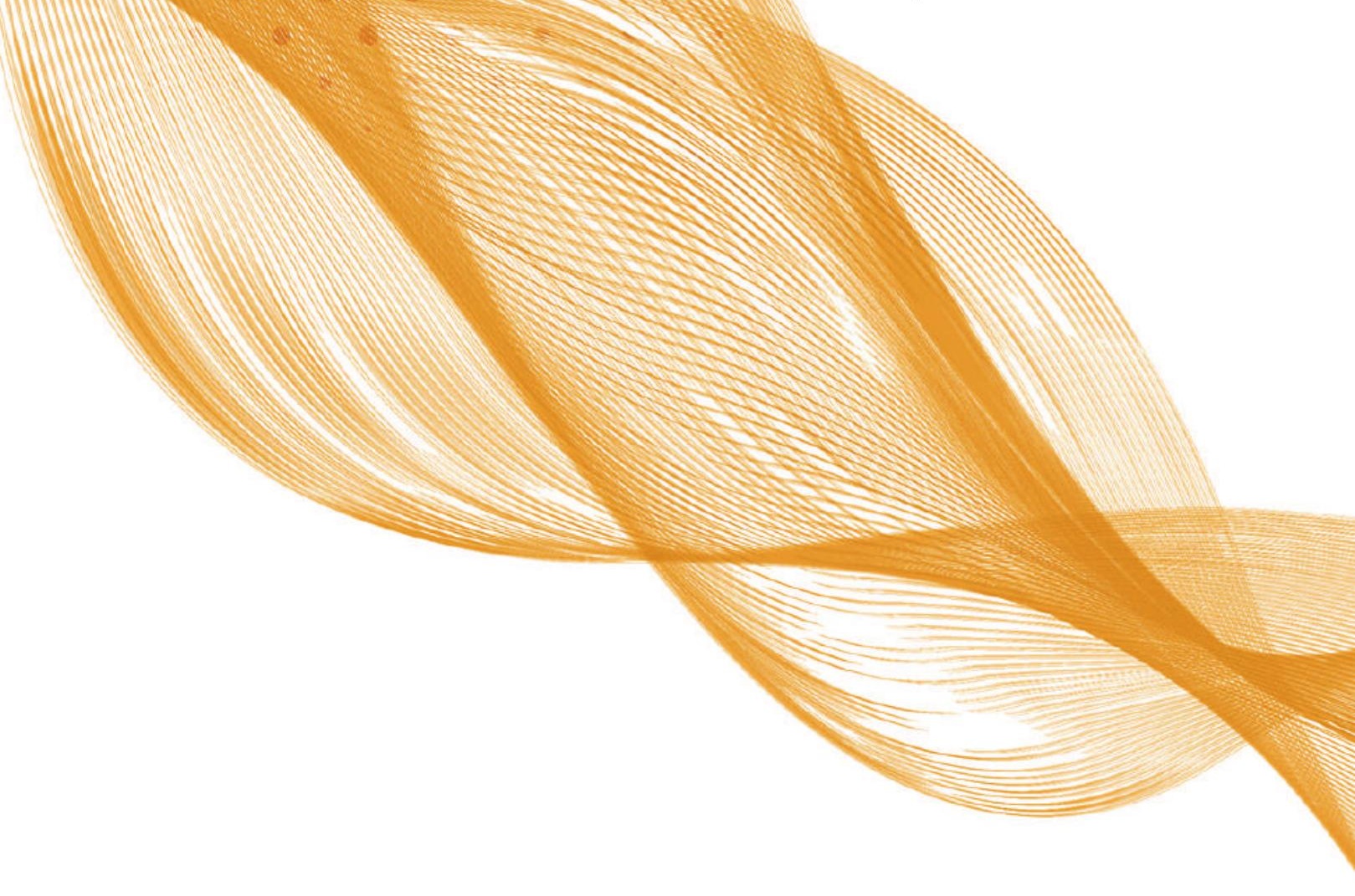




\section{INTRODUÇÃO}

As empresas do segmento automotivo estão inseridas em um mercado bastante competitivo e sujeito às oscilações da economia. As montadoras, agentes de maior poder na cadeia de suprimentos, aderiram às práticas just-in-time visando aumento da eficiência, redução de estoques, confiabilidade na entrega de produtos e sincronismo entre os elos da cadeia, as quais estão inseridas nos arranjos de condomínio industrial e consórcio modular (HOLWEG, 2008). O modelo tradicional de relacionamento entre indústrias e seus fornecedores, baseado na competição, vem perdendo espaço para modelos baseados na cooperação e nas alianças de longo prazo, que integram alguns dos conceitos do gerenciamento das cadeias de suprimentos e a prática do JIT nos arranjos de condomínio industrial e consórcio modular. Estes arranjos implicam em uma nova distribuição de responsabilidades, quase sempre acompanhadas de maior terceirização da produção de bens e da prestação de serviços (NÓBREGA JR, 2000).

O Brasil, fazendo parte do BRIC, que engloba os países emergentes, é considerado país atrativo para se instalarem novas plantas, abrigando atualmente vinte e cinco montadoras. Algumas características desse mercado atrativo são o crescimento acelerado do mercado de veículos, as plantas com custos baixos em determinadas localidades e um enorme portfólio de motorização (ASSOCIAÇÃO DOS FABRICANTES DE VEÍCULOS AUTOMOTORES,

2009). Dessa forma, as montadoras simplificam produtos, investem em novas parcerias e alianças estratégicas com fornecedores. Novas configurações (consórcio modular e condomínio industrial), que trazem os fornecedores para dentro ou ao redor do site da montadora, propiciando redução de custos logísticos, redução de plataformas, aumento de modelos por plataformas e o uso de arquitetura de produto modular.

As empresas competitivas, que operam em ambientes com ciclos de vida de produtos curtos, têm incorporado a modularização como uma estratégia competitiva que lhes ajudasse responder às demandas mais rápidas, para controlar a complexidade, a flexibilidade do ganho, o risco e os investimentos com os parceiros.
Utilizando sistemas modulares, as empresas estão integrando uma tecnologia mais avançada nos produtos, tais como chips de computador nos carros, nos dispositivos em casa, e nos dispositivos de uma comunicação que podem executar diversas programações de funções.

A modularização é um conceito no projeto de produto onde o produto final é construído de um número de módulos do produto. Os módulos são montados para configurar um grande número de variações do produto final. (MIKKOLA, 2006). De acordo com o autor, o projeto modular dos produtos possui um caminho de sentido único para conseguir um desempenho de produto mais elevado sem incrementar o custo de manufatura em uma maneira desproporcional.

A modularização, hoje uma estratégia competitiva em manufatura, ganhou a atenção, desde que foi ligada mais especificamente às estratégias do projeto de grandes multinacionais e como uma aproximação para introduzir novos produtos bem sucedidos. A emergência da modularização está sendo acompanhada por estruturas de organização "modulares", novas estratégias da gestão do conhecimento, que permitem às empresas desenvolverem produtos mais eficazmente e com flexibilidade (CHUNG, 2005).

De acordo com Worren, Moore e Cardona (2002), o produto modular e a arquitetura do processo são fontes importantes da flexibilidade estratégica para as empresas que enfrentam um ambiente dinâmico, porque ambos são pré-requisitos para a customização e a redução drástica do tempo de ciclo.

Para Kotabe e Mol (2007), a indústria automobilística no Brasil fornece um ambiente excelente para examinar os antecedentes e os resultados da estratégia de modularização no projeto e na produção dos automóveis. Sendo o único país que hospeda todos os fabricantes de carros globais no mundo, esses fabricantes identificaram o Brasil como um ambiente que oferece as melhores condições para as aplicações de métodos alternativos e inovativos da produção. 
Neste artigo consideramos como objetivo principal estudar esses arranjos procurando identificar os fatores que contribuem para facilitar a adoção de práticas que podem impactar na qualidade dos produtos, na confiabilidade dos prazos de entrega, na flexibilidade de composto (mix) e na redução de custos de produção e assumimos como hipótese que a adoção dos novos arranjos é em função das dificuldades de implementação do JIT, já que uma das condições é a localização de suas bases muito próxima do local de fornecimento e também o volume a ser atendido e ofertado pela montadora em função das demandas de mercado, dessa forma atraindo parceiros para o site.

\section{REVISÃO BIBLIOGRÁFICA}

\subsection{JUST-IN-TIME (JIT)}

De acordo com Holweg (2008), o JIT é um sistema onde o principal objetivo é gerar lucro, através da redução de custos via eliminação de desperdícios e do incremento de produtividade via melhorias no fluxo produtivo. Desperdícios geram somente custo e tempo, portanto, não agrega valor (a peça não sofre nenhuma transformação). A utilização de recursos excessivos tais como homem, máquina, material e recursos de facilidades geram a superprodução, definido por Alves (2007) como o pior dos desperdícios. De acordo com Heckert (2007), para produzir JIT, isto é, produzir e entregar a peça certa, na quantidade necessária, no momento correto, é preciso não gerar defeitos para o processo subseqüente. Desta forma pode-se estabelecer um fluxo cadenciado e sem interrupções ao longo da cadeia produtiva. Neste processo os arranjos de condomínio industrial e consórcio modular são imprescindíveis, pois com os parceiros lado a lado, eliminam-se muitos defeitos nos processos, desperdícios e retrabalhos, o fluxo é contínuo e o lead time é muito mais curto se comparado com uma linha tradicional.

Para Kotabe (2007), outro ponto importante para o suprimento JIT refere-se à localização geográfica dos fornecedores em relação à montadora. Muitas vezes, o fornecedor chega a construir sua fábrica no próprio terreno da montadora, é o caso das montadoras estudadas neste artigo. O JIT aumenta, ainda, a flexibilidade de resposta e a velocidade do fluxo de produção. Por fim, a confiabilidade das entregas também é aumentada através da ênfase na manutenção preventiva e da flexibilidade dos trabalhadores.

Por outro lado, as principais limitações do JIT referem-se à necessidade de que a demanda seja razoavelmente estável, para que se consiga balancear os recursos e a complexidade dos roteiros de produção, caso haja grande variedade de produtos. Uma evolução do JIT tradicional é o chamado JIT Seqüenciado (JITS). Neste tipo de JIT, as peças são entregues pelo fornecedor diretamente na linha de montagem da montadora, já na seqüência em que serão colocadas nos automóveis. Este tipo de fornecimento é considerado como o de melhor relação benefício-custo de implantação. Com o JITS as entregas tornam-se mais freqüentes ainda, em lotes cada vez menores (geralmente o suficiente para cerca de duas horas de produção).

\subsection{ARRANJOS DE PRODUÇÃO NA INDÚSTRIA AUTOMOBILÍSTICA NO BRASIL}

A redefinição organizacional ao longo da cadeia automotiva, a partir da sua estruturação por níveis de fornecedores, segue a estratégia de produção modular, segundo a qual um pequeno número de fornecedores está voltado para a entrega de subconjuntos, módulos e sistemas diretamente às linhas de montagem das montadoras, segundo just in time e just in sequence. Esses arranjos produtivos são os condomínios industriais e o consórcio modular resultantes da re-divisão de tarefas no interior da cadeia produtiva, envolvendo a transferência de tecnologia e de algumas atribuições antes próprias das montadoras para os fornecedores de autopeças e componentes, que se tornam cada vez mais especializados. (SALERNO e DIAS, 2000). Conseqüentemente, verifica-se uma estreita relação entre as montadoras e os fornecedores através de um movimento articulado desde o desenvolvimento do projeto à montagem do produto. Esses fornecedores se reorganizaram em torno de uma rede de suprimentos, para a entrega de componentes e módulos em qualquer região, obedecendo a uma hierarquia na sua disposição 
ao longo da cadeia de suprimentos, cabendo aos fornecedores de primeiro nível organizar e gerir os demais grupos de fornecedores, bem como montar sistemas e entregá-los às montadoras (STEVENSON, 2009).

Os novos arranjos de organização da produção alteraram por completo os formatos de produzir e os relacionamentos entre montadoras e fornecedores, principalmente nos casos de condomínio industrial e consórcio modular, nos quais alguns fornecedores instalam-se desde alguns metros de distância (a maioria dos casos de condomínio industrial) até mesmo dentro da própria linha de montagem final da montadora (consórcio modular).

\subsubsection{CONDOMÍNIO INDUSTRIAL}

Atualmente, o conceito básico de uma fábrica de automóveis é a de uma empresa com uma série de operações industriais, construindo componentes ou comprando-os de terceiros, estocando-os, de forma a alimentar um processo de montagem, sendo agrupados, individualmente ou em conjuntos, a uma estrutura central, que ao final, completo, se transforma em um veículo. Este trabalho é realizado, naturalmente, por operários da empresa.

Em uma fábrica automatizada e com uma configuração de condomínio industrial, os resultados são facilmente percebidos: menores custos, riscos, gastos com mão de obra e custos sociais, descarte dos custos de estoque. Por desdobramento, o custo final é menor ou o lucro é maior, ou ainda as chances de sobrevivência são maiores nesta atividade extremamente competitiva e na quais todas as marcas do mundo têm maior capacidade de produção que de vendas. (REICHHART; HOLWEG, 2008).

No condomínio industrial, no qual alguns fornecedores de subconjuntos ou módulos, escolhidos pela montadora, se instalam nas suas proximidades, essa proximidade facilita a entrega de seus produtos justin-time e/ou just-in-sequence à montadora, ou na linha de montagem final dos veículos. Nesse arranjo é a empresa montadora que decide quem irá participar como empresa fornecedora; que suprimentos serão fornecidos por meio do condomínio; onde os fornecedores se localizarão; e como deverão ser realizadas as entregas com relação à freqüência, às especificações técnicas e ao preço dos suprimentos (PIRES, 2008).

Ainda de acordo com Pires (2007), a montadora por meio desse arranjo organizacional pode produzir com estoque mínimo e ao mesmo tempo alcançar alta produtividade e flexibilidade no chão de fábrica. A montadora utiliza, em toda a sua cadeia de suprimento, um sistema logístico composto por um operador e por um sistema de troca de dados eletrônicos (EDI - Eletronic Data Interchange), os quais garantem a entrega de cada fornecedor na seqüência da produção programada. Por meio do EDI, a montadora envia aos fornecedores informações, a cada uma hora e meia ou duas horas, a respeito da seqüência de produção, a fim de que os produtos programados sejam entregues diretamente na linha de montagem final. A coleta e a entrega desse material são de responsabilidade do operador logístico. Por conseguinte, para cada dia de produção realizada de acordo com a necessidade programada pela montadora, os fornecedores têm seu pagamento efetuado.

\subsubsection{CONSÓRCIO MODULAR}

O que distingue um arranjo de consórcio do condomínio industrial é a porcentagem de valor agregado industrialmente pela montadora, mínimo no caso do consórcio modular, segundo Salerno et al. (1998). O consórcio modular pode ser conceituado, segundo Pires (2004), como um caso radical de terceirização entre montadora e uns poucos fornecedores chamados modulistas, no qual:

- os modulistas assumem a montagem prévia do módulo sob sua responsabilidade e sua posterior montagem, diretamente na linha de produção da montadora. Também assumem os investimentos em equipamentos e ferramentas, e a gestão da cadeia de suprimentos do módulo;

- a montadora providencia a planta e a linha de montagem final, executa a coordenação da mesma e o teste final dos autoveículos. 
O consórcio modular foi concebido a fim de realizar a produção num ciclo menor e com custos menores do que no modelo tradicional de montagem, permitido à montadora concentrar-se na coordenação de projetos, no marketing, na qualidade e nas vendas e pós- vendas (PIRES, 2004).

Segundo Dias (1998), os prazos dos contratos são mais longos comparados com prazos de contratos de relacionamentos tradicionais. Womack et al. (2005) aludiram que o estabelecimento de contratos de longo prazo permite o compartilhamento de informações sobre custos e técnicas de produção entre as empresas, melhora o produto e reduz atividades que não agregam valor, o que possibilita a redução de custos ao longo do período de produção. A necessidade de reduzir os custos de logística e os custos de gestão dos estoques aumenta a importância da proximidade entre as instalações da montadora e suas fornecedoras (SALERNO et al..1998).

Um dos objetivos do consórcio modular é o repasse de atividades de montagem aos modulistas de forma a permitir a redução dos custos e do tempo de montagem do produto, uma vez que várias tarefas são realizadas em paralelo (PIRES, 2004). Logo, a montagem final está submetida a tarefas de dependência prévia, configurando um caminho crítico para a montagem. Porém, a vantagem da produção paralela não é a única característica responsável pela redução do tempo, mas também a forma de gerir e organizar as atividades dos modulistas.

\section{METODOLOGIA DA PESQUISA}

A pesquisa utilizada nesse artigo é caracterizada como exploratória e descritiva, como método de procedimento o estudo de múltiplos casos e como método de análise de dados, a abordagem qualitativa, que tem como objetivo principal auxiliar na compreensão dos problemas. (YIN, 2001).

Em razão do objetivo desta pesquisa que é estudar o condomínio industrial e o consórcio modular na indústria automobilística a metodologia se divide em duas partes: a primeira refere-se a definição da base teórica adotada; a segunda a pesquisa em algumas montadoras para sustentar a proposição teórica. A pesquisa se iniciou com um amplo levantamento de informações sobre estratégias de operações e competitividade na indústria automobilística. Essas informações foram obtidas principalmente de dados secundários, já publicados sendo que as principais fontes utilizadas nesta pesquisa foram as seguintes: internet, publicações e periódicos disponíveis tanto na biblioteca da Unesp em Bauru quanto na biblioteca na Unimep em Santa Bárbara D'Oeste e serviços de clipping eletrônico.

A segunda parte desta pesquisa se concentrou no mapeamento da indústria automotiva brasileira para identificar a ocorrência desses arranjos. A partir desse mapeamento foram identificadas seis plantas, das principais montadoras, que constituíram a base dos estudos empíricos realizados, são elas:

1. Volkswagen em São Bernardo do Campo-SP: Essa planta produtiva representa um dos ícones da indústria automotiva e da industrialização brasileira. Devido a essa postura do passado em gerenciamento, essa unidade tem como pontos fracos (custos fixos elevados, excessiva complexidade operacional, baixa competitividade, dificuldade de implantação de novas filosofias e conceitos operacionais). Após perder mercado para os concorrentes a unidade passou por uma reestruturação, adotou uma nova forma de produzir veículos, adotando o conceito de condomínio industrial, para tornar-se uma planta produtiva e eliminar seus pontos fracos e tornarse competitiva. Além dessa nova adoção muitos pontos automatizados e ilhas robotizadas foram implementados, passando a unidade por uma reformulação em produtos e tecnologia de processos radicais. A adoção do condomínio industrial na unidade mudou radicalmente a forma de produzir, já que os sistemas agora ficam sob responsabilidade dos fornecedores parceiros alocados dentro da unidade. Segundo dados da 
Automotive Business (2005) a empresa aplicou dois bilhões de reais em uma estrutura com alto nível de automatização e modernidade.

2. Volkswagen em Taubaté-SP: A fábrica de Taubaté é considerada uma das mais modernas do país, com cento e setenta robôs em operação e índices de automação que chegam a 80\% (na estamparia). A média de horas de treinamento é de cinco horas/mês/empregado, superior à média da indústria de transformação nos Estados Unidos (três horas e quarenta e cinco minutos/ mês/empregado). Com o intuito de ampliar para todos os fornecedores parceiros a adoção dos sistemas JIT e Kanban a unidade vem incentivando seus fornecedores a instalar fábricas próximas de Taubaté, já que o volume de vendas é atrativo e a proximidade dos parceiros é condição primordial para obtenção de resultados com JIT.

3. Volkswagen em São José dos Pinhais-PR: Essa unidade reúne uma amostra do que existe de mais atualizado em matéria de equipamentos para a produção de automóveis: cabine de pintura robotizada, cabine de solda a laser e máquinas de medições automatizadas com braços que se movem sozinhas. O layout da planta tem o formato de um $Y$, em que a armação, a pintura e a montagem ficam em cada uma de suas "pernas", as quais convergem para o Centro de Comunicação, que se localiza no centro do ipsilon (Y). Importante ressaltar nesse arranjo, devido à proximidade com os parceiros permite ganhos na identificação e resolução de problemas à medida que eles ocorram. Dessa forma o foco concentrase tanto na qualidade dos produtos fabricados, como na confiabilidade de prazos de entrega, flexibilidade de composto e a redução de custos de produção.

4. Volkswagen em Resende-RJ: Inaugurada em novembro de 1996, o consórcio modular implantado em Resende, caso único permite a redução de custos de produção e de investimentos, diminuição de estoques e tempo de produção dos veículos, aumento da eficiência e da produtividade, além de tornar mais flexível a montagem dos produtos e garantir maior qualidade ao produto final. Cabe à Volkswagen o controle de qualidade e o desenvolvimento do produto, tendo sempre como objetivo a satisfação do consumidor. Esse arranjo, único nas fábricas, é um caso radical de terceirização (outsourcing - troca de competências entre montadora e parceiros instalados dentro da linha de montagem final). A única fábrica de caminhões do grupo e no Brasil o caso único.

5. General Motors em Gravataí-RS: O condomínio industrial conta com a parceria de dezessete fornecedores sistemistas, instalados dentro do complexo industrial. É um processo integrado entre montadora e sistemistas. Esse condomínio industrial permite fazer um carro com a participação dos fornecedores desde a fase inicial do desenvolvimento do produto até a fase final de montagem. É a fábrica mais produtiva da GM no mundo.

6. Ford em Camaçari-BA: Esse arranjo contempla diversas empresas parceiras, em um sistema misto de condomínio industrial e consórcio modular. É adotado o modelo de produção denominado montagem modular seqüenciada, com operações just-in-time. Na fábrica de Camaçari os fornecedores acompanharam a Ford no projeto e reduziram o tempo de produção de um carro de uma semana para um dia. Com a redução de todo o ciclo produtivo para apenas um dia a capacidade total de produção da fábrica saltou para duzentos e cinqüenta mil carros por ano, o que permite que a cada oitenta segundos um veículo entre no pátio da montadora para ser transportado para o pontode-venda.

\section{ANÁLISE COMPARATIVA ENTRE OS ARRANJOS ESTUDADOS}

Para essa análise consideramos cinco dimensões: as políticas de recursos humanos, os processos logísticos, a gestão de relacionamento com fornecedores, o planejamento do produto e a gestão da produção. 


\subsection{POLÍTICAS DE RECURSOS HUMANOS}

As políticas de $\mathrm{RH}$ no condomínio industrial da Volkswagen em São Bernardo do Campo, em São José dos Pinhais e em Taubaté são as políticas comuns de uma montadora, enfatizando o treinamento e o benchmarking com a matriz. Investe em horas de treinamento por funcionário e a política de cargos e salários segue uma diretriz de mercado, não se diferenciando em desempenho.

No entanto, no consórcio modular da Volkswagen em Resende, por ser um caso único, existem políticas diferenciadas para cargos e salários, na maioria das vezes conseguindo reter o funcionário. Internamente os modulistas usam a mesma estrutura de $\mathrm{RH}$ da Volkswagen.

No condomínio industrial da General Motors em Gravataí as políticas de $\mathrm{RH}$ seguem uma premiação por reconhecimento e desempenho, e esta política está adequada com os atuais padrões do mercado. A empresa pratica habilidades para desenvolvimento do conhecimento através de constantes treinamentos, intercâmbio de idéias, ferramentas e conceitos, intercâmbio de profissionais entre outros.

No arranjo misto da Ford em Camaçari a política de $\mathrm{RH}$ segue o padrão da cidade onde está localizada, mão de obra mais acentuada do lado feminino, pois o custo é menor, no restante segue o padrão normal de cargos e salários.

\subsection{PROCESSOS LOGÍSTICOS}

A logística no condomínio industrial da Volkswagen em São Bernardo do Campo é diversificada, parte dos fornecedores fornecem pelo sistema JIT, outra parte integra um parque interno de fornecedores, há também um Centro de Consolidação de Cargas, onde o operador logístico interno recebe as peças e as entrega na linha, na ordem de montagem dos veículos (seqüenciamento), fazendo o processo de picking. Pequenos módulos podem ser trazidos de fábricas de autopeças da região pelo sistema JIT, recebidos e entregues na linha de montagem.
Na Volkswagen em São José dos Pinhais a logística de entrada neste condomínio industrial é de responsabilidade do operador logístico interno, exercendo as funções de coleta, transporte, acondicionamento, separação e disponibilidade interna para os parceiros. Além da gestão do transporte interno, o escoamento de produtos, envolvendo o operador logístico externo.

No condomínio industrial da Volkswagen em Taubaté, em função da prática do JIT, a unidade não tem estoque. Porém, há estoque de peças com fornecedores que trabalham em conceitos convencionais, ou seja, as entregas não são JIT. Há um crescente número de empresas instalando-se na cidade de Taubaté e próximo da montadora, dessa forma viabiliza-se o JIT. Há entregas freqüentes dos fornecedores para a montadora, contribuindo para uma logística eficiente.

No consórcio modular da Volkswagen Caminhões a montadora detém o controle sobre a compra e entrega aos modulistas, pois há uma considerável redução de custos de compra se comparados às empresas participantes negociarem isoladamente. Internamente de acordo com o programa de produção enviado aos parceiros, o material interno é disponibilizado e acondicionado da maneira mais eficaz e eficiente no módulo de cada modulista para agregar à montagem do produto na linha de produção. Os operadores logísticos interno e externo são os responsáveis para garantir a janela de tempo acordada no programa de produção, dessa forma atingindo nível elevado com compartilhamento de know how e de produtividade exigido pela montadora. Há sistemas de informação que controlam a logística da montadora e interligam todas as fornecedoras. Por meio deles, a área de planejamento e controle da produção realiza entre outros, o balanceamento do mix diário de produção, o gerenciamento da demanda e das chamadas JITS para as fornecedoras, e o seqüenciamento de produtos.

A logística interna na General Motors em Gravataí se caracteriza pelos suprimentos JIT e JIT seqüenciado conforme a ordem de produção na linha de montagem final. A montadora trabalha com operadores logísticos internos e externos garantindo os suprimentos dos módulos internos e à distribuição do produto acabado, 
os parceiros estão interligados através de ferramentas de Tecnologia de Informação com a montadora. O operador logístico faz coleta pelo sistema milk run, se necessário consolida a carga em pontos estratégicos nas regiões de maiores índices de fornecimento.

A logística na fábrica da Ford em Camaçari percorre o seguinte processo: utiliza-se um JIT de 3000 Km, saindo de São Bernardo do Campo num Centro de Consolidação de Cargas, recebendo os conjuntos dos principais fornecedores e enviando para Camaçari, coordenados pelo operador logístico da Ford. São aproximadamente cento e quarenta carretas ininterruptas por dia, numa operação complexa, segura e viável em relação a manter estoques internos.

\subsection{GESTÃO DE RELACIONAMENTO COM FORNECEDORES}

$\mathrm{Na}$ Volkswagen de São Bernardo do Campo, o condomínio industrial conta com treze fornecedores que estão instalados fisicamente dentro da montadora para abastecer o sistema produtivo. Dessa forma o relacionamento e resolução de problemas entre montadora e parceiros são mais rápido, transparente e preciso.

No condomínio industrial da Volkswagen em São José dos Pinhais, devido à proximidade entre os participantes,são quatorze parceiros, há vantagens para os parceiros que produzem os veículos. A montadora também compra grande parte dos suprimentos que são entregues em consignação aos fornecedores JITS. Os fornecedores instalados no condomínio industrial fabricam os produtos conforme a programação da produção elaborada pela montadora. Essa produção é coletada (em intervalos de aproximadamente duas horas e trinta minutos) pela operadora de logística interna, disponibilizando-a em locais ao lado da linha de montagem final.

O relacionamento com os quatorze fornecedores, no condomínio industrial da Volkswagen em Taubaté é integrado e transparente, pois uma percentagem dos parceiros está alocada internamente e outra externamente mas muito próxima, o que permite um sincronismo entre as partes para atingir as metas fixadas pela montadora.

No consórcio modular da Volkswagen em Resende, no relacionamento entre as partes há uma integração total, transparente, sincronizada, existe a prática de outsourcing num nível elevado, troca de knowhow dos módulos entre montadora e parceiros (sete parceiros), co-produção de componentes. As plantas são dedicadas à montadora e os contratos entre os participantes são de longo prazo (seis anos). Os fornecedores são escolhidos pela montadora através dos critérios envolvendo as prioridades competitivas: custo, qualidade, flexibilidade, rapidez, confiabilidade de produto e entrega, velocidade e produção limpa. Base de fornecedores é muito pequena.

$\mathrm{Na}$ General Motors em Gravataí os sistemistas (dezessete) têm contrato com a montadora até o tempo de vida útil do carro. O relacionamento no condomínio industrial é transparente, integrado com a montadora. Há em alguns módulos a participação no desenvolvimento em conjunto do módulo com o sistemista, tornando a produção do módulo mais flexível e aberto a inovações tecnológicas por parte de ambos. A decisão em optar por uma arquitetura de produto modular faz com que essa unidade tenha uma base de fornecedores muito pequena, com exceção de motores (core business), todos os demais módulos são montados por fornecedores sistemistas.

Sendo a Ford em Camaçari a montadora com maior número de parceiros de todos os arranjos existentes (trinta e um), os fornecedores de módulos de componentes estão instalados no próprio complexo industrial da fábrica, proporcionando um relacionamento, velocidade nas informações e transparência nos processos.

\subsection{PLANEJAMENTO DO PRODUTO}

$\mathrm{Na}$ Volkswagen em São Bernardo do Campo a estratégia é seguir a matriz, com algumas modificações no produto, pois a empresa sede está num país diferente. A matriz projeta os principais módulos do veículo e elabora o plano estratégico 
para a montadora. Ainda é embrionária a estratégia de desenvolvimento em conjunto com os parceiros, mas existe.

Na Volkswagen em São José dos Pinhais os produtos são definidos pela matriz e adaptados ao país de lançamento. Neste condomínio industrial são usados:

1. Sistemas de gestão da qualidade (certificações);

2. Determinação de índices de performance e ranking mundial de fidelidade de resultados;

3. Auditoria de sistemas, adotado nas empresas alemãs, redução de custos e confiabilidade de prazos de entrega;

4. Desenvolvimento de novos projetos.

A participação de fornecedores de módulos é determinada basicamente pela necessidade da montadora, e também pelo domínio tecnológico das empresas parceiras relativo aos seus produtos e processos. Percebe-se que os fornecedores e os módulos adotam os mesmos programas da montadora.

No condomínio industrial de Taubaté os gestores da unidade vêm incentivando as empresas a se aproximarem do condomínio, em breve os esforços em conjunto iniciar-se-ão entre montadora e sistemistas para compartilhamento do projeto de produto. No momento ainda é algo que está em estudo e amadurecimento por ambas as partes.

No consórcio modular da Volkswagen em Resende os produtos são definidos em conjunto com as matrizes e adaptado ao país no qual vai ser produzido. A montadora escolhe o produto e em alguns poucos módulos ela compartilha o desenvolvimento de algumas fases do produto, visando ganhos ao envolver os parceiros no detalhamento do produto, alterações em conjunto para melhorias de custo, qualidade, flexibilidade, rapidez, confiabilidade de produto e entrega. Essa prática vem se disseminando cada vez mais, às vezes está restrita a um módulo ou vários, de acordo com o grau estratégico do módulo para a montadora.
Na General Motors em Gravataí a orientação mestra vem da matriz, mas adaptada ao país de origem. A configuração da unidade proporciona um diferencial competitivo ao promover novos processos e produtos, a unidade está se tornando independente de projeto de produto da matriz, e também quanto aos investimentos em produto à unidade independe da matriz. As partes mais complexas do produto geralmente são projetadas na matriz (estamparia, e motor), demais são projetadas no país sede. O sistemista tem que ter como competência a capacidade técnica gerencial e financeira para responder pelo projeto, escolha de fornecedores e compras de peças.

AFordem Camaçarinãoé diferente das outras unidades, a matriz define o projeto de produto em conjunto com a unidade do país, mantendo os módulos de core business, deixando para o local onde a montadora está instalada a definição dos outros módulos, bem como os parceiros. É de responsabilidade da montadora se utiliza a parceria como fonte de know how em conjunto.

\subsection{GESTÃO DA PRODUÇÃO}

Como já visto anteriormente, o sistema de produção utilizado no condomínio industrial da Volkswagen em São Bernardo do Campo é o JIT, os parceiros fornecem de forma seqüenciada e em tempo real para a montadora. Os módulos seguem a seqüência do programa de produção. Utiliza-se de muitas ferramentas no sistema produtivo como o poka yoke e o Kanban. O layout é híbrido (processo e celular), com índice de automação elevado, proporcionando lead times curtos se comparados com uma fábrica tradicional, dessa forma a fábrica consegue altos índices de produtividade.

Os fornecedores instalados no condomínio industrial da Volkswagen em São José dos Pinhais fabricam os produtos conforme a programação da produção elaborada pela montadora. Essa produção é coletada (em intervalos de aproximadamente duas horas e trinta minutos) pela operadora de logística interna, disponibilizando-a em locais ao lado da linha de montagem final. No condomínio industrial a 
programação da produção e as chamadas JITS são enviadas aos fornecedores via EDI. Os fornecedores devem informar imediatamente após análise da programação a montadora sobre as restrições que podem causar perda de produção.

No Centro de Comunicação ocorre a integração das áreas, facilitando o fluxo de informações e o acesso rápido às diversas áreas. A linha de montagem final é única, composta por quatro etapas distintas, em forma de Y. A fim de aumentar a área de entrega dos suprimentos dos fornecedores JITS (JIT Seqüenciado):

- a primeira etapa da linha de montagem é formada por skids, sistemas paralelos de suportes acomodados sobre esteiras, nos quais o veículo e o montador deslocam-se juntos;

- a segunda etapa é composta por "elefantes" (máquinas que fazem o transporte aéreo da carroceria), que são auto-ajustáveis em altura, possibilitando uma melhor ergonomia para os funcionários montadores;

- a terceira etapa também é composta pelo sistema de skids;

- a quarta etapa é formada pelo sistema de esteiras, nas quais é feito o acabamento dos veículos em fase final de montagem.

Essa estrutura física e organizacional e a forma de trabalho que a Volkswagen implantou possibilitam que sejam produzidos veículos a partir de um estoque baixo de suprimentos, com atendimento à qualidade conforme especificações, possibilitando custos menores, com alta produtividade e flexibilidade no chão de fábrica. Essa estrutura está baseada em um eficiente sistema logístico bem como um sistema de tecnologia de informação (TI) que abrange parte da cadeia de suprimentos. Esses sistemas garantem a entrega de cada fornecedor na seqüência programada da produção.

A distância média de aproximadamente oitocentos metros de percurso entre a planta da montadora e os parceiros instalados no parque interno traz algumas vantagens para os participantes, comprovadas no estudo de campo, tais como:

- rapidez na solução de problemas com suprimentos (substituição ou reparo) e diminuição do custo logístico (de embalagens e dispositivos especiais);

- a distância entre plantas possibilita redução de custos de transporte nacional, a eliminação da falta de suprimentos devido a acidente de trânsito com caminhão, ou devido à queda de barreira ou de ponte, a diminuição dos estoques, conseqüentemente dos custos de inventário (financeiros), e de manuseio;

- maior flexibilidade;

- diminuição dos custos administrativos (gerenciamento);

- facilidade de resolver problemas em conjunto pessoalmente;

O início do processo produtivo dos fornecedores se dá no momento que eles recebem as chamadas JITS. Nesse momento, elas ficam conhecendo todas as características do produto para o qual elas vão fornecer parte dele. A chamada JITS somente é enviada quando não há nenhuma restrição relativa ao veículo a ser produzido, ou seja, se todos os suprimentos necessários para a sua produção estarão nos pontos de uso onde serão agregados a ele. A maioria dos fornecedores recebe as chamadas JITS no momento da saída da carroceria da pintura e o seu envio para a linha de montagem final. A partir desse momento, tem-se, em média, duas horas e trinta minutos para que os suprimentos a serem fornecidos por elas estejam no ponto de uso, na linha de montagem final. Esse transporte é realizado pela operadora logística interna, sendo a única exceção a Johnson Controls, que é ela própria que faz e entrega os bancos no ponto de uso na linha de montagem final da Volkswagen.

No condomínio industrial da Volkswagen em Taubaté o emprego do JIT, facilita o fluxo de produção. Nesta unidade as entregas são feitas diretamente na linha de produção do cliente a cada uma hora e quarenta minutos com este processo o fornecedor eliminou 
uma área de estocagem de $244 \mathrm{~m} 2$ e reduziu em 50\% os estoques, melhorando o controle de qualidade, fazendo economia de embalagens e tornando mais estável a programação da produção. A fábrica de Taubaté é considerada uma das mais modernas do País, com cento e setenta robôs em operação e índices de automação. A produtividade é alta, um diferencial deste condomínio industrial.

No consórcio modular da Volkswagen em Resende utiliza-se o JIT e MTO, fazer conforme pedido fechado. Há uma co-dependência entre montadora e modulistas, pois os mesmos respondem por todo o processo produtivo. A personalização do produto é um diferencial do modelo, a montadora criou uma área específica para gerenciar esses clientes: (SVESolicitação de veículos Especiais). Entregam e fazem a montagem final na linha, a montadora se responsabiliza pela qualidade do produto final.

No consórcio modular a programação é enviada aos módulos e a sua matriz via e-mail. Também, os módulos, as suas matrizes e os fornecedores externos devem informar a montadora às restrições que podem causar perda de produção.

A montagem de chassis utiliza esteiras mecânicas, pontes rolantes e talhas, que poupam esforço ao montador e aumentam a produtividade. A linha de montagem é a primeira climatizada no Brasil. A planta de Resende incorpora uma tendência cada vez mais presente nas montadoras de todo o mundo, a saber, a maior participação e o envolvimento dos fornecedores, cada vez mais provendo conjuntos e subconjuntos montados previamente.

Adicionalmente, há inúmeras outras mudanças nas relações entre montadoras e autopeças como a engenharia simultânea, colocando lado a lado engenheiros da montadora e de seus fornecedores mais centrais para desenvolver produtos de melhor qualidade em menores prazos e custos, o envolvimento de longo prazo, o maior compartilhamento de informações e a política de custos abertos. A tendência à integração dos sistemas e modularização por parte dos fornecedores é parte da criação de um sistema enxuto de fornecimento com a redução do número de fornecedores diretos na primeira camada e mudança no papel e responsabilidade dos fornecedores (HOLWEG, 2008). O fornecimento de subconjuntos facilita a montagem final, porque requer menor esforço de montagem, diminuindo assim os custos de montagem e reduz os problemas de qualidade porque a maior parte dos subsistemas pode ser previamente testado. Além disso, há benefícios em logística, com menor número de movimentações e menor espaço alocado (as peças isoladamente ocupam mais espaço do que os subconjuntos já montados). Os fornecedores podem se tornar capazes de integrar diversas peças e componentes, esforço antes de responsabilidade da montadora, agregando assim maior valor aos seus produtos. Assim, são necessárias novas formas de aprendizado para viabilizar a transição de uma grande ênfase nas competências funcionais para as competências de integração de sistemas. O consórcio modular é um passo adiante nessas tendências mundiais na indústria de relacionamento entre montadora e seus fornecedores.

O desenvolvimento de novos produtos é realizado pela Volkswagen Caminhões, e é uma das suas principais responsabilidades. Esse desenvolvimento utiliza a abordagem da engenharia simultânea, envolvendo uma equipe de engenheiros de produto e de processo, embora ocorra a participação dos módulos no desenvolvimento de novos produtos, a sua maior participação é no processo produtivo. A montagem dos módulos tem contribuído bastante para melhoria dos produtos da Volkswagen Caminhões, que atualmente emprega a metodologia Quality Function Deployment (QFD - Desdobramento da Função Qualidade), para desenvolver ou alterar especificações de projeto de um produto, considerando as necessidades dos seus clientes.

$\mathrm{Na}$ planta de Resende existem módulos que estão dentro da montadora. Existem, também, as suas matrizes, e os fornecedores da montadora e das matrizes dos módulos, que estão localizadas a centenas de quilômetros. Em conseqüência disso, há situações que são tratadas entre a montadora e seus fornecedores externos, a montadora e os módulos, a montadora e as matrizes dos módulos, os módulos e suas matrizes e os módulos e os fornecedores da 
montadora. Todavia, a prática de JITS é realizada, preferencialmente, com fornecedores externos próximos à planta da Volkswagen, a fim de que não ocorram prejuízos à qualidade dos suprimentos fornecidos devido a problemas de transporte.

A General Motors em Gravataí usa de sistemas de puxar (JIT/Kanban). Grande flexibilidade, pois produz conforme pedido. Os módulos fluem com mais rapidez, pois o fluxo de componentes é menor se comparado a uma fabrica sem esses arranjos. Não há personalização de produtos nesta fábrica. A produção modular no condomínio industrial, traz vantagens: otimização das despesas de engenharia, redução de tempo para projeto do produto, redução de custos estruturais, flexibilidade, compartilhamento de custos de serviço. No condomínio industrial os sistemistas fornecem $80 \%$ do valor agregado do carro entregues na forma de módulo. A linha de montagem final tem formato de um $T$ para reduzir os tempos de movimentação de veículos, módulos e componentes e viabilizar a montagem do veículo sem ter estoques junto à linha de montagem, dessa forma diminuí o lead time e agiliza o processo.

Existem ainda outras prestadoras que estão no complexo automotivo. O condomínio industrial de Gravataí possuí sistemistas fazendo entregas para a montadora a cada meia hora ou até a cada quinze minutos, é um JIT muito sincronizado. Uma diferença deste condomínio industrial está nos fornecedores que estão no site e participam da elaboração do projeto e do desenho de cada sistema, dessa forma há um compartilhamento de conhecimento.

A General Motors idealizou uma meta neste condomínio, a redução do custo de produção (por ser um dado estratégico, o mesmo não foi divulgado na pesquisa de campo), devido à flexibilidade do modelo. Na planta de Gravataí existem muitos ganhos se comparados com uma fabricação tradicional. A fábrica tradicional perde muito em flexibilidade se comparada ao condomínio industrial, pois no condomínio industrial, a planta é integrada, dando maior visibilidade à cadeia de suprimentos. Quanto a estoques na linha de produção, as fabricas tradicionais possuem um fluxo de material mais significativo em quantidade, no que tange às peças ao longo das linhas.

Em Gravataí, não existe esse problema, pois o JIT seqüenciado elimina o estoque na linha de montagem final; a vantagem de produzir em módulos os veículos proporciona um aumento na flexibilidade da planta, mesmo sendo veículos de variabilidade considerável.

$\mathrm{Na}$ Ford em Camaçari a produção utiliza-se do JIT, facilitado pela disposição do layout. No processo produtivo, os fornecedores de módulos de componentes, entregam sistemas tão completos quanto possível, o que praticamente elimina os estoques. Nessa fábrica todo o ciclo produtivo dura apenas um dia. A capacidade total é de duzentos e cinqüenta mil carros por ano, o que permite que a cada oitenta segundos um veículo entre no pátio da montadora para ser transportado para o ponto-de-venda. O trabalho é muito sincronizado após a análise comparativa, com o intuito de verificar e apontar as diferenças mais significativas entre os arranjos pesquisados no campo, abaixo, os pontos considerados diferenciados:

- Constatou-se que os sete módulos do consórcio modular são mais pró-ativos do que as empresas que formam os condomínios industriais estudados no sentido de encontrar solução antes dos problemas ocorrerem, pois as atividades que cada módulo realiza possibilitam que os problemas sejam previstos, antes de ocorrerem de fato;

- Todavia, nos dois arranjos o relacionamento comercial entre a montadora e suas fornecedoras e os módulos não são transparente, cooperativo e de confiança mútua. É diretivo, radical e autoritário por parte da montadora;

- O desenvolvimento de produtos ocorre da "mesma forma" no condomínio industrial e no consórcio modular, ou seja, há participação das fornecedoras (em alguns casos e outros não) e dos módulos segundo interesse da montadora e domínio tecnológico deles. No entanto, no consórcio modular os sete modulistas estão sob o mesmo teto da montadora e diariamente seus representantes entram em contato, portanto, pode-se afirmar que há maior participação dos módulos do que das 
fornecedoras na melhoria e no desenvolvimento dos auto-veículos produzidos;

- Tanto no arranjo organizacional condomínio industrial, como no consórcio modular, constatouse que a organização do processo produtivo e a disposição espacial das fornecedoras, próximas em relação à planta da montadora, influenciam no relacionamento entre essas empresas. Como nos dois casos o gerenciamento do processo produtivo é realizado pela montadora, bem como a aquisição da maior parte dos suprimentos, suas políticas, programas e práticas são predominantes e influenciam diretamente o comportamento de fornecedores (ou modulistas) que integram os arranjos. Portanto, o gerenciamento da montadora conduz os fornecedores (ou modulistas) à busca progressiva de melhor desempenho no tocante à qualidade do produto, à flexibilidade do composto, e à confiabilidade de prazo de entrega e à redução de custos;

- A importância do JIT, nos arranjos dá-se pelos parceiros estarem muito próximos, mas as matrizes do negócio estão localizadas geralmente no sudeste do país, onde se concentra a maior população de fornecedores tanto de primeira camada como de segunda das montadoras estudadas nesse artigo.

\section{CONCLUSÕES}

Com a implantação na indústria automobilística do conceito de condomínio industrial econsórciomodular foi possível reduzir, de forma expressiva, seus custos operacionais, principalmente os custos relacionados com a compra de insumos, a movimentação e os estoques de materiais e componentes, o transporte do fornecedor até a planta e agregar valor ao produto final. Somam-se a estas vantagens uma série de outras vantagens como o compartilhamento dos custos fixos com fornecedores, a difusão de inovações tecnológicas e organizacionais e o aumento da competitividade num mercado caracterizado por grandes empresas com altos níveis de investimentos em tecnologia e pessoal.
Como o processo produtivo, no condomínio industrial e no consórcio modular, se caracterizam pela codependência entre a montadora e os parceiros, isto permite que as montadoras operem com a demanda puxada, não necessitando de estoques, reduzindo conseqüentemente seus custos com manutenção, obsolescência e estrutura física para acondicionar os materiais. Possibilita, ainda, a coleta de materiais dos fornecedores por um só veículo, através do modelo Milk Run, o que reduz os custos com transporte e o tempo de ressuprimento, proporcionando maior confiabilidade ao processo e também reduz consideravelmente o custo com compras.

Além disto, os processos devem ser precisos no atendimento à programação da produção e às especificações da área de Engenharia e Qualidade da montadora. Os produtos devem ser entregues pelos fornecedores e módulos à montadora no tempo solicitado, conforme as especificações desta, na quantidade e qualidade em relação às quais foram homologados, e no preço contratado, dessa forma a utilização do JIT é primordial para conseguir atender os quesitos acima.

A organização do processo produtivo e a disposição dos parceiros e dos módulos próximas e/ou dentro em relação à planta da montadora influenciam no relacionamento entre essas empresas nos dois arranjos. Esta influência é maior no consórcio modular, pois os módulos realizam diariamente as operações produtivas e participam da tomada de decisão acerca delas. Muito diferente do arranjo tradicional, pois a proximidade dos parceiros é mais distante. No condomínio industrial e no consórcio modular a proximidade física entre montadora, parceiros e módulos diminui o tempo e os custos para solucionar problemas operacionais diários. Há também a possibilidade de se promover encontros com os representantes das empresas envolvidas em minutos em qualquer local dos arranjos, condomínio industrial e consórcio modular, para tratar de assuntos comuns, sendo que no consórcio modular o tempo e os custos de deslocamento são menores. Importante destacar no caso do condomínio industrial a presença do residente na planta da montadora, considerado uma extensão da empresa fornecedora, 
se comparados ao arranjo tradicional, isto não ocorre.

\section{REFERÊNCIAS}

[1] ALVES, J. M. O sistema just in time reduz os custos do sistema produtivo. In: Congresso Internacional de Custos, 1, UNICAMP. s/d. Campinas. Disponível em: $<$ http://libdigi.unicamp.br/document/?view=32>. Acesso em: 08 set. 2007.

[2] AUTOMOTIVE BUSINESS. Nova Anchieta: uma revolução dentro da fábrica pioneira da Volkswagen. Disponível em: $<$ http://www.automotivebusiness.com.br/vw.htm>. Acesso em: 01 fev. 2005.

[3] CHUNG, M. Is it new paradigm? modular production system in Hyundai. In: GERPISA Thirteen Annual Colloquium, Anais 2005, Paris.

[4] GENERAL MOTORS DO BRASIL. Sobre a General Motors: A Companhia. Disponível em: <http://www.chevrolet. com.br/>. Acesso em: 11 mai. 2007.

[5] HECKERT, C. R.; FRANCISCHINI, P. G. Variações do Just-in-time na indústria automobilística brasileira. In: Encontro Nacional de Engenharia de Produção, 18, Rio de Janeiro, 1998. Disponível em: <http://www.iautomotivo.com/ variacoesjit.PDF>. Acesso em: 08 set. 2007.

[6] HOLWEG, M. The Genealogy of lean production. Journal of Operations Management, v. 25, p. 420-37, 2008.

[7] HOWARD, M. Modularization and the impact on supply relationships. Operations \& Production Management, v. 27, n. 11, p. 1192-1212, 2007

[8] KOTABE, M.; MURRAY, J. Y. Antecedents and outcomes of modular production in the brazilian automobile industry: a grounded theory approach. Journal of International Business Studies, 2007.

[9] MIKKOLA, J. H. Product development \& management association capturing the degree of modularity embedded in product architectures. J Prod Innov Manag, v. 23, p. 128-146, 2006.

[10] NÓBREGA JR, J. I. C. Metodologia para análise estratégica de projetos de cadeias de abastecimento industriais. 2000. 102f. Dissertação (Mestrado em Administração) - Universidade Federal de Santa Catarina, Florianópolis, 2000.
[11] PIRES, S. R. I. Gestão da cadeia de suprimentos (supply chain management): conceitos, estratégias e casos. São Paulo: Atlas, 2004

[12] PIRES, S. R. I. SACOMANO NETO, M. New configurations in supply chains: the case of a condominium in Brazil's automotive industry journal. Supply Chain Management: An International Journal Year, v. 13, Issue 4, p. 328-334, 2008.

[13] PIRES, S. R. I.; SACOMANO NETO, M. Organização da produção, desempenho e inovações na cadeia de suprimentos da indústria automobilística brasileira. Revista de Ciências da Administração • v. 9, n. 19, p. 34-53, set./dez. 2007 -

[14] REICHHART, A.; HOLWEG, M. Co-located supplier clusters: forms, functions and theoretical perspectives. International Journal of Operations \& Production Management, v. 28, n. 1, p. 53-78, 2008.

[15] SALERNO Z., DIAS, A. V. C. Product design modularity, modular production, modular organization. International Colloquium "The World that Changed the Machine", Paris: Gerpisa, 2000.

[16] SALERNO, Z; DIAS, A. V. C. Mudanças e persistências no padrão de relações entre montadoras e autopeças no Brasil: proximidade, global e follow sourcing, parcerias e co- design revisitados. Relatório de Pesquisa. DEP, EPUSP, 1998

[17] STEVENSON, M. Supply chain flexibility: an interfirm empirical study. International Journal of Operations \& Production Management, v. 29, n. 9, p. 946-971, 2009.

[18] VOLKSWAGEN DO BRASIL. Fábricas. São José dos Pinhais/PR. Disponível em:

$<$ http://www.vw.com.br/NovoSite/>. Acesso em: 11 maio 2009 .

[19] WOMACK, J. P.; JONES, D. T. Lean Consumption. Harvard Business Review, Mar 2005.

[20] WORREN, N.; MOORE, K.; CARDONA, P. Modularity, strategic flexibility and firm performance: a study of the home appliance industry. Strategic Management Journal, v. 23, n. 12, p. 1123-1140, 2002.

[21] YIN, R. K. Estudo de Caso:Planejamento e Métodos. 2. ed. Porto Alegre: Bookman, 2001. 


\section{CAPÍTULO 3}

\section{PRODUÇÃ̃O MAIS LIMPA: ESTUDO DE CASO EM UMA INDÚSTRIA ALIMENTÍCIA}

Jordana Dorca dos Santos

Thaís Helena Leite Nogueira

Vanio Faquin

Luani Back

Resumo: Dentro do contexto industrial a geração de resíduos sólidos é crescente, uma vez que parte das matérias-primas utilizadas nos processos produtivos não é incorporada aos produtos fabricados, tornando-se resíduo. Desta forma, o presente trabalho possui o objetivo de analisar o processo produtivo de uma indústria alimentícia de biscoito, visando identificar e comparar oportunidades de produção mais limpa, tendo como foco a geração de resíduos sólidos provenientes do processo produtivo, assim como identificar qual medida seria a mais indicada. Após descriçáo e análise do processo produtivo da indústria de biscoito foram propostas três medidas de Produção Mais Limpa, cada uma em um dos nivels de prioridade estabelecidos pelo Centro Nacional de Tecnologias Limpas: redução na fonte, reciclagem interna e reciclagem externa. A fim de comparar qual das oportunidades propostas é mais vantajosa para o empreendimento, realizou-se uma avaliação que confrontam os aspectos relacionados com a implantação das técnicas, por meio da valoração dos seus impactos. Desta forma o treinamento de pessoal apresentou-se mais vantajoso para o empreendimento. Indica-se que o treinamento dos funcionários seja realizado com o objetivo de evitar desperdícios, por meio da padronização das receitas e tarefas. Conclui-se assim que as perdas na fabricação de biscoitos podem ser reduzidas através da implementação de técnicas de produção mais limpa.

Palavras chave: Produção mais limpa, Resíduos, Biscoito. 


\section{INTRODUÇÃO}

No início do processo de industrialização o meio ambiente possuía somente a função primordial de prover recursos naturais. O resultado desse pensamento, assimilado pela sociedade, gerou e agravou os impactos ambientais referentes ao processo de industrialização e desenvolvimento, principalmente por práticas econômicas descompromissadas a resiliência do meio ambiente (LAYRARGUES, 2000).

De acordo com Molinari et al. (2013), ao longo dos anos a demanda por matérias-primas tem aumentado em ritmo acelerado. A escassez de recursos naturais em um futuro próximo é iminente caso não sejam tomadas providências para reverter essa situação. Dado isso, torna-se importante à busca para um modelo ideal de sustentabilidade que não agrida o meio ambiente e ao mesmo tempo não comprometa o desenvolvimento das organizações.

Uma parte das matérias-primas, ao ser utilizada nos processos produtivos, torna-se resíduo que é descartado em lixões ilegais, incinerado ou dispostos em aterros sanitários, o que afeta diretamente a qualidade do meio ambiente ambiental e urbano. Isso ocorre porque a quantidade de matérias-primas que entram no processo produtivo não é a mesma que sai na forma de produtos ou subprodutos, consequentemente são geradas perdas (MOLINARI et al., 2013).

Segundo Silva e Leal (2004) faz-se imprescindível que sejam adotadas medidas para amenizar os impactos ambientais, desde a geração dos resíduos até a sua destinação final. Individualmente, no que se refere aos resíduos sólidos industriais, por serem de caráter variado, gerados em diversos ramos de produção, estes necessitam de destinação final diferenciada e apropriada para os mesmos.

Sabendo que a geração de resíduos é algo presente na grande maioria das indústrias é preciso que estas adotem práticas que minimizem os impactos gerados por suas atividades. Um método que colabora com esse objetivo é a Produção Mais Limpa, que busca atrelar a minimização de impactos ambientais e a produtividade. Diante deste cenário, o presente trabalho tem por objetivo analisar o processo produtivo de uma indústria alimentícia de biscoito, visando identificar oportunidades de Produção Mais Limpa com foco na geração de resíduos sólidos.

\section{PRODUÇÃO MAIS LIMPA}

De acordo com PNUMA (1990), o termo Produção Mais Limpa $(P+L)$ é aplicação contínua de uma estratégia ambiental, sendo esta aplicada aos processos produtivos, produtos e serviços, com o intuito de melhorar a produção e gerar um benefício econômico. Além desses fatores, a $\mathrm{P}+\mathrm{L}$ prevê a redução dos riscos ao meio ambiente e também a saúde humana.

O Conceito de $\mathrm{P}+\mathrm{L}$ pode ser resumido em uma série de estratégias, práticas ou condutas com o intuito de reduzir ou evitar a emissão de poluentes atmosféricos, efluentes líquidos, geração de resíduos sólidos e outros impactos ao meio ambiente, ou seja, uma série de ajustes ao processo produtivo. Estas ações possuem caráter preventivo, de modo a evitar a geração de poluentes ou ainda com a elaboração de alternativas para reutilização e reciclagem (CNTL, 2003).

Esta nova abordagem de gerenciamento surgiu para modificar os métodos convencionais, com foco principal no final do processo, ou seja, nas tecnologias de tratamento da poluição, com a incorporação de novos equipamentos e instalações nos pontos de descarga dos poluentes, para assim atender as regulamentações da legislação ambiental (BARBIERI, 2004).

Em contra partida, de acordo com o Centro Nacional de Tecnologias Limpas (2003) o enfoque lógico deve privilegiar as soluções voltadas para a prevenção e minimização. Neste contexto as indústrias necessitam atuar na fonte geradora, buscando alternativas para o desenvolvimento de um processo eco-eficiente.

Segundo Barbieri (2004), existe uma sequência de prioridades a ser seguida para a escolha de técnicas de $P+L$ a serem adotadas: prevenção, redução, reuso e reciclagem, tratamento com recuperação de materiais e energias, tratamento e disposição final.

O CNTL (2010) estabelece as prioridades da produção mais limpa: evitar a geração de resíduos e 
emissões (nível 1). Os resíduos que não podem ser evitados devem, preferencialmente, ser reintegrados ao processo de produção da empresa (nível 2). $\mathrm{Na}$ sua impossibilidade, medidas de reciclagem fora da empresa podem ser utilizadas (nível 3), assim como pode-se perceber na Figura 2.

Figura 1 - Fluxograma de priorização de níveis de $\mathrm{P}+\mathrm{L}$

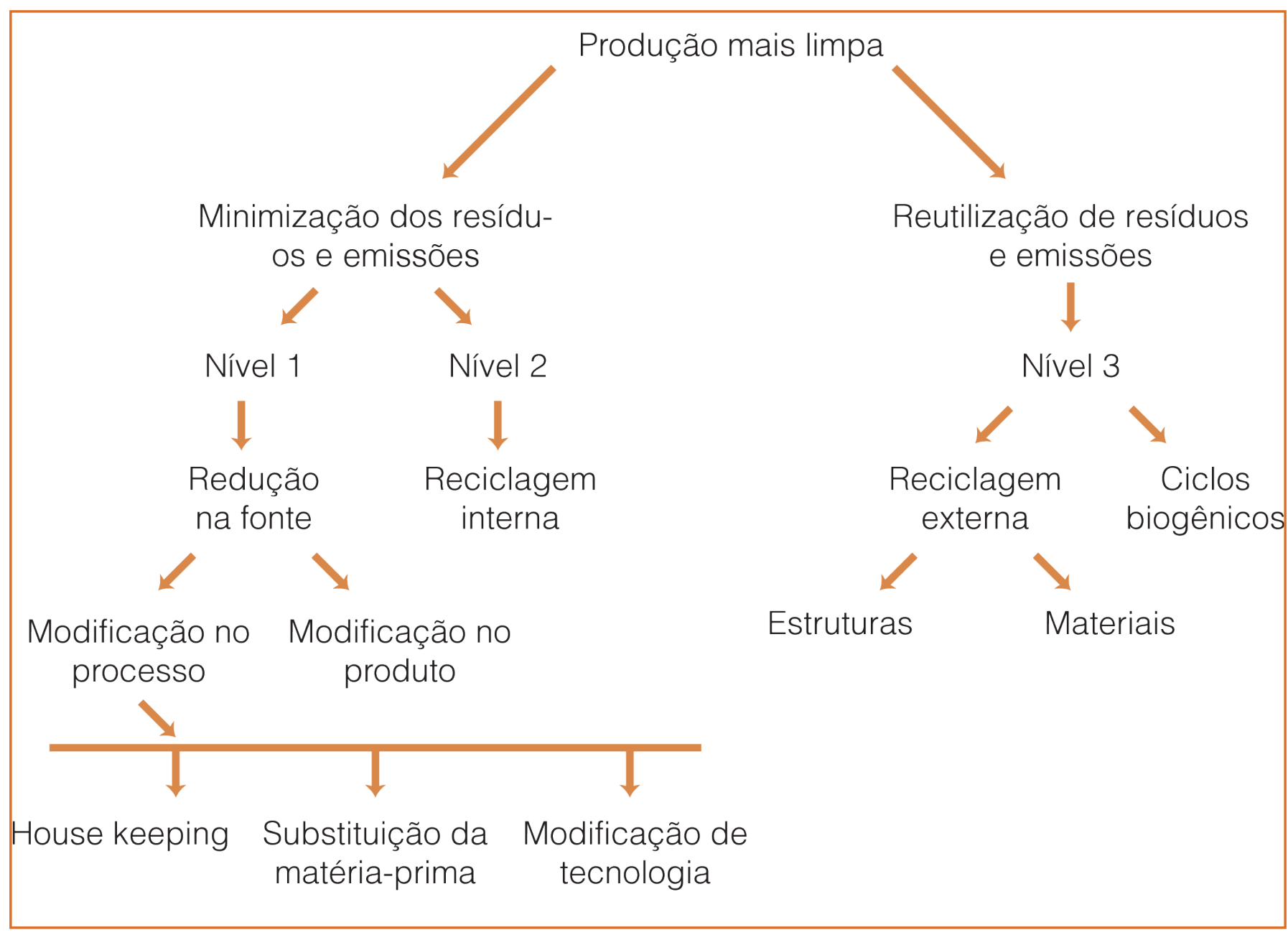

Fonte: CNTL (2010).

Porém, vale ressaltar que atualmente existem ainda certas barreiras quanto à prática de produção mais limpa: a resistência a mudanças, a não existência de políticas nacionais que deem suporte às atividades de $\mathrm{P}+\mathrm{L}$ e as barreiras econômicas que dificultam $\mathrm{O}$ desenvolvimento e adoção de técnicas de $\mathrm{P}+\mathrm{L}$ nos diversos setores industriais (UNIDO/UNEP, 1995).

Existem três tipos de condutas empresariais frente à gestão ambiental: negligente, cautelosa e responsável. Empresas negligentes caracterizam-se por desconsiderar a questão ambiental e legislação pertinente, enquanto as cautelosas têm por objetivo, neste sentido, não descumprir a lei, apresentando uma postura reativa. Os empreendimentos são caracterizados como responsáveis quando apresentam postura proativa, buscando melhoria contínua quanto a questão ambiental, estando desta forma mais abertas a adoção de técnicas de produção mais limpa. A distribuição das empresas de acordo com essas condutas varia em relação ao segmento do setor produtivo e as características econômicofinanceiras da empresa (ABETRE, 2006).

\section{INDÚSTRIA DE BISCOITOS}

O Brasil ocupa a posição de $2^{\circ}$ maior produtor mundial 
de biscoitos, com o registro de 1.206 milhões de toneladas produzidas em 2009, o que representou 2,5\% de crescimento sobre 2008 em que foram produzidas 1.177 milhões de toneladas (SIMABESP, 2010).
Contudo, é importante lembrar que o Paraná, neste setor, representa apenas $4 \%$ da produção brasileira, assim como indica o gráfico 1.

\section{Segmentação Regional de Consumo de Biscoitos}
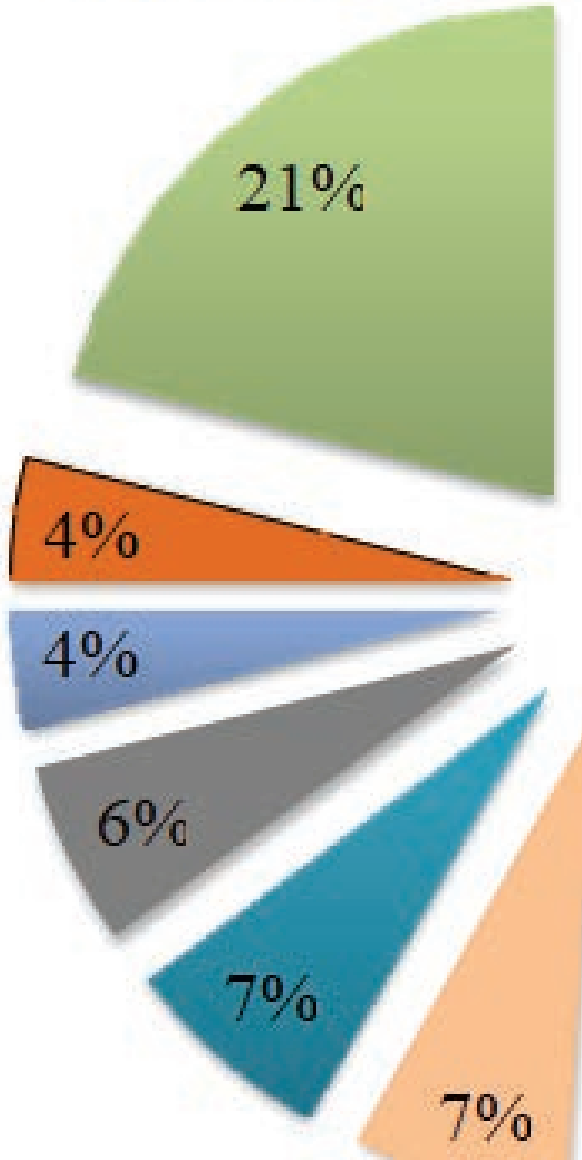
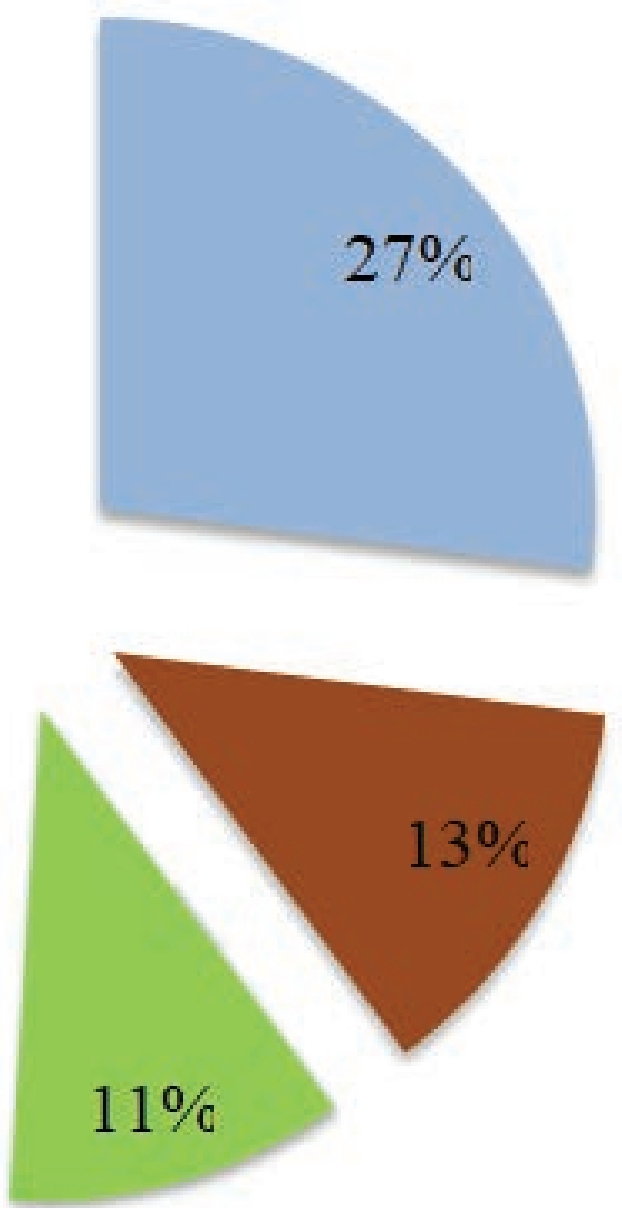

SP

RJ

MG

CE

BA

$\mathrm{SC}$

RS

PR

Demais

Fonte: Sindicato da Indústria de Massas Alimentícias e Biscoitos no Estado de São Paulo (2010)

Para o sucesso deste setor, são consumidas grandes quantidades de insumos de produção, como farinha, açúcar, embalagem, etc. Esta é uma realidade um pouco preocupante, já que o consumo de matériaprima e embalagens vem crescendo de forma acelerada e consequentemente contribui para a geração de resíduos, como plástico, papelão, metais, entre outros.

\subsection{ESTUDO DE CASO: PROCESSO PRODUTIVO}

O estudo de caso foi realizo em uma indústria de biscoitos localizada no estado do Paraná. Partindo da premissa que existem diversos impactos ambientais relacionados à produção alimentícia, para este estudo, serão levantadas as oportunidades de melhorias nos três níveis de prioridades de $\mathrm{P}+\mathrm{L}$ neste setor industrial.

O processo básico de fabricação de biscoitos consiste em selecionar as matérias-primas, misturá-las, moldar os biscoitos, assar, resfriar e embalar. Um fluxograma simplificado do processo produtivo apresenta-se na Figura 2: 
Figura 2 - Fluxograma do processo produtivo

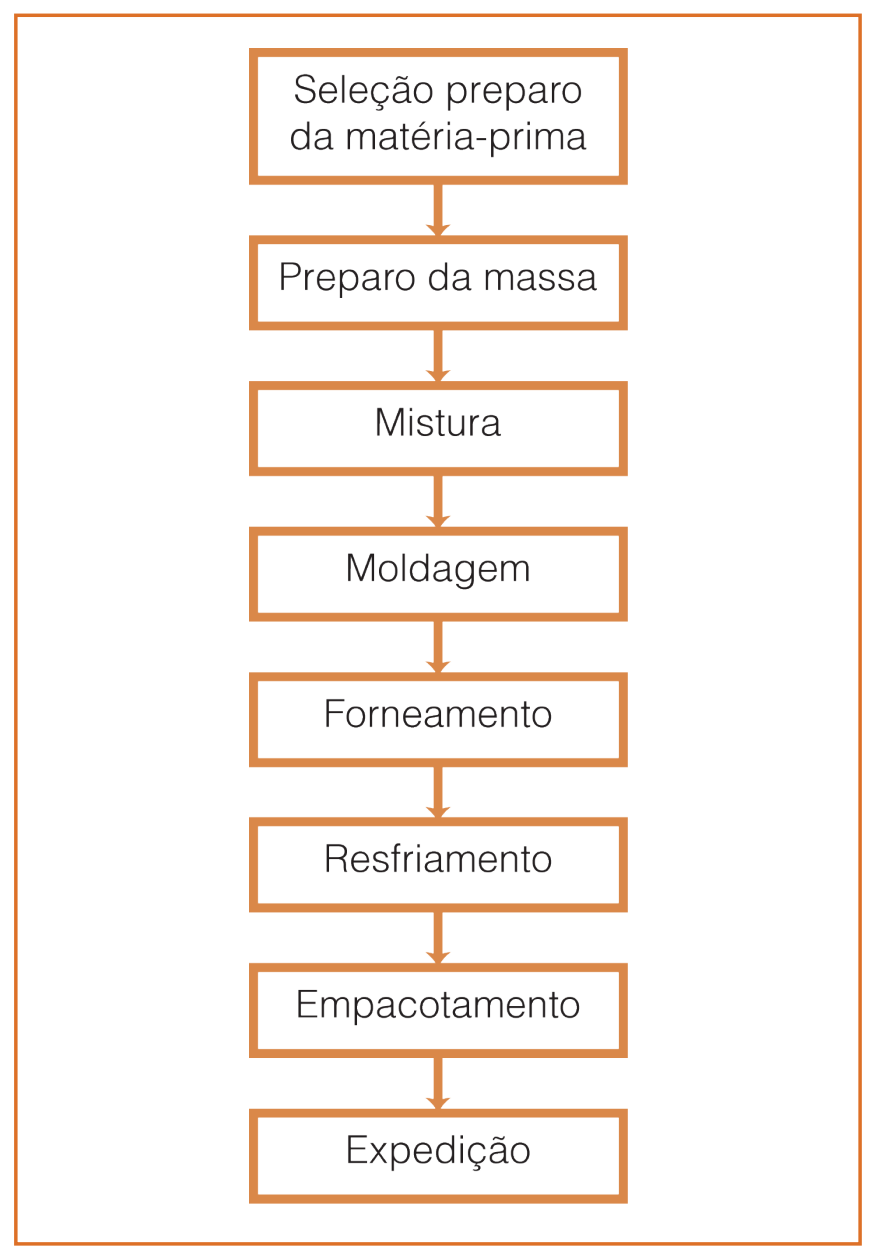

Antes de iniciar a fabricação do produto programado para o dia, as matérias-primas a serem utilizadas são pesadas e separadas de acordo com a formulação. A mistura e amassamento da massa são realizados em recipientes de aço inoxidável, denominados de carrinhos (beth).

Após adicionar todos os ingredientes no carrinho, o mesmo é acoplado na batedeira a qual é responsável por misturar os ingredientes. A massa é então cilindrada e cortada, ou seja, moldada, possibilitando a obtenção da espessura e formato final do biscoito.

Após os biscoitos serem moldados, estes seguem para fornos esteira, aquecidos a gás, dividido em zonas que permitem o controle isolado das temperaturas de acordo com a necessidade do biscoito: umidade, cor, textura e dimensões.

Após o forneamento dos biscoitos, eles são submetidos ao resfriamento em esteiras transportadoras para a troca térmica natural com o ambiente. Os biscoitos são direcionados, por meio de canaletas vibratórias, inicialmente às embaladoras individuais e posteriormente para a embalagem secundária.

\subsection{OPORTUNIDADES DE P+L}

As perdas relacionadas à fabricação de biscoito consistem principalmente em resíduos orgânicos, de produtos defeituosos ou massa perdida nas fases de preparo e modelagem dos biscoitos, como se pode visualizar no Quadro 1. Além destes, resíduos como EPIs descartadas são gerados em menor quantidade.

Segundo a ABNT NBR 10004 de 2004, que classifica os resíduos sólidos quanto aos seus riscos potenciais ao meio ambiente e a saúde pública, todos os descartes listados abaixo são definidos como: Classe II B, resíduo inerte, não perigoso.

Quadro 1 - Geração de resíduos sólidos na fabricação de biscoitos

\begin{tabular}{|c|c|c|}
\hline$n^{\circ}$ & Fonte & Descrição \\
\hline 1 & $\begin{array}{c}\text { Recepção e } \\
\text { preparo da matéria } \\
\text { prima }\end{array}$ & Papel e papelão \\
\hline 2 & $\begin{array}{l}\text { Preparo da massa } \\
\text { e moldagem dos } \\
\text { biscoitos }\end{array}$ & Massa verde contaminada \\
\hline 3 & Forneamento & \\
\hline 4 & Resfriamento & Biscoitos defeituosos \\
\hline 5 & $\begin{array}{c}\text { Empacotamento e } \\
\text { Expedição }\end{array}$ & $\begin{array}{l}\text { Biscoitos danificados e } \\
\text { embalagens descartadas } \\
\text { (papelão e plástico) }\end{array}$ \\
\hline 6 & Funcionários & $\begin{array}{l}\text { EPIs usados (luvas, } \\
\text { máscaras e outros) }\end{array}$ \\
\hline
\end{tabular}

Os resíduos gerados no processo produtivo representam as perdas ocorridas, ou seja, prejuízo econômico na indústria. Além disso, o manejo inadequado dos resíduos provoca diversos impactos ambientais, contaminando desta forma o solo, os recursos hídricos e degradando a qualidade atmosférica.

Com isso, a adoção de medidas de produção mais limpa caracteriza-se por ações proativas, com a 
minimização ou reutilização dos resíduos. Assim sendo, sugere-se três medidas de produção mais limpa relacionadas com a geração de resíduos sólidos no processo produtivo da fabricação de biscoitos, descritas no Quadro 2.

Quadro 2: Oportunidades de produção mais limpa

\begin{tabular}{|c|c|l|}
\hline Oportunidades de P+L & Nível & \multicolumn{1}{c|}{ Descrição } \\
\hline Treinamento de pessoal & 1 & $\begin{array}{l}\text { Capacitação regular } \\
\text { dos funcionários para } \\
\text { terem maior cuidado na } \\
\text { manipulação das massas e } \\
\text { produtos treinamento para } \\
\text { calibração de equipamentos, } \\
\text { a fim de reduzir as perdas no } \\
\text { processo produtivo. }\end{array}$ \\
\hline $\begin{array}{c}\text { Reaproveitamento de } \\
\text { massa }\end{array}$ & 2 & $\begin{array}{l}\text { Recomenda-se que seja } \\
\text { colocada uma proteção para } \\
\text { coletar pedaços de massa } \\
\text { verde que transbordam ou } \\
\text { caem do equipamento. }\end{array}$ \\
\hline $\begin{array}{c}\text { Coprocessamento de } \\
\text { resíduos }\end{array}$ & 3 & $\begin{array}{l}\text { Encaminhamento dos } \\
\text { biscoitos danificados e } \\
\text { defeituosos para fabricação } \\
\text { de ração animal. }\end{array}$ \\
\hline
\end{tabular}

As oportunidades de $\mathrm{P}+\mathrm{L}$ levantadas, e apontadas no quadro 2, não levam em consideração os custos e ganhos econômicos que seriam ocasionados de sua implementação, sendo que estes podem variar de acordo com o porte da indústria.

O treinamento básico de pessoal deve conter orientações principalmente quanto à manipulação dos produtos, visto que, uma das fontes de geração de resíduos é a falta de cuidados na fase de empilhamento, na qual o manuseio incorreto do produto pode acarretar em perdas em grande escala.

Além disso, sugere-se que os funcionários recebam treinamentos relacionados à calibração de equipamentos e manutenção preventiva e corretiva, junto aos colaboradores responsáveis.

Esta atividade contribuirá para a otimização de tempos e lucros da indústria devido à diminuição da quebra de equipamentos, reprocessamento e descarte de produtos. O treinamento e capacitação de colaboradores correspondem a uma redução na fonte, que esta atribuída a uma medida de $\mathrm{P}+\mathrm{L}$ - nível 1. Recomenda-se ainda que no treinamento seja estabelecida uma padronização na execução das tarefas e das receitas (formulação dos biscoitos) de acordo com a capacidade dos equipamentos e máquinas. Esta atitude conduzirá a uma minimização no consumo dos insumos.

Quanto ao reaproveitamento de massa, verificou-se que na cilindragem e corte dos biscoitos pequenas quantidades de massa verde são perdidas e contaminadas, pois caem das plataformas. Desta forma a instalação de dispositivos de proteção permitirá que não ocorra a contaminação da massa podendo retornar ao processo, atenuando o desperdício na produção de biscoitos. A reinserção da massa verde no processo produtivo representa uma reciclagem interna, uma medida de $\mathrm{P}+\mathrm{L}$ de nível 2.

Segundo Corassa et al. (2014), os resíduos da indústria de biscoitos, normalmente, possuem altos valores energéticos, por apresentarem elevados níveis de açúcares e gorduras, e portando indicados para serem incorporados a fabricação de ração animal. Destaforma, os biscoitos danificados devido à falta de cuidados dos colaboradores, ou aqueles que devido aos padrões estéticos (cor e textura) não são comercializados, podem ser enviados ao coprocessamento em fábricas de ração, caracterizando assim uma medida de $\mathrm{P}+\mathrm{L}-$ nível 3, que corresponde a reciclagem externa.

\subsection{AVALIAÇÃO DAS OPORTUNIDADES DE P+L}

A fim de comparar qual das às oportunidades de $\mathrm{P}+\mathrm{L}$ proposta é mais vantajosa para o empreendimento, realizou-se uma avaliação que confrontam os aspectos relacionados com a implantação das técnicas propostas. A comparação consiste na elaboração de uma matriz de valoração dos impactos benéficos gerados pelas três medidas de Produção Mais Limpa. Para tal valoração, os aspectos utilizados foram: frequência da ocorrência de determinado impacto e sua abrangência de acordo com o Quadro 3. 
Quadro 3: Itens considerados na caracterização dos impactos

\begin{tabular}{|c|c|c|c|c|c|}
\hline n & $\begin{array}{l}\text { Frequência } \\
\text { (f) }\end{array}$ & $n$ & $\begin{array}{l}\text { Abrangência } \\
\text { (a) }\end{array}$ & & \\
\hline 1 & $\begin{array}{l}\text { Maior ou } \\
\text { igual a uma } \\
\text { vez ao ano }\end{array}$ & 1 & $\begin{array}{l}\text { Ganho contido } \\
\text { aos limites da } \\
\text { indústria }\end{array}$ & Pontuação & \\
\hline 2 & $\begin{array}{c}\text { Maior ou } \\
\text { igual a uma } \\
\text { vez por } \\
\text { semestre }\end{array}$ & 2 & $\begin{array}{l}\text { Ganho de } \\
\text { importância } \\
\text { municipal }\end{array}$ & \multirow{3}{*}{ Soma } & \multirow{3}{*}{$\begin{array}{l}\text { Soma } \\
\text { simples da } \\
\text { pontuação } \\
\text { de cada } \\
\text { técnica de } \\
P+L\end{array}$} \\
\hline 3 & $\begin{array}{c}\text { Ao menos } \\
\text { uma vez ao } \\
\text { mês }\end{array}$ & 3 & $\begin{array}{l}\text { Ganho de } \\
\text { relevância } \\
\text { regional }\end{array}$ & & \\
\hline 4 & $\begin{array}{l}\text { Frequência } \\
\text { semanal ou } \\
\text { superior }\end{array}$ & 4 & $\begin{array}{l}\text { Ganho de } \\
\text { relevância } \\
\text { global }\end{array}$ & & \\
\hline
\end{tabular}

As técnicas de $\mathrm{P}+\mathrm{L}$ propostas, os impactos associados a sua implantação caracterização dos impactos e a caracterização são apresentados no Quadro 4.

Quadro 4: Valoração dos impactos das técnicas de $\mathrm{P}+\mathrm{L}$

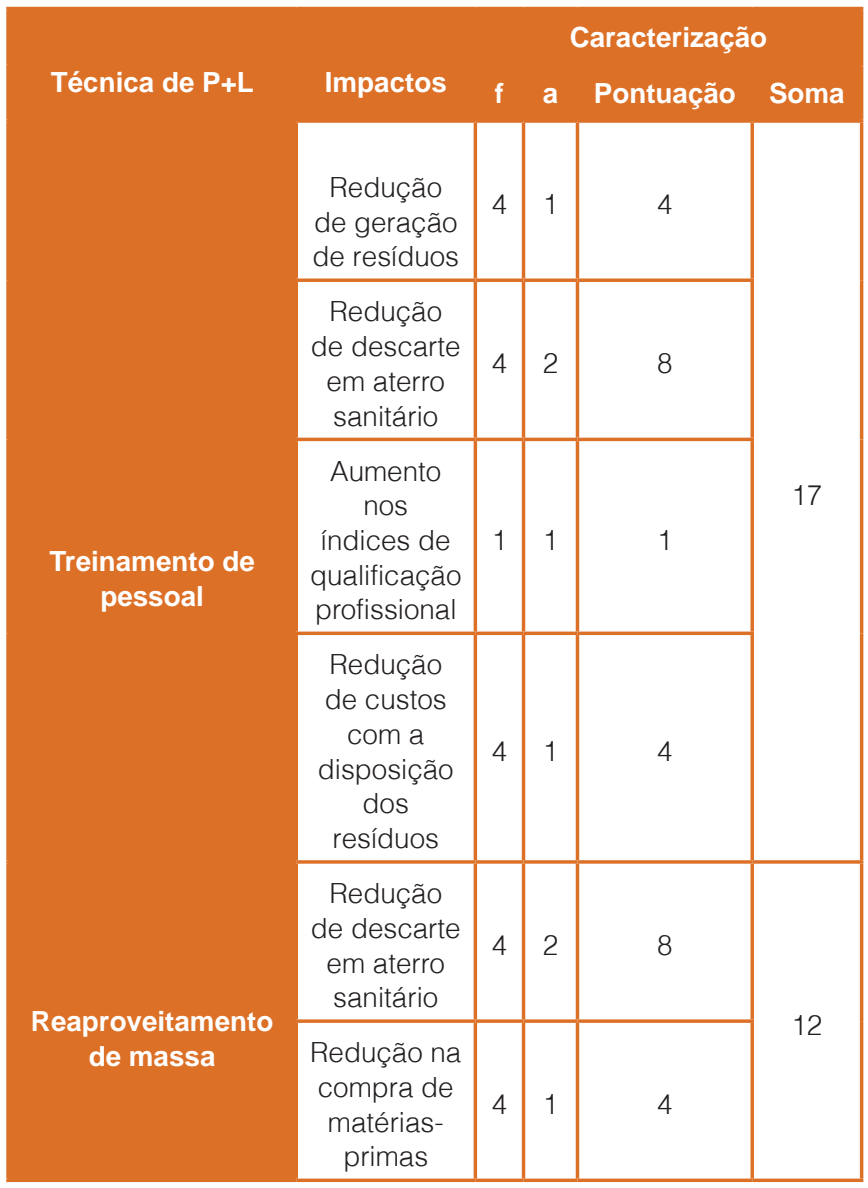

\begin{tabular}{|c|c|c|c|c|c|}
\hline \multirow[b]{2}{*}{ Técnica de P+L } & \multirow[b]{2}{*}{ Impactos } & \multicolumn{4}{|c|}{ Caracterização } \\
\hline & & $f$ & a & Pontuação & Soma \\
\hline \multirow[t]{2}{*}{$\begin{array}{l}\text { Coprocessamento } \\
\text { de resíduos }\end{array}$} & $\begin{array}{l}\text { Redução } \\
\text { de descarte } \\
\text { em aterro } \\
\text { sanitário }\end{array}$ & 4 & 2 & 8 & \multirow[t]{2}{*}{12} \\
\hline & $\begin{array}{l}\text { Possível } \\
\text { lucro ao } \\
\text { empreendi- } \\
\text { mento }\end{array}$ & 4 & 1 & 4 & \\
\hline
\end{tabular}

Pode-se perceber por meio do quadro 4 que o treinamento de pessoal é a oportunidade de $\mathrm{P}+\mathrm{L}$ mais vantajosa à indústria de biscoitos, com 17 pontos. A avaliação vem a confirmar a prioridade de ações de Produção Mais Limpa estabelecidas pelo CNTL (2010), na qual a não geração de resíduos e emissões enquadra-se no nível 1, onde os riscos ao meio ambiente são reduzidos dada a não geração de poluição. Nas demais medidas de P+L ocorrem a geração de resíduos, entretanto sugere-se a reciclagem interna e externa dos mesmos.

\section{CONCLUSÃO}

A Produção Mais Limpa é uma ferramenta que pode ser considerada como um importante aliado no gerenciamento de resíduos sólidos industriais. O estudo de caso apresentado mostra que as perdas de produtos na fabricação de biscoitos podem ser reduzidas através da implementação de técnicas de $\mathrm{P}+\mathrm{L}$ voltadas para a geração de resíduos sólidos, sendo que no estudo em questão foram propostas oportunidades nos três níveis de prioridade: redução na fonte, reciclagem interna e reciclagem externa.

O método de comparação, utilizado no presente estudo, para avaliar qual seria a opção de $\mathrm{P}+\mathrm{L}$ demonstrou que o treinamento de pessoal é a técnica mais vantajosa a ser empregada dado os benefícios associados à mesma. Entretanto, todas as oportunidades de $\mathrm{P}+\mathrm{L}$ são válidas e cabe também ao empreendedor selecioná-las, uma vez que não se avaliou a relação custo- benefício.

Por fim, é importante que as indústrias entendam que as estratégias de Produção Mais Limpa devem ser aplicadas e aprimoradas constantemente, a fim de minimizar os impactos ambientais gerados pela 
produção de resíduos em seus processos produtivos.

\section{REFERÊNCIAS}

[1] ABETRE. Associação Brasileira de Empresas de Tratamento de Resíduos. Perfil do setor de tratamento de resíduos e serviços ambientais. São Paulo, 2006.

[2] BARBIERI, J. C. Gestão ambiental empresarial: conceitos, modelos e instrumentos. $2^{-}$ed. São Paulo: Saraiva, 2004.

[3] CETESB. Secretaria Estadual do Meio Ambiente. Guia Técnico Ambiental de Produtos Lácteos - Série P+L. Companhia de Tecnologia de Saneamento Ambiental. Federação das Indústrias do Estado de São Paulo (FIESP). São Paulo- SP. 2008

[4] CIESP. Centro de Indústrias do Estado de São Paulo. Produção Mais Limpa (P+L). São Paulo- SP. 2013. Disponível em: <http://www.ciesp.com.br/acoes/producao-mais-limpa$\mathrm{pl} />$.

[5] CNTL. Centro Nacional de Tecnologias Limpas. Implementação de Programas de Produção mais limpa. Porto Alegre: CNTL SENAI- RS. 2003.

[6] CORASSA, et al. Farelo de biscoito na alimentação de porcas em lactação. Pesquisa Agropecuária Tropical. v. 44, n. 1, p. 42-49. Gioânia, 2014.
[7] LAYRARGUES, P.P. Educação ambiental nos anos 90. Mudou, mas nem tanto. Políticas Ambientais, Rio de Janeiro, 2000

[8] MOLINARI, M. A. et al. Avaliação de oportunidades de produção mais limpa para a redução de resíduos sólidos na fabricação de tintas. Produção, v. 23, n. 2, p. 364-374, abr./ jun. 2013.

[9] PNUMA. Consumo e produção sustentável. Disponível em: <http://www.pnuma.org.br/interna. php?id=63>. Acesso em: set. 2015.

[10] SILVA, Aline Pereira; LEAL, Antônio Cezar. Diagnóstico da geração e destinação dos resíduos sólidos industriais nas empresas de presidente prudente - SP. Instituto de Ciência e Tecnologia em Resíduos e Desenvolvimento Sustentável. Congresso Brasileiro de Ciência e Tecnologia em Resíduos e Desenvolvimento Sustentável. Florianópolis, 2004.

[11] SIMABESP. Sindicato das Indístrias de Massas Alimentícias e Biscoitos no Estado de São Paulo. RELEASES. São Paulo- SP, 2009. Disponível em: <http://www.simabesp. org.br/site/escolha_releases_simabesp.asp?id=4>. Acesso em: set. 2015.

[12] UNIDO/UNEP. Manual de avaliação de $P+L$, traduzido por CNTL/SENAI. Porto Alegre, 1995. 


\section{CAPÍTULO 4}

\section{ESTUDO PARA ALTERAÇÃ̃O NO PROCESSO DE UM CONJUNTO SOLDADO PARA UM CONJUNTO FUNDIDO: UM ESTUDO DE CASO}

Mario Fernando Mello

Alexandre Possa

Marcelo Rosseto Ludwig

Resumo: Com a crescente evolução no ramo metal mecânico as mudanças dentro dos processos produtivos nas organizações também se fazem necessárias. A busca constante na reduçáo de desperdícios e na modernização para melhoria dos produtos é objetivo para a empresa continuar sendo competitiva no mercado. Como consequência disso e de alguns problemas relatados pelo setor de pós-venda da empresa onde foi realizado o estudo, surgru a necessidade de realizar uma melhoria nos rodados de plantio e transporte de uma plantadeira, visando também à redução de custo com a alteração do processo, evitando a quebra do conjunto como em alguns casos relatados, e garantindo assim a qualidade do mesmo. Sera estudada a viabilidade da alteração dos rodados de conjuntos soldados para conjuntos fundidos. Desta forma, este trabalho tem como objetivo a melhoria na qualidade final dos produtos, evitando a insatisfação dos clientes, trazendo ganhos de espaço no mercado e eliminando possíveis custos com pós-venda em relação à troca de peças e assistência técnica. Este trabalho foi realizado em uma grande indústria do setor metal mecânico nos meses de fevereiro a maio de 2015 , com a identificação do problema feita por uma equipe do setor comercial e pós-venda. Ficou demonstra da no decorrer do trabalho que a troca de processo do conjunto rodado soldado para conjunto fundido e viavel, resultando em benefícios para a empresa e para clientes.

Palavras chave: Rodado, Processos, Custos. 


\section{INTRODUÇÃO}

O setor agrícola tem experimentado uma grande evolução de mecanização nos últimos anos. Os produtores desejam produzir mais e mais rápido, sabendo que a agricultura depende muito do clima, é imprescindível que as tarefas da lavoura sejam feitas em tempo hábil e dentro do período estipulado e favorecido pelo clima. Cada etapa tem seu período pré-determinado lembrando que isso varia de região para região, seja para preparar o solo, para plantar ou para colher, fora desse período o produtor terá prejuízo podendo até perder toda sua produção.

Sabendo disso, as empresas necessitam aprimorar seus processos produtivos observando detalhes, que muitas vezes acabam passando despercebidos ou que não enxergamos a olho nu. Empresas com processo enxutos são as que mais conseguem se diferenciar das demais em seu ramo de mercado. Desta maneira deve-se aperfeiçoar cada vez mais os processos, trazendo reduções nos custos e melhorando a cada dia os produtos através da inovação.

Devido a estas situações, este trabalho tem como proposta realizar um estudo de caso para melhorar e substituir o processo de fabricação dos rodados das plantadoras e semeadoras produzidas pela empresa, os quais hoje são produzidos através da soldagem de componentes para o processo de fundição, reduzindo assim custos com processos, diminuindo o número de pessoas envolvidas para a produção dos componentes, e consequentemente melhorando o projeto do item. Esta alteração também trará melhorias de qualidade ao produto, pois o mesmo em algumas situações apresenta problemas de quebra a campo.

O estudo foi realizado em uma empresa do ramo metal mecânico localizada na cidade de Não-Me-Toque/RS. Sabe-se que a competitividade nesse ramo está cada vez mais acirrada, fazendo com que a busca para se obter vantagem perante as outras seja cada vez maior. Isso faz com que os olhares se voltem aos detalhes nos processos de fabricação ineficientes. Custos com operações desnecessárias, alta rotatividade de pessoas, entre outros diversos desperdícios acabam se tornando fatores que necessitam ser melhorados.

\section{REVISÃO BIBLIOGRÁFICA}

Neste capítulo serão descritos alguns conceitos e a visão de alguns autores a respeito do tema do artigo.

\subsection{GESTÃO DA QUALIDADE}

Segundo Slack, et al. (2009) qualidade é a conformidade coerente com as expectativas dos consumidores, ou seja, significa fazer certo as coisas, mas as coisas que a produção precisa fazer certo irão variar de acordo com o tipo de operação. Sendo assim, todas as operações encaram qualidade como um objetivo particularmente importante perante as expectativas dos consumidores implicando também na sobrevivência da empresa no mercado.

Desta forma, com as grandes mudanças que estão ocorrendo no mundo empresarial, as ameaças à sobrevivência só aumentam e as empresas precisam estar atentas a elas, melhorando a qualidade de seus processos e produtos.

Para Campos (2004), a razão de existência e permanência no mercado global de uma empresa são seus clientes. Por isso, toda administração de uma empresa deve estar norteada à qualidade, seja essa na produção, logística, ou em qualquer processo, é a busca continua da satisfação dos clientes, mas também atingir a satisfação e necessidades de todo o núcleo envolvido, tais como: clientes, funcionários, acionistas, comunidade, enfim, todos os envolvidos direta e indiretamente com a corporação. Ainda para o mesmo autor, com a sociedade envolvida em tantas mudanças, e como a empresa é inserida em diversas regiões de diferentes culturas, para que a empresa possa sobreviver é necessário que a mesma esteja em constante desenvolvimento de novos produtos e serviços (com produtos melhores, mais acessíveis, novas tecnologias com maior confiabilidade), e para que sejam produzidos novos produtos é preciso ter novos e melhores processos que garantam a qualidade dos produtos produzidos. Com este cenário de inovação contínua, a empresa acaba tendo como referência o cliente e seus concorrentes, e isso se constitui na garantia de sobrevivência da empresa. 
Portanto, na garantia da qualidade quanto menor for a deficiência de um produto, maior será sua qualidade, ou seja, a probabilidade de ocorrer algum tipo de falha será menor.

\subsubsection{FERRAMENTAS DA QUALIDADE}

Existem as chamadas ferramentas da qualidade que auxiliam para uma boa gestão da qualidade. Algumas delas foram usadas neste trabalho com o objetivo de identificar falhas, priorizar ações e definir um plano de ação.

\subsubsection{MÉTODO DE ANÁLISE DE PARETO}

O Método de Análise de Pareto é uma ferramenta de estratificação muito importante para o gerenciamento de processos. Segundo Campos (2004) o Método de Análise de Pareto permite:

a) Dividir um problema grande num grande número de problemas menores e que são mais fáceis de serem resolvidos com o envolvimento das pessoas da empresa;

b) Como o Método de Análise de Pareto é baseado sempre em fatos e dados, ele permite priorizar projetos;

c) $\mathrm{Da}$ mesma forma o método permite o estabelecimento de metas concretas e atingíveis.

Assim, o Método de Análise de Pareto é um método muito simples e muito poderoso para o gerenciamento, pois ajuda a classificar e priorizar problemas. Ainda segundo o mesmo autor, a estratificação seguida da coleta de dados e a visualização gráfica apresentada no Diagrama de Pareto permitem priorizar quantitativamente os itens mais importantes e, essa sequência de operações pode ser repetida várias vezes sempre tomando os itens prioritários como novos problemas até serem localizados e quantificados os vários projetos de solução de problemas.

Para Miguel (2001) a análise de Pareto é representada por um gráfico onde são utilizadas barras e linhas que representam as frequências das ocorrências por ordem decrescente nas barras. Assim é possível identificar a contribuição das causas para um dado acontecimento.

\subsubsection{DIAGRAMA DE CAUSA E EFEITO}

Segundo Miguel (2001) é uma forma gráfica utilizada como método de análise para representar fatores de influência (causas) sobre um determinado problema (efeito). Também é conhecido por diagrama de Ishikawa ou diagrama espinha de peixe, devido sua forma. Para classificar as causas de um problema, define-se o "efeito", que deverá ser apontado à direita e traçando, à esquerda, uma larga seta, apontando para o efeito. Posteriormente, consideram-se as ramificações, que são os fatores detalhados considerados como causas secundárias. Fatores mais particularizados serão descritos em ramificações menores e assim por diante.

Para Paladini, 2011 os recursos humanos sempre desempenharam papel bastante específico no esforço pela qualidade nas organizações. Eles são os agentes de transformação, ou seja aqueles que efetivamente mudam a organização em termos de qualidade. Por isso a correta utilização das ferramntas da qualidade depende excluisvamente dos recursos humanos. No Diagrama de Causa e Efeito, saber identificar as possíveis causas para posteriormente hierarquizar as mais importantes é um papel que requer envolvimento de todos pois desde as formas de resolução mais simples como as mais complexas serão objeto de estudos. Desta forma, pouco adianta saber tecnicamente usar a ferramenta se não há envolvimento e comprometimento dos recursos humanos para consecução da mesma.

\subsubsection{MATRIZ GUT}

Segundo Kepner e Tregoe (1991) A Matriz GUT é uma importante ferramenta da qualidade que contribui para a tomada de decisão. Como metodologia para a tomada de decisão, permite a alocação de recursos nos tópicos considerados mais importantes, contribui para a elaboração de um planejamento estratégico, é de simples implementação, serve para análise de qualquer matéria e pode ser utilizada para classificação de assuntos diversos. 
ferramenta é priorizar as ações de forma racional, levando em consideração a gravidade, a urgência e a tendência do fenômeno, permitindo escolher a melhor alternativa para aquele momento.

A pontuação a ser dada a cada problema varia de 0 (zero) a 5 (cinco) para os ítens gravidade, urgência e tendência de acordo com o grau de importância daquele problema que está sendo analisado. Após esta pontuação definida, multiplicam-se os três itens para obtenção do grau final ou GUT total. Na figura 1 está demonstrado um modelo de Matriz GUT.

Figura 1 - Modelo Matriz GUT

\begin{tabular}{|c|c|c|c|c|}
\hline Problema & $\begin{array}{c}\text { Gravidade } \\
\text { G }\end{array}$ & $\begin{array}{l}\text { Urgência } \\
\text { U }\end{array}$ & $\begin{array}{c}\text { Tendência } \\
\text { T }\end{array}$ & $\begin{array}{l}\text { GUT - } \\
\text { Total }\end{array}$ \\
\hline & & & & \\
\hline & & & & \\
\hline & & & & \\
\hline
\end{tabular}

Fonte: Elaborada pelos autores

\subsection{PROCESSO DE SOLDA}

A soldagem é o processo de juntar peças metálicas, sendo este um dos mais importantes processos industriais na fabricação e transformação de componentes metálicas. Processo este que também é utilizado na recuperação de peças desgastadas, para a aplicação de revestimentos de características especiais sobre superfícies metálicas e para corte. Para Modenesi (2012), o sucesso da soldagem está associado a diversos fatores, como a sua relativa simplicidade operacional. Por outro lado, apesar desta simplicidade, não se pode esquecer que a soldagem por ser muitas vezes um processo "traumático" para o material, envolvendo, em geral, a aplicação de uma elevada densidade de energia em um pequeno volume do material, o que pode levar a importantes alterações estruturais e de propriedades dentro e próximo da região da solda.

Ainda segundo o mesmo autor, a falta de conhecimento ou a simples desconsideração das implicações desta característica fundamental pode resultar em problemas inesperados, muitas vezes graves. Estes problemas podem se refletir em atrasos na fabricação ou em gastos inesperados, quando o problema é prontamente detectado, ou mesmo em perdas materiais e, eventualmente, de vidas, quando o problema é levado às suas últimas consequências. Normalmente quase todos os produtos de uma empresa são montagens e os seus processos exigem a união de peças de diferentes materiais.

No campo de soldagem, segundo Modenesi (2012), podem ser encontrados mais de cinquenta processos de soldagem, porém nem todos têm aplicação industrial.

Uma maneira de classificar os processos de soldagem consiste em agrupá-los em dois grandes grupos baseando-se no método dominante para produzir a solda:

a) Processos de soldagem por pressão;

b) Processos de soldagem por fusão.

A união dos materiais metálicos já era conhecida desde os anos 3000 ou 4000 a.C., um exemplo típico é a brasagem, utilizando ligas de ouro e cobre, ou então de chumbo e estanho. Obviamente, que as únicas fontes de energia conhecidas naquela época se restringiam à linha ou ao carvão vegetal, de modo que esta limitação não permitiu o progresso das maiorias das técnicas de união de metais.

Dentre as vantagens da brasagem estão: as montagens podem ser unidas em condições praticamente livres de tensão, montagens complexas podem ser unidas em vários estágios com o uso de metais de adição a temperaturas progressivamente mais baixas, juntas por abrasamento requerem um pouco ou nenhum acabamento, além da remoção do fluxo e pôr fim a junta é vedada e condutiva.

Apesar de sua aparente simplicidade, a soldagem envolve uma gama muito grande de conhecimentos, que são implicitamente empregados durante a execução de uma junta soldada. A soldagem é, na verdade, uma somatória de conhecimentos que engloba as áreas de metalurgia, mecânica, química, elétrica e também física aplicada. O conhecimento dessas áreas é essencial para garantir a confiabilidade das juntas soldadas. 


\subsection{PROCESSO DE FUNDIÇÃO}

Com o objetivo de fabricar peças metálicas existe o processo de fundição. Segundo Penkatis (2012) os metais são fundidos e adicionados aos moldes, com as características dos modelos das peças a serem fabricadas. Os moldes mais utilizados são em areia. A mesma autora estima que mais de $80 \%$ das peças fundidas produzidas utilizam moldes feitos de areia aglomerada.

Na figura 2 está demonstrada uma representação esquemática da fundição em molde de areia. Percebem-se os canais de escoamento do líquido até chegar no modelo de peça a ser fundido.

Figura 2 - Representação esquemática da fundição em molde de areia

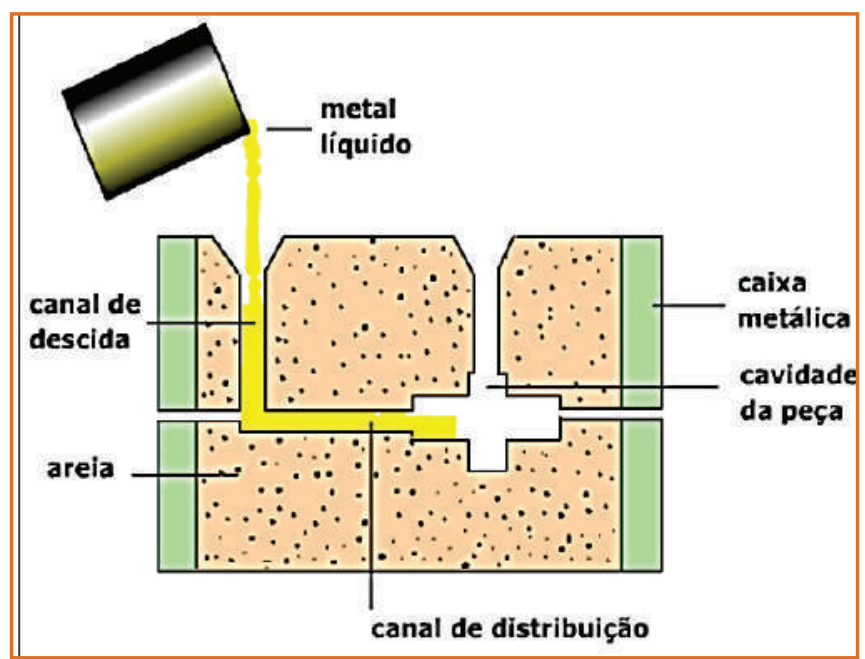

Fonte: Centro de Informação Metal Mecânica, 2010.

Conforme Lima (2006), o ferro fundido é, em geral, destinado aos processos de fundição ou forjamento e, a exemplo do aço, pode ser ligado a outros elementos metálicos ou não metálicos, com o intuito de melhorar suas propriedades e possibilitar a sua utilização em aplicações específicas.

Ainda segundo o mesmo autor, quando desejado, os lingotes de ferro fundido não ligado, obtidos no processo siderúrgico, são submetidos a um processo de fundição juntamente com os seguintes elementos: carbono, silício, enxofre, manganês e fósforo em proporções adequadas ao desempenho esperado do material. No entanto, para todos os tipos de ferro fundido, ligados ou não, o carbono estará sempre presente com uma proporção superior a $2 \%$ em relação ao volume total.

\subsection{CONCEITOS E REFERÊNCIAS SOBRE CUSTOS}

Segundo Bornia (2010), custo é o valor dos insumos usados na fabricação dos produtos da empresa. Exemplo desses insumos são matérias, trabalho humano, energia elétrica, máquinas e equipamentos, entre outros. O custo também é um gasto, porém quando utilizado nos fatores de produção para fabricação de um produto ou execução de serviço, consideramos como custo. Custo é o consumo de valores para determinados fins. Então, podemos dizer que custo será o sacrifício feito e medido para a obtenção de objetivos.

Segundo Migliorini (2006), quando estruturado um sistema de custos é um dos assuntos que mistura as metas simples de um tratamento de dados complexos, além de ser necessário definir seus objetivos. As empresas apuram seus custos com vistas:

a) Ao atendimento das exigências legais, quanto á apuração de resultados de suas atividades e avaliação de estoques;

b) Ao conhecimento dos custos para a tomada de decisões corretas e o exercício de controle;

c) Ao conhecimento dos custos para a tomada de decisões corretas e o exercício de controles.

\subsubsection{CUSTOS FIXOS E VARIÁVEIS}

Para Migliorini (2006) custos fixos decorrem da manutenção da estrutura produtiva da empresa, independentemente da quantidade que venha a ser fabricada dentro do limite da capacidade instalada. Como exemplo desses comportamentos são o custo do aluguel e a depreciação. Para o mesmo autor, os custos variáveis aumentam ou diminuem conforme o volume de produção. São exemplos deste comportamento os custos da matéria-prima (quanto mais se produz, maior a necessidade) e da energia elétrica (quanto mais se produz, maior é o uso de máquinas e equipamentos elétricos). 


\section{PROCEDIMENTOS METODOLÓGICOS}

Este estudo caracteriza-se como um estudo de caso que segundo Yin (2009) é o método preferido quando as questões "como" ou "por que" são propostas; o investigador tem pouco controle sobre os eventos e o enfoque está sobre um fenômeno contemporâneo. Para Gil (1999) os estudos de caso apresentam diversas características, que variam de acordo com o critério adotado, ou das variáveis observadas.

Diante desse contexto este estudo de caso se caracteriza como critério exploratório uma vez que os pesquisadores buscaram inicialmente entender o processo produtivo dentro da empresa. Além disso, foi feito uma revisão bibliográfica com os principais conceitos e referências nos assuntos relativos à solda, fundição, custos e gestão da qualidade. Também é caracterizado como descritivo pelo fato dos pesquisadores terem feito uma coleta de dados envolvendo as ações para a troca de conjunto soldado, para conjunto fundido, uma vez que no capítulo 4 serão demonstradas as ferramentas utilizadas, bem como seus resultados. Este trabalho também destaca-se como explicativo, uma vez que teve o foco de identificar e explicar as ações e atividades que contribuem para atingimento do objetivo principal do trabalho.

A identificação do problema foi feita através da equipe de pós-vendas e comercial, por meio de reclamações dos clientes alegando problemas com o equipamento durante a sua utilização. Essas informações são utilizadas para a melhoria dos produtos. Através disso, veio a necessidade de melhorar o projeto e o processo de fabricação do Conjunto Rodado. O trabalho foi desenvolvido nos meses de fevereiro a maio de 2015 em uma empresa do setor metal mecânico localizada no norte do Estado do Rio Grande do Sul.

\section{RESULTADOS}

A primeira etapa foi a da identificação do problema. Para identificar o problema foram observados os pontos que estavam gerando desconforto ou incômodo tanto para o cliente quanto para a empresa. Para esta etapa foi utilizada a ferramenta da qualidade chamada Diagrama de Causa e Efeito ou Diagrama de Ishikawa. 
Figura 3 - Diagrama de causa e efeito

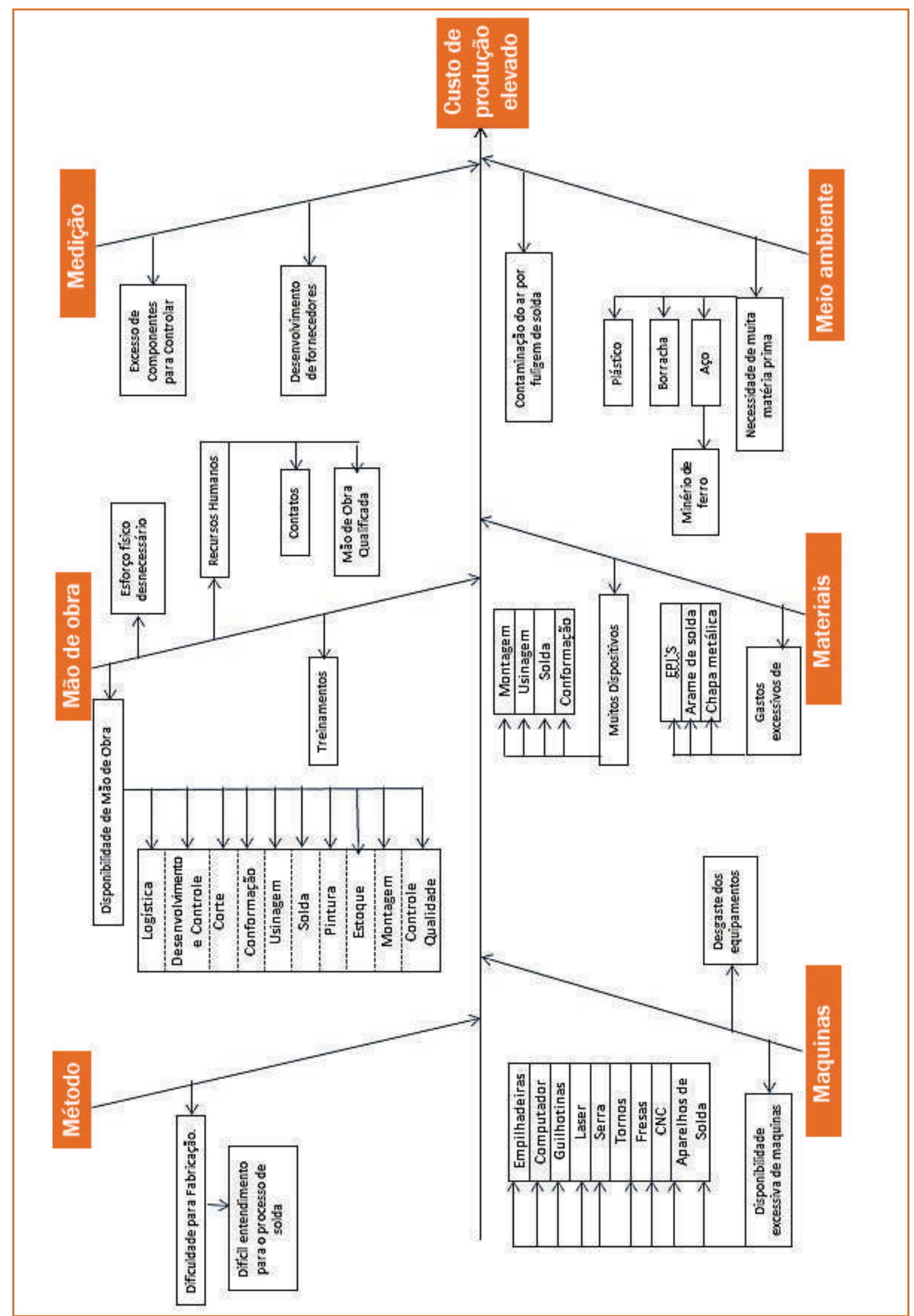


Na figura 3 está demonstrada a utilização do Diagrama de Causa e Efeito, tendo como efeito o custo de produção elevado e as possíveis causas que levam a este elevado custo. Percebe-se que na causa "mão de obra" foi onde apareceu a maior quantidade de possíveis causas do problema. Em seguida, notouse também, na causa "máquina" a segunda maior quantidade de possíveis causas. Ou seja, nas causas "mão de obra" e "máquinas" residem as maiores situações que precisam ser resolvidas.

Utilizando-se o Diagrama de ISHIKAWA pode-se identificar que existem várias melhorias a serem realizadas no produto. Resumindo, os resultados do diagrama são:
EFEITO: Custo de produção elevado.

CAUSAS: grande quantidade de processos como: corte, solda, conformação, transporte entre outros, excesso de dispositivos e alta necessidade de matériaprima.

A seguir, a matriz GUT (Gravidade X Urgência X Tendência), foi usada para identificar os principais pontos a serem alterados, organizando-se em ordem todas as situações críticas do projeto e do processo, através de pontuações atribuídas a cada problema levantado no diagrama de causa e efeito. 
Figura 4 - Matriz GUT

\begin{tabular}{|c|c|c|c|c|c|}
\hline Problema & G & U & $\mathbf{T}$ & Resultado & Prioridade \\
\hline Dificuldade para fabricação & 4 & 5 & 5 & 100 & \\
\hline Difícil entendimento no processo de solda & 4 & 5 & 5 & 100 & 200 \\
\hline Disponibilidade de mão de obra excessiva & 4 & 4 & 5 & 80 & \\
\hline Logística & 2 & 1 & 2 & 4 & \\
\hline Programação & 3 & 3 & 3 & 27 & \\
\hline Desenvolvimento Controle & 2 & 3 & 3 & 18 & \\
\hline $\begin{array}{ll}\text { Corte } \\
\end{array}$ & 2 & 1 & 3 & 6 & \\
\hline Conformação & 2 & 2 & 3 & 12 & \\
\hline Usinagem & 1 & 1 & 3 & 3 & 298 \\
\hline Solda & 4 & 5 & 5 & 100 & \\
\hline Pintura & 2 & 2 & 3 & 12 & \\
\hline Estoque & 1 & 1 & 2 & 2 & \\
\hline Montagem & 2 & 3 & 3 & 18 & \\
\hline Controle de Qualidade & 2 & 2 & 4 & 16 & \\
\hline Treinamentos & 3 & 3 & 4 & 36 & 36 \\
\hline Esforço físico desnecessário & 2 & 2 & 3 & 12 & 12 \\
\hline Recursos Humanos & & & & & \\
\hline Contratos & 2 & 2 & 2 & 8 & 44 \\
\hline Mão de Obra Qualificada & 3 & 3 & 4 & 36 & \\
\hline Excesso de componentes para controlar & 2 & 2 & 3 & 12 & 12 \\
\hline Desenvolvimento de fornecedores & 1 & 1 & 2 & 2 & 2 \\
\hline Disponibilidade excessiva de maquinas. & 4 & 4 & 5 & 80 & \\
\hline Empilhadeiras & 2 & 2 & 3 & 12 & \\
\hline Computador & 2 & 1 & 2 & 4 & \\
\hline Laser & 2 & 2 & 3 & 12 & \\
\hline Guilhotina & 1 & 1 & 1 & 1 & \\
\hline Serra & 2 & 2 & 2 & 8 & 237 \\
\hline Tornos & 2 & 2 & 2 & 8 & \\
\hline Fresas & 1 & 2 & 2 & 4 & \\
\hline CNC & 2 & 2 & 2 & 8 & \\
\hline Aparelho de Solda & 4 & 5 & 5 & 100 & \\
\hline Desgaste dos Equipamentos & 4 & 5 & 5 & 100 & 100 \\
\hline Muitos Dispositivos & 3 & 3 & 4 & 36 & \\
\hline \begin{tabular}{l|l} 
Montagem \\
\end{tabular} & 2 & 2 & 3 & 12 & \\
\hline Usinagem & 1 & 2 & 3 & 6 & 104 \\
\hline Solda & 3 & 4 & 4 & 48 & \\
\hline Confomacão & 1 & 1 & 2 & 2 & \\
\hline Gastos excessivos de insumos & 2 & 3 & 3 & 18 & \\
\hline EPI's & 3 & 3 & 4 & 36 & \\
\hline Arame de solda & 4 & 5 & 5 & 100 & 194 \\
\hline Chapa Metálica & 3 & 3 & 4 & 36 & \\
\hline Tubos & 1 & 2 & 2 & 4 & \\
\hline Utilização excessiva dos recursos naturais & 3 & 3 & 3 & 27 & 27 \\
\hline Necessidade de matéria prima & 2 & 2 & 3 & 12 & \\
\hline AçO & 4 & 4 & 4 & 64 & Or \\
\hline Borracha & 2 & 2 & 3 & 12 & 96 \\
\hline \begin{tabular}{|l} 
Plástico \\
\end{tabular} & 2 & 2 & 2 & 8 & \\
\hline
\end{tabular}

Fonte: Elaborada pelos autores

Na figura 4 estão destacados em cor diferente as notas dos itens de problema com maior pontuação, e em consequência consegue-se identificar quais itens estão tornado o produto com um custo mais elevado. Para a realização e avaliação da matriz GUT foi utilizada uma pontuação de 0 a 5, conforme o modelo 
padrão da tabela 1.

Figura 5 - Graus de avaliação da Matriz GUT

\begin{tabular}{|c|c|c|c|}
\hline PONTUAÇÃO & G=GRAVIDADE & U=URGÊNCIA & T=TENDÊNCIA \\
\hline 5 & GRAVISSIMO & AÇÃO IMEDIATA & AGRAVA RAPIDAMENTE \\
4 & AÇÃO RAPIDA & AGRAVA EM CURTO PRAZO \\
3 & GRAVE & AÇÃO NORMAL & AGRAVA EM MÉDIO PRAZO \\
2 & POUCO GRAVE & AÇÃO LENTA & AGRAVA EM LONGO PRAZO \\
1 & MENOR GRAVIDADE & PODE ESPERAR & ACOMODAR \\
\hline
\end{tabular}

Fonte: Kepner e Tregoe, 1991, adaptada pelos autores

Na etapa seguinte, após a análise da Matriz GUT, foi elaborado o Gráfico de Pareto, ordenando as informações e os números encontrados através da matriz, e dessa forma conseguiu-se observar quais serão os pontos mais críticos para serem melhorados.

Gráfico 1 - Gráfico de Pareto

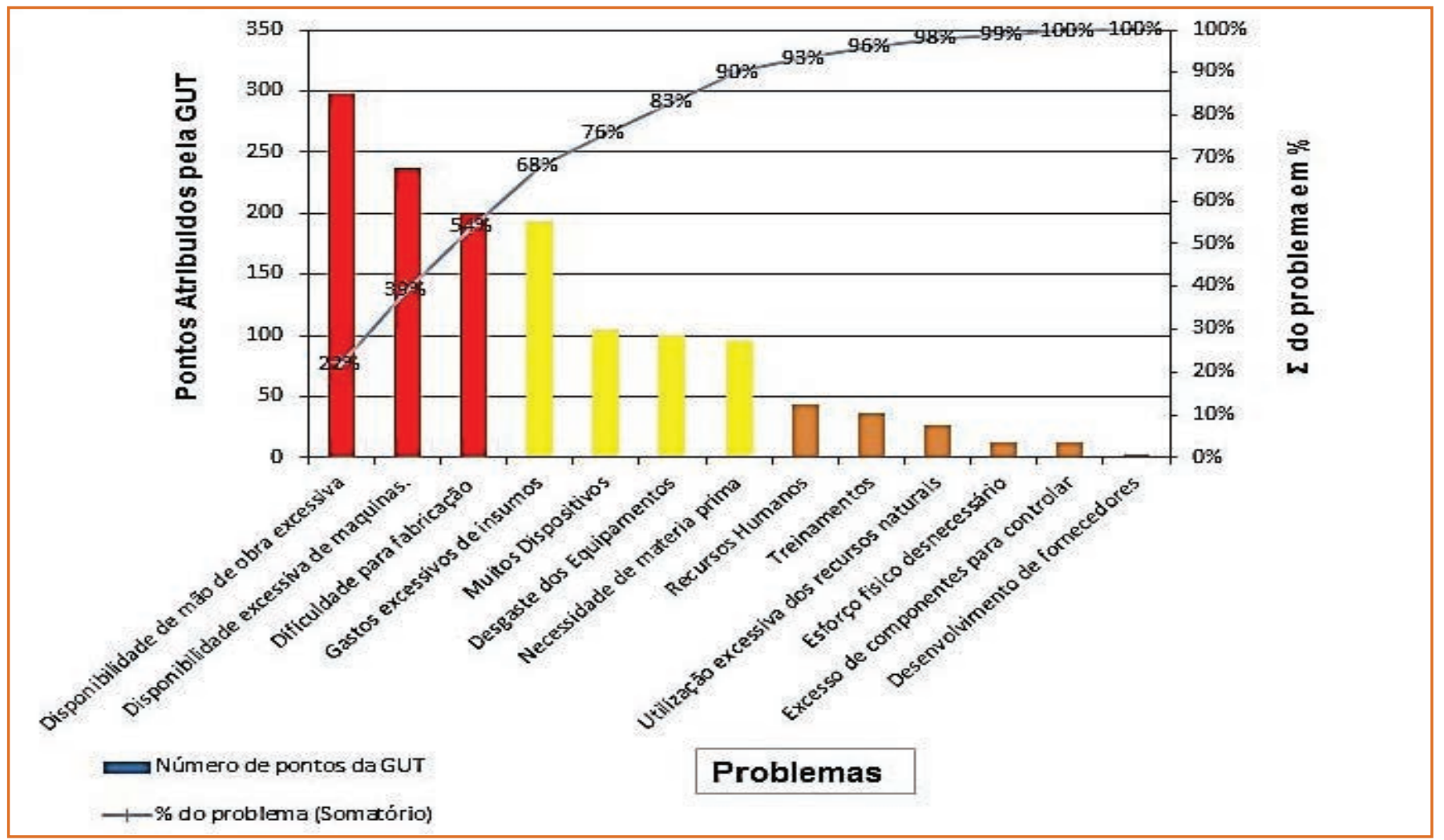

Fonte: Elaborado pelos autores

- gráfico 1 estão demonstradas as pontuações definidas pela Matriz GUT ordenadas por prioridades. Verifica-se que 54\% do problema identificado pelo Diagrama de Causa e Efeito está concentrado em três causas:
a) Disponibilidade excessiva de mão de obra;
b) Disponibilidade excessiva de máquinas;
c) Dificuldade para a fabricação

Portanto com a utilização adequada das ferramentas da qualidade consegue-se identificar e priorizar ações que geram problemas para a fabricação e por consequência possíveis falhas à campo afetando a satisfação dos clientes. Fica evidenciado, também, que tratando de três causas 54\% do problema pode ser resolvido. 
Com base nestes dados, foram reunidos os principais envolvidos de cada setor para a demonstração e debate dos dados levantados. Nesta etapa várias reuniões de trabalho foram realizadas e a conclusão chegada é que a melhor solução para resolver os problemas do Conjunto Rodado Soldado era desenvolver um novo projeto para este conjunto, porém, não mais soldado e sim fundido. Um dos elementos que ajudou a definir este novo caminho foi que em outros processos de fabricação anteriormente analisados, problemas semelhantes em relação ao processo de soldagem já haviam sido detectados e também foram substituídos alguns componentes para o processo de fundição, gerando redução de custos e melhor qualidade dos mesmos.

Nos conjuntos soldados atuais são necessários vários processos para se obter o produto final. O mesmo é composto por três componentes bases, que são: Suporte Rodado, Braço Esquerdo Rodado e Braço Direito Rodado.

Já o projeto proposto, passará a ter apenas duas peças, eliminando os processos de corte laser, de dobra, de usinagem e o principal, foram eliminados todos os processos de solda.

O gráfico 2 indica o comparativo do ganho obtido com o projeto proposto, substituindo o processo de solda por processo fundido.

Gráfico 2 - Comparativo projeto atual x projeto novo

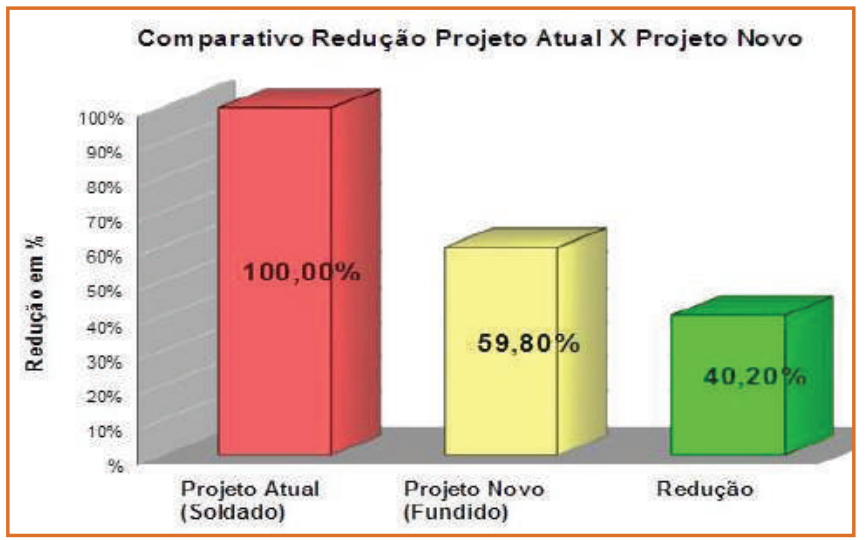

Fonte: Elaborado pelos autores

Como fica demonstrado no gráfico 2 a redução de custos com o processo de fabricação sendo alterado para processo fundido. Nesta etapa houve uma redução significativa de 40,20\% com o novo processo fundido. Outra vantagem percebida é que o novo processo proporcionará maior rigidez para o conjunto fundido, eliminado assim problemas que estavam ocorrendo no processo de solda.

Por solicitação da empresa, para manter o sigilo de suas planilhas de custos, não foi autorizado que se detalhassem as reduções de custos até atingir o percentual de $40,20 \%$ demonstrado no gráfico 2. Assim para manter-se a reserva solicitada pela empresa destacamos esta, como uma das limitações do presente trabalho. Porém, sem prejuízo ao objetivo principal, ficou evidenciada a importância das ferramentas da qualidade na busca de soluções para problemas nas organizações.

\section{CONSIDERAC̄ÕES FINAIS}

É importante observar que cada vez mais as empresas buscam alternativas para melhoria da qualidade de seus produtos, bem como redução de custos em seus processos produtivos. Neste contexto, o emprego de técnicas da Gestão da Qualidade não só se mostram úteis, mas também necessárias na busca de melhor competitividade garantindo o sucesso do negócio.

A utilização de algumas das ferramentas da qualidade auxiliou a identificar os problemas existentes no Conjunto Rodado Soldado, mostrando que era necessária a busca de uma nova solução tendo em vista problemas de custos e de reclamação de clientes. Ficou evidenciado pelo estudo que no atual processo de soldagem são necessários várias etapas para se obter o produto final. Já o processo de fundição passará a ter somente duas peças eliminando-se assim os processos de corte, dobra, usinagem e principalmente todos os processos de solda.

Destaca-se ainda a importância deste trabalho para utilização do mesmo no meio acadêmico, bem como para empresas que procuram identificar causas de problemas em processos produtivos, melhorando assim sua competitividade. 
Para finalizar, mesmo considerando que este estudo traga contribuições é importante mencionar que existiram limitações no uso de dados, a pedido da empresa pesquisada. Assim novas incursões de pesquisa podem ampliar os conhecimentos de pesquisadores e acadêmicos, uma vez que o tema, embora não seja novo, é de muita relevância.

\section{REFERÊNCIAS}

[1] BORNIA, A. C. Análise gerencial de custos: aplicação em empresas modernas. 3. ed. São Paulo: Atlas,2010.

[2] CAMPOS, V. F. TQC - Controle da Qualidade Total, no estilo japonês. Nova Lima - MG: INDG Tecnologia e Serviços Ltda, 2004.

[3] CENTRO DE INFORMAÇÃO METAL MECÂNICA. Disponível em http://www.cimm.com.br/portal/. Acesso em 15 out 2010.

[4] GIL, A. C. Métodos e Técnicas de pesquisa social. 5. ed. São Paulo: Atlas, 1999.

[5] KEPNER, C. \& TREGOE, B. O Novo Administrador Racional . São Paulo: Makron Books, 1991.
[6] LIMA, M. A. M. Introdução aos Materiais e Processos para Designers. Nova Edição. Rio de Janeiro: Editora Ciência Moderna Ltda, 2006.

[7] MEGLIORINI, E. Custos (Analise e Gestão). 2ºed. São Paulo: Pearson Prentice Hall, 2006.

[8] MIGUEL, P. A. C. Qualidade: enfoques e ferramentas. São Paulo: Arttliber Editora, 2001.

[9] MODENESI, P.J. MARQUES, P. V. SANTOS, D. B. Artigo: Introdução a Soldagem. Belo Horizonte: UFMG, 2012.

[10] PENKATIS, G. Impacto ambiental gerado pela disposição de areia de fundição: estudo de caso. Dissertação (Mestrado) Programa de Pós-Graduação em Ciência Ambiental (PROCAM), Univrsidade de São Paulo, São Paulo, 2012.

[11] SLACK, N. CHAMBERS, S. e JOHNSTON, R. Administração da Produção. São Paulo EDITORA ATLAS S. A. -2009

[12] YIN, R. K. Estudo de caso: planejamento e métodos. 2. ed. Porto Alegre: Bookman, 2009. 


\section{CAPÍTULO 5}

PROPOSTA PARA SISTEMATIZAÇÃO DO PROCESSO DE REMANUFATURA DE PRODUTOS REJEITADOS NO CENTRO DE DISTRIBUIÇÃO DE UMA EMPRESA IMPORTADORA DE ELETRODOMÉSTICOS

Luiz Carlos da Silva Junior

Marcos Francisco Ietka

Renato Cristofolini

Claiton Emilio do Amaral

Gilson Joáo dos Santos

Resumo: Este trabalhollapresenta uma proposta para sistematização do processo de remanufatura dos produtos rejeitados no centro de distribuição de uma empresa importadora de eletrodomésticos. Para elaboração dessa proposta foram utilizados indicadores de devoluções e o mapeamento do processo de encaminhamento dos produtos rejeitados, mostrando a origem do problema até a etapa do descarte dos produtos. Inicialmente, foram definidas as famílias de produtos que seriam estudadas para o levantamento dos indicadores. Os indicadores direcionaram os valores para a aplicação da remanufatura, as tratativas e osmétodos que conduziram as etapas do desenvolvimento das atividades. Com base nas características dos motivos que originaram o rejeito dos eletrodomésticos e a estratificação da coleta de dados, foi elaborado uma proposta de atividades no intuito de organizar e orientar uma possível implementação de mudanças sugeridaspela área da empresa responsável pelo processo de remanufatura. Essa proposta apresentou como resultado a possibilidade de reaproveitamento dos produtos rejeitados, proporcionando um retorno financeiro significativo somado aos ganhos com a redução dos impactos ao meio ambiente. Junto com a proposta foi mencionado um resultado potencial que colabora com o atendimento do setor de pós-vendas. 


\section{INTRODUÇÃO}

A proposta de remanufatura foi escolhida em função do novo cenário industrial, que determina responsabilidade sem relação a destinação dos produtos rejeitados.

A sustentabilidade abrangeaspectos econômicos, sociais e ambientais. Tais aspectos consistem um processo sistêmico que agrega os interesses da empresa na qual realizou-se a proposta. A sociedade necessita conhecer e conviver mais com essas atividades sustentáveis, mostrar a necessidade atuais em relação ao meio ambiente.

Os produtos remanufaturados podem ser mais vantajosos e lucrativos, uma vez que o valor agregado do produto seja competitivo e a sua aceitação do mercado seja bem explorada. A remanufatura proporcionará uma redução de custos no processo importador, contribuirá comas condições estabelecidas e resultará em benefícios para o meio ambiente.Uma das etapas antes da remanufatura é a logística reversa dos produtos. A logística reversa em um cenário competitivo favorece a lucratividade e atende os interesses sociais, ambientais e governamentais para a existência da sustentabilidade.

Para Rogers e Tibben-Lembke (1998), a logística reversa é o processo de planejamento, que necessitada implementação e controle de fluxo eficientes, do baixo custo de matérias primas, de estoques em processo e produtos acabados, além de traçar o ponto de consumo até o ponto de origem, para o propósito de recuperação de valor ou descarte apropriado para a coleta e tratamento do lixo.

\section{REVISÃO DA LITERATURA}

A pesquisa abrange especificamente um estudo detalhado nos canais de distribuição e logística reversa como subsídio para ação estratégica de um centro de distribuição de produtos eletrodomésticos importados. Enfatiza-se, portanto, a logística reversa e seus objetivos, a característica de uma distribuição física ou centro de distribuição, e o processo de remanufatura e suas características.

\subsection{LOGÍSTICA REVERSA}

A Logística reversa é um processo que ainda está em fase de adaptações e implementação no Brasil e no mundo. Segundo Leite (2003), a necessidade de atender as solicitações dos clientes e a preocupação com o meio ambiente, fizeram com que muitas empresas aderissem essa filosofia. Com relação ao meio ambiente, através das legislações ambientais, as empresas têm obrigação em fazer estudos de descarte de materiais para não haver degradação do mesmo. Diante disso, elaboram políticas e programas para descartes do lixo industrial e administrativo, e um dos meios para isso é através da logística reversa. De acordo com Lacerda (2002), a compressão crescente com as margens derentabilidade acarretada pela internacionalização da economia, leva muitas empresas abuscarem oportunidades em focos ainda não explorados, por meio de operações inovadoras e mais competitivas.

\subsubsection{A ATIVIDADE DE LOGÍSTICA REVERSA}

A abertura de mercados ao comércio internacional, a migração de capitais, a uniformização e a expansão tecnológica, o avanço do comércio eletrônico e a expansão dos meios de comunicação, conduzem a uma constante mudança nos hábitos, conceitos e procedimentos das instituições. Há que se destacar, concomitantemente a essa necessidade competitiva da logística reversa, a contribuição dessa estratégia para a sustentabilidade social das empresas, cuja reputação implica em aumento ou diminuição de sua competitividade. Assim, tal logística tem um componente técnico (modo de operação), um componente social (sustentabilidade) e um componente ambiental (preservação dos recursos naturais).

A área da logística empresarial que planeja, opera e controla o fluxo e as informações logísticas correspondentes, do retorno dos bens de pósvenda e de pós-consumo ao ciclo de negócios ou ao ciclo produtivo, por meio dos canais de distribuição reversos, agregando valores de diversas naturezas econômico, ecológico, legal, logístico de imagem corporativa, entre outros. (LEITE, 2003, p.16). 


\subsubsection{CANAIS DE DISTRIBUIÇÃO REVERSOS}

A importância econômica da distribuição, seja sob o aspecto conceitual mercadológico ou sob o aspecto concreto operacional da distribuição física, revelase cada vez mais determinante para as empresas, tendo em vista os crescentes volumes transacionados, decorrentes da globalização dos produtos e das fusões de empresas, e a necessidade de se ter o produto certo, no local certo, no tempo certo (LEITE, 2003). Na figura 1 podemos entender o fluxo do canal de distribuição de pós-consumo:

Figura 1 - Canais de distribuição de pós-consumo.

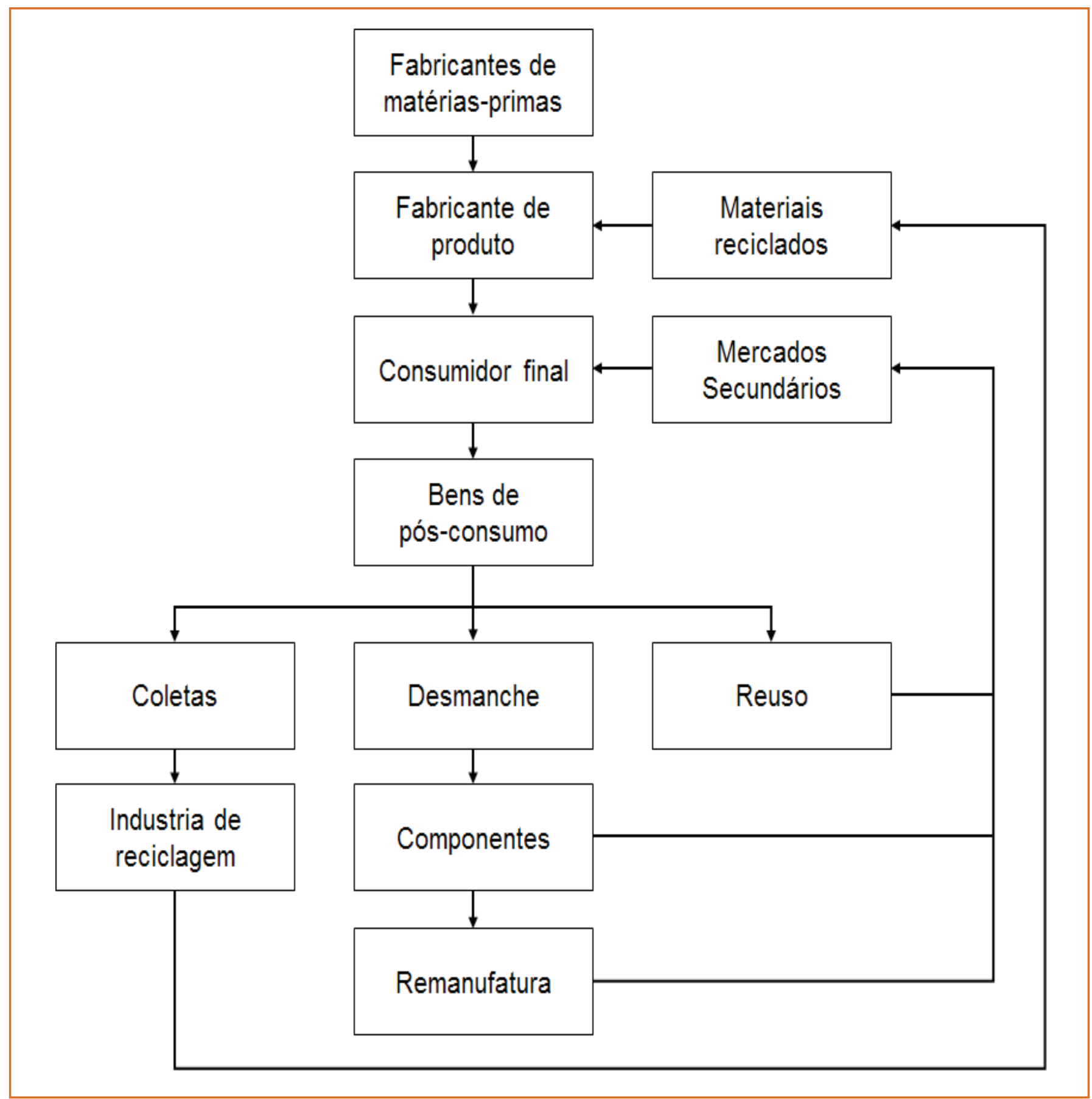

Fonte: Adaptado de Leite (1999, p24).

Para Rogers e Tibben Lembke (1998) esse processo é geralmente composto por um conjunto de atividades que uma empresa realiza para coletar, separar, embalar e expedir itens usados, danificados ou 
obsoletos dos pontos de consumo até os locais de reprocessamento, revenda ou de descarte. Existem variantes com relação ao tipo de reprocessamento que os materiais podem ter, dependendo das condições em que estes entram no sistema de logística reversa, conforme se verifica na figura 2 :

Figura 2 - Atividade típica do processo logístico reverso

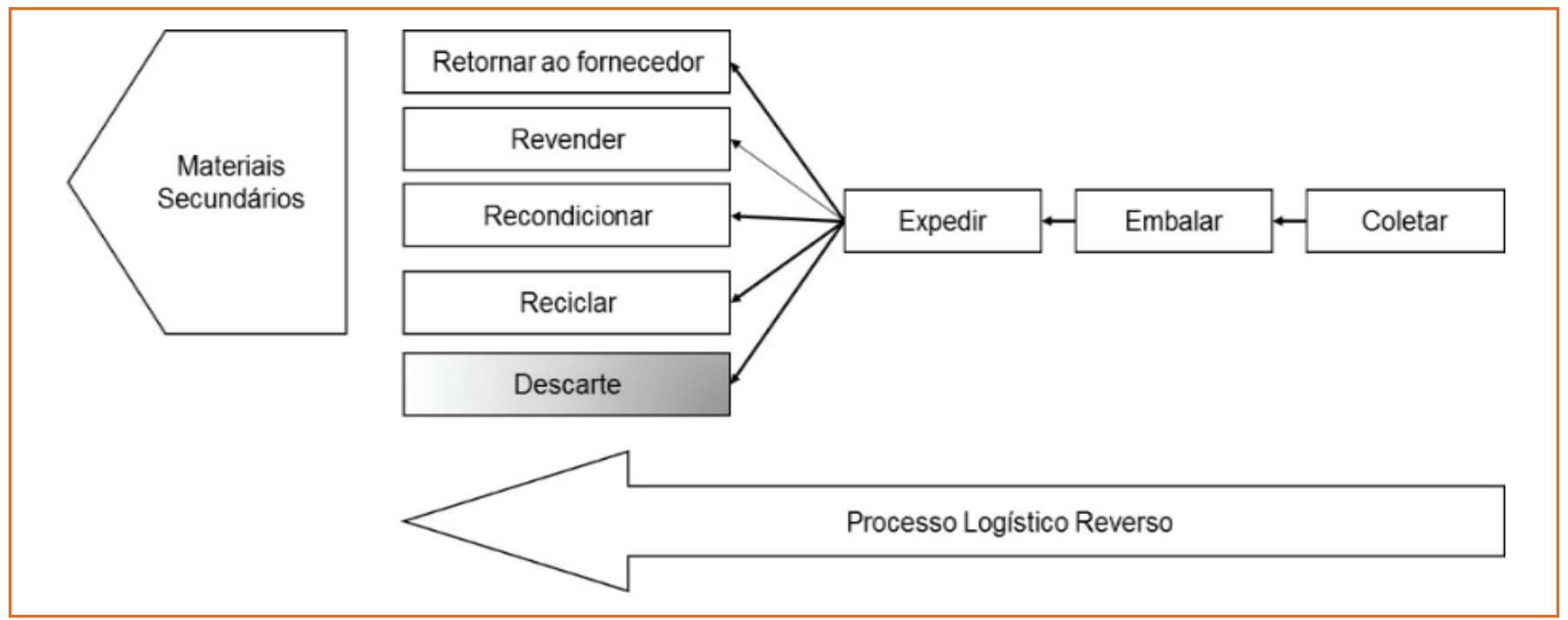

Fonte: Adaptado de LACERDA, 2002, p.478.

\subsubsection{CANAIS DE DISTRIBUIÇÃO REVERSOS PÓS- VENDA}

A logística reversa de pós-venda tem como característica o retorno de produtos com pouco ou nenhum uso e que apresentaram problemas de responsabilidade do fabricante ou distribuidor ou, ainda, por insatisfação do consumidor com os produtos (ROGERS e TIBBEN-LEMBKE,1998). Denomina-se de logística reversa de pós-venda a área específica de atuação que se ocupa do equacionamento e operacionalização do fluxo físico e das informações logísticas correspondentes de bens de pós-venda, sem uso ou com pouco uso, os quais por diferentes motivos, retornaram aos diferentes elos da cadeia de distribuição direta. Podemos identificar na figura 3, as áreas de atuação da logística reversa e as etapas do pós-consumo e do pós-venda, caracterizando suas etapas e o ciclo reverso do processo. 
Figura 3 - Atividades típicas do processo logístico reverso

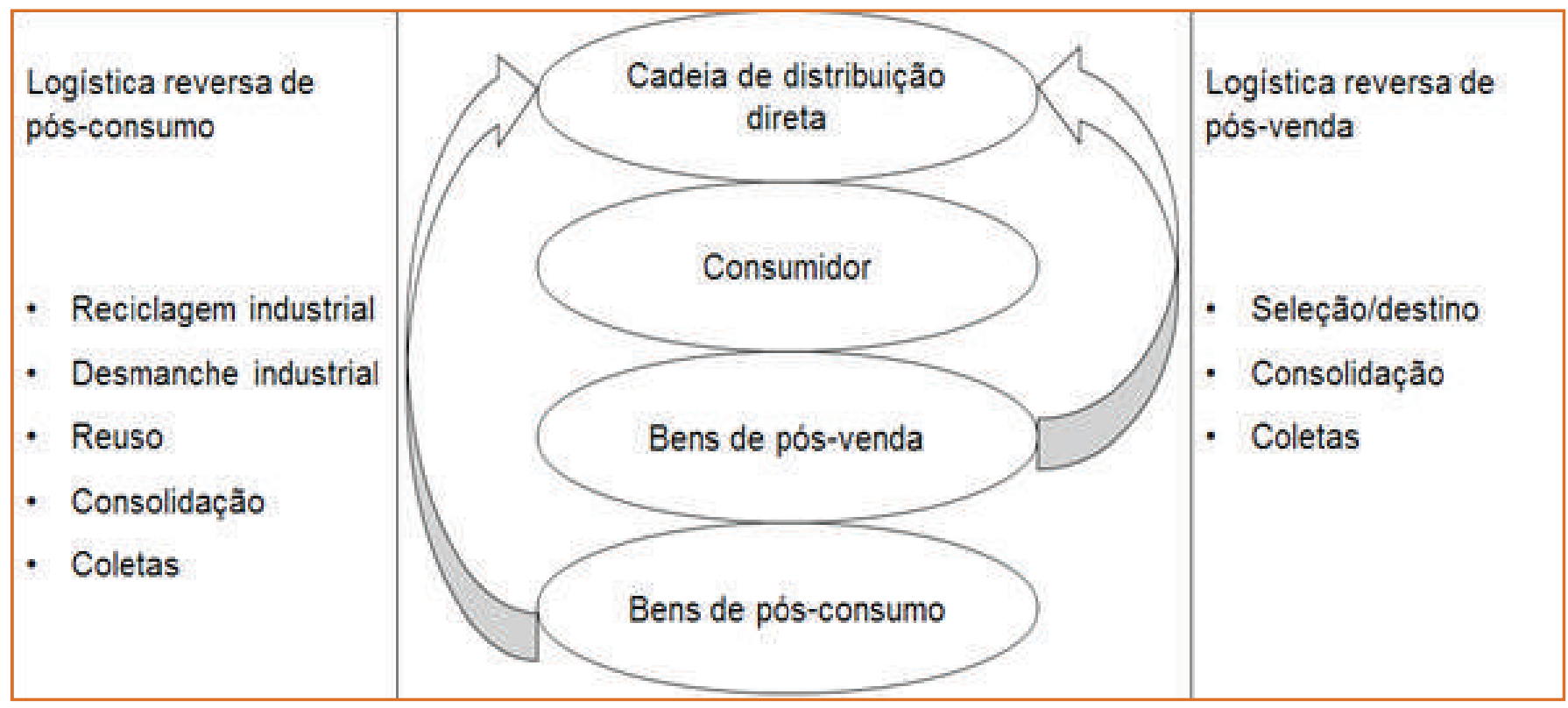

Fonte: Adaptado Leite, 2003, p17

\section{2- DISTRIBUIÇÃO FÍSICA}

Conforme Novaes (2007 apud GOMES et al., 2012, p.3),ressalta que "algumas empresas, em meados dos anos 50, depararam-se com a necessidade de transportar seus produtos da fábrica para o depósito ou para as lojas de seus clientes". Desde então, a logística evoluiu todos os seus conceitos, processos de operação e filosofias, sendo um deles a agregação de valor ao produto, separada em valor de lugar, tempo, qualidade e informação NOVAES (2007 apud GOMES et al., 2012, p.3). Segundo Kobayashi (2000 apud HENRIQUE, 2005, p.23), o sistema de distribuição física é formado por "percursos logísticos", "bases logísticas" e por um "sistema de gestão", conforme a figura 4.

Figura 4- Estrutura de distribuição física
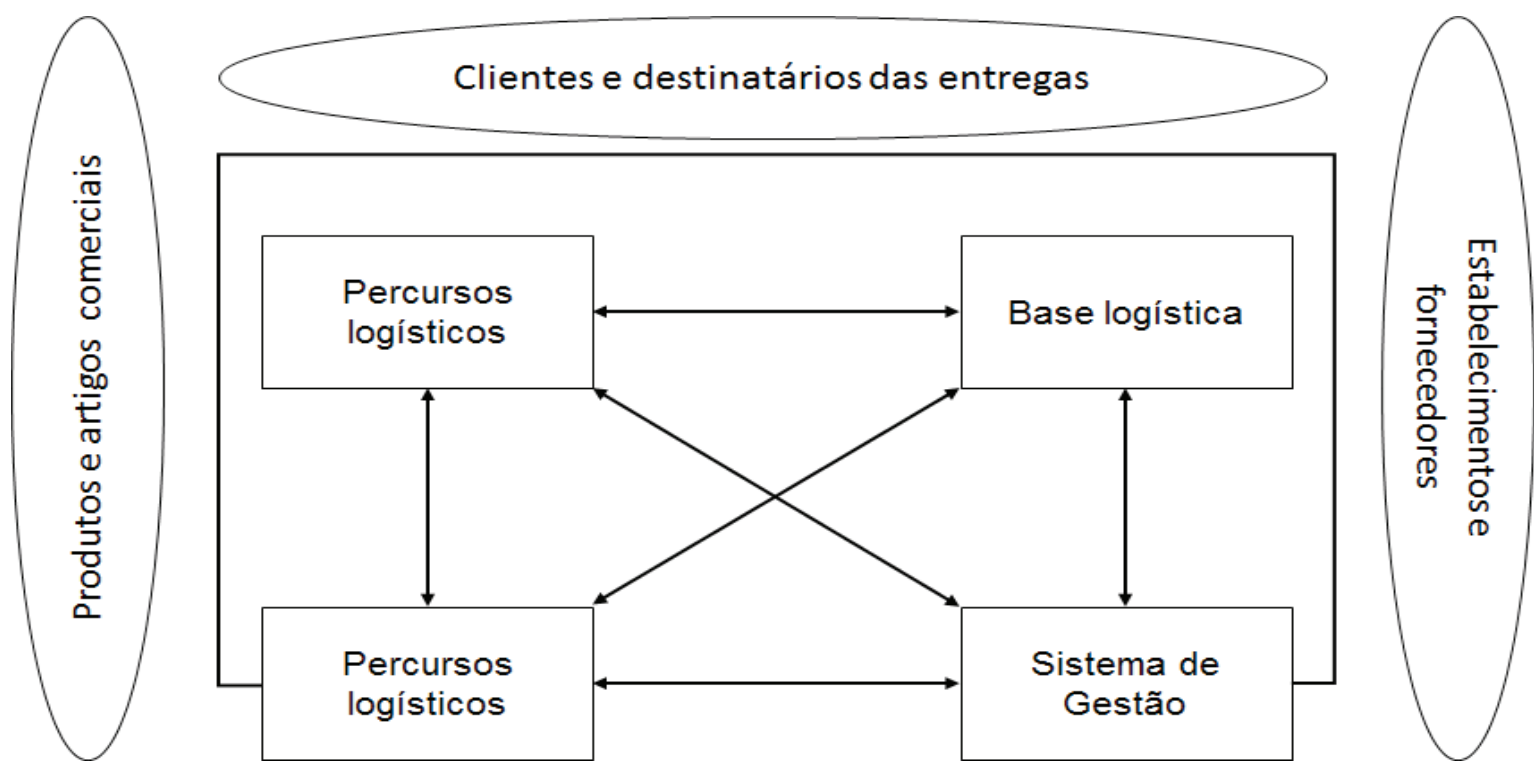

Fonte: Kobayashi (2000 apud HENRIQUE, 2005, p.23). 
Novaes (2007 apud GOMES et al., 2012, p.4), explica que "nas operações de distribuição física, temos empresas varejistas, transportadoras e atacadistas, que se caracterizam pela distribuição, recebendo as mercadorias e distribuindo-as de forma fracionada".A cadeia de distribuição clássica se forma por um canal de apenas um nível, ou seja, entre o fabricante e o consumidor existe apenas o varejista, fazendo papel de intermediário (NOVAES, 2007 apud GOMES et al, 2012, p.4). Entretanto, para Ballou (2009 apud GOMES et al., 2012, p.4), "a distribuição abrange vários níveis, sendo que o varejista não é o único intermediário, e em alguns casos há um canal direto entre o fabricante e o cliente".

\subsection{REMANUFATURA}

A remanufatura é uma estratégia de fim-de-vida do produto que reduz o uso de matérias-primas e energia de maneira geral. O interesse econômico da remanufatura se deve à preservação total ou parcial do valor agregado ao produto durante seu design e manufatura. Kerr e Ryan (2001), consideram a remanufatura a maneira mais eficaz de manter os produtos em um ciclo fechado. Pela remanufatura os produtos são restaurados para a condição de novos e possuem a mesma função e a mesma qualidade de produtos novos. Dessa forma, a remanufatura de peças e produtos reduz o custo ambiental e econômico tanto na manufatura de produtos novos quanto na sua disposição final.
Considerando a remanufatura nas indústrias, Sundin (2004), informa que o processo de remanufatura é um processo industrial em que volumes consideráveis de produtos similares são reunidos, desmontados e recuperados a fim de ter uma nova vida útil. O produto usado recolhido, chamado de core, é inspecionado e desmontado e então passa pelas seguintes etapas: testes, reparos, limpeza, inspeção das partes, atualização, substituição de peças e remontagem.

O segmento de produtos remanufaturados atualmente atende uma pequena participação no mercado. De acordo com Leite (2009), consequentemente, ações convenientemente dirigidas à preservação ambiental dentro dessa visão contributiva de marketing social e ambiental, certamente serão recompensadas com salutares retornos de uma imagem diferenciada como vantagem competitiva.

\subsubsection{O sistema da remanufatura}

O sistema da remanufatura é mais amplo e mais complexo que o processo em si, pois envolve todos os processos internos e externos da produção, desde o recolhimento do produto usado até a distribuição e acompanhamento do produto remanufaturados. A figura 5 mostra o sistema de remanufatura, que é definido como o sistema de coleta de produtos usados, remanufatura do produto e entrega do produto remanufaturados ao cliente. 
Figura 5 - O sistema de remanufatura

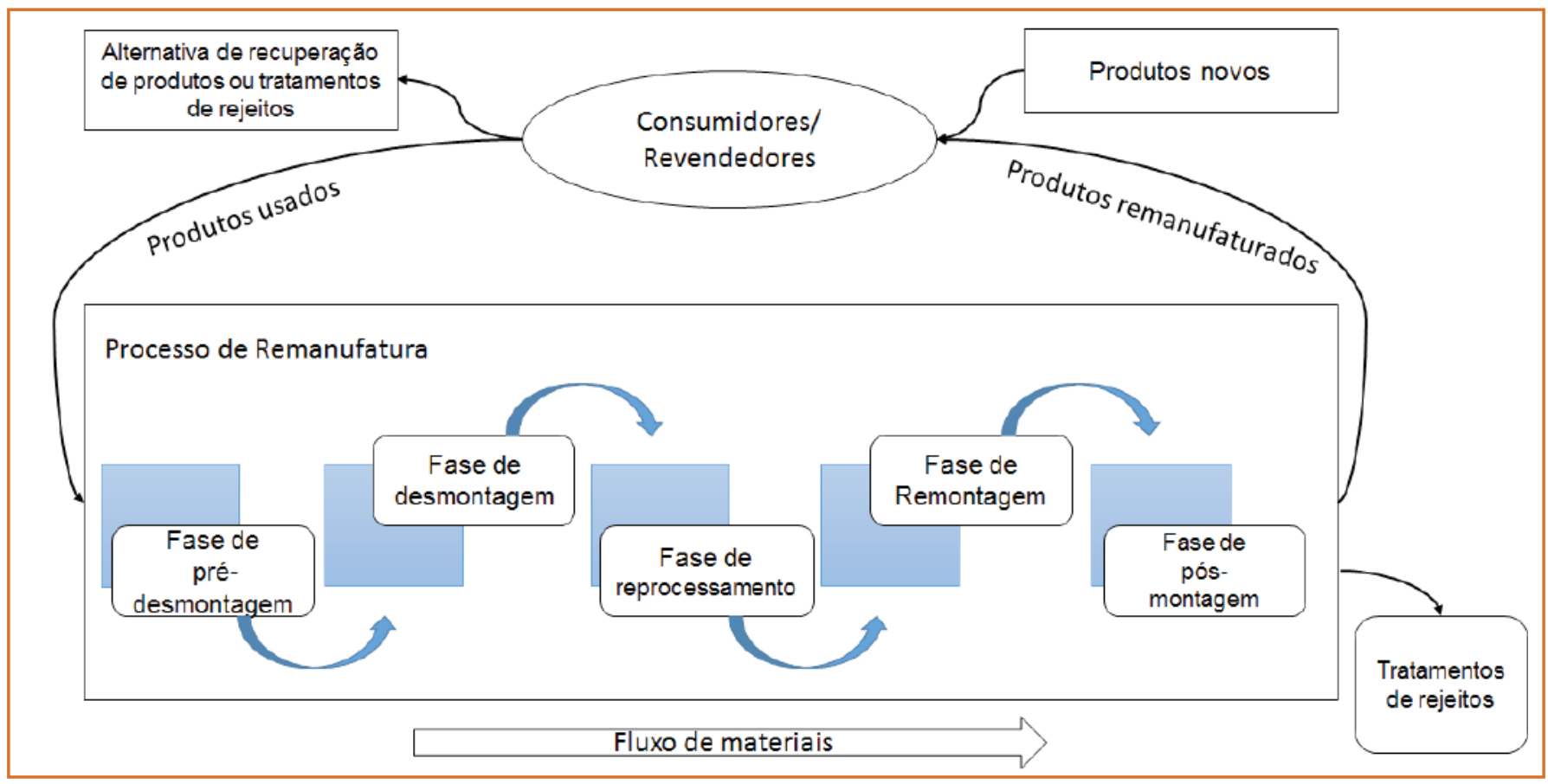

Fonte: adaptado de ÖSTLIN, 2008.

No planejamento tradicional, esclarecem Corrêa, Gianesi e Caon (1997), os produtos possuem uma lista técnica contendo a estrutura de componentes e a ficha de processos de fabricação.

Krikke (1998) estabelece cinco níveis em que os produtos retornados podem ser recuperados: nível de produto, módulo, partes, recuperação seletiva de partes e material.

\subsubsection{MOTIVOS PARA REMANUFATURAR}

As principais motivações que levam as empresas a se engajar na remanufatura são econômicas, ecológica ou relativas às legislações e normas. Östlin, Sundin e Björkman (2008), salientam que a principal resposta dada por empreendedores quando questionados sobre os motivos pelo qual praticam a remanufatura é o retorno econômico. A remanufatura é capaz de acarretar reduções de custos tanto para o remanufaturador quando para o consumidor (ÖSTLIN,2008). Em muitos casos, de acordo com Östlin, Sundin e Björkman (2008), a remanufatura apresenta-se como uma política estratégica da empresa, e tem como objetivo proteger a marca e os produtos contra o mercado de segunda mão.
Produtos remanufaturados sem preocupações ambientais podem causar impactos negativos ao meio ambiente, especialmente quando se trata de produto cujo principal impacto ambiental está na fase de uso.

Os principais motivadores para que uma empresa ingresse em um sistema de remanufatura podem ser sintetizados em: lucro, políticas empresariais e considerações ambientais. Contudo, um sistema de remanufatura bem-sucedido não precisa estar fundamenta do nesses três aspectos.

\section{MÉTODOS E APLICAÇÕES PRÁTICAS}

Quando tratamos de produtos importados, na empresa estudada, o intervalo de tempo da expedição até o recebimento no centro de distribuição gira em torno de 90 a 120 dias dependo dos processos alfandegários. Em outros casos, alguma falha na produção resulta em produtos com problemas funcionais e com informações erradas, que no decorrer do processo passavam pelo centro de distribuição e eram relatados pelos clientes. Esses produtos são rejeitados e destinados ao descarte no final de cada mês. Em muitos casos aguardam um longo periódo devido as normas e legislações que balizam esse processo. Sendo uma problema 
para empresa, as pesquisas e aplicações poderão proporciona uma oportunidade de valoriazação desse produtos e colaborando com a sustentabilidade.

\subsection{CLASSIFICAÇÃO DOS DESCARTES}

O descarte dos produtos rejeitados que não são direcionados para a comercialização é realizado no final de cada mês. Essa venda tem a participação principal da área de Pós-Vendas da empresa que realiza um leilão com empresas interessadas em reutilização e que estão aptas para destinar o fim legal para os produtos. A quantidade de produtos do primeiro trimestre de 2015 atingiu 1.877 unidades, sendo que nesse mesmo periódo no ano de 2014 representava 556 unidades descartadas evidenciando um aumento de 237\% em 2015.

Estratificando os dados do histórico do ano 2014, podemos destacar os motivos que originaram 0 descarte desses produtos. Na figura 6 mostra-se o Gráfico de Pareto com motivos e a participação no acumulado geral dos produtos rejeitados descartados.
Figura 6 - Gráfico de Pareto do descarte por motivos

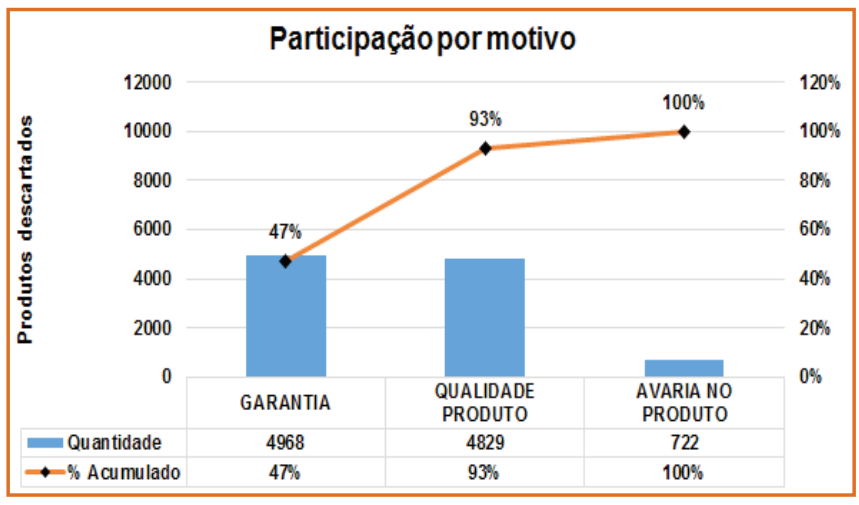

Fonte: primária.

Sabendo os índices e seus respectivos motivos, podemos destacar a possibilidade de recuperação de produtos na classificação de dois dos três motivos relacionados. Com o surgimento dessa oportunidade de recuperação, estudou as características de cada modelo conforme o quadro 1 , onde caracteriza-se cada os principais motivos de devolução.

Quadro 1 - Quadro de característica dos motivos e responsáveis

\begin{tabular}{|c|c|c|c|}
\hline MOTIVos & CARACTERÍSTICAS & $\begin{array}{l}\text { PRINCIPAL } \\
\text { MOTIVO }\end{array}$ & ÁREAS \\
\hline $\begin{array}{l}\text { Assistência } \\
\text { técnica / garantia }\end{array}$ & $\begin{array}{l}\text { Produtos de devoluções de assistência técnicas autorizadas pela empresa, sem } \\
\text { recuperação do produto. }\end{array}$ & Funcional & $\begin{array}{l}\text { Pós-Vendas / } \\
\text { Garantia }\end{array}$ \\
\hline $\begin{array}{l}\text { Qualidade do } \\
\text { produto }\end{array}$ & $\begin{array}{l}\text { Produtos de devoluções varejistas que apresentaram problemas funcionais ou de } \\
\text { alguma anomalia que desvia a característica de um produto novo ou completo, sendo } \\
\text { que o consumidor tem o prazo de troca estabelecido pelo varejista conforme o direito } \\
\text { do consumidor. }\end{array}$ & Funcional & $\begin{array}{l}\text { Pós-Vendas / } \\
\text { Garantia }\end{array}$ \\
\hline $\begin{array}{l}\text { Avarias no } \\
\text { produto }\end{array}$ & $\begin{array}{l}\text { Produtos de devoluções de varejistas e transportadoras que apresentaram avarias no } \\
\text { decorrer do ciclo de movimentação do produto ou algum sinistro durante o processo } \\
\text { de entrega. }\end{array}$ & Estético & $\begin{array}{l}\text { Pós-Vendas } \\
\text { / Garantia e } \\
\text { Qualidade }\end{array}$ \\
\hline $\begin{array}{l}\text { Produto } \\
\text { incompleto }\end{array}$ & $\begin{array}{l}\text { Produtos de devoluções varejistas ou transportadoras que apresentam a ausência de } \\
\text { acessórios e embalagens. Produtos de mostruário ou workshop. }\end{array}$ & Estético & Comercial \\
\hline
\end{tabular}

\subsection{NECESSIDADE DO ESTUDO}

Após realizar a coleta dos dados do primeiro trimestre do ano de 2015, a estratificação desses dados resultou em uma margem de produtos rejeitados por motivos que possibilitam uma tratativa e recuperação do produto, sendo que o descarte de avarias no produto correspondem $1 \%$, descarte por garantia representa

Fonte: primária.

$3 \%$ e o descarte por qualidade do produto totalizam $96 \%$.

A participação dos produtos de origem da "qualidade produto" representa $96 \%$ de todos dos descartes do primeiro trimestre do ano de 2015, representado pela quantidade de 1.800 unidades descartadas. Para entender esse índice, a figura 7 apresenta o diagrama 
de causa e efeito das devoluções por esse motivo de foco no motivo de qualidade do produto. qualidade e seus principais desvios e falhas com o

Figura 7 - Diagrama de causa e efeitos dos produtos descartados.

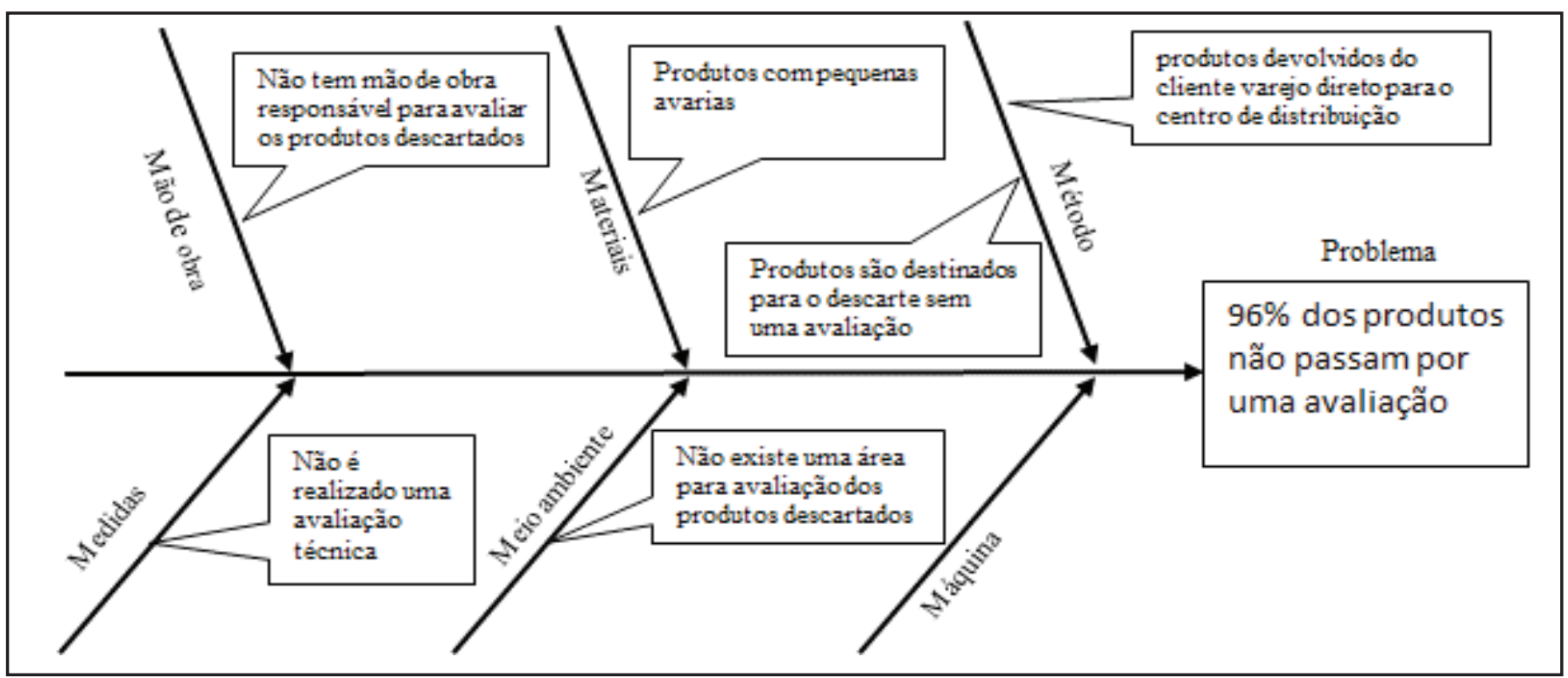

Fonte: primária.

Na figura 8 representou-se o processo de devolução por qualidade do produto. As etapas configuram as atividades que dão origem do produto para o seu descarte. A falta de critérios e avaliações nesse processo gera um passivo e um prejuízo no faturamento da empresa. 
Figura 8 - Mapa do processo de devolução de qualidade do produto

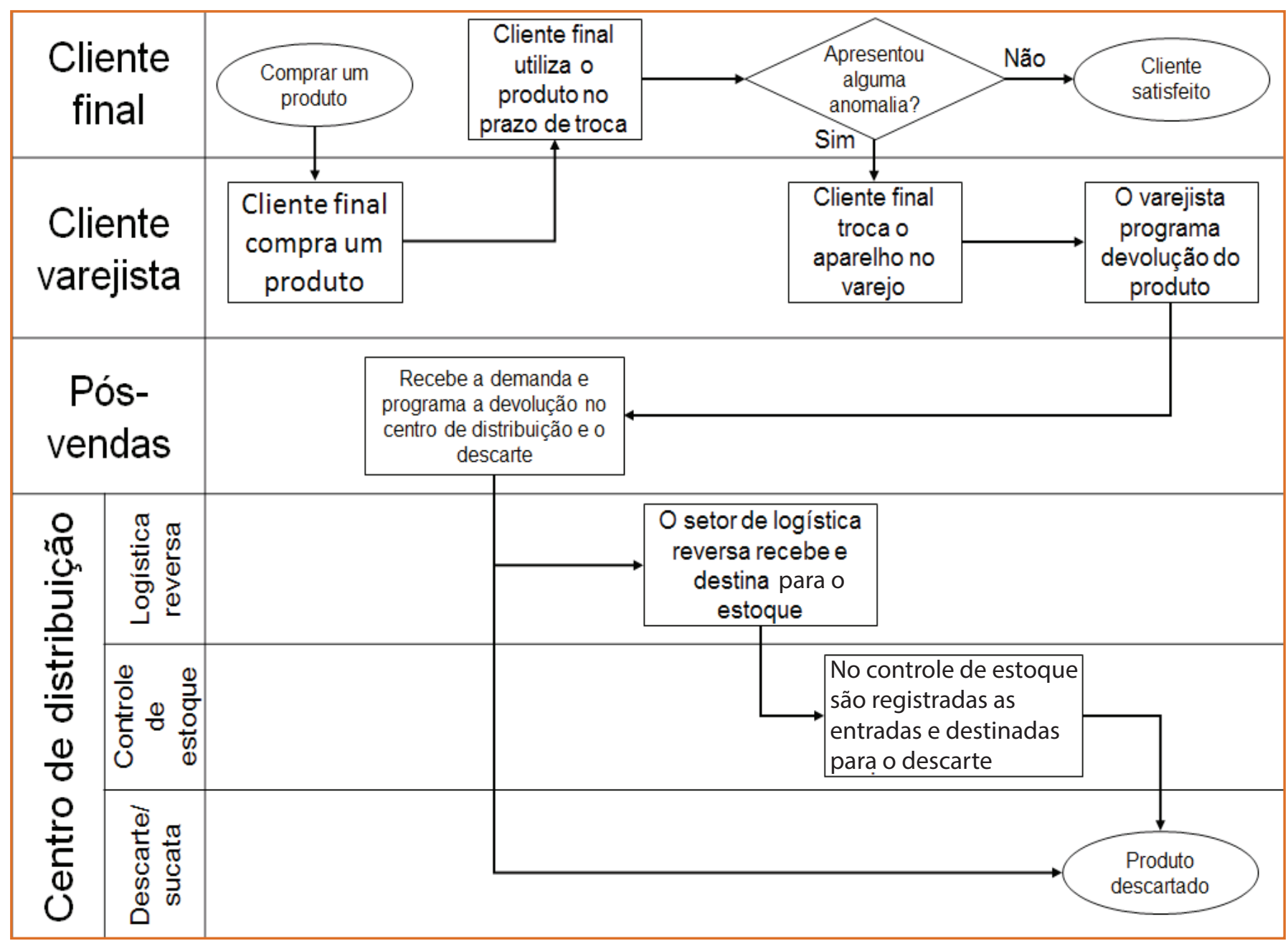

Fonte: primária.

\subsection{PROPOSTA DE REMANUFATURA}

A fim de reaproveitar os produtos rejeitados no centro de distribuição da empresa importadora de eletrodomésticos, a proposta em questão envolve vários setores diretamente para a aplicação e estruturação das atividades da remanufatura. A inicialização desse processo começa pela segregação dos produtos rejeitados em uma área determinada no estoque e que seja identificada por uma etiqueta diferenciada.

Um fator importante desse processo é a identificação diferenciada dos produtos que serão remanufaturados, assim que não ocorra uma mistura dos produtos rejeitados com os produtos no fluxo de faturamento. A segregação será vinculada com classificação e identificação por cada produto inspecionado. Sua classificação passará por três etapas de destinação o desenvolvimento das atividades. Com o propósito de remanufaturar os produtos rejeitados por motivo de qualidade e avarias no produto, a principal atividade é a inspeção funcional, onde já podemos descartar os produtos que não apresentam a possibilidade de remanufatura no primeiro estágio. Esse primeiro estágio é realizado com a orientação de um check-list idêntico ao realizado com os produtos importados no ato do recebimento. Dessa forma, podemos avaliar o produto com a visão de um novo.

Nesse primeiro estágio, o técnico responsável pela análise relaciona todas as necessidades para a recuperação simples do produto, podendo anotar desde uma troca de embalagem até a reposição de algum acessório faltante ou danificado. No segundo estágio, querefere-se aos produtos que não passaram pela aprovação na avaliação funcional, 
isto é, apresentaram algum tipo de falha nas funções básicas requisitadas nas orientações do check-list do produto. Nessa etapa, o técnico relata o problema do produto e verifica a possibilidade de recuperar o produto com a condição e utilização de peças e componentes disponíveis no momento. No último estágio do processo, o técnico classifica o produto para a desmontagem e reuso das peças reutilizáveis e descarta os materiais restantes para reciclagem. Nesse estágio o produto não apresenta a viabilidade de recuperação por apresentar problemas estruturais e técnicos de alto custo operacional. Porém, há a possibilidade de criação de um estoque de peças de reposição para suprir as necessidades do segundo estágio do processo de remanufatura, quando o técnico lista as necessidades para recuperar o produto.

Para um melhor entendimento, o Anexo Aapresenta a proposta do mapa do processo de remanufatura desenhado para o centro de distribuição de uma empresa importadoras de eletrodoméstico. Em um segundo momento, foram separados 100 produtos de qualquer modelo que foram rejeitados para o descarte. Nesse produtosforam realizadas inspeções conforme o processo proposto cujo resultado foi evidente que $47 \%$ dos produtos apresentavam características de recuperação, ou seja, apenas alguns reparos no seu sistema funcional, assim sendo remanufaturado no segundo estágio. Os produtos para remanufatura no primeiro estágio tiveram uma participação de $31 \%$, e outros $22 \%$ destinados para o reuso de peças, que será realizado no terceiro estágio.

\section{RESULTADOS POTENCIAIS}

Com a aplicação da proposta em prática, além do novo segmento que a empresa poderá atuar, mostrando sua competitividade e responsabilidade quanto a sustentabilidade, o retorno econômico será um recurso para manter os custos e projetar investimento para a aplicação da remanufatura em outros centros de distribuição e até mesmos nas outrasplantas fabris da empresa. Com isso, criando um ciclo sustentável em todos os seus segmentos de produtos. onde o tempo de entrega de peças para atender um cliente em especial poderá ser reduzido, caso no processo de remanufatura identifique-se necessidades para o atendimento. Uma das consequências importantes da aplicação da remanufatura no centro de distribuição é a criação de um estoque de peças remanufaturas para atender as assistências técnicas autorizadas da empresa. Com isso, otimiza-se todos os recursos proporcionados da remanufatura e reduzse o tempo de espera das peças requisitadas para a fábrica.

\section{CONCLUSÃO}

Através da pesquisa, procurou-se mostrar a logística reversa voltada à recuperação de produtos. O processo de logística reversa em questão caracterizou-se como sendo de devoluções, com foco na reutilização dos produtos inspecionados e rejeitados no centro de distribuição, por meio da atividade de remanufatura, cujos elementos direcionadores foram questões econômicas e de responsabilidade ambiental.

Assim, a atividade de remanufatura e logística reversa, que se resumem à combinação de eficiência econômica com respeito ao meio ambiente, passam pela busca da maior eficiência na utilização dos recursos de um sistema econômico.

Para a implantação da proposta é preciso o consenso de todas as áreas legais da empresa importadora de produtos eletrodomésticos. De modo que a comunicação e os interesses estejam alinhados e que isso se transforme em uma oportunidade para o investimento e a elaboração estrutural do processo, já que trata-se de um novo segmento.

A proposta condiz com os objetivos e visões da empresa, cujos resultados poderão sersignificativos quando comparados aos indicadores informados. O segmento, no entanto, é uma tendência das novas diretrizes ambientais governamentais que responsabiliza a empresa pelo o seu produto desde a criação até o seu pós-consumo.

As possibilidades dessa proposta, cria expectativas de expansão em outras unidades da empresa no 
intuito de minimizar os estoques de produtos rejeitados estruturando o processo de remanufatura em todas as linhas de produtos.

\section{REFERÊNCIAS}

[1] CORRÊA, H.; GIANESI, I. G. N. e CAON, M. Planejamento, programação e controle da produção: MRP II/ERP- conceitos, uso e implantação. São Paulo:Gianesi Corrêa \& Associados: Atlas, 1997.

[2] GOMES, Daniel Marques et al. Análise do processo de roteirização em uma empresa atacadista. 2012. $18 \mathrm{f}$. Monografia (Especialização em Logística) - Faculdade Pitágoras, Uberlândia.

[3] HENRIQUE, Neide. Análise Descritiva da Distribuição Física dos Produtos da Empresa Equisul Indústria e Comercial Ltda. 2005. 79f. Monografia (Especialização em Administração) - Universidade do Vale do Itajaí, São José.

[4] KERR, W. e RYAN, C. Eco-efficiency gains fron remanufacturing: $A$ case study of photocopier remanufacturing at Fuji Xerox Australia. Journal of Cleaner Production, vol.9, p.75-81, 2001.

[5] KRIKKE, H. Recovery strategies and reverse logistics network design. Holanda: Beta - Institute for Business Engineeringand Technology Application, 1998.
[6] LACERDA, L. Logística reversa, uma visão sobre os conceitos básicos e as práticas operacionais. Centro de Estudos em Logística, COPPEAD UFRJ,2002. Disponível em: http://www.ilos.com.br.Acesso em: 14 de fevereiro de 2015.

[7] LEITE, P.R. Logística reversa: meio ambiente e competitividade. 2. Ed. São Paulo: Pearson/Prentice Hall, 2009.

[8] LEITE, P.R. Logística reversa: meio ambiente e competividade. São Paulo: Prentice Hall, 2003.

[9] ÖSTLIN, J. On Remanufacturing System: Analysing and Managing Material Flows and Remanufacturing Processes in Production Systems. Dissertação de mestrado, Linköping University: Linköping, Suécia: 2008.

[10] ÖSTLIN, J; SUNDIN, E e BJÖRKMAN, M. Business Drivers for Remanufacturing. Proceedings of CIRP Life Cycle Engineering Seminar - 15으 edition, Sidney, Australia: 2008.

[11] ROGERS, D. S., TIBBEN-LEMBKE, R. S. (1998) Going Backwards: Reverse Logistics Trends and Practices. University of Nevada, Reno- ManagemDisponível em: <http:// www.rlec.org/reverse.pdf>. Acessoem: 30 de janeiro de 2015

[12] SUNDIN, E. Product and Process Desing for Successful Remanufacturing PhD Dissertations, Linköping's Universitet, 2004 


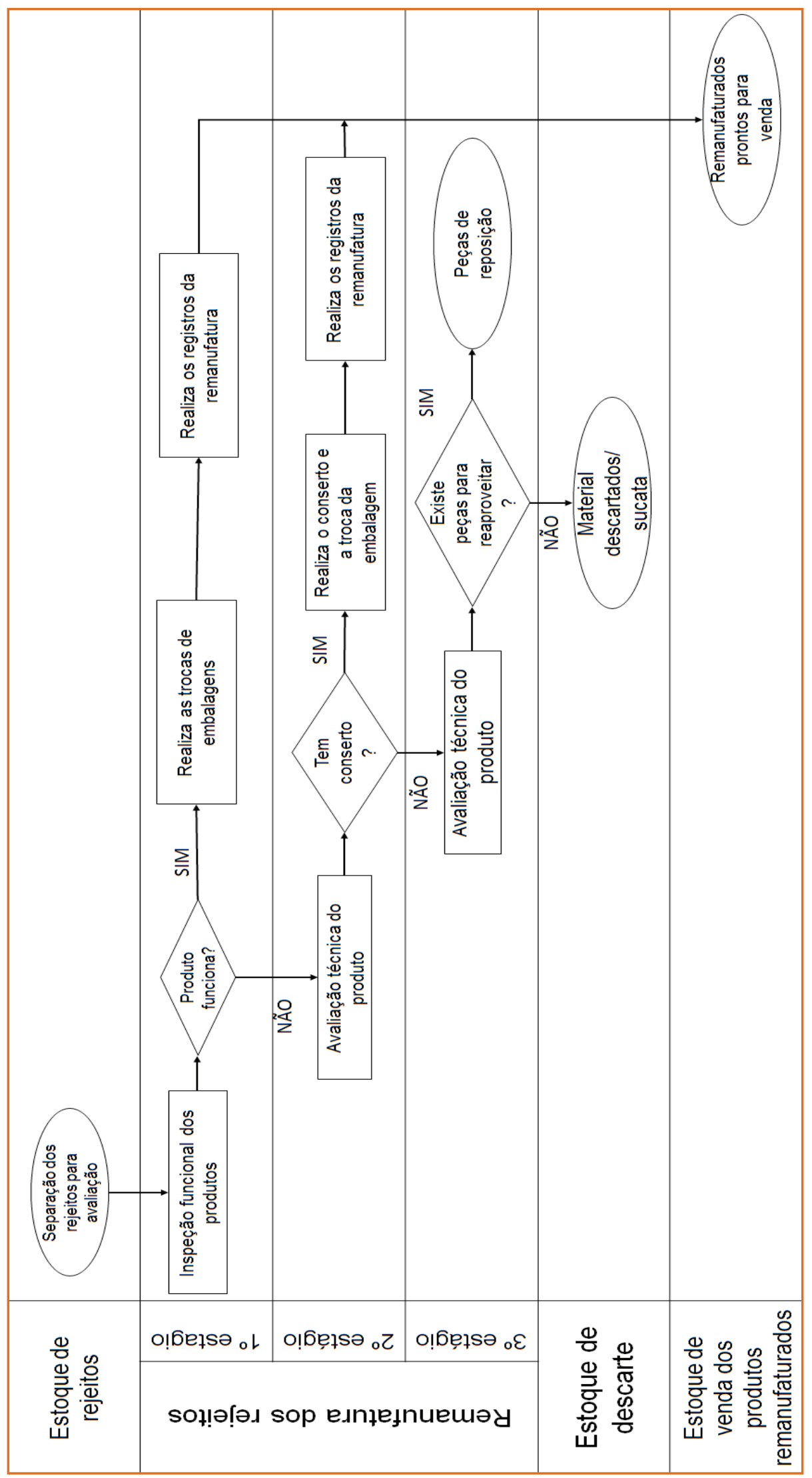

Fonte: primária. 


\section{CAPÍTULO 6}

INGORPORAÇÃO DOS PRINCÍPIOS LEAN NOS AMBIENTES MAKETO-STOCK (MTS) E MAKE-TO-ORDER (MTO) - UM ESTUDO COMPARATIVO EM UMA EMPRESA METALÚRGICA

André Luís Almeida Bastos

Guilherme César Silva Mendes

Resumo: Este trabalho buscou identificar o nível de internalização dos Principios Lean em dois ambientes de manuffatura (Make-to-Stock - MTS e Make-to-Order - MTO) de uma mesma organizaçáo. Utilizou-se de um questionário aplicados individualmente aos colaboradores, nos diferentes niveis hierárquicos da organização. Após a compilação de dados foi possível identificar que os princípios lean com maior nivel de incorporação no ambiente MTS são os principios 11 (Respeito entre parceiros), 2 (Fluxo contínuo) e 7 (Controle visual). Enquanto que no ambiente MTO os princípios com maior nivel de percepção de incorporação são os princípios 11. (Respeito entre parceiros) 10 (Desenvolvimento de pessoal) e 9 (Desenvolvimento de líderes). Através dos resultados obtidos, foi possível concluir que na organização estudada, a incorporação dos princípios lean tem acontecido de maneira distinta nos dois ambientes de manufatura.

Palavras chave: Princípios Lean, Ambientes de Manufatura, Make-to-Stock, Make-to-Order 


\section{INTRODUÇÃO}

A concorrência acirrada e os clientes cada vez mais exigentes têm forçado as empresas a buscarem por novas formas de gerir seus recursos e manteremse competitivas. O Lean Manufacturing constitui-se em um novo paradigma de gestão dos processos da organização, que tem sido implementado em inúmeras organizações no mundo inteiro, visando à manutenção da competitividade por meio da eliminação de desperdícios, defeitos e redução de estoques. Inicialmente a aplicação de seus conceitos na indústria automotiva, em um modelo de produção em massa, trouxe resultados expressivos, o que até então tem feito surgir inúmeros estudos relacionados ao comportamento dessa filosofia japonesa em ambientes de manufatura make-to-stock (MTS). Todavia, com o crescente numero de sistemas produtivos mais flexíveis, tais como o que encontra-se no ambiente de manufatura Make-to-Order (MTO), há a necessidade de estudo desta filosofia nestes diferente modelos de sistemas produtivos.

Spear e Bowen (1999) e Ghinato (2000) afirmam que a simples aplicação de práticas oriundas do Lean Mnufacturing não garante que este paradigma esteja implementado e, segundo Womack e Jones (2004), as maiores dificuldades enfrentadas pelas empresas que estão implementando o Lean Manufacturing são devido à falta de compreensão dos princípios fundamentais da filosofia. Quando a incompreensão de tais princípios ocorre já desde a liderança da organização, é de se esperar que encontre capilaridade nos diversos níveis hierárquicos, ameaçando o pleno êxito da incorporação do paradigma enxuto em toda a organização.

Neste sentido, torna-se relevante diagnosticar o nível de incorporação dos quatorze princípios Lean entre os diferentes tipos de ambientes de manufatura (MTO e MTS) de uma organização, de tal forma a verificar os princípios melhor incorporados, bem como os menos incorporados, de tal forma a identificar se a maior ou menor incorporação destes principios corroboram para as particularidades de cada um destes ambientes de manufatura. Dessa forma, o objetivo geral deste trabalho consiste em avaliar o nível de percepção da incorporação dos princípios Lean em dois diferentes ambientes de manufatura de uma mesma organização.

\section{REVISÃO BIBLIOGRÁFICA}

\subsection{LEAN MANUFACTURING E PRINCÍPIOS LEAN}

O lean manufacturing consiste numa filosofia, originada no Sistema Toyota de Produção, e que tem sido aplicada em diversos tipos de sistemas produtivos como uma estratégia operacional visando o incremento dos níveis de qualidade dos produtos, da produtividade e, conseqüente, da competitividade, por meio de criação de fluxos contínuos. Intrinseco à filisofia lean, há um conjunto de estratégias que tem como objetivo eliminar desperdícios nos processos, nos produtos e na organização, possibilitando a empresa atender, de forma competitiva, as necessidades de cada cliente (HINES e TAYLOR, 2000; SILVA, 2008). Numa visão operacional, Vollmann (2006) aponta que o objetivo é reduzir significamente os níveis de estoque e os tempos de processamento e respostas às necessidades dos clientes, tudo isso com menos mão-de-obra e menos utilização de recursos.

Womack e Jones (2004) salientam ainda que a participação do funcionário na aplicação do pensamento enxuto, internalizando seus princípios, é de extrema importância para a construção e sustentação da cultura Lean na organização. E segundo Ouchi (1982) os fatores culturais também interferem na implementação de um novo modelo de produção, devendo ser dada extrema importância para a administração de pessoas e da cultura existente, objetivando compreender as particularidades na fase de implementação de qualquer modelo que seja adotado.

Os 14 princípios do Modelo Toyota de Produção, apontados por Liker (2005), que amparam a aplicação do Lean Manufacturing são: 1ํ) Basear as decisões administrativas em uma filosofia de longo prazo, mesmo em detrimento de metas financeiras de curto prazo; $2^{\circ}$ ) Criar um fluxo de processo contínuo para trazer os problemas à tona; $3^{\circ}$ ) Usar sistemas puxados para evitar a superação; $4^{\circ}$ ) Nivelar a carga de trabalho - trabalhar como a tartaruga, não como a lebre; 5) Construir uma cultura de parar e resolver os problemas, obtendo a qualidade logo na primeira tentativa; 6으) Tarefas padronizadas são a base para a melhoria contínua e a capacitação dos funcionários; 
$7^{\circ}$ ) Usar o controle visual para que nenhum problema fique oculto; 8o) Usar somente tecnologia confiável e completamente testada que atenda aos funcionários e processos; 9) Desenvolver líderes que compreendam completamente o trabalho, que vivam a filosofia e a ensinem aos outros; 10) Desenvolver pessoas e equipes excepcionais que sigam a filosofia da empresa; 11ㅇ) Respeitar a sua rede de parceiros e de fornecedores desafiando-os e ajudando-os a melhorar; 12) Ver por si mesmo para compreender totalmente a situação; 13) Tomar decisões lentamente por consenso considerando completamente todas as opções e implementá-las com rapidez; 14ํ) Tornarse uma organização de aprendizagem por meio da reflexão incansável (Hansei) e da melhoria contínua (Kaizen). É importante frisar que, segundo Mann (2005), a absorção dos princípios enxutos pela cultura organizacional é um processo bastante lento, e dessa forma, recorre-se primeiramente à implementação de práticas e ferramentas enxutas.

Um grande obstáculo identificado na implantação da filosofia lean nas empresas, segundo diversos estudiosos, consiste no aspecto cultural das pessoas (ACHANGA et al, 2006; MANN, 2005), as quais, invariavelmente oferecem resistências ao rompimento com os antigos paradigmas de gestão da produção. De fato, Ohno (1997) já havia observado que um dos principais empecilhos na adoção desta filosofia nos sistemas produtivos ocidentais consiste nas diferenças culturais significativas entre as empresas japonesas e americanas, o que trouxe insucesso na aplicação da filosofia lean em algumas tentativas.

O trabalho de Sellitto et al.(2010) aponta que resultados de pesquisas empíricas revelam que apenas cerca de $10 \%$ das empresas de manufatura tem sido bemsucedidas na implementação do Lean Manufacturing, atribuindo-se a este resultado o fato desta filosofia não constituir-se apenas em ferramentas e técnicas mas, que exige uma mudança de postura empresarial, em muitos casos negligenciada. Ainda segundo este trabalho, a implementação da mentalidade enxuta requer elementos constitutivos baseados em gerenciamento interfuncional, trabalho em equipe, desenvolvimento organizacional, estratégia e cultura de melhoria contínua.

\subsection{AMBIENTES DE MANUFATURA}

Numa organização, as atividades de gerenciamento da demanda devem combinar com a estratégia definida pela empresa, com a capacidade produtiva e com as necessidades dos clientes. Tais elementos definem quatro diferentes ambientes de Manufatura, a saber: MTS (Make-to-Stock), ATO (Assemble-to-Order), MTO (Make-to-Order) e ETO (Engineering-to-Order). No presente trabalho descreve-se as características dos ambientes MTS e MTO, baseando-se em Martins e Laugeni (2006).

No ambiente Make-to-Stock (MTS), são produzidos produtos padronizados baseados em previsões de demandas e nenhum produto customizado é produzido. Este ambiente apresenta a vantagem da rapidez na entrega dos produtos, com atendimento do pedido do cliente quase imediato, mediante a retirada do produto acabado do estoque. Além disso, o lead time é muito reduzido, sendo ideal para a gestão de produtos com demanda bastante previsível. Entretanto, o volume de estoques a serem mantidos para o pronto atendimento pode significar um grande volume de capital investido haja vista que os pedidos são feitos com base no estoque de produtos acabados e a interação com dos clientes com os projetos dos produtos é muito pequena e/ou rara.

No ambiente make-to-order (MTO), o projeto básico pode ser desenvolvido a partir dos contatos iniciais com os clientes, mas a produção só começa após o recebimento formal do pedido (chegada do pedido firme). Neste caso, os prazos de entrega tendem a ser longos, pois os produtos costumam ser projetados ao mesmo tempo em que estão sendo produzidos e a interação do cliente com o projeto dos produtos é bem extensiva. Este ambiente de manufatura possui a vantagem de se trabalhar com baixos estoques de produtos acabados, sendo adequado para produtos com demanda pouco frequente, que possuem alto custo de estocagem ou que são perecíveis. Para fins de gestão de estoques, a empresa deverá fazer previsões a respeito das MP e dos componentes mais críticos, adquiri-los e estocá-los. 


\section{PROCEDIMENTOS METODOLÓGICOS}

Para este estudo foi adotada a pesquisa exploratória, a fim de mapear melhor a situação da empresa em estudo. Dessa forma, tem como base o estudo de caso e, quanto à abordagem, a pesquisa é quantitativa.

Para obtenção dos resultados foi aplicado um questionário elaborado por Bastos e Barbetta (2014) sobre a incorporação dos 14 (catorze) princípios da filosofia Lean - conforme ilustrado no Anexo, em uma empresa metalúrgica que contenha os dois ambientes de manufatura e que já iniciou o processo de implantação do Lean Manufacturing. As perguntas foram respondias em escala, sendo a opção um discordo totalmente até a opção cinco concordo totalmente, os dados gerados pelo questionário foram tabulados s para análise e comparação de resultados.

O questionário aplicado para análise dos objetivos propostos neste trabalho foi aplicado individualmente aos gestores e operadores das áreas operacionais de interesse da pesquisa, sendo respondido por supervisores, líderes, processistas e operadores das respectivas áreas. Do ambiente MTS foram entrevistados 49 pessoas do grupo de operadores e 5 pessoas do grupo de líderes, enquanto que no ambiente MTO foram entrevistados 39 pessoas do grupo de operadores e 9 pessoas do grupo de líderes. A média dos resultados foi calculada entre todas as respostas por princípio e, calculados o desvio padrão e o coeficiente de variação, de acordo com as equações (1) e (2), respectivamente, para mensurar a variabilidade entre as respostas dos entrevistados (BARBETTA, 2002).

$$
\begin{array}{r}
\text { Desvio padrão }(\mathrm{s})=\sqrt{\frac{\sum\left(\mathrm{x}_{\mathrm{i}}-\mathrm{x}\right)^{2}}{\mathrm{~N}-1}} \text { equação } 1 \\
\qquad v=100 \cdot \frac{\mathrm{s}}{\bar{X}} \text { equação 2 }
\end{array}
$$

\section{RESULTADOS \\ 4.1 RESULTADOS DO AMBIENTE MAKE-TO-STOCK}

O ambiente MTS obteve o nível de incorporação dos princípios lean propostos por Liker (2005) em 3,77 pontos de média, resultado considerando a classificação de 1 (pontuação mínima) até 5 (pontuação máxima) indicada pela escala do questionário aplicado. Como pode ser observado na Tabela 1, os princípios com um maior nível de percepção de incorporação no ambiente MTS são os princípios 11, com média 4,19 pontos, o princípio 2, com média de 4,15 pontos.

\begin{tabular}{|c|c|c|c|c|}
\hline & PRINCÍPIO & MÉDIA & DEV. PAD. & C.V (\%) \\
\hline 1 & Filosofia de longo prazo & 3,54 & 1,07 & 29,32 \\
\hline 2 & Fluxo continus & 4,15 & 1,20 & 31, 6 B \\
\hline 3 & Sistema puxado & 3,51 & 1,20 & 34,15 \\
\hline 4 & Nivelamento de trabalho & 3,99 & 1,34 & 37,06 \\
\hline 5 & Cultura de parar e resolver & 2,98 & 1,54 & 49,27 \\
\hline 6 & Padhonizaçäo das atividades & $3, \mathbf{8 8}$ & 1,15 & 29,73 \\
\hline 7 & Controle visual & 4,06 & 1,20 & 29,83 \\
\hline 8 & Temologịa confiâuel & 3,91 & 1,26 & 33,26 \\
\hline 9 & Desenvolvimento de líderes & 3,63 & 1,32 & 39,53 \\
\hline 18 & Desemolvimento de pessoas & 3,95 & 1,21 & $\mathbf{3 2 , 3 9}$ \\
\hline 11 & Respeito entre parceiros & 4,19 & 1,06 & 26,00 \\
\hline 12 & Observaçāo pessoal & 3,45 & 1,28 & 38,96 \\
\hline 13 & Decisões por consenso & 3,61 & 1,21 & 33,87 \\
\hline 14 & Melhoria continua & 3,88 & 1,20 & $\mathbf{3 2}, \mathbf{\pi}$ \\
\hline
\end{tabular}

Tabela 1 - Resultado geral do ambiente de manufatura Make-to-Stock 
O princípio 11, que aborda o respeito entre parceiros foi o princípio que se destacou com o maior nível de internalização entre os setores incluídos no ambiente MTS, porém deve-se ressaltar que o princípio 11 obteve um coeficiente de variação de $26 \%$ entre as respostas, que segundo Martins e Domingues (2011), é considerado um valor médio de coeficiente de variação. Pode-se concluir que há uma divergência razoável de percepção entre os entrevistados a respeito deste princípio.

O princípio 2, que aborda o fluxo contínuo no sistema produtivo foi o segundo princípio com maior pontuação no ambiente MTS com a nota de 4,15 pontos, em contrapartida este princípio apresentou um coeficiente de variação de $31,6 \%$ entre as respostas, que segundo Martins e Domingues (2011) é um valor alto. Sendo assim, este princípio apresenta destaque frente aos outros no ambiente MTS, porém com uma alta divergência entre os entrevistados. De acordo com Martins e Laugeni (2005) os produtos do ambiente MTS são padronizados e nenhum produto customizado é produzido neste ambiente, com base nesta fundamentação, entende-se o fato de o princípio 2 obter uma alta pontuação neste ambiente, uma vez que os produtos e processos contidos nos setores dentro deste ambiente são singulares, torna-se facilitado a execução de equalização e sincronização de operações visando um fluxo continuo.

Os princípios com maiores oportunidades de melhoria no ambiente MTS foram os princípios 5, 12 e 3. Com pontuações de 2,98; 3,45 e 3,51 respectivamente.

O princípio 5, que trata da cultura de parar e resolver os problemas obteve o menor desempenho entre os 14 princípios lean no ambiente MTS, porém o coeficiente de variação observado entre as respostas foi de $49,3 \%$, valor que é considerado alto. Portanto, o princípio 5 apresentou o pior desempenho no ambiente MTS com uma alta divergência de opiniões entre os entrevistados. Segundo Martins e Laugeni, o ambiente MTS trabalha com um alto nível de estoques de produto. Segundo Ohno (1997), os defeitos gerados durante o processo acabam sendo encobertos devido ao estoque elevado, dificultando desta forma, a visualização dos defeitos em sua origem e a tomada de ações. Um ponto de discordância encontrado na baixa pontuação deste princípio, foi o fato de o princípio do controle visual ter obtido uma pontuação elevada, frente a estes resultados, pode-se concluir que as informações levantadas no controle visual do ambiente MTS na organização pesquisada não são utilizados de forma a tomada de ações corretivas imediatas no processo.

O princípio 12, que aborda a observação pessoal, obteve o segundo pior desempenho no ambiente MTS, apresentando um coeficiente de variação de 38,9\%, demonstrando que há uma grande divergência de opiniões entre os entrevistados quanto a este princípio. Relacionando a baixa pontuação do princípio 12 , com a baixa pontuação do princípio 5, cultura de parar e resolver e a alta pontuação do princípio 7 , controle visual, conclui-se que no ambiente MTS da organização pesquisada, existe o uso da ferramenta de identificação de problemas, porém os resultados não são observados e utilizados para medidas de correção imediata em sua totalidade.

\subsection{RESULTADOS DO AMBIENTE MAKE-TO-ORDER}

O ambiente de manufatura MTO obteve o nível de incorporação dos princípios lean propostos por Liker (2005) em 3,41 pontos de média, resultado considerando a classificação de 1 (pontuação mínima) até 5 (pontuação máxima) indicada pela escala do questionário aplicado. Como pode ser observado na Tabela 2, os princípios com maior percepção de incorporação no ambiente MTO são os princípios 11, com média 3,94 pontos, o princípio 10, com média de 3,82 pontos. 


\begin{tabular}{|c|c|c|c|c|}
\hline & PRINCÍPIO & MÉDIA & DEV. PAD. & C.V $(\%)$ \\
\hline 1 & Filosofia de longo prazo & 3,65 & 1,17 & 32,00 \\
\hline 2 & Fluxe contíne & $\mathbf{3 , 1 4}$ & 1,31 & 41,49 \\
\hline 3 & Sistema puxado & 2,37 & 1,36 & 57,41 \\
\hline 4 & Nivelamento de trabalho & 3,52 & 1,37 & 39,066 \\
\hline 5 & Cultura de parar e resolver & 3,04 & 1,52 & 49,68 \\
\hline 6 & Padhonizaçäo das atividades & $\mathbf{3 , 4 1}$ & 1,21 & 34,59 \\
\hline 7 & Controle visual & 3,65 & 1,24 & 33,95 \\
\hline 8 & Tecrologia confiấwel & $\mathbf{3 , 5 3}$ & 1,19 & 33,42 \\
\hline 9 & Desenvolvimento de líderes & 3,70 & 1,31 & 38,41 \\
\hline 10 & Deserwolvimento de pessoas & 3,82 & 1,31 & $\mathbf{3 6 , 5 1}$ \\
\hline 11 & Respeito entre parceiros & 3,94 & 1,25 & 33,21 \\
\hline 12 & Observaçāo persoal & 3,39 & 1,29 & 46,56 \\
\hline 13 & Decisőes por consenso & 3,16 & 1,37 & 45,76 \\
\hline 14 & Melhoria contína & 3,49 & $1,4 B$ & 42,91 \\
\hline
\end{tabular}

O princípio 11, que aborda o respeito entre parceiros foi o princípio destaque entre os demais princípios no ambiente MTO, porém o coeficiente de variação apresentado entre as respostas foi de 33,2\%, que segundo Martins e Domingues (2011) é um valor elevado. Conclui-se que apesar deste princípio apresentar a maior pontuação de percepção de incorporação entre os demais, as opiniões entre os entrevistados apresentam uma alta divergência entre si.

O princípio 10, que diz respeito ao desenvolvimento de pessoas obteve o segundo maior resultado no ambiente MTO, segundo Martins e Domingues (2011), o valor de $36,5 \%$ do coeficiente de variação apresentado entre as respostas obtidas para este princípio é elevado. Portanto, chega-se à conclusão de que o princípio 10 apresenta um alto índice de incorporação frente aos demais princípios no ambiente MTO, porém com elevado grau de divergência de opiniões entre os entrevistados.

Os princípios com maiores oportunidades de melhoria no ambiente MTO foram os princípios 3, 5 e 13. Com pontuações de 2,37; 3,04 e 3,16 respectivamente.

O princípio 3, sistema puxado, obteve o pior desempenho no ambiente MTO, porém deve-se ressaltar que o coeficiente de variação apresentado entre as respostas foi de 57,41\%, diante destas considerações, pode-se concluir que o princípio 3 apresenta uma baixa percepção de incorporação no ambiente MTS, porém com um elevado grau de divergência de opinião entre os entrevistados. Segundo Martins e Laugeni, os produtos fabricados no ambiente MTO costumam ser projetados ao mesmo tempo em que são produzidos, outro ponto em questão é a alta variabilidade de pedidos e quantidades demandadas, segundo Corrêa e Gianesi (1996), a estes parâmetros de produção a recomendação é a de se utilizar o sistema empurrado de programação da produção. Ao observar estas informações, justifica-se o baixo desempenho deste princípio no ambiente MTO.

O princípio 5, que aborda a cultura de parar e resolver, obteve a segunda menor pontuação no 
ambiente MTO. O valor do coeficiente de variação das respostas foi de $49,6 \%$, portanto pode-se concluir que este princípio não apresenta uma alta percepção de incorporação no ambiente MTO, porém com um elevado grau de divergência de respostas entre os entrevistados. Segundo Martins e Laugeni (2005), os prazos de entrega dos produtos no ambiente MTO costumam ser longos, frente ao baixo resultado apresentado em relação a incorporação do princípio 5 no ambiente MTO, pode-se concluir que a cultura de parar e resolver os problemas não está difundida nos setores que compõem este ambiente de manufatura, mesmo que teoricamente, haja tempo disponível para esta prática.

\subsection{COMPARAÇÃO DE RESULTADOS MAKE-TO- STOCK E MAKE-TO-ORDER}

De forma geral, o ambiente MTS obteve uma maior pontuação, com uma média de 3,77 pontos. O ambiente MTO obteve uma média de 3,41 pontos. O princípio 11 foi o princípio que obteve maior pontuação tanto no ambiente MTS, como no ambiente MTO e o princípio 5 esteve entre os três princípios com pior desempenho nos dois ambientes. O ambiente MTO obteve apenas no princípio 1 uma maior pontuação que o ambiente mts, nos outros princípios, o ambiente MTS obteve uma maior pontuação. No ambiente MTS, os princípios com maiores pontuações foram o 11, 2 e 7 , os princípios com menores pontuações foram o 5 ,
12 e 3. Enquanto no ambiente MTO os princípios com maiores pontuações foram os princípios 11, 10 e 9 e os princípios com menores pontuações foram o 3, 5 e 13. As pontuações obtidas pelos dois ambientes podem ser observadas na Figura 1.

Os princípios que apresentaram maior convergência de resultados entre os dois ambientes foram os princípios 5 e 12.

No princípio 12, observação pessoal, os ambientes MTS e MTO apresentaram os resultados mais próximos, com uma variação percentual de 1,79\% entre as duas pontuações. Sendo que o ambiente MTS obteve o resultado de 3,45 pontos, enquanto que o ambiente MTO obteve o resultado de 3,39 pontos.

No princípio 5, que aborda a cultura de parar e resolver, os dois ambientes apresentaram uma variação percentual de $1,83 \%$, sendo o segundo menor valor dentre os 14 princípios. O ambiente MTS obteve 2,98 pontos, enquanto que o ambiente MTO obteve 3,04 pontos. Em ambos os ambientes, este princípio apresentou uma baixa pontuação em relação aos demais princípios, o que demonstra que indiferente das singularidades inerentes a cada ambiente de manufatura, o fato de a cultura de parar e resolver problemas não está disseminada totalmente na organização como um todo. 


\section{Comparação de Resultados MTS x MTO}

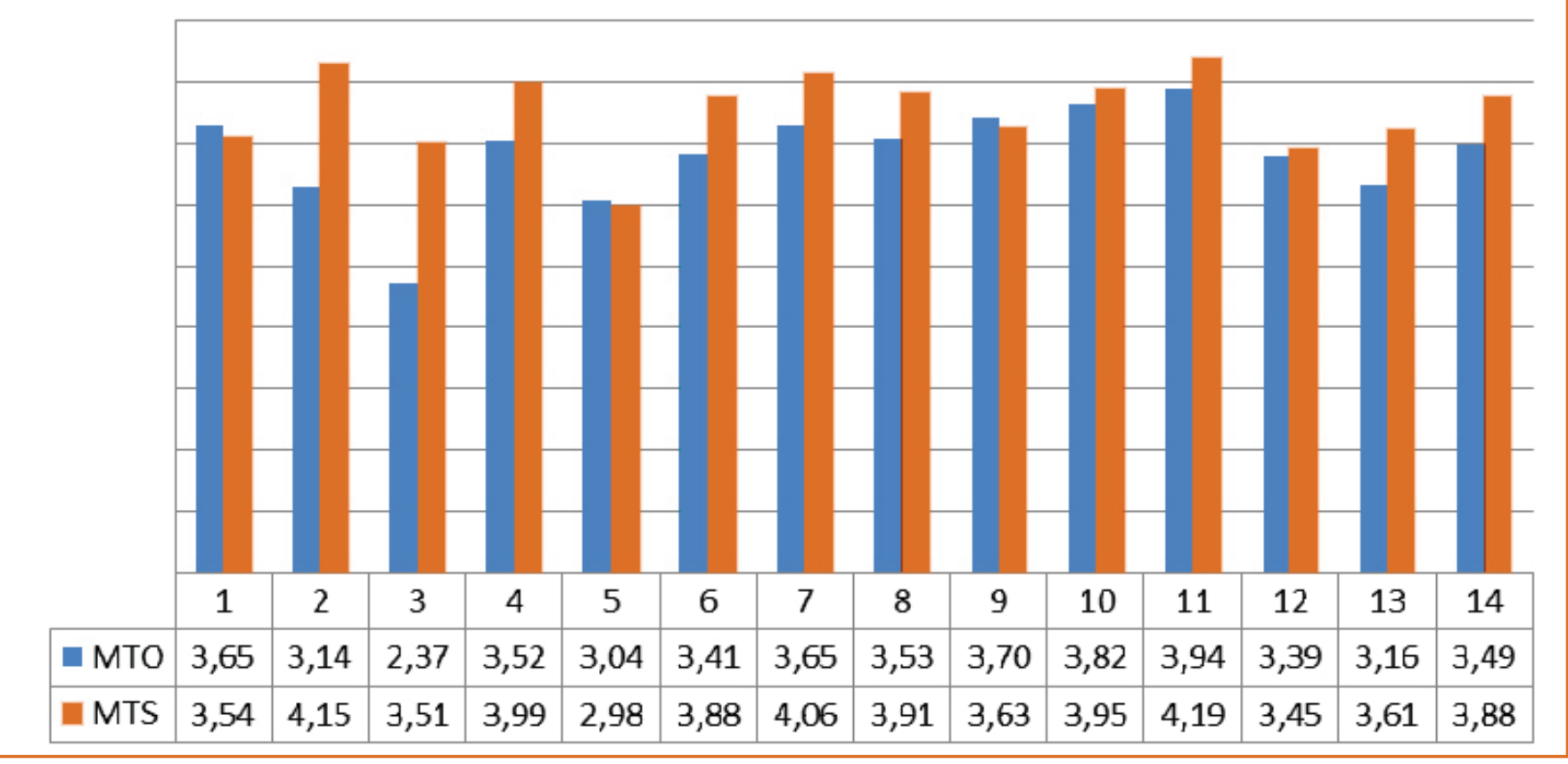

\begin{tabular}{|c|c|c|c|}
\hline \multicolumn{4}{|c|}{ 14 Princípios do Lean Manufacturing } \\
\hline 1 & Filosofia a longo prazo & 8 & Tecnologia confiável \\
\hline 2 & Fluxo contínuo & 9 & Desenvolvimento de líderes \\
\hline 3 & Sistema puxado & 10 & Desenvolvimento de pessoas \\
\hline 4 & Nivelamento de trabalho & 11 & Respeito entre parceiros \\
\hline 5 & Cultura de parar e resolver & 12 & Observação pessoal \\
\hline 6 & Padronização das atividades & 13 & Decisão por consenso \\
\hline 7 & Controle visual & 14 & Melhoria contínua \\
\hline
\end{tabular}

Os princípios com maior divergência de resultados entre os ambientes MTS e MTO foram os princípios 2 e 3.

O princípio 3, sistema puxado, obteve a maior variação percentual entre os dois ambientes, com o valor de 39,01\%. O ambiente MTS obteve o resultado de 3,51 pontos, enquanto o ambiente MTO obteve o resultado de 2,37 pontos. Frente aos resultados, conclui-se que o ambiente MTS possui uma maior percepção de incorporação do princípio 3 na organização pesquisada. Conforme aponta Martins e Laugeni, o ambiente MTS apresenta a característica de produtos padronizados e com uma baixa variabilidade, enquanto que o ambiente MTO apresenta uma alta variabilidade de característica de produtos, e por vezes, o projeto é executado durante a fabricação do mesmo. Outra consideração feita por Correa e Gianesi (1996), é que quando os produtos apresentam uma variabilidade de processos e demandas, como o ambiente MTO apresenta, é sugerido o uso do sistema empurrado de programação de produção. Frente a estes dados, conclui-se que devido as singularidades dos dois ambientes, é esperado que o ambiente MTS apresente uma maior percepção de incorporação deste princípio.

O princípio 2, que aborda o fluxo contínuo, obteve uma variação percentual de $27,5 \%$ entre os dois resultados. O ambiente MTS apresentou o resultado de 4,15 pontos, enquanto que o ambiente MTO apresentou o 
resultado de 3,14 pontos, portanto conclui-se que na organização onde a pesquisa foi realizada, o ambiente MTS apresenta uma maior percepção de incorporação do principio 2. De acordo com Martins e Laugeni (2005), os produtos no ambiente MTS são padronizados e possuem uma previsibilidade de pedidos, enquanto os produtos MTO são negociados diretamente com o cliente e apresentam customizações, outro fator, é que na empresa onde a pesquisa foi realizada, os itens do ambiente MTS possuem uma faixa de peso menor comparado com os produtos do ambiente MTO da organização, destaforma, os itens MTS apresentamuma maior facilidade de movimentação e não necessitam da grandes áreas para serem manipulados, enquanto que devido a variabilidade de tamanho e peso das peças, os setores do ambiente MTO necessitam de maiores áreas para serem manipulados. Frente a estas informações pode-se concluir que o fato de o princípio 2, fluxo continuo, ser mais incorporado no ambiente MTS da organização se deve aos fatos das inerências do processo dos dois ambientes e das características dos setores na organização pesquisada.

\section{CONCLUSÕES}

A partir do questionário adaptado de Bastos e Barbetta (2014) foi possível fazer a avaliação da percepção da incorporação dos princípios Lean em uma organização com ambientes de manufatura distintos (MTO e MTS), bem como avaliar a divergência de percepção entre gestores e subordinados de um mesmo ambiente de manufatura.

No ambiente MTS os princípios que se destacaram com as maiores pontuações de percepção de incorporação foram os princípios 11, 2 e 7 . Os princípios com menores pontuações foram os princípios 5, 12 e 13, todos com um elevado coeficiente de variação nas respostas apresentadas. No ambiente MTO, os princípios que se destacaram com as maiores pontuações de percepção de incorporação foram os princípios 11, 10 e 9. Os princípios com menores pontuações foram os princípios 2, 4 e 9, todos com um elevado coeficiente de variação nas respostas obtidas.

$\mathrm{Na}$ comparação entre os dois ambientes da organização, o princípio 11 - Respeito entre parceiros, obteve a maior pontuação entre os 14 princípios nos dois ambientes. O princípio 5 - Cultura de parar e resolver, esteve presente entre os três princípios com menor pontuação nos dois ambientes. Ao realizar a comparação entre o percentual de variação obtido entre o resultado dos dois ambientes, pode-se concluir que os princípios com percepção de incorporação mais convergentes entre os dois ambientes são os princípios 1, 5 e 12. Enquanto que os princípios que apresentaram maior divergência de resultados entre os dois ambientes foram os princípios 2, 3 e 13, sendo que nestes três princípios o ambiente MTS obteve um nível maior de incorporação que o ambiente MTO. O princípio 9 - Desenvolvimento de líderes, apresentou um alto percentual de variação de opiniões entre líderes e colaboradores nos dois ambientes, conclui-se, que as singularidades dos dois ambientes não afetam a divergência de opiniões entre líderes e operadores dos dois ambientes. O ambiente MTO apresentou apenas no princípio 1 uma pontuação maior que o ambiente MTS, nos demais princípios, o ambiente MTS obteve as maiores pontuações.

Dessa forma, conclui-se que 0 ambiente MTS apresenta uma maior percepção de incorporação dos princípios Lean em relação ao ambiente MTO na organização onde a pesquisa foi realizada. Segundo Martins e Laugeni (2005), no ambiente make-to-stock os produtos são padronizados e as quantidades demandadas não sofrem tanta variabilidade quanto os produtos do ambiente make-to-order, que por sua vez, apresenta produtos com altos níveis de customização, que inclusive podem ocorrer durante a fabricação dos mesmos, desta forma apesar do consenso entre autores, tais como Schonberger (1993), Shinohara (1998), Womack Ross e Jones (1992), acerca da aplicabilidade do Lean Manufacturing em qualquer tipo de empresa, a base referencial disponível na literatura, tais como Shingo (1996) e Ohno (1997) é predominantemente focada nos casos dos processos produtivos seriados da indústria automobilística, como é o caso do ambiente MTS da organização pesquisada. Frente a estas informações, pode-se concluir que o ambiente MTS da organização pesquisada apresenta uma maior percepção de incorporação dos princípios Lean entre os entrevistados na organização devido as 
características deste ambiente de manufatura.

\section{REFERÊNCIAS}

[1] ACHANGA, P.; SHELAB, E.; ROY, R. \& NELDER, G Critical success factors for lean implementation within SMEs. Journal of Manufacturing Technology, 17(4), 460-471, 2006.

[2] BARBETTA, P.A. Estatística aplicada às ciências sociais. 5aㅡ. Ed. Ver. Florianópolis. Ed da UFSC, 2002.

[3] BASTOS, A. L. A.; BARBETTA, P. H. Modelo para Avaliação da Internalização dos Princípios Lean Manufacturing - Uma Validação entre os Gestores de um Setor Produtivo de uma Indústria Têxtil. IV Congresso Brasileiro de Engenharia de Produção. Ponta Grossa, 2014.

[4] CORRÊA, H. L.; GIANESI, I. G. N. Just In Time, MRPII e OPT: Um Enfoque Estratégico. São Paulo: Editora Atlas, 1996.

[5] GHINATO, P. Produção \& Competitividade: Aplicações e Inovações. Recife: Ed.: Adiel T. de Almeida \& Fernando M.

C. Souza, Edit. da UFPE, 2000

[6] HINES, P.; TAYLOR, D. Guia para implementação da manufatura enxuta. 2. ed. São Paulo: IMAM, 2004. 62 p, il. Tradução de: Going Lean: a guide to implementation.

[7] LIKER, J. O modelo Toyota, 14 Princípios de Gestão do Maior Fabricante do Mundo. Porto Alegre: Bookman, 2005

[8] MANN, D. W. Creating a Lean culture: tools to sustain Lean conversions. New York: Productivity Press, 2005. 224p.

[9] MARTINS, G. A.; DOMINGUES, O. Estatística Geral e Aplicada. 4a edição. São Paulo: Atlas. 2011.

[10] MARTINS, Petrônio G; LAUGENI, Fernando P.. Administração da Produção. São Paulo: Saraiva, $2^{2}$ ed., 2006.

[11] MONDEN, Y. Produção Sem Estoques: Uma Abordagem Prática ao Sistema de Produção da Toyota. São Paulo: IMAM, 1984
[12] NAKAJIMA, Seiichi. Introdução ao TPM Total Productive Maintenance. São Paulo: IMC, 1989. 106 p.

[13] OHNO, Taiichi. O sistema Toyota de Produção além da produção em larga escala, Trad. Cristina Schumacher, Artes Médicas, Porto Alegre, 145p., 1997.

[14] OUCHI, W. G. Teoria Z: como as empresas podem enfrentar o desafio japones.4. ed. São Paulo: Ed. Fundo Educativo Brasileiro, 1982

[15] SCHONBERGER, Richard J. Técnicas Industriais Japonesas.4aㅡ edição. São Paulo: Pioneira, 1993

[16] SHARMA, Anand; MOODY, Patrícia E. A Máquina Perfeita: Como vencer na nova economia produzindo com menos recursos. 1ed, São Paulo: Editora PearsonBrasil, $2003,288 p$

[17] SHINGO, S. Sistema toyota de produção: do ponto-devista de engenharia de produção. Porto Alegre: Bookmann, 1996.

[18] SHINOHARA, Isao. New Production System: JIT Crossing Industry Boundaries. Productivity Press, 1988. 197 p.

[19] SILVA, J. P. A. R. Lean Manufacturing. Portugal, 2008.

[20] SPEAR, S.J.; BOWEN, H.K. Decoding the DNA of the Toyota Production System. Harvard Business Review. Set-Out 1999

[21] WOMACK, James P.; JONES, Daniel T.; ROOS, Daniel. A Máquina que Mudou o Mundo. 13ª edição. Rio de Janeiro: Campus, 1992. $347 \mathrm{p}$.

[22] WOMACK, J; JONES, D. A Mentalidade Enxuta nas Empresas: elimine o desperdício e crie riquezas. 5 ed. Rio de Janeiro: Campus, 2004.

[23] VOLLMANN, T. E. Sistemas de planejamento e controle da produção para o gerenciamento da cadeia de suprimento. Porto Alegre: Bookman, 2006.

[24] ZACCARELLI, Sérgio Batista. Programação e controle da produção. 5aㅡ edição. São Paulo: Pioneira, 1979 


\section{CAPÍTULO 7}

\section{APLICAÇÃO DA REENGENHARIA DE PROCESSOS: ESTUDO DE CASO EM UMA INDÚSTRIA DE CHAPAS DE PAPELÃO ONDULADO}

Everaldo Veres Zahaikevitch

Itamar Braga Lemes

Andréia Gura

Antônio Cecílio Silvério

Juliana Vitória Messias Bittencourt

Resumo: Este estudo está voltado para uma Indústria de Fabricação de Chapas em Papelão Ondulado, localizada no Estado do Paraná, por essa empresa ter fácil acesso as informações contidas no estudo a ser apresentado, o presente trabalho foi desenvolvido com intuito de identificar através de análise contábil e relatórios gerenciais, a necessidade de implantação da reengenharia de processos. De uma forma geral o objetivo deste trabalho foi identificar em que medida a reengenharia pode afetar a capacidade produtiva, alterando assim a rentabilidade da empresa objeto deste estudo. Também pode-se verificar com o estudo onde há mão de obra ociosa. podendo esta ociosidade ser remanejada de forma mais eficaz e eficiente elevando sua produtividade e aproveitando destes benefícios para aumentar sua capacidade produtiva, focar em seus processos, averiguar onde realmente seria viável a implantação da reengenharia para que desta forma seu faturamento sobre as receitas de vendas aumente significativamente. A metodologia utilizada para o levantamento de dados desta pesquisa foi através de bibliografia em livros. O estudo de caso foi aplicado na própria empresa e posteriormente feito a comparação, que através destes dados coletados, analises documentos e estudos, pode-se dar a implantaçáo do replanejamento do processo defasado.

Palavras chave: Controladoria. Reengenharia. Reengenharia de Processos. 


\section{INTRODUÇÃO}

Reengenharia é um replanejamento da forma atual dos processos de uma empresa, obtendo um melhor desempenho em agilidade e praticidade em seus indicadores, no entanto vem buscar a reinvenção, a readequação de processos, de estruturas, visa um redesenho dos processos atuais para um melhor desempenho, objetivando o lucro da empresa (THOMAS, 1996).

Conforme Thomas (1996, p. 22), "reengenharia é o ato de repensar e reprojetar de forma radical os processos de uma empresa para obter grandes progressos em indicadores críticos de desempenho como custo, qualidade, serviços e agilidade".

Sendo assim, observa-se que para a organização a reengenharia é uma ferramenta que agrega benefícios em seu produto e em seus processos, ela cria novos meios de comercialização extraindo assim uma maior eficácia, analisando seus métodos de trabalho e observando os resultados dessa modificação em seu desempenho final (THOMAS, 1996).

Empresas têm buscado métodos, como a reengenharia para poderem se manter no mercado, aonde se preocupam cada vez mais com relação a produtividade, com vistas em um melhor resultado e controle de desperdícios, percebendo em alguns casos que há necessidade de implantação da reengenharia de processos para um melhor aproveitamento da capacidade produtiva e para se manter competitiva no mercado atual (KOCK, 1995).

Diante deste contexto surge a seguinte questão: em que medida a reengenharia pode afetar a capacidade produtiva, alterando assim a rentabilidade da empresa.

Pressupõe-se que: há ociosidade de mão de obra em determinados pontos chaves do processo produtivo, que a implantação da reengenharia poderá diminuir de forma significativa o desperdício da capacidade produtiva, e alocar melhor a mão de obra ociosa da empresa objeto.

Desta forma, o objetivo geral deste trabalho foi identificar em que medida a reengenharia pode afetar a capacidade produtiva, alterando assim a rentabilidade da empresa objeto deste estudo. Com base no objetivo geral foram definidos os seguintes objetivos específicos, sendo eles: definir o processo produtivo da empresa a fim de entendê-lo para tornar possível a análise necessária; levantar possíveis desperdícios e ociosidade de mão de obra no processo produtivo; identificar alterações que possam interferir de forma positiva no processo produtivo da empresa.

\section{REFERENCIAL TEÓRICO}

Para esta revisão literária foram abordados tópicos correlacionados como a Controladoria, Controller, Reengenharia e Reengenharia de Processos na busca de um maior entendimento.

\subsection{CONTROLADORIA}

A Controladoria evidencia uma estrutura lógica do processo de decisão empresarial, dando cautela ao trabalho em equipe e a gestão participativa, assumindo a responsabilidade de estimular o trabalho, potencializando os profissionais, para fazer acontecer (FIGUEIREDO e CAGGIANO, 2008).

Portanto, a controladoria deve estar inteiramente ligada na empresa para poder dar um suporte ao empresário em sua tomada de decisão envolvendo o planejamento, sendo a mesma considerada um sistema de informação que se destina a auxiliar os gestores nas tomadas de decisões (FIGUEIREDO e CAGGIANO, 2008).

Conforme Nakagawa, (1993, p. 48) conceitua controladoria como "a obrigação de se prestar contas dos resultados obtidos, em função das responsabilidades que decorrem de uma delegação de poder", diante disso diga-se que essa expectativa será sempre a gestão eficiente dos negócios da empresa, sendo todos responsáveis na elaboração dos objetivos e das metas estabelecidas dentro de seu poder de autoridade.

Segundo Perez Junior (1997, p. 36), as funções de controladoria podem ser resumidas da seguinte 
maneira:

a) Informação - Compreende os sistemas contábeis-financeirosgerencias; b) Motivação - Refere-se aos efeitos dos sistemas de controle sobre o comportamento; c) Coordenação visa centralizar informações com vistas à aceitação de planos. O Controller toma conhecimento de eventuais inconsistências dentro da empresa e assessora a direção, sugerindo soluções; d) Avaliação - interpreta fatos, informações e relatórios, avaliando os resultados por área de responsabilidade, por processos, por atividades etc.; e) Planejamento - Assessora a direção da empresa na determinação e mensuração dos planos e objetivos; f) Acompanhamento - Verifica e controla a evolução e o desempenho dos planos traçados a fim de corrigir falhas ou de revisá-los.

Dessa forma, entende-se que a controladoria tem como alvo garantir informações corretas ao processo decisório, auxiliando e dando suporte nas tomadas de decisões colaborando com os gestores na busca da eficácia gerencial (PEREZ JUNIOR, 1997).

\subsubsection{CONTROLLER}

O Controller é o supervisor do departamento da controladoria, sua função é por meio do gerenciamento das informações levantadas, cuidar zelosamente pela continuidade da empresa, fazendo com que as atividades desenvolvidas dentro da empresa alcancem resultados esperados pela organização (NAKAGAWA, 1993).

Segundo Figueiredo e Caggiano (2008, p. 53).

Os controladores foram inicialmente recrutados entre os indivíduos das áreas de contabilidade e finanças das empresas, por possuírem, em função do cargo que ocupam uma visão ampla da empresa que os habilita a enxergar as dificuldades com um todo e propor soluções gerais. Além disso as informações que chegam ao controller são predominantemente de natureza quantitativa, física, monetária, ou ambas.

Sendo então, o controller da empresa tem em mãos informações necessárias, utilizando-se destas dando suporte para a tomada de decisão, com planejamento e controle e com as devidas informações levantadas, cabe ao controller assessorar de forma independente na conclusão de números e das medições desses índices de qualidade de informações quantitativas e qualitativas (FIGUEIREDO e CAGGIANO, 2008).

\subsection{REENGENHARIA}

Inicialmente deve-se saber priorizar, escolher e selecionar as atividades inseridas em processos que serão objeto da reengenharia, verificando-se uma discussão por parte gestora e controladora para que esse sistema de reengenharia seja implantado onde realmente há necessidade, essa analise, no entanto deve ser feita sobre o levantamento de dados da controladoria (RICARDO, 2002).

A reengenharia vem na maioria das vezes substituir processos operacionais por processos informatizados, tendo auxilio das tecnologias de informações, tem sido responsável por uma série de mudanças drásticas no deslocamento de informações, processos de sistema administrativo de uma série empresarial, esses níveis estratégicos, operacionais e táticos, tendo vários critérios e técnicas de propostas pela reengenharia, levando a um controle mais eficaz, um levantamento permanente para a direção, e os gestores (KOCK, 1995).

As empresas veem sentindo-se estimuladas a aplicar princípios e metodologias do redesenho de processos, à medida que tomavam conhecimento de experiências bem sucedidas, mudanças, que posteriormente viriam a dar certo nos processos escolhidos (RICARDO, 2002). 
Para as empresas a reengenharia é uma forma bastante questionável, pois, ela questiona a forma atual dos processos, a forma em que está sendo trabalhado, como está alocada seus devidos fins, suas devidas estruturas na organização, o que de melhor pode ser redesenhado, onde há necessidade de implementação, o que essa empresa tem por melhorar, revisando o planejamento, para garantir seus melhores recursos nas tarefas distribuídas. Com objetivo de implantar formas de processos mais eficazes, chegando a resultados mais precisos, melhor qualidade, menor desperdícios, preparando, listando as possíveis falhas no processo e não deixando de medir e avaliar os resultados obtidos na mudança (THOMAS, 1996).

Desta maneira as empresas visam um melhor desempenho para com sua organização, tendo um melhor fluxo de produtividade seguido de lucratividade, sendo assim, verem a necessidade de implantação de uma reengenharia informatizada, a reengenharia é algo conceitualmente novo nessas empresas, mas que apoia as técnicas gerenciais que em muitos casos já foram testadas e aprovadas e em prováveis casos tiveram êxito (NAKAGAWA, 1996).

Com isso percebe-se que a reengenharia em muitos casos depende de tempo para implantar a mudança proposta, exigindo na maioria das vezes uma realocação de pessoal, treinamentos, uma quebra de resistência à mudança, ultrapassando obstáculos, o que faz com que adaptação a reengenharia tome mais tempo do que a implantação ao processo. Mas também verifica-se uma visão ampla, o que significa que os processos replanejados envolvem normalmente varias áreas da empresa, melhorando o processo de montagem da organização como um todo, não podendo esquecer de que se corre o risco de não dar certo, por que a reengenharia procura modificar o que se faz, buscando-se principalmente grandes ganhos em sua eficácia (KOCK, 1995).

A abordagem de reengenharia costuma ser adotada nas empresas no momento em que as mesmas sentem a necessidade de reformular seus processos, nesse caso, é aconselhável reavaliar e reprojetar a estrutura da empresa, porém esses processos podem ser aplicados individualmente ou em partes. Em geral, isto exige a aprovação por parte gestora da empresa, e para que os mesmos possam medir essa mudança tanto nos processos individuais como em toda a empresa (HAMMER e CHAMPY, 1994).

\subsubsection{REENGENHARIA DE PROCESSOS}

Com a Reengenharia de processos as empresas procuram replanejar seus fluxos de informações dentro da organização, dos sistemas administrativos e os produtivos, buscando aperfeiçoar os processos defasados, com intuito de aumentar a eficiência de seu desenvolvimento (THOMAS, 1996).

Segundo Kock (1995, p. 14) "reengenharia de processos é uma metodologia que se fundamenta numa série de técnicas de gestão anteriores voltadas à melhoria da produtividade e qualidade". Diga-se então que a Reengenharia de Processos funciona como uma eliminação dos custos desnecessários, é o redesenho do processo proporcionando importantes mudanças dentro da organização, inovar e renovar o processo por um todo (KOCK, 1995).

Segundo Hammer e Champy (1994, p. 41):

$$
\begin{aligned}
& \text { Definem reengenharia de processo } \\
& \text { como a atividade de repensar } \\
& \text { fundamentalmente e reestruturar } \\
& \text { radicalmente os processos empresariais } \\
& \text { para alcançar melhorias drásticas em } \\
& \text { indicadores críticos e contemporâneos } \\
& \text { de desempenho, tais como custos, } \\
& \text { qualidade, atendimento e velocidade. }
\end{aligned}
$$

Contudo deve-se observar que a reengenharia de processos visa um nível diferente de mudanças, ela significa a realização do trabalho de uma maneira radicalmente nova e de melhoria no processo, essa melhoria seria a realização desse mesmo processo só que com uma maior e melhor eficiência (HAMMER e CHAMPY, 1994). 


\section{MATERIAIS E MÉTODOS}

Este tópico apresenta a metodologia utilizada para a realização deste trabalho, a qual abrange a classificação da pesquisa quanto: aos objetivos, aos procedimentos, à abordagem do problema, ao universo e a amostra.

Para o desenvolvimento deste trabalho foi realizada inicialmente pesquisa bibliográfica, que na concepção de Gil (2010, p. 44), "A principal vantagem da pesquisa bibliográfica reside no fato de permitir ao investigador a cobertura de uma gama de fenômenos muito mais ampla do que aquela que poderia pesquisar diretamente".

Essa vantagem torna-se particularmente importante quando o problema da pesquisa requer dados dispersos pelo espaço.

Assim a pesquisa quanto aos seus objetivos é classificada como descritiva, pois de acordo com Gil (2010, p. 43) "as pesquisas descritivas têm como objetivo primordial a descrição das características de determinada população ou fenômeno ou, então, o estabelecimento de relações entre variáveis".

A presente pesquisa teve como Universo uma empresa no ramo de fabricação de chapas em papelão ondulado, deste modo à amostragem teve por acessibilidade, sendo possível a analise dos documentos concedidos pela empresa, como: relatórios internos de gerenciamento e também demonstrações contábeis.

Com base nos dados obtidos foram transcritos os mesmos em tabelas para facilitar sua interpretação. Portanto os dados coletados foram analisados qualitativamente e quantitativamente, fornecendo assim índices e padrões para que a empresa tenha por base em questão como está sua situação referente à necessidade de implantação da reengenharia de processo.

Além disso, está pesquisa apresentará uma abordagem qualitativa e quantitativa, pois conforme cita Gil (2010, p. 48), "Na pesquisa qualitativa a reflexão teórica do pesquisador ocorre durante ou quase no final do processo de coleta, na pesquisa quantitativa o pesquisador já tem conceitos pré estruturados sobre a realidade que vai ser seu fruto de pesquisa".

O estudo foi realizado no período de Janeiro e Fevereiro de 2013 bem como comparados com os períodos Abril e Maio de 2013, ocorrendo então em duas etapas, na primeira etapa foram levantados dados referente a capacidade produtiva atual e o esperado, em seguida, a segunda etapa foi executada a partir de informações do quanto essa capacidade produtiva estava sendo afetada, sendo então feito sua comparação referente aos resultados obtidos, através de relatórios regenciais e analises contábeis, que possibilitaram uma maior verificação para o relatório final do trabalho.

\section{INTERPRETAÇÃO E ANÁLISE DOS DADOS}

Em discernimento ao objetivo proposto neste trabalho, foram analisados dados relativos aos processos produtivos de uma empresa que atua no ramo produtivo em chapas de papelão ondulado, que não teve sua razão social discriminada no trabalho muito menos sua localização, para manter sua integridade empresarial, tendo em vista que a empresa atua no mercado de fabricação chapas em Papelão Ondulado desde Março de 2010.

A partir de dados comparativos levantados através de planilhas aplicadas aos gestores e comparados com resultados anteriores, informações geradas através do banco de dados de gerenciamento da empresa, dentre as quais, relatórios financeiros, de produção, relatórios gerenciais, estoque, demonstrativos contábeis e fiscais. Também comparando-se dados de vendas mensais e anuais, evidenciou-se alguns pontos relevantes que contemplaram com o objetivo deste estudo, para a realização dessas análises foram verificados com o auxilio dos gestores, os processos produtivos da empresa, evidenciados nos períodos de Janeiro e Fevereiro de 2013 e nos períodos de Abril e Maio de 2013. Nesta primeira apuração foi verificado a capacidade de produção diária da máquina fabricante de chapas em papelão ondulado, verificando-se que a capacidade de produção da mesma equivalem 
há 9 toneladas de chapas em papelão ondulados para cada uma hora de produção trabalhadas, onde constatou-se que ao término do expediente, não estariam chegando ao resultado esperado que seria em média de 72 toneladas de chapas em papelão ondulado no final de cada dia de trabalho. Neste ponto foi surgiu então a possibilidade de uma reengenharia de processos, o qual de acordo com a controladoria da empresa poderia ter significativo resultado final na DRE da empresa.

De acordo com os novos levantamentos a fim de restruturação, o resultado que se tinha diariamente era de 65,25 toneladas diárias, após esses dados levantados, foi que houve o interesse por partes dos gestores, onde após interpretação, optaram em analisar diariamente e mensalmente esses valores, tanto em capacidade produtiva quanto em seu faturamento.

Sendo assim, foi constatado que sua capacidade de produção estava sendo afetada devido a uma margem de paradas que estava ocorrendo no processo produtivo, portanto esse seria um primeiro ponto de análise dos motivos que estava afetando a capacidade de produção.

Após verificação pode-se dizer que essas paradas seriam devido ao acumulo de refugos que envolvia o processo. Foram então calculados que essa margem era equivalente há 9,38\% de horas paradas no dia, que para cada 8 horas trabalhadas, paravam-se 45 minutos em um total diário, porém, não somente em uma só parada, mas sim, para cada 60 minutos trabalhados haveria uma parada de 5,63 minutos, sendo assim esses 9,38\% equivalem a uma perda de capacidade produtiva de 0,844 toneladas $(844 \mathrm{Kg})$ de chapas em papelão ondulado por hora de produção, equivalente há 6,75 toneladas de chapas em papelão ondulado que poderiam ser produzidos a mais em um total de produção diária. Ou seja, onde a expectativa de produção diária seria o esperado em 72 toneladas de chapas em papelão ondulado, estariam produzindo em média 65,25 toneladas.

Após esses dados levantados foram analisados juntamente com os gestores que colaboraram com o estudo deste trabalho, foi constatado que há uma grande perda na sua capacidade produtiva bem como em seu faturamento, que automaticamente deve aumentar conforme sua capacidade de produção aumenta gradativamente.

Para um melhor entendimento foram destacados os seguintes levantamentos dessas informações, demostrados na tabela 01 .

Tabela 01: Capacidade de Produção Atual X Capacidade de Produção Esperada

\begin{tabular}{|l|l|l|}
\hline CAPACIDADE PRODUTIVA ATUAL/MÊS & \multicolumn{1}{l|}{ CAPACIDADE PRODUTIVA ESPERADA/MÊS } & 162 \\
\hline $\begin{array}{l}\text { Toneladas de chapas em papelão } \\
1566\end{array}$ & $\begin{array}{l}\text { Toneladas de chapas em papelão } \\
1728\end{array}$ & \\
\hline
\end{tabular}

Fonte: Elaborado pelos autores

Após estas informações houve dedicação significativa por parte dos gestores em fazer com que essa capacidade produtiva fosse utilizada de maneira que não tivesse essa grande margem de paradas ocasionando em perda de produção. Onde então foi estudada a possibilidade de implantação da reengenharia de processos, visando sanar essas perdas de capacidade produtiva e expandindo sua produção em sua capacidade total. Sendo assim, foram estudados através de documentos de dados levantados no período de Janeiro de 2013 e Fevereiro de 2013, a melhor hipótese de implantação desta reengenharia de processos, a fim de redesenhar o processo onde estava sendo o maior foco de perda em produção.

Assim sendo, em conjunto com todos os setores de processos envolvidos e após analisados de forma que viesse a proporcionar um melhor desempenho e maior ênfase em sua capacidade produtiva da fabricação de chapas em papelão ondulado, foi juntamente com os gestores implantado uma máquina automatizada para 
fazer o serviço que até então vinha ocasionando nesta, perda de sua capacidade produtiva. Após verificação e através de dados gerenciais coletados, constatouse que após a implantação da reengenharia, onde foi significativamente relevantes e indispensáveis na comparação de como sua capacidade produtiva deixa de ser afetada devida esta reestruturação de processos, o qual foi o estudo deste trabalho.

Pode-se fazer uma verificação mais apurada nos resultados obtidos após a reengenharia logo baixo como demonstra tabela 02.

Tabela 02: Comparações Referente a Capacidade Produtiva e Valores de Faturamento Evidenciados antes e depois da Reengenharia

\begin{tabular}{ll|l|l|}
$\begin{array}{l}\text { ANTES DA REENGENHARIA JANEIRO/FEVEREIRO } \\
\text { DE } 2013\end{array}$ & $\begin{array}{l}\text { APÓS A REENGENHARIA ABRILIMAIO } \\
\text { DE } 2013\end{array}$ & \multicolumn{1}{|l}{ DIFERENÇA TON. } \\
\hline $\begin{array}{l}\text { Toneladas de chapas em papelão } \\
3132\end{array}$ & $\begin{array}{l}\text { Toneladas de chapas em papelão } \\
\text { \% }\end{array}$ & 3246 & 10,34 \\
\hline
\end{tabular}

Fonte: Elaborado pelos autores.

Conforme dados levantados juntamente com os setores envolvidos, dentre eles, o setor de contabilidade da empresa, o setor fiscal, os controllers, controladoria, o processo produtivo e com a ajuda dos gestores da empresa, foi possível através destes números levantados, fazer uma análise mais ampla do processo que estava defasado, onde pode-se confrontar os dados levantados e demostrar via exposição dos custos correlacionados a essas perdas de produção no referido período.

O que se pôde observar no decorrer da pesquisa, é que a empresa trabalha com venda total de sua produção, portanto um aumento na quantidade produzida seria também relacionado ao aumento de faturamento, e, porém nesse caso, aumentaria os custos de produção, conforme demonstrado na tabela 03.

Tabela 03: Descrição dos Custos Evidenciados no Período

\begin{tabular}{|c|c|c|c|c|c|}
\hline \multicolumn{2}{|c|}{$\begin{array}{l}\text { ANTES DA REENGENHARIA } \\
\text { JANEIRO/FEVEREIRO DE } 2013\end{array}$} & \multicolumn{2}{|c|}{ APÓS A REENGENHARIA ABRIL/MAIO DE 2013} & DIFERENÇA R\$ & DIFERENÇA \% \\
\hline MATÉRIA PRIMA & $\mathrm{R} \$ 5.167 .800,00$ & MATÉRIA PRIMA & $\mathrm{R} \$ 5.702 .400,00$ & $R \$ 534.600,00$ & 10,34 \\
\hline MÃO DE OBRA & $\mathrm{R} \$ 64.108,00$ & MÃO DE OBRA & $\mathrm{R} \$ 49.538,00$ & $-\mathrm{R} \$ 14.570,00$ & $-22,73$ \\
\hline $\begin{array}{l}\text { TRANSPORTE/ } \\
\text { REFUGOS }\end{array}$ & $\mathrm{R} \$ 36.000,00$ & TRANSPORTE/REFUGOS & $\mathrm{R} \$ 8.000,00$ & $-\mathrm{R} \$ 28.000,00$ & $-22,22$ \\
\hline & & $\begin{array}{l}\text { FRETE ENTREGA DAS } \\
\text { CHAPAS }\end{array}$ & $\mathrm{R} \$ 58.320,00$ & & \\
\hline & & COLA & $\mathrm{R} \$ 15.033,60$ & & \\
\hline & & DEPRECIAÇÃO MÁQUINA & $\mathrm{R} \$ 8.106,96$ & & \\
\hline & & ENERGIA ELÉTRICA & $\mathrm{R} \$ 472,00$ & & \\
\hline & & IMPOSTOS & $\mathrm{R} \$ 72.462,60$ & & \\
\hline TOTAL & R\$ 5.267.908,00 & TOTAL & $R \$ 5.914 .333,16$ & $R \$ 646.425,16$ & 12,27 \\
\hline
\end{tabular}

Fonte: Elaborado pelos autores.

Os custos anteriores não foram evidenciados na tabela por que a empresa não disponibilizou os mesmos, e por que o aumento desses acontece naturalmente conforme o aumento da produção, portanto é importante salientar que a diferença analisada é o aumento significativo na capacidade produtiva devido a eliminação das paradas de máquina, a redução de ociosidade de mão de obra e a redução do transporte de refugos e vale lembrar que esse aumento de vendas, gerou também para empresa um giro de caixa muito maior durante um mesmo período de tempo, verifica-se então que após a reengenharia e cálculos 
mensurados pelos departamentos, constatou-se alguns pontos de relevância sendo eles o seguinte:

Houve um aumento de 12,27\% nos custos para a produção das chapas em papelão, pois como sua capacidade de produção aumentou, consequentemente aumentaram alguns custos. Dentre essa margem de aumento de custo destaca-se:

- A Matéria Prima, com um aumento de 10,34\%.

- Ouve também um aumento de custo nos materiais secundários que seria a Cola que faz parte do processo de produção das chapas de papelão ondulado com valor de $\mathrm{R} \$ 15.033,60$.

- O frete para a entrega dessa diferença de produção, com um valor de $\mathrm{R} \$ 58.320,00$, no período, pois a entrega é por conta do emitente.

- O valor de $\mathrm{R} \$ 8.106,96$ é devido a depreciação da máquina instalada.

Também obteve um aumento de energia elétrica, evidenciado pelo setor de Elétrica Industrial da empresa, onde os motores instalados juntamente com a nova instalação da máquina aumentaria consequentemente o consumo dessa energia em $\mathrm{R} \$$ 472,00 no período.
Na questão fiscal, o aumento da produção gerou um aumento também nas aquisições de produtos ligados a produção, portanto estes geraram créditos, contudo, o aumento das vendas também aumentou o débito de impostos, conforme o valor listado de $\mathrm{R} \$ 72.462,60$.

Seguindo assim com a apuração dos dados, e, em um mesmo contexto do estudo de caso, outro fato relevante foi constatado, uma ociosidade de mão de obra, pois, para a execução destas tarefas de retirada dos refugos gerados, devido a produção das chapas em papelão ondulado, os mesmos eram posteriormente carregados em caminhões para o destino de reciclagem, evidenciou-se em seguida uma redução de 22,73\% em sua mão de obra no carregamento e descarregamento desses refugos, onde havia a utilização de funcionários para a execução destas tarefas, não há mais necessidade, pois, a própria máquina ao sair estes refugo já vai enfardando os mesmos deixando-os prensados, pronto para o carregamento.

Constatou-se também que houve uma redução de $22,22 \%$ no custo com transportes destes refugos.

Portanto na tabela a seguir pode-se ter uma visão dos valores que representaram a implantação final da reengenharia do processo, estudo deste projeto.

Tabela 04: Comparações Referente a Capacidade Produtiva e Valores de Faturamento Evidenciados antes e depois da Reengenharia

\begin{tabular}{|c|c|c|c|c|c|}
\hline \multicolumn{2}{|c|}{$\begin{array}{l}\text { ANTES DA REENGENHARIA JANEIROI } \\
\text { FEVEREIRO DE } 2013\end{array}$} & \multicolumn{2}{|c|}{ APÓS A REENGENHARIA ABRIL/MAIO DE 2013} & DIFERENÇA & \multirow[t]{2}{*}{$\begin{array}{l}\text { DIF. } \\
\%\end{array}$} \\
\hline $\begin{array}{l}\text { TONELADAS NO } \\
\text { PERÍODO }\end{array}$ & 3132 & $\begin{array}{l}\text { TONELADAS NO } \\
\text { PERÍODO }\end{array}$ & 3456 & 324 & \\
\hline FATURAMENTO & $\mathrm{R} \$ 6.577 .200,00$ & FATURAMENTO & $\mathrm{R} \$ 7.257 .600,00$ & $\mathrm{R} \$ 680.400,00$ & 10,34 \\
\hline CUSTOS & $R \$ 5.267 .908,00$ & CUSTOS & $\mathrm{R} \$ 5.914 .333,16$ & $\mathrm{R} \$ 646.425,16$ & 12,27 \\
\hline TOTAL & R\$ 1.309.292,00 & TOTAL & R\$ 1.343.266,84 & $\mathbf{R} \$ 33.974,84$ & 2,59 \\
\hline
\end{tabular}

Fonte: Elaborado pelos autores.

Através do presente estudo de caso constatouse então que, por mais que houve um aumento de $12,27 \%$ nos custos, aumento esse devido ao maior volume e capacidade de produção, o seu faturamento sobre vendas também aumentou, chegando a 10,34\%, devido a sua maior capacidade produtiva e melhor aproveitamento, a partir desses dados levantados constatou-se que houve um aumento de 2,59\% de liquidez no período de apuração dos dados coletados, com essas margens de apuração constata-se logo abaixo, qual o tempo necessário para que esse investimento (prensa $R \$ 194.567,00$; instalações $R \$$ 
48.641,75, totalizando $R \$ 243.208,75)$ tenha seu retorno financeiro verificando a tabela 05.

Tabela 05

\begin{tabular}{|c|c|c|}
\hline VALOR DO INVESTIMENTO DECRESCENTE & DIFE & \\
\hline $\mathrm{R} \$ 226.221,33$ & ABRIL DE 2013 & $\mathrm{R} \$ 16.987,42$ \\
\hline$R \$ 209.233,91$ & MAIO DE 2013 & $\mathrm{R} \$ 16.987,42$ \\
\hline $\mathrm{R} \$ 192.246,49$ & JUNHO DE 2013 & $\mathrm{R} \$ 16.987,42$ \\
\hline $\mathrm{R} \$ 175.259,07$ & JULHO DE 2013 & $\mathrm{R} \$ 16.987,42$ \\
\hline $\mathrm{R} \$ 158.271,65$ & AGOSTO DE 2013 & $\mathrm{R} \$ 16.987,42$ \\
\hline $\mathrm{R} \$ 141.284,23$ & SETEMBRO DE 2013 & $\mathrm{R} \$ 16.987,42$ \\
\hline $\mathrm{R} \$ 124.296,80$ & OUTUBRO DE 2013 & $\mathrm{R} \$ 16.987,42$ \\
\hline $\mathrm{R} \$ 107.309,38$ & NOVEMBRO DE 2013 & $\mathrm{R} \$ 16.987,42$ \\
\hline $\mathrm{R} \$ 90.321,96$ & DEZEMBRO DE 2013 & $\mathrm{R} \$ 16.987,42$ \\
\hline $\mathrm{R} \$ 73.334,54$ & JANEIRO DE 2014 & $\mathrm{R} \$ 16.987,42$ \\
\hline $\mathrm{R} \$ 56.347,12$ & FEVEREIRO DE 2014 & $\mathrm{R} \$ 16.987,42$ \\
\hline $\mathrm{R} \$ 39.359,70$ & MARÇO DE 2014 & $\mathrm{R} \$ 16.987,42$ \\
\hline $\mathrm{R} \$ 22.372,28$ & ABRIL DE 2014 & $\mathrm{R} \$ 16.987,42$ \\
\hline $\mathrm{R} \$ 5.384,86$ & MAIO DE 2014 & $\mathrm{R} \$ 16.987,42$ \\
\hline$-R \$ 0,00$ & JUNHO DE 2014 & $\mathrm{R} \$ 5.384,86$ \\
\hline
\end{tabular}

Fonte: Elaborado pelos autores.

Entende-se que o valor destinado á aquisição do imobilizado juntamente com o valor de aplicação destinado as instalações da prensa, serão reembolsados em um período de aproximadamente de 15 meses. Contudo esses valores podem variar devido ao andamento da produção, pois os cálculos foram evidenciados sobre a capacidade produtiva de 8 horas diárias, todavia que a empresa trabalha com venda total de sua produção, conforme dados levantados pelos setores de produção juntamente com os controllers da empresa, mas o que fica evidente, é que em um tempo não significativo a empresa poderá cobrir este investimento.

\section{CONSIDERAÇÕES FINAIS}

Portanto conclui-se que o presente trabalho e estudo de caso traz um enfoque prático no qual a utilização de uma reengenharia de processos, ao ser empregado, pode ser muito rentável em uma entidade. Fica evidente que para o surgimento de informações, que irão dizer ou não há necessidade de uma implantação ou reestruturação, deverá existir um banco de informações confiáveis, as quais podem trazer através de análises setoriais como: controladoria, contabilidade, e de gerenciamentos, a busca de novas formas de extrações de lucro, ou redução de custos, enfim, o que poderá ser positivo para a empresa, e que poderá ser alcançado analisando caso a caso os processos seguidos nesta. Essas melhorias podem aumentar a competitividade, e melhor qualidade na produção, isso faz com que novos horizontes possam ser explorados pelos gestores de uma organização.

Neste caso prático foi verificado que com a implantação da reengenharia de processos, a empresa obteve um aumento de sua capacidade produtiva, aonde trouxeIhe a possibilidade de atender mais clientes em um mesmo tempo, e aumentar o faturamento e resultados contábeis da empresa, o que anteriormente não era possível, pois não conseguia-se relacionar 100\% a capacidade produtiva com os pedidos que a empresa tinha até então. Obteve também redução de mão de obra, que até então estava sendo ociosa dentro da organização, que a partir de então foi melhor alocada e remanejada com um melhor aproveitamento desta dentro da empresa, entretanto contatou-se que houve diminuição nos custos de frete com o carregamento 
destes refugos gerados.

Consequentemente com esse resultado positivo obtido pela organização, esses novos horizontes poderão ser analisados de forma mais concreta a fim de que esse aumento de produção venha a satisfazer melhor seus clientes com relação a quantidade e qualidade do produto e serviço.

\section{REFERÊNCIAS}

[1] FIGUEIREDO, S.; CAGGIANO, P. C. Controladoria Teoria e Prática. São Paulo: Atlas, 2008.

[2] GIL, A. C. Como Elaborar Projetos de Pesquisa. 5aㅡ Ed. São Paulo: Atlas, 2010.

[3] HAMMER, M.; CHAMPY, J. Reengenharia: Revolucionando a empresa em função dos clientes da concorrência e das grandes mudanças gerencias. Rio de Janeiro: Atlas, 1994.
[4] INSTITUTO FEDERAL PARANÁ. Normas para Apresentação de Trabalhos Acadêmicos do IFPR. Curitiba, 2010.

[5] KOCK, N. F. Reengenharia de Processos PROI. Petrópolis: Vozes, 1995.

[6] NAKAGAWA, M. Introdução à controladoria, conceitos, sistemas, implementação. São Paulo: Atlas, 1993.

[7] PEREZ JUNIOR, J. H.; PESTANA, A. O.; FRANCO, S. P. C. Controladoria de Gestão, Teoria e Prática. São Paulo: Atlas, 1997.

[8] RICARDO, C. E. Reengenharia de Processos: o Desafio da Mudança. Revista On Line. FECAP, 2012. Disponível em <http://www.fecap.br> Acesso em: 05 de dez. de 2012.

[9] THOMAS, C. C. Reengenharia dos Processos Empresariais. Rio de Janeiro: Record, 1996.

[10] YIN, R. K. Estudo de Caso, Planejamento e Métodos. Porto Alegre: Bookman, 2001. 


\section{CAPÍTULO 8}

\section{USO de diAgRAMAS DE CAUSA E EFEITO PARA PLANEJAMENTO DA SÍNTESE DE UM PIGMENTO POLIMÉRICO À BASE DE POLIANILINA}

Robson Couto da Silva

Sergio Mazurek Tebcherani

Evaldo Toniolo Kubaski

Thiago Sequinel

João Luiz Kovaleski

Resumo: Esse trabalho visa demonstrar a utilização de diagramas de causa e efeito (diagramas de Ishikawa) como ferramentas para o planejamento na síntese química de um pigmento polimérico eletrocrômico a partir da polimerização da anilina em meio ácido, produzindo a polianilina na forma de sal de esmeraldina. Esses diagramas são ferramentas com finalidade de verificar a relação entre um resultado obtido (efeito) e todas as possibilidades de contribuição para se chegar a esse resultado (causa). A partir desse trabalho, pode-se obter um melhor equacionamento das diversas variáveis que fazem parte de uma síntese química e, desse modo, filtrar os parâmetros que mais influenciam nas propriedades desejadas do produto. A partir da divisão dos parâmetros de síntese em 6 grupos distintos: meio ambiente, materiais, máquinas mão de obra medida e método, pretende-se determinar a melhor condição para obtenção da propriedade denominada de eletrocromismo (alteração na coloração de um material quando submetido a uma diferença de potencial). Os materiais que apresentam tal propriedade estão sendo estudados em diferentes componentes eletrônicos, para aplicaçóes que variam desde a construção civil até áreas como fabricação de lentes e indústria aeroespacial, destacando-se pela facilidade de controle dos dispositivos desenvolvidos, o que justifica a obtenção e caracterização do pigmento.

Palavras chave: Diagrama de causa e efeito, Polianilina, eletrocrômico. 


\section{INTRODUÇÃO}

Os métodos para gestão industrial utilizam diversas técnicas para planejamento, coleta e disposição das informações. Essas técnicas, necessárias para solução de um problema, são denominadas de ferramentas da qualidade.

As ferramentas da qualidade são de grande importância para a implementação de um sistema de qualidade, o qual é capaz de melhorar o desempenho de serviços, produtos e processos, além das condições de trabalho.

Dentre as ferramentas de qualidade destacamse aquelas que fazem parte do grupo de métodos estatísticos elementares, ou seja, que devem ser de conhecimento de todos envolvidos em um determinado processo, tais como os fluxogramas, folhas de verificação, histogramas, os diagramas de dispersão, diagramas de Pareto, amostragem, análise de variância, diagramas de causa e efeito, entre outras.

Os diagramas de causa e efeito, foco de estudo desse trabalho, são ferramentas com finalidade de verificar a relação entre um resultado obtido (efeito) e todas as possibilidades que contribuíram para que se chegue a esse resultado (causa). Nesse trabalho esses diagramas serão utilizados para melhor planejar os diferentes parâmetros que influenciam na obtenção do polímero polianilina, na forma de sal de esmeraldina. Além disso, serão avaliados dentre esses parâmetros, quais devem ser enfatizados para que se consiga a propriedade denominada de eletrocromismo.

\section{OS DIAGRAMAS DE CAUSA E EFEITO}

Os diagramas de causa e efeito foram desenvolvidos por Kaoru Ishikawa que trabalhou como engenheiro de controle de qualidade em companhias japonesas.

Esse diagrama também passou a ser conhecido por outros nomes, tais como: diagramas de Ishikawa, diagrama espinha de peixe (devido a seu formato) ou diagrama $6 \mathrm{M}$.

Ishikawa, a partir de seu diagrama, queria fornecer uma ferramenta para ser utilizada por não especialistas para analisar e resolver problemas.
A partir disso, esses diagramas passaram a ser utilizados para encontrar, classificar e documentar variações de qualidade, fornecendo importantes informações em processos como "brainstorming" e planejamento de produção (CAMPOS, 1992; WERKEMA, 1995).

O diagrama de Ishikawa é composto por um conjunto de causas (processo) e por um efeito (produto, resultado ou problema).

As causas são divididas em 6 seguimentos, os quais indicam onde os problemas no processo podem ocorrer, são eles:

a. Material: São as matérias-primas ou insumos utilizados no processo. Nessa causa diversos fatores podem ser analisados, tais como: qualidade da matéria-prima (material em conformidade com especificação), fornecedores, condição de recebimento, propriedades, entre outros;

b. Mão de obra: Esse item se refere às pessoas envolvidas no processo, fatores como qualificação, motivação, condição de saúde, treinamento, são analisados nessa causa;

c. Máquina: Trata-se dos equipamentos utilizados. Verifica-se o dimensionamento correto da máquina, manutenção, depreciação, programação, operação, etc;

d. Medida: Refere-se aos parâmetros utilizados no processo. Exemplos de variáveis analisadas nessa causa: temperatura, tempo, população amostral, peso, gênero, dimensão, entre outros;

e. Meio ambiente: Essa causa considera o local onde ocorre o processo e/ou suas características: limpeza, iluminação, espaço físico, umidade, relevo, clima, etc;

f. Método: Tem-se nessa causa os procedimentos utilizados para realização do processo, as metodologias adotadas para a realização de uma pesquisa, a seleção das variáveis a serem medidas, as técnicas a serem empregadas em um trabalho (CAMPOS, 1992; WERKEMA, 1995). 
Os diagramas de causa e efeito, devido a sua simplicidade de aplicação, vêm sendo utilizados por diferentes setores para melhorias em áreas como planejamento e melhorias de processo. Gorny (2013) utilizou essa ferramenta para analisar as causas de acidentes ocupacionais. Nesse trabalho ele identificou causas como ambiente inadequado, soluções técnicas incorretas e erro humano. Por meio dos diagramas foi possível transmitir com clareza essas causas e relacioná-las com os problemas, para então indicar soluções para diminuir a incidência desses acidentes.

Outra aplicação para os diagramas foi descrita por Fauziah et al. (2013) onde se verificaram os principais fatores críticos a serem analisados para investimentos em $\mathrm{Tl}$ bem sucedidos (investimentos financeiro, estratégico, interno, tecnológico, entre outros).

A partir dos diagramas de causa e efeito Hekmatpanah (2011) conseguiu reduzir as perdas em um dos processos em dez vezes, o que resultou na diminuição aproximada de $0,92 \%$ de geração de resíduo de óleo em uma companhia de óleo no Irã.

Decker et al. (2010) utilizou os diagramas de causa e efeito para melhorar a transferência de conhecimentos de novas graduandas em enfermagem em cenários clínicos. Nesse trabalho, foram abordados problemas como erros de medicação e atrasos em tratamentos, ajudando a entender a implicação de um processo de administração dos medicamentos de forma completa e seus efeitos em processos como fisiopatologia e sintomatologia.

Outras aplicações são encontradas na literatura para utilização de diagramas de causa e efeito, desde como técnica para tomada de decisões até como ferramenta para auxiliar em análises de falhas em processos FTA (análise da árvore de falhas) e FMEA (análise dos modos e efeitos das falhas) (BILSEY; LIN, 2012; MEYER, 2003; BATZIAS, 2012; ARVANITOYANNIS; VARZAKAS, 2007).

\section{OS MATERIAIS ELETROCRÔMICOS}

Atualmente muitos estudos têm despertado interesse em materiais opticamente ativos, também chamados de cromógenos, os quais apresentam grandes potenciais de aplicação em diversas áreas, tais como: setor automobilístico, aeroespacial, construção civil, fabricação de lentes, aproveitamento de energia, entre outros. Esses materiais se caracterizam por sua capacidade de alteração na suas cores quando recebem um estímulo ou uma variação nas condições do meio em que se encontram. Dentre os materiais cromógenos, existe uma classe que possibilita a alteração reversível de coloração quando submetida a uma diferença de potencial adequada, são os chamados materiais eletrocrômicos (GRANQVIST, 2005). Devido à capacidade de se controlar com facilidade os campos elétricos aplicados, esses materiais se destacam pela possibilidade de construção de dispositivos onde se tem um maior controle das propriedades ópticas do que em outros dispositivos que dependem de fatores como temperatura ou incidência de radiação UV, mais difíceis de controlar. Essa propriedade torna o estudo dos materiais eletrocrômicos, bastante promissor.

Dessa forma, os materiais eletrocrômicos podem ser definidos como "aqueles que passam por uma mudança reversível de cor quando sofrem um processo de redução (ganho de elétrons) ou oxidação (perda de elétrons) a partir da passagem de uma corrente elétrica" (MORTIMER, 2005).

Uma definição mais abrangente também foi dada por Somani e Radhakrishnan (2002), onde se definem material eletrocrômico e o eletrocromismo:

Material eletrocrômico é aquele que muda de cor de maneira persistente, porém reversível através de uma reação eletroquímica denominada eletrocromismo. O eletrocromismo é uma mudança visível e reversível de transmitância ou reflectância associada com uma reação de oxirredução induzida. A mudança de cor é comumente entre um estado transparente e um colorido, ou por dois estados coloridos. (SOMANI; RADHAKRISHNAN 2002). 


\section{A POLIANILINA}

Dentre os diferentes materiais que apresentam a propriedade do eletrocromismo, nessa pesquisa elencou-se a polianilina, devido a sua facilidade de síntese, baixo custo e sua capacidade de proporcionar a criação de dispositivos eletrocrômicos convencionais.

Esse polímero foi relatado primeiramente em 1862 por Letheby que obteve um material sólido negro a partir da oxidação anódica da anilina. Esse material foi primeiramente denominado como "negro de anilina" e naquela época era utilizado como corante para a indústria têxtil. A polianilina somente passou a ter interesse tecnológico a partir da década de 1980, como material condutor de eletricidade em sua forma denominada esmeraldina.

A fórmula estrutural da polianilina é demonstrada na figura 1 e consiste de uma fração de unidades reduzidas contendo um grupo amina (y) e uma fração de unidades oxidadas contendo o grupo imina (1-y).

Figura1 - Fórmula estrutural genérica da polianilina

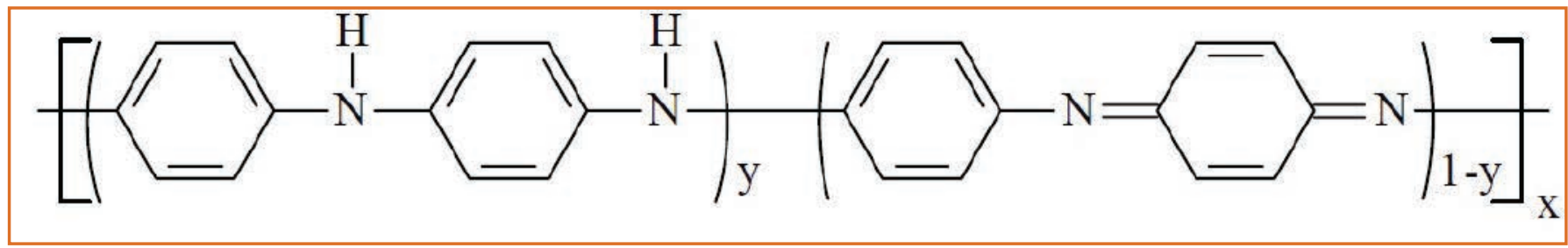

O valor de y na estrutura da figura 1 pode variar de 0 (polianilina completamente oxidada, contendo somente - grupo imina, espécie quinóide) a 1 (polianilina completamente reduzida, contendo somente o grupo amina, espécie benzenóide). Na tabela 1 têm-se os diferentes estados de oxidação da polianilina e suas respectivas cores:

Tabela 1 - Designação, estados de oxidação e cores das diferentes formas de polianilina

\begin{tabular}{|l|l|l|}
\multicolumn{2}{c}{ Designação } & \multicolumn{1}{c|}{ Estados de oxidação } \\
\hline Leucoesmeraldina & 1 & Amarelo \\
\hline Protoesmeraldina & 0,75 & Verde claro \\
\hline Esmeraldina & 0,5 & Verde \\
\hline Nigranilina & 0,25 & Azul \\
\hline Pernigranilina & 0 & Violeta \\
\hline
\end{tabular}

Fonte: Cristovan (2009)

Na forma de Esmeraldina, a polianilina pode ser encontrada na forma de base esmeraldina (EB) que é isolante e apresenta coloração azul escura e na forma de sal de esmeraldina (ES) que é condutora e apresenta a coloração verde (material a ser obitdo nessa pesquisa). Para que se tenha o sal de esmeraldina é possível a obtenção direta por síntese química (a qual será melhor descrita na seção 5), síntese eletroquímica ou deve-se proceder com um processo de dopagem da base esmeraldina, a qual é feita em solução ácida aquosa, sendo esse processo de dopagem denominado de protonagem (dopagem tipo $p$ ). A figura 2 demonstra essas duas estruturas.

A dopagem é um processo reversível, pois não causa danos à cadeia polimérica. No caso da protonação, os nitrogênios imina resultam em radicais cátions responsáveis pela condutividade elétrica e sua carga é compensada pelo ânion do ácido protônico. O grau de protonação depende de seu estado de oxidação e do pH da solução ácida dopante (FOSSATI, 2006; ALMADA, 2007; RODRIGUES, 2004; BAZITO, 2002; GONÇALVES, 2013; CRISTOVAN, 2009). 
Figura 2 - Processo de dopagem da polianilina com ácido protômico, onde EB é a base esmeraldina e ES é o sal de esmeraldina

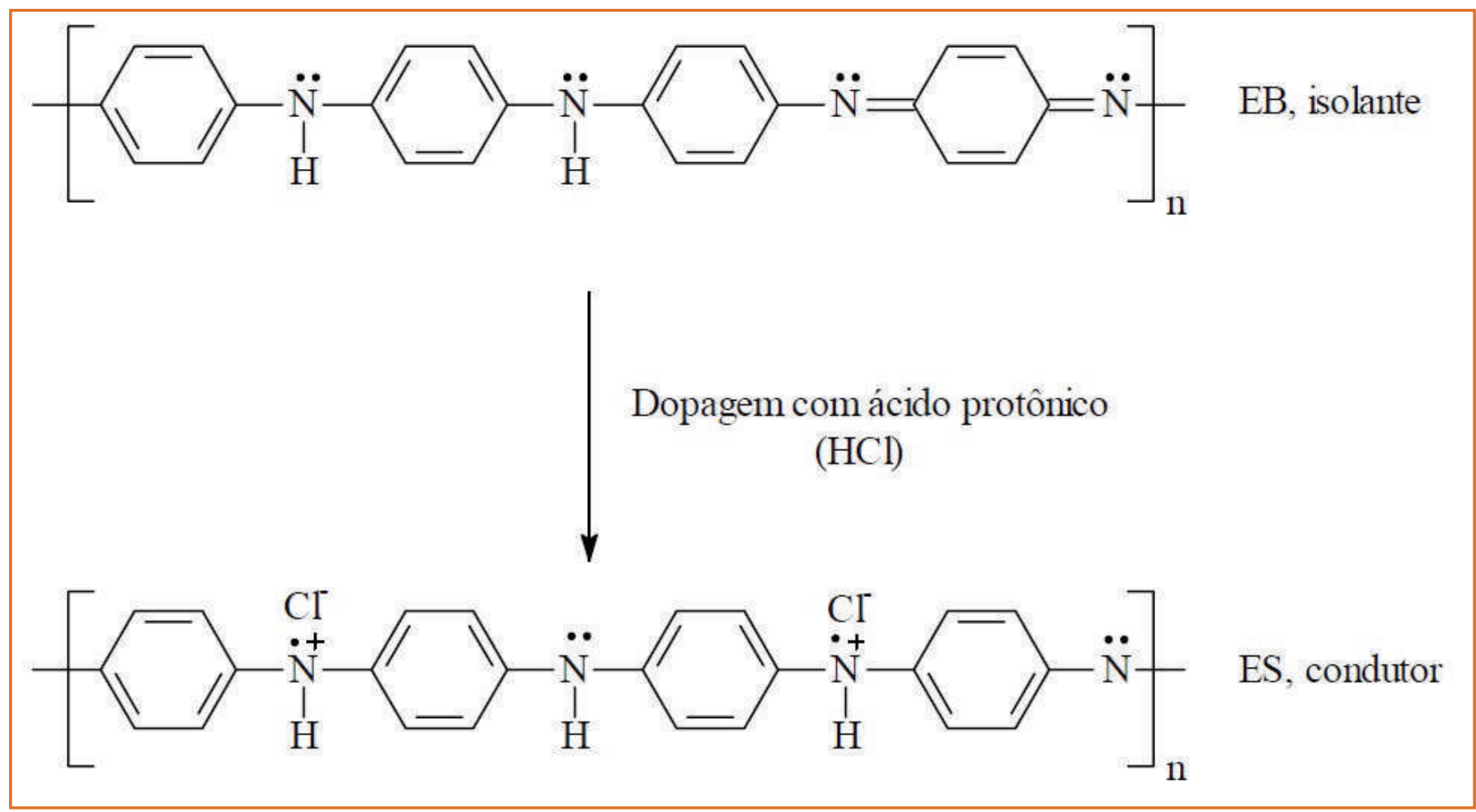

5. APLICAÇÃO DE DIAGRAMAS DE CAUSA E EFEITO PARA PLANEJAMENTO DA SÍNTESE DA POLIANILINA

A obtenção da polianilina pode ser feita via síntese química ou eletroquímica. Nesse trabalho optou-se pela síntese química, por permitir a produção de um polímero com alto peso molecular e elevada pureza, - que favorece conseguir-se a propriedade do eletrocromismo no material. Além disso, consegue-se relativamente maiores quantidades do material quando comparadas àquelas obtidas eletroquimicamente (CRISTOVAN, 2009). Outro fator pré estabelecido foi a escolha da obtenção da polianilina na forma de sal de esmeraldina, única forma onde o polímero se apresenta como um material condutor, facilitando-se assim atingir o eletrocromismo do material na forma de um pigmento.

$\mathrm{Na}$ figura 3 é apresentado o diagrama de causa e efeito para o planejamento da síntense da polianilina. Nesse diagrama, o seguimento meio ambiente referese aos locias onde a pesquisa será desenvolvida e o seguimento mão de obra refere-se às pessoas envolvidas nas fases de obtenção e caracterização do polímero envolvido.

O seguimento método está relacionado com o procedimento experimental que será empregado, o qual tem início com o estudo bibliográfico, o qual permite visualizar o estado da arte de maneira mais ampla e fornencer as informações para embasamento das próximas etapas da pesquisa. Nesse seguimento, definem-se as matérias-primas em potencial no processo de obtenção (as quais serão melhor discutidas quando for abordado o seguimento material) e o tipo de síntese aplicada. As sínteses químicas da polianilina citadas na literatura geralmente baseiam-se no processo de oxidação química da anilina descrita por McDiarmid (1992) onde se utiliza o meio ácido a partir do ácido clorídrico e o persulfato de amômio como agente oxidante.

Após definidas as matérias-primas, parte-se então para a obtenção do polímero (a partir dos parâmetros que serão dicutidos no seguimento medida), o qual 
após a síntese passará por um processo de filtragem e posterior secagem.
Finalmente, serão confeccionadas amostras para caracterização da estrutura e das propriedades do pigmento e confirmação de seu caráter eletrocrômico.

Figura 3 - Diagrama de causa e efeito para planejamento da síntese da PAN

Diagrama de causa efeito para pesquisa científica - PPGEP $(19 / 04 / 15)$

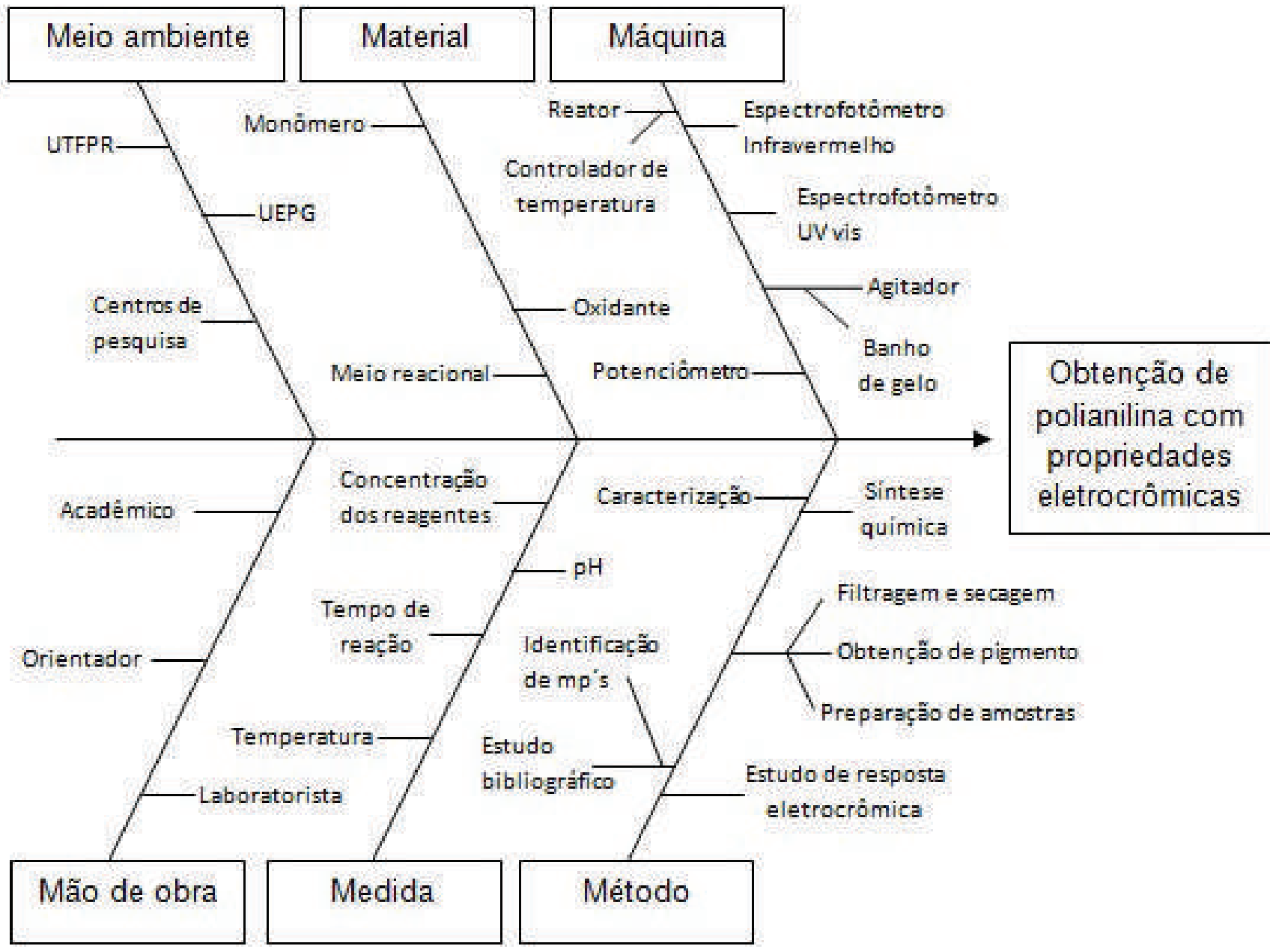

\section{Causas}

\section{Efeito}

O seguimento material refere-se às matérias-primas elencadas no processo de obtenção da polianilina. Embora não se tenha variação no monômero empregado (anilina), diferentes agentes oxidantes e ácidos responsáveis pelo meio reacional e dopagem do polímero são citados na literatura.

Mostafei e Zoriasatein (2012) obtiveram a polianilina a partir do ácido canforsulfônico, utilizando o persulfato de amônio como agent oxidante. Nesse trabalho, o polímero foi misturado a nano esferas de $\mathrm{ZnO}$, formando um compósito, porém a adição do ZnO acarretou em redução da condutividade elétrica da polianilina, que pura apresentou uma condutividade de 0,025 S/cm.

O ácido sulfúrico também foi utilizado como meio reacional e para dopagem da polianilina, a qual apresentou a propriedade do eletrocromismo. 
Verificou-se para esse caso que quanto maior a concentração do $\mathrm{H}_{2} \mathrm{SO}_{4}$, menor o tempo de resposta do filme eletrocrômico formado (THUMMARUNGSAN; PATTAVARAKORN, 2014).

Atassi et al. (2008) obtiveram a polianilina na forma de sal de esmeraldina com uma condutividade de $1,7 \mathrm{~S} / \mathrm{cm}$. Foi utilizado o meio reacional a partir do ácido clorídrico e o persulfato de amônio como agente oxidante. A dopagem foi feita por meio do ácido p-tolueno sulfônico.

Diferentes agentes oxidantes foram testados por Vivekanandan et al. (2011) e por Rodrigues (1991). No primeiro trabalho, a utilização de um meio reacional de ácido sulfúrico e o dicromato de potássio como oxidante permitiram a obtenção de um material com codutividade de 0,27 S/cm. Já no segundo trabalho foram utilizados o persulfato de amônio, o dicromato de potássio e o iodato de potássio como agentes oxidantes em meio reacional de ácido clorídrico. Verificou-se que o persulfato de amônio foi o melhor agente oxidante para esse trabalho, onde se coseguiu uma condutividade de $22,80 \mathrm{~S} / \mathrm{cm}$.

Salih (2010) verificou a influência dos ácidos 2,5 dimetilbenzeno sulfônico, 4-hidroxi-m-benzeno disulfônico e 3-cloro-4-hidroxibenzeno sulfônico como dopantes para a condutividade da polianilina obtida em meio ácido de $\mathrm{HCl}$, utilizando o persulfato de amônio como agente oxidante. Os maiores valores foram, obtidos com o primeiro dopante citado, com valor de $0,001 \mathrm{~S} / \mathrm{cm}$.

No seguimento medida da figura 3, têm-se os parâmetros de síntese que apresentam maior influência nas propriedades do polímero obtido. O $\mathrm{pH}$ foi intensamente investigado por Cristovan (2009). A partir desse trabalho, confirmou-se a sua grande influência no rendimento da síntese e na propriedade do material sintetizado. Fora observado que para valores menores $\mathrm{pH}$ se têm maiores rendimentos e grau de polimerização durante a síntese química. A condutividade também apresentou-se maior para valores de $\mathrm{pH}$ mais ácidos. Esse comportamento já havia sido reportado anteriormente por MacDiarmid (1992), conforme demonstrado na figura 4, onde uma base esmeraldina foi protonada com uma solução aquosa de $\mathrm{HCl}$ :

Figura 4 - Condutividade da Esmeraldina em função do pH da solução de $\mathrm{HCl}$

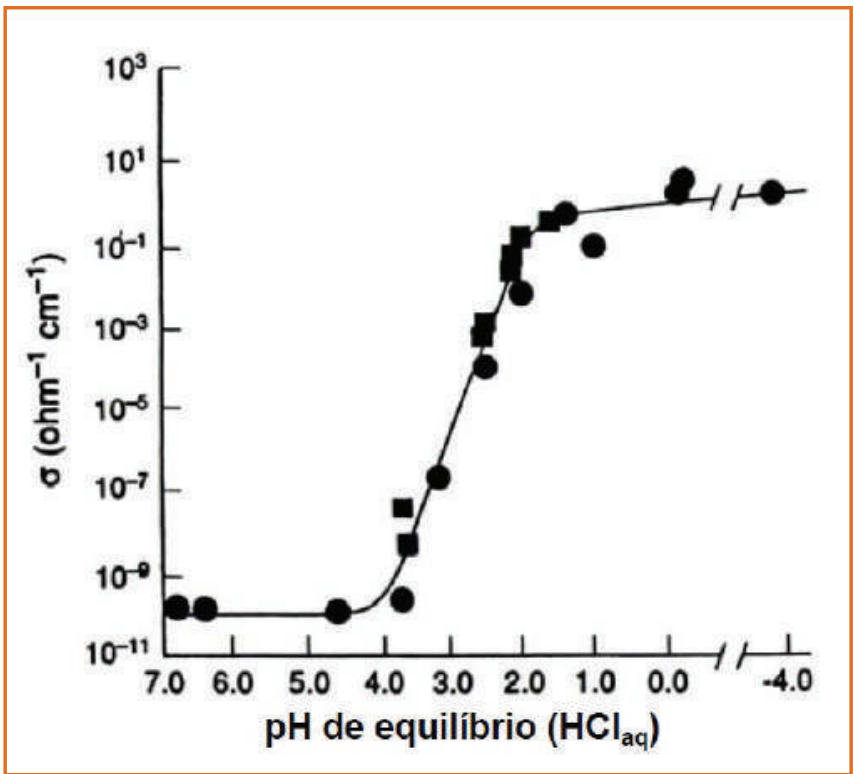

A concentração do monômero em relação à concentração do agente oxidante também tem influência nas propriedades do polímero formado. Quando se tem uma maior concentração do monômero em relação ao oxidante, a tendência é ter-se cadeias poliméricas com maiores massas moleculares, o que acarretá em um acréscimo na condutividade elétrica. Os maiores valores de condutividade são obtidos em concentrações 4:1 (RODRIGUES, 1991; CRISTOVAN 2009).

Os parâmetros tempo e temperatura são bastante variados dentro da literatura. Existem trabalhos que relatam tempos de reação de 20 minutos (VIVEKANADAN, 2011) até mais de 10 horas entre agitação e repouso (RODRIGUES,1991). Em relação à temperatura, a maioria dos trabalhos da literatura seguem a temperatura proposta por MacDiarmid (1992) onde a reação é mantida entre temperaturas entre 0 e $-5^{\circ} \mathrm{C}$. Porém, existem trabalhos que relatam a síntese na temperatura ambiente (ATASSI, 2008; HASSAN E HUSSEIN, 2014). Em geral, maiores tempos de reação e menores temperaturas favorecem o rendimento da síntese e permitem formação de polímeros com 
maiores massas moleculares. (CRISTOVAN 2009).

Finalmente, o seguimento máquina da figura 3 refere-se aos equipamentos utilizados para síntese da polianilina (reator, controlador de temperatura, agitador e banho de gelo) e àqueles para as técnicas de caracterização de suas propriedades (espectrofotômetros IR e UVvisível e potenciômetro).

A espectroscopia na região do infravermelho foi utilizada por Hasan e Hussein (2014) para caracterizar a polianilina pura e com a presença de dopantes. Foi verificado que os picos apresentaram-se na mesma região do espectro para todas as amostras. Os picos também apresentaram-se na mesma região e com intensidades similares quando se compararam os espectros da esmeraldina na forma de sal e de base (ATASSI, 2008), conforme demonstrado na figura 5 :

Figura 5 - Espectro de infravermelho da esmeraldina (a) sal (b) base

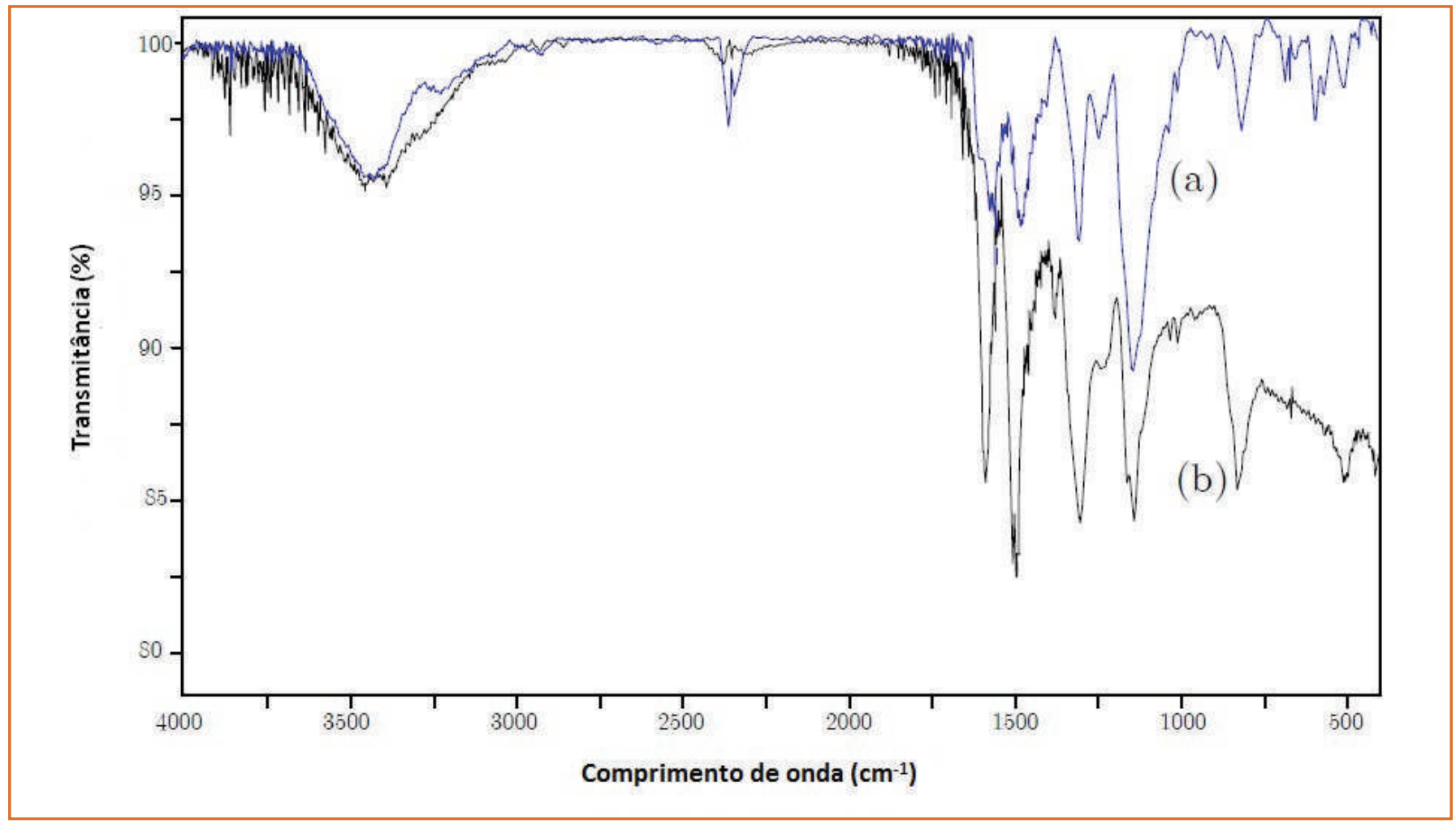

As regiões dos picos do espectro e suas respectivas atribuições para o sal de esmeraldina são demonstradas na tabela 2:
Em relação à espectroscopia na região do UV-vis, a figura 6 demonstra um espectro de absorção da base esmeraldina e do sal de esmeraldina dissolvidos em ácido dimetilsufóxido (DMSO): 
Tabela 2 - Bandas observadas em espectro infravermelho do sal de esmeraldina e suas possíveis atribuições

\begin{tabular}{|l|l|}
\hline Comprimento de onda $(\mathbf{c m}-\mathbf{1})$ & Atribuição \\
\hline $590-700$ & Alongamento C $-\mathrm{Cl}$ \\
\hline 684 & Vibração NH2 \\
\hline 814 & Flexão C - H fora do plano (benzeno 1,4 dissubstituído) \\
\hline 1148 & Flexão C - H de aromático no plano \\
\hline 1245 & Alongamento C - C \\
\hline 1246 & C - N de amina secundária aromática \\
\hline 1306 & Flexão N - H \\
\hline 1482 & Vibrações C - C de anéis benzênico \\
\hline 1560 & Vibrações C = C de anés quinônicos \\
\hline 1580 & Presença de imina protonada \\
\hline 1653 & Flexão NH2 \\
\hline 3220 & Alongamento NH2 \\
\hline
\end{tabular}

Fonte: Adaptado de Atassi (2008); Rodrigues (1991); Yilmaz (2007)

Figura 6 - Espectro de absorção na região UV-vis para a base esmeraldina (EB - linha sólida) e sal de esmeraldina (ES - linha pontilhada) dissolvidos em DMSO

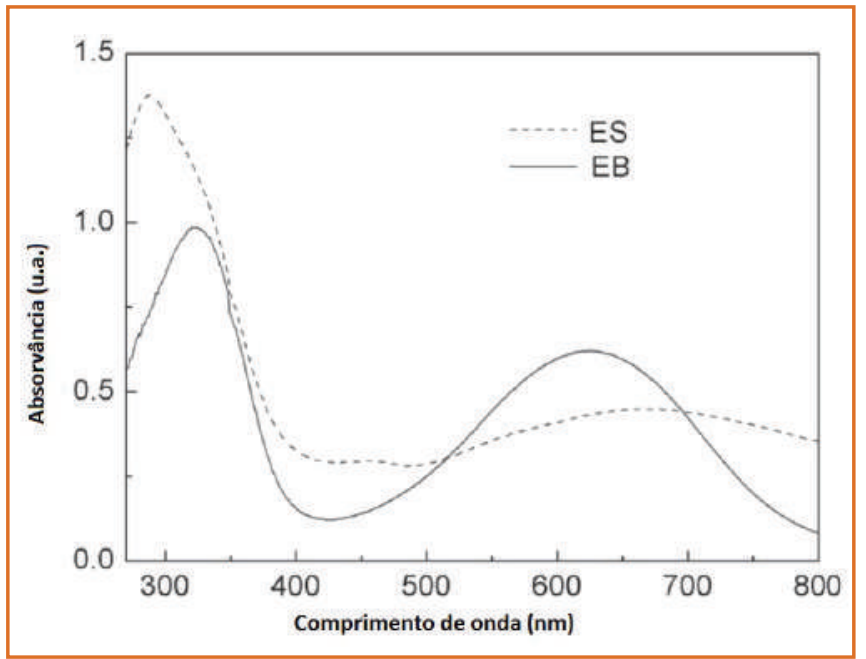

O espectro da base esmeraldina na figura 6 apresenta duas bandas de absorção características nas faixas 320 e $625 \mathrm{~nm}$. A primeira banda refere-se à transição $\pi-\pi^{*}$ dos anéis benzenóides (incluindo estruturas aminas), a segunda é referente à excitação dos anéis quinóides (incluindo iminas), transições $n-\pi$ *

A esmeraldina na forma de seu sal apresenta bandas nas faixas de $290 \mathrm{~nm}$ e $450 \mathrm{~nm}$, além de uma terceira mais larga na faixa de entre 650 a $850 \mathrm{~nm}$. A primeira refere-se ao deslocamento para direita da mesma banda presente na base esmeraldina (transição $\pi$ - $\pi$ *dos anéis benzenóides), as duas bandas seguintes atribuem-se a protonação dos átomos de nitrogênio nos grupos iminas. O nitrogênio e seus anéis quinóides na vizinhança se tornam radicais cátions semiquinóides, gerando essas duas bandas de absorção, devido à presença da transição de polarização $\pi^{*}$ (450nm) e bipolarização (transição de polarização $\pi, 650$ a $850 \mathrm{~nm})$. Desse modo, as duas últimas bandas relatam o nível de dopagem e formação da polarização na estrutura, os quais representam os estágios de protonação na cadeia da polianilina. Logo, as duas últimas bandas referem-se a uma excitação localizada no anel quinóide, atribuindo-se à transferência de carga dos anéis benzenóides adjacentes, no qual cada lado contribui com um elétron em média.

Quando se parte de uma dopagem da base esmeraldina para se obter o sal de esmeraldina, por exemplo, o decréscimo da banda de absorção da polianilina não dopada em $625 \mathrm{~nm}$ é proporcional ao aumento da banda de absorção da polianilina dopada (650 a 850nm).

É importante salientar que a posição e intensidade das bandas podem sofrer pequenos deslocamentos em função dos diferentes parâmetros experimentais utilizados. Outros solventes citados na literatura que também são utilizados na técnica são o n-metil-2pirrolidona (NMP) e o clorofórmio (FOSSATI, 2006; 
RODRIGUES, 2004; GUL, et al., 2013; GUL, et al., 2015; NGUYEN, et al., 2014; MAMMA, et al., 2013).

O potenciômetro, indicado na figura 3 , permite a realização de um ensaio denominado de voltametria cíclica que consiste em uma varredura cíclica de potencial a uma determinada velocidade, registrandose a resposta da corrente. O experimento voltamétrico, inicia-se com a aplicação de um potencial em um valor no qual nenhuma reação acontece. Com a variação do potencial para regiões mais negativas (catódicas) ocorre a redução do composto em solução, gerando um pico de corrente proporcional à concentração deste composto. Quando o potencial atingir um valor onde nenhuma reação de redução ocorre, o potencial é deslocado para o sentido oposto até o valor inicial. No caso de uma reação reversível, os produtos que foram gerados no sentido direto e se localizam próximos à superfície do eletrodo são oxidados, gerando um pico simétrico ao pico da redução. Dessa forma, o voltamograma cíclico é obtido a partir de um gráfico corrente em função do potencial aplicado.

A voltametria cíclica típica para um filme de polianilina (sal de esmeraldina) é demonstrada no trabalho de Hwang, Quilitz e Schmidt (2007) e no trabalho de Mattoso (1996) e é apresentada na figura 7.

Figura 7- Voltametria cíclica de um filme de sal de esmeraldina com indicação das cores observadas nas diferentes regiões de potencial

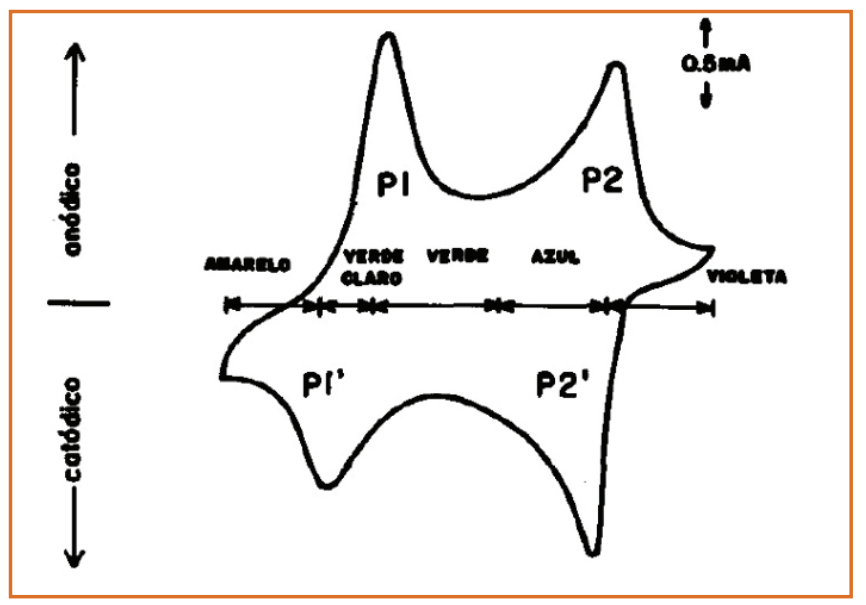

O voltamograma cíclico foi feito na faixa entre $-0,2 \mathrm{~V}$ e $1,0 \mathrm{~V}$, com uma velocidade de varredura de $50 \mathrm{mV} / \mathrm{s}$. A resposta eletroquímica da figura 7 é idêntica para a polianilina obtida química ou eletroquimicamente, contendo dois pares redox (P1 e P2), sendo que o par de picos $\mathrm{P} 1$ se referem à conversão dos estados de oxidação leucoesmeraldina (amarelo) e esmeraldina (verde). Os picos P2, no potencial mais positivo estão associados à conversão entre os estados esmeraldina e pernigranilina (MATTOSO, 1996).

\section{CONCLUSÃO}

A partir da utilização de um diagrama de causa e efeito, separou-se os parâmetros de influência na síntese química da polianilina em seis seguimentos. Essa divisão permitiu analisar cada uma das variáveis de síntese de maneira isolada.

Os diferentes resultados encontrados na literatura proporcionaram uma visão mais ampla das possibilidades que podem ser empregadas para maximizar cada parâmetro que influencia na obtenção do sal de esmeraldina com uma maior condutividade, o que provavelmente permitirá ter-se um pigmento com respostas eletrocrômicas.

Destacam-se dentre os parâmetros observados: uso de meios reacionais com pH ácidos (abaixo de 2), concentração de monômero em relação ao agente oxidante de 4:1, uso de menores temperaturas e maiores tempos de reação. Finalmente, verificou-se os resultados das caracterizações feitas em outras pesquisas, as quais servirão de comparativo com as propriedades da polianilina obtida.

\section{REFERÊNCIAS}

[1] ALMADA, G. F. Estudo da proteção à corrosão pelo uso de polímeros condutores. 2007. 116f. Dissertação (Mestre em Ciências) - Instituto de Química da Universidade de São Paulo, São Paulo, 2007.

[2] ARVANITOYANNIS, I.S.; VARZAKAS,T.H. Application of failure mode and effect analysis (FMEA), cause and effect analysis and Pareto diagram in conjunction with HACCP to a potato chips manufacturing plant. International Journal of Food Science and technology. v.42, ed. 12, p. 1424-1442, dez. 2007. 
[3] ATASSI, Y. et al. Synthesis and characterization of chloride doped polyaniline by bulk oxidative chemical polymerization. Doping effects on electrical codutivity. Higher Institute for applied Science and Technology, Damascus, 2008.

[4] BATZIAS, D. F. Transforming incomplete fault tree to Ishikawa diagram as an alternative method for technology transfer. In: INTERNATIONAL CONFERENCE ON COMPUTACIONAL METHODS IN SCIENCES AND ENGINEERING (ICCMSE), 7., 2009, Rhodes, Grécia, v. 1504, p.1035-1038, 2012

[5] BAZITO, F. F. Estudo espectroeletroquímico de um copolímero alternado de PANI e PPS: PPSA - poli(sulfeto de fenileno fenilenamina). 2002. 151 f. Tese (Doutor em Química) - Instituto de Química da Universidade de São Paulo, São Paulo, 2002

[6] BILSEL, R. Ufuk; LIN, Dennis K.J. Ishikawa cause and effect diagrams using capture techniques. Quality technology and quantitative management. v. 9, ed. 2, p. 137-152, jun. 2012.

[7] CAMPOS, V. F. Controle da qualidade total (no estilo japonês) 3. ed. Rio de Janeiro: Bloch editores S.A., 1992.

[8] CRISTOVAN, F. H. Preparação e caracterização de blendas PANI/ABS. 2009. 181 f. Tese (Doutor em Ciência) Programa de Pós-Graduação em Química da Universidade Federal de São Carlos, São Carlos, 2009.

[9] DECKER, S. et al. Synergistic Integration of Concept Mapping and Cause and Effect Diagramming Into Simulated Experiences. Clinical simulation and nursing. Texas, v.6, p. 153-159, 2010.

[10] FAUZIAH, A.; GHANI, A.; ARYATI, W.; HABIBAH, $N$. Ishikawa diagram of critical factors for information technology investment success: A conceptual model. In: INTERNATIONAL CONFERENCE ON INFORMATION SYSTEMS MANGEMENT AND EVALUATION (ICIME), 4.,2013, Rmit, Vietnã, ICIME 2013. p. 27-34.

[11] FOSSATI, D. Dispositivo eletrocrômico híbrido constituído por polianilina sulfonada e V2O5. 2006. 78 f. Dissertação (Mestre em Química) - Programa de Pós-Graduação em Química, Universidade Federal do Paraná, Curitiba, 2006.

[12] GONÇALVES, G. E. Condutividade alternada de Polianilina embebida com nanopartículas de óxido de estanho e índio. 2013. 169 f. Tese (Doutor em Engenharia de Materiais) - Programa de Pós-Graduação em Engenharia de Materiais da REDEMAT, Universidade Federal de Ouro Preto, Ouro Preto, 2013

[13] GORNY, A. The use of Ishikawa diagram in occupational accidents analysis. In: INTERNATIONAL SYMPOSIUM ON OCCUPATIONAL SAFETY AND HYGIENE (SHO), 9., 2013, Guimarães, Portugal, SHO 2013. p. 224-226.

[14] GRANQVIST, C. G. Electrochromic devices. Journal of the European Ceramic Society, Uppsala, v.25, p. 2907-2912, abr. 2005.
[15] GUL, S. et al. Synthesis and characterization of processable polyaniline salts. Journal of Physics, Peshawar, v.439, p. 1-10, 2013.

[16] GUL S. et al. Effect of high temperature on the electrochemical and properties of emeraldine salt doped with DBSA and sulfuric acid. Journal of Chemistry, Peshawar, vol. 2015, p. 1-9, jan. 2015

[17] HASAN, S. M.; HUSSEIN, Z.A The effect of H2SO4 as a doping agent on the structure of polyaniline prepared at room temperature. International Journal of Application or Innovation in Engineering \& Management, Baghdad, vol. 3, p. 486-493, jan. 2014

[18] HEKMATPANAH, M. The application of cause and effect diagram in the oil industry in Iran: The case of four liter oil canning process of Sepahan Oil Company. African Journal of business management. Ardestan, Irã, v.5, ed. 26, p. 1090010907, oct. 2011.

[19] HWANG, T.; QUILITZ, M.; SCHMIDT, H. Comparasion of the electrochromic properties of films made of Silica/ Polyaniline composite nanoparticles and films made of pure Polyaniline. Journal of New Materials for Electrochemical Systems, Inchon, v. 10, p. 237-242, mai. 2007

[20] MACDIARMID, A.G.; EPSTEIN, A.J. Polyaniline: synthesis, chemistry and processing. New aspects of organic chemistry II, Philadelphia, p. 271, 1992.

[21] MAMMA, K. et al. Effect on poly $(\mathrm{C} 6 \mathrm{H} 5 \mathrm{NH} 2)$ emeraldine salt by $\mathrm{Fe} 3 \mathrm{Cl}$ and $\mathrm{KMnO} 4$ as secondary dopants. American Journal of Polymer Science \& Engineering. Jimma, v. 1, p. 2-13, may. 2013

[22] MATTOSO, L. H. C. Polianilinas: Síntese, estrutura e propriedades. Química Nova, São Carlos, v. 19, p. 388-399, abr. 1996

[23] MEYER, V.R. Measurement uncertainty of liquid chromatographic analyses visualized by Ishikawa diagrams. Journal of Chromatographic Science. v. 41, ed. 10, p. 580, nov/dez. 2003.

[24] MORTIMER, R. J. Electrochromic organic and polymeric materials for display applications. Displays, Florida, v.27, p. 2-18, set. 2006.

[25] MOSTAFEI, A.; ZOLRIASATEIN, A. Synthesis and characterization of conducting polyaniline nanocomposites containing $\mathrm{ZnO}$ nanorods. Progress in Natural Science: Materials International, v.22, p. 273-280, ago. 2012.

[26] NGUYEN, H. D. et al. pH sensitivity of emeraldine salt polyaniline and poly(vinyl butyral) blend. Advance in Natural Sciences: Nanoscience and Nanotechnology. Ho Chi Minh, v. 5, p. $1-5,2014$

[27]RODRIGUES, M. A. Propriedades eletroquímicas e eletrocrômicas de poli(anilina)preparada quimicamente. 1991. 109 f. Tese (Doutor em Química) - Instituto de Química da Universidade Estadual de Campinas, Campinas, 1991. 
[28] RODRIGUES, P. C. Síntese, caracterização e correlações estrutura/propriedades de redes mistas de Polianilina/ Poliuretano com arquitetura molecular pré-desenhada. 2004. 102 f. Tese (Doutor em Ciências) - Programa de Pós Graduação em Química, Universidade Federal do Paraná, Curitiba, 2004.

[29] SALIH, R. Synthesis, identification and study of electrical conductivity of doped polyaniline. Arabian Journal of Chemistry, v.3, p. 155-158, apr. 2010.

[30] SOMANI, P. R.; RADHAKRISHNAN, S. Electrochromic materials and devices: present and future. Materials Chemistry and Physics, Panchawatti, v.77, p. 117-133, set. 2002.

[31] THUMMARUNGSAN, N. PATTAVARAKORN, D. Eletrochromic performances of conductive polyaniline copolymer. International Journal of Chemical Engineering and Aplications, vol. 5, n. 2, p. 176-180, apr. 2014.
[32] VIVEKANANDAN, J. et al. Synthesis, characterization and conductivity study of polyaniline prepared by chemical oxidative and electrochemical methods. Archives of Applied Science Research, vol. 3, n. 6, p. 147-153, 2011.

[33] WERKEMA M. C. C. As ferramentas da qualidade no gerenciamento de processos 1. ed. Belo Horizonte: Sografe, 1995.

[34] YILMAZ, F. Polianyline: Syntesis, chracterization, solution properties and composites. 2007. $148 \mathrm{f}$. Tese (Doctor of Philosophy in Polymer Science and Technology) - School of Natural and Applied Science of Middle East Technical University, Beirut, 2007. 


\title{
CAPÍTULO 9
}

\section{AVALIAÇÃo doS NíVEIS DE CALOR DO FORNO DE QUEIMA DE PRODUTOS CERÂMICOS EM UMA EMPRESA EM CACOAL - RO}

\author{
Alessandro Aguilera Silva \\ Leandro Valkinir Kester \\ Juander Antônio de Oliveira Souza \\ André Grecco Carvalho \\ Graziela Luiz Franco Martinez
}

Resumo: O ambiente laboral pode expor os trabalhadores a condições desfavoráveis devido a presença dos riscos ambientais e ocupacionais, entre eles o calor. Este causa desconforto e pode aumentar o risco de acidentes de trabalho, provocando danos consideráveis a integridade física e a saúde dos trabalhadores. Os agentes de riscos quando presentes no ambiente laboral acima dos limites de tolerância estabelecidos pela legislação brasileira caracterizam o ambiente como insalubre, para tanto, se devem realizar medições ambientais, utilizando-se de equipamentos específicos para constatar se há insalubridade no ambiente. Nessa tônica, fundamentado nos parâmetros da NormaRegulamentadora - NR - 15 Atividades e Operações Insalubres, o presente trabalho apresenta uma avaliação dos níveis de calor dos setores de trabalho correlacionados ao forno utilizado para a queima de produtos cerâmicos em uma empresa localizada no município de Gacoal - RO. Quanto à metodologia utilizada tratou-se de uma pesquisa descritiva quantitativa com pesquisa de campo e os diferentes resultados encontrados foram comparados com os limites de toleráncia estabelecidos pela NR - 15 em seu anexo n`3. Neste contexto, se fazem necessárias mudanças indispensáveis visando à integridade física e a saúde dos trabalhadores que atuam no forno de queima. A principal contribuição da pesquisa foi identificar que os níveis de calor no setor de Queima/ Túnel e em Fornos se encontram acima do estabelecido pela NR - 15 em seu anexo $n^{\circ} 3$. São apresentadas algumas sugestões que visam proporcionar um ambiente laboral onde o agente de risco calor possa ser minimizado e controlado, contribuindo para o bem estar dos trabalhadores.

Palavras chave: Calor, Fornos, Insalubridade, NR-15, Trabalhadores. 


\section{INTRODUÇÃO}

De acordo com informações da Prefeitura do município de Cacoal (2015), o município se localiza geograficamente na Mesorregião Leste Rondoniense, ao longo da BR-364, ao sul da capital do estado, distante aproximadamente $480 \mathrm{~km}$ da capital Porto Velho.

E segundo informações do Instituto Brasileiro de Geografia e Estatística - IBGE (2015) censo de 2010 a população era de 78.574 mil habitantes e, estimada para 2014 em 86.556 mil habitantes. E juntamente com o município de Pimenta Bueno/RO, a região leste é considerada a região do estado que concentra a maior quantidade de unidades produtivas de cerâmicas vermelhas, tal fato se deve pela concentração de matéria-prima necessária para a produção dos produtos cerâmicos.

Neste contexto, as cerâmicas vermelhas utilizam fornos para a queima dos produtos cerâmicos, desencadeando temperatura elevada, decorrente das fontes de calor liberadas em grande quantidade de energia no ambiente laboral.

Pereira (2005) menciona que os fatores influenciadores das trocas térmicas compreeendem a temperatura do ar, a umidade relativa do ar, a velocidade do ar e o tipo de atividade metabolismo do indivíduo.

Contudo, Girardi e Gadegast (2012) ressaltam que a exposição a essa sobrecarga térmica causa inúmeras doenças, interferindo ou prejudicando no desempenho físico e mental do trabalhador, além de deixa-lo mais suscetível ao acidente.

Desta forma, o segmento cerâmico é um ambiente laboral considerado insalubre, onde alguns agentes que se fazem presentes são pertinentes, ou seja, são característicos da atividade em questão, como o calor, sendo este parâmetro quantificável, para tanto, medições ambientais, utilizando instrumentos específicos devem ser realizadas, buscando a constante promoção da segurança e saúde no trabalho.

\section{REVISÃO BIBLIOGRÁFICA 2.1 SETOR CERÂMICO}

De acordo com a Associação Brasileira de Cerâmica - ABCERAM (2015) o setor cerâmico é amplo e heterogêneo, cabendo dividi-lo em subsetores ou segmentos em função de inúmeros fatores, como matérias-primas, propriedades e áreas de utilização. Desta forma, a classificação é adotada em cerâmica vermelha, materiais de revestimento (placas cerâmicas), cerâmica branca, materiais refratários, isolantes térmicos, fritas e corantes, abrasivos, vidro, cimento e cal e cerâmica de alta tecnologia/cerâmica avançada. Para tanto, esta pesquisa, focará somente na classificação de cerâmica vermelha.

\subsection{FORNOS}

A cerâmica vermelha possui processo produtivo relativamente curto, compreendendo as etapas de extração, dosagem, desintegração, mistura, laminação, extrusão ou corte, secagem, queima e expedição.

A NR - 14 (BRASIL, 2014) estabelece que os fornos para qualquer utilização, devem ser construídos solidamente, revestidos com material refratário de forma que o calor radiante não ultrapasse os limites de tolerância estabelecidos pela NR - 15, garantindo a integridade e o bem estar dos trabalhadores. Nessa tônica, a Norma determina medidas de segurança para a instalação e manuseio seguro das tarefas executadas pelos trabalhadores.

\subsection{APARELHOS PARA AVALIAÇÃO}

A NR - 15 (BRASIL, 2014) em seu anexo n 3 - Limites de Tolerância para exposição ao calor, determina os aparelhos que devem ser adotados para se realizar as medições ambientais do agente de risco calor. Neste contexto, os aparelhos são:
a. Termômetro de bulbo úmido natural;
b. Termômetro de globo;
c. Termômetro de mercúrio comum. 
radiante (tg) na carga térmica do organismo o qual é acoplada a globo de cobre. Já o termômetro de bulbo úmido natural (tbn) consiste na escala de $0^{\circ} \mathrm{C}$ e $100^{\circ} \mathrm{C}$ que é acoplado em recipiente com água destilada, medindo a capacidade de troca entre a pele e o meio através da evaporação da água, sendo este influenciado pela umidade relativa e pela velocidade do ar. E o termômetro de bulbo seco (tbs) mede a capacidade de troca térmica entre a pele e o meio, por meio da condução, sendo este influnciando pela velocidade do ar e somente sendo utilizado quando o ambiente laboral envolver carga solar.

\subsection{LEGISLAÇÃO}

As Normas Regulamentadoras - NR's fornecem orientações acerca dos procedimentos obrigatórios relacionados à Segurança e Medicina do trabalho no Brasil.

A Lei (BRASIL, Lei oㅡ 6.514 de 22 de dezembro 1977) Altera o Capítulo V do Título II da Consolidação das Leis do Trabalho (Arts. 154 a 201), relativo à Segurança e Medicina do Trabalho.

E a Portaria (BRASIL, Portaria $n^{\circ} 3.214$ de 9 de junho de 1978) Aprova as Normas Regulamentadoras - NR - do Capítulo V, Título II, da Consolidação das Leis do Trabalho, relativas à Segurança e Medicina do Trabalho.

De acordo com o Ministério do Trabalho e Emprego - MTE (2015) atualmente existem em vigor 36 (trinta e seis) NR's aplicáveis que possuem o objetivo de promover a Segurança e a Saúde no trabalho nas mais diferentes atividades econômicas do país.

A NR - 15 (BRASIL, 2014) em seu anexo $n^{\circ} 3$, determina que a exposição ao calor deva ser avaliada através do "Índice de Bulbo Úmido - Termômetro de Globo" (IBUTG) definido pelas equações 1 e 2:

a. Ambientes internos ou externos sem carga solar - IBUTG = 0,7 tbn + 0,3 tg (Eq. 1);

b. Ambientes externos com carga solar - IBUTG = $0,7 \mathrm{tbn}+0,1 \mathrm{tbs}+0,2 \mathrm{tg}$ (Eq. 2).

Onde:

-a) tbn = temperatura de bulbo úmido natural;

-b) tg = temperatura de globo;

-c) tbs = temperatura de bulbo seco.

\subsubsection{ATIVIDADES E OPERAÇÕES INSALUBRES}

A NR - 15 (BRASIL, 2014) estabelecem que sejam consideradas atividades ou operações insalubres as que se desenvolvem acima dos limites de tolerância previstos nos anexos $n^{\circ} 1,2,3,5,11$ e 12 e nas atividades mencionadas nos anexos $n{ }^{\circ} 6,13$ e 14 da respectiva NR.

\subsubsection{LIMITES DE TOLERÂNCIA PARA EXPOSIÇÃO AO CALOR}

De acordo com a NR - 15 (BRASIL, 2014) há duas formas de estabelecer os limites de tolerância para exposição ao calor, em regime de trabalho intermitente. A primeira é com períodos de descanso no próprio local de prestação de serviço, sendo este considerado tempo de serviço para todos os efeitos legais conforme $N R$ - 15 anexo $n^{\circ} 3$. Neste contexto, de acordo com o índice obtido através das medições ambientais, o regime de trabalho intermitente será definido no quadro 1. A determinação do tipo de atividade (leve, moderada ou pesada) é feita consultando-se o quadro 3. 
Quadro 1:Regime de Trabalho Intermitente.

\begin{tabular}{|c|c|c|c|}
\hline \multirow{2}{*}{$\begin{array}{l}\text { Regime de Trabalho Intermitente com Descanso no Próprio } \\
\text { Local de Trabalho (por hora) }\end{array}$} & \multicolumn{3}{|c|}{ Tipo de Atividade } \\
\hline & Leve & Moderada & Pesada \\
\hline Trabalho contínuo & Até 30,0 & Até 26,7 & Até 25,0 \\
\hline $\begin{array}{l}45 \text { minutos trabalho } \\
15 \text { minutos de descanso }\end{array}$ & 30,1 a 30,6 & 26,8 a 28 & 25,1 a 25,9 \\
\hline $\begin{array}{l}30 \text { minutos trabalho } \\
30 \text { minutos descanso }\end{array}$ & 30,7 a 31,4 & 28,1 a 29,4 & 26,0 a 27,9 \\
\hline $\begin{array}{l}15 \text { minutos trabalho } \\
45 \text { minutos descanso }\end{array}$ & 31,5 a 32,2 & 29,5 a 31,1 & 28 a 30 \\
\hline $\begin{array}{l}\text { Não é permitido o trabalho, sem adoção de medidas adequadas de } \\
\text { controle. }\end{array}$ & Acima de 32,2 & Acima de 31,1 & Acima de 30,0 \\
\hline
\end{tabular}

Fonte: BRASIL (2014)

A segunda forma de estabelecimento é com períodos de descanso em outro local (local de descanso). Para tanto, se deve determinar a taxa de metabolismo média ponderada para uma hora, determinada pela equação 3 , representada pela seguinte fórmula:

$M=\underline{M t} \times T t+M d \times T d \quad$ (Eq. 3)

60

Sendo:

a) Mt - taxa de metalismo no local de trabalho;

b) Tt - soma dos tempos, em minutos, em que se permanece no local de trabalho;

c) Md - taxa de metabolismo no local de descanso;

d) Td - soma dos tempos, em minutos, em que se permanece no local de descanso.

Desta forma, após obtido a taxa de metablismo média ponderada, o limite de tolerância também é obtido, comparando o valor encontrado com os valores descritos no quadro 2.

\begin{tabular}{|c|c|}
\hline \multicolumn{1}{|c|}{ M (Kcal/h) } & Máximo IBUTG \\
\hline 175 & 30,5 \\
\hline 200 & 30,0 \\
\hline 250 & 28,5 \\
\hline 300 & 27,5 \\
\hline 350 & 26,5 \\
\hline 400 & 26,0 \\
\hline 450 & 25,5 \\
\hline 500 & 25,0 \\
\hline
\end{tabular}

Quadro 2: Limites de Tolerância para Exposição ao Calor, em Regime de Trabalho Intermitente com Período de Descanso em Outro Local (Local de Descanso). Fonte: BRASIL (2014)

Contudo, para se obter as taxas de metabolismo no local de trabalho e no local de descanso, observa-se o disposto no quadro 3. 
Quadro 3: Taxas de Metabolismo por Tipo de Atividade. Fonte: BRASIL (2014)

\begin{tabular}{|c|c|}
\hline Tipo de Atividade & Kcal/h \\
\hline Sentado em Repouso & 100 \\
\hline $\begin{array}{l}\text { Trabalho Leve } \\
\text { Sentado, movimentos moderados com braços e tronco (ex: datilografia). } \\
\text { Sentado, movimentos moderados com braços e pernas (ex: dirigir). } \\
\text { De pé, trabalho leve, em máquina ou bancada, principalmente com os braços. }\end{array}$ & $\begin{array}{l}125 \\
150 \\
150\end{array}$ \\
\hline $\begin{array}{l}\text { Trabalho Pesado } \\
\text { Trabalho intermitente de levantar, empurrar ou arrastar pesos (ex: remoção com pá). } \\
\text { Trabalho fatigante. }\end{array}$ & 440 \\
\hline
\end{tabular}

E para se obter o valor do IBUTG médio ponderado para uma hora, se utiliza a equação 4 , representada pela seguinte fórmula:

\section{$\overline{\text { IBUTG }}=\underline{\text { IBUTGt } x T t+\text { IBUTGd } x \text { Td }} \quad$ (Eq. 4)}

60

Sendo:

a) IBUTGt - valor do IBUTG no local de trabalho;

b) IBUTGd - valor do IBUTG no local de descanso;

c) $\mathrm{Tt}$ - soma dos tempos em minutos em que se permanece no trabalho;

d) Td - soma dos tempos em minutos em que se permanece no local de descanso.

\section{METODOLOGIA}

As considerações foram realizadas a partir de estudo de caso em uma cerâmica vermelha no município de Cacoal/RO e respeitando as diretrizes de divulgação impostas pela empresa, para o desenvolvimento desta pesquisa será atribuído o nome de empresa $X$.

O método de pesquisa foi à abordagem quantitativa. Quanto à natureza, pode ser considerada pesquisa básica, pois se pretende gerar novos conhecimentos acerca dos níveis de calor nos setores correlacionados ao forno de queima de produtos cerâmicos nesta empresa X, comparando-os com os limites de tolerância estabelecidos pela NR - 15 anexo $n^{\circ} 3$ (SIENA, 2007).

Do ponto de vista dos objetivos, trata-se de uma pesquisa descritiva que segundo Gil (2006) tem a finalidade de descrever as características de uma população ou fenômeno, desta forma, para realizar essa descrição utiliza-se de técnicas de coletas de dados como questionário e observação.

Do ponto de vista dos procedimentos técnicos, o estudo caracteriza-se como pesquisa bibliográfica, através de levantamento e análise de material já publicado, como artigos científicos, livros, relatórios técnicos, etc. E como pesquisa de campo realizando coleta de dados dos níveis de calor do forno de queima junto a esta empresa, bem como estudo de caso pois visa conhecer a empresa X em particular (GIL, 2009).

\subsection{DELIMITAÇÃO DA PESQUISA \\ 3.1.1 DELINEAMENTO DA PESQUISA}

Foi realizado levantamento dos setores de trabalho que estão correlacionados ao forno de queima dos produtos cerâmicos. Para o levantamento e a avaliação dos locais de trabalho, além da estratégia de observação, se utilizou de um medidor de nível de estresse térmico da marca Instrutherm, modelo TGD 300 , devidamente calibrado que realiza as medições de temperatura de bulbo seco, bulbo úmido natural, globo e IBUTG, determinando os níveis de calor dos setores correlacionados ao forno de queima.

Nessa lógica, o trabalho consiste em avaliar os níveis de calor dos setores de trabalho correlacionados ao forno utilizado para a queima de produtos cerâmicos, comparando os níveis obtidos com os limites de 
tolerância estabelecidos pela NR - 15 em seu anexo $n^{\circ} 3$, verificando se existe insalubre nestes ambientes laborais, bem como sugerindo melhorias em seus setores de trabalho.

\subsection{POPULAÇÃO, AMOSTRA E MÉTOdO DE COLETA DOS DADOS}

Para o desenvolvimento da pesquisa se adota 0 procedimento da amostragem não probabilística. Lakatos (2001) menciona que esta seleção "permite a utilização de tratamento estatístico que possibilita compensar erros amostrais e outros aspectos relevantes para representatividade e significância da amostra".

A coleta de dados será quantitativa, através de medições com instrumento específico e os diferentes resultados obtidos serão comparados com a legislação brasileira. Desta forma, foram realizadas medições ambientais nos seguintes setores:

\section{a. Enforma e Desenforma Túnel Contínuo; \\ b. Queima/Túnel e em Fornos.}

Neste contexto, foram selecionados tais setores, por entender que são estes que estão diretamente ligados ao forno túnel contínuo. Nessa tônica, foram realizadas as descrições dos setores de trabalho, no que concerne a descrição do local, bem como a identificação dos cargos em atividade em cada setor. Tais descrições e identificações são demonstradas nos quadros de reconhecimento dos riscos 4 e 5 .

Quadro 4: Quadro de Reconhecimento de Riscos do Setor de Enforma e Desenforma.

\section{Setor: Enforna e Desenforna Túnel Contínuo}

- Descrição do Local: Estrutura metálica, piso de cimento áspero, ventilação natural, iluminação natural e artificial por meios de lâmpadas, cobertura de zinco;

- Cargos em Atividade no Setor: Enforna e Desenforna;

- Risco Exposto: Físico;

- Agente de Risco: Calor;

- Tipo de Exposição: Habitual e Intermitente;

- Fonte Geradora: Forno Túnel Contínuo;

- Meios de Propagação: Pelo Ar;

- Possíveis Danos a Saúde Relacionado ao Risco: Exaustão e Desitração.
Os trabalhadores deste setor, retiram as telhas e os tijolos dos vagonetes de transporte advindo da etapa da secagem, colocando-as em outro vagonete para a queima no forno túnel contínuo, logo após está etapa, se retira os produtos cerâmicos e os colocam em carrinhos para posterior direcionamento para estocagem e expedição. Na figura 1 é demonstrada a saída dos produtos do forno túnel contínuo, onde tais produtos serão resfriados e remanejados em outros carrinhos para serem direcionados para a armazenagem.

Figura 1: Saída dos Produtos do Forno Túnel Contínuo.

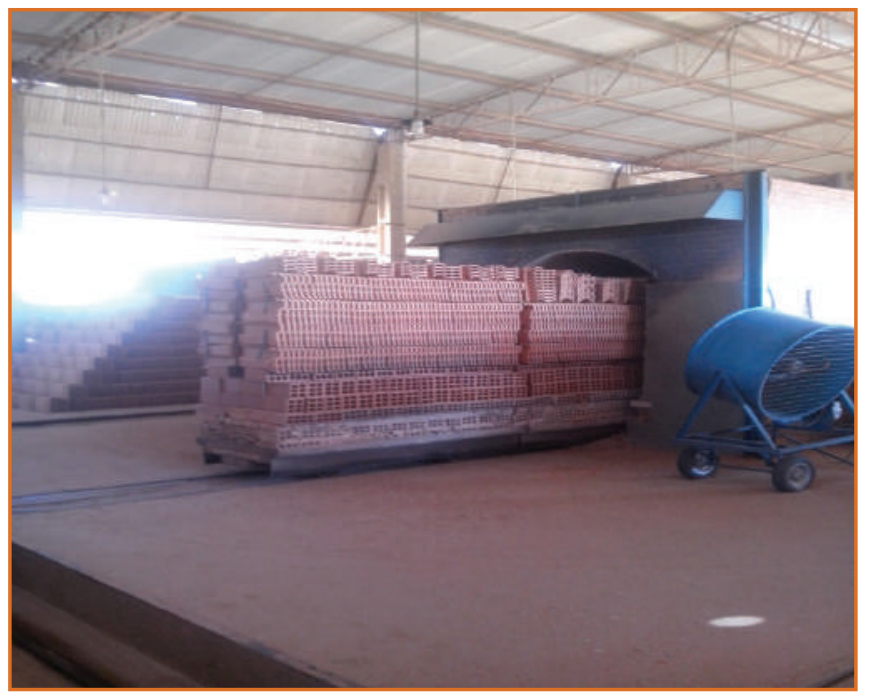

Fonte: Autor (2015)

Desta forma, conforme figura 1 esta saída do forno juntamente com a entrada do mesmo, se caracteriza o setor de Enforma e Desenforma em questão.

As informações do outro Setor que compreende a Queima/Túnel e em Fornos se acham demonstradas a seguir no quadro 5 . 
Quadro 5: Quadro de Reconhecimento de Riscos do Setor de Queima/Túnel e em Fornos.

\section{Setor: Queima/Túnel e em Fornos}

- Descrição do Local: Estrutura metálica, piso de cimento áspero, ventilação natural, iluminação natural e artificial por meios de lâmpadas fluorescentes, cobertura de zinco;

- Cargos em Atividade no Setor: Operador de Porta Forno e Queimador;

- Risco Exposto: Físico;

- Agente de Risco: Calor;

- Tipo de Exposição: Habitual e Permanente;

- Fonte Geradora: Forno Túnel Contínuo;

- Meios de Propagação: Pelo Ar;

- Possíveis Danos a Saúde Relacionado ao Risco: Exaustão e Desitração.

Fonte: Dados da Pesquisa (2015)

Os trabalhadores deste setor, no que concerne o Operador de Porta de Forno, realiza o monitoramento do abastecimento do forno para queimar os produtos cerâmicos, além de gerenciar a sua temperatura, já o Queimador realiza as mesmas atividades do Operador, atuando como auxiliar deste. Na figura 2 é demonstrada o forno túnel contínuo especificamente no abastecimento do forno de lenha.

Figura 2: Abastecimento do forno de lenha.

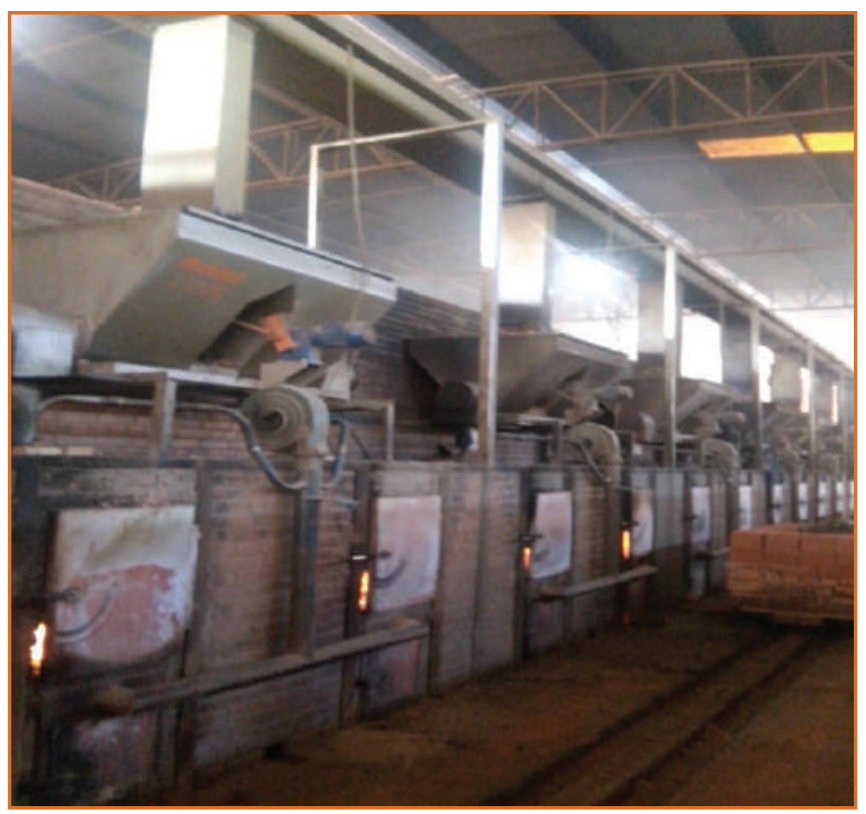

Fonte: Autor (2015)

E conforme figura 2 o monitoramento do abastecimento do forno de lenha e o gerenciamento da sua temperatura caracteriza o setor de Queima/Túnel e em Fornos em questão

Assim, a coleta de dados foi realizada no âmbito destes 2 (dois) setores no mês de fevereiro de 2015, e as medições foram realizadas de acordo com a NR - 15 anexo $n^{\circ} 3$, se avaliando os níveis de IBUTG conforme a metodologia da NR - 15, bem como da Norma de Higiene Ocupacional - NHO 06 da Fundação Jorge Duprat e Figueiredo - FUNDACENTRO.

Contudo, visando melhor entendimento da atuação dos 2 (dois) setores no forno túnel contínuo, na figura 3 é demonstrada o forno em sua visão geral.

Figura 3: Forno Túnel Contínuo.

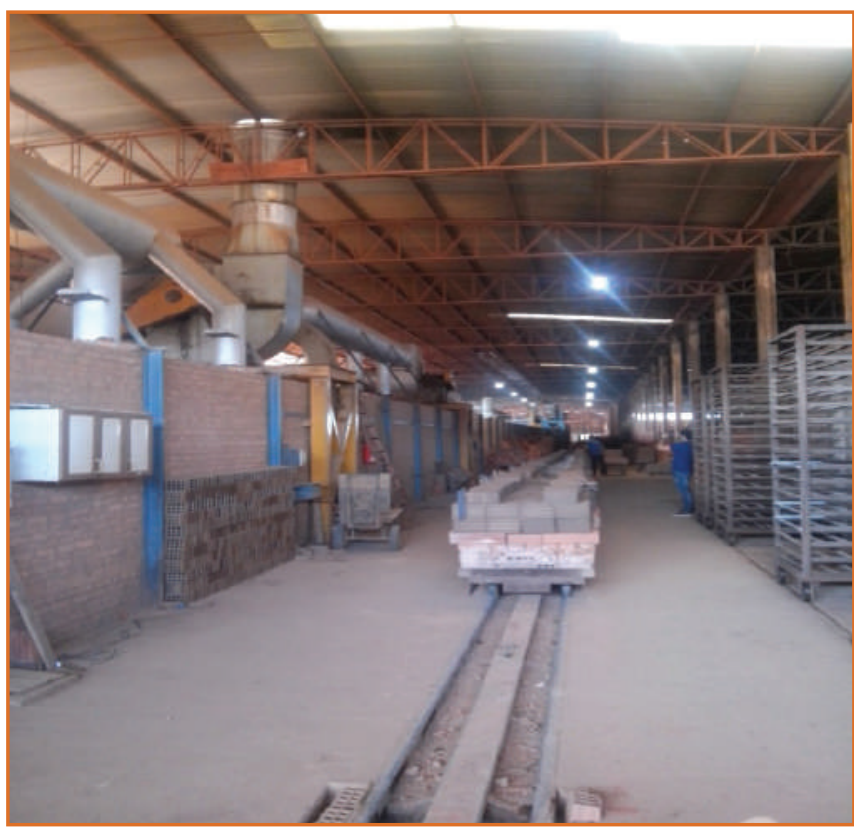

Fonte: Autor (2015)

O forno túnel contínuo possui aproximadamente 160 metros de comprimento e sua fonte de energia térmica é a queima de cavaco de madeira. Sua zona de queima varia de $800^{\circ} \mathrm{C}$ a $1700{ }^{\circ} \mathrm{C}$ aproximadamente com ciclo de queima de aproximadamente 48 horas. Possui tijolos refratários em sua estrutura interior e tijolos vermelhos em sua estrutura externa. Como já mencionado anteriormente, 2 (dois) setores atuam no forno túnel contínuo, o setor de Enforna e Desenforna Túnel Contínuo e o setor de Queima/Túnel e em Fornos, divididos em 5 turnos de 6 horas cada, possuindo horário fixo dos turnos. 


\section{RESULTADOS E DISCUSSÕES}

As avaliações no forno túnel contínuo foram realizadas levando em consideração a forma de como as atividades são realizadas na empresa $X$, ou seja, através das atividades dos 2 (dois) setores que estão diretamente associados a este forno.

Os dados levantados e os resultados das avaliações dos níveis de calor dos 2 (dois) setores se acham demonstradas nos quadros 6 e 7 .

Quadro 6: Quadro de Avaliação Quantitativa do Setor de Enforma e Desenforma.

Setor: Enforma e Desenforma Túnel Contínuo - Agente Nocivo - Calor

\begin{tabular}{|l|l|l|l|}
\hline Locais & IBUTG Medido ${ }^{\circ} \mathrm{C}$ & Taxa Metabolismo Kcal/h & IBUTG Max. Permitido. ${ }^{\circ} \mathrm{C}$ \\
\hline Desenforna - Túnel Móvel Continuo & 28,8 & 300 & 28,1 a 29,4 \\
\hline Enforna - Túnel Móvel Continuo & 28,3 & 300 & 28,1 a 29,4 \\
\hline
\end{tabular}

Fonte: Dados da Pesquisa (2015)
Conforme quadro 6 relacionado ao setor de Enforma e Desenforma Túnel Contínuo, a atividade desenvolvida de Desenforma - Túnel Móvel Contínuo, se adotou regime de trabalho intermitente com descanso no próprio local de trabalho (por hora) bem como se adotou atividade desenvolvida como moderada 300 $\mathrm{Kcal} / \mathrm{h}$ de acordo com o quadro 3. Desta forma, o IBUTG encontrado foi de $28,8^{\circ} \mathrm{C}$, assim, comparando tal resultado com o quadro 1 e como se adotou atividade moderada de acordo com o quadro 3 , o limite de tolerância IBUTG máximo permitido é de $28,1^{\circ} \mathrm{C}$ a $29,4^{\circ} \mathrm{C}$. Diante do exposto, o IBUTG medido e admitido para essa atividade em questão não contempla o calor, sendo considerada Salubre de acordo com a legislação brasileira, por estar abaixo do limite de tolerância, baseado na NR - 15 anexo $n^{\circ} 3$, onde preconiza a exposição aos níveis de calor. E para a atividade de Enforma, também se adotou atividade desenvolvida como moderada $300 \mathrm{Kcal} / \mathrm{h}$ de acordo com o quadro 3, e o IBUTG encontrado foi de $28,3^{\circ} \mathrm{C}$, comparando tal resuldado com o quadro 1, o limite de tolerância IBUTG máximo permitido é de $28,1^{\circ} \mathrm{C}$ a $29,4^{\circ} \mathrm{C}$. Diante do exposto o IBUTG medido e admitido para essa atividade em questão também não contempla o calor, sendo considerada Salubre de acordo com a legislação brasileira, por estar abaixo do limite de tolerância, baseado na NR - 15 anexo n³.

Quadro 7: Quadro de Avaliação Quantitativa do setor de Queima/Túnel e em Fornos.

\begin{tabular}{|c|c|c|c|}
\hline \multicolumn{2}{|c|}{ Setor: Queima/Túnel e em Fornos - Agente Nocivo - Calo } & \multicolumn{2}{|c|}{ Tipo - Sobrecarga Térmica } \\
\hline Local & IBUTG Medido ${ }^{\circ} \mathrm{C}$ & Taxa Metabolismo Kcal/h & IBUTG Max. Permitido. ${ }^{\circ} \mathrm{C}$ \\
\hline Fornalha Túnel Contínuo & 35,1 & 440 & 28,1 a 29,4 \\
\hline
\end{tabular}

Fonte: Dados da Pesquisa (2015)

Conforme quadro 7 relacionado ao setor de Queima/ Túnel e em Fornos, a atividade desenvolvida de Fornalha Túnel Contínuo, se adotou regime de trabalho intermitente com descanso no próprio local de trabalho (por hora) bem como se adotou atividade desenvolvida como moderada $440 \mathrm{Kcal} / \mathrm{h}$ de acordo com o quadro 3. Assim, o IBUTG encontrado foi de $35,1^{\circ} \mathrm{C}$ e comparando tal resultado com o quadro 1 e como se adotou atividade moderada de acordo com o quadro 3, o limite de tolerância IBUTG máximo permitido é de $28,1^{\circ} \mathrm{C}$ a $29,4^{\circ} \mathrm{C}$. Neste contexto, o IBUTG medido e admitido para essa atividade em questão é considerada Insalubre com percentual de $20 \%$, baseado na NR - 15 anexo $n^{\circ} 3$, onde se 
preconiza que exposições a níveis de calor superiores aos limites de tolerância fixados nos quadros 1 e 2 geram direito a Insalubridade de grau médio - $20 \%$. Contudo, ainda se evidencia que para as funções de Operador de Porta Forno e Queimador não é permitido o trabalho, sem a adoção de medidas adequadas de controle, haja vista que o IBUTG obtido foi de $35,1^{\circ} \mathrm{C}$, considerando que para o tipo de atividade adotada (atividade moderada) a NR - 15 anexo n`3 quadro 1 determina limite de $31,1{ }^{\circ} \mathrm{C}$. Nessa tônica, além de gerar Insalubridade para as funcões desenvolvidas neste setor, a NR - 15 estabelece que as funções só poderam continuar se houver medidas adequadas de controle.

\section{SUGESTÕES E MELHORIAS}

Buscando a promoção e o bem dos trabalhadores que atuam no forno túnel contínuo, são sugeridas algumas melhorias para os setores avaliados. Para o setor de Enforma e Desenforma Túnel Contínuo, no que concernem os locais das atividades de Desenforma - Túnel Móvel Contínuo e da ativividade de Enforma - Túnel Móvel Contínuo, os níveis de calor obtidos permaneceram abaixo dos limites de tolerância estabelecidos pela legislação brasileira NR - 15, porém, deve haver medidas constantes de controle que visem contribuir para a segurança e o bem estar dos trabalhadores. Desta forma, sugere-se algumas ações combinadas, como:

a) Orientar os funcionários sobre a importância do consumo de água (mínimo de 2 litros por dia);

b) Melhorar a ventilação do ambiente, instalando exaustor e/ou ventilador com maior potência;

c) Reavaliar as medições de temperatura de calor em epócas mais quentes do ano;

d) Realizar treinamentos, orientações e adequações dos funcionários para adaptação ao calor;

e) Mesmo estando dentro dos limites de tolerância, para as atividades desenvolvidas neste setor, se deve adotar o ciclo de trabalho determinado para o tipo de atividade que adotou (moderada) e para o níveis de calor obtidos $\left(28,3^{\circ} \mathrm{C}\right.$ e $\left.28,8^{\circ} \mathrm{C}\right)$ que de acordo com a NR - 15 anexo $n^{\circ} 3$ quadro 1 é de 30 minutos de trabalho e 30 minutos de descanso.
Para o setor de Queima/Túnel e em Fornos, no que concerne o local da atividade de Fornalha Túnel Contínuo, onde são desempenhadas as funções do Operador de Porta Forno e Queimador, medidas devem ser implantas de forma rápida e urgente, haja vista que o IBUTG obtido não se permite o trabalho, sem adoção de medidas adequadas de controle.

Logo, ações devem ser planejadas e executadas com a finalidade de diminuir a níveis aceitáveis de acordo com a legislação brasileira, bem como adotar ações contínuas visando o conforto destes trabalhadores, assim, sugere-se algumas ações combinadas, como:

a) Orientar os funcionários sobre a importância do consumo de água (mínimo de 2 litros por dia);

b) Adotar regime de trabalho que faça com que o trabalhador permaneça menor tempo em trabalho e maior tempo em descanso ( por hora ), realizando atividade mais leve e em temperatura mais amena;

c) Melhorar a ventilação do ambiente, através de exaustores e/ou ventiladores;

d) Reavaliar as medições de temperatura de calor em epócas mais quentes do ano;

e) Realizar treinamentos, orientações e adequações dos funcionários para adaptação ao calor;

f) Realizar rodízios no setor, visando diminuir o tempo de exposição ao calor do forno;

g) Estudos e desenvolvimento de projeto para implantação de barreiras isolantes do calor.

\section{CONCLUSÃO}

Os resultados permitiram atingir os objetivos propostos, da avaliação dos níveis de calor dos setores de trabalho correlacionados ao forno utilizado para a queima de produtos cerâmicos, bem como permitiu conhecer a real situação dos profissionais que trabalham expostos a altas temperaturas neste segmento ainda pouco explorado no âmbito da Engenharia de Segurança do Trabalho.

Desta forma, se constatou que o setor de Queima/Túnel e em Fornos se encontra extremamente acima do limite de tolerância quando comparado com o anexo $n^{\circ} 3$ da $N R$ - 15, sendo considerada atividade Insalubre. E no setor de Enforma e Desenforma Túnel Contínuo, este se 
encontram dentro do limite de tolerância estabelecido pela NR - 15 anexo $n^{\circ} 3$, portando sendo considerada não Insalubre.

Contudo, as avaliações nos 2 (dois) setores correlacionados ao forno túnel contínuo demonstram a importância em obter estudos na área de segurança e saúde no trabaho, haja vista que o setor representa geração de emprego e renda na região centro leste de Rondônia. Neste contexto, faz-se necessário maior ênfase neste segmento, no tocante a investimentos e melhorias no processo de produção, nos aspectos de segurança do trabalho, bem como no fator humano, buscando sempre priorizar a promoção e o bem estar dos trabalhadores.

\section{REFERÊNCIAS}

[1] ABCERAM. Associação Brasileira de Cerâmicas. 2015. Disponível em: <http://www.abceram.org.br/site/index. php?area $=4 \&$ submenu=47> . Acesso em março de 2015.

[2] GIRARDI, Guilherme Augusto. GADEGAST, Rogério Zingano. Serviço Nacional de Aprendizagem Industrial. Departamento Nacional Saúde e Segurança do Trabalho, volume 5 / Departamento Regional de Santa Catarina. Brasília: SENAI/DN, 2012

[3] GIL, Antônio Carlos. Como elaborar projetos de pesquisa. $4^{\mathrm{a}}$ ed. $8^{\mathrm{a}}$ reimp. São Paulo. Atlas, 2006.

[4] GIL, Antônio Carlos. Estudo de Caso. São Paulo: Atlas, 2009.

[5] IBGE-Instituto Brasileiro de Geografia e Estatistica. 2015. Estimativas populacionais para os municípios brasileiros em 01.07.2014. Disponível em: <http://www.ibge.gov.br/home/ estatistica/populacao/estimativa2014/estimativa_dou.shtm>. Acesso em março de 2015.
[6] IBGE - Instituto Brasileiro de Geografia e Estatistica. 2015. Cidades. Cacoal/Rondônia. População residente. Disponível em: <http://cidades.ibge.gov.br/xtras/temas.ph p?lang $=\&$ codmun $=110004 \&$ idtema $=16 \&$ search $=1$ ls $\%$ EDnte se-das-informa\%E7\%F5es>. Acesso em março de 2015.

[7] MTE. Ministério do Trabalho e Emprego. 2015. Normas Regulamentadoras. Disponível em: <http://portal.mte.gov. $\mathrm{br} /$ legislacao/normas-regulamentadoras-1.htm>. Acesso em fevereiro de 2015.

[8] BRASIL. Ministério do Trabalho. Norma Regulamentadora no 14. Manuais de Legislação Atlas. Editora Atlas S.A. São Paulo. 73를 edição, 2014.

[9] BRASIL. Ministério do Trabalho. Norma Regulamentadora no 15. Manuais de Legislação Atlas. Editora Atlas S.A. São Paulo. 73aㅡ edição, 2014.

[10] FUNDACENTRO - Fundação Jorge Duprat Figueiredo. 2015. Avaliação da Exposição Ocupacional ao Calor. Disponível em: <http://www.fundacentro.gov.br/biblioteca/ normas-de-higiene-ocupacional>. Acesso em fevereiro de 2015.

[11] PEREIRA, Alexandre Demetrius. Tratado de Segurança e Saúde Ocupacional: Aspectos técnicos e jurídicos. Vol. IV. Editora LTDA, São Paulo, 2005.

[12] LAKATOS, E. M. ANDRADE. M. Metodologia do trabalho científico: procedimentos básicos, pesquisa bibliográfica, projeto e relatório, publicações e trabalhos científicos. 6. ed. - São Paulo: Atlas, 2001.

[13] PREFEITURA DE CACOAL - RONDÔNIA - BRASIL. 2015. Geografia. Disponível em: <http://www.cacoal.ro.gov. br/?pagina=geografia $>$. Acesso em abril de 2015.

[14] SIENA, O. Metodologia da pesquisa científica: elementos para a elaboração e apresentação de trabalhos acadêmicos. Porto Velho: [s.n.], 2007. 


\section{CAPÍTULO 10}

\section{DOAÇÃO DE ÓRGÃOS: UM ENFOQUE LOGÍSTICO NO CONJUNTO HOSPITALAR DE SOROCABA}

\section{Délvio Venanzi}

Orlando Roque da Silva

Angelo Palmisano

Resumo: A gestão dal cadeia de suprimentos é pouco estudada no setor hospitalar, principalmente na doaçăo de órgãos para ser transplantado em outros pacientes. Este estudo se caracteriza como uma abordagem exploratória e descritiva, que utiliza como método de abordagem o dedutivo, como método de procedimento, o estudo de caso e como método de análise de dados, a pesquisa qualitativa e a conclusiva. Como instrumento de pesquisa for utilizado um questionário semi-estruturado para os membros dos hospitais. Este estudo de caso mostrou que os principais problemas na captação e distribuição de órgãos do Conjunto Hospitalar de Sorocaba bem como o alto lead time podem ser melhorados a partir do efetivo gerenciamento logístico da cadeia de órgáos.

Palavras chave: cadeia de suprimentos hospitalar, doação de órgãos, conjunto hospitalar 


\section{INTRODUÇÃO}

O setor hospitalar, objeto de nosso estudo, é notadamente de fundamental importância à população pela prestação de serviços de atenção à saúde, além de sua relevância econômica. No Brasil, 20 milhões de pacientes internos são admitidos ao ano e os gastos hospitalares representam 3,5\% de seu Produto Interno Bruto (LA FORGIA e COUTTOLENC, 2008). O setor também se caracteriza por diversas particularidades que são resultadas de uma complexa interação entre um grande número de poderosas partes interessadas que têm objetivos divergentes (SINGH et al., 2006). Conter os custos e manter a qualidade da atenção e a segurança do paciente desafia gestores de serviços de saúde e formuladores de políticas públicas (MONTGOMERY e SCHNELLER, 2007). A aplicação de práticas de gestão da cadeia de suprimentos em hospitais pode oferecer expressivas oportunidades de aperfeiçoamento dos processos e de melhor utilização dos recursos para a prestação dos serviços de saúde.

Materiais e logística são, juntamente com recursos humanos e administração financeira, fatores críticos para o desenvolvimento de atividades de atenção à saúde e para a excelência operacional da organização hospitalar. Do ponto de vista da SCM Chopra e Meindl descrevem-na como a gestão de atividades de negócios e relacionamentos (1) internamente e na organização, (2) com os fornecedores imediatos, (3) com os fornecedores de primeira e segunda camada e com os clientes ao longo da SCM e (4) com toda a SCM (Supply Chain Management - Gestão da Cadeia de Suprimentos).

Uma organização de saúde é um sistema produtivo de atenção à saúde, onde o setor de abastecimento integra-se como subsistema para atender as necessidades de insumos (materiais de consumo) e de equipamentos (materiais permanentes) daqueles que desenvolve e disponibiliza os produtos, que são os profissionais de saúde. As atividades de atenção à saúde são atividades complexas, assentadas sobre uma cadeia produtiva que incorpora seqüências de ações definidas para a geração de seus produtos (os chamados "procedimentos"). Cada procedimento demanda um mix específico de insumos (bens) e processos de trabalho (serviços), cuja composição pode variar entre diferentes organizações e até segundo os diferentes tipos de pacientes e profissionais de uma mesma organização. Não só os produtos oferecidos em organizações de saúde são complexos e pressupõem elevada qualificação profissional, mas os insumos utilizados em sua produção são cada vez mais sofisticados e numerosos. (VECINA \& REINHARDT, 2002).

O conceito de cadeia de suprimentos destaca a integração interna e externa dos participantes de todas as etapas - "desenvolvedores" do produto, fornecedores de insumos, responsáveis pela logística de aquisição, armazenamento e distribuição dos insumos e responsáveis pela fabricação e distribuição final do produto, incluindo o próprio cliente final.

O transplante envolve o processo de acondicionamento, armazenagem e transporte de órgãos dentro de um lead time (tempo de execução de uma tarefa) prédeterminado pelo tempo de isquemia de cada órgão (tempo em que o órgão fica sem vascularização), a isquemia leva à obstrução do fluxo sanguíneo para os tecidos periféricos, o que é conhecido como fenômeno de não reperfusão. Esta obstrução tem caráter progressivo, com formação de trombos na micro circulação, agregação plaquetária, edema celular e tecidual.

A progressão deste fenômeno leva à irreversibilidade das lesões teciduais e morte do membro ou retalho micro cirúrgico; quanto maior o tempo de isquemia, pior o prognóstico, e isso estão atrelados diretamente ao lead time, desde o momento em que efetivamente é diagnosticada a morte encefálica, até se percorrerem as distâncias entre o centro de captação e o efetivo transplante, então quanto mais rápido ocorrerem esse processo, melhor será o resultado do transplante para o paciente receptor.

Além disso, também estão envolvidos aspectos mais específicos como o agendamento de salas cirúrgicas, material e equipamentos especializados. Este processo inicia-se após a identificação da morte encefálica do potencial doador e sua notificação à Central de Transplante; sua efetividade, por sua vez, depende de duas prioridades competitivas: velocidade e rapidez (Hayes et al, 2008), e precisão com que o processo 
é conduzido, esses dois fatores são imprescindíveis, cruciais para o paciente receptor.

Nas últimas décadas o transplante de órgãos transformou-se de experimento em opção terapêutica capaz de prolongar a vida de pacientes terminais. Uma questão que suscita divergências são as estratégias para o aumento da captação de órgãos. O transplante é para muitos pacientes, sinônimo de melhor qualidade de vida e maior sobrevida; para outros a única chance de sobrevivência. No entanto, a nobreza dos objetivos do aumento de captação de órgãos não justifica utilizar métodos não éticos. Nenhum processo pode ser considerado como tal se durante seu transcorrer não se primou em manter atitude compatível com os princípios que regem o comportamento ético. Para isso a legislação brasileira busca constantemente através de várias discussões, lapidar para extrair a melhor distribuição justa dos órgãos doados.

Nesse contexto a SCM entra como fator de vantagem competitiva contribuindo para a diminuição do lead time, pois o mesmo é fator crucial na vida do paciente, a integração entre os elos da cadeia, a gestão de informações, a organização e preparação para que o órgão chegue no tempo e em condições para ser utilizado em outro ser humano, são de suma importância para o processo total dessa cadeia de suprimentos envolvendo a captação e a distribuição de órgãos.

A não efetivação dos transplantes devido a problemas na cadeia de suprimentos corresponde grandemente pelos insucessos dos procedimentos. Na verdade, grande parte do que poderia vir a ter melhor resultado, acabam tendo desfechos muito ruins, perda de órgãos devido ao lead time excessivo que ficou exposto ao trâmite, desde antes de sua captação e efetivo transplante no cliente receptor.

Esses entraves estão associados com o lead time desde a confirmação da morte encefálica (realização dos exames necessários para tal comprovação e, portanto a disponibilidade dos equipamentos), a captação e retirada desses órgãos doados até o transplante no paciente/cliente receptor. A necessidade de mudar o processo é pertinente, já que existe muito mais demanda do que oferta, e quando são ofertados pela família de um possível doador, os elos no que tange à velocidade na cadeia podem definitivamente acabar prejudicando todo o processo, e conseqüentemente acabar com talvez a única esperança de continuidade da vida de um paciente terminal. Dessa forma formulase a seguinte questão problema a ser verificada nesta pesquisa: a resolução de problemas dos pontos falhos na cadeia de suprimentos de doação de órgãos que geram lead times altos são fontes de vantagem competitiva para essa cadeia?

\section{JUSTIFICATIVA}

La Forgia e Couttelenc (2008) apontam, com base em dados de 2004, que $45 \%$ dos gastos em saúde são financiados por recursos públicos. Segundo os autores, os gastos com saúde no Brasil são altos, quando comparados a países semelhantes, e os gastos hospitalares são o maior componente dos gastos em saúde no país, representando $67 \%$ do total. Isso mostra que o hospital é uma peça chave neste sistema, pois concentra a maior parte dos recursos para a prestação de serviços de atenção à saúde.

Segundo La Forgia e Couttolenc (2008), os hospitais no Brasil são responsáveis pela admissão de 20 milhões de pacientes internos ao ano, e apesar de suprimentos representarem uma parcela considerável das despesas hospitalares e ser um fator crítico na prestação de um serviço de saúde adequado há irregularidades e desperdício no fluxo destes materiais. Segundo os autores, gerenciar a cadeia de suprimentos pode trazer aos hospitais melhora na utilização de recursos e ganhos de qualidade na assistência à saúde.

Outra questão importante no setor é a não existência de integração no processo de prestação de serviços de atenção à saúde e entre os componentes do setor (VECINA e MALIK, 2007). Para os autores, é fundamental aprimorar a gestão nos hospitais públicos e privados em busca da eficiência, reconhecer todos os envolvidos na prestação da atenção médico hospitalar à saúde e buscar uma atuação sinérgica entre estes para que todos possam ganhar. Ao identificar os desafios do setor, verificamos que a SCM pode apoiar e contribuir para uma melhor utilização dos recursos e 
uma melhor prestação de serviços de saúde por parte dos hospitais.

Dessa forma, a justificativa baseia-se em contribuir através do levantamento de situações-problemas e resolução destas na captação e distribuição de órgãos doados. Além da utilização de métodos e ferramentas da SCM que possam contribuir significativamente para o melhor desenvolvimento e gerenciamento de todos os processos que participam dos transplantes, buscando através da análise dos problemas atuais, mostrar quais são as causas dentro da SCM que impedem melhores respostas para alcance de resultados satisfatórios.

\section{METODOLOGIA}

Esta pesquisa é caracterizada como exploratórias e descritivas, que utilizam como método de abordagem dedutivo (do geral para o particular); como método de procedimento, o estudo de caso e como método de análise de dados, a abordagem qualitativa, que tem como objetivo principal auxiliar na compreensão dos problemas; e a abordagem conclusiva, geralmente mais formal e estruturada, que tem por objetivo testar hipóteses específicas e examinar relações. (MALHOTRA, 1988). Essa pesquisa é classificada quantos aos fins como sendo exploratória e quanto aos meios de investigação, como pesquisa de campo, por meio do método de estudo de caso (YIN, 1994) e bibliográfica. Conforme Yin (1994), o estudo de caso investiga fenômenos contemporâneos inseridos em algum contexto da vida real, quando as fronteiras entre fenômeno e contexto não são muito claras e são utilizadas múltiplas fontes de evidência.

Como método de análise de dados, a pesquisa é classificada como de abordagem qualitativa, pois o problema de pesquisa exigiu que fossem ouvidas as pessoas do nível de coordenação do Serviço de Procura de Órgãos e Tecidos do Conjunto Hospitalar de Sorocaba, a fim de obter opiniões, suas concepções sobre os reais problemas de captação de órgãos envolvendo os pacientes, como resultado, houve um consenso entre as entrevistas e os envolvidos.

Quanto a técnicas e instrumentos de pesquisa, as fontes de dados e informações que foram investigadas no
Conjunto Hospitalar de Sorocaba foram pessoas que lá trabalham, bem como os documentos elaborados. Optou-se, nesse caso, por realizar técnicas de coleta de dados de observação direta intensiva: a entrevista e a observação direta, com um instrumento de pesquisa - um questionário semi-estruturado.

\section{REVISÃO BIBLIOGRÁFICA}

\subsection{GESTÃO DA CADEIA DE SUPRIMENTOS NO SETOR HOSPITALAR}

Segundo Pereira (2002), é perceptível para a sociedade e, especialmente, para os usuários do serviço médico-hospitalar que os hospitais precisam estar preparados para cuidar de demandas extremas. É diante de situações críticas que a competência da empresa hospitalar é testada. Assim, a gestão deve estar organizada para responder às necessidades de todos pacientes, em especial dos que ingressam pela porta da emergência, sem hora marcada. Esse tipo de demanda coloca a prestação do serviço médicohospitalar no rol das atividades mais complexas no mercado, responsável por preservar a saúde e a vida dos pacientes. Ressalta-se a importância do lead time nessa situação.

Essa responsabilidade vital é que torna a eficiência e eficácia da gestão da cadeia de suprimentos no hospital e seus elos interligados, essencial para o sucesso dos objetivos do hospital. Ainda sobre o assunto, Pereira (2002) comenta que a necessidade de se adotar inovações no sistema de logística de qualquer hospital, em última instância, está relacionada com um fato extremamente sensível: da eficiência e da eficácia dessa atividade depende, muitas vezes, a própria vida do paciente, no caso específico deste projeto: a captação de órgãos para salvar vidas de outros pacientes.

De acordo com Ribeiro (2004), a logística hospitalar representa um dos maiores desafios da administração hospitalar, principalmente, quando se avalia o tamanho da sua importância em atender às necessidades do hospital, seja no serviço de apoio, higienização, lavanderia, manutenção, bem como os auxiliares de diagnósticos, hemodiálise, centro cirúrgico, banco de sangue, especialidades médicas e transplante de 
órgãos, objeto principal deste estudo.

Com base no que foi discorrido até o momento, podese inferir que um dos principais objetivos dos hospitais é o de melhorar a condição da saúde de seus pacientes e que, para tanto, necessita de ferramentas de gestão capazes de minimizar os traumas do internamento. Nesse contexto a gestão da cadeia de suprimentos com suas ferramentas: integração, velocidade (execução dos serviços), tecnologia, confiabilidade e acuracidade das informações entre os elos, contribuem para um nível de serviço desejado por todos os pacientes e também pelo setor.

Nesse caso específico, a logística hospitalar, utilizada como ferramenta de gestão, pode assegurar-se de que todos os recursos necessários para o tratamento dos pacientes estejam disponíveis no lugar certo e na hora certa. Para tanto, é necessário que haja um eficiente esquema de planejamento das atividades de compras, armazenagem, gerenciamento de materiais em estoque, bem como na distribuição desses materiais destinados ao uso em atividades hospitalares. Por conseqüência, um bom sistema de gerenciamento dessas atividades deve procurar minimizar os elevados custos primando pela eficácia operacional do setor.

É comum em um hospital o uso contínuo de uma infinidade de materiais de uso técnico específico. Caso o responsável por essa atividade não possua um amplo conhecimento sobre o manuseio e gerenciamento desses itens, podem ser criados problemas não só para quem trabalha diretamente com os materiais como para quem se utiliza dos serviços prestados. (FRANCHETTI, 2002). No caso de captação de órgãos é crucial o envolvimento e o gerenciamento de todos os elos na cadeia, no tocante ao lead time extremamente pequeno, desde o momento da necessidade da captação até a transplantação do órgão no paciente/ cliente receptor.

\subsection{PRÁtICAS DA GESTÃO DE CADEIAS DE SUPRIMENTOS NO SETOR HOSPITALAR}

Segundo Goldstein et al. (2002) foram realizados estudos sobre os efeitos de localização, estratégia, tecnologia e adoção das prioridades competitivas: qualidade do serviço, tempo de atendimento e velocidade e preparação dos métodos para que essa dimensão tempo seja atendida, qualquer que seja o tipo de serviço, pois impacta na vantagem competitiva e desempenho do negócio. Kumar et al. (2008) propuseram o redesenho da cadeia de suprimentos da saúde em Cingapura a fim de reduzir o custo em logística e na aquisição de materiais médicos e de medicamentos, além das práticas citadas acima e uma preocupação com a dimensão tempo. Dessa forma um desenho genérico de uma SCM do setor hospitalar pode ser representado na figura 1.

No setor hospitalar, dentro da proposta a que se propõe o estudo de caso, faz-se necessário, nas práticas da SCM de acordo com o posicionamento de autores anteriormente citados, uma discussão dentro da cadeia, focando a prioridade competitiva tempo, fator crucial nesse estudo e como medir esse desempenho, fator de vantagem competitiva na proposta do projeto. Conforme as pesquisas em medição de desempenho avançavam, o surgimento de trabalhos em áreas funcionais. 


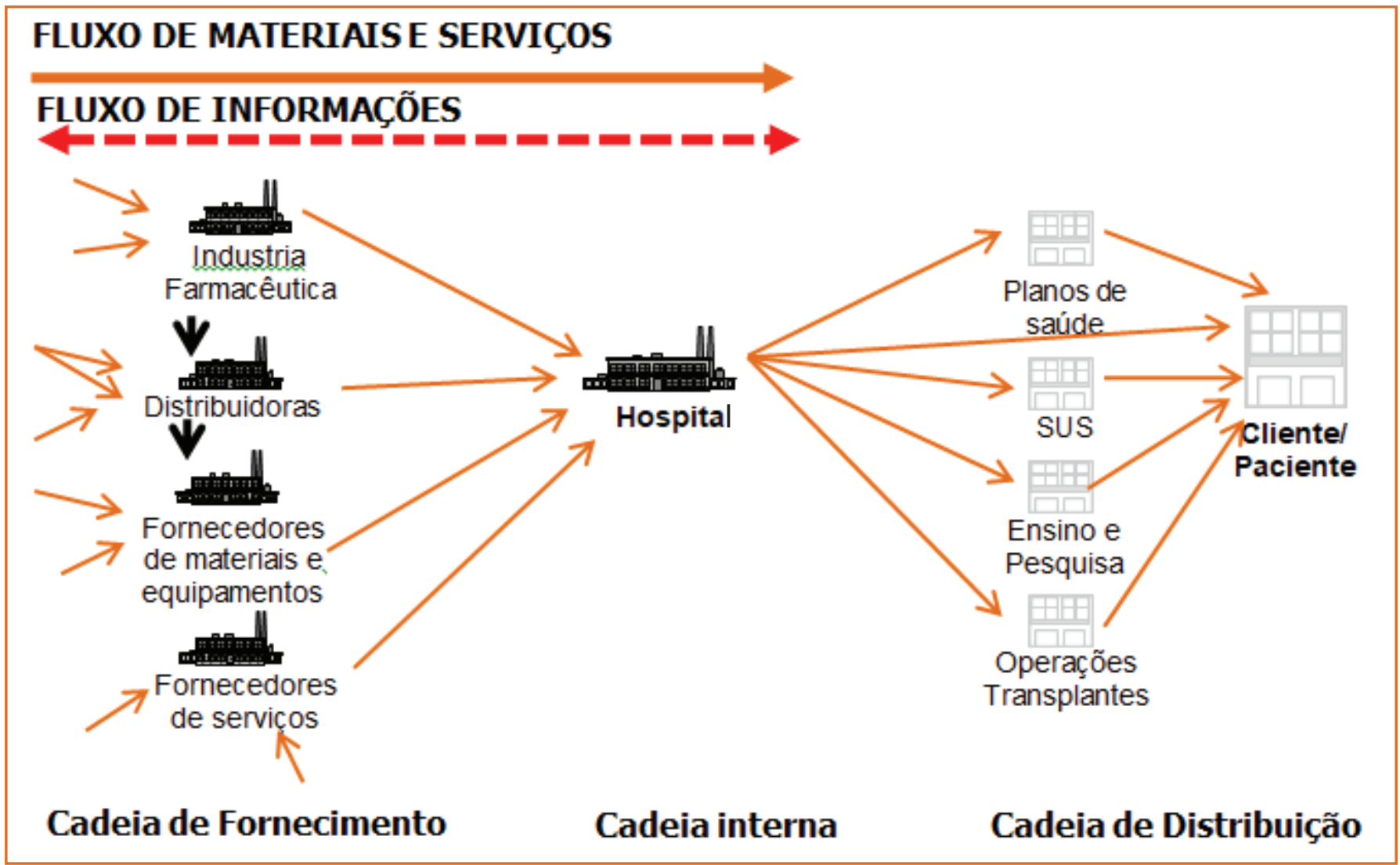

Fonte: Adaptado de Pires (1995)

Assim, nesta linha, Carpinetti (2000) constatou que a prática de medição de desempenho não financeiro passou a ser valorizada como um instrumento importante para:

- Gerenciar o desempenho da organização;

- Identificar pontos críticos que comprometam o desempenho e que devam ser alvos de melhorias;

- Obter parâmetros confiáveis para a comparação entre empresas e entre os setores das empresas.

- Auxiliar o processo de implantação e gerenciamento das melhorias e mudanças.

Os indicadores de desempenho tradicionais e os não financeiros devem ser integrados dentro de um sistema único, onde se devem considerar informações disponíveis, para fornecer o nível necessário de dados em termos de acurácia e confiabilidade, quanto ao nível de serviço prestado pelo hospital. Os gestores, ao conceber e programar um sistema de medição de desempenho deve resolver questões como o desenvolvimento de metodologias para a coleta das medidas, assim como a sua periodicidade e destino.

\section{PLANEJAMENTO DE UMA AÇÃO LOGÍSTICA: TRANSPLANTES DE ÓRGÃOS}

A atividade de transplante de órgãos é um dos produtos da organização hospitalar de ponta. Envolve uma logística complexa, coordenada em conjunto pela Central de Notificação, Captação e Distribuição de Órgãos (CNCDO) e pelo Serviço de Procura de Órgãos e Tecidos (SPOT) conhecidos antes como OPO (Organização de Procura de Órgãos).

O planejamento geral dos transplantes de órgãos considera, no mínimo, os seguintes integrantes da cadeia logística: doador, receptor, equipe médica e hospital do possível doador, CNCDO, SPOT e equipe de transplante. Pesquisa realizada por Infante (2007) 
indica que a taxa de insucesso na realização de transplantes é da ordem de 30\% em função da recusa de autorização da família do doador. Os 70\% restantes se devem a problemas de natureza logística. Em síntese, o referido autor concluiu, após consultar amostras significativas no estado de São Paulo, que realizar transplantes com sucesso é coordenar atividades de pessoas, equipamentos, materiais, serviços de transporte e comunicação, bem como outros recursos, de modo que as ações aconteçam no tempo e nos locais programados. Por trás de um transplante bem sucedido estão múltiplos procedimentos, como se pode observar na cadeia em torno da realização de transplantes mostrada na Figura 2 e Figura 3.

Figura 2: Cadeia de transplante de órgãos do conjunto hospitalar de Sorocaba - parte 1

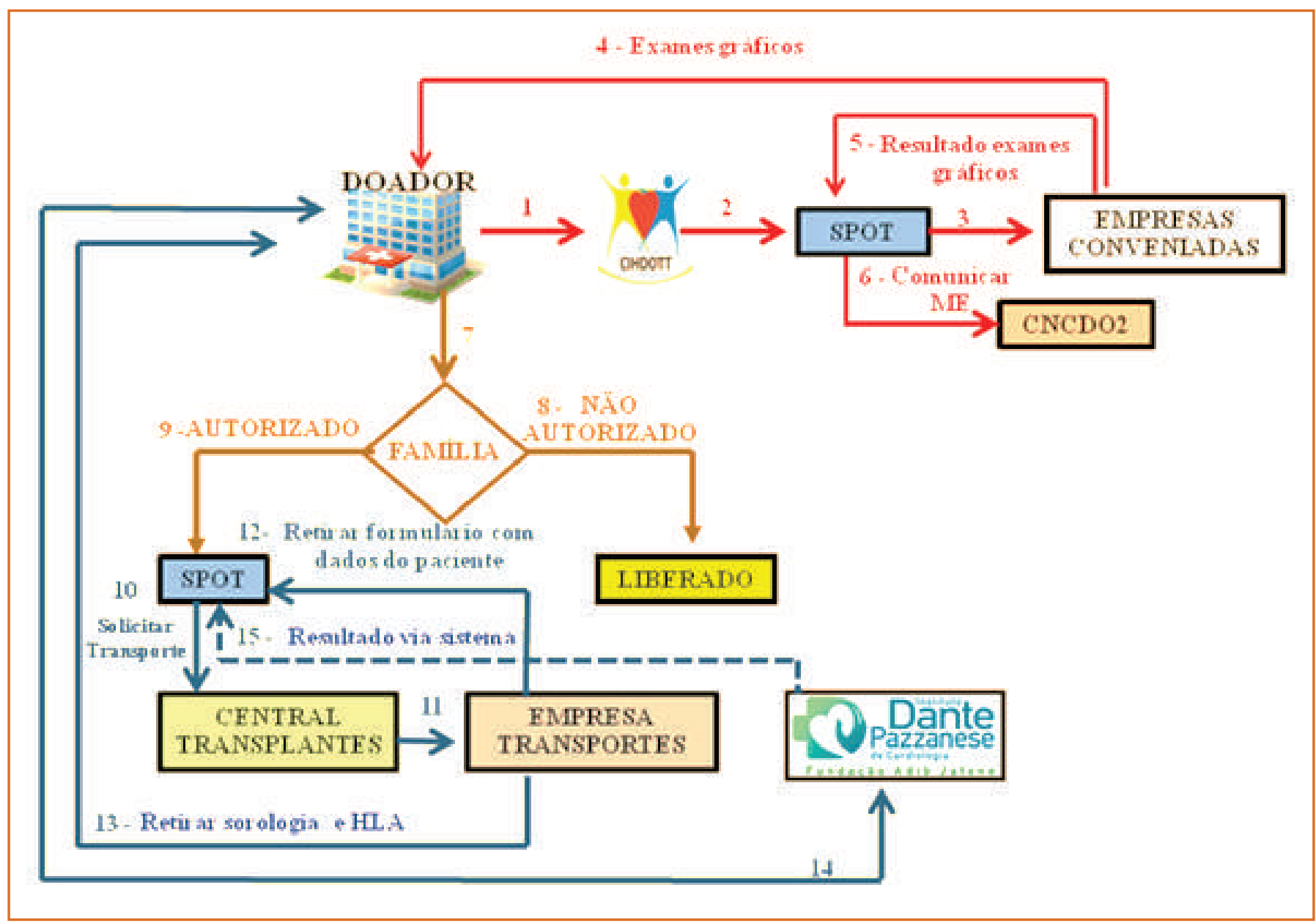

Fonte: Os autores

Obtida a autorização da família em doar osórgãos, iniciase o complexo processo de realização do transplante, que exige um planejamento logístico detalhado. Transporte, armazenagem, $\mathrm{TI}$, equipamentos e outros recursos são considerados sob diversas alternativas de realização. O nível de falha nesse processo deve estar próximo à zero, por isso é necessária à aplicação das ferramentas logísticas em todo o processo. 
Figura 3: Cadeia de transplante de órgãos do conjunto hospitalar de Sorocaba - parte 2

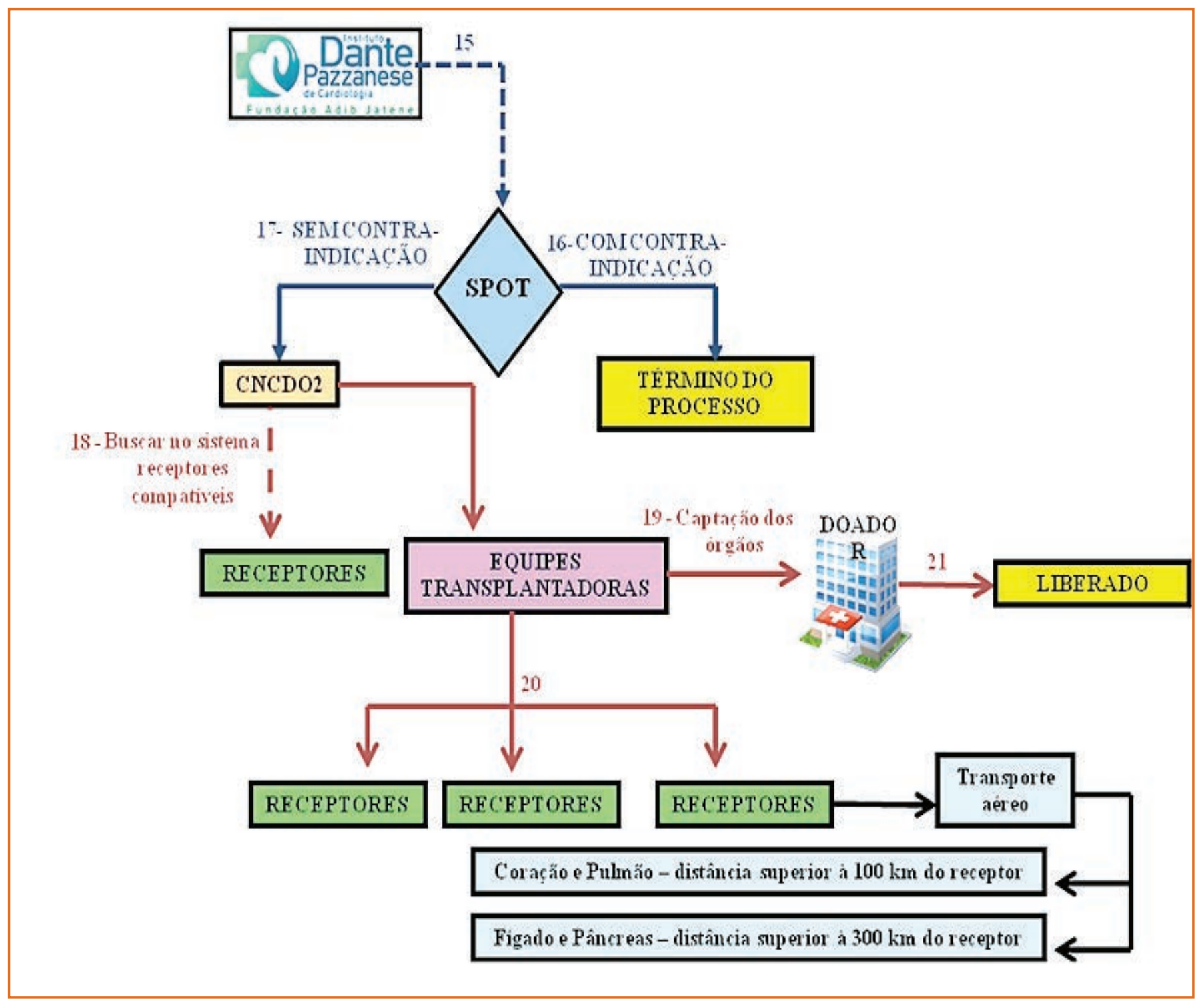

Fonte: Os autores

\subsection{MORTE ENCEFÁLICA COMO MECANISMO PARA A DOAÇÃO DE ÓRGÃOS}

De acordo com Infante (2007), a determinação de morte com base em critérios cardiorrespiratórios foi afetada pelo avanço no campo dos transplantes de órgãos. Nos anos 1960, a parada cardíaca era necessária para atestar a morte e permitir a subseqüente obtenção de órgãos. Esta limitação restringia as oportunidades do sucesso dos transplantes, porque os órgãos precisavam ser rapidamente coletados e transplantados. A necessidade crescente de órgãos doados, associados ao desperdício potencial do suporte às funções vegetativas em pacientes com morte encefálica, serviu com ímpeto para o desenvolvimento dos critérios para determinação de morte neurológica.

Com o avanço no campo dos transplantes de órgãos, a comunidade médica necessitava de uma definição confiável de morte para que os tecidos do cadáver pudessem ser doados de forma ética antes do início da deterioração que acompanha a interrupção da circulação e respiração. Em 1968, um comitê ad hoc da Escola de Medicina de Harvard concordou em discutir a questão da definição de morte, estabelecendo dois propósitos: a) identificar o momento da morte em pacientes com suporte mecânico para realocar recursos dispendiosos para os vivos, assim como 
informar aos familiares se os pacientes estavam vivos ou realmente mortos; b) identificar pessoas mortas de quem órgãos vitais podiam ser obtidos de maneira ética para transplantes.

O Informe do comitê foi marco no desenvolvimento dos critérios de morte encefálica. Suas exigências eram quatro: ausência de responsividade cerebral; ausência de movimentos induzidos ou espontâneos; ausência de respiração espontânea, exigindo o uso de ventilador; ausência de reflexos do tronco encefálico e tendinosos profundos. O Informe Harvard também recomendou um eletro encefalograma isoelétrico, porém reconheceu não ser obrigatório. Especificava ainda duas condições nas quais o diagnóstico de morte encefálica deveria ser excluído: hipotermia e intoxicação por drogas, ambas capazes de simular o estado de morte encefálica. Finalmente, recomendava exames durante o período de vinte e quatro horas, para revelar a persistência de tal condição. Apesar das críticas, o informe forneceu a estrutura essencial para permitir aperfeiçoamentos adicionais dos critérios encefálicos. (INFANTE 2007).

Desde então, a morte encefálica se tornou um conceito bem reconhecido, embora, com freqüência, pouco entendido. De acordo com a Comissão para os Estudos dos Problemas Éticos na Pesquisa Comportamental Médica e Biomédica, morte encefálica é um quadro clínico num paciente portador de doença estrutural ou metabólica conhecida, de caráter completa e indubitavelmente irreversível, expressando falência total de todas as funções de todo o encéfalo, inclusive do tronco encefálico, quadro clínico este que persiste de maneira invariável por um período mínimo de seis horas. Em decorrência disto, as definições médicas de morte encefálica diferem em todo o mundo. Em muitos países europeus foram adotadas definições de morte tendo como foco apenas a função do tronco encefálico. Por outro lado, nos Estados Unidos, a definição de morte encefálica requer demonstração de ausência de atividade tanto cortical quanto do tronco encefálico.

Embora na opinião da maioria dos autores a morte encefálica possa ser diagnosticada unicamente por meio de critérios clínicos, em algumas situações recomenda-se a confirmação dos achados clínicos por exame complementar que evidencie a ausência de fluxo sanguíneo ou de eletrogênese encefálicos. Tais exames que podem ser feitos são: angiografia cerebral, mapeamento cerebral por radionuclídeo, eletro encefalograma (EEG) e estudos dos potenciais evocados do tronco encefálico, não necessariamente são realizados todos estes exames, na maioria das vezes, apenas o eletro encefalograma (EEG) em intervalos determinados segundo a Resolução 1480/97, juntamente com os demais exames clínicos é suficiente para comprovar tal diagnóstico. Se ao final da avaliação há evidências de morte encefálica (ME), deve-se aguardar um período mínimo de observação para uma segunda avaliação (exame clínico e, se necessário, complementar) para se fazer o atestado de óbito do paciente.

Após o diagnóstico de morte encefálica, o médico deve informar a Central de Notificação, Captação e Distribuição de Órgãos do Estado. Cada estado da federação tem uma Central que coordena a captação e alocação de órgãos, baseada na fila única, estadual ou regional. Essa notificação é compulsória, independente do desejo familiar de doação ou da condição clínica do potencial doador de converter-se em doador efetivo. A seguir, a família deve ser consultada e orientada sobre o processo de doação de órgãos. A entrevista deve ser clara e objetiva. Segundo a literatura, esta conversa pode ser realizada pelo próprio médico do paciente, pelo médico da Unidade de Terapia Intensiva (UTI) ou pelos membros da equipe de captação, que devem estar preparados para prestar todas as informações que a família necessitar.

\section{ESTUDO DE CASO: CONJUNTO HOSPITALAR DE SOROCABA}

O estudo foi realizado no Serviço de Procura de Órgãos e Tecidos do Conjunto Hospitalar de Sorocaba (SPOT) antes chamado por OPO (Organização de Procura de Órgãos). Foi constituído de entrevistas com responsáveis pelo funcionamento desse serviço. A SPOT do Conjunto Hospitalar de Sorocaba é responsável por vários municípios da região. A SPOT tem seu funcionamento no horário comercial, não ficam aberta 24 horas como no caso da CNCDO2, mas durante a noite e aos finais de semana e feriados, a 
enfermeira responsável fica de "plantão à distância", disponível para os hospitais da abrangência da SPOT, para casos de ME suspeitos e confirmados.

Sobre o horário de funcionamento do SPOT, ser apenas em horário comercial é bastante questionável, pois com certeza compromete muito o devido suporte para os trâmites do processo de doação de órgãos, esta deveria ter seu funcionamento na mesma equivalência da CNCDO, funcionando 24 horas. A SPOT auxilia os hospitais desde o início do protocolo da ME até o momento da captação dos órgãos, assim que o hospital através das CIHDOTTs ou não, entra em contato com a SPOT do Conjunto Hospitalar, é orientado sobre os exames clínicos e após isso a SPOT entra em contato com as empresas conveniadas para a realização do(s) exame (s) gráfico(s).

Empresas essas contratadas pela Secretaria de Estado da Saúde, que atuam como prestadoras de serviços, e entram na lista das SPOTs através de licitação pública; no entanto tais empresas atendem a todas as SPOTs do Estado de São Paulo, e as SPOTs devem respeitar sempre que se faz necessário o(s) exame(s) gráfico(s), o limite de quilometragem abaixo de $50 \mathrm{Km}$ de distância da SPOT solicitante, isso devido localização das empresas e a custos, pois quanto mais próxima está a empresa da SPOT menor o valor pago pelo exame pela Secretaria de Estado da Saúde, mas se não for possível deve-se então verificar as empresas que estão a mais de $50 \mathrm{Km}$ da SPOT.

A empresa mais próxima da SPOT do Conjunto Hospitalar está em Campinas, quando não está disponível é acionada a próxima empresa que fica localizada em São Paulo, tais empresas prestadoras desses exames gráficos assim que contatadas têm o prazo máximo de até 6 horas para ir até o hospital do doador, realizar o exame e entregar o laudo a SPOT via e-mail ou fax, não têm para isso nenhuma norma, mas para manter um melhor controle da duração desse processo se convencionou juntamente com tais empresas tal condição.

No entanto, a dimensão territorial desses 47 municípios que estão sob a administração da SPOT do Conjunto Hospitalar de Sorocaba, é bastante abrangente já que no quesito distância, a cidade mais próxima está localizada a apenas 4,6 Km da SPOT, enquanto que a mais distante está a exatos $279 \mathrm{Km}$ de distância, evidenciando assim a complexidade logística, e o desafio em gerenciar as captações nesses 47 municípios, dentro das condições impostas pela localização difusa dessas empresas contratadas pela Secretaria de Estado da Saúde, mesmo porque no lead time inicial desse processo, são necessários 2 exames clínicos. É necessário observar no quesito lead time, os intervalos necessários entre os exames clínicos e gráficos, que são determinados pela faixa etária do possível doador, como: de sete dias a dois meses incompletos intervalo de 48 horas: dois eletros encefalogramas; de dois meses a um ano incompleto intervalo de 24 horas: dois eletros encefalogramas; de um ano a dois anos incompletos intervalo de 12 horas: dois eletros encefalogramas e acima de dois anos intervalo de 6 horas: um eletro encefalograma.

Esta situação de dependência para a realização dos exames gráficos, dessas empresas contratadas localizadas, não exatamente onde deveriam mais próximas dos hospitais onde estão os possíveis doadores, é extremamente complicado para o sucesso das captações de órgãos, pois quanto mais demorar em se iniciar o processo de confirmação de ME, corre-se o risco de o possível doador vir a sofrer um ataque cardíaco, e perder-se a valiosa oportunidade de realizar a captação de diversos órgãos, no caso da autorização da família.

A SPOT também solicita junto a Central de Transplante de São Paulo, o transporte para coletar no hospital onde está o doador a sorologia e o HLA (são genes importantes no desenvolvimento de doenças autoimunes e responsáveis pela rejeição de transplantes de órgãos e tecidos), e levá-la até o Instituto Dante Pazzanesse, em São Paulo, mas primeiro o motorista passa na SPOT do Conjunto Hospitalar de Sorocaba para retirar a autorização de Material Biológico, sendo que obviamente essa autorização deveria ser feita através das ferramentas de TI (Tecnologia da Informação), o que agilizaria muito o processo, reduzindo o transit time dessa Cadeia de Suprimentos.

Sem contar que uma única empresa terceirizada é responsável por esse importante serviço, muitas vezes 
é utilizado até motos para diminuir o tempo gasto no trânsito, partindo dessa condição observamos o lead time como sendo bastante prejudicado, pois dependerá muito das condições de trânsito existentes naquele momento. Assim que o motorista recebe a sorologia e o HLA no hospital do doador, é anotado em documento próprio o horário; e quando é entregue no Instituto de Cardiologia Dante Pazzanese também é feito anotação do horário, o Instituto funciona 24 horas por dia, o tempo médio para a liberação dos resultados é de 3 horas, salvo a necessidade de repetições em caso de resultados duvidosos ou inconclusivos.

Quando o resultado da sorologia e do HLA ficam disponíveis a SPOT reúne todos os exames, anota o horário do envio do e-mail ou fax para a CNCDO2 com todos os exames anexados e a partir desde momento, a $\mathrm{CNCDO} 2$ têm até 6 horas para analisar a viabilidade da captação (órgãos em condições de transplante) e providenciar o transporte das equipes transplantadoras até o hospital onde se encontra o doador, bem como no mesmo momento realizar a triagem em seu sistema de todos os receptores compatíveis, procurando aperfeiçoar o processo de forma a aproveitar todos os órgãos que forem captados para transplante, e isso dependerá sumariamente e totalmente da logística: localização do doador, tempo de isquemia de cada órgão (tempo que o órgão vai permanecer fora do organismo no líquido conservante, submerso em gelo), modal utilizado para locomoção das equipes transplantadoras, condições de trânsito quando utilizado o modal rodoviário, condições de tráfego como: clima e outros quando utilizado o modal aéreo, e a localização dos receptores (hospitais onde já devem estar sendo internados para o tempo de jejum necessário para a realização do transplante).

Cada equipe transplantadora leva os órgãos captados de sua especialização, exemplo à equipe que captou o coração é responsável por transplantá-lo, somente com os rins é diferente, uma equipe vem faz a captação e os rins ficam no poder e responsabilidade da SPOT, depois outra equipe é que fará o transplante.

Quando se faz necessário o transporte terrestre, a CNCDO2 informa a Central de Transplantes, que busca primeiro o serviço do próprio governo, como o uso dos aviões da FAB (Forças Armadas Brasileiras) e do Águia do Polícia Militar; se não for possível para essas corporações fazerem o transporte, a Central de Transplante solicita entre as empresas aéreas privadas, vagas para alocarem as equipes transplantadoras para irão fazer captações de órgãos ou mesmo o transplante de órgãos, para isso é destinado recursos financeiros para pagamento das despesas aéreas das equipes transplantadoras.

Se for viável captar todos os órgãos e tecidos incluindo pele e ossos, levará em média 10 horas, a maioria das vezes esse tempo é menor porque não se capta todos os órgãos e tecidos como os ossos, por exemplo, isso devido à demanda dos Bancos de Tecidos MúsculosEsqueléticos, mesmo assim esse tempo é variável conforme a habilidade e experiência de cada equipe, como também das condições anatômicas dos órgãos do doador, visto que os órgãos a serem captados são cuidadosamente retirados, suas estruturas (veias e artérias) clampeadas e preparadas com toda técnica necessária para poderem ser transplantados nos receptores (anastomose das veias e artéria); isso reflete no tempo que leva para ser entregue o corpo do doador à sua família que gira em torno de 18 a 24 horas, desde o momento em que é informada à família que seu ente querido está com ME (Morte Encefálica).

Primeiro é verificado nos registros da CNCDO1, depois na CNCDO2, se não encontrado receptor compatível é feita uma busca na lista do SNT (Sistema Nacional de Transplantes). No atual modelo de SCM de transplantes da região em que a SPOT é responsável, que são 47 municípios, assim que é verificada a ME, a sorologia e o HLA do paciente é colhida e levada até o Instituto de Cardiologia Dante Pazzanese em São Paulo, o que contribui muito para atrasar todo processo que poderia ser muito mais rápido e eficiente se fosse realizado aqui em Sorocaba, isso reduziria o lead-time da espera pelo resultado do exame, para se proceder efetivamente à captação dos órgãos; processo que se iniciaria com a confirmação de que o paciente doador é viável, com a conseqüente localização através do sistema pelos receptores compatíveis e a admissão no hospital em que se encontra o doador das equipes transplantadoras. 
O modal utilizado para recolher o material da sorologia e o HLA, é o rodoviário que não é muito eficiente, tendo em vista as condições de trânsito que é, em muitos horários de maior demanda de tráfego extremamente lento, como no caso de enormes congestionamentos na cidade de São Paulo, local onde fica o laboratório de referência para a realização desse exame. Outro grande entrave da SCM da região de Sorocaba é quando ocorre uma $\mathrm{ME}$ em algum município em que é da responsabilidade da SPOT de Sorocaba, esta entra em contato com as empresas conveniadas para a realização dos exames gráficos para a devida comprovação da ME, o que ocorre é a localização dessas empresas não estarem muito de acordo com a real necessidade da urgência, por exemplo, em se realizar os exames para a comprovação da ME, estão localizadas muito distantes do hospital onde está o potencial doador; o que novamente compromete toda a operação da captação e retirada dos órgãos; pois é outro fator complicado, aumentando novamente o lead time do processo da captação para depois de converter em efetivo transplante, penalizando a eficiência da cadeia.

Exemplificando: ocorreu uma morte encefálica em Itu, a SPOT de Sorocaba recorreu à lista das empresas conveniadas, é a mais próxima estava localizada em Campinas, mas ao ligar não foi possível contatar os responsáveis, que estavam em outros compromissos, e, portanto a empresa mais próxima foi contatada em Higienópolis, na grande São Paulo; ficando assim evidente a discrepância logística existente. Outra questão são os custos, por exemplo: se para a empresa o hospital em que ela fará os exames gráficos (Eletroencefalograma ou o Doppler Transcraniano), estiver a $50 \mathrm{Km}$ de sua localização será cobrado do Estado $\mathrm{R} \$ 600,00$ (seiscentos reais), se estiver a uma distância superior é cobrado $R$ \$1.200,00 (um mil e duzentos reais), o que com certeza torna o processo muito oneroso.

A idade para ser considerado um doador é a partir sete dias de vida até 80 anos. A lista dos receptores deve ser atualizada de três em três meses, se não for atualizada pelas equipes espalhadas por todo 0 território brasileiro, quando há captações de órgãos não é possível fazer a devida triagem dos receptores e com isso, por negligência de alguma equipe, um receptor pode não ser contemplado com o órgão que necessita, para auxiliar no acompanhamento de sua situação, os pacientes receptores recebem um número de cadastro que lhes dá acesso ao SNT, e com isso eles podem fazer questionamentos junto a Unidade de Saúde em que estão sendo atendidos.

A cidade de Sorocaba possui o aparelho de Eletroencefalograma, que fica disponível apenas para os casos de constatação de ME no próprio hospital, não sendo possível deslocá-lo para as cidades próximas.

Dessa forma deve-se sempre procurar gerenciar o processo da captação e efetivo transplante, de modo a otimizar ao máximo tais recursos (órgãos doados), pois envolvem muitos elementos incalculáveis do ponto de vista emocional para a família do doador, que após serem informadas da ME e entrevistadas por profissionais envolvidos no processo de doação, solicitando-as a autorização para a doação dos órgãos de seu ente querido, desejam que seu gesto de incomparável empatia e altruísmo em prol de outras pessoas que necessitam de tais doações de órgãos.

Efetivamente se convertam em transplantes, para isso é extremamente vital o correto gerenciamento dos componentes da cadeia, a otimização de todo processo, envolvendo o transporte, a infra-estrutura da SPOT, bem como a correta distribuição dos laboratórios mais bem localizados, investimentos em TI visto que é muito precário os meios de comunicação que são utilizados, por exemplo: ainda usa-se o fax para enviar e receber documentos, como também o modal utilizado que poderia ser mais bem direcionado para outro mais rápido, e um aspecto bastante contundente a necessidade de se ter um laboratório de referência para realização do exame de sorologia e HLA, mais próximo.

Enfim precisa-se continuar por uma busca constante por melhorias que estão intimamente relacionadas na tomada de decisão de uma análise bastante minuciosa das condições e viabilidades logísticas; pois como observado nessa pesquisa o fator de lead time está intrinsicamente ligado ao sucesso do complexo processo como é a Cadeia de Suprimentos de um 
transplante de órgãos.

Pois quando analisadas e estrategicamente verificadas todas as possibilidades e esforços em melhorar o sistema, como buscar fornecedores (empresas prestadoras de exames gráficos), localização de tais empresas, como também a urgente necessidade de ter um laboratório de referência mais próximo para os exames de sorologia e HLA, pois impacta diretamente no tempo total do processo, bem como investir em $\mathrm{TI}$, fazendo tais ajustes e mudança de postura frente a uma causa de extrema nobreza é possível realizar importantes mudanças, como:

- Reduzir a permanência do doador hospitalizado (liberando mais uma vaga na UTI para outro paciente que necessite com conseqüente diminuição do custo envolvido em manter esse doador que está em um quadro irreversível);

- Reduzir o tempo do resultado da sorologia e HLA (laboratório mais próximo);

- Reduzir o tempo da entrega do corpo a família do doador e consequentemente amenizar parte de seu sofrimento;

- Aumentar drasticamente a qualidade dos órgãos doados; (menor lead time impacta em melhores condições dos órgãos captados);

- Reduzir o tempo do resultado dos exames gráficos (contratando empresas mais próximas aos hospitais);

- Aumentar significativamente o número de órgãos transplantados (menor tempo leva ao melhor aproveitamento do órgão);

- Redução dos custos (laboratórios mais próximos, menor valor pago), menor gasto com transporte.

- Redução do lead time por investimento em Tecnologia da Informação.

Se as autoridades competentes tomarem conhecimento, de todos esses problemas e quiserem mesmo resolvê-los, farão um imenso gesto de respeito e carinho a todas as pessoas que poderão passar por uma situação dessas, quer na condição de um possível doador estando em uma condição de ME irreversível; ou estando do outro lado da problemática, a condição bastante conflitante emocionalmente: os familiares do possível doador; pois o menor lead time possível é muitíssimo importante para os dois lados da situação, fazendo que de certa forma, o sofrimento seja amenizado.

Vemos, portanto que um planejamento logístico aplicado à área da saúde, é inquestionavelmente essencial para a vida de muitas pessoas, pode significar em muitas ocasiões a continuidade da vida ou não, visto que está totalmente conjugado em todos os processos onde requer agilidade, eficiência, rapidez e integração dos elos da Cadeia de Suprimentos, do qual os serviços de atendimento à saúde são oferecidos, e nesta pesquisa sobre a SCM, a constatação imediata de como a aplicação das ferramentas logísticas e o correto gerenciamento da Cadeia são vitais.

\section{CONSIDERAÇÕES FINAIS}

Foi possível através desse estudo de caso verificar os principais problemas da SCM da Captação e Distribuição de Órgãos do Conjunto Hospitalar de Sorocaba, através de um levantamento do real funcionamento dessa Cadeia, evidenciando assim claramente onde se encontram os gargalos. Através desta constatação foi possível enumerar soluções que podem com certeza ser implantadas nesta importante modalidade de prestação de serviços à nossa sociedade: a captação, distribuição e transplante de órgãos.

Neste estudo de caso ficou evidente que a aplicação da Logística é extremamente capaz de direcionar qualquer tomada de decisão frente à necessidade de solucionar problemas, pois a aplicação de todas as suas eficientes ferramentas permitem realizar uma análise fidedigna de cada problema da SCM de qualquer área do conhecimento e, portanto é completamente aplicável na busca de quaisquer situações em que existam evidências de problemas com fatores como: tempo, infra-estrutura e qualquer tipo de fluxo de demanda.

Também foi bastante perceptível que a análise logística dessa Cadeia de Suprimentos e o apontamento das melhorias através da integração dos elos que a formam, e que podem ser perfeitamente executáveis 
pelas autoridades, são em essência capazes também de modificarem do ponto de vista moral, concedendo ao sistema mais equidade, justiça e ética, pois através de alterações nos elos dessa SCM, diminuirá significativamente o lead time em que doadores ficam em seus leitos de UTI, o lead time que as famílias desses doadores ficam expostas ao sofrimento de ter que esperar ao fim desse processo de doação, e o lead time em que os receptores estão esperando ansiosamente um telefonema avisando-os que alguém fez este gesto de extremo amor e altruísmo, pois é neles que está o alto valor agregado de todo esse processo.

Sendo assim nessa SCM, os segundos, minutos e horas são extremamente fatores de vantagem competitiva na busca pela continuidade da vida, pela redução dos valores percentuais mais incalculáveis que existem: a perda de um paciente receptor na fila de espera por um órgão que deixou de ser captado por falta de soluções na integração desta SCM.

\section{REFERÊNCIAS}

[1] BALLOU, R.H., The evolution and future of logistics and supply chain management, Produção, Vol. 16, n. 3, pp. 375 386, 2006.

[2] BOWERSOX, D J.; CLOSS, D J. Logística Empresarial: O Processo de Integração da Cadeia de Suprimento. São Paulo: Editora Atlas S.A., 2001.

[3] CARPINETTI, L. C. R. Proposta de um modelo conceitual para o desdobramento de melhorias estratégicas. Gestão \&Produção, v. 7, n.1, 2000.

[4] CHOPRA, S.; MEINDL, P., Gerenciamento da cadeia de suprimentos: estratégia, planejamento e operação. São Paulo: Prentice Hall, 2003

[5] FRANCHETTI, S.M.M. Manual de segurança e regras básicas em laboratório. São Paulo: Universidade Estadual Paulista Júlio de Mesquita, 2008.

[6] HAYES, R. H.; PISANO, G. P.; UPTON, D. M.; WHEELWRIGHT, S. C. Operations, Strategy and Technology, Pursuing the Competitive Edge. New York: John Willey \& Sons, 2008.

[7] INFANTE, Maria \& SANTOS, Maria Angélica Borges dos. A organização do abastecimento do hospital público a partir da cadeia produtiva: uma abordagem logística para a área de saúde. Ciênc. saúde coletiva [online]. 2007, v. 12, n. 4, p. 945-954
[8] KUMAR, A., OZDAMAR, L. E ZHANG, N., Supply chain redesign in the healthcare industry of Singapore, Supply Chain Management: An International Journal, Vol. 13, n. 2, pp. 95 - 103, 2008

[9] LA FORGIA, G. M. E COUTTOLENC, B. F., Hospital Performance in Brazil - The Search for Excellence. Washington, DC: The World Bank, 2008.

[10] LAMBERT, D. M.; COOPER, M. C.; PAGH, J. Supply chain management: implementation issues and research opportunities. International Journal of Logistics Management, vol. 9, no. 2, 1998

[11] LI, S., RAGU-NATHAN, B., RAGU-NATHAN, T.S. E RAO, S.S., The impact of supply chain management practices on competitive advantage and organizational performance, Omega, Vol. 34, pp. 107 - 124, 2006.

[12] LI, S., RAO, S.S., RAGU-NATHAN, T.S. E RAGUNATHAN, B., Development and validation of a measurement instrument for studying supply chain management practices, Journal of Operations Management, Vol. 23, pp. 618 - 641, 2005.

[13] MALHOTRA, M. K. E GROVER, V., An assessment of survey research in POM:from constructs to theory, Journal of Operations Management, Vol. 16, pp. 407 -425, 1998.

[14] MONTGOMERY, K. E SCHNELLER, E.S., Hospital's strategies for orchestrating selection of physician preference items, The Mildbank Quarterly, Vol. 85, n. 2, pp. 307 - 335, 2007

[15] PEREIRA, J.M. A importância da logística no âmbito hospitalar. Notícias hospitalares gestão de saúde em debate, São Paulo, n. 37, jun./jul. 2002. Disponível em <http://www. prosaude.org.br/noticias/jun2002/pgs/gestao.htm > . Acesso em: 20 set. 2010.

[16] RIBEIRO, A. O CPFR como Mecanismo de Integração da Cadeia de Suprimentos: Experiências de Implementação no Brasil e no Mundo. Artigos COPPEAD 2004.

[17] SIMCHI-LEVI, D.; KAMINSKY, P. Cadeia de suprimentos: projeto e gestão. 3a. ed. Porto Alegre: Bookman, 2010.

[18] SINGH, M., RICE, J.B. E RIQUIER, D., Transforming the global health care supply chain, MIT Center for Transportation and Logistics. Disponível em http://ctl.mit.edu. Acesso em 08/10/2011

[19] SLACK, N.; LEWIS, M.; BATES, H. The Two worlds of operations management research and practice - can they meet, should they meet?. International Journal of Operations \& Production Management, v. 24, n. 4, p. 372-87, 2004.

[20] TAN, K. C., Supply chain management: practices, concerns and performance issues, Journal or Supply Chain Management, Vol. 30, n. 1, pp. 42 - 53, 2002.

VECINA NETO, G. E MALIK, A.M., Tendências na assistência hospitalar, Ciência \& Saúde Coletiva, Vol. 12, n. 4, pp. 825 - 839, 2007. 
[21] VECINA NETO, G. E REINHARDT FILHO, W., Gestão de recursos materiais e de medicamentos, Série Saúde e Cidadania, Vol. 12. São Paulo: Faculdade de Saúde Pública da Universidade de São Paulo, 2002.
[22] YIN, R. K. Case Study Research, Design and Methods. 2. ed. London: Sage, 1994. 


\section{CAPÍTULO 11}

\section{AVAMACGÃO DOS NÍVEIS DE VIBRAÇÃO E RUÍDO NAS OPERAÇÕES DE ROÇADA E DESGALHAMENTO COM MOTOPODAS}

\section{Vitor Hugo Breda Barbosa}

Stanley Schettino

Luciano José Minette

Amaury Paulo de Souza

Maria Gristina Martins

Resumo: As maquinas auxiliam os trabalhadores nas operações de roçada e desgalhamento, atividades cuja realização expōe os trabalhadores a elevadas cargas físicas. Dentre diversas máquinas, as motosserras e as motopodas estão entre as mais demandadas para auxiliar os trabalhadores. O surgimento destas máquinas nas operações florestais trouxe grandes beneficios aos trabalhadores, que deixaram os machados e as operações manuais lentas e de baixa produtividade para realizá-tas com maior rendimento e menor esforço físico. Dessa forma, este estudo objetivou realizar a avaliação dos niveis de vibração e ruído gerados pelas máquinas nas operações de roçada e desgalhamento, sendo base para estudos visando à melhoria dos níveis de qualidade, eficiência e produtividade, ainda preservando a integridade física e a saúde do trabalhador. A avaliaçâo ocupacional da vibração e do ruído baseou-se nos critérios de avaliação estabelecidos pela Norma Regulamentadora № 15 (NR-15), Anexos 8 e 1, respectivamente. De acordo com a norma ISQ 5349 de 2001 e em conformidade com a diretiva da Comunidade Européia 2002/44/EC, nenhuma das máquinas avaliadas e utilizadas nas operações de roçada e desgalbamento semimecanizados emitem níveis vibração dentro dos limites de referência da norma. Ao comparar os níveis de ruído gerado pelas máquinas avaliadas com o que define a NR-15, concluiu-se que todas as máquinas emitem ruídos superiores ao recomendado. Os resultados apontam que essas máquinas são potencialmente capazes de gerar danos à saúde e a integridade física dos trabalhadores.

Palavras chave: Saúde do trabalhador: Segurança do trabalho; Operaçoes florestais. 


\section{INTRODUÇÃO}

As maquinas auxiliam os trabalhadores nas operações de roçada e desgalhamento, atividades cuja realização expõe os trabalhadores a elevadas cargas físicas. Dentre diversas maquinas, as motosserras e as motopodas estão entre as mais demandadas para auxiliar os trabalhadores.

O surgimento das motosserras e motopodas nas operações florestais trouxe grandes benefícios aos trabalhadores desse meio, que deixaram os machados e as operações manuais lentas e de baixa produtividade para ingressar no corte florestal semimecanizado, que, segundo Sant'Anna e Malinowski (2002), admitem que se consiga uma produtividade individual relativamente alta, com investimento inicial baixo, além de poder ser feito em áreas onde o acesso é complexo e a declividade muito elevada. Estas máquinas expõem o trabalhador a níveis de vibração que são relevantes à saúde humana, sendo necessária a avaliação do sistema maquina-homem e o controle para a correta utilização.

Segundo Saliba (2009) a vibração é um movimento oscilatório de um corpo devido a forças desequilibradas de componentes rotativos e movimentos alternados de uma máquina ou equipamento. Se o corpo vibra, descreve um movimento oscilatório e periódico, envolvendo deslocamento num tempo. Assim, envolvida no movimento tem-se a velocidade, aceleração e freqüência.

O mesmo autor descreve ainda que a Convenção № 148 da Organização Internacional do Trabalho (OIT) estabelece que o termo "vibrações" compreende toda vibração transmitida ao organismo humano por estruturas sólidas e que seja nociva à saúde ou contenha qualquer outro tipo de perigo.

As vibrações podem ser transmitidas ao corpo como um todo ou apenas algumas partes como mãos e braços. As operações de roçada e desgalhamento geram vibração que atinge as mãos dos trabalhadores.

O ruído pode ser considerado um som indesejável ou até mesmo um estímulo auditivo que não contém informações úteis para a tarefa em execução (IIDA, 2003).
Muitos estudos evidenciaram sérios efeitos (psicológicos e fisiológicos) do ruído no homem, tais como: perda da concentração, embaraço nas conversações, perda dos reflexos, diminuição da inteligibilidade das palavras, irritação permanente, perda auditiva até a surdez permanente, insegurança quanto à eficiência dos atos, dores de cabeça, estresse; distúrbios cardiovasculares, fadiga, distúrbios hormonais, loucura, gastrite, disfunção digestiva, aumento da freqüência cardíaca, alergias, contração dos vasos sangüíneos, distúrbios do sono entre outros (NORONHA, TRAVAGLIA FILHO e GARAVELLI, 2005).

Para Saliba (2009) de acordo com a Norma ISO, os principais efeitos vasculares devido à exposição à vibração no sistema mão-braço podem ser de ordem vascular, neurológica, osteoarticular e muscular. De acordo co lida (2003) em trabalhadores florestais que usam motosserras, há uma degeneração gradativa do tecido vascular e nervoso, causando perda da capacidade manipulativa e tato nas mãos, dificultando o controle motor.

Por meio deste estudo, que tem como objetivo realizar a avaliação dos níveis de vibração e ruído gerados pelas máquinas nas operações de roçada e desgalhamento, será possível propor melhorias na forma de realização das atividades, com maior conforto, bem-estar, saúde e segurança dos trabalhadores, levando, consequentemente, à melhoria dos níveis de qualidade, eficiência e produtividade.

\section{MATERIAL E MÉTODOS}

\subsection{CARACTERIZAÇÃO DA AMOSTRAGEM}

Este estudo foi desenvolvido no Município de Andrelândia, Estado de Minas Gerais, localizada na Mesorregião do Sudeste Mineiro, situada a 985 metros de altitude e na coordenada geográficas $21^{\circ} 43^{\prime} 04^{\prime \prime}$ de latitude sul e 4418'44" de longitude oeste.

O clima é caracterizado tropical de altitude (tipo Cwb segundo Köppen) e temperatura média anual em torno dos $19^{\circ} \mathrm{C}$, tendo invernos secos e frios, frequentemente com ocorrências de geadas em algumas áreas, e verões úmidos com temperaturas mais altas. $\mathrm{O}$ índice 
pluviométrico anual é superior a 1.500 milímetros (mm).

\subsection{DESCRIÇÃO DAS ATIVIDADES}

Este estudo foi realizado com as operações de roçada e desgalhamento semimecanizado, que segundo Machado (2014), toda operação mecanizada é realizada com máquinas motoras, quando possuem equipamentos e ferramentas acoplado a elas e, ou, quando contém mecanismos com movimentos relativos ao acionamento direto.

A atividade de roçada é desenvolvida por um único trabalhador, com o objetivo de manter as mudas florestais livres da competição e dos efeitos indesejados das ervas daninhas. Nesta atividade, o trabalhador abastece a máquina (motoroçadeira) com combustível para o funcionamento do motor, se deslocando pela área segurando a roçadeira com ambas as mãos. A partir deste momento é iniciado o trabalho da roçada, com algumas pausas para e descanso para necessidades pessoais.

Enquanto que na atividade de desgalhamento a equipe de trabalho é composta por dois operadores de motopoda e um ajudante para movimentação de galhos, em áreas com topografia desde plana até fortemente onduladas (inclinação de até $36^{\circ}$ ).

Contudo, Silva (2013) alerta para os perigos envolvendo a utilização incorreta desta máquina. Os riscos da motopoda muitas vezes são ignorados pelos seus operadores devido à falta de treinamento correto, desconhecimento das normas de segurança para se utilizar o equipamento, falta dos equipamentos de proteção individual e dos riscos que estão sujeitos.

\subsection{MODELOS E MARCAS DE MÁQUINAS ESTUDADAS}

Os modelos e marcas de motopodas e moto roçadeiras analisadas estão descritas na Tabela 1 abaixo.
Tabela 1- Modelos e marcas de motopodas e motorroçadeiras

\begin{tabular}{|ll|}
\hline Roçada semimecanizada & $\begin{array}{l}\text { Desgalhamento } \\
\text { semimecanizado }\end{array}$ \\
\hline Still - KKA 85R - HT & Still - KA 85 R - HT \\
Still - FS 280 & Husqvarna - 327P5x \\
& EFCO Branco - Stark 42 \\
\hline
\end{tabular}

\subsection{CRITÉRIOS DE AVALIAÇÃO}

A avaliação foi realizada por meio da metodologia do grupo homogêneo de exposição, tendo sido analisado o ciclo de trabalho que compõe a atividade dos trabalhadores expostos. Foram realizadas medições em cada operação que compõe o ciclo de trabalho, bem como a determinação dos respectivos tempos de duração.

\subsubsection{VIBRAÇÃO}

A avaliação ocupacional de vibração baseou-se nos critérios de avaliação estabelecidos pela NR 15, anexo 8. Essa norma estabelece que perícia, visando à comprovação ou não da exposição, deve tomar por base os limites de tolerância definidos pela Organização Internacional para Normalização - ISO, em suas normas ISO 2.631 e ISO/DIS 5.349 ou suas substitutas.

A avaliação dos riscos de exposição à vibração mãobraço, foram realizadas de acordo com as partes $1 \mathrm{e}$ 2 da norma ISO 5349 de 2001 e a prescrição mínima de segurança recomendada pela Directiva Européia.

Para avaliação da vibração foi utilizado um acelerômetro tri-axial da marca MAESTRO 01 DB, que mensura a aceleração ponderada segundo as coordenadas ortogonais $\mathrm{x}, \mathrm{y}$ e $\mathrm{z}$ transmitida aos membros superiores. Os valores da exposição diária a vibração mão-braço de acordo com a ISO 5349-1 são expressas num período de 8 horas A (8):

Sendo:

$$
A(8)=a h v \sqrt{\frac{T}{T_{o}}}
$$

T = é a duração total diária da exposição à vibração, 
$\mathrm{T}_{\circ}$ = é a duração de referência de 8 h (28800 s).

Se o trabalho consiste em várias operações com diferentes valores de vibração, de acordo com a norma ISO 5349, a exposição diária às vibrações $A(8)$ foi obtida utilizando a fórmula:

$$
A(8)=\sqrt{\frac{1}{T_{o}} \sum_{i=1}^{n} a_{h v i}^{2} T_{i}}
$$

Onde:

$a^{2}{ }_{\text {hvi }}=$ é o valor total de vibração por operação,

$\mathrm{n}=$ é o número individual de exposição a vibração,

$\mathrm{T}_{\mathrm{i}}=$ é o tempo de duração da operação.

Conforme recomendado pela norma ISO 5349(2001) foram medidas as vibrações nas três direções $x, y$ e z, sendo comparado o valor Global A(8) encontrado com os limites permitidos pela norma.

\subsubsection{RUÍDO}

A avaliação ocupacional do ruído baseou-se nos critérios de avaliação estabelecidos pela NR 15, anexo 1. A norma estabelece que os níveis de ruído contínuo ou intermitente devem ser medidos em decibéis $(\mathrm{dB})$ com instrumento de nível de pressão sonora operando no circuito de compensação "A" e circuito de resposta lenta (SLOW). As leituras devem ser feitas próximas ao ouvido do trabalhador.

Foi utilizado um medidor de nível de pressão sonora fabricado pela HISeg Instrumentos de Medição Ltda, modelo DL - 4200, devidamente calibrado. O aparelho utilizado é recomendando pela norma NBR 10151, por já apresentar em seu display o nível de pressão sonora equivalente ponderado em "A" (LAeq). O aparelho está referendando pela norma IEC - 61672-1.

\section{RESULTADOS E DISCUSSÃO}

\subsection{VIBRAÇÃO}

O critério da Comunidade Européia para a avaliação ocupacional estabelece os níveis limites de vibração de 2,5 a $5,0 \mathrm{~m} / \mathrm{s}^{2}$. A Tabela 2 apresenta os níveis de vibração global emitido pelas máquinas avaliadas nas atividades de roçada e desgalhamento semimecanizados.

Observa-se que para o operador de motopoda durante a atividade de roçada estava exposto a um nível de vibração maior na mão esquerda (correspondente à alça dianteira) para todas as máquinas avaliadas.

Entretanto, na atividade de desgalhamento, o principio de exposição à vibração foi parecido para a atividade de roçada. Apenas o modelo EFCO Branco PT 2500 Start 42, apresentou maior vibração para a mão direita em relação com a mão esquerda. 
Tabela 2 - Níveis de vibração global emitido pelas máquinas avaliadas nas atividades de roçada e desgalhamento semimecanizados

\begin{tabular}{|c|c|c|c|c|c|c|c|c|c|c|c|}
\hline Atividade & $\begin{array}{l}\text { Máquina } \\
\text { Modelo }\end{array}$ & Mão & $\begin{array}{l}\text { RPM } \\
\text { Lenta }\end{array}$ & $\operatorname{Max}$ & $\begin{array}{l}X \\
\mathrm{~m} / \mathrm{s}^{2}\end{array}$ & $\begin{array}{l}\mathrm{Y} \\
\mathrm{m} / \mathrm{s}^{2}\end{array}$ & $\begin{array}{l}\mathrm{Z} \\
\mathrm{m} / \mathrm{s}^{2}\end{array}$ & $\begin{array}{l}\text { Global } \\
\text { Aeq }\end{array}$ & $\begin{array}{l}\text { Global } \\
A(8)\end{array}$ & $\begin{array}{l}\text { Exposição } \\
\text { a Nível de } \\
\text { Alerta }\end{array}$ & $\begin{array}{l}\text { Nível } \\
\text { Limite } \\
\text { de } \\
\text { exposição }\end{array}$ \\
\hline \multirow{4}{*}{ Roçada } & \multirow{2}{*}{$\begin{array}{l}\text { Stihl - KA 85R } \\
- \text { HT }\end{array}$} & $\mathrm{D}$ & 2.800 & 10.300 & 2,82 & 4,45 & 1,87 & 5,60 & 5,60 & 1h $40 \mathrm{~min}$ & $6 \mathrm{~h} 28 \mathrm{~min}$ \\
\hline & & $E$ & 2.800 & 10.300 & 4,20 & 4,19 & 1,98 & 6,29 & 6,29 & 1h 13min & $5 \mathrm{~h} 05 \mathrm{~min}$ \\
\hline & \multirow{2}{*}{ Stihl - FS 280} & $\mathrm{D}$ & 2.200 & 9.700 & 3,45 & 6,00 & 3,62 & 7,79 & 7,79 & $51 \mathrm{~min}$ & 3h 18min \\
\hline & & $E$ & 2.200 & 9.700 & 3,85 & 7,13 & 2,87 & 8,62 & 8,62 & $41 \mathrm{~min}$ & 2h $41 \mathrm{~min}$ \\
\hline \multirow{6}{*}{$\begin{array}{l}\text { Desgalha- } \\
\text { mento }\end{array}$} & \multirow{2}{*}{$\begin{array}{l}\text { Stihl KA 85R } \\
- \text { HT }\end{array}$} & $\mathrm{D}$ & 2800 & 9800 & 3,24 & 2,84 & 2,11 & 4,78 & 4,78 & $2 \mathrm{~h} 10 \mathrm{~min}$ & $8 \mathrm{~h} 47 \mathrm{~min}$ \\
\hline & & E & 2800 & 9800 & 2,81 & 4,70 & 2,84 & 6,19 & 6,19 & 1h 19min & $5 \mathrm{~h} 14 \mathrm{~min}$ \\
\hline & \multirow{2}{*}{$\begin{array}{l}\text { Husqvarna } 325 \\
\text { P5 }\end{array}$} & $\mathrm{D}$ & 3.300 & 10.000 & 2,48 & 2,09 & 2,56 & 4,09 & 4,09 & 2h 59min & $\begin{array}{l}11 \mathrm{~h} \\
55 \mathrm{~min}\end{array}$ \\
\hline & & $E$ & 3.300 & 10.000 & 2,70 & 2,90 & 3,78 & 5,47 & 5,47 & 1h $41 \mathrm{~min}$ & $6 h$ 40min \\
\hline & \multirow{2}{*}{$\begin{array}{l}\text { EFCO Branco } \\
\text { PT } 2500 \text { Start } 42\end{array}$} & $\mathrm{D}$ & 2.320 & 10.800 & 7,25 & 4,12 & 3,39 & 9,03 & 9,03 & $36 \mathrm{~min}$ & $2 \mathrm{~h} 25 \mathrm{~min}$ \\
\hline & & $E$ & 2.320 & 10.800 & 5,69 & 3,60 & 3,15 & 7,46 & 7,46 & $52 \mathrm{~min}$ & $3 \mathrm{~h} 34 \mathrm{~min}$ \\
\hline
\end{tabular}

A máquina EFCO Branco PT 2500 Start 42 utilizada no desgalhamento semimecanizado pode ser considerada a menos indicada para o desenvolvimento das operações estudadas, já que com apenas 36min a mesma já aciona o nível de alerta, permitindo ao trabalhador uma jornada de trabalho de $2 \mathrm{~h} 25 \mathrm{~min}$.

A máquina Husqvarna 325 P5 utilizada no desgalhamento semimecanizado é a que menos expõe o trabalhador ao risco de vibração, pois seu nível de alerta é de $1 \mathrm{~h} 41 \mathrm{~min}$. e o limite de exposição diária de $6 \mathrm{~h} 40$ min., seguida pela máquina Stihl KA 85R HT 1h 19min e o limite de exposição de 5h 14min.

Noentanto, todasasmotopodasutilizadasnasatividades de roçada e desgalhamento semimecanizados emitem níveis de vibração ao trabalhador florestal superiores ou muito próximos ao limite recomendado.

A tabela 3 apresenta a estimativa de ocorrência dos episódios de branqueamento nos dedos em 10\% do grupo de trabalhadores expostos nas máquinas avaliadas.
Tabela 3 - Estimativa da exposição necessária para a ocorrência dos episódios de branqueamento nos dedos em $10 \%$ dos expostos (anos) nas máquinas avaliadas

\begin{tabular}{|c|c|c|c|}
\hline \multirow[t]{2}{*}{ Máquina Modelo } & $\begin{array}{l}\text { Vibração } \\
\text { Global } \\
\text { A(8)m/s² }\end{array}$ & \multicolumn{2}{|c|}{$\begin{array}{l}\text { Exposição necessária } \\
\text { para a Ocorrência } \\
\text { dos episódios de } \\
\text { branqueamento nos } \\
\text { dedos } \\
\text { em } 10 \% \text { dos expostos } \\
\text { (anos) }\end{array}$} \\
\hline & Mão & $\begin{array}{l}\text { Mão Direita } \\
\text { Roçada }\end{array}$ & Mão \\
\hline Stihl - KA 85R - HT & 6,29 & 5,17 & 4,50 \\
\hline Stihl - FS 280 & 8,62 & 3,62 & 3,23 \\
\hline & \multicolumn{3}{|c|}{ Desgalhamento } \\
\hline Stihl - KA 85R - HT & 6,19 & 6,08 & 4,59 \\
\hline Husqvarna - 325P5 & 5,47 & 7,13 & 5,24 \\
\hline $\begin{array}{c}\text { EFCO Branco - PT } \\
2500 \text { Start } 42\end{array}$ & 7,46 & 3,08 & 3,79 \\
\hline
\end{tabular}

De acordo com as avaliações realizadas a máquina EFCO Branco - PT 2500 Start 42 é a que pode expor o trabalhador ao maior risco de incidência do Fenômeno de Raynaud (Síndrome dos dedos brancos). 
De acordo com as avaliações realizadas, em especial com os dois melhores resultados, a máquina Husqvarna 325 P5, produz 12,7\% a menos de vibração em comparação com a máquina da Stihl KA 85R, sendo a que possivelmente poderia expor menos os trabalhadores ao risco da incidência do Fenômeno de Raynaud (Síndrome dos dedos brancos), entretanto, cabe a ressalva de que em análise estatística pode demonstrar que a diferença talvez não seja significante entre as duas máquinas.

Outro ponto importante a ser considerado é que as máquinas estavam utilizando correntes diferentes, sendo a corrente da STHIL KA $85 R$ de $1.1 \mathrm{~cm} \mathrm{3/8} \mathrm{e}$ a da HUSQVARNA 325 P5 de 1,3 cm 3/8. A diferença da bitola das correntes pode afetar a vibração, uma vez que estando a corrente de $1,1 \mathrm{~cm}$ mais folgada na canaleta do sabre, com o movimento e o contato com a superfície da madeira pode acarretar em maior vibração. Além deste ponto, a corrente de 1,3 cm também apresenta a vantagem de ter maior durabilidade em comparação com a de 1,1 cm. Teles e Marzano (2013), encontraram que o tempo em que a motopoda está em operação, expõe o operador à vibração, fica abaixo do tempo limite de utilização da mão esquerda, determinada pela norma

Em muitos sistemas de engenharia, o ser humano atua como parte integrante do mesmo. A transmissão de vibração para o ser humano resulta em desconforto e perda de eficiência, podendo constituir um risco em potencial para os trabalhadores, uma vez que as vibrações podem desencadear perturbações neurológicas ou musculares, vasculares e lesões ósteo-articulares, no caso das vibrações transmitidas ao sistema mão-braço e patologias na região lombar e lesões da coluna vertebral, para o caso das vibrações transmitidas a todo o organismo (SOEIRO, 2008).

\subsection{RUÍDO}

A Tabela 4 apresenta os níveis de ruído emitidos pelas máquinas avaliadas nas atividades de derrubada e traçamento e desgalhamento. Nela expõe-se a necessidade do uso de protetor auricular para sua atenuação a níveis abaixo de $85 \mathrm{dBA}$, valor previsto como limite de tolerância ao ruído contínuo para uma jornada de trabalho de 8 horas, pela norma NR-15.

Segundo Couto (2012) deve ser estabelecido um tempo de pausa para conforto em ambiente com nível de pressão sonora superior a 80 dBA. No caso deste estudo a percentagem de pausa para a jornada de trabalho do operador de motopoda igual a 5\%.

Tabela 4 - Níveis de ruído emitidos pelas máquinas avaliadas nas atividades de roçada e desgalhamento semimecanizados

\begin{tabular}{|llll|}
\hline Atividade & $\begin{array}{l}\text { Modelo } \\
\text { Avaliado }\end{array}$ & Valor & $\begin{array}{l}\text { Valor } \\
\text { Recomendado } \\
\text { NR 15 dB (A) }\end{array}$ \\
Roçada & $\begin{array}{l}\text { Stihl - KA 85R } \\
- \text { HT }\end{array}$ & 88,68 & 85 \\
\cline { 2 - 4 } & Stihl - FS 280 & 95,65 & 85 \\
\hline & $\begin{array}{l}\text { Stihl - KA 85R } \\
- \text { HT }\end{array}$ & 91,13 & 85 \\
\hline Desgalhamento & $\begin{array}{l}\text { Husqvarna - 325 } \\
\text { P5 }\end{array}$ & 87,75 & 85 \\
\hline & $\begin{array}{lll}\text { EFCO Branco - } \\
\text { PT 2500 Start 42 }\end{array}$ & 88,46 & 85 \\
\hline
\end{tabular}

A Stihl FS 280 pode ser considerada a máquina mais prejudicial ao aparelho auditivo e a EFCO Branco PT 2500 Start 42 a menos ruidosa. No entanto, todas as máquinas utilizadas na roçada e no desgalhamento semimecanizados emitem níveis de ruído superiores aos limites de tolerância fixados na NR 15.

Os níveis de ruído encontrados incluem pequenas pausas e tempo de deslocamento na faixa de trabalho assim como entre uma faixa e outra. Acredita-se que se desconsiderassem esses momentos os níveis de ruído gerados pelas máquinas seriam superiores aos valores encontrados.

No trabalho realizado por FILDER et al (2012) e Moraes (2013), também encontraram para as atividade de roçada e desgalhamento semimecanizada, nível acima do tolerado pela NR-15. Atribuiram este fator, justificando o uso de máquinas movidas a motor de dois tempos que apresenta um acentuado nível de ruído quando o equipamento é acelerado. Sendo necessário, de acordo com fazer o uso de protetores auriculares para que o trabalhador fique em segurança na atividade que o mesmo esta exercendo, não tendo 
prejuízos à saúde, pois o excesso de ruído causa, apesar de lentamente, detrimento à audição podendo chegar a surdez.

A exposição ao ruído e o envelhecimento são consideradas as principais causas da perda auditiva em adultos, todavia, apenas o ruído é um fator passível de intervenção (DOBIE, 2008). A Perda Auditiva Induzida pelo Ruído Ocupacional (PAIRO) pode ser prevenida utilizando-se medidas coletivas e/ou individuais que ajudam a reduzir os níveis de ruído que atingem o trabalhador (EL-DIB et al., 2007). Ainda, segundo os autores, as medidas de proteção contra níveis elevados de ruído no trabalho devem ter, prioritariamente, caráter coletivo, a partir do controle da emissão na fonte principal de exposição, da propagação do agente no ambiente de trabalho e de ações no nível administrativo e de organização do trabalho. Entretanto, essas medidas são, usualmente, consideradas de alto custo e com tecnologia de difícil implantação; enquanto o equipamento de proteção auditiva tem sido a opção mais comum pela viabilidade, menor custo, relativa efetividade, e fácil acesso.

É interessante observar que o ruído ocupacional impõe ao trabalhador dificuldades de comunicação (na detecção, discriminação, localização e identificação das fontes sonoras, assim como na inteligibilidade de fala), de manutenção da atenção e concentração, de memória, além do estresse e fadiga excessiva. Estes são fatores sabidamente envolvidos na gênese de acidentes do trabalho. Consequentemente, parece haver relação causal entre ruído ocupacional e acidente do trabalho, o que remete de imediato para o campo da prevenção dos acidentes de trabalho (DIAS et al., 2006).

\section{CONCLUSÕES}

Das máquinas avaliadas a que provavelmente mais expõe o trabalhador florestal aos riscos da vibração é a EFCO Branco PT 2500 Start 42 e as que podem oferecer menos riscos ao trabalhador é a Husqvarna 325 P5 e a Stihl KA 85R HT. Porém, de acordo com a norma ISO 5349 de 2001 e em conformidade com a diretiva da Comunidade Européia 2002/44/EC, nenhuma das máquinas utilizadas nas operações de roçada semimecanizada e desgalhamento semimecanizado emitem níveis vibração dentro dos limites de referência da norma.

Ao comparar os níveis de ruído gerado pelas máquinas avaliadas com o que define a NR 15 pode-se perceber que todas as máquinas emitem ruídos superiores ao recomendado. Sendo a Stihl FS 280 a máquina mais ruidosa e a EFCO Branco PT 2500 Start 42 a menos ruidosa.

\section{REFERÊNCIAS}

[1] DIAS, A.; CORDEIRO, R.; GONÇALVES, C. G. O. Exposição ocupacional ao ruído e acidentes do trabalho. Cad. Saúde Pública, Rio de Janeiro, 22(10):2125-2130, out, 2006

[2] DOBIE, R. A. The burdens of age-related and occupational noise-induced hearing loss in the United States. Ear and Hearing, v. 29, n.4, p. 565-77, ago. 2008.

[3] EL-DIB, R. P. et al. A systematic review of the interventions to promote the wearing of hearing protection. São Paulo Medical Journal, v. 125, n. 6, p. 362-9, nov. 2007

[4] FIEDLER, N. C; SONE, E. H; VALE, A. T; JUVÊNCIO, J. F; MINETTE, L. J. Avaliação dos riscos de acidentes em atividade de poda de árvores na arborização urbana do Distrito Federal. Revista Árvore, Viçosa, v. 30, n. 2, p. 223233, 2006.

[5] FIEDLER, N.C.; SILVA, E. N.; MAZIERO, R.; JUVANHOL, R. S. J.; GONÇALVES, S. B. Caracterização de fatores humanos e analise das condições de trabalho em atividades de implantação de florestas de produção. Revista Científica Eletrônica de Engenharia Florestal Re.C.E.F. Ano X - Volume 19 - Número 1 - Fevereiro 2012 - Garça, SP

[6] IIDA, I. Ergonomia: projeto e produção. São Paulo: Editora Edgar Blücher Ltda, 2003.

[7] MACHADO, C. C. Colheita florestal. Viçosa, Editora UFV, Terceira Edição, 2014. 543 p.

[8] MORAES, F. Avaliação da iluminância, conforto térmico e ruído na implantação e manutenção florestal nas Microrregiões Caparaó e centro Sul-ES. Trabalho final de conclusão de curso (graduação), Universidade Federal do Espírito Santo, 2013.

[9] Noronha, E.H.; Travaglia Filho, U.J.E.; GARAVELLI, S.L. Quantificação dos níveis de ruídos num estande de tiros da PM do Distrito Federal [periódico on-line]. Centro de Ciências de Educação e Humanidades - CCEH. Universidade Católica de Brasília, jun 2005; vol. I; no 3.

[10] SALIBA, T. M. Manual prático de avaliação e controle de vibração: PPRA. São Paulo: Editora LTr, 2009 
[11] SANT'ANNA, C. M.; MALINOVSKI, J. R. Análise de fatores humanos e condições de trabalho de operadores de motosserra de Minas Gerais. Cerne, Lavras, v. 8, n. 1, p. 115121, 2002.

[12] SOEIRO, N.S. Curso de Fundamentos de Vibração e Balanceamento de Rotores. Belém: UFPA-ELETRONORTE, 2008.
[13] TELES, M. T; MARZANO, F. L. C. Avaliação dos níveis de vibração e ruído de atividades semimecanizadas na colheita de madeira danificada pelo vento. Simpósio do Programa de Educação Tutorial em Economia Domestica, 2013. Viçosa MG. 


\section{CAPÍTULO 12}

INOVAÇÃO TEGNOLÓGICA: ANÁLISE DO SISTEMA

PRODUTIVO EM UMA EMPRESA

Everaldo Veres Zahaikevitch

Ricardo Santin

Andréia Gura

Antônio Cecílio Silvério

Augusto Faber Flores

Resumo: A contabilidade de Custos como ferramenta para tomada de decisão é de fundamental importância, diante disso fica evidente a necessidade de sua utilização, o objetivo desse estudo é analisar a viabilidade de uma mudança no sistema produtivo em uma empresa do ramo ceramista, verificando assim a confiabilidade de um sistema de custos na tomada de decisão. Este estudo de casolbuscou uma análise qualitativa da empresa, utilizando como forma de auxílio o custeto variável, a margem de contribuição e o ponto de equilíbrio, analisou-se os resultados de quatro períodos e posteriormente uma previsão de mudança no setor produtivo com a utitizaçáo de uma inovação tecnológica com a finalidade de diminutir os custos e aumentar a capacidade produtiva da empresa. O prazo de retorno do investimento se tornou indispensavel para a conclusão do trabalho, descrevendo a importância da mudança no setor produtivo da organização.

Palavras chave: Custeio variável. Ceramista. Inovação. 


\section{INTRODUÇÃO}

Com o avanço da tecnologia as indústrias não conseguem acompanhar as inovações, desta forma, somente será utilizada uma nova tecnologia quando se alterar em algum aspecto o processo produtivo, segundo Oslo (2005, p.55) "A inovação de um processo é a implementação de um novo método." Com uma inovação podemos diminuir custos, aumentar produção, melhorar a qualidade de um produto ou serviço.

Muitos são os motivos que obrigam uma empresa a procurar por inovações. Assim, Goffin e Mitchell (2005, p.2 apud Lima et al, 2007, p.2) diz que: "Avanços tecnológicos, mudanças no ambiente da firma, mudanças nas necessidades dos consumidores e competitividade intensa são os fatores que levam a firma a buscar por inovações".

Na indústria cerâmica, a intensa competitividade é o fator de maior influência sobre os gestores, por existir muitas empresas fabricando um mesmo produto e em um mesmo município. Em segundo lugar, os avanços tecnológicos acontecem rapidamente, não sendo possível para pequenas indústrias acompanhar essas inovações.

Em tempos de crise, a concorrência aumenta, e, na maioria das micro indústrias não se conhece com clareza os custos dos produtos, assim, os gestores não sabem o ponto de equilíbrio, ficando impossível ser calculado a quantidade da produção que precisa ser vendida para cobrir seus custos.

Sem essas informações os gestores se preocupam em vender toda sua produção, não se importando com o preço e com a margem de contribuição que esse produto está agregando ao seu resultado.

Diante disso, fica evidente a real importância de um sistema de custos relacionado a tomada de decisões em uma empresa. Com relação a contabilidade de custos no auxílio a decisão, Martins (2003, p. 22) destaca que:

Com o significativo aumento de competitividade que vem ocorrendo na maioria dos mercados, seja industriais, comerciais ou de serviços, os custos tornam-se altamente relevantes quando da tomada de decisões em uma empresa. Isto ocorre pois, devido à alta competição existente, as empresas já não podem mais definir seus preços apenas de acordo com os custos incorridos, e sim, também, com base nos preços praticados no mercado em que atuam.

Neste quadro de alta competitividade, é vital a administração e o conhecimento dos custos de produção visando o auxílio na tomada de decisão, para que o gestor possa utilizar-se das devidas informações para obter melhores resultados na administração da empresa.

De acordo com Pires e Patrocínio (2004, p. 1) "para que o administrador possa planejar, realizar, coordenar, controlar e executar os processos, necessita informações confiáveis para a tomada de decisão." Sem as devidas informações, torna-se impossível ao gestor tomar decisões corretas, pois sempre existirá uma dúvida em relação aos resultados que serão alcançados

O presente trabalho, visando uma análise nos custos das inovações, para um melhor aproveitamento no sistema produtivo pretende responder a seguinte argumentação da pesquisa: De que maneira uma mudança no processo produtivo com a utilização de uma inovação tecnológica impactará na produção, na margem de contribuição e nos lucros de uma empresa do ramo ceramista?

\section{FUNDAMENTAÇÃO TEÓRICA \\ 2.1 CONTABILIDADE GERENCIAL}

A contabilidade gerencial visa produzir informações de acordo com as necessidades de tomada de decisão. Dessa forma, ela transforma dados registrados nas demonstrações financeiras em informações de cunho gerencial. Ela constitui de usuários internos da empresa, ou seja, os diretores, os administradores.

Segundo ludícibus (2000, p.27) A Contabilidade 
Gerencial, num sentido mais amplo, está direcionada exclusivamente para a administração da empresa, procurando somar informações que se encaixem de maneira válida e efetiva no modelo decisório das empresas. A Contabilidade Gerencial é caracterizada, como um enfoque especial contendo várias técnicas e procedimentos contábeis já conhecidos e tratados na Contabilidade de custos, financeiras e de balanços etc. colocados numa perspectiva diferente, num grau de detalhe mais analítico ou numa forma de apresentação e classificação diferenciada de maneira a auxiliar os gerentes das entidades em seu processo decisório.

O contador gerencial se tornou tão responsável pelo sucesso da empresa quanto o administrador, visto a importância da informação gerencial para a decisão, utilizando não apenas simples demonstrações, mas todos os documentos possíveis, desde balanços até relatórios da administração.

A contabilidade gerencial está diretamente ligada à contabilidade de custos, apesar de utilizar dados de outros setores da contabilidade, seu principal apoio está na contabilidade de custos, onde se encontram as principais informações do período, assim, diz Martins (2003, p.21): "Passou a contabilidade de custos a ser encarada como uma eficiente forma de auxílio no desempenho dessa nova missão, a gerencial".

\subsection{CONTABILIDADE DE CUSTOS}

A contabilidade de custos é a forma como vemos os gastos incorridos na preparação de produtos. Custo conforme Martins (2003): "O que deve ser despedido (em dinheiro, tempo, esforço, etc.) para se obter algo".

De acordo com Faria, a contabilidade de custos tem por objetivo a compilação, determinação e análise dos dados necessários para uma decisão segura, a qual é de vital importância para uma empresa que pretenda obter lucro pelos serviços prestados. Atribuir um preço de venda que não seja suficiente para cobrir os custos envolvidos na produção redundará em prejuízo para a firma.

É um sacrifício necessário para se obter resultado, um trabalho realizado com o objetivo de receber algo em troca. Por isso é necessário fazer uma análise de custos bem feita, sendo possível de imediato o aumento do lucro da empresa.

Segundo Bruni e Famá (2004, p.24)

A contabilidade de custos pode ser definida como o processo ordenado de usar os princípios da contabilidade geral para registrar os custos de operação de um negócio. Dessa forma, com operações coletadas das operações e das vendas, a administração pode empregar os dados contábeis e financeiros para estabelecer os custos de produção e distribuição, unitários ou totais, para um ou para todos os produtos fabricados ou serviços prestados, além dos custos das outras diversas funções do negócio, objetivando alcançar umas operações racionais, eficientes e lucrativas.

A contabilidade de custos vem sendo utilizada para auxilio no setor gerencial há poucas décadas, com isso, ainda tem muito a ser desenvolvida. Os princípios contábeis geralmente aceitos foram desenvolvidos para avaliação de estoques e não para auxiliar na administração das empresas. É um meio desenvolvido para coletar, interpretar e organizar os dados, com a finalidade de se obter uma apuração e demonstração dos resultados de certo período. Por ter se tornado uma informação extremamente confiável, a contabilidade de custos vêm sendo utilizada como uma excelente forma de auxilio, no controle e na tomada de decisão.

\subsubsection{CUSTEIO VARIÁVEL OU DIRETO}

O custeio variável ou direto aplica somente os gastos variáveis como custo dos produtos, os gastos fixos são considerados como despesas, eliminando os rateios. Esse custeio será adotado no decorrer deste trabalho por conter algumas vantagens no uso gerencial, pois apresenta a margem de contribuição e o ponto de equilíbrio que serão abordados na sequência.

Conforme Martins (2003, p.16) são agregados aos custos dos produtos, seus custos variáveis, sem 
os custos fixos, que por sua vez são tratados como despesa. Esse método não é aceito para utilização externa, é muito utilizado apenas para fins gerenciais por conter informações importantes como Margem de contribuição, Ponto de equilíbrio Contábil.

Margem de Contribuição: O conceito de margem de contribuição é um dos mais importantes conceitos quando se analisa tanto o preço de venda de um produto, como o resultado de um determinado mês. É relação entre custo, volume e lucro. É o excesso da receita de venda sobre os custos variáveis. De acordo com Martins (2003, p. 199) "é a diferença entre as receitas e a soma de custos e despesas variáveis". O conceito de margem de contribuição é especialmente útil no planejamento empresarial porque fornece informações sobre o potencial de lucro da empresa. Pode-se dizer que, é o quanto sobra do preço de um produto após subtrairmos dele todos os custos variáveis, ou seja aqueles que só ocorrem no momento da venda da produção.

Ponto de Equilíbrio Contábil: Também denominado de ponto de ruptura, é onde as receitas e as despesas totais se encontram, gerando assim um resultado nulo. O nível de operação no qual as receitas e os custos de uma empresa são exatamente iguais. Em equilíbrio, uma empresa não tem lucro nem prejuízos operacional. Para Martins (2003, p.274) "é a capacidade de operação mínima sem ter prejuízos". O ponto de equilíbrio é útil no planejamento empresarial, especialmente quando as operações se expandem ou encolhem. O ponto de equilíbrio será alcançado quando a soma da margem de contribuição totalizar o montante suficiente para cobrir todos os custos e despesas fixas.

\subsection{INOVAÇÃO TECNOLÓGICA}

Um dos desafios do século XXI é o gerenciamento de uma maneira geral. Com o acelerado crescimento das relações profissionais e o alto índice de informações que temos de absorver todos os dias, torna-se cada vez mais necessária à interação entre o ser humano e a tecnologia. Mas para que esse objetivo seja atingido, é preciso que todos saibam como lidar com a inovação tecnológica, ou seja, como administrar as diversas possibilidades de acompanhá-la.

Em muitos casos, a inovação dependerá mais de como for elaborada a gestão do que de outros fatores. Sob este ponto de vista, a inovação depende da estratégia da gestão, capaz de antecipar necessidades, monitorar a tecnologia, controlar custos; da promoção de flexibilidade; da cooperação com centros exteriores de conhecimento, da formação contínua (REIS, 2008).

Os aspectos organizacionais, a estrutura financeira $e$ comercial, estão envolvidos no processo de inovação, pois, irão dar suporte para a nova forma de tomar decisões e até mesmo na forma de administrar, provocando uma melhoria de processo e na empresa como um todo, tendo maior velocidade nas resoluções de seus problemas.

\section{METODOLOGIA}

É de suma importância para a elaboração de um trabalho científico, utilizar métodos que mostrem e apontem o melhor caminho a ser seguido para que o mesmo seja contemplado por todos.

Para que o trabalho se desenvolva, neste capítulo serão abordados os métodos e procedimentos da pesquisa utilizados para a elaboração do mesmo. Gil (2010, p.26) afirma que: "Pode-se definir método como caminho para se chegar a determinado fim, e método científico como o conjunto de procedimentos intelectuais e técnicos adotados para se atingir o conhecimento".

Quanto aos objetivos; o estudo é do tipo descritivo, utilizando-se de coleta de dados padronizadas. A pesquisa descritiva tem como principal objetivo descrever características de determinada população ou fenômeno. De acordo com Andrade (1995, p.98) "os fatos são observados, registrados, analisados, classificados e interpretados, sem que o pesquisador interfira neles".

O estudo descritivo exige do pesquisador uma delimitação precisa de técnicas, métodos, modelos e teorias que orientarão a coleta e interpretação dos dados, conforme Beuren (2013 p.81): "A pesquisa 
descritiva preocupa-se em observar os fatos, registrálos, analisá-los, classificá-los e interpretá-los, e o pesquisador não interfere neles". Esta pesquisa será descritiva registrando os dados sobre os custos de produção, analisando os custos antes e após a mudança no sistema produtivo.

Quanto aos procedimentos; bibliográfica, reunindo materiais já elaborados, principalmente livros e artigos científicos, conforme Santos et al (2007, p.127) "É um estudo organizado sistematicamente com base em materiais publicados." Foi feito um estudo da contabilidade gerencial, contabilidade de custos, se aprofundando no sistema de custeio que será adotado.

Estudo de caso, caracterizado, segundo Beuren (2013, p.84), "pelo estudo de um único caso". Onde, um estudo aprofundado de determinada situação, poderá gerar riqueza de informações e possível resolução de problemas relacionados ao assunto estudado. Foi feito um levantamento de todos os custos no ciclo operacional fazendo um comparativo antes e após a mudança no processo produtivo.

Quanto à abordagem do problema, foi qualitativa, descrevendo a complexidade de determinado problema, concebendo uma análise aprofundada do fenômeno que foi estudado.

Beuren (2013, p. 91) observa: "Os estudos que empregam uma metodologia qualitativa podem descrever a complexidade de determinado problema, analisar a interação de certas variáveis, e compreender e classificar processos dinâmicos vividos por grupos sociais".

$\mathrm{Na}$ pesquisa qualitativa concedem-se analises mais profundas, esta abordagem visa destacar características não observadas por meio de um estudo quantitativo. Foi feita uma análise sobre uma mudança no processo produtivo, visando aumentar a produtividade e diminuir os custos.

A população e a amostra também devem ser delimitadas. Como se trata de um estudo de caso pretende-se fazer uma pesquisa com apenas uma única empresa, assim sendo, a amostra utilizada na pesquisa será uma única empresa. De acordo com Beuren (2013, p.118) "População ou universo da pesquisa é a totalidade de elementos distintos que possui certa paridade nas características definidas para determinado estudo".

\section{ESTUDO DE CASO}

A empresa alvo deste estudo não apresenta nenhum tipo de controle sobre os ativos imobilizados. Objetivando um valor mais próximo ao praticado pelo mercado, será feito um levantamento, os ativos adquiridos usados ou que já foram totalmente depreciados serão reavaliados a um preço próximo ao de mercado, levando como base o tempo de uso e o estado de conservação dos mesmos. Para os ativos adquiridos novos e/ou não depreciados totalmente, serão utilizados os valores das notas fiscais.

AMatériaPrimautilizadanaindústriacerâmicaésomente argila apropriada que pode ser encontrada facilmente em vários lugares da região de Prudentópolis, deve ser seguida uma série de processos de legalização junto aos órgãos regulamentadores, sendo os principais: Instituto Ambiental do Paraná - IAP, Departamento Nacional de Produção Mineral - DNPM. Logo após a jazida ser devidamente autorizada, pode ser iniciada a lavra.

A empresa não faz a compra da MP utilizada no processo produtivo, a mesma dispõe de uma jazida de extração própria, localizada a 6 quilômetros da fábrica, não dispõe ainda de nenhum tipo de controle sobre a utilização da MP, simplesmente calcula a MP utilizada no processo anualmente a partir de um índice médio informado pelos profissionais responsáveis pela contabilidade, sendo 1,5 m3 de argila para cada

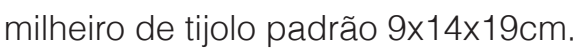

Para o cálculo da matéria Prima utilizada, temos os pesos unitários dos produtos, e sabemos que para o tijolo 9x14x19 são necessários 1,5 m3 de argila para cada milheiro, sendo assim, $2.250 \mathrm{~kg}$ (peso por milheiro) divididos por 1,5 m3 (necessários para cada milheiro) temos $1.500 \mathrm{~kg}$ a cada m3 de argila. Divido o peso de cada milheiro de produto por 1.500 (peso por m3de argila) chegando ao consumo de MP necessária 
para cada milheiro de cada produto.

Assim teremos $1,5 \mathrm{~m} 3$ de argila para cada milheiro de tijolos 9x14×19, 1,7666667m3 de argila para cada milheiro de tijolos $11,5 \times 14 \times 24$ e para cada milheiro de lajotas $\mathrm{H} 7 \times 25 \times 19$, e ainda $1,0666667 \mathrm{~m} 3$ de argila para cada milheiro de tijolos 2 furos.

Como a empresa é proprietária da jazida de extração a mais de quinze anos, será desconsiderado a exaustão da mesma e será adotado o valor da argila para ser adquirida nas redondezas da fábrica. Para o cálculo do custo da argila será adotado o valor de $\mathrm{R} \$ 5,00$ para cada m3 de argila que foi informado pelo empresário sendo o valor cobrado pelo mercado local, conforme relatório das vendas, fornecido pelo empresário.

Dados referentes aos meses de janeiro a abril antes da mudança no processo produtivo:

Dados do mês de janeiro: a empresa teve uma

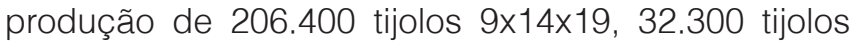
11,5×14x24, 29.500 Lajotas $h 7 \times 25 \times 19$ e 14.500 tijolos 2 furos, tendo um consumo mensal de $434,253 \mathrm{~m} 3$ de argila, chegamos a um custo total com matéria prima de $R \$ 2.171,27$.

Dados do mês de fevereiro: a empresa apresentou uma produção de 254.235 tijolos 9x14x19, 21.000 tijolos $11,5 \times 14 \times 24,34.400$ lajotas $h 7 \times 25 \times 19$, sendo seus respectivos consumos por milheiro 1,5 m3, 1,767 m3 e 1,767 m3, chegando a um consumo mensal de $479,22 \mathrm{~m} 3$ de argila, com um custo total de $\mathrm{R} \$ 2.396,10$.

Dados do mês de março: A produção referente ao

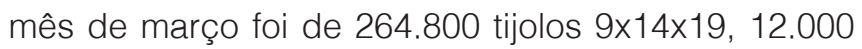
tijolos $11,5 \times 14 \times 24$, e 37.800 lajotas $h 7 \times 25 \times 19$, com um consumo mensal de matéria prima de 485,18 m3, totalizando $R \$ 2.425,90$ os custos com matéria prima.

Dados do mês de abril: a empresa teve uma produção

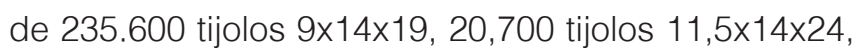
37.300 lajotas $h 7 \times 25 \times 19,5.000$ tijolos 2 furos, apresentando um consumo mensal de $461,91 \mathrm{~m} 3$ de argila, chegando a um custo total com matéria prima de $R \$ 2.309,55$.
Na sequência é apresentado as demonstrações dos resultados dos exercícios e tomam por base o custeio variável a escolha desse sistema de custeio, foi feita visando uma abordagem gerencial da empresa, para tomada de decisão, o custeio adotado é o que melhor apresenta a margem de contribuição e ponto de equilíbrio.

No mês de janeiro a empresa apresentou um lucro líquido de $R \$ 16.228,50$, seus custos fixos foram de $R \$$ 24.378,09, os custos variáveis, onde estão os valores de Matéria prima, combustíveis, insumos, luz e a Mão de obra referente a produção, foram de $\mathrm{R} \$ 32.279,21$.

Para o cálculo da margem de contribuição serão deduzidos os custos variáveis do montante de vendas, ficando assim:

Quadro 01: Margem de contribuição mês de janeiro

\begin{tabular}{|ll|l|} 
Receita & $\mathrm{R} \$ 79.907,00$ & $100 \%$ \\
\cline { 2 - 3 } (-) Custos variáveis & $\mathrm{R} \$ 32.279,21$ & $40,39 \%$ \\
\hline = Margem de contribuição & $\mathrm{R} \$ 47.627,79$ & $59,61 \%$ \\
\hline
\end{tabular}

Fonte: Os autores

Para o ponto de equilíbrio, serão divididos os custos e despesas fixas pela \% da margem de contribuição.

$$
\begin{gathered}
P E=\text { Custos fixos/MC } \\
P E=24.378,09 / 0,5961 \\
P E=R \$ 40.895,97
\end{gathered}
$$

No mês de fevereiro, a venda bruta foi de $R \$$ $87.761,30$, os custos variáveis foram de $\mathrm{R} \$ 36.047,68$, e as despesas fixas, $R \$ 24.163,99$. Para o cálculo da margem de contribuição serão deduzidos os custos variáveis do montante de vendas, ficando assim:

Quadro 02: Margem de contribuição mês de fevereiro

\begin{tabular}{|l|l|l|} 
Receita & $\mathrm{R} \$ 87.761,30$ & $100 \%$ \\
\hline $\begin{array}{l}\text { (-) Custos variáveis } \\
\text { = Margem de contribuição }\end{array}$ & $\mathrm{R} \$ 36.047,68$ & $41,07 \%$ \\
\hline
\end{tabular}

Fonte: Os autores

Para o ponto de equilíbrio, serão divididos os custos e 
despesas fixas pela margem de contribuição.

$$
\begin{gathered}
P E=24.163,99 / 0,5892 \\
P E=R \$ 41.007,83
\end{gathered}
$$

Assim, a empresa precisaria vender ao menos $R \$$ 41.007,83 para cobrir suas despesas e não apresentar prejuízo no mês de Fevereiro.

No mês de março, os custos variáveis foram de $R \$$ $38.547,14$, os custos fixos foram de $\mathrm{R} \$ 23.944,71$. Cálculo da margem de contribuição e referente ao mês de março:

Quadro 03: Margem de contribuição mês de março

\begin{tabular}{|l|l|l|} 
Receita & $\mathrm{R} \$ 88.078,00$ & $100 \%$ \\
\hline (-) Custos variáveis & $\mathrm{R} \$ 38.547,14$ & $43,76 \%$ \\
\hline = Margem de contribuição & $\mathrm{R} \$ 49.530,86$ & $56,23 \%$ \\
\hline
\end{tabular}

Fonte: Os autores

Para o ponto de equilíbrio, serão divididos os custos e despesas fixas pela margem de contribuição.

$$
\begin{gathered}
P E=23.944,71 / 0,5623 \\
P E=R \$ 42.579,56
\end{gathered}
$$

Assim, a empresa precisaria vender ao menos $R \$$ 42.579,56 para cobrir suas despesas e não apresentar prejuízo no mês de março.

No mês de abril a empresa apresentou uma venda bruta de $R \$ 84.534,00$, seus custos fixos foram de $R \$$ $24.587,17$, os custos variáveis foram de $\mathrm{R} \$ 39.799,42$.

Para o cálculo da margem de contribuição serão deduzidos os custos variáveis do montante de vendas, ficando assim:

Quadro 04: Margem de contribuição mês de abril

\begin{tabular}{|l|l|l|} 
Receita & $\mathrm{R} \$ 84.534,00$ & $100 \%$ \\
\hline $\begin{array}{l}\text { (-) Custos variáveis } \\
\text { = Margem de contribuição }\end{array}$ & $\mathrm{R} \$ 39.799,42$ & $47,08 \%$ \\
\hline & $\mathrm{R} \$ 44.734,58$ & $52,91 \%$ \\
\hline
\end{tabular}

Fonte: Os autores
Para o ponto de equilíbrio, serão divididos os custos e despesas fixas pela margem de contribuição e multiplicando pela venda total.

$P E=24.587,17 / 0,5291$

$P E=R \$ 46.461,86$

Assim, a empresa precisaria vender ao menos $R \$$ 46.461,86 para cobrir suas despesas e não apresentar prejuízo no mês de Abril.

\subsection{MUDANÇA NO PROCESSO PRODUTIVO}

A inovação alvo deste estudo é a aplicação de um sistema semi automatizado para o transporte dos produtos, substituindo o método manual hoje empregado pela empresa. Neste novo método pretende-se estudar a viabilidade da mudança abordando a substituição de parte da mão de obra por uma empilhadeira e o aumento da capacidade de secagem nas instalações, substituindo as prateleiras fixas com baixa capacidade de estocagem utilizadas pela empresa por prateleiras móveis com uma maior capacidade de estocagem e secagem.

A empilhadeira será responsável pelo transporte dos produtos desde a fabricação até o processo de secagem, e após a secagem fará o transporte dos mesmos até a queima, dispensando assim o uso de carrinhos manuais utilizados pela empresa. As prateleiras móveis serão reutilizadas na produção toda vez que forem esvaziadas pela área de queima, estabelecendo assim um rodízio nas mesmas.

A empresa dobrou a capacidade de armazenamento em uma pequena parte da secagem graças ao uso da empilhadeira, permitindo que seja utilizado o espaço aéreo, com duas prateleiras móveis de altura, totalizando assim 4 metros, onde com as prateleiras fixas poderiam ser utilizados apenas 2 metros de altura. Com o aumento na capacidade de secagem a empresa aumentará em aproximadamente 60.000 tijolos/mês sua produção.

Dados referentes aos meses de janeiro a abril depois da mudança no processo produtivo: 
No mês de janeiro a empresa apresentou um lucro líquido de $R \$ 21.983,47$, seus custos fixos foram de $R \$$ $26.428,09$, os custos variáveis foram de $\mathrm{R} \$ 32.680,51$.

Para o cálculo da margem de contribuição serão deduzidos os custos variáveis do montante de vendas, ficando assim:

Quadro 05: Margem de contribuição mês de janeiro

\begin{tabular}{|l|l|l|} 
Receita & $\mathrm{R} \$ 88.907,00$ & $100 \%$ \\
\hline (-) Custos variáveis & $\mathrm{R} \$ 32.680,51$ & $36,75 \%$ \\
\hline = Margem de contribuição & $\mathrm{R} \$ 56.226,49$ & $63,24 \%$ \\
\hline
\end{tabular}

Fonte: Os autores

Para o ponto de equilíbrio, serão divididos os custos e despesas fixas pela \% da margem de contribuição.

$$
\begin{gathered}
P E=26 \cdot 428,09 / 0,6324 \\
P E=R \$ 41.788,88
\end{gathered}
$$

Assim, a empresa precisaria vender ao menos $\mathrm{R} \$$ 41.788,88 para cobrir suas despesas e não apresentar prejuízo no mês de Janeiro.

No mês de fevereiro, a venda bruta foi de $\mathrm{R} \$ 99.761,30$, os custos variáveis foram de $R \$ 37.169,04$, e as despesas fixas, $\mathrm{R} \$ 26.213,99$.

Para o cálculo da margem de contribuição serão deduzidos os custos variáveis do montante de vendas, ficando assim:

Quadro 06: Margem de contribuição mês de fevereiro

\begin{tabular}{|l|l|l|} 
Receita & $\mathrm{R} \$ 99.761,30$ & $100 \%$ \\
\hline (-) Custos variáveis & $\mathrm{R} \$ 37.169,04$ & $37,25 \%$ \\
\hline = Margem de contribuição & $\mathrm{R} \$ 62.592,26$ & $62,74 \%$ \\
\hline
\end{tabular}

Fonte: Os autores

Para o ponto de equilíbrio, serão divididos os custos e despesas fixas pela margem de contribuição.

$$
\begin{gathered}
P E=26.213,99 / 0,6274 \\
P E=R \$ 41.780,59
\end{gathered}
$$

Assim, a empresa precisaria vender ao menos $\mathrm{R} \$$ 41.780,59 para cobrir suas despesas e não apresentar prejuízo no mês de Fevereiro.

No mês de março, os custos variáveis foram de $R$ \$ $39.844,92$, os custos fixos foram de $\mathrm{R} \$ 25.994,71$.

Cálculo da margem de contribuição e referente ao mês de março:

Quadro 07: Margem de contribuição mês de março

\begin{tabular}{|l|l|l|} 
Receita & $\mathrm{R} \$ 108.078,00$ & $100 \%$ \\
\hline (-) Custos variáveis & $\mathrm{R} \$ 39.844,92$ & $39,81 \%$ \\
\hline = Margem de contribuição & $\mathrm{R} \$ 60.233,08$ & $60,18 \%$ \\
\hline
\end{tabular}

Fonte: Os autores

Para o ponto de equilíbrio, serão divididos os custos e despesas fixas pela margem de contribuição.

$$
P E=25.994,71 / 0,6018
$$$$
P E=R \$ 43.190,53
$$

Assim, a empresa precisaria vender ao menos $\mathrm{R} \$$ 43.190,53 para cobrir suas despesas e não apresentar prejuízo no mês de março.

No mês de abril a empresa apresentou uma venda bruta de $R \$ 96.534,00$, seus custos fixos foram de $R \$$ $26.637,17$, os custos variáveis foram de $R \$ 41.077,58$.

Para o cálculo da margem de contribuição serão deduzidos os custos variáveis do montante de vendas, ficando assim:

Quadro 08: Margem de contribuição mês de abril

\begin{tabular}{|l|l|l|}
\hline Receita & $\mathrm{R} \$ 96.534,00$ & $100 \%$ \\
\hline (-) Custos variáveis & $\mathrm{R} \$ 41.077,58$ & $42,55 \%$ \\
\hline = Margem de contribuição & $\mathrm{R} \$ 55.456,42$ & $57,44 \%$ \\
\hline
\end{tabular}

Fonte: Os autores

Para o ponto de equilíbrio, serão divididos os custos e despesas fixas pela margem de contribuição e multiplicando pela venda total. 
$P E=26.637,17 / 0,5744$

$P E=R \$ 46.367,81$

Assim, a empresa precisaria vender ao menos $R \$$ 46.367,81 para cobrir suas despesas e não apresentar prejuízo no mês de Abril.

Comparação entre antes e depois da mudança no sistema produtivo: Mês de Janeiro.

Gráfico 01 - Janeiro

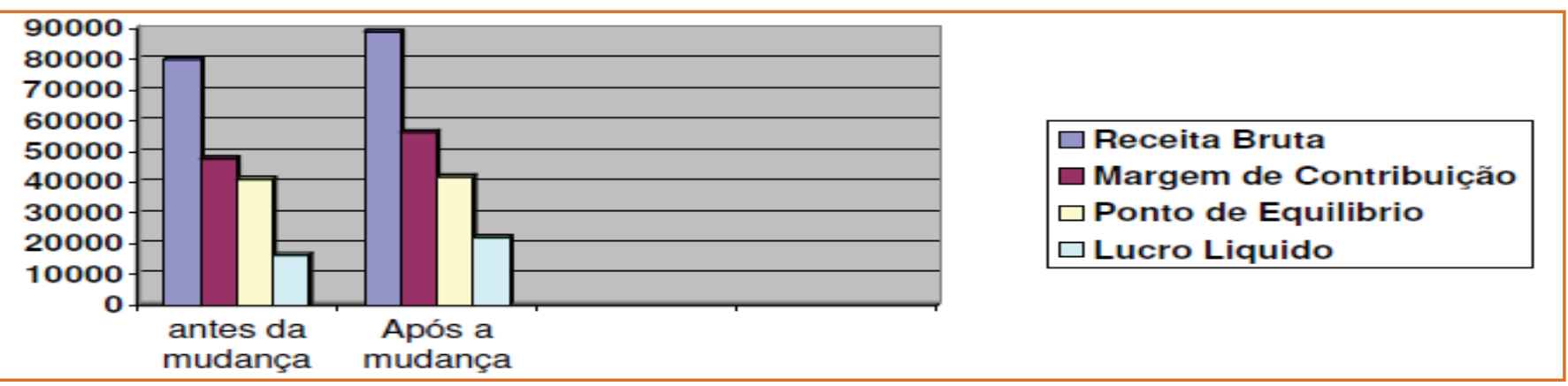

Fonte: Os autores

Com base no gráfico 1, referente ao mês de janeiro, fica evidente o aumento na receita bruta, na margem de contribuição e por consequência no lucro líquido, evidenciando assim a viabilidade financeira em uma mudança no sistema produtivo.

\section{Gráfico 02 - Fevereiro}

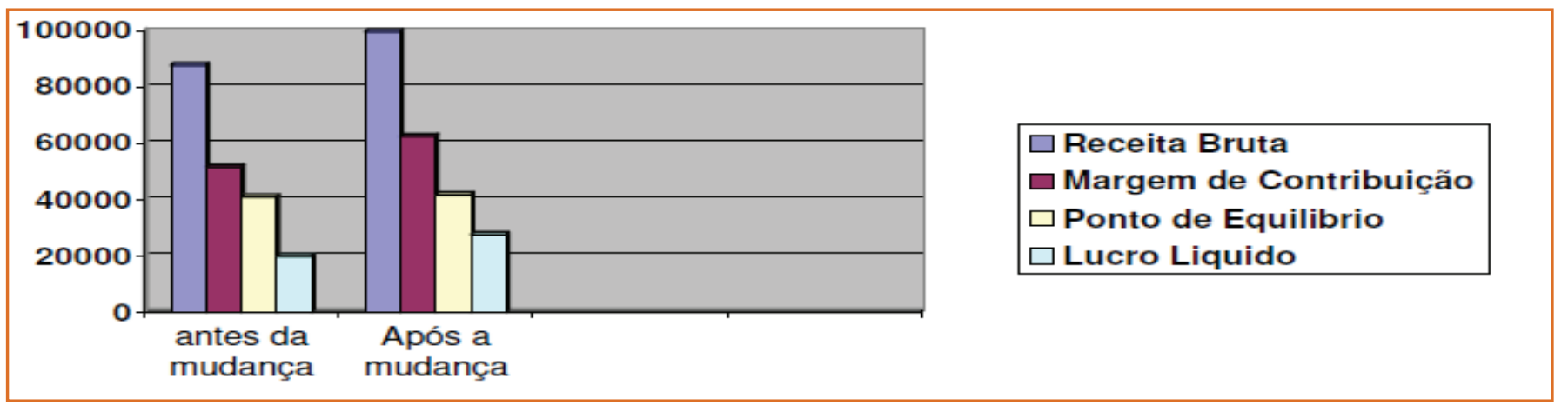

Fonte: Os autores

Com base no gráfico 2, referente ao mês de fevereiro, a empresa obteve um aumento considerável nos lucros e na receita bruta, porem o ponto de equilíbrio teve uma oscilação desconsiderável.

\section{Gráfico 03 - Março}

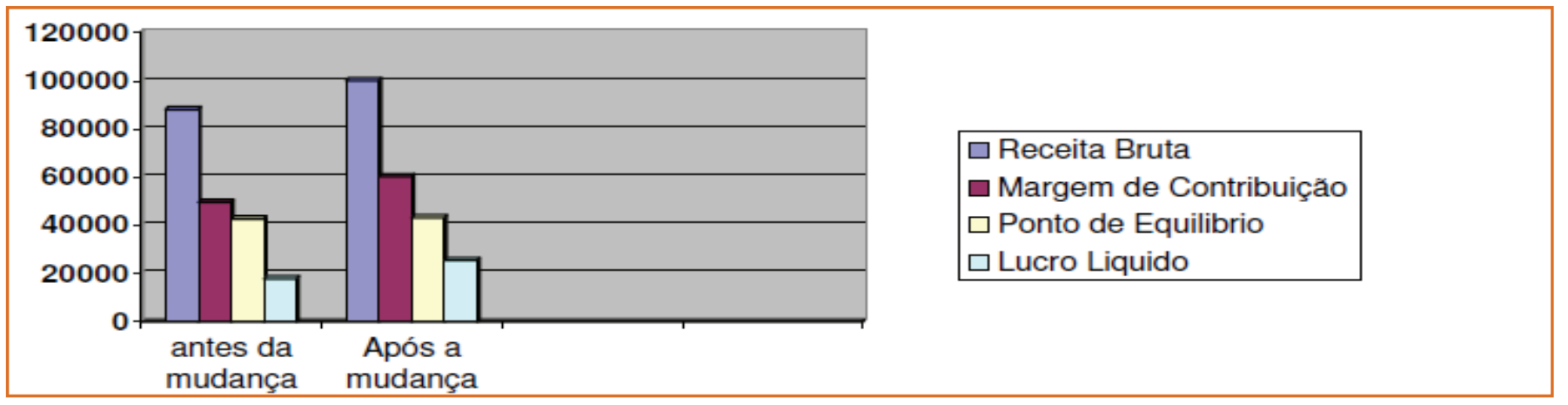

Fonte: Os autores 


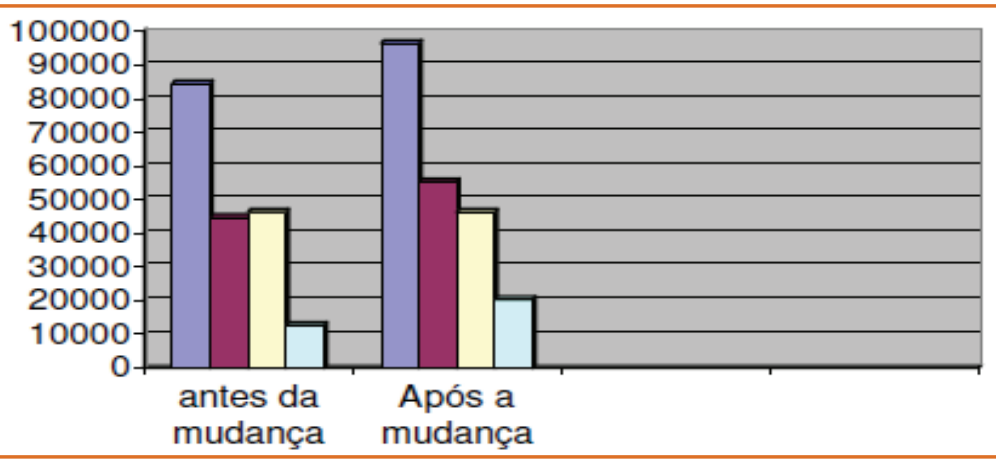

$\square$ Receita Bruta
$\square$ Margem de Contribuição
$\square$ Ponto de Equilibrio
$\square$ Lucro Liquido

Fonte: Os autores

Com base no gráfico 4, referente ao mês de abril, o ponto de equilíbrio manteve-se ainda com pouca oscilação, a receita bruta teve um aumento considerável, a margem de contribuição e o lucro apresentaram um aumento considerável.

\section{CONCLUSÕES}

O objetivo geral deste trabalho consistiu em realizar um estudo sobre uma mudança no sistema produtivo através de uma inovação tecnológica para o aumento da capacidade no setor de secagem de uma indústria cerâmica com a finalidade de diminuir custos e aumentar os lucros.

A margem de contribuição aumentou em todos os exercícios, o aumento maior foi de $24 \%$ e tendo uma média de aumento de $21,17 \%$. O ponto de equilíbrio teve uma pequena oscilação nos quatro exercícios, em média $1,33 \%$, de janeiro a março foram aumentos e em abril teve uma redução de $-0,20 \%$.

A argumentação da pesquisa: De que maneira uma mudança no processo produtivo com a utilização de uma inovação tecnológica impactará na produção, na margem de contribuição e nos lucros de uma empresa do ramo ceramista, chega à conclusão de que apesar de todos os aumentos com os custos e despesas, houve um aumento na produtividade e ao final dos quatro exercícios a empresa obteve um aumento médio de $44,26 \%$ nos lucros líquidos em cada exercício estudado.

\section{REFERÊNCIAS}

[1] ANDRADE, Maria Margarida de: Introdução à metodologia do trabalho cientifico: elaboração de trabalhos acadêmicos, São Paulo: Atlas, 1995.

[2] BEUREN Ilse Maria; Como elaborar trabalhos monográficos em contabilidade, 3aㅡ Ed. São Paulo:Atlas, 2013.

[3] BRUNI, Adriano Leal. FAMÁ, Rubens. Gestão de Custos e Formação de Preços. São Paulo: Atlas, 2004.

[4] GIL, Antonio Carlos. Como elaborar projetos de pesquisa , 5 Ed. São Paulo: Atlas, 2010.

[5] IUDÍCIBUS, Sérgio de; Teoria da Contabilidade, São Paulo: Atlas,2000.

[6] LIMA, André Fernandes; BASSO, Leonardo Fernando Cruz; KAYO, Eduardo Kazuo; KIMURA, Herbert. Risco e inovação de produtos: um estudo de empresas manufatureiras brasileira, Universidade Presbiteriana Mackenzie, 7응 congresso USP de controladoria e contabilidade, 2007.

[7] Manual de OSLO. Diretrizes para coleta e interpretação de dados sobre inovação, 3를 Ed, 2005; Traduzido por FINEP - Financiadora de Estudos e Projetos - Disponível em (www. oei.es/salactsi/oslo4) acesso em 4 ago. 2015.

[8] MARTINS, Eliseu. Contabilidade de custos, 9a Ed. São Paulo: Atlas, 2003.

[9] PIRES, Wanderlei Augusto Filho, PATROCíNIO, Marcelo Clemente do: A contabilidade de custos como ferramenta para tomada de decisão, Fundação Escola de Comércio Álvares Penteado, Congresso de Custos, 2004. 
[10] REIS, Dálcio Roberto dos. Gestão da Inovação Tecnológica. Barueri, São Paulo: Manole. 2008,
[11] SANTOS, Gisele do Rocio Cordeiro Mugnol, et al: Orientações e dicas práticas para trabalhos Acadêmicos, Curitiba: Ibpex, 2007. 


\section{CAPÍTULO 13}

\section{ANÁLISE DAS PERDAS EM PROCESSOS PRODUTIVOS EM EMPRESAS DE TRANSFORMAÇÃo LOCALIZADAS NO PERÍMETRO DA ZONA INDUSTRIAL DE SUAPE/PE}

Juliana Valença de Sousa

Taciana de Barros Jerônimo

Fagner José Coutinho de Melo

Joás Tomaz de Aquino

Resumo: Este estudo é de cunho qualitativo e tem como objetivo analisar os principais fatores de perdas nos processos produtivos nas indústrias manufatureiras que utilizam o Just in Time (JIT) localizadas na Zona Industrial de SUAPE/PE. A coleta de dados ocorreu por meio de questionários e entrevistas estruturadas. Esta resposta será de forma descritiva para melhor esclarecimento do fenômeno, pois há escasso conhecimento sobre o problema pesquisado. Os resultados encontrados apontam que os objetivos apresentados para sua implantaçáo foram o aumento da produtividade e a redução de custos dentro da seção de manufatura. O percentual sobre a percepção da redução de perdas e na economia de recursos está em torno de $52 \%$ em relação à percepção das melhorias.

Palavras chave: Just in Time, Perdas, Processos Produtivos 


\section{INTRODUÇÃO}

$\mathrm{Na}$ atual conjuntura política, econômica e social que o Brasil vive, juntamente com o aumento da concorrência entre as organizações, vem forçando um direcionamento das empresas por transformações em seus processos produtivos no sentido de se tornarem mais flexíveis. Dessa forma, para uma empresa atender o mercado e manter-se competitiva, se faz necessário maior flexibilização na produção e a busca contínua pelo aumento de sua produtividade e eficiência (BORNIA, 1995; CUNHA; SEVERIANO FILHO; WANDERLEY, 2002), e para o atendimento dessa necessidade pode-se adotar, por exemplo, o Sistema Toyota de Produção (STP) e o Just In Time (JIT).

Os dois exemplos anteriores promovem eficiência produtiva, por meio da eliminação de desperdícios. Além de maior envolvimento dos funcionários, já que o JIT também funciona como uma filosofia de produção (SLACK; JOHNSTON, 2007; MOTTA, 2011) atacando sistematicamente qualquer processamento que não agregue valor ao produto (MOROZ, 2009; SHINGO, 1986).

Diante a este cenário, o presente trabalho visa analisar as perdas através do STP nas linhas de produção de empresas que utilizem o JIT e que estejam dentro do perímetro de SUAPE. A justificativa da escolha do Complexo Industrial Portuário Eraldo Gueiros SUAPE é a sua importância como ativo facilitador de negócios para o estado de Pernambuco (SUAPE, 2010; OLIVEIRA, 2013). Ele está localizado na Região Metropolitana de Recife - RMR, entre as cidades de Ipojuca e Cabo de Santo Agostinho, no litoral Sul pernambucano. Ele possui várias empresas ao seu entorno e, a cada dia, promove a inclusão de novas empresas, como exemplo: a chegada da montadora Toyota, que irá implantar um centro de distribuição (CD) com a finalidade de abastecer as concessionárias das regiões vizinhas, entre outros casos. Gerando uma movimentação na ordem de $\mathrm{R} \$ 3$ bilhões nos próximos anos para dinamizar os empreendimentos locais e nacionais (MORAES; CLEMENTE, 2015).

\section{REVISÃO DA LITERATURA 2.1. O SISTEMA TOYOTA DE PRODUÇÃO}

Frente às novas necessidades demandadas pelo mercado, as empresas viram-se obrigadas a se reorganizarem e a mudarem seus modelos de gerenciamento de processos, para uma abordagem mais enxuta, como o STP. Este é um sistema de produção considerado mais eficiente, flexível, ágil e inovador (SHINGO, 1996a; 1996b).

Ele tem importância, principalmente, por não ser apenas mais um modelo, ou uma técnica de produção japonesa "milagrosa" de "estoque zero", e sim uma filosofia de negócio que otimiza a organização visando o melhor atendimento às necessidades do cliente. Da mesma forma que melhora a segurança e a moral de seus membros. O STP apoia-se em um encadeamento de valores, processos, técnicas, filosofia e fundamentos de longo prazo com foco no cliente, como se pode observar na Figura 1, também conhecida como a casa do STP. Nela há dois pilares de sustentação, são eles: pilar Jidoka (palavra japonesa para autonomação ou automação com toque humano) e o Just in Time.

Figura 1 - O sistema Toyota de produção

\begin{tabular}{|c|c|c|c|}
\hline \multicolumn{4}{|c|}{$\begin{array}{l}\text { Melhor Qua lidade - Menor Custo - Menor Lead Time - Mais Segurança - Mora } \\
\text { Alto - Envolvimento } \\
\text { através da redução do fluxo de produção pela eliminação dos desperdícios }\end{array}$} \\
\hline \multirow{6}{*}{$\begin{array}{l}\text { JUST-IN-TIME } \\
\text { A Pesacerta, } \\
\text { Na Quantidade Certa, } \\
\text { NoTempo Certo } \\
\text { - Planejamento Takt time } \\
\text { - Fluxo Continuo } \\
\text { - Sistema Puxado } \\
\text { - Kanban } \\
\text { - Set Up (Troca Rápica de } \\
\text { Ferramentas) } \\
\text { - Logistíca Integrada - } \\
\text { Entrega/Delivery }\end{array}$} & \multicolumn{2}{|c|}{ Pessoas \& Equipe de Trabalho } & \multirow{6}{*}{$\begin{array}{l}\text { JIDOKA } \\
\text { Qualidade no Setor } \\
\text { "Tornar os Problemas Visiveis" } \\
\text { - Poka Yoke- Paradas } \\
\text { Automáticas } \\
\text { - Andon } \\
\text { - Separação Pessoa-Máquina } \\
\text { - Verificando Erros } \\
\text { - Controle de Qualidade no } \\
\text { Setor } \\
\text { - Soluacão na Origem dos } \\
\text { Problemas (5 Por quês?) }\end{array}$} \\
\hline & \multirow{4}{*}{\multicolumn{2}{|c|}{ 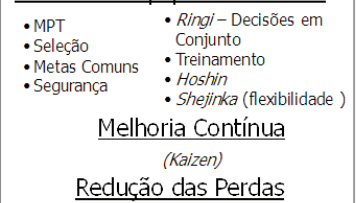 }} & \\
\hline & & & \\
\hline & & & \\
\hline & & & \\
\hline & $\begin{array}{l}\text { - Genchi Genbutsu } \\
\text { Sujar as mãos } \\
\text { - } 5 \text { Por quês }\end{array}$ & $\begin{array}{l}\text { - Visão Para as Perdas - } \\
\text { ordem visual } 5 \mathrm{~S} \\
\text { - Solução de Problemas } \\
\text { - Soikufu (criatividade) }\end{array}$ & \\
\hline \multicolumn{4}{|c|}{ Produção Nivelada (Heijunka) } \\
\hline \multicolumn{4}{|c|}{ Manutenção Produtiva Total, Processos Estáveis e Padronizados } \\
\hline \multicolumn{4}{|c|}{ Gerenciamento Visual (5S) } \\
\hline \multicolumn{4}{|c|}{ Filosofia Tovota } \\
\hline
\end{tabular}

Fonte: Adaptado de Liker (2005, p.51).

O foco em qualidade ocorre pela "humanização da interface entre operador e máquina" (SLACK; JOHNSTON, 2007, p. 465), ou seja, através de dispositivos ou máquinas ou sistemas ligados ou não a outros sistemas, sendo os mesmos automáticos ou 
não, manipulados ou não pelo toque humano, que objetivam a identificação de qualquer falha (PERGHER; RODRIGUES; LACERD, 2011). Em caso de detecção de falhas ou problemas há uma parada automática, para que este exercite seu julgamento, proponha uma solução corretiva e investigue as suas causas.

\subsection{O SISTEMA JUST IN TIME}

O Just in Time (JIT) de acordo com Slack e Johnston (2007) e Moreira (2009), significa produzir bens e serviços exatamente no momento em que são necessários - não antes, para não existir estoque, nem depois, para não gerar espera; e assim, manter apenas os processos juntos (SHIMOKAWA, 2011).

Ele possui um conjunto de várias práticas, ferramentas e técnicas analíticas que auxiliam o gerenciamento da produção na eliminação dos desperdícios. Slack e Johnston (2007, p. 469) listam os seguintes aspectos relacionados a esse sistema: "práticas básicas de trabalho; projeto para manufatura; foco na produção; máquinas pequenas e simples; arranjo físico e fluxo; TPM (do inglês total Productive Maintenance ou Manutenção Preditiva); redução de set up; envolvimento total das pessoas; visibilidade; fornecimento JIT".

O JIT funciona também como modelo, técnica ou método de planejamento e controle de produção, do tipo fazer-contra-pedido (ou make-to-order), ou seja, manter em estoque seus recursos transformadores ou seus recursos a serem transformados. Encurtando o tempo de lead time (ou tempo de processamento). Nesse caso, trabalha-se em um sistema onde as peças devem ser retiradas pelos processos posteriores, através de "etiquetas de controle" denominado pela palavra japonesa kanban (OHNO; MITO, 1988; KUMAR; PANNEERSELVAM, 2007). Acarretando uma melhor "sincronização" de produtos ou partes destes, e separá-los por frequência de produção (ANTUNES et al., 2008) para redução de perdas e desperdícios.

\subsection{TIPOS DE PERDAS OU DESPERDÍCIOS}

Conforme Shingo (1986, p. 131) "a função processo consiste de processamento, inspeção, transporte e estocagem". Porém, apenas o processamento agrega valor. Ohno e Mito (1988, p. 73) corroboram usando o termo desperdício como "movimento repetido e desnecessário que deve ser imediatamente eliminado".

Sobre a quantidade e a classificação dos tipos de perdas ou desperdícios, Shingo (1996), Ohno e Mito (1988), Liker (2005) e Antunes et al. (2008) enumeram oito tipos, a saber:

a) Produção - há dois tipos, por quantidade, gerando uma superprodução e por antecipação, ou seja, produzindo antes do tempo pré-estabelecido. É considerado uma das mais danosas pelo STP e podem ser informações retidas ou estoque físico;

b) Espera - podem ser enumerados em: espera do operador, espera no processo, espera do lote, espera do equipamento, geram filas e alta taxa de utilização dos equipamentos;

c) Transporte - por movimentação desnecessária ou excessiva de estoque, materiais, peças, produtos acabados ou em processos. Uma das causas se deve a um layout inadequado, falta ou insuficiência de treinamento, dentre outras;

d) Processamento - desperdícios por superprocessamento, por inadequação, extra, incorreto - ou ainda, por excesso de qualidade;

e) Estoque - em excesso de material, de matériasprimas, em processamento, e de produtos acabados. As possíveis causas geradoras são a "falsa sensação de segurança", que processam grandes lotes com tempos de set up, lead time e sincronização incorretos;

f) Movimentação - são as movimentações desnecessárias por parte dos operadores, ações que não agregam valor;

g) Defeitos - são irregularidades que afetam às especificações técnicas, de qualidade, de conformidade de peças, subcomponentes e produtos acabados, não atendendo aos requisitos de projeto e de uso. Possíveis causas relacionadas ao treinamento inadequado da mão de obra obrigando sucessivas inspeções desnecessárias;

h) Desperdício da criatividade dos funcionários trata-se de "perda de tempo, ideias, habilidades, melhorias e oportunidades de aprendizagem por 
não envolver ou não escutar seus funcionários" (LIKER, 2007, p. 54).

\section{ABORDAGEM METODOLÓGICA}

Este estudo é de cunho qualitativo, procura responder ao objetivo de analisar os principais fatores de perdas nos processos produtivos nas indústrias manufatureiras localizadas na Zona Industrial de SUAPE. A análise será de forma descritiva para melhor esclarecimento do fenômeno (GIL, 2007), pois há escasso conhecimento sobre o problema pesquisado (CERVO BERVIAN; SILVA, 2001; MARCONI; LAKATOS, 2006).

Aplicou-se o método de abordagem do tipo dedutiva, com a técnica de investigação observacional não participante (GIL, 2007; STRAUSS; CORBIN, 1994). Para o levantamento de dados foram utilizados questionários compostos por perguntas fechadas dicotômicas do tipo "sim" ou "não", e perguntas que pedemgraudeconcordância, através daescala de Likert (LIKERT, 1932). Para a elaboração do questionário foi, primeiramente, realizada a pesquisa bibliográfica, na qual: livros, dissertações, teses, artigos em periódicos foram utilizados para a composição da base teórica da pesquisa (SILVA, 2001). Os principais elementos que compõem o questionário são: Implantação do JIT (com 14 questões); Pessoas e Equipe de Trabalho para o STP (com 24 questões); Melhorias e Perdas (com 25 questões). Totalizando 63 questões. Para que as empresas participassem dessa pesquisa foram aplicados dois requisitos: (i) a empresa estar instalada dentro do complexo Portuário de SUAPE, denominada Zona Industrial (ZI); (ii) a empresa deve utilizar o Just in Time na sua linha de produção. O questionário está apresentado no Anexo 1.

Dessa forma, após a identificação nas páginas da website do Porto de Suape (SUAPE, 2010) de 102 empresas no total, foram classificadas nos dois requisitos anteriorme descritos sete empresas. As empresas são classificadas por porte (SEBRAE, 2010), em função do número de pessoas ocupadas e do setor de atividade investigada em: médio porte (4 empresas) - possuem 100 a 499 pessoas empregadas e de grande porte (3 empresas), com mais de 500 funcionários. Para elas, o questionário foi enviado por e-mail.

\section{RESULTADOS}

Nesta seção serão apresentados os resultados da aplicação dos questionários. Foi constatado que os entrevistados são do sexo masculino, faixa etária entre 31 e 40 anos, com nível de escolaridade superior. Eles possuem graduação em engenharia mecânica, gestão da produção, gestão de projetos e gestão empresarial. A maioria deles se graduou há mais de 10 anos, em instituições de ensino público; e trabalham na mesma área há cerca de 14 anos, e na mesma empresa há mais de 3 anos.

Sobre a implantação do JIT, conforme as respostas para a pergunta "A organização precisava implantar o JIT? Onde? e Por quê?" Percebe-se que era necessária a implantação (43\% das empresas) na seção de manufatura a fim de aumentar a produtividade e diminuir os custos. A maior parte das empresas ,71\%, afirmaram que trabalham com produção repetitiva.

Silva (2015) e Ballestero-Alvarez (2010) sugerem que para se implantar o JIT é necessário que a empresa passe por algumas etapas e use determinadas métricas, técnicas e ferramentas. Acerca desses aspectos perguntou-se "O fluxo de materiais foram simplificados? E as suas consequências?" As respostas (71\%) permitem inferir, que as empresas elaboraram fluxogramas para acompanhar o fluxo de matérias, gerando uma eliminação de atividades consideradas desnecessárias, aumentando a flexibilidade dentro da empresa. Elas afirmaram que utilizam o Kanban para puxar o fluxo desses processos, bem como, para a diminuição do tamanho dos lotes, sendo melhor facilitado pelo agrupamento desses recursos em células, e tendo como ferramenta de controle estatístico de processo (CEP). Mas, de maneira contraditória as empresas não deram autonomia para essas células.

É importante que se ressalte no JIT, a importância nas pessoas no processo, pois, elas são os principais atores responsáveis pelo controle das perdas e dos desperdícios. Por isto, elas devem estar envolvidas 
e compromissadas à empresa; por sua vez, as empresas devem ouvir seus funcionários (LIKER; MEIER, 2007). Neste sentido, para melhor entender este paradoxo foram estudadas as pessoas e as equipes de trabalho nas empresas estudo de caso. Foi observado que os funcionários possuem as seguintes características: multifuncionalidade (85\%), sentimento de pertencimento de trabalhar em grupo (71\%), bom entrosamento e comunicação horizontal. Todos os funcionários pesquisados entendem que a participação deles no processo irá melhorar o desempenho da empresa. Destaca-se que para estimular este sentimento; os entrevistados já tiveram oportunidade de visitar outras empresas que usam o JIT nas suas linhas de produção (85\%), o que ajudou a alavancar os resultados quando ocorre o treinamento (85\%). Ou seja, todas as empresas treinaram os seus funcionários sobre a implementação, e a filosofia do JIT. Em 85\% das vezes os funcionários aplicam corretamente o que foi outrora ensinado sobre o JIT. Outro destaque é que $71 \%$ dos funcionários das empresas estudo de caso acham que tem autonomia de parar as máquinas, caso seja detectado algum problema. Já a avaliação das perdas está descrita no Quadro 1.

Quadro 1 - Sobre a percepção da redução das perdas pelos entrevistados

\begin{tabular}{|c|c|c|c|c|c|c|}
\hline Questão & Descrição & $\begin{array}{l}\text { Discordo } \\
\text { totalmente }\end{array}$ & Discordo & $\begin{array}{l}\text { Não concordo, } \\
\text { nem discordo }\end{array}$ & Concordo & $\begin{array}{l}\text { Concordo } \\
\text { totalmente }\end{array}$ \\
\hline 03 & $\begin{array}{l}\text { Há a percepção do funcionário em relação à } \\
\text { melhoria no setor onde trabalha? }\end{array}$ & 0 & 0 & 2 & 0 & 5 \\
\hline 04 & $\begin{array}{l}\text { Houve uma redução da quantidade de estoque } \\
\text { em processo? }\end{array}$ & 0 & 0 & 0 & 4 & 3 \\
\hline 05 & $\begin{array}{l}\text { Houve uma redução efetiva dos estoques de } \\
\text { produtos acabados? }\end{array}$ & 0 & 0 & 1 & 1 & 5 \\
\hline 06 & Houve uma redução do tamanho dos lotes? & 2 & 1 & 2 & 0 & 2 \\
\hline 07 & $\begin{array}{l}\text { O tempo de espera, ou seja, as filas } \\
\text { diminuíram? }\end{array}$ & 0 & 0 & 1 & 1 & 5 \\
\hline 08 & O transporte excessivo diminuiu? & 1 & 0 & 2 & 2 & 2 \\
\hline \multicolumn{2}{|c|}{ TOTAL } & 3 & 1 & 8 & 8 & 22 \\
\hline \multicolumn{2}{|c|}{ Frequência Relativa } & $7 \%$ & $4 \%$ & $19 \%$ & $19 \%$ & $52 \%$ \\
\hline
\end{tabular}

Fonte: Os Autores (2015).

Na perda por produção foi identificado que não há elaboração por quantidade e ou por antecipação. Foi identificado que houve a redução de perdas em relação aos estoques: em processo; de estoques de produtos acabados; do tamanho dos lotes; do tempo de espera; do transporte excessivo; de produtos defeituosos, da necessidade de retrabalho; de movimentação desnecessária por parte do operador de máquinas. E como consequência, o ambiente de trabalho tornou-se mais salutar.

Com relação à perda por espera, foi identificado que não há tempo sem a realização de algum processo, não ocorrem filas entre as etapas de produção. Há uma adequada programação e sincronização da produção e do balanceamento entre as linhas. Isso é confirmado, pois 6 entrevistados afirmaram que conhecem o lead times de cada produto, e há sempre a produção com objetivo de elaborar pequenos lotes.

Outro destaque é que 5 entre 7 empresas estudadas, responderam assertivamente sobre a definição e o agrupamento dos recursos em layout em formato de célula, aumentando dessa forma a flexibilização dos fluxos produtivos, informacionais e dos materiais. Fato que diminui a movimentação e transporte entre as linhas produtivas de forma desnecessária ou excessiva. Neste sentido, o operador dedica o seu tempo somente na preparação, junto à máquina, não necessitando se afastar para providenciar materiais que não estão com ele, evitando a perda da movimentação em si dos funcionários. No Quadro 2 está o compêndio das perdas identificadas nas empresas estudo de caso, as sete primeiras perdas são referentes ao processo do STP/JIT, e as três últimas são referentes ao processo 
de manutenção que auxilia na redução das principais

analisados

perdas, por isto não podem ser deixados de ser

Quadro 2 - Compêndio de concordância das perdas pelos entrevistados

\begin{tabular}{|c|c|c|}
\hline Perda & Descrição & $\begin{array}{l}\text { Percentual de } \\
\text { Concordância }\end{array}$ \\
\hline \multirow[t]{2}{*}{ Produção } & Diminuição da produção de produtos para estoque & $85 \%$ \\
\hline & Redução no tamanho dos lotes & $28 \%$ \\
\hline Espera & $\begin{array}{l}\text { Redução do tempo de espera de materiais, informações, pessoas ou equipamentos que não } \\
\text { estão preparados }\end{array}$ & $85 \%$ \\
\hline Transporte & Redução do transporte excessivo de produtos que não agregam ao processo produtivo & $56 \%$ \\
\hline Processamento & Fluxo do processo ocorre em pequenos lotes & $85 \%$ \\
\hline \multirow{4}{*}{ Estoque } & Redução sistemática da quantidade de estoques em processo & $100 \%$ \\
\hline & Os tempos de ciclo são conhecidos & $85 \%$ \\
\hline & Takt time para saber quantas unidades podem ser fabricadas para suprir a demanda & $71 \%$ \\
\hline & Lead times de cada produto são conhecidos & $85 \%$ \\
\hline Movimentação & $\begin{array}{l}\text { A partir do início do set up, o operador dedica o seu tempo somente na preparação junto à } \\
\text { máquina }\end{array}$ & $71 \%$ \\
\hline Defeito & Houve redução de produtos defeituosos e retrabalhos nos processos de fabricação & $85 \%$ \\
\hline \multirow{3}{*}{ Quebra } & $\begin{array}{l}\text { Operadores conhecem as operações básicas de seus equipamentos e identifica } \\
\text { anormalidades }\end{array}$ & $85 \%$ \\
\hline & Preferência pela manutenção preventiva & $100 \%$ \\
\hline & $\begin{array}{l}\text { Plano de manutenção para equipamentos mais críticos por paradas acidentais por quebra ou } \\
\text { falhas em equipamentos }\end{array}$ & $85 \%$ \\
\hline Set up longo & $\begin{array}{l}\text { Inspeção diária dos equipamentos, manutenção em pequenos reparos, substituição de peças } \\
\text { por mudança de linha de produção e ajustes de ferramentas }\end{array}$ & $85 \%$ \\
\hline Paradas frequentes & Redução das falhas dos equipamentos na linha de produção & $71 \%$ \\
\hline
\end{tabular}

Fonte: Os Autores (2015).

Contudo, não foi identificado pela pesquisa se há desperdício da criatividade dos funcionários, por não envolver ou ouvir seus funcionários. Ou seja, as empresas aplicam parte da filosofia do JIT, mas não confiam em sua mão de obra para a resolução dos problemas.

\section{CONCLUSÕES}

Os recursos estão ficando cada vez mais escassos, por isto eles devem ser utilizados de maneira racional, e em tempos de crise como a que o Brasil vive no presente momento, esse ensinamento deve ser utilizado em todos os processos produtivos. Assim, é oportuno analisar as causas das perdas elas se encontram em dois eixos centrais, a saber: falta de uma visão sistêmica por parte da gerência em relação à necessidade do treinamento e formação de pessoas; falta de uma análise detalhada dos processos que geram as perdas.

Diante desse fato foi possível identificar as perdas em indústrias manufatureiras dentro do Complexo Industrial - Suape, de acordo com a base conceitual do JIT. Acerca da primeira causa das perdas, foi constatado que houve um nível de concordância de que a melhor forma de repasse dos conhecimentos necessários, para o entendimento do JIT, tantos aos funcionários como para os fornecedores seriam o de cunho "prático", ou seja, através de visitas préagendadas em outras empresas que já possuam o JIT implantado no setor que deve ser "estudado". Mas, ainda é importante desenvolver profissionais habilitados e criar uma estrutura de aprendizagem organizacional, com o intuito de disseminar a cultura do JIT e da eliminação das perdas (MORGAN; LIKER, 
2006).

Com relação ao segundo eixo foi constatado que há um rígido controle sobre a classificação de materiais, utilizando para tal, a classificação $A B C$ e o Diagrama de Pareto, com periodicidade mensal. O percentual sobre a percepção da redução de perdas e na economia de recursos está em torno de $52 \%$, em nível de concordância em relação às melhorias percebidas no setor, bem como a diminuição de estoque em processos e estoques acabados, assim como a diminuição do transporte excessivo, e da movimentação desnecessárias, do tamanho dos lotes (mesmo ainda não alcançado o ponto ótimo de lote unitário sugerido pela literatura), o tempo de espera ocasionado por longos setups, e a diminuição de produtos defeituosos.

Afora isso, é necessário salientar, que economizar recursos significa respeito, cuidado, atenção, aprimoramento contínuo, conhecimento e ordenação no ato de trabalhar. Este aspecto depende e muito da cultura onde for implantando o JIT. Deve haver valorização dos funcionários, por meio do estímulo da capacidade do individuo, envolvimento direto acerca da rotina do sistema, delegação de poderes e autonomia para agir na resolução de problemas considerados rotineiros.

\section{REFERÊNCIAS}

[1] ANTUNES, J. et al. Sistemas de Produção: Conceitos e Práticas para Projeto e Gestão da Produção Enxuta. Porto Alegre: Bookman, 2008.

[2] BALLESTERO-ALVAREZ, M. E. Gestão de Qualidade, Produção e Operações, São Paulo: Atlas, 2010.

[3] BORNIA, A. C. Mensuração das perdas dos processos produtivos: uma abordagem metodológica de controle interno. Tese (Doutorado em Engenharia de Produção) Programa de Pós-Graduação de Engenharia de Produção, Universidade Federal de Santa Catarina, 1995.

[4] CERVO, A. L., BERVIAN, P. A.; SILVA, R. Metodologia Científica. 6. ed. São Paulo: Pearson Prentice Hall, 2007.
[5] CUNHA, C. A. C. da; SEVERIANO FILHO, C.; WANDERLAY, J. M. C. Produtividade de manufatura celular puxada versus linear empurrada: estudo de caso em uma fábrica de calçados esportivos. In: ENEGEP 2002 - Anais do XXII Encontro Nacional de Engenharia de Produção. Curitiba, 2002

[6] GIL, A. C. Como elaborar projetos de pesquisa. São Paulo: Atlas, 2007

[7] KUMAR, C. S.; PANNEERSELVAM, R. Literature review of JIT-KANBAN system. The International Journal of Advanced Manufacturing Technology, v. 32, n. 3-4, p. 393-408, 2007.

[8] LIKER, J. K. O Modelo Toyota: 14 princípios de gestão do maior fabricante do mundo. Porto Alegre: Bookman, 2005.

[9] LIKER, J. K.; MEIER, D. O Modelo Toyota: manual de aplicação: um guia prático para implementação dos 4PS da Toyota. Porto Alegre: Bookman, 2007.

[10] LIKERT, R. A. Technique for measurement of attitudes. Archives of Psychology, v. 140, n. 1, p. 5-55, 1932.

[11] MARCONI, M. de A.; LAKATOS, E. M. Metodologia científica. 5.ed. São Paulo: Atlas, 2007.

[12] MORAES, J.; CLEMENTE, A. Toyota confirma galpão de peças no Complexo Portuário de Suape. Diário de Pernambuco, Recife, 04 mai. 2015. Disponível em: <http://www. diariodepernambuco.com.br/app/noticia/ economia/2015/02/11/internas_economia,560380/toyotaconfirma-galpao-de-pecas-no-complexo-portuario-desuape.shtml>. Acesso em: 04 mai. 2015.

[13] MOREIRA, D. A. Administração da Produção e Operações. 2. ed. rev. e ampl. São Paulo: Cengage Learning, 2009

[14] MORGAN, J. M., LIKER, J. K. The Toyota Product Development System: integrating people, process and technology. New York: Productivity Press, 2006.

[15] MÓROZ, G. Avaliação da aplicação da manufatura enxuta para a indústria moveleira. 2009. 107 f. Dissertação (Mestrado em Engenharia de Produção) Campus Ponta Grossa. Universidade Tecnológica Federal do Paraná, 2009.

[16] MOTTA, P. C. Ambiguidades metodológicas do Just-InTime. Organizações \& Sociedade, Brasília, DF, 1996. v.4.no 07, p.117-131. Disponível em: <http://www.revistaoes.ufba. br/viewarticle. php?id=824>. Acesso em: 25 jun. 2011.

[17] OHNO, T.; MITO, S. Just-in-time for today and tomorrow. Cambridge, Massachusetts: Productivity Press, 1988.

[18] OLIVEIRA, R. V. Suape em construção, peões em luta: o novo desenvolvimento e os conflitos do trabalho. Cad. $\mathrm{CRH}$, Salvador, v. 26, n. 68, p. 233-252, Aug. 2013. Disponível em: <http://www.scielo.br/scielo.php?script=sci arttext\&pid=S0103-49792013000200003\&lng =en\&nrm =i so>. Acesso em:19 abr. 2015. 
[19] PERGHER, I.; RODRIGUES, L. H.; LACERD, D. P. Discussão teórica sobre o conceito de perdas do Sistema Toyota de Produção: inserindo a lógica do ganho da Teoria das Restrições. Gest. Prod., São Carlos, v. 18, n. 4, p. 673686, 2011. Disponível em: <http://www.scielo.br/scielo. php?script=sci_arttext\&pid =S0104-530X2011000400001\&ln $\mathrm{g}=$ en\&nrm=iso $>$. Acesso em: 19 abr. 2015.

[20] RODRIGUES, M. V. Entendendo, aprendendo e desenvolvendo sistemas de produção Lean Manufacturing, Rio de Janeiro: Elsevier, 2014.

[21] SEBRAE (Org), Anuário do trabalho na micro e pequena empresa: 2009. 3. ed. / Serviço Brasileiro de Apoio às Micro e Pequenas Empresas; Departamento Intersindical de Estatística e Estudos Socioeconômicos - Brasília; São Paulo: SEBRAE; DIEESE, 2010.

[22] SHIMOKAWA, K. O nascimento do lean: conversas com Taiichi Ohno, Eji Toyoda e outras pessoas que deram forma ao Modelo Toyota de gestão, Porto Alegre: Bookman, 2011.

[23] SHINGO, S. O Sistema Toyota de Produção do ponto de vista da Engenharia de Produção, Porto Alegre: Bookman, 1996a.

[24] SHINGO, S. Sistemas de produção com estoque zero. O sistema Shingo para melhorias contínuas. Porto Alegre: Bookman, 1996b.

\section{ANEXO 1}

\section{QUESTIONÁRIO PESQUISA - PERDAS DO JIT/STP}

Conforme a utilização do Just In Time. Por favor, assinale apenas uma alternativa de resposta para cada questão, observando o grau de códigos utilizados: D.T. - Discordo totalmente; D. - Discordo; N.C.N.D - Não concordo, nem discordo; C. - Concordo; C.T. - Concordo totalmente

\section{QUESTIONÁRIO SOBRE O JIT}

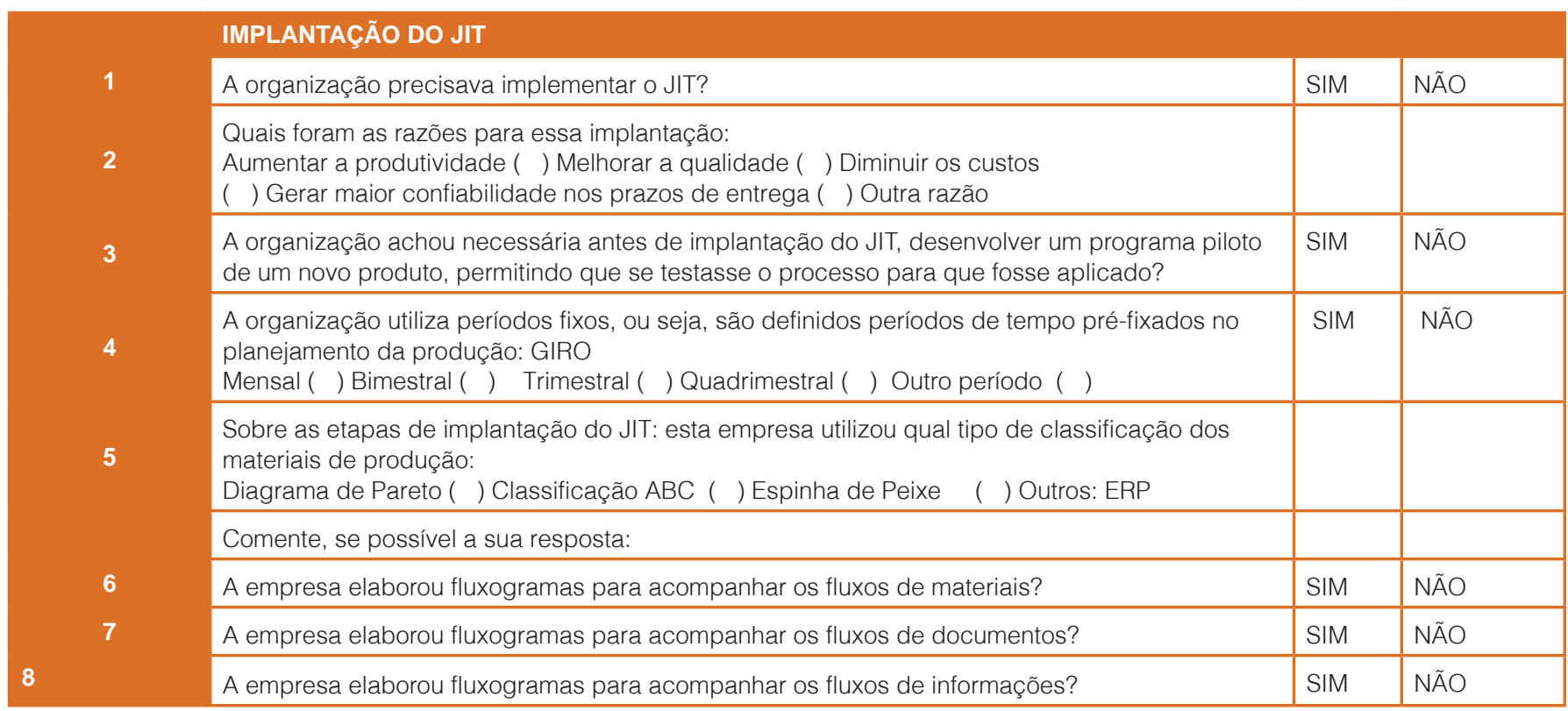

[25] SHINGO, S. Zero Quality Control: Source Inspection and the Poka-Yoke System. Cambridge: Productivity Press, 1986.

[26] SILVA, E. L. Metodologia da pesquisa e elaboração de dissertação - 3. ed. rev. atual. - Florianópolis: Laboratório de Ensino a Distância da UFSC, 2001. 121p.

[27] SILVA, R. W. Análise das dificuldades de implantação do lean manufacturing. estudo de caso em uma empresa do ramo moveleiro em Indaial/SC. 2015. 96f. TCC (Trabalho de Conclusão de Curso) - Universidade Regional de Blumenau, Centro de Ciências Tecnológicas, Departamento de Engenharia de Produção e Design, Curso de Engenharia de Produção, Blumenau, 2015

[28] SLACK, N., B, S., JOHNSTON, R. Operations management. 5 ed. Edinburgh Gate, Harlow, Essex CM20 2JE, : Prentice Hall / Financial Times / Pearson Education, 2007

[29] STRAUSS, A.; CORBIN, J. Basics of qualitative research: grounded theory procedures and techniques. Newbury Park, CA: Sage Publications, 1994.

[30] SUAPE (Complexo Industrial Portuário) Complexo de Suape. Disponível em: <http://www.suape.pe.gov.br/ complexo_suape.asp>. Acesso em: 23 ago. 2015. 
Os fluxos foram simplificados, ou seja, houve a eliminação de atividades consideradas desnecessárias para que aumentasse a flexibilidade dentro da empresa?

10

Houve a definição e o agrupamento dos recursos em células (layout celular) em função dos fluxos e processos?

Foram desenvolvidos e implantados os procedimentos de controle, como o CEP (Controle Estatístico de Processo)?

\begin{tabular}{|l|l|}
\hline SIM & NÃO \\
\hline SIM & NÃO \\
\hline SIM & NÃO \\
\hline SIM & NÃO \\
\hline SIM & NÃO \\
\hline SIM & NÃO \\
\hline
\end{tabular}

\section{MELHORIAS x PERDAS}

1
O (A) sr(a) concorda que a melhoria implantada com o JIT dentro da organização aumentou a satisfação do seu consumidor/cliente. (DE QUE FORMA: NÍVEL DE ATENDIMENTO)

Comente, se possível a sua resposta:

Passou-se a entregar os pedidos nos prazos estabelecidos pelo cliente.

Comente, se possível a sua resposta:

Houve aumento de melhoria no seu setor.

Comente, se possível a sua resposta:

Reduziu-se a quantidade de estoques em processo.

Comente, se possivel a sua resposta:

Houve uma efetiva diminuição da produção de produtos para estoque.

Comente, se possível a sua resposta:

Houve redução no tamanho dos lotes.

Comente, se possível a sua resposta:

Percebe-se a redução do tempo de espera de materiais, informações, pessoas ou equipamentos que não estão preparados.

Comente, se possivel a sua resposta:

Diminuiu o transporte excessivo de produtos que não agregam valor ao processo produtivo.

Comente, se possivel a sua resposta:

Existe um plano de manutenção focalizando principalmente os equipamentos considerados críticos?

Há preferência pela manutenção preventiva em vez da manutenção corretiva?

Houve redução das falhas dos equipamentos na linha de produção.

Comente, se possível a sua resposta: de seus equipamentos, lubrificando regularmente, auxiliando o pessoal de manutenção em pequenos reparos e na substituição de peças básicas? (MANUTENÇÃO AUTÔNOMA)

Os operadores conhecem as operações básicas de seus equipamentos e estão envolvidos na investigação de anomalias compartilhando ideias com o pessoal de manutenção?

Houve redução de produtos defeituosos e retrabalhos nos processos de fabricação?

O LEC - Lote Econômico é calculado com periodicidade?

Os tempos de ciclo são conhecidos?

A empresa utiliza o takt time para saber quantas unidades podem ser fabricadas para suprir a encomenda do cliente?

\begin{tabular}{|c|c|c|c|c|}
\hline SIM. & & NÃO & & \\
\hline D.T. & D. & N.C.N.D & C. & C.T. \\
\hline D.T. & D. & N.C.N.D & C. & C.T. \\
\hline D.T. & D. & N.C.N.D & C. & C.T. \\
\hline D.T. & D. & N.C.N.D & C. & C.T. \\
\hline D.T. & D. & N.C.N.D & C. & C.T. \\
\hline D.T. & D. & N.C.N.D & C. & C.T. \\
\hline D.T. & D. & N.C.N.D & C. & C.T. \\
\hline SIM & & NÃO & & \\
\hline SIM & & NÃO & & \\
\hline D.T. & D. & N.C.N.D & C. & C.T. \\
\hline SIM & & NÃO & & \\
\hline SIM & & NÃO & & \\
\hline SIM & & NÃO & & \\
\hline SIM & & NÃO & & \\
\hline SIM & & NÃO & & \\
\hline SIM & & NÃO & & \\
\hline
\end{tabular}


19 A partir do inicio do setup, o operador dedica o seu tempo somente na preparação junto à máquina não necessitando se afastar para providenciar materiais que não estão com ele, ou no local onde deveria estar?

Existem quadros i ndicadores de desempenho nesta fábrica?

Existe sinalização com o objetivo de alertar as áreas de apoio quando necessário a intervenção no processo produtivo?

Os lead times de cada produto principais são conhecidos?

\begin{tabular}{|l|l|l|l|} 
SIM & & NÃO & \\
SIM & & NÃO & \\
\hline SIM & & NÃO & \\
SIM & & NÃO & \\
\hline SIM & & NÃO & \\
\hline
\end{tabular}

Qual o tipo de produção preponderante nesta organização?

( ) Produção repetitiva ( ) Produção sob encomenda ou em pequenos lotes ( ) Ambas ( ) Nenhuma das respostas anteriores. 


\section{CAPÍTULO 14}

\section{A LOGÍSTICA DO TRANSPORTE DE CARGA INDIVISÍVEL SUPERDIMENSIONADA: O TRAJETO DE ROTOR DA TURBINA DE HIDRELÉTRICA ENTRE ARARAQUARA (SP) E BELO MONTE (PA)}

Carolina Carvalhaes Cauduro Orlandi

Natália Francisca Madi

Bruno Ricioli de Andrade

Julio Cesar Raymundo

Mauricio Dutra

Resumo: O presente estudo visa descrever e analisar a logística empregada no transporte de rotor de turbina hidrelétrica produzido pela unidade fabril da Andritz Hydro, em Araraquara, no Estado de São Paulo, com destino à Usina de Belo Monte, no Pará. Para tanto, foi necessário observar a literatura, a legislação e as particutaridades de se transportar uma carga indivisivel superdimensionada como o referido rotor. Desta forma, com o auxílio de pesquisa bibliografica e informações disponibilizadas por agentes envolvidos na operação, destacase a movimentação de alta complexidade realizada com sucesso, a qual foi amparada em amplo e detalhado plano logístico. Tal estratégia de deslocamento fundamentou-se em estudos de viabilidade estrutural e geométrico, alem autorizações especiais de trânsito, profissionais capacitados e veículos especiais para trasladar, pelo país, com a peça de grandes dimensões até seu destino. Ademais, devido ao longínquo e difícil acesso do percurso, a intermodalidade, nesse caso, composta pelos modais rodoviário, marítimo e fluvial foi uma ferramenta importante para superar alguns dos obstáculos logísticos, bem como, zelar pela eficiência do transporte da volumosa carga. Qutrossim, ante o êxito da manobra objeto desse estudo, não é de se admirar que ela tornou-se referência no meio especializado.

Palavras chave: Carga indivisível superdimensionada, Transporte, Rotor de turbina 


\section{INTRODUÇÃO}

O presente estudo visa conceituar e explicar o procedimento de transporte de cargas indivisíveis superdimensionadas e, a partir desse referencial teórico, relacionar a questão ao estudo de caso utilizado para transportar o rotor de turbina de unidade geradora de usina hidrelétrica produzido pela empresa Andriz Hydro, em Araraquara (SP), com destino a Belo Monte (PA).

A Usina Hidrelétrica de Belo Monte está distante dos grandes pólos industriais, mas, ao mesmo tempo, necessita de vários equipamentos de alta tecnologia o que implica no transporte desses instrumentos por longos percursos. Não obstante o longínquo trajeto, grande parte do material destinado à implementação da usina é constituído de peças de dimensões excepcionais, o que dificulta o transporte.

Nesse sentido, consoante a rígida legislação de trânsito que regulamenta a movimentação de cargas especiais que extrapolam os limites estipulados pelos órgãos competentes, caberá ao responsável pela carga o preenchimento de alguns requisitos imprescindiveis, como o requerimento de uma autorização especial de trânsito e detalhado planejamento logístico.

O transporte do rotor de turbina em questão foi realizado de forma intermodal. Na primeira fase, o caminho entre Araraquara e o Porto de Santos foi percorrido através de uma gigantesca composição veicular por modal rodoviário. Já a segunda fase realizada entre o Porto de Santos e Belo Monte foi realizado por modal aquaviário, primeiramente em modal marítimo via cabotagem até Belém e, posteriormente, via modal fluvial até Belo Monte.

Entre os obstáculos a serem transpostos por essa operação, tem-se os rigorosos requisitos legais, a grande distância exigida na movimentação, os altos custos logísticos do país, além de transcurso de trecho de serra em meio a área de grande fluxo de veículos entre um grande pólo industrial e o maior porto do país.

Diante de pesquisas bibliográficas, exploratórias e de estudo de caso junto às empresas envolvidas no translado da peça em questão, nota-se que, embora complexa, a movimentação da carga especial superdimensionada em comento foi realizada com êxito e seguiu a legislação competente.

Em razão disso, é importante, conhecer a logística adotada no traslado do rotor de turbina entre Araraquara e Belo Monte, haja vista seu o resultado positivo, o que possibilita traçar estratégias similares para outros produtos.

\section{CARGA INDIVISÍVEL}

Para o Departamento Nacional de Infraestrutura de Transportes (DNIT), autarquia federal vinculada ao Ministério dos Transportes, carga indivisível é definida pela Resolução 01/16 do órgão,conforme trecho transcrito a seguir:

Carga indivisível é a carga unitária com peso e/ou dimensões excedentes aos limites regulamentares, cujo transporte requeira o uso de veículos especiais com lotação (capacidade de carga), dimensões, estrutura, suspensão e direção apropriadas. São exemplo de carga indivisível, entre outras: máquinas, equipamentos, peças, pás eólicas, vagões, transformadores, reatores $e$ guindastes.

De maneira simplificada, carga indivisível é aquela que além de não poder ser fracionada, ultrapassa os limites regulamentados pelo órgão competente e, por essa razão, precisa ser transportada por um veículo especial.

Segundo o artigo 4, inciso VIII da Resolução 01116 do DNIT:

Veículo especial é aquele construído com características específicas, destinado ao transporte de cargas indivisíveis excedentes em peso elou dimensões, assim como, os dotados de equipamentos para prestação de serviço especializado, que se configurem como carga permanente (grifos nossos). 
A recente atualização na legislação visa normatizar o uso de rodovias por veículos ou combinações de veículos, além de equipamentos transportadores de cargas que extrapolem os limites de peso ou dimensões previstas na legislação.

De acordo com orientações do DNIT, tal renovação no texto infra legal foi de grande valia para acompanhar as inovações tecnológicas que vem modernizando os veículos e os equipamentos e manter-se alinhado aos anseios do mercado e da sociedade.

Conforme regulado pelo DNIT, carga indivisível é aquela cujo veículo transportador de carga excede as dimensões fixadas pelo Conselho Nacional de Trânsito (CONTRAN), ou seja, de acordo com a Resolução 210/06 deste Conselho, é a carga que ultrapassa 2,60 metros de largura, 4,40 metros de altura, e comprimento (14 metros em veículos simples, 18,15 metros em veículos articulados e 19,80metros em veículos com reboque), além de peso.

Nesse sentido, caso um veículo ou uma composição de veículo e carga necessite transportar carga indivisível mesmo excedendo as dimensões trazidas pelo CONTRAN, ele pode requerer uma Autorização Especial de Trânsito (AET), conforme abordado em tópico subsequente.

Assim, além de AET, caso os veículos especiais ou conjuntos transportadores extrapolem os limites impostos, deverão trazer essa advertência especial em sua placa traseira, segundo regulamentação do artigo 11 da Resolução 11116 do DNIT.

\section{AUTORIZAÇÃO ESPECIAL DE TRÂNSITO (AET) E OUTRAS EXIGÊNCIAS}

De acordo com o artigo 21, inciso XIV do Código de Trânsito Brasileiro (CTB):

Compete aos órgãos e entidades executivos rodoviários da União, dos Estados, do Distrito Federal e dos Municípios, no âmbito de sua circunscrição, dentre outros, vistoriar veículos que necessitem de autorização especial para transitar e estabelecer os requisitos técnicos a serem observados para a circulação desses veículos.

Já o artigo 101 do mesmo Código de Trânsito Brasileiro prevê:

\begin{abstract}
Ao veículo ou combinação de veículos utilizado no transporte de carga indivisível, que não se enquadre nos limites de peso e dimensões estabelecidos pelo CONTRAN, poderá ser concedida, pela autoridade com circunscrição sobre a via, autorização especial de trânsito, com prazo certo, válida para cada viagem, atendidas as medidas de segurança consideradas necessárias.
\end{abstract}

Em suma, de acordo com o dispositivo supracitado, os veículos de carga indivisível que excederem as dimensões estabelecidas pelo CONTRAN poderão requerer autorização especial de trânsito (AET) para realizarem seu trajeto.

Ainda sobre o artigo 101 do CTB, o parágrafo segundo determina que a AET não escusa o beneficiário de respectivas responsabilidades em caso de danos e prejuízos que o veículo ou combinação de veículos provocarem a outrem.

De qualquer forma, ainda que o transportador tenha responsabilidade por danos decorrentes de sua operação, os órgãos de trânsito tem outros mecanismos para garantir a segurança nas movimentações complexas de carga e impor diversos outros meios de controle.

Assim, cabe aos veículos de cargas excedentes o estabelecido no artigo 28 da Resolução 01116 do DNIT: "Os veículos destinados ao transporte de cargas indivisíveis e os veículos especiais com peso total bruto combinado (PTCB) superior a 74 toneladas(t) ficam sujeitos ao pagamento de TUV (tarifa de utilização da via)", sendo esta mais uma razão para o elevado custo da operação logística. 
E essa não é, nem de longe, a única imposição sobre as cargas excedentes, pois, caso o objeto do transporte exceda os limites abaixo transcritos, haverá a necessidade da indicação de um engenheiro mecânico como responsável pela segurança do trâmite.

Nesse diapasão, prevê o artigo 23 da Resolução 01116 do DNIT:

Sempre que um conjunto transportador ou o veículo especial apresenta peso total bruto combinado (PTBC) igual ou superior a $100 \mathrm{t}$, ou largura igual ou superior a $6 \mathrm{~m}$ ou altura superior a 5,5m será exigida a indicação de um engenheiro mecânico como responsável técnico pelo transporte previsto que aprovará a combinação veicular de carga de AET quanto à segurança (grifos nossos).

Não obstante as regulamentações citadas acima, cabe ainda às locomoções de cargas indivisíveis de grandes proporções a adoção de detalhado planejamento, conforme descrito no artigo 9o da Resolução 01116 do DNIT, "quando o peso bruto total (PTB) for superior a 288 deverá ser submetido um EVE com todas as obras de arte especiais do itinerário. "

Segundo o DNIT, no inciso XXV do artigo 4ํㅡㄹ de sua Resolução 01/16, entende-se por Estudo de Viabilidade Estrutural (EVE) aquele que examine a capacidade das obras de artes especiais presentes no trajeto a ser percorrido pelo volume excedente, bem como, a viabilidade da realização desse deslocamento. Este estudo deve ser realizado por empresa especializada em engenharia.

Ainda de acordo com o mesmo órgão, outra avaliação muito importante no transporte desse tipo de carga é o Estudo de Viabilidade Geométrica (EVG) que compreende a verificação de gabaritos verticais, horizontais e outras intervenções, como túneis, curvas, viadutos e etc., conforme disposto no inciso XXVI da mesma resolução acima comentada.

Tais estudos são realizados com seriedade e profundidade e requerem antecedência de seis meses a um ano antes da operação, pois são eles que, baseados em roteirização do percurso, vistoria física e profunda apuração técnica, detectarão a viabilidade da locomoção da carga, bem como, eventuais necessidades de modificações, fortificações ou adequações.

Em síntese, a carga indivisível que ultrapassar os limites legais não está impossibilitada de transitar, contudo deve estar sinalizada e solicitar AET junto ao órgão competente, além de observar outros requisitos de acordo com suas características. Ou seja, dependendo de seu tamanho, peso e especificidade, pode também sofrer outras imposições como os já vistos, EVE, EVG, TUV, dentre outros. Ainda assim, se cumpridos todos os requisitos de controle e segurança, caso haja qualquer dano, este será imputado ao responsável.

\section{TRANSPORTEDACARGASUPERDIMENCIONADA COM DESTINO A BELO MONTE}

A Usina Hidrelétrica de Belo Monte ilustrada pela figura 1 adiante, foi parcialmente inaugurada em 5 de maio de 2016 com previsão de entrar em plena atividade em 2019. Quando pronta, será uma das maiores do mundo e gerará 11.233,1 megawatts (MW) através de suas vinte e quatro turbinas, consoante notícia divulgada pela Revista Isto É.

Figura 1 - Usina Hidrelétrica de Belo Monte atualmente

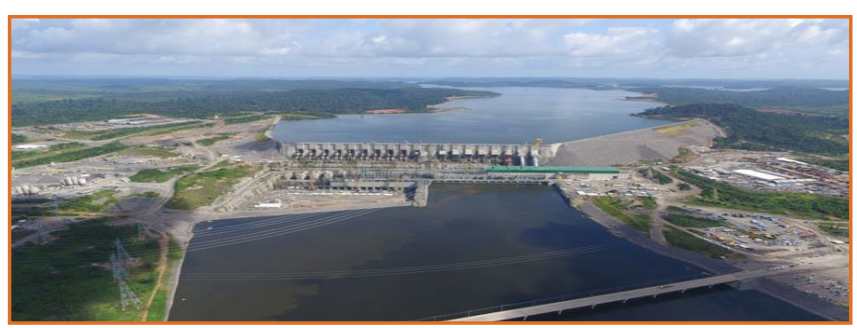

Dentre as peças mais importantes da hidrelétrica, temse o objeto do presente estudo, ou seja, o rotor (ou roda) de turbina hidrelétrica produzido pela empresa Andritz Hydro em Araraquara com destino a Belo 
Monte.

Segundo informações da Transdata, trata-se de uma peça indivisível e superdimensionada de 320 toneladas com custo de $R \$ 10$ milhões, sendo $R \$ 3$ milhões destinados somente ao seu transporte. Ademais, levou dois anos para ser fabricada e precisou de nove meses para traçar o de seu plano logístico, dada a complexidade do transporte, como será demonstrado do tópico seguinte.

\subsection{TRANSPORTE DE ROTOR DE TURBINA DE ARARAQUARA ATÉ BELO MONTE}

O Transporte do rotor de turbina em debate foi realizado via transporte terrestre e aquaviário, sendo que os referidos deslocamentos serão descritos em subitens subsequentes apartados para fins de melhor compreensão.

\subsection{TRANSPORTE DO ROTOR DE ARARAQUARA ATÉ O PORTO DE SANTOS (SP)}

Feitas as devidas considerações conceituais, traçadas as perspectivas de contextualização, bem como, delimitado o objeto de estudo, passa-se, portanto, à exposição específica do tema, ou seja, a discorrer sobre transporte do primeiro rotor de turbina produzido pela empresa Andritz Hydro em Araraquara (SP) até Belo Monte (PA), o que foi realizado de forma intermodal, conforme informações da Revista O Carreteiro.

No entanto, neste momento, para fins didáticos, será destacado somente o fragmento do transporte da peça de Araraquara até o Porto de Santos (SP). O referido percurso, de cerca de $530 \mathrm{Km}$ foi concluído em trinta e um dias e esteve sob responsabilidade da Transdata, transportadora especializada em movimentação de cargas complexas, conforme informações da própria empresa.

De acordo com a Revista $\mathrm{O}$ Carreteiro, o rotor de turbina hidrelétrica em questão, representado pela figura 2 a seguir, foi o maior já produzido pela Andritz até hoje e tem grandes dimensões, pois pesa 320 toneladas e mede 8,5 metros de diâmetro e 5 metros de altura, sendo que no trajeto até o cais santista o percurso ficou ainda mais complexo, pois a composição que realizou o seu transporte tinha dimensões ainda maiores, com impressionantes 108 metros de comprimento e 675 toneladas de PBT, razão pela qual, sua velocidade média marcou 15 quilômetros por hora $(\mathrm{Km} / \mathrm{h})$.

Figura 2 - Rotor de Turbina de Usina Hidrelétrica

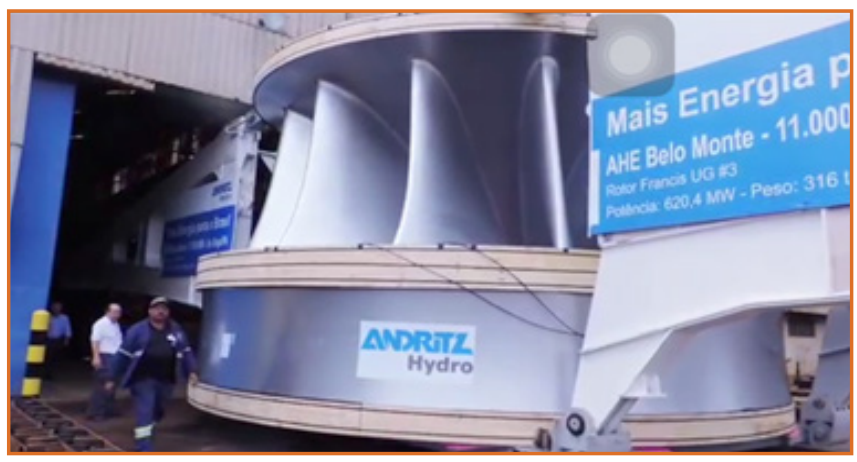

Nesse sentido, gravações do Programa Pé na Estrada de outubro de 2015 divulgaram que, para esta operação de transporte foram utilizados três cavalos mecânicos Volvo FH 16 de 750 cavalos, sendo que cada um deles, tem capacidade de arraste de 250 toneladas. Tais caminhões 8X4 permitem mais precisão à operação por contarem com, dentre outros avanços tecnológicos, caixa de câmbio automática I-shif, responsável pela troca automática de marcha de forma sincronizadae em tempo real, o que permite maior segurança e ausência de trancos, o que é de suma importância para uma operação como essa.

Além dos três modernos cavalos mecânicos, a carga foi transportada por uma composição de dois conjuntos conhecida como carreta gôndola, com 18 eixos cada um, ou seja, 36 eixos que, por sua vez, tem 8 pneus em cada, totalizando 288 nas carretas transportadoras, segundo lições da Revista O Carreteiro.

Ensina ainda a Revista O Carreteiro que, a vultuosa operação de movimentação contou ainda com uma viga transportadora projetada especialmente para a operação que, por sua vez, tem a função de acomodar a peça transportada e equilibrar seu peso ao distribuílo entre suas linhas de eixo. 
Sobre as supracitadas carretas gôndola e a viga projetada para a operação, conceitua o inciso VIII, do artigo 4ํㅡㄹ da Resolução 01116 do DNIT: "Gôndola, viga, plataforma intermediária, espaçador, "skid", articulados ou não, são acessórios empregados no transporte de cargas indivisíveis superdimensionadas e superpesadas".

Ademais, o deslocamento da carga requereu um planejamento logístico minucioso que levou cerca de nove meses para ser preparado, pois todo o trajeto teve que ser mapeado com cautela, a fim e se conferir a capacidade de pontes, viadutos e melhor caminho a ser adotado, além de possíveis interferências no percurso. Trata-se do Estudo de Viabilidade Estrutural (EVE) e do Estudo de Viabilidade Geométrica (EVG) já abordados oportunamente nesse estudo, capazes de indicar se a operação é possível, viável e segura.

Além da parte técnica, o transporte da peça indivisível superdimensionada demanda o competente e prévio requerimento de licenças de tráfego, conforme já conceituada em momento anterior neste artigo.

Já descritos os números para ilustrar a complexidade da operação, faz-se necessário agora, descrever os detalhes do trajeto em si, o que se demonstrará a seguir.

Em 12 de setembro de 2015, segundo O Carreteiro, a composição deixou Araraquara (SP) para começar o seu vagaroso percurso rodoviário até o Porto de Santos. A despeito dessa modalidade de transporte utilizada nessa fase do trajeto prescreve o Ministério dos Transportes:

Transporte rodoviário é o realizado sobre rodas nas vias de rodagem pavimentadas ou não para transporte de mercadorias e pessoas, sendo na maioria das vezes realizados por veículos automotores (ônibus, caminhões, veículos de passeio, etc.). Como possui, na maioria dos casos, preço de frete superior ao hidroviário e ferroviário, é adequado para o transporte de mercadorias de alto valor ou perecíveis, produtos acabados ou semi-acabados.

Segundo informações do Portal Morada, saindo de Araraquara rumo ao porto santista os veículos seguiram escoltados pela Rodovia Washington Luiz (SP - 310), e passaram, dentre outras, pelas cidades de São Carlos e Rio Claro até chegar em Cordeirópolis (SP).

Sobre escolta, dispõe a Resolução 01116 do DNIT em seu artigo $4^{\circ}$, inciso XXII:

\begin{abstract}
Escolta é o acompanhamento e custódia, realizado por empresa de escolta credenciada e ou Polícia Rodoviária Federal, de determinado conjunto veicular ou comboio de veículos, quando excederem os limites de dimensão elou peso regulamentado.
\end{abstract}

Segundo registro presente na figura 3 ulterior e de acordo com informações do Correio Popular, em Cordeirópolis, a carga passou a ser acompanhada pela concessionária CCR - AutoBAn (antiga Companhia de Concessões Rodoviárias).

Figura 3 - Composição de transporte de rotor pelo interior paulsta

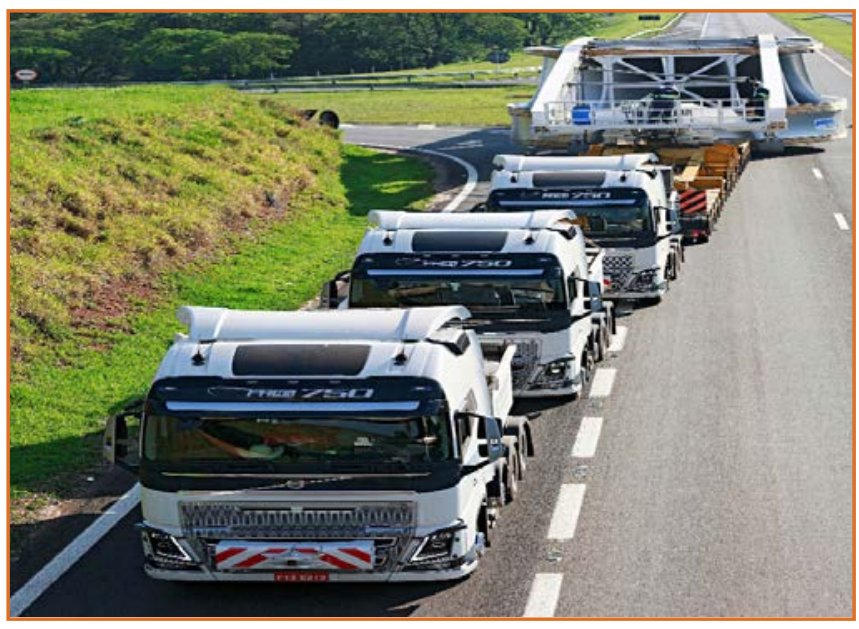

Durante a rota de cerca de $150 \mathrm{Km}$ sob responsabilidade da AutoBAn, a roda de turbina passou pela Rodovia Anhanguera e Bandeirantes sempre escoltada e durante à noite por ter menor movimento, conforme ilustrado pela figura 4 posterior. Tal operação foi 
dividida em cinco etapas da seguinte forma, de acordo com o que veiculou a própria concessionária:

Figura 4 - Operação noturna de transporte de rotor de turbina

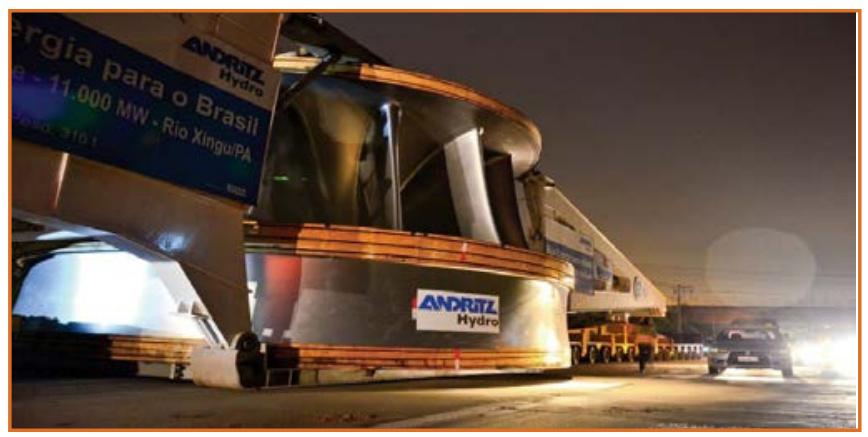

$\mathrm{Na}$ primeira etapa, foi percorrido o trajeto entre Cordeirópolis e Limeira: A composição entrou no Sistema Anhanguera-Bandeirantes a partir do Km 158 da pista sul (sentido interior-capital) da Via Anhanguera (SP - 330) acessando, o Km 173 da Rodovia dos Bandeirantes até o Km 163.

Na segunda etapa, por sua vez, o comboio seguiu do Km 163 ao 125, até a altura do município de Santa Bárbara D' Oeste. Já na terceira e quarta etapas, a peça percorreu o trecho de Campinas, entre os $\mathrm{Km}$ 125 ao 6.

Por fim, na quinta etapa sob responsabilidade da AutoBAN, o comboio seguiu do Km 64 ao 24 até o Rodoanel Mário Covas (SP- 021). Nesse ponto, já sob encargo da concessionária CCR Rodoanel, houve necessidade de se retirar as defensas do pedágio para que a carga pudesse atravessar o local sem ter sua largura comprometida, conforme noticiou o Programa Pé na Estrada.

Em consonância com o disposto pela Transdata, o carregamento seguiu então, para escolta e responsabilidade da Ecovias, concessionária que recebeu a carga no trecho Leste do Rodoanel Mário Covas (SP - 021) e seguiu para Santos pela Rodovia dos Imigrantes (SP - 160). Tal parcela do percurso é ilustrada pela imagem 5 abaixo colacionada.

Figura 5 - Mapa do Acesso ao Rodoanel Mário Covas

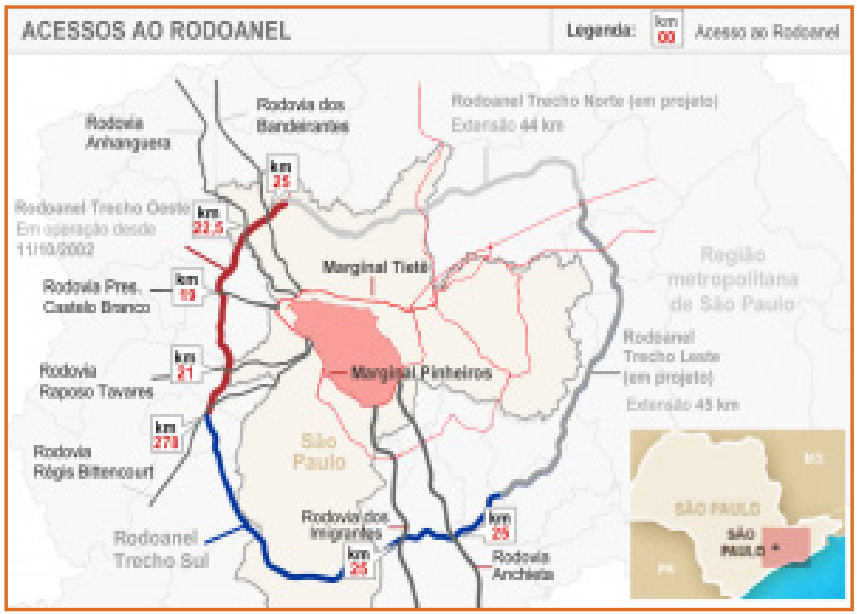

A escolta acima descrita e ilustrada na fotografia 6 subsequente foi novamente realizada por comboio com o intuito de trazer maior controle e segurança à operação. Nesse aspecto, nenhum carro poderia sair do comboio, sob pena da operação ser cancelada. Outra possibilidade de cancelamento ou suspensão da operação, segundo a Revista $\bigcirc$ Carreteiro, seria devido a condições climáticas desfavoráveis, o que não ocorreu.

Figura 6 - Transporte de rotor de turbina pela Avenida dos Imigrantes

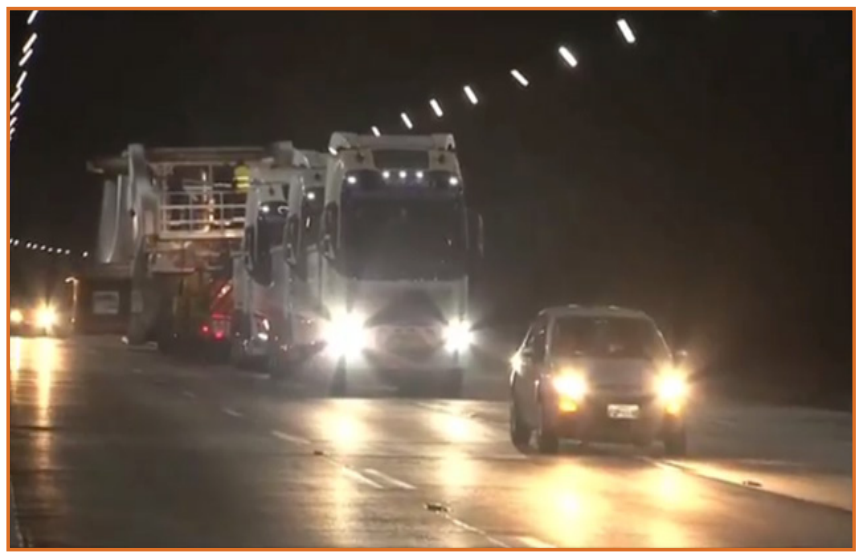

Ainda sob a regência da Ecovias, ao chegar ao final da Rodovia dos Imigrantes, no $\mathrm{Km} \mathrm{58}$, próximo ao município de Cubatão, a composição seguiu pela pista sul da Rodovia Anchieta (SP - 150) até o seu termo, conforme informou o site da empresa. 
Agora sob tutela da Guarda Portuária, a carga cruzou o viaduto Paulo Bonavides, no bairro da Alemoa, para finalmente ser entregue, no terminal Deicmar, localizado no Saboó, à margem direita do Porto de Santos, conforme informou a Transdata. Dias depois, com a chegada do navio, a roda de turbina que estava armazenada no terminal foi posicionada próxima ao costado do navio para embarque.

A peça que, até então havia sido transportada somente por via terrestre, mais precisamente, pelo modal rodoviário, foi então içada pelo guindaste do próprio navio, conforme demonstrado pela imagem 7 abaixo, de tal sorte que o navio e sua carga seguiram então para o Porto de Belém, no Pará, conforme descrito pela Norte Energia e melhor explicado em tópico posterior.

Figura 7 - Içamento de rotor de turbina por navio no Porto de Santos

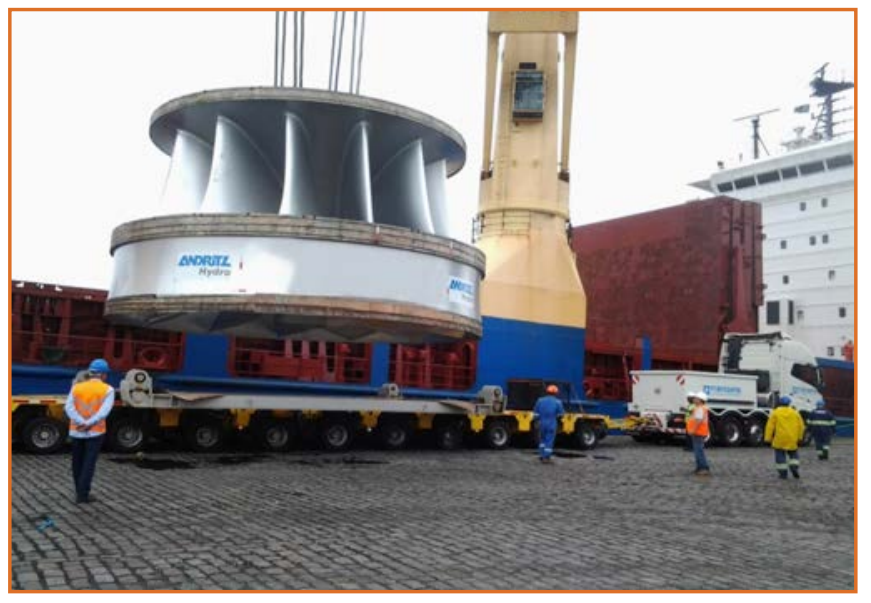

Sobre guindaste, equipamento utilizado para içar o rotor para o navio e ilustrado na imagem acima, preconiza o inciso X do artigo 4ํㅡ da Resolução 01116 do DNIT: "Guindaste é o veículo especial para levar, movimentar e baixar materiais, podendo ser auto propelido ou montado sobre caminhão" ou navio.

\subsection{TRANSPORTE DO ROTOR DE SANTOS ATÉ BELO MONTE}

Após o embarque no porto de Santos, o rotor seguiu até Belém (PA) por meio do transporte aquaviário, na modalidade marítima em uma viagem de cerca de dez dias.

Sobre o transporte aquaviário disserta Keedi (2012):

Os modos de transporte do sistema
aquaviário são o marítimo, fluvial, e
lacustre, em que as navegações ocorrem
em vias aquáticas, respectivamente em
mares e oceanos, rios e lagos, podendo
ser realizadas entre portos de um
mesmo país ou entre portos de dois ou
mais países. Os veículos utilizados são
os navios, os barcos, barcaças e suas
variações, podendo ser de todos os
tamanhos, formatos, tipos, finalidades
etc., apresentando capacidades
extraordinárias de transporte de carga,
que atingem centenas de milhares de
toneladas.

Já Werneck (2008) ressalta que "o transporte marítimo divide-se em transporte de cabotagem, quando a viagem é feita entre portos localizados num mesmo país, e de longo curso, quando entre portos de países distintos, mesmo que com diversas escalas num só país". Como frisado pelo autor, "essa classificação não leva em consideração a distância entre os portos" e sim, o território em que o transporte é efetuado.

Keedi (2012) salienta também que a navegação se executada em águas distintas (doce e salgada), também é considerada cabotagem: "Quando a navegação ocorre envolvendo mar e rio ou mar e lago, ela continua sendo considerada uma navegação de cabotagem, como é o caso de um exemplo entre Rio Grande e Manaus".

Após a chegada ao Porto de Belém, a roda de turbina foi então transportada por modal fluvial até Belo Monte por balsas especializadas, conforme ilustrado na imagem 8 abaixo. 
Figura 8 - Transporte de rotor de turbina por meio de balsa reforçada

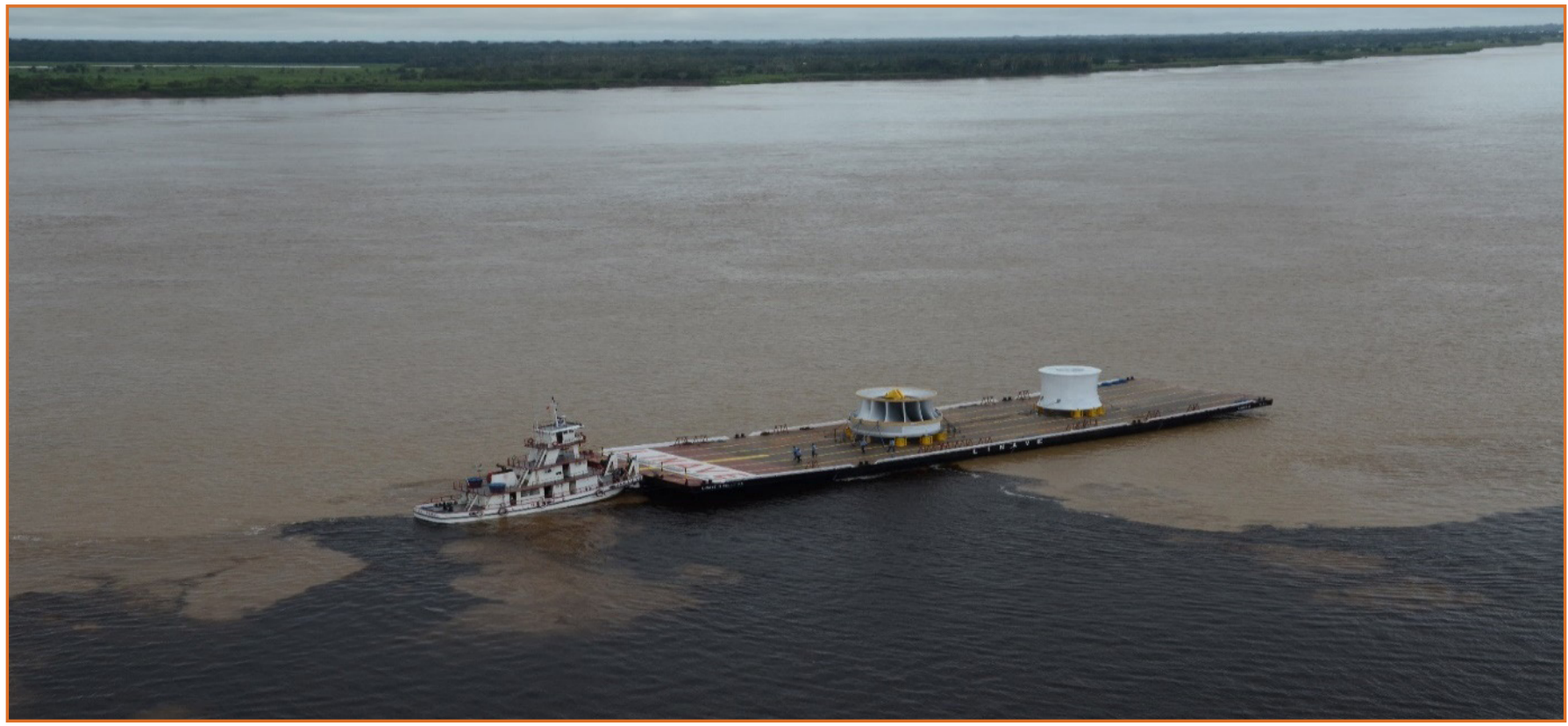

Tal navegação ocorreu pelo Rio Amazonas e, Bacia Hidrográfica "Amazônica", segundo ilustração 9 posteriormente no Rio Xingu, ambos localizados na a seguir.

Figura 9 Rios Amazonas (horizontal), Xingú (vertical). Belo Monte (sul) e Belém (Nordeste)

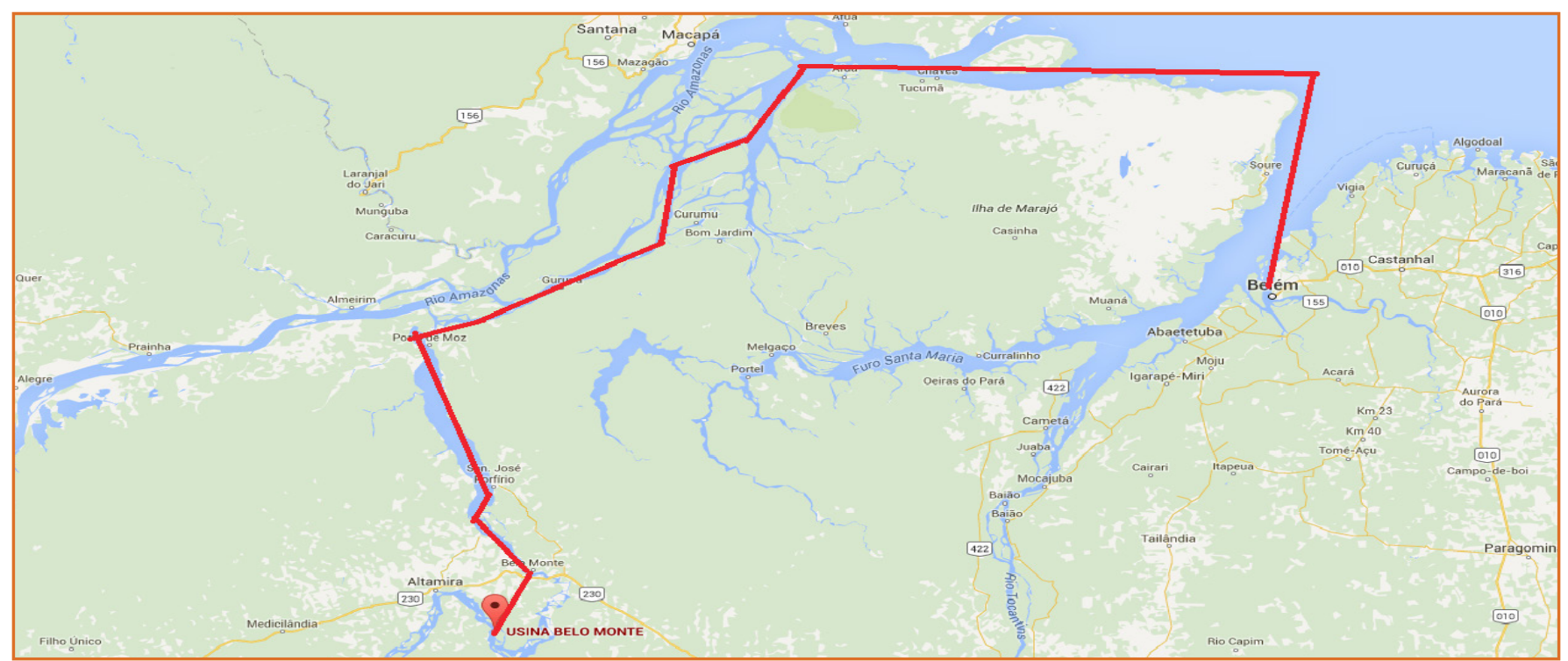

Ao final do trajeto fluvial, o rotor chegou ao seu destino: a Estação de Transbordo de Carga da Norte Energia, situada no rio Xingu (PA). Ao desembarcar por meio de uma ponte rolante, estampada na figura 10 susbsequente, a peça seguiu para a área de estocagem de equipamentos no Sítio Belo Monte a bordo de uma carreta com 16 eixos, com 256 pneus, percorrendo seis quilômetros do terminal até o canteiro de obras. 
Figura 10: Desembarque de rotor na Estação de Transbordo de Carga por ponte rolante

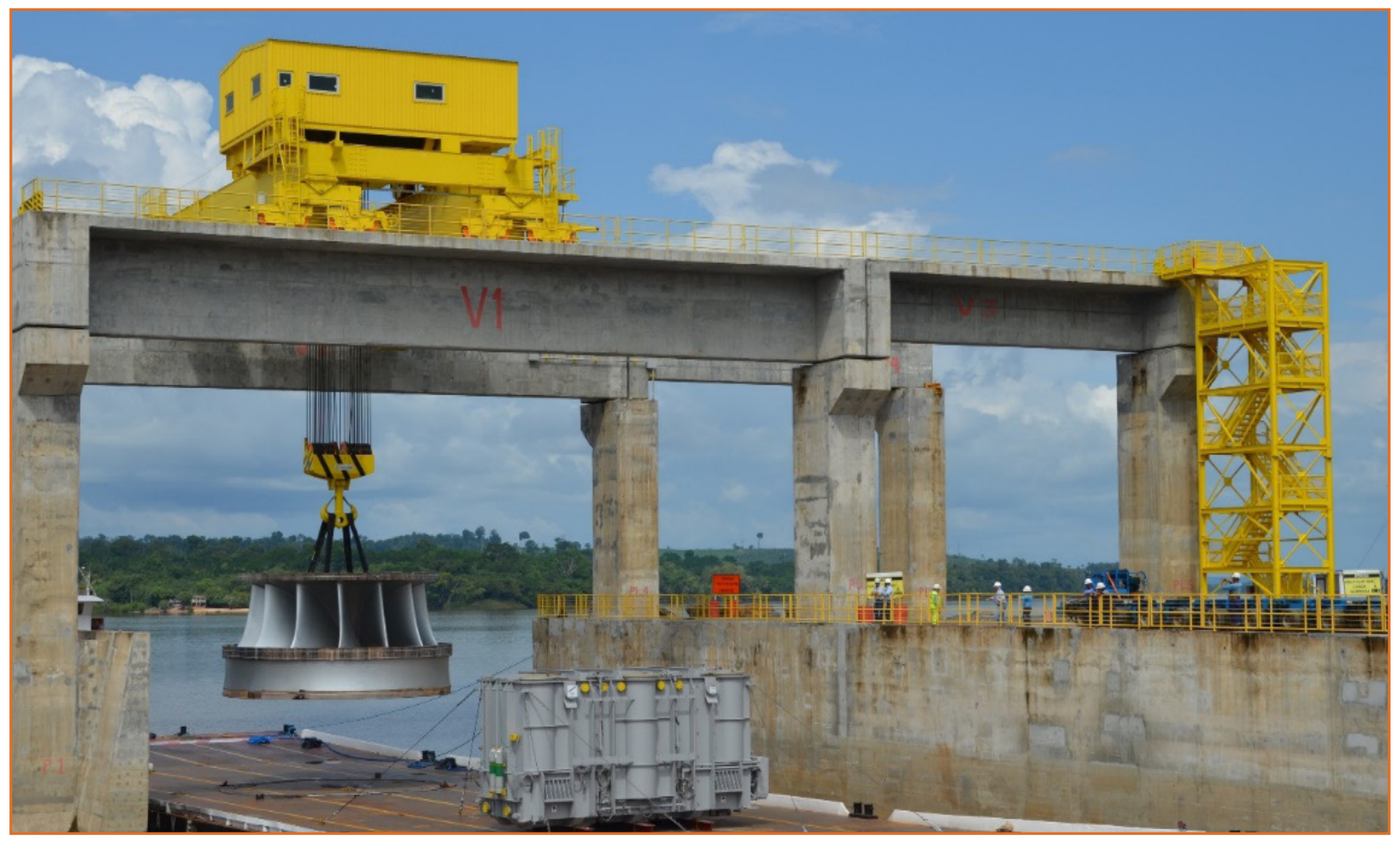

\section{CONSIDERAÇÕES FINAIS}

Após todo o levantamento do presente artigo é evidente a que a logística de transporte é de suma importância para um empreendimento do tamanho da Usina de Belo Monte.

É incontestável que uma peça, juntamente com - conjunto para transporte personalizado para a operação, que pesa mais de 600 toneladas exige um planejamento e estudo logístico altamente competente e equipamentos apropriados, o que além de complexo implica também em significativos custos.

Cabe ainda salientar que o cumprimento de todos os requisitos legais junto aos órgãos competentes não escusa o responsável pela movimentação da carga em caso de danos e prejuízos que o veículo ou combinação de veículos provocarem, ou seja, mesmo seguindo todas as exigências, o transporte em si continua sendo um momento crítico e que deve ser executado de maneira impecável. Para tanto, devem ser utilizados equipamentos adequados, profissionais capacitados e empresas especializadas.

A Transdata, empresa especializada na movimentação de cargas complexas foi a empresa responsável pelo traslado do rotor da turbina hidrelétrica em questão até o Porto de Santos, o que foi realizado sem nenhuma intercorrência, ou seja, seguiu todas as exigências legais e dos órgãos competentes para atuar com precisão.

O percurso do rotor até seu destino foi realizado de forma intermodal. A primeira parte do traslado se deu através de modal rodoviário entre Araraquara (SP) e o Porto de Santos (SP). Já a segunda parte consistiu no deslocamento de Santos até Belo Monte por navio, barcaça e caminhão. A logística empregada nesse percurso foi detalhadamente elaborada por quase 1 ano e custou cerca de $\mathrm{R} \$ 3$ milhões, o que é ainda mais contrastante se comparado ao custo de tempo de produção da peça, com respectivos, $\mathrm{R} \$ 10$ milhões e 2 anos. 
A complexidade do transporte do rotor em sua inteira logística chama a atenção por um fato curioso quando comparado a cargas não especiais: a velocidade média da peça no transporte aquaviário é superior ao do transporte rodoviário. As variáveis e empecilhos do modal rodoviário impactam consideravelmente o transporte de cargas especiais, como citado ao longo do presente trabalho. Ao compararmos com o modal aquaviário, as barreiras notavelmente diminuem restringindo-se apenas ao cuidadoso e moroso embarque e desembarque da peça.

Para enfatizar ilustrar o mencionado citada acima, basta comparar o tempo médio e quilometragem da peça percorrida em ambos os modais. No rodoviário, a peça desloca-se por de $530 \mathrm{~km}$ ao longo de trinta e um dias entre Araraquara e Santos enquanto a distância entre Santos e Belém é de 3027 km e têm a duração total de doze dias.

O transporte já é caro e complexo, mas o translado de uma carga indivisível superdimencionada é ainda mais, pois diversas exigências legais devem ser cumpridas, dado ao grande volume e potencial danoso de alguma intercorrência.

\section{REFERÊNCIAS}

[1] ANDRITZ. Disponível em: https://www.andritz.com/hyandritz-hydro-brasil-limitada-sao-paulo-brazil. Acesso em 20 maio. 2016.

[2] CÓDIGO DE TRÂNSITO BRASILEIRO. Disponível em: http://www.ctbdigital.com.br/. Acesso em 20 abr. 2016.

[3] CONCECIONÁRIA CCR AUTOBAN. Disponível em: http://www.autoban.com.br/noticias. Acesso em 29 abr. 2016.

[4] CONCESSIONÁRIA CCR RODOANEL. Disponível em: http://www.rodoaneloeste.com.br/. Acesso em 31 maio. 2016.
[5] CONSELHO NACIONAL DE TRÂNSTO. Disponível em http://www.guiadotrc.com.br/lei/res1298.asp. Acesso em 20 abr. 2016

[6] DEPARTAMENTO NACIONAL DE TRÂNSITO. Disponível em http://www.denatran.gov.br/ctb.htm. Acesso em 20 abr. 2016.

[7] ISTO É. Disponível em: http://www.istoedinheiro.com.br/ noticias/economia/20160505/dilma-participa-inauguracaooperacao-comercial-usina-belo-monte/369684. Acesso em 17 maio. 2016.

[8] KEEDI, Samir. ABC do Comércio Exterior: abrindo as primeiras páginas. 4 ed. São Paulo: Aduaneiras, 2011.

[9] MINISTÉRIO DOS TRANSPORTES. Disponível em: <http://www.transportes.gov.br/transporte-aquaviariorelevancia/52-sistema-de-transportes/1436-conceitoshidroviarios.html> Acesso em: 22 abr. 2016.

[10] NORTE ENERGIA S.A. Disponível em: <http:// norteenergiasa.com.br/site/2015/02/21/apos-viagem-de-5mil-km-novo-rotor-gigante-chega-a-belo-monte/> Acesso em 12 maio. 2016

[11] _. Disponível em: <http://norteenergiasa.com.br/ site/2015/01/15/rotor-de-320-toneladas-ja-esta-a-caminhode-belo-monte/> Acesso em 12 maio. 2016.

[12] O CARRETEIRO. Disponível em: <http://www.ocarreteiro. com.br/revista/operacao-gigante-ate-nos-detalhes/> Acesso em 5 maio. 2016.

[13] PÉ NA ESTRADA. Disponível em: https://www.youtube. com/watch?v=oq5gJXuuJM4. Acesso em 04 maio. 2016.

[14] PORTAL MORADA. Disponível em: http://portalmorada. com.br/noticias/policia/transporte-de-rotor-vai-durar-90dias-de-araraquara-a-belo-monte:53670. Acesso em 04 maio. 2016

[15] TRANSDATA. Disponível em: <http://transdata.com.br/ megaoperacao-de-transporte-de-um-dos-maiores-rotoresfabricados-no-mundo/> Acesso em 12 maio. 2016.

[16] WERNECK, Paulo. Comércio Exterior \& Despacho Aduaneiro. 4 ed. Curitiba: Juruá, 2008. 


\section{CAPÍTULO 15}

Marcelo Gorri Mazzali

Ieda Kanashiro Makiya

Francisco Ignácio Giocondo Cesar

Resumo: Sabe-se que toda transportadora que trabalhar com produtos farmacêuticos deve manter um Responsável Técnico com Registro no respectivo CRF e todos devem ser solidários no controle e garantia da qualidade, assim como a sua gestão por garantir a qualidade dos medicamentos em toda sua cadeia até o consumo final. Sempre que identificar alguma irregularidade, deve solicitar as devidas correções e adequações afim de garantir a qualidade do produto. Este trabalho tem o objetivo de verificar como é a atuação do profissional farmacêutico dentro da cadeia logistica de fármacos, em transportadora visto a atual regulamentaçáo e controle mais eficiente do sistema, dadas as especificidades do produto, intrinsecamente relacionadas à segurança e saúde pública, com sérios desdobramentos vinculados ao gerenciamento de riscos dessa cadeia. Para análise do perfil dos profissionais atuantes nesse segmento, desenvolveu-se um survey no estado de São Paulo, compreendendo as cidades de Campinas, Americana, Jundial, Limeira, Valinhos, Vinhedo, Hortolândia e São Paulo, devido à proximidade do Aeroporto de Viracopos, origem da distribuição de grandes lotes desses produtos, e ao Projeto de Lei n. 542 de 2013, que torna obrigatória a presença de farmacéutico responsável técnico nos quadros das empresas transportadoras de medicamentos e insumos farmacêuticos para o Estado de São Paulo. Os dados foram levantados em transportadoras, operadores logísticos, centros de distribuição e armazenadores. Ao total foram entrevistados 221 empresas que atuam com a cadeia de produtos farmacêuticos.

Palavras chave: descarte, lixo eletrônico, estudantes universitarios. 


\section{INTRODUÇÃO}

A área de logística e transporte farmacêutico no Brasil vem crescendo ano após ano, sendo o principal modal de deslocamento desta carga, o transporte rodoviário, o cuidado na conservação dos produtos farmacêuticos durante o processo de transporte é fundamental, pois incorpora os princípios de segurança e eficácia terapêutica, essenciais para que um produto farmacêutico esteja apropriado ao consumo humano. Tais características devem manter-se íntegras, através de toda a cadeia produtiva e de distribuição, mediante a fidelidade às premissas estabelecidas para cada uma das fases que integram o sistema (FIGUEIREDO et al., 2003).

Segundo (ZARDO, HUMBERTO, 2012), o desafio do gerenciamento da qualidade na cadeia logística da área do transporte, pode ser definido como o processo de planejar, implementar e controlar de forma eficiente, efetiva e sistemática, utilizando serviços e informações de um ou mais pontos de origem aos pontos de distribuição e consumo.

No Brasil ainda há problemas em relação a legislação na forma de lei ou resolução, custos e responsabilidades tanto do fabricante como do transportador, falta de transporte especializado na cadeia do frio e fracionamento de carga, não há uma obrigatoriedade de que o transporte deva ser feita com os critérios qualitativos da carga, somente há menções em relação de manter a mesma qualidade durante o transporte, por estes motivos a carga que deveria ser transportada em um caminhão refrigerado ou isotérmico por exemplo, acaba sendo transportado como carga seca normal (FIGUEIREDO et al., 2003).

Como é uma área ainda pouco explorada e dinamizada no Brasil, este estudo avalia a atuação do profissional farmacêutico na área de qualidade e operacional, visto sua responsabilidade técnica, civil e criminal durante o processo de transporte, quando não objetivadas a manter as características qualitativas até o consumo final, pode trazer riscos à saúde pública e riscos fitossanitários.

Tendo como objetivo principal, mostrar a importância do farmacêutico em transportadoras, atuando diretamente com a qualidade e operacional, garantindo desta forma as propriedades qualitativas dos produtos farmacêuticos até o consumidor final e não só como um cumpridor de legislação para a transportadora perante os órgãos legisladores.

\section{REVISÃO DE LITERATURA 2.1 QUALIDADE}

Paraentender sobre a qualidade, énecessário conhecer o significado do termo. A palavra qualidade, vem do latim 'qualitate', qualidade é hoje uma palavra chave muito difundida nas empresas: fácil de falar e difícil de fazer. Ao mesmo tempo, existe pouco entendimento do que vem a ser qualidade, definição da qualidade possui uma extrema diversidade de interpretação, dada por diversos autores, que procuram dar uma definição simples para que seja assimilável a todos os níveis das organizações (MELLO et al., 2009).

A dificuldade em definir qualidade está na renovação das necessidades futuras do usuário em características mensuráveis, de forma que o produto possa ser projetado e modificado para dar satisfação por um preço que o usuário possa pagar (OLIVEIRA, 2004).

\subsection{GESTÃO DA QUALIDADE}

Segundo (OLIVEIRA, 2004), "sistema de gestão da qualidade é apenas um conjunto de recursos e regras mínimas, implementado de forma adequada, com o objetivo de orientar cada parte da empresa para que execute de maneira correta e no tempo devido a sua tarefa, em harmonia com as outras, estando todas direcionadas para o objetivo comum da empresa: ser competitiva (ter qualidade com produtividade)", entendendo-se como qualidade a satisfação dos clientes e produtividade, fazer mais com cada vez menos recursos.

Para (CARVALHO E PALADINI, 2005), a Gestão da Qualidade consiste no conjunto de atividades coordenadas para dirigir e controlar uma organização com relação à qualidade, englobando o planejamento, - controle, a garantia e a melhoria da qualidade. Já a Qualidade Total trata-se do modo de gestão de uma organização, centrado na qualidade, baseado 
na participação de todos os seus membros, visando ao sucesso a longo prazo, por meio da satisfação do cliente e dos benefícios para todos os membros da organização e sociedade.

\subsection{TRANSPORTE TERRESTRE DE CARGAS}

O transporte rodoviário de cargas no Brasil é uma atividade econômica de natureza comercial, exercida por pessoa física ou jurídica em regime de livre concorrência, e depende de prévia inscrição do interessado em sua exploração no Registro Nacional de Transportadores Rodoviários de Cargas - RNTR-C da Agência Nacional de Transportes Terrestres - ANTT, Regulado pela Lei no 11.442, de 5 de janeiro de 2007.

Por ser o modal mais utilizado, segundo estimativas da Associação Nacional dos Transportes de Cargas (NTC), circulam pelo Brasil cerca de 60 milhões de toneladas de carga/ano.
(ZARDO, 2016) afirma que o transporte continua sendo essencial para que seja atingido o objetivo logístico, que consiste em disponibilizar o produto certo, na quantidade certa, na hora certa e no lugar certo, ao menor custo possível, podendo proporcionar soluções competitivas para os clientes, neste sentido, o transporte possui um papel fundamental no desempenho de várias dimensões do serviço ao cliente.

A logística de transporte constitui um grande problema por apresentar um sistema complexo que demanda tempo, treinamento de pessoal, roteirização, dimensionamento de frota de veículos e localização (DISTRIBUIÇÃO E TRANSPORTES, 2014; FIGUEIREDO, et al., 2003).

Gráfico 1 - Matriz Brasileira de Transportes, adaptado de Plano Nacional de Logística e Transportes 2013.

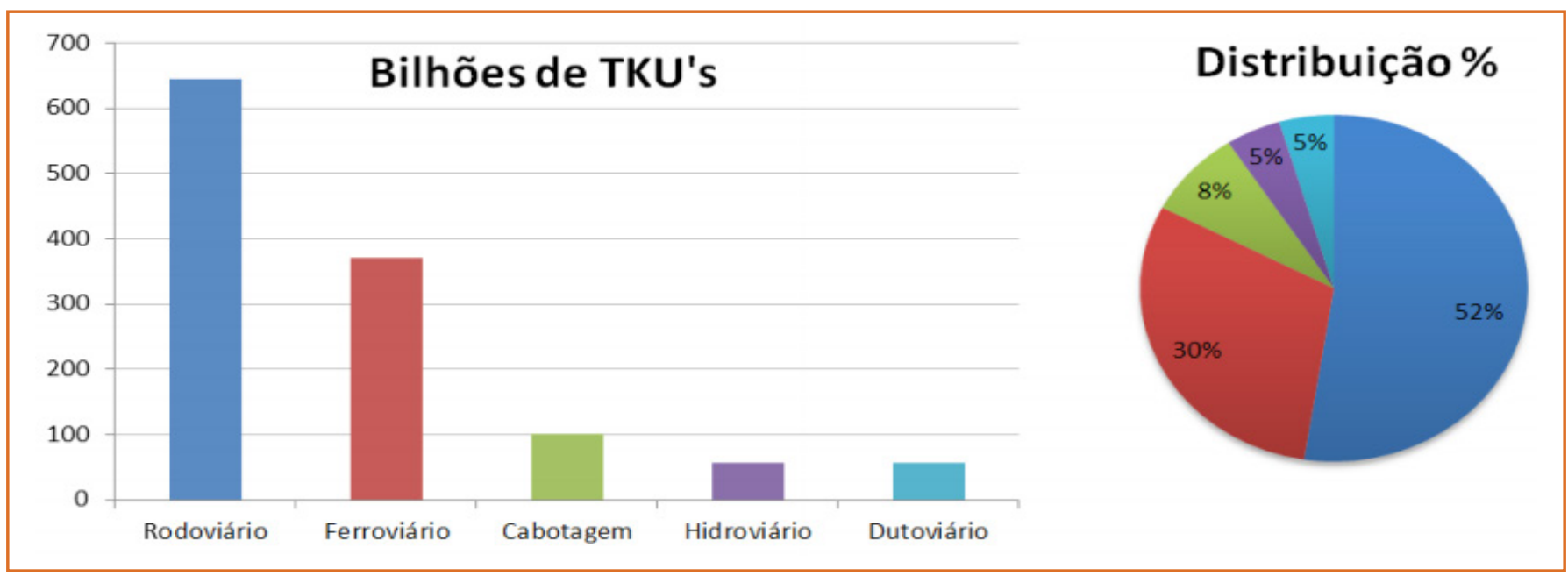

\subsection{TRANSPORTE DE PRODUTOS FARMACÊUTICOS}

Em (WHO, 2011), manter a qualidade dos produtos farmacêuticos, todas as etapas da cadeia de distribuição devem cumprir com as legislações e regulamentações. Todas as atividades de logística de produtos farmacêuticos devem ser realizadas de acordo com os princípios das boas práticas de fabricação (BPF), boas práticas de armazenagem (BPA), boas práticas de distribuição (BPD) e boas práticas de transporte (BPT), estas etapas do transporte influenciam diretamente na segurança e eficácia dos medicamentos, porém não são bem desempenhadas, em relação à garantia da qualidade dos medicamentos, pelas transportadoras, pois as legislações brasileiras que referenciam essas etapas são muito deficitárias, tornando a fiscalização, pelos órgãos reguladores, ineficientes.

O transporte de produtos farmacêuticos no Brasil é 
referenciado ainda por legislações muito antigas. As normas que citam essas etapas datam de $1973 \mathrm{com}$ a Lei 5991/73 com a Lei 6360/76.

No transporte de medicamentos a malha rodoviária gera ainda mais transtornos. Para atender grandes distâncias o custo da operação encarece para o consumidor final e coloca em risco a qualidade do produto devido à demora desse processo. Fatores como temperatura, tempo de armazenagem, forma de acondicionamento, umidade, luz, se não muito bem controlados podem gerar instabilidade aos produtos diminuindo a eficácia, segurança e qualidades, podendo gerar graves problemas de saúde, (VERGARA, 2006).

No transporte de produtos farmacêuticos, um dos itens mais importantes é a temperatura. A condição interna do veículo, a quantidade de volumes, distância do trajeto, duração da viagem, o carregamento e descarregamento, podem influenciar diretamente na perda da eficácia do produto, em virtude da oscilação de temperatura e umidade, (RODRIGUES, 2006).

Segundo (MELLO et al., 2009), O binômio tempo e temperatura consistem em controlar, eliminar ou diminuir o número de riscos durante o processamento, manipulação e distribuição destes produtos.

A verificação e manutenção da cadeia de frio estendemse desde o recebimento da matéria prima ou produto final, passando pelo armazenamento e transporte, tendo como objetivo assegurar as características dos produtos, evitar perdas das propriedades farmacológicas e econômicas, fornecendo ao consumidor produtos de ótima qualidade, (OLIVEIRA, 2004).

Não olhar para esse cenário é assumir riscos que envolvem a saúde pública. Todo produto farmacêutico possui uma faixa de temperatura de conservação, independentemente de qual seja, deve ser mantida durante toda a sua vida, (DORNIER, 2000).

\subsubsection{PAPEL DO FARMACÊUTICO TRANSPORTADORA E CADEIA DO FRIO}

EM

Segundo a Deliberação no 295, de 22 de dezembro de 2012 do CRF-SP e RESOLUÇÃO № 433 de 26 de abril de 2005 do CFF.

Tabela 1: Atribuições essenciais do Farmacêutico que atua nas empresas transportadoras

\begin{tabular}{|l|l|l|}
\hline $\begin{array}{l}\text { Conhecer, interpretar e cumprir a legislação sanitária } \\
\text { e demais normas correlatas mantendo-se atualizado; }\end{array}$ & $\begin{array}{l}\text { Assegurar que todos os } \\
\text { medicamentos transportados se } \\
\text { encontrem devidamente registrados } \\
\text { junto à autoridade sanitária; }\end{array}$ & $\begin{array}{l}\text { Criar programas de inspeção, entre os quais } \\
\text { os procedimentos de limpeza predial e dos } \\
\text { veículos e controle de pragas do armazém / } \\
\text { terminal e dos veículos. }\end{array}$ \\
\hline $\begin{array}{l}\text { Supervisionar e adequar segundo as normas de } \\
\text { Boas Práticas os procedimentos operacionais e a } \\
\text { conferência de documentos em todas as etapas } \\
\text { do serviço de transporte, entre eles a coleta, o } \\
\text { desembarque no Armazém ou Terminal, o manuseio } \\
\text { ou separação, o carregamento e entrega ao } \\
\text { destinatário; }\end{array}$ & $\begin{array}{l}\text { Estudar, avaliar e implantar as } \\
\text { normas das Boas Práticas de } \\
\text { Transporte e suas adequações; }\end{array}$ & $\begin{array}{l}\text { Acompanhar as ocorrências operacionais } \\
\text { (avarias, extravios, sobras) e assegurar } \\
\text { o cumprimento dos prazos para } \\
\text { solução, visando manter a segurança e } \\
\text { rastreabilidade dos produtos; }\end{array}$ \\
\hline $\begin{array}{l}\text { Criar programas de monitoramento de Temperatura } \\
\text { e Umidade no Armazém / Terminal e no trajeto do } \\
\text { veículo de transporte, caso necessário; }\end{array}$ & $\begin{array}{l}\text { Participar do desenvolvimento } \\
\text { de programas de estudo do } \\
\text { monitoramento de temperatura no } \\
\text { trajeto de transporte e acompanhar } \\
\text { a implantação das medidas } \\
\text { corretivas / preventivas; }\end{array}$ & $\begin{array}{l}\text { Realizar a Padronização dos Procedimentos } \\
\text { Operacionais. }\end{array}$ \\
\hline
\end{tabular}

Fonte: Adaptado pelo autor da Deliberação no 295, de 22 de dezembro de 2012 


\section{METODOLOGIA}

A estrutura do trabalho aborda primeiramente uma revisão bibliográfica dos principais conceitos de qualidade, de transporte, qualidade do transporte, gestão de qualidade, papel do farmacêutico em transportadora e cadeia do frio, cadeia do frio.

Após a revisão bibliográfica, a aplicação do trabalho baseou-se em um estudo estatístico realizado em várias empresas transportadoras na região de Campinas-SP.

\section{4.. ESTUDO DE CASO}

O estudo de caso aqui apresentado é de empresas transportadoras de produtos farmacêuticos na região de Campinas-SP, onde visa verificar-se a atuação do farmacêutico nestas empresas transportadoras tanto do lado da qualidade como também na área operacional.

\section{DISCUSSÃO E RESULTADOS}

Nosso espaço amostral foi composto de dados levantados em transportadoras. Ao total foram entrevistadas 180 empresas transportadoras que atuam com a cadeia de produtos farmacêuticos na região de Campinas, Valinhos, Vinhedo, Jundiaí, Hortolândia, Indaiatuba, Americana, Sumaré, onde 145 empresas retornaram as entrevistas conforme mostrado no Gráfico 2 a seguir.

Segundo dados levantados no site do CRF-SP, hoje o estado de São Paulo possui cerca de 676 transportadoras, sendo estas cadastradas junto ao órgão.

Gráfico 2 - Perfil das empresas transportadoras entrevistadas

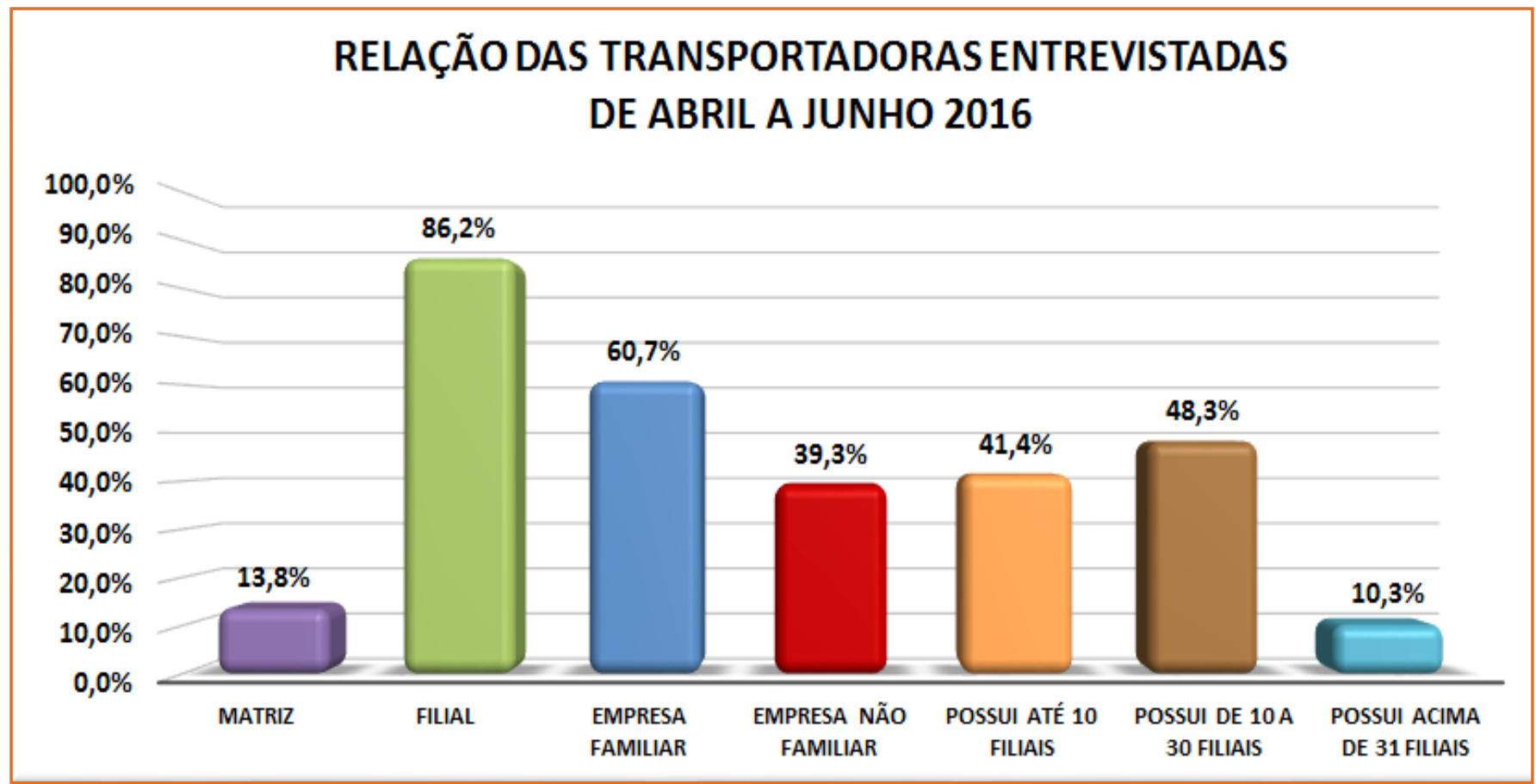

Das empresas entrevistadas $13,8 \%$ são matriz e $86,2 \%$ filial, das quais ainda 60,7\% empreendem grupo familiar na estrutura de direção para 39,3\% de empresas composta por acionistas não familiares, onde $41,4 \%$ possuem até 10 filiais, $48,3 \%$ de 10 a 30 filiais e 10,3\% acima de 31 filiais, predominando-se então grupo familiar na constituição da empresa e uma maior concentração de filiais nesta região. 


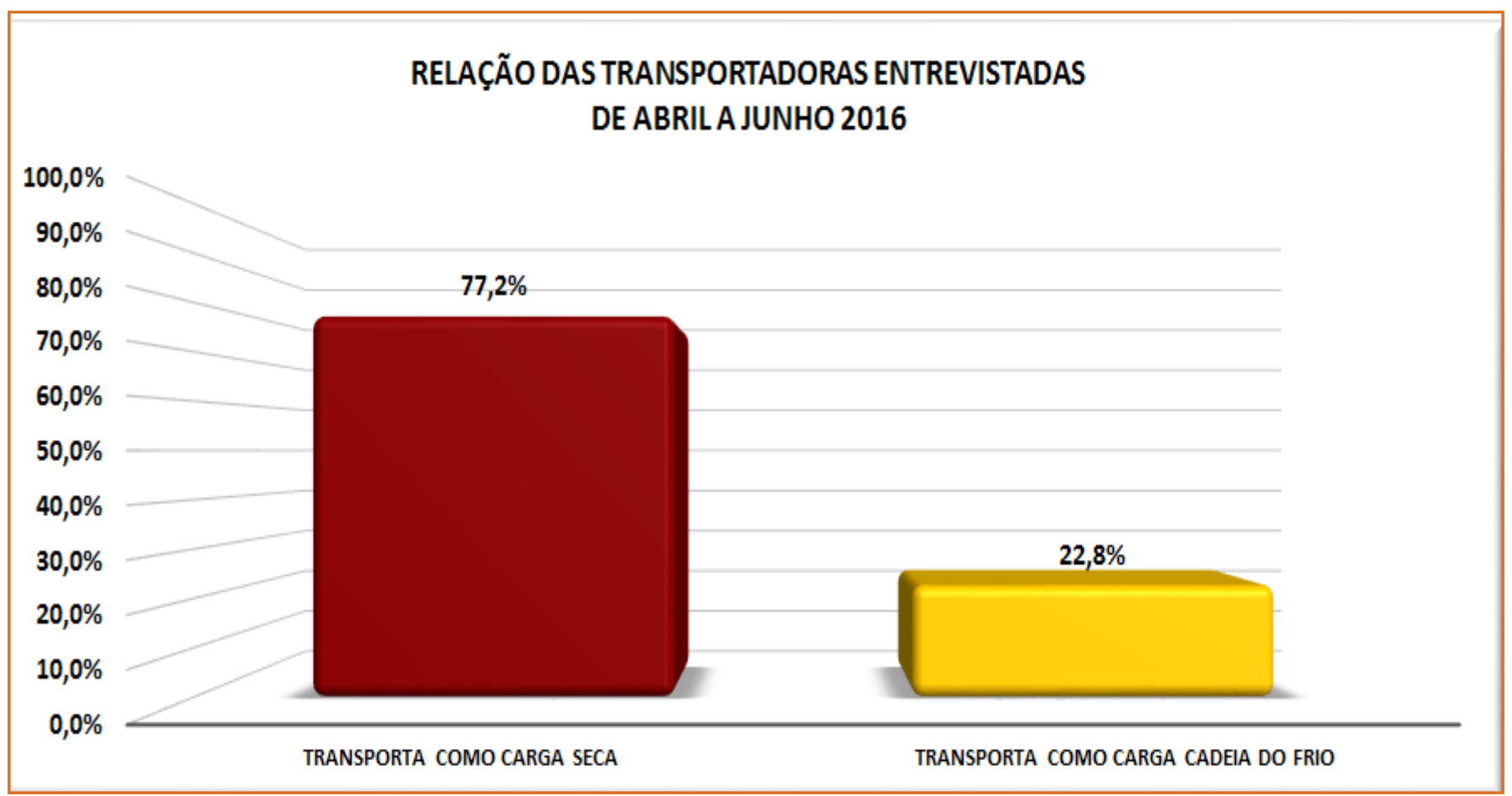

Das 145 empresas que responderam ao questionário, $77,2 \%$ transporta as mercadorias farmacêuticas como carga seca normal e somente $22,8 \%$ transportam corretamente como carga da cadeia do frio, seguindo as boas práticas de mercado. Como a grande maioria transporta como carga seca, o produto apresenta maior probabilidade de danos farmacológicos, perdendo então sua totalidade em eficiência e eficácia.

Gráfico 4 - Perfil das empresas transportadoras entrevistadas

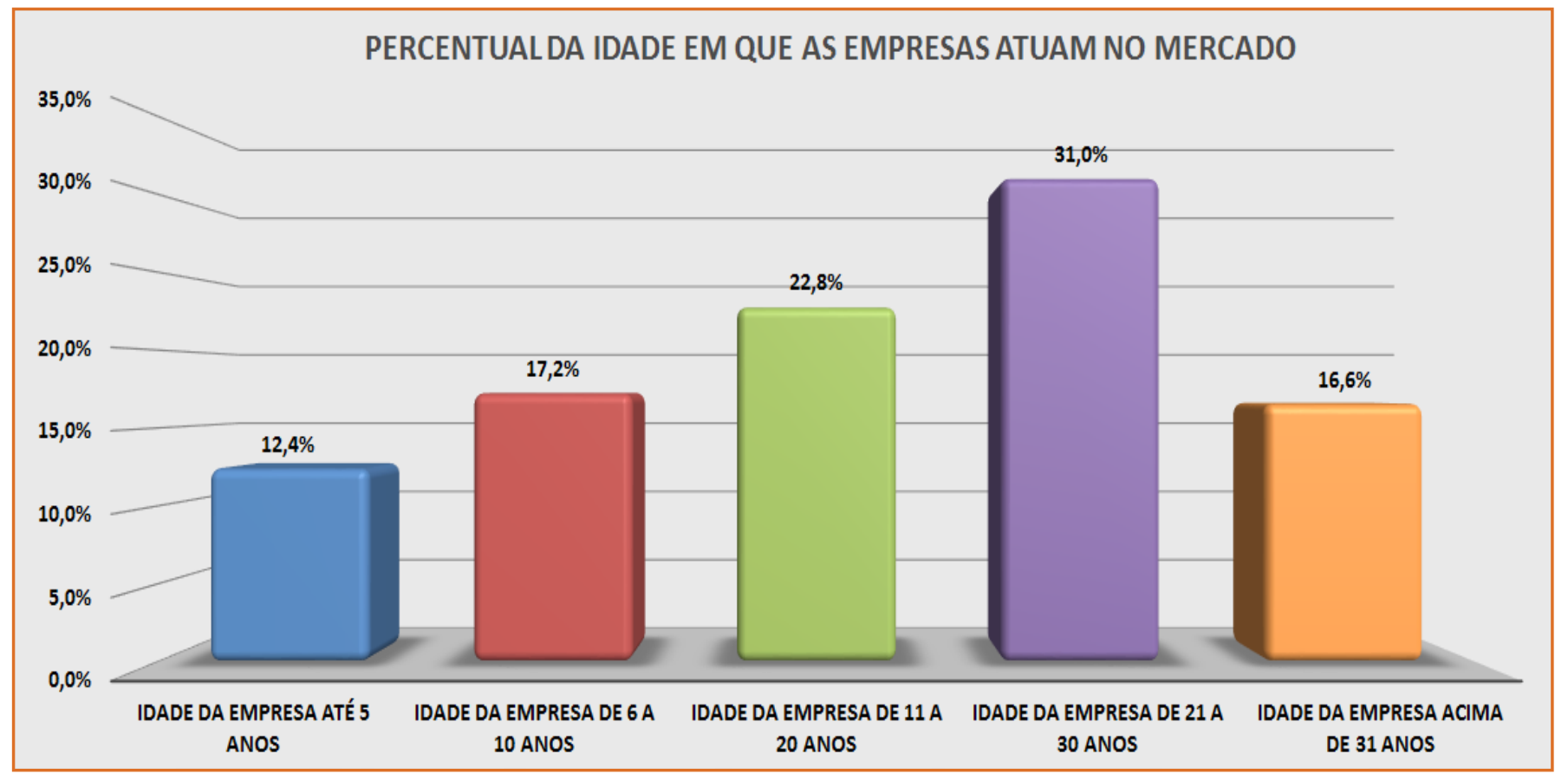




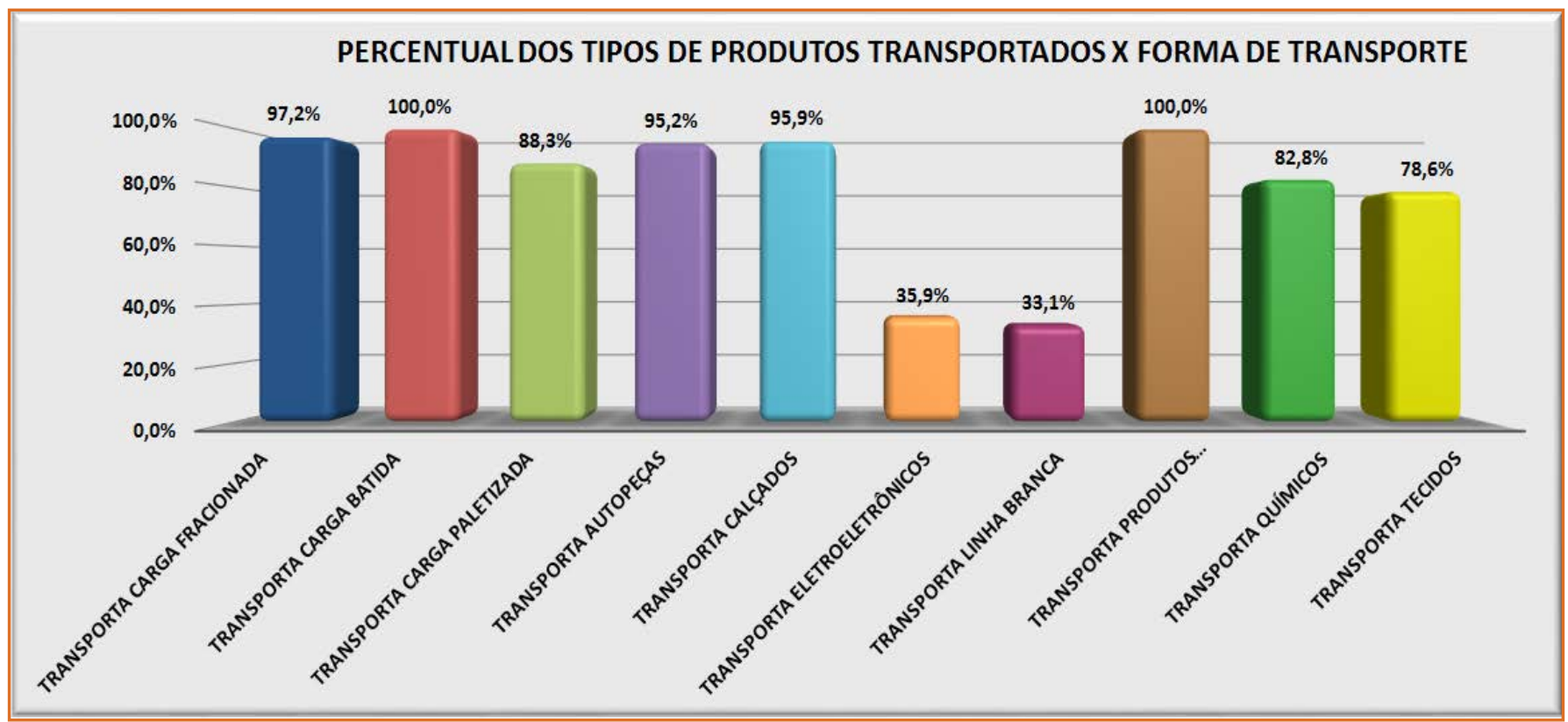

Em referência ao tipo de produto transportado por estas empresas, temos que $88,3 \%$ a $97,2 \%$ transportam carga fracionada e paletizada, e 100\% também transportam cargas batidas, de 78,6\% a
95,9\% transportam, tecidos, calçados, autopeças, eletroeletrônicos, produtos químicos e 100\% transportam produtos farmacêuticos, lembrando que somente $22,8 \%$ transporta como cadeia do frio conforme Gráfico 3.

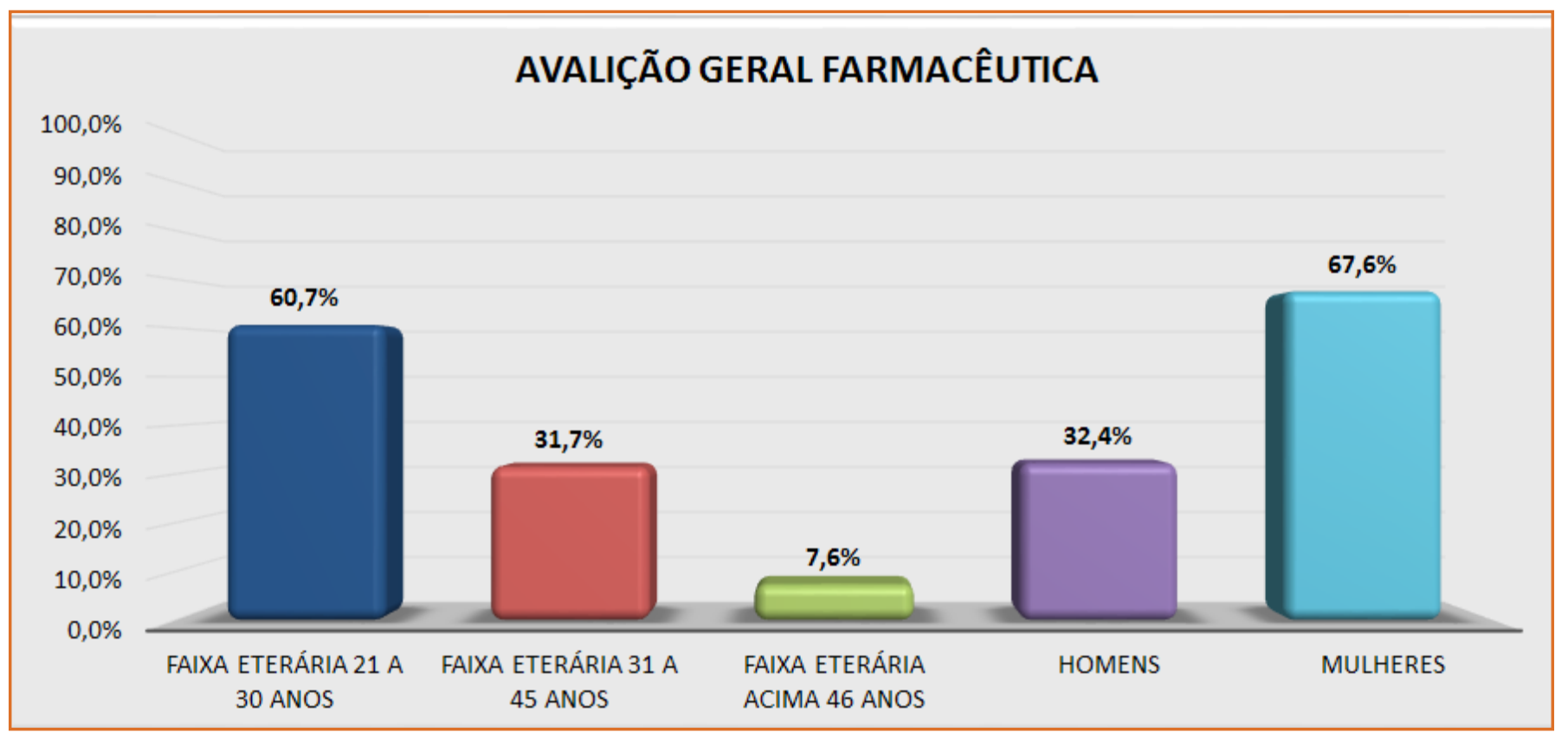


O perfil dos farmacêuticos é de 32,4\% de homens para $67,6 \%$ de mulheres, a predominância dos entrevistados tem entre 21 e 30 anos de idade, que corresponde à
$60,7 \%$, sendo que também há uma predominância de 31 a 45 anos com 31,7\% e 7,6\% acima de 46 anos.

Gráfico 7 - Perfil do tempo de atuação dos farmacêuticos entrevistados

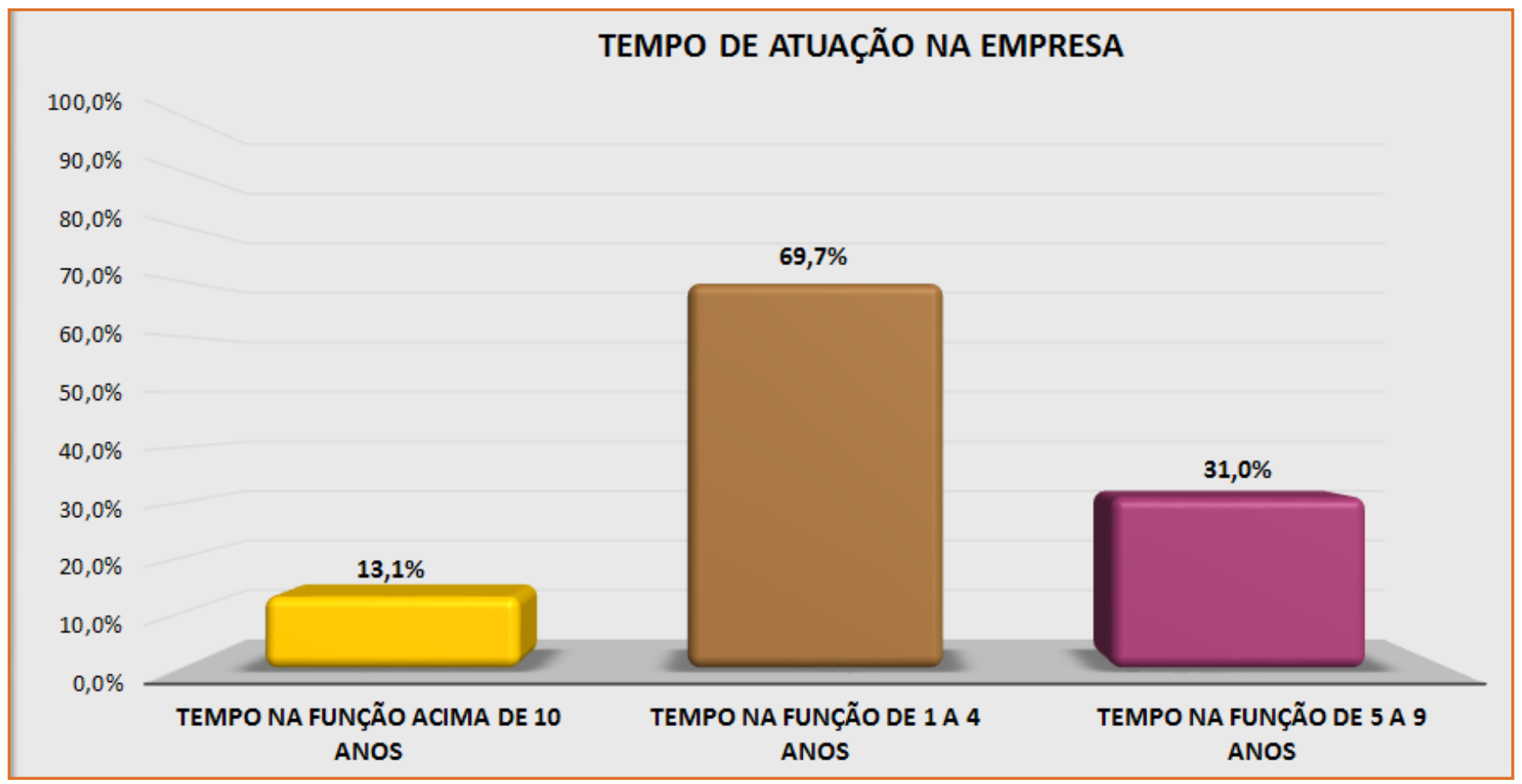

Nota-se que a uma predominância de recém formados atuantes nesta empresas englobando 69,7\% de 1 a 4 anos de experiência, para $31,0 \%$ de 5 a 9 anos na função e somente $13,1 \%$ acima de 10 anos, isso pode trazer um dado importante quanto ao tunover da empresa onde há uma grande rotatividade de profissional, que pode ser devido a salário, função exercida, trabalho condizente com o que é obrigado por legislação.

Gráfico 8 - Perfil do tipo de pós-graduação que fez

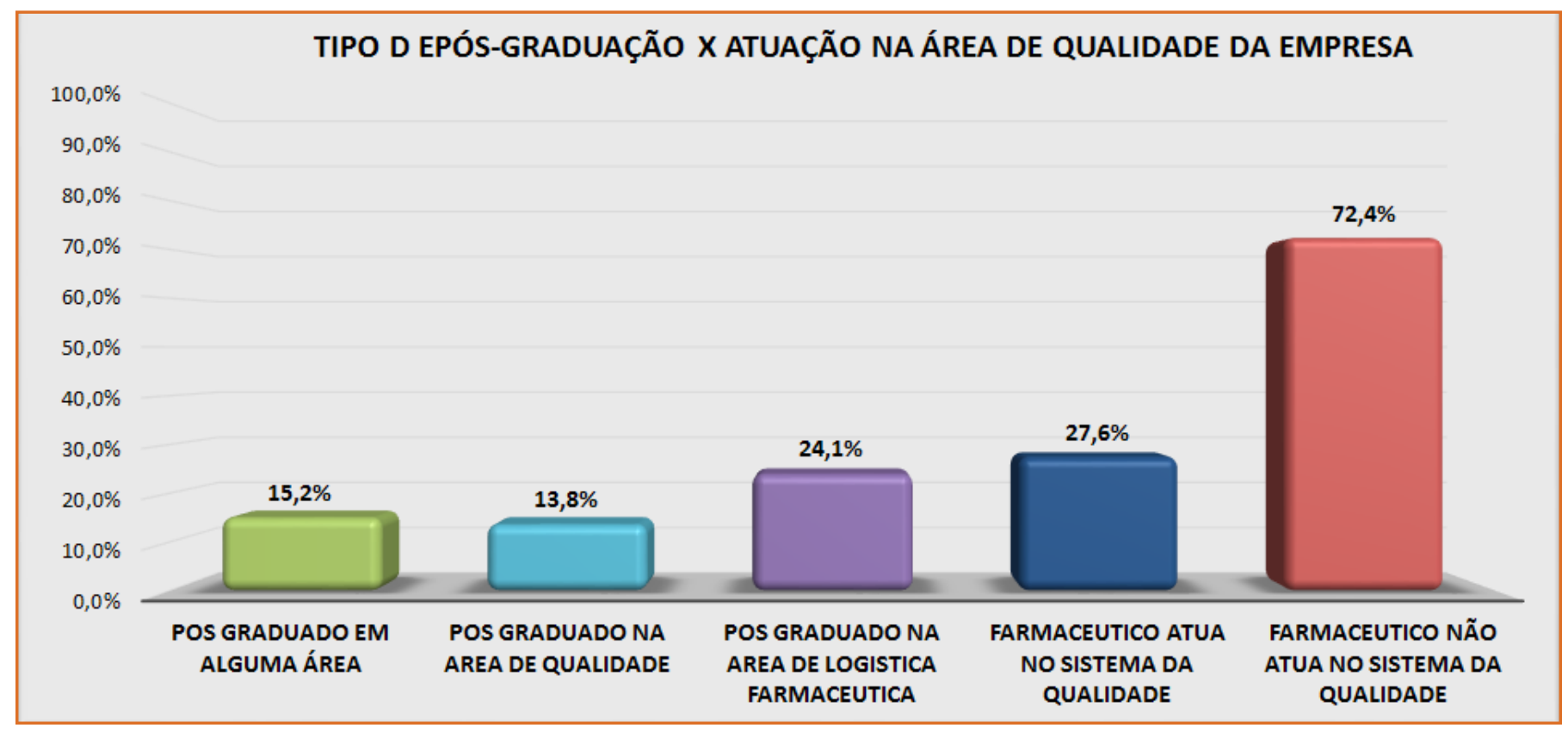


Neste gráfico podemos notar que somente $53,1 \%$ dos farmacêuticos possuem pós-graduação, onde 13,8\% é na área de qualidade, $24,1 \%$ na área de logística farmacêutica, 15,2\% fez algum tipo de pós-graduação e que 46,9\% não fez nenhuma pós graduação.

Dos entrevistados 72,4\% não atua no sistema da qualidade e somente $27,6 \%$ atuam.

Gráfico 9 - Tipos de certificações que as empresas possuem

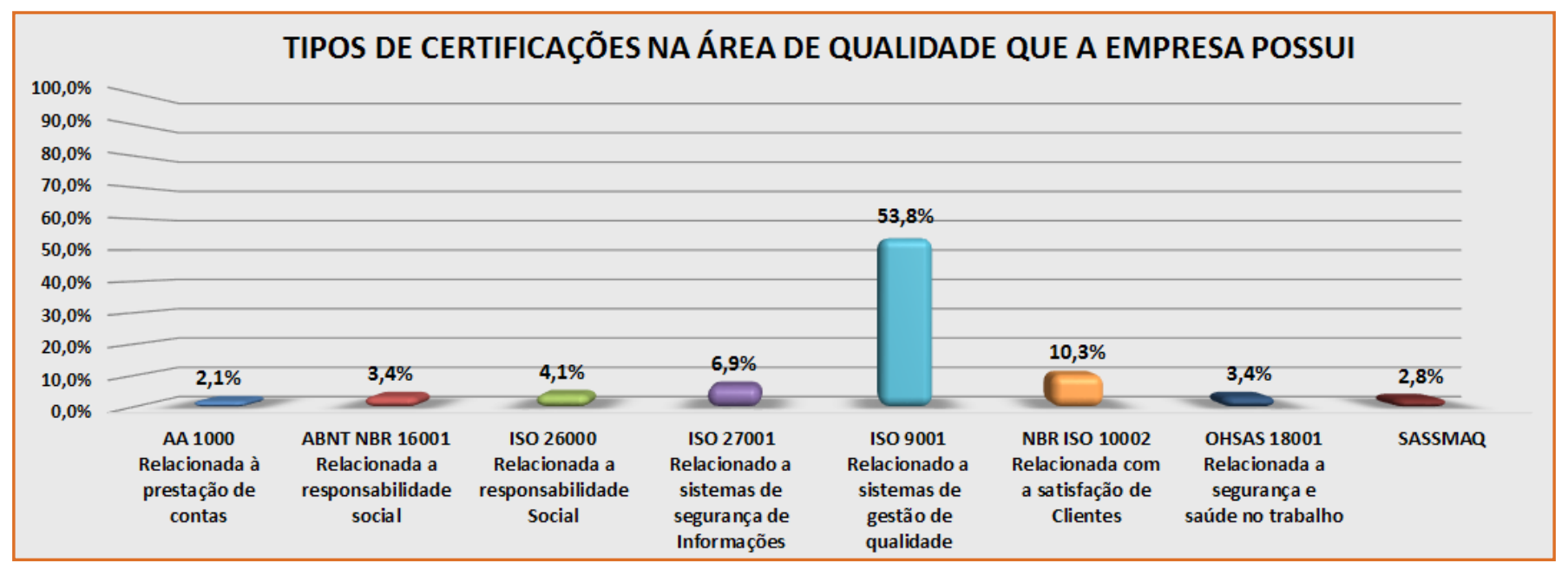

\section{CONCLUSÕES}

Inicialmente no trabalho foi muito comentado sobre a atuação do farmacêutico na gestão da qualidade em empresas transportadoras de produtos farmacêuticos, onde este é uma peça chave para o sucesso da empresa de forma a garantir que o produto final chegue ao consumidor com total qualidade de efeito farmacológico esperado, diminuindo quaisquer riscos de eventos adversos, intoxicação ou efeitos colaterais. Podemos concluir pelos dados que há uma gama grande de farmacêuticos recém-formados sem muita experiência na área de logística e que demonstram pouco conhecimento de gestão de qualidade e simplesmente estão cumprindo a parte de legislação vigente, não se preocupando muito com as mercadorias, com a desculpa que os gerentes ou donos não querem este tipo de serviço, principalmente por ser de empresa familiar.

Nota-se ainda que na grande maioria destas empresas os sócios-diretores assim como as gerências não querem aplicar este conceito devido ao custo, tempo de permanência do farmacêutico na empresa para desenvolver este tipo de trabalho dentro da área de gestão de qualidade.
Fica claro que uma pequena quantidade das empresas entrevistadas, o nível de serviço é outro, pois além de terem pós-graduação na área de logística e qualidade, atuam na área de qualidade da empresa e possuem tempo de experiência no trabalho além de serem conhecedores de gestão de qualidade e aplicam este conceito na realidade, trazendo vários benefícios à empresa como fidelidade de clientes, alta qualidade dos processos logísticos garantindo desta forma a qualidade do produto até o consumidor final, a equipe operacional é bem treinada e orientada entendendo o processo como um todo e não parcialmente, comprometimento com a mercadoria.

De forma objetiva, foi evidenciado que poucos farmacêuticos conhecem e aplicam o conceito de gestão da qualidade farmacêutica, é algo que o CFF poderia começar a trabalhar junto a comissão de matrizes curriculares tanto do CFF como dos CRF's, para que o farmacêutico saia da faculdade com um conhecimento melhor do que é gestão farmacêutica e a sua real necessidade de aplicação, pois pudemos evidenciar que em poucas empresas aplicadas este conceito de gestão, o nível de serviço é de excelente qualidade. 


\section{REFERÊNCIAS}

[1] MINISTÉRIO DA SAÚDE. LEI 5991, DE 17 DE DEZEMBRO DE 1973. Brasília, DF. Disponível em: http://www.anvisa.gov. br/legis/consolidada/lei_5991_73.htm. Acesso em: 10 mar. 2016.

[2] MINISTÉRIO DA SAÚDE. LEI 6360, DE 23 DE SETEMBRO DE 1976. Disponível em: http://www.anvisa.gov.br/legis/ consolidada/lei_6360_76.pdf. Acesso em: 10 mar. 2016.

[3] CONSELHO FEDERAL DE FARMÁCIA. RESOLUÇÃO No 365, DE 2 DE OUTUBRO DE 2001. Disponível em: http:// www.crfsp.org.br/legislacao/784-resolucao-365-de-2-deoutubro-de-2001.html. Acesso em: 10 mar. 2016.

[4] CONSELHO FEDERAL DE FARMÁCIA. RESOLUÇÃO N 433, DE 26 DE ABRIL DE 2005. Disponível em: http://www. crfsp.org.br/legislacao/751-resolucao-433-de-26-de-abrilde-2005.html. Acesso em: 10 mar. 2016.

[5] CARVALHO, MARLY MONTEIRO, PALADINI, EDSON PACHECO. Gestão da Qualidade: Teoria da Qualidade. Rio de Janeiro: Campos. 2005.

[6] DISTRIBUIÇÃO E TRANSPORTES. São Paulo: Conselho Regional de Farmácia de São Paulo. Comissão Assessora de Distribuição e Transportes, ed.2, 2009. Disponível em: http:// www.crfsp.org.br/comissoes-assessoras-/343-um-roteirogeral-do-ambito-farmaceutico.html. Acesso em: 10 mar. 2016.

[7] DORNIER, PHILIPPE-PIERRE et al. Logística e operações globais: texto e casos. São Paulo: Atlas, 2000.
[8] FIGUEIREDO, KLEBER FOSSATI; FLEURY, PAULO FERNANDO; WANKE, PETER, MARQUES,VITOR; LACERDA,LEONARDO; RIBEIRO,ALINE. Logística e Gerenciamento da Cadeia de Suprimentos: Planejamento do Fluxo de Produtos e dos Recursos. 1. ed. 3 reimpressão. São Paulo: Atlas, 2003.

[9] MELLO, CARLOS HENRIQUE PEREIRA, SILVA, CARLOS EDUARDO SANCHES DA, TURRIONE, JOÃO BATISTA E SOUZA, LUIS GONZAGA MARIANO DE. ISO 9001: 2008 Sistema de Gestão da Qualidade para Operações de Produção e Serviços. Editora: Atlas. São Paulo. 2009.

[10] OLIVEIRA, OTÁVIO J.. Gestão da qualidade: tópicos avançados. São Paulo: Pioneira Thomson Learning, 2004.

[11] RODRIGUES, MARCUS VINICIUS. Ações para Qualidade, Gestão Integrada para Qualidade. Rio de Janeiro. Editora: Qualitymark. 2006.

[12] VERGARA, SYLVIA CONSTANT. Gestão da Qualidade. Editora FGV. 3ํㅡㄹição. Rio de Janeiro. 2006.

[13] WORLD HEALTH ORGANIZATION. Model guidance for the storage and transport of time-and-temperature-sensitive pharmaceutical products. Technical Report Series, n.961, annex 9, p.324-367. Geneva, Switzerland, 2011.

[14] ZARDO, HUMBERTO. Boas práticas de armazenamento, transporte e distribuição de medicamentos: contribuição para visão integrada das necessidades. Instituto Racine, 2012. In: Revista fármacos e medicamentos, v.66, ago/set/ out, 2011. Disponível em: http://www.racine.com.br/index. php. Acesso em: 10 mar. 2016. 


\section{CAPÍTULO 16}

\section{GESTÁO DE ESTOQUE: UMA ANÁLISE DOS ESTOQUES EM UMA UNIDADE FABRIL DE ESQUADRIAS DE ALUMÍNIO}

\section{Michele Domingos Schneider}

\section{Renan Cittadin Perito}

Julio Cesar Zilli

Adriana Carvalho Pinto Vieira

Resumo: A gestáo de estoques tem se tornado um tema de relevância nas organizações, em virtude do volume de capital dispendido na manutenção, quando não geridos corretamente. Neste sentido, o presente estudo tem como objetivo analisar a gestão de estoques em uma empresa de esquadrias de alumínio. Metodologicamente, caracteriza-se como uma pesquisa de campo, documental com abordagem qualitativa, com enfoque nos pontos críticos do setor. Foi elaborada a ctassificação $A B C$ dos itens em estoque com a finalidade de identificar os produtos de maior rotatividade no estoque. Após a classificação foi elaborado os cálculos de estoques, para se chegar à análise dos excessos em unidades e excessos financeiros. O diagnostico mostra a atual situação do estoque, evidenciando alto índice de excessos de estoques em grande parcela dos itens estocados. Portanto, recomenda-se para a organização o estabelecimento de níveis de estoque por grupo de produtos, por meio dos métodos de estoques mínimo e máximo possibilitando a mensuração e acompanhamento contínuo dos volumes comprados e dos niveis de estoque até que se atinjam os níveis de estoque desejados.

Palavras chave: Controle de Estoques, Curva ABC, Gestão de Estoques. 


\section{INTRODUÇÃO}

O cenário competitivo e o ritmo acelerado das mudanças, na atualidade, tem exigido das organizações mudanças rápidas e constantes análises de seus processos internos e externos. Neste sentido, as organizações estão cada vez mais, buscando desenvolver métodos eficazes para organizar, reorganizar e estruturar os processos internos, a fim de manter a competitividade nos mercados onde estão inseridas.

A aplicação de métodos eficientes de controle e gestão de estoques, permitem o desenvolvimento de estratégias capazes de diferenciação de preços, de formal tal que possíveis ineficiências nestes processos poderão deixar de ser um problema, tornando-se um diferencial competitivo para as organizações (BALLOU 2005).

Mas para que ocorra o controle, verifica-se que a implantação de políticas de estoque parte de um gerenciamento realizado pelo administrador de materiais, que orienta, na maioria das vezes, a redução de custos da empresa (VIANA, 2002).

Ademais, a respeito do que trata a área de compra e o setor de estoque, estes devem trabalhar em sintonia, uma vez que o setor de compras pode solicitar mais produtos do que sua necessidade e capacidade, gerando maiores custos financeiros à empresa (DIAS 2009).

A empresa que procura alcançar sucesso interliga o estoque com diversas áreas da empresa, a fim de captar os melhores recursos em relação aos seus concorrentes (CHING 2001). Por outro lado, a não aplicação desta política de estoque poderá acarretar excesso de materiais, falta de localização, falta de espaço, falta de produtos, que muitas vezes acarretam custos de estoque à empresa, entre outros (DIAS, 2009).

O presente estudo foi realizado numa empresa de esquadrias de alumínio, cuja atividade é a produção de portas e janelas. Todavia, no referido estudo foi abordado a gestão de estoques e, mais especificamente, a atuação desta empresa na questão de estocagem e lucros/desperdícios ocorridos em face de estratégias ineficientes. Além disso, suas possíveis restrições, os níveis de estoque mínimo e máximo, o tempo de ressuprimento de estoque, seu giro, localização, classificação de criticidade e popularidade, entre outros.

Nesta perspectiva, foi constatada a possibilidade de aplicação dos resultados obtidos dentro da empresa de esquadrias de alumínio, o qual também poderá ser concluído a sua viabilidade e melhora na questão de estocagem e resolução de problemas quanto aos lucros e desperdícios encontrados.

\section{REFERENCIAL TEÓRICO}

\subsection{ESTOQUES}

Para Dias (2009), a função de estoque acaba se tornando função estratégica para o ambiente empresarial, podendo exercer diferentes papéis, dependendo da finalidade dos objetivos. Torna-se um amortecedor, impulsionando as vendas e também garantindo o desejo do cliente, que é receber o produto no mesmo momento em que executa a compra. Serve como investimento financeiro por meio da compra de grandes lotes, servindo de proteção contra possíveis altas nos preços e possuindo a vantagem de ter a disponibilidade imediata mediante aos concorrentes.

Para Viana (2002, p. 118): "em qualquer empresa, a preocupação da gestão de estoques está em manter o equilíbrio entre as diversas variáveis componentes do sistema, tais como: custo de aquisição, de estocagem e de distribuição".

O gerenciamento do estoque está constituído de um equilíbrio que procura manter na racionalização a capacidade de compra e capacidade de consumo, sem afetar a necessidade dos consumidores (VIANA, 2002).

Conforme Slack et al. (2006), o estoque é considerado capital imobilizado da empresa, representando um investimento parado. Diante desses fatos, o estoque demonstra alguns atritos na organização.

Por outro lado, Teodoro e Pozo (2012), exemplificam os 
custos mais impactantes para a empresa, quais sejam de transporte, distribuição, estocagem e serviços aos clientes, influenciando no custo do produto vendido e despesas com vendas. A partir da constatação da falta de controle sobre estes custos, é importante que se desenvolva práticas gerenciais capazes de atingir determinadas necessidades quanto a diminuição de custos.

Segundo Viana (2002), estoque não é apenas a função de armazenagem, mas sim um processo estratégico da logística, que controla o fluxo de materiais e informações entre clientes e fornecedores. Desta forma, o sucesso de gerenciamento só será possível com a aplicação dos conceitos de logística.

As organizações estão alterando quase sempre sua cadeia de suprimento para diminuir impactos causados, quase sempre, por seus processos organizacionais ineficientes. Assim, para aumentar seus lucros é importante haver integração e vinculação da logística integrada, representada pelas operações internas e externas. Estas operações melhoraram vantagens competitivas de mercado (BERTAGLIA, 2003).

\subsection{PLANEJAMENTO E CONTROLE DE ESTOQUES}

Conforme Dias (2009), hoje a função de estoque não é mais vista como uma simples atividade, e sim um processo amplo, havendo ligação nos diversos setores da empresa, onde um setor auxilia o outro, influenciando ou sendo influenciado por decisões, a fim de trazerem benefícios à empresa. Atualmente, todo planejamento de estoque se dá por meio de sistemas, que controla toda a previsão de consumo e demanda, estabelecendo quantidades, tipos de produto e quando o cliente necessita comprar.

Afirma Dias (2009) o sistema de planejamento de estoque, por meio dos dados sistêmicos também auxiliar no controle de estoques de produtos acabados e vendidos. Estas previsões são garantidas por meio de dados obtidos durante o cadastramento de um pedido.

Um controle eficiente é aquele que mantém inventários periódicos, a fim de garantir a contagem correta dos itens estocados, deixando o saldo mais próximo da realidade, pois, possuem grande influência no balanço fiscal e nos impostos, tendo como finalidade diminuir os valores supérfluos em estoque (POZO, 2007). O controle de estoques auxilia em estabelecer ações corretivas, a fim de obter garantir a prevenção de falhas nos processos produtivos (DIAS, 2009).

O Controle é de suma importância administrativa na qual consiste em medir e corrigir o desempenho de qualquer atividade. Assim, o controle de estoque estabelece padrões e ações corretivas, a fim de obter garantir a prevenção de falhas alcançando seus objetivos (DIAS, 2009).

Afirma Viana (2002), os sistemas de informação possuem papel estratégico, por meio deles se identifica a quantidade de dados necessários para eficiência dos processos, é de suma importância para obtenção dos resultados em tempo real, modernização de procedimentos envolvendo a estrutura organizacional para assegurar a melhoria dos serviços.

Segunda Moura (2004) uma gestão de estoque só será eficaz a partir do momento em que o gestor tenha aquisição de informações que estão diretamente envolvidas neste processo, como mencionado abaixo as áreas relacionadas ao gerenciamento de estoques, são: i) Compras; ii) Acompanhamento; iii) Gestão de armazenagem; iv) Planejamento; v) Controle de produção; e vi) Gestão de distribuição física.

Segundo Ballou (1995), estabelecer e controlar os variados níveis de estoques e a sua localização é apenas uma parte do problema de planejamento logístico global. O objetivo mais importante é evitar que falte material.

\subsection{CLASSIFICAÇÃO ABC}

De acordo com Gasnier (2011, p. 39): "as classificações são processos de categorização de Pareto baseado em determinado critério considerado relevante para a priorização dos esforços de gerenciamento dos itens em estoque".

Na visão de Dias (2009), a curva ABC é uma ferramenta 
utilizada para o controle de estoques, na gestão de materiais, utilizada para identificar e classificar os itens por grau de importância. Os itens receberam atenção adequada, mediante a classificação e desenvolvemse políticas de estoque de acordo com a importância e criticidade de cada material.

A Curva $A B C$ recebe esse nome em "razão da divisão dos dados obtidos em três categorias distintas, denominadas classes A B e C" (POZO, 2007, p. 93).

Conforme Viana (2002), a curva ABC é um método aplicável em qualquer situação no qual é possível determinar as prioridades, na qual cumpre-se primeiro as tarefas com maior frequência do que a outra, de modo que essas tarefas representem a maior parte das obrigações de todo o conjunto.

Para Dias (1993), a curva ABC tem sua relevância denominada de acordo como ocorre a classificação dos itens, no qual essa classificação é determinada pela demanda.

A análise consiste na verificação, em certo espaço de tempo normalmente seis meses a um ano de consumo em valor monetário ou quantidade dos itens de estoque, para que eles possam ser classificados em ordem decrescente de importância. Aos itens mais importantes de todos, segundo a ótica do valor ou da quantidade, dá-se a dominação de itens classe A, aos intermediários, itens classe B, e aos menos importantes, itens classe C. (MARTINS; ALT 2002, p.162).

Segundo Vendrame (2008) é de suma importância a utilização da curva $A B C$, mas para isso é importante alguns fatores, como: comparar a quantidade de itens utilizados de acordo com o período analisado; código ou a forma utilizada para a identificação do produto; preço unitário dos produtos; cálculo de valor de consumo total; analisar os itens em forma de valor decrescente; e o valor de Faturamento total.
Figura 01 - Curva ABC padrão

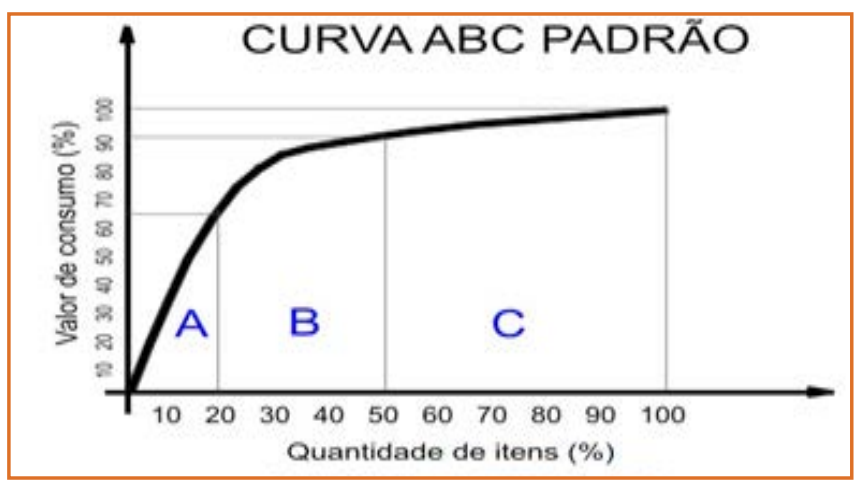

Fonte: Gestão Industrial (2004).

Conforme Slack et al. (2006), a representação da Curva $A B C$ está definida como:

a. O item A é o mais representativo, apresentados em 20\% de itens, que representam $80 \%$ dos valores em estoque;

b. O item B é o grupo qual possui valores médios. É apresentado em 30\% de itens, qual representa $10 \%$ do valor total;

c. O item C é o que menos representa resultado. Compreende cerca de $50 \%$ do total de tipos de itens estocados, representando apenas 10\% do valor total de itens.

Conforme Dias (1993) A utilização da curva ABC facilita também a definição das políticas de vendas, capazes de modelar acordo com a venda dos produtos melhora também o planejamento de produção, podendo ser aplicados em industriais, comércios ou prestação de serviços para diminuir seus custos.

\section{METODOLOGIA}

O estudo é classificado como pesquisa descritiva, bibliográfica, documental e de campo. Conforme Gil (2008) a pesquisa descritiva trata das características de uma determinada população ou fenômenos conciliando as variáveis relações entre os mesmos.

A pesquisa de campo é realizada baseada pela coleta de dados oriundos do local e do alvo de estudo, onde se observou os fatos do ambiente e o desenvolvido de ferramentas capazes de coletar dados necessários 
para propor uma melhor fundamentação do estudo (VERGARA, 2010).

Para a analise a área do almoxarifado da Empresa em estudo, foram utilizados dados do estoque e, entrevista semiestruturada aplicada à população de 20 (vinte) pessoas que possuem uma rotina com este estoque. Foram entrevistados todos os funcionários que mantém contato com o almoxarifado, configurando dessa forma um senso, onde se buscou informações concretas para abranger validação dos aspectos objetivados.

A coleta de dados primários foi realizada por meio de uma planilha onde constam dados da gestão estoque.

A pesquisa procura ter embasamento prático tendo vista o desenvolvimento teórico, assim trazendo as duas práticas a contribuir com as necessidades do controle de estoque, especificamente melhorar a classificação dos itens, melhoramento dos níveis de estoque.

\section{RESULTADOS E DISCUSSÕES}

A empresa em estudo atua no ramo de fabricação de esquadrias de alumínio na cidade de Urussanga/ SC, desde 1979. O parque fabril conta com $30.600 \mathrm{~m}^{2}$, extensão de $244.000 \mathrm{~m}^{2}$. Conta com 1.200 funcionários diretos.

No setor de almoxarifado é possível detectar problemas na identificação e localização dos materiais, resultando em atrasos na separação e entrega dos materiais para a produção. O que se pode notar são informações desencontradas que ocorrem no setor sendo, um deles, a acuracidade dos estoques, ou seja, a falta de itens, há o registro dos materiais e não se encontrando o material físico disponível. Ou seja, impactando diretamente no desempenho da organização.

Segundo Cortez (20013) falhas vem ocorrendo com muita frequência das indústrias brasileiras, são devido ao fato de que existe deficiência nos processos produtivos de chão de fábrica, influenciando na falta de padrões, procedimentos e capacitação da mão de obra e principalmente dos executivos que não se envolvem diretamente com os processos.
Ainda Cortez (2013). As áreas industriais brasileiras deixam de produzir aproximadamente $50 \%$ de sua capacidade produtiva, mesmo que a empresa trabalhe em carga máxima. Esses efeitos são refletidos no preço do produto final e acabam sendo repassados ao cliente final, assim impactando diretamente na competitividade.

No final do ano de 2014 foi implantado um sistema informatizado para controle das entradas e saídas do almoxarifado, porém, identificou-se certo grau de despreparo de funcionários, de modo que nem todos os envolvidos no processo possuem conhecimento suficiente sobre a utilização das funções do sistema de estoque. Em outras palavras, pode-se dizer que os funcionários não utilizam de maneira correta o sistema eletrônico implantado, desenvolvido para proporcionar melhorias organizacionais.

Antes de começar a reestruturação do almoxarifado, a empresa possuía aproximadamente 650 (seiscentos e cinquenta) itens, sua grande maioria obsoleta. Com a ajuda de novas ferramentas para o gerenciamento dos estoques, como a classificação ABC e calculo de estoques, os quais serão apresentados na sequencia, a empresa passa para um estoque ativo de 208 itens.

Por meio do levantamento e da análise de dados e posterior classificação ABC dos itens em estoque, realizou-se cálculo de consumo mensal e anual, de forma que se tornou possível a identificação dos itens que possuem maior e menor rotatividade. Para fins de cálculos, utilizou-se dos critérios de consumo anual médio e anual total dos itens em estoque, resultandose na média de consumo mensal, a qual classificou a curva $A B C$ apresentada.

O método de classificação $A B C$, qual foi aplicado ao setor de estoque, sendo necessário analisar os itens que mais possuem saída perante os produtos de maior relevância. Sendo que A e B possui maior rotatividade.

Com intuito de realizar a classificação $A B C$ foi necessário analisar os itens de acordo com as saídas de estoque para consumo, no sentido de identificar os produtos de maior relevância. Assim os dados 
apresentados foram classificados em três sistemas, os produtos com maior rotatividade, os de importância intermediária e itens de menor relevância.

Desta forma, dos 208 itens em estoque, 42 itens foram classificados como A, 62 itens foram classificados como B e 104 foram classificados como C. A seguir, verifica-se a tabela da classificação $A B C$, baseado na Tabela 1.

Tabela 01- Porcentagem de itens da Curva ABC

\begin{tabular}{|c|c|c|c|}
\hline CLASSE & ITENS & VALOR & ITENS \\
\hline A & 42 & $91,52 \%$ & $20,19 \%$ \\
\hline B & 62 & $7,62 \%$ & $29,81 \%$ \\
\hline C & 104 & $0,86 \%$ & $50,00 \%$ \\
\hline
\end{tabular}

A classificação ABC ficou estabelecida da seguinte forma:

- Categoria A: os itens classificados no grupo A, contemplam 42 itens, os quais 20,19\% dos itens estocados e $91,52 \%$ do valor do estoque. Sendo assim é importante dar uma atenção a estes itens procurando diminuir o risco de um alto custo de estoque.

- Categoria B: Conta com 29,81\% dos itens do estoque sendo representado por 7,62 \% do valor. Nesta classificação os itens podem possuir uma frequência maior, sendo comprado em menores lotes com maiores frequências, facilitando assim o inventario que pode ser feito de maneira manual.

- Categoria C: Conforme a tabela já mencionada e não menos importante do que as outras classes, esta apresenta $50 \%$ dos itens, mas apenas 0,86\% do valor total. A classe $\mathrm{C}$ não se faz necessário possuir grandes quantidades, mas sim a quantidade mínima, para que haja uma pequena parcela de giro na empresa, os itens se mal administrados podem ser considerados estoque parado.

Após a classificação $A B C$, procedeu-se o cálculo e definição dos níveis de estoque por produto, utilizando-se como parâmetros os indicadores de estoque máximo, médio e mínimo. Assim, verificou-se que diversos produtos que possuem estoque maior, eram os que menos tinham saída. Por outro lado, em muitos casos, os itens que possuíam estoque menor, eram os que mais tinham rotatividade.

A curva $A B C$ forneceu aos gestores uma maneira de perceber que o setor possuí produtos mais caros em relação aos outros, e que sua representação foi notada nos percentuais apresentados e nos valores financeiros totais, assim facilitou a maneira de chamar a atenção dos gestores, influenciando nas decisões tomadas em relação aos custos e o controle referente as compras para os abastecimentos

Desta forma, o plano de análise é aumentar o controle de forma classificada, a fim de garantir a quantidade ideal em estoque, tendo em vista as práticas do inventário para garantir possíveis falhas a respeito do estoque físico e o estoque sistêmico. O Quadro 1 apresenta os cinco itens que comprovam que o almoxarifado sofre com excessos.

Quadro 1 - Cálculos dos Estoques item ACCONT00017

\begin{tabular}{|l|l|}
\hline Código & ACCONTO0017 \\
\hline Média & $42.192,00$ \\
\hline Custo unit. & $\mathrm{R} \$ 2,16$ \\
\hline Lead Time & 2 \\
\hline Saldo atual & $19.878,00$ \\
\hline Est.Min. & $2.812,80$ \\
\hline Est.Max. & $5.625,60$ \\
\hline Excesso & $14.252,40$ \\
\hline Valor $\mathrm{R} \$$ & $\mathrm{R} \$ 30.785,18$ \\
\hline &
\end{tabular}

O item ACCONT00017 está muito acima do seu limite. Percebe-se que seu estoque atual é de 19,878,00 unidades, para calcular o estoque mínimo foi utilizado a média anual multiplicado pelo lead time sendo de 2 dias, palavra esta que significa o tempo em que o fornecedor leva para fazer a próxima entrega do item.

Com a realização do cálculo, se constatou que seu estoque mínimo está em torno de 2.812,80 unidades. Verificou-se, também, que seu estoque máximo é o que causa maiores problemas, pois trata de acúmulo de grande investimento, apresentando estoque de $5.625,60$ unidades. 
Pode-se dizer que este item tem um estoque alto por receio que falte item para a demanda. Logo, percebeu-se que seu excesso é de aproximadamente $14.252,40$ unidades, causando um valor imobilizado de $R \$ 30.785,18$.

Quadro 2 - Cálculos dos Estoques item ACPARA00009

\begin{tabular}{|l|l|}
\hline Código & ACPARA00009 \\
\hline Média & $35.379,33$ \\
\hline Custo unit. & $\mathrm{R} \$ 0,02$ \\
\hline Lead Time & 15 \\
\hline Saldo atual & $269.541,00$ \\
\hline Est.Min. & $17.689,67$ \\
\hline Est.Max. & $35.379,33$ \\
\hline Excesso & $234.161,67$ \\
\hline Valor $\mathrm{R} \$$ & $\mathrm{R} \$ 4.683,23$ \\
\hline
\end{tabular}

Quanto ao item ACPARA00009, possui um estoque atual de 269.541,00 unidades, apresentando uma média de 35.379,33 unidades no qual conta com estoque mínimo de 17.689,67 unidades, e que seu estoque máximo é de 35.379,33 unidades, por apresentar um lead time de 15 dias, poderia ter um nível de estoque mínimo como ideal.

Verificando-se a diferença existente, está se dá pelo estoque máximo menos o estoque atual, onde apresentou um excesso de 234.161,67 unidades, representando o valor de $\mathrm{R} \$ 4.683,23$.

Quadro 3 - Cálculos dos Estoques item ACPARA00010

\begin{tabular}{|l|l|}
\hline Código & ACPARA00010 \\
\hline Média & $31.429,58$ \\
\hline Custo unit. & $\mathrm{R} \$ 0,01$ \\
\hline Lead Time & 15 \\
\hline Saldo atual & $158.823,00$ \\
\hline Est.Min. & $15.714,79$ \\
\hline Est.Max. & $31.429,58$ \\
\hline Excesso & $127.393,42$ \\
\hline Valor $\mathrm{R} \$$ & $\mathrm{R} \$ 1.273,93$ \\
\hline
\end{tabular}

Quanto ao item ACPARA00010, possui um estoque atual de 158.823,00 unidades, apresentando uma média de 31.429,58 unidades no qual conta com estoque mínimo de 15.714,79 unidades, e que seu estoque máximo é de 31.429,58 unidades, por apresentar um lead time de 15 dias, poderia ter um nível de estoque mínimo como ideal.

Verificando-se a diferença existente, está se dá pelo estoque máximo e o estoque atual, onde apresentou um excesso de $127.393,42$ unidades, representando o valor de $R \$ 1.273,93$.

Quadro 4 - Cálculos dos Estoques item ACREBI00011

\begin{tabular}{|l|l|}
\hline Código & ACREBI00011 \\
\hline Média & $25.633,00$ \\
\hline Custo unit. & $\mathrm{R} \$ 0,07$ \\
\hline Lead Time & 10 \\
\hline Saldo atual & $100.899,00$ \\
\hline Est.Min. & $8.544,33$ \\
\hline Est.Max. & $17.088,67$ \\
\hline Excesso & $83.810,33$ \\
\hline Valor $\mathrm{R} \$$ & $\mathrm{R} \$ 5.866,72$ \\
\hline
\end{tabular}

Quanto ao item ACREBI00011, possui valor investido em excesso, apresentando $R \$ 5.866,72$, possuindo uma média de 25.633,00 unidades. Seu mínimo representa 8.544,33 unidades, conta com estoque máximo de 17.088,67 unidades em relação aos outros itens analisados não apresenta tanto problema por apresentar um valor unitário baixo.

Ainda, o item apresenta um excesso de 83.810,33 unidades. Esse excesso existe por receio de falta de material, pois possui um lead time alto de 10 dias.

Como as compras não estão sendo gerenciadas corretamente, o item é comprado mais do que se necessita, sendo o estoque atual do item 100.899,00 unidades. 
Quadro 5 - Cálculos dos Estoques item ACABRA00001

\begin{tabular}{|l|l|}
\hline Código & ACABRA00001 \\
\hline Média & $24.392,33$ \\
\hline Custo unit. & $\mathrm{R} \$ 0,06$ \\
\hline Lead Time & 12 \\
\hline Saldo atual & $125.871,00$ \\
\hline Est.Min. & $9.756,93$ \\
\hline Est.Max. & $19.513,87$ \\
\hline Excesso & $106.357,13$ \\
\hline Valor $\mathrm{R} \$$ & $\mathrm{R} \$ 6.381,43$ \\
\hline
\end{tabular}

Quanto ao item ACABRA00001, possui um estoque atual de 125.871,00 unidades, apresentando uma média de 24.392,33 unidades no qual conta com estoque mínimo de 9.756,93 unidades, e que seu estoque máximo é de 19.513,87 unidades, por apresentar um lead time de 12 dias, poderia ter um nível de estoque mínimo como ideal.

Verificando-se a diferença existente, está se dá pelo estoque máximo menos o estoque atual, onde apresentou um excesso de 106.357,13 unidades, representando o valor de $\mathrm{R} \$ 6.381,43$.

Assim, verifica-se que todos os 05 itens apresentados acima possuem excessos com base na classificação $A B C$, será mais fácil definir os lotes de compra. Os excessos de saldo serão reduzidos gradativamente, conforme sua localização no layout, pois, facilitará a sua contagem, aumentando a precisão da operação compra e, consequentemente, os espaços no almoxarifado. O Quadro 6, apresenta o resumo dos excessos por classe.

Quadro 6 - Situação Geral dos itens

\begin{tabular}{|l|l|l|l|}
\hline EXCESSOS & ITENS & \multicolumn{1}{l}{ UNIDADES } & R\$ \\
\hline Grupo A & 9 & $984.936,47$ & $113.269,19$ \\
\hline Grupo B & 45 & $1.846 .189,94$ & $1.832 .947,20$ \\
\hline Grupo C & 93 & $1.222 .783,59$ & $2.351 .156,18$ \\
\hline Total & 147 & $4.053 .910,00$ & $4.297 .372,56$ \\
\hline
\end{tabular}

Do total dos 208 itens em estoque, observou-se que 9 itens do grupo A apresentam estoques em excesso, totalizando $984.936,47$ unidades e $\mathrm{R} \$ 113.269,19$. Os itens do grupo B, 45 encontram excessos de estoques, na ordem de 1.846.189,94 unidades e $\mathrm{R} \$ 1.832 .947,20$. Dos 108 itens do grupo C, 93 destes apresentam excessos, envolvendo 1.222.783,59 unidades e $R \$$ $2.351 .156,18$

Analisando a totalidade dos itens em estoque, dos 208 itens, 147 encontram-se em quantidades superiores as necessidades da organização, levando-se em consideração o consumo médio e os lead times. O montante envolvido nos excessos totaliza 4.053.910,00 unidades e $\mathrm{R} \$ 4.297 .372,56$.

Com a classificação concluída, passa-se a uma nova renegociação com os fornecedores. Após o posicionamento da curva, mudam-se as estratégias da empresa, seus procedimentos entre outros, tendo em vista que essas mudanças beneficiam a maximização dos desperdícios, benefícios esses que podem vir ao curto médio e longo prazo.

No estudo se fez presente os métodos de gerenciamento de estoques, no qual esses métodos devem interligar tanto os fenômenos humanos que ocorrem no setor, tanto para aplicação das melhores teorias, uma delas na qual trouxe resultado foi a curva $A B C$. Portanto na gestão é importante que as políticas de estoques aplicadas se tornem regras e que todos devem cumprir, assim quando bem implantadas proporcionam um aumento de qualidade.

Tabela 02 - Representação total do estoque

\begin{tabular}{|l|l|}
\hline Consumo Médio Mensal (Unid) & $3.810 .267,59$ \\
\hline Saldo atual (Unid) & $5.120 .995,00$ \\
\hline Excesso (Unid) & $4.053 .910,00$ \\
\hline Cobertura Estoques (meses) & 1,34 \\
\hline Excesso (R\$) & $4.297 .372,56$ \\
\hline
\end{tabular}

Por fim, os dados constatados com excesso foram apresentados e contabilizados por meio do sistema da empresa. Assim, avaliaram-se as perdas com os excessos de estoques e constatou-se que a redução dos excessos será feita gradativamente, de modo que haja um equilíbrio entre a demanda e a quantidade que será utilizada pelo estoque. 
Com a alta competitividade a empresa passou a verificar que seus estoques estavam gerando custos representativos, seu excesso estava chegando a ser avaliado em mais de 4.2 milhões de reais, fato é que existiam itens com grande valor agregado o que aumento ainda mais este valor dos excessos.

A avaliação qualitativa dos dados proporcionou que o cálculo da curva $A B C$ auxilie na retomada do aumento de capital, um menor custo de armazenagem e cálculos que estabeleçam a capacidade ideal de produção, assim facilitar o andamento das melhorias implantadas na gestão de estoques.

Os objetivos foram alcançados, com os dados e a tabulação das informações, foi possível identificar os principais excessos girando em torno de 4.053.910,00 de unidades, sabendo que a empresa em média possui uma demanda de aproximadamente 3.810.267,59 com o registrado desta defasagem se identificou o quanto em valor monetário a empresa estava deixando de arrecadar.

Foi constatado também que as quantidades de alguns itens do estoque foram capazes de manter o estoque, sem que seja realizada uma nova compra do mesmo, antes não existiam cálculos referentes ao tempo de cobertura, através desses dados foi possível sua identificação. Resultando na redução de custos e um ganho de espaço para a armazenagem de outros produtos

Durante a pesquisa foi constatado que a empresa possui grande deficiência em minimizar custo, mas por outro lado possui um ponto positivo, a de possuir poder aquisitivo muito alto pois mantem altos níveis de estoques.

Como a tabela acima nos mostra o cálculo base foi registrado durante os últimos (12) doze meses, ela possui uma média mensal de em unidades de aproximadamente (4) quatro milhões de itens com giro de estoque, quantidade essa que vem sendo reduzida para melhorar a qualidade dos serviços prestados e de processos internos qualificados, a apresentação dos dados foi capaz de provar que tudo isso pode se reduzir com ferramentas administrativas e uma satisfação aos gestores.

Segundo Moura (2004) o nível que se seja alcançar só será possível com base no lead-time, a demanda / consumo. Só assim ocorrera um bom desenvolvimento de um planejamento capaz de suprir todas as necessidades da organização, evitando o risco de não conseguir atender a demanda

\section{CONSIDERAÇÕES FINAIS}

Os principais pontos analisados no estudo têm como destaque o planejamento adequado dos estoques, assim melhorando os recursos financeiros da empresa, e, aumentando o capital de giro da mesma, possibilita a redução dos itens, desperdícios e seus excessos, quando se utiliza as ferramentas necessárias, com a curva $A B C$ apresentada, no qual demonstrou os itens que possuem maiores demanda. Cabe dizer que para uma empresa sair a frente de seus concorrentes, na maioria das vezes os gestores devem aprimorar o gerenciamento de armazenagem de maneira eficiente, garantindo a sobrevivência e a competitividade.

Constatou-se que a empresa possui grande potencial para crescer ainda mais. Portanto, é importante que a empresa não perca o foco em melhorar a área referente a cadeia de suprimentos que engloba diversos métodos de aplicação entre eles o planejamento de estoque. De acordo com a pesquisa foi possível verificar que os inventários devem ser constantes para diminuir as variações de insumos, para que não haja investimentos desnecessários.

O presente estudo realizado desempenhou com sucesso o objetivo proposto expressando as deficiências do modelo atual de gestão. Assim, a partir do estudo se propõe um plano de capacidade que demostraram o cenário dos itens, de que cada produto reafirmando que eles devem ser reduzidos e que ao final do próximo ano a empresa consiga estimar seu ganho financeiro, por meio desde estudo.

Desta forma, foi mapeado o estoque dos itens da empresa estudada, constatando-se a localização indevida dos itens armazenados, onde se verificou necessário a realização da classificação $A B C$ para 
finalmente constar os itens com maior e menor rotatividade.

Ou seja, os resultados obtidos apresentaram-se positivos em diversos aspectos, como o melhoramento da área e informações mais precisas em relação ao seu saldo, entre outros. O modelo desenvolvido foi capaz de promover resultados capazes não só melhorar os fatores e cálculos matemáticos, contudo aumentou a frequência de pedidos e períodos almejando a estabilidade da demanda, assim não causando alterações de que possam influenciar os processos.

O sistema de informação auxilia no processo de como planejar, executar, medir e ajustar, são fatores essenciais para uma gestão de estoque eficiente e eficaz. E evidente perceber como o gerenciamento de estoques influencia a necessidade de minimizar custos, assim gerar grandes resultados com poucos investimentos.

Em relação a falta de acuracidade, os destaques foram os registros, materiais que são gerados de forma onerosa por coleta inadequada dos dados, roubo de espaços de outros itens a localização e identificação incorreta. Conforme já dito a partir do estudo os objetivos foram almejados, pois o mesmo identificou, por meio do referencial teórico com base na literatura, o principal problema é a falta de acuracidade e falta de planejamento nas organizações de estoque.

Os cálculos óbitos surtiram efeito, depois de ser analisado os resultados, que possibilitou verificar que existia evidencias negativa entre os lotes de compra, sendo itens que eram comprados em excessos sendo superior à média consumida durante o período, ao final do processo representou um alto valor monetário, assim percebeu-se a necessidade de investir na estruturação do setor.

Conforme a metodologia, considerações foram feitas referentes aos cálculos de estoque que representa grande investimento financeiro, por meio desses cálculos pode garantir a longo prazo decisões quanto a compra e venda. Por fim a empresa percebeu a importância de se executar métodos que identifiquem estratégias com finalidade de mudar as políticas de excessos de estoques.

\section{REFERÊNCIAS}

[1] BALLOU, R. H. Logística empresarial. São Paulo: Atlas, 1995.

[2] - Gerenciamento da cadeia de suprimentos/ logística empresarial. 5aㅡ ed. Porto alegre: Bookman, 2006.

[3] BERTAGLIA, P. R.. Logística e gerenciamento da cadeia de abastecimento. São Paulo: Ed. Saraiva, 2003.

[4] CHING, H. Y.. Gestão de estoques: na cadeia de logística integrada. 4aㅡ ed. São Paulo: Atlas, 2001.

[5] CORTEZ, R. Produzir sem perdas: o caminho e planejar bem. 2013. Disponível em: < http://www.celso-foelkel.com. br/artigos/outros/6_Producao\%20sem\%20perdas.pdf>. Acesso em: 04 Nov. 2015

[6] DIAS, M. A. P. Administração de materiais: uma abordagem logística. 4aㅡ Ed. São Paulo, Atlas, 1993.

[7] _. Administração de materiais: princípios, conceitos e gestão. 5a. Ed. São Paulo: Atlas, 2009.

[8] GASNIER, D. G.. A Dinâmica dos estoques. São Paulo: Instituto IMAM 2002.

[9] GIL, A. C.. Como elaborar projetos de pesquisa. 4aㅡ ed. São Paulo: Atlas, 2008.

[10] MOURA, C. E. Gestão de Estoques. 1. ed. Rio de Janeiro: Editora Ciência Moderna Ltda., 2004.

[11] POZO, H.. Administração de recursos matérias e patrimoniais. 4르ed. São Paulo: Atlas, 2007.

[12] SLACK, N.; CHAMBERS, S.; JOHNSTON, R. Administração da produção. São Paulo, Atlas, 2006.

[13] STOCKTON, R. S.. Sistema básico de controle de estoques. 1a. ed. São Paulo: Atlas, 1976.

[14] TEODORO, R. A. F.; POZO, H.. Gestão de custos em logística: uma proposta para aprimorar custos de transporte para as micro e pequenas empresas. Revista de tecnologia Aplicada. Faculdade Campo Limpo Paulista. V. 1, n. 1. p. 3-11. 2012 (jan/abr).

[15] VENDRAME, F. C. Administração de Recursos Materiais e Patrimoniais, 2008, 66 p. Apostila da Disciplina de Administração, Faculdades Salesianas de Lins.

[16] VERGARA, S. C.. Métodos de pesquisa em administração. 4aed. São Paulo: Atlas, 2010. 277 p.

[17] VIANA, J.. Administração de matérias: um enfoque prático. São Paulo: Atlas, 2002. 


\section{CAPÍTULO 17}

\section{MELHORIAS NO FORNECIMENTO DE PEÇAS DE REPOSIÇÃO APÓS A IMPLEMENTAÇÃO DO PROCESSO S\&OP EM UMA MONTADORA}

Rafael Bonades da Silva

Nilson José Fernandes

Rogério Santana Peruchi

Naiara Faiad Sebba Calife

Resumo: O processo S\&QP (Sales and Operation Planning) é uma ferramenta utilizada pela empresas para planejan e executar o planejamento estratégico. Traz como vantagens o aumenta da integração entre os setores, a maior assertividade nas previsões de demanda, atém de promover uma maior agilidade de respostas diante mudanças de mercado. $O$ foco da pesquisa fol analisar as informações de uma empresa montadora do setor de máquinas agricolas após a implementação do processo de S\&OP no setor de planejamento de peças de reposição. Tratou-se de uma pesquisa aplicada, quantitativa, qualitativa, de cunho exploratório, em que o método utilizado foi o estudo de caso. A coleta dos dados foi separada em informações quantitativas (análise de indicadores) e qualitativas (entrevistas com clientes). Foram verificadas uma redução no valor dos estoques de aproximadamente $14 \%$ e um aumento de $29 \%$ no nível de atendimento ao cliente. A aplicação de uma pesquisa de satisfação identificou que houve a percepção dos clientes quanto ao melhor nível de atendimento.

Palavras chave: S\&Op, Indicadores, Gestão de Estoques. 


\section{INTRODUÇÃO}

Em análise ao contexto de economia globalizada, os quais empresas capitalistas estão inseridas, observase a importância da adaptação destas quanto ao atendimento das necessidades dos clientes. Prestar um serviço de qualidade ao cliente não é mais considerado como um diferencial competitivo, mas sim uma obrigação.

Segundo Dias (2004), para se garantir níveis excepcionais de atendimento e disponibilidade de bens e serviços, as empresas devem recorrer à previsão de demanda, ou seja, buscar no histórico de vendas e oscilações do mercado uma forma de prever o comportamento do consumo, garantindo a disponibilidade dos produtos no exato momento da demanda.

Completando ainda o ciclo de consumo, as organizações tendem também a direcionar seus esforços no pós-venda, como processo fundamental para a retenção de clientes. Moreira (1989) classifica, por exemplo, o pós-venda como um dos fatores mais importantes de diferenciação no fornecimento, tendo a capacidade muitas vezes de fidelizar os clientes, devido sua rápida resposta quanto às expectativas de consumo.

Assim, o planejamento de vendas e operações, também chamado de S\&OP (do inglês Sales and Operation Planning), torna-se um processo fundamental para as empresas. Segundo APICS (1995), S\&OP é um processo de planejamento estratégico que visa direcionar os negócios para alcançar vantagem competitiva. Uma pesquisa realizada em 2010, pelo Instituto de Logística e Supply Chain (ILOS), aponta que $62 \%$ das empresas brasileiras já utilizam o S\&OP em suas operações, e que outros 14,1\% pensam em utilizar (JULIANELLI, 1992).

Oliva \& Watson (2011) evidenciaram em um estudo de caso que o processo S\&OP consegue gerar alinhamento entre diferentes áreas de uma mesma empresa, mesmo existindo incentivos contraditórios à colaboração interfuncional. Bower (2006) cita em sua pesquisa que a implementação do processo S\&OP promove os seguintes benefícios para as organizações: aumento das margens operacionais
(14\%), aumento da margem bruta (4\%), redução de perdas de inventário (55\%) e aumento de receita com novos produtos (17\%).

Neste contexto, o objetivo deste artigo foi analisar os ganhos alcançados nos níveis de estocagem e nos níveis de atendimento ao cliente após a implementação de um processo S\&OP em empresa multinacional localizada no interior do estado de Goiás. A empresa onde foi realizado o estudo de caso atua no ramo de máquinas agrícolas, sendo o estudo realizado mais especificamente no departamento de peças de reposição.

O trabalho foi dividido em cinco etapas. A primeira tratou da introdução ao contexto da problemática, seguido do referencial bibliográfico, que trouxe a base de conhecimento já construído por outros autores. Em terceiro foi apresentada a metodologia e a forma de pesquisa, seguido da apresentação empírica e demonstração do estudo de caso. Por fim foi apresentada a conclusão do trabalho.

\section{REFERENCIAL TEÓRICO \\ 2.1 O PROCESSO DE NEGÓCIO}

O entendimento sobre o negócio é vital para a compreensão da complexidade de processos que movem uma organização. Para Hammer \& Champy (1994) os processos de negócio são abordados como sendo um conjunto de atividades de entrada e saída simultâneas, ou seja, o cliente recebendo o produto final que lhe convém e o fornecedor recebendo o valor pelo bem fornecido.

Para se alcançar um alinhamento estratégico nas operações, deve-se ter uma visão voltada para processos, não para pessoas. Para Cardoso (2005), o plano estratégico de um negócio é uma formalização dos principais objetivos e metas que a empresa espera atingir nos próximos períodos. É uma afirmação da direção o qual a empresa quer seguir e demonstra o tipo de negócio e/ou as linhas de produtos, mercados, em que a empresa pretende atuar. Já o plano funcional demonstra como a empresa espera atingir esses objetivos, ou seja, o modo de fazer. Estes dois planos devem estar inteiramente relacionados e serem 
coesos nas tomadas de decisões, atendendo sempre as estratégias da empresa.

\subsection{PLANEJAMENTO DE VENDAS E OPERAÇÕES (S\&OP)}

Segundo Dwaraknath et al. (2015) o planejamento de vendas e operações (S\&OP) tem como objetivo - equilíbrio entre oferta e demanda, bem com o alinhamento dos processos que os mantêm integrados. Se a demanda é maior que a oferta, há risco de faltar produto para os clientes, além de decorrer em aumentos de custo para suprir as falhas de planejamento. Pode ainda haver a perda de venda perante os concorrentes, com consequente redução do market share. Porém, se a oferta é maior que a demanda, aumentam-se os estoques de produtos finais, que também significa aumento de custos, neste caso no capital imobilizado.

O S\&OP não é somente um módulo de sistema de computação ou uma sigla da moda. Ele deve ser encarado como um processo fundamental para as empresas que desejam perpetuar seu negócio por longos períodos.

Assim, quando falamos de S\&OP, nos referimos a uma ferramenta de apoio ao planejamento e execução das estratégias da organização. O S\&OP traz grandes vantagens para as empresas, pois aumenta a integração entre os setores, proporciona uma maior assertividade nas previsões de demandas, além de promover maior agilidade de respostas frente a mudanças de mercado.

Para O'Keeffe (2004), o S\&OP é uma ferramenta utilizada pela alta administração para planejar e executar o planejamento estratégico da empresa, auxiliando na construção de planos e cenários diversos para as áreas de venda, produção e compras, e também verificar e avaliar os possíveis cenários de riscos ao negócio da empresa. Além disto, é capaz de gerenciar, monitorar e controlar o desempenho e as variações dos planos traçados para vendas e produção, bem como ponderar os impactos relacionados ao valor imobilizado em estoques.
Segundo Pires (1995), um processo de S\&OP deve considerar todas as informações obtidas do mercado, as estratégias e as limitações de recursos e capacidades. Todas essas informações são componentes básicos do S\&OP, para a previsão de vendas e o planejamento da produção.

Arrozo (2006) cita que no processo de S\&OP há cinco etapas fundamentais. Elas são:

a) Previsão Estatística: nesta etapa utiliza-se de análises estatísticas para a construção de uma série de dados de planejamento para o período. Essa base de dados auxilia na construção de cenários futuros, além de ajudar a determinar padrões de eventos, que podem incluir aspectos econômicos, políticos, climáticos, etc.

b) Plano de Vendas: trata-se de um documento detalhado com as estratégias e táticas comerciais para atingir o objetivo de venda em um determinado período. Nesse documento são identificados os clientes, inferido os volumes de vendas necessários e proposto o portfólio de produtos que serão ofertados, entre outras informações.

c) Plano de Operações: trata-se do documento detalhado com as estratégias e ações operacionais para se alcançar o volume demandado/ofertado. Isso engloba os departamentos de produção, de materiais, de logística e qualidade. O documento detalha as operações internas, atentando-se para a capacidade, produtividade, novos projetos e produtos, manutenção de equipamentos, etc.

d) Definição de Cenário: uma vez analisadas as informações históricas e os planos de operações e vendas, são elaborados os possíveis cenários de operação. Estas projeções irão auxiliar o corpo diretivo da organização a traçar o melhor plano para atingir os objetivos traçados pela empresa.

e) Comunicação para Organização: o plano escolhido pela direção da empresa deve ser comunicado apropriadamente para todos os envolvidos da organização. A comunicação é peça fundamental para que todos saibam seus papeis e responsabilidades no processo.

A Figura 1 a seguir ilustra as integrações e interdependências do processo S\&OP. 
Figura1 - Visão esquemática do processo S\&OP.

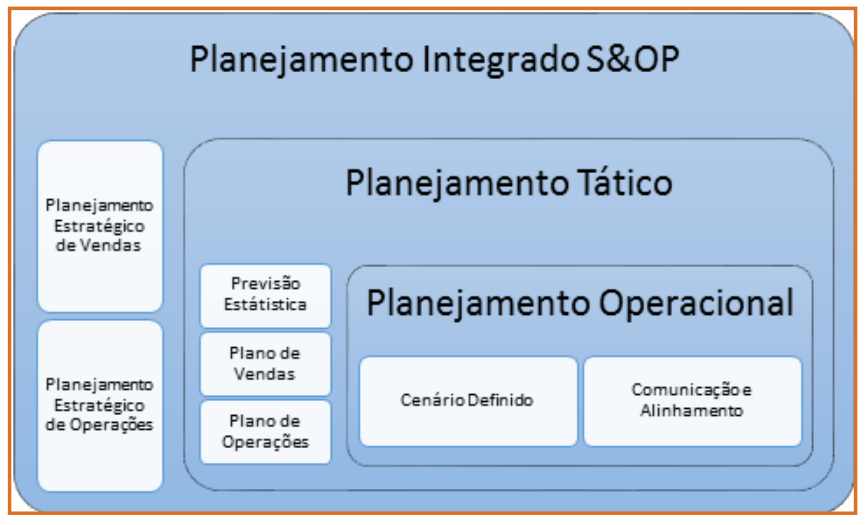

Fonte: Adaptado de Arrozo (2006)

Embora as vantagens da implementação do processo S\&OP sejam notórias, não obstantes sãos as dificuldades de implementação do processo nas organizações, isto devido muito provavelmente à necessidade de uma abordagem pragmática para a condução deste processo. Segundo MacGougan (2003) os aspectos relacionados abaixo são fundamentais para as empresas desejam adotar $\mathrm{o}$ processo:

a) Mudança de Cultura: toda a organização precisa se adaptar ao novo processo, todos os níveis hierárquicos devem estar integrados para a construção de uma nova cultura organizacional.

b) Integridade das Informações: as informações levadas para análise nas reuniões de S\&OP jamais devem ser manipuladas para adequar-se a um resultado desejado.

c) Limitação do Sistema: as informações utilizadas para as tomadas de decisões devem ser apresentadas de forma compreensível, podendo ser compreendida por todos os níveis da organização.

\subsection{PLANEJAMENTO DE DEMANDA}

Dias (2004) comenta que uma vez existindo a diferença entre o fornecimento e a demanda de produtos, resultado de uma lacuna de tempo do início da produção de um produto até a sua disponibilização para os consumidores, as empresas devem recorrer à previsão de demanda para antecipar o comportamento do mercado, permitindo assim que os consumidores encontrem seus produtos no momento em que desejarem. Pellegrini (2000) afirma que as previsões de demanda desempenham um papel-chave no atendimento dos clientes, sendo fundamentais para a gestão eficiente das organizações.

Segundo Ballou (2006), o planejamento e o controle das atividades da cadeia de suprimentos dependem das estimativas apuradas quanto ao volume de produtos e serviços a serem processados. Tais estimativas ocorrem tipicamente na forma de planejamentos e previsões. Porém, não é responsabilidade exclusiva do profissional de logística elaborar a previsão geral da empresa. Muito provavelmente esta tarefa será atribuída ao marketing, ao planejamento econômico ou a um grupo especialmente formado para isso.

Ainda de acordo com Ballou (2006), a previsão dos níveis de demanda é vital para a empresa como um todo, à medida que proporciona a entrada básica para o planejamento e controle de todas as áreas funcionais (logística, marketing, produção, finanças, outras). Os níveis de demanda e os momentos em que estas ocorrem afetam fundamentalmente os índices de capacidade, as necessidades financeiras e a estrutura geral de qualquer negócio. Cada uma das áreas funcionais tem problemas específicos de previsão. Ballou (2006) apresenta também que existem vários métodos de previsões disponíveis. Tais métodos são classificados nas seguintes categorias:

a) Qualitativo: são métodos produzidos através de pesquisas, julgamentos ou análises comparativas, sendo utilizados na construção das previsões quantitativas.

b) Projeção Histórica: trata-se do método de análise que se baseia em dados históricos, sem grandes variações e tendências, para a previsão da demanda futura.

c) Causais: são métodos que baseiam-se em análises de causa e efeito. Podem ser estatísticos, no caso de modelos de regressão, ou descritivos, no caso de ciclos de vida de produtos. 


\section{METODOLOGIA DE PESQUISA}

O foco da pesquisa consistiu em analisar as informações de uma empresa do setor de maquinas agrícolas após a implementação do processo de S\&OP no planejamento de peças de reposição. Segundo a classificação apresentada por Navarro \& Lima (2006), o trabalho realizado tratou-se de uma pesquisa aplicada, quantitativa, qualitativa, de cunho exploratório, em que o método utilizado foi o estudo de caso, por se tratar de um evento atual onde as fontes de informações são baseadas na bibliografia já existente e em dados coletados na empresa analisada.

A aplicação metodológica para o desenvolvimento do trabalho atendeu as seguintes etapas:

a) Revisão bibliográfica: foi realizada de maneira a suportar as discussões que envolvessem as melhorias obtidas após a implementação do processo S\&OP. Foram pesquisados autores e livros relevantes quanto ao tema.

b) Revisão dos Processos Operantes: foi analisado o processo de planejamento de demanda no departamento de peças de reposição da empresa, o qual buscou-se identificar como a organização foi impactada com a implementação do processo $\mathrm{S \& OP}$

c) Informações Coletadas: $O$ banco de dados disponível para a coleta de informações foram de 4 anos consecutivos (2011 à 2014), sendo portanto este o período de referência do estudo de caso apresentado neste trabalho. O processo S\&OP foi implementado na empresa no ano de 2011. A coleta dos dados foi separada em informações quantitativas (análise de indicadores) e qualitativas (entrevistas com clientes), que foram descritos respectivamente nos itens c. 1 e c. 2 .

c.1) Análise de Indicadores: as informações foram obtidos utilizando-se o banco de dados da empresa avaliada. Os indicadores verificados foram:

Valor em Estoque Total (VeT): trata-se do valor total imobilizado nos estoques de peças de reposição, que é composto pelo valor das peças estocadas (Ve), mais o valor das peças em trânsito $(\mathrm{Vt})$, mais o valor das peças que está em pedido com os fornecedores $(\mathrm{Vf})$.
Índice de Atendimento ao Cliente (x\%): é o indicador mais importante para a empresa, pois mensura o número de pedidos atendidos em sua totalidade, ou

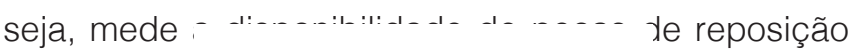
para o clie $V e+V t+V f=V e T$ do como o indicador é caıurauv.

Em que p1, p2, p3,..,pn, são os números de pedidos de um mesmo cliente que são entregues sem falhas em itens ou quantidades, e n é a quantidade total de pedidos real: $-\ldots-\ldots \ldots-1 \ldots-1: \ldots+\ldots$

$$
x \%=\frac{p 1+p 2+p 3+\ldots+p n}{n}
$$

Estes indica!

ados de forma sigilosa pela empresa avaliada. Visando explicitar os resultados alcançados com a implementação do processo S\&OP, foi estabelecido como referencial os indicadores alcançados no inicio do processo de implementação, ou seja, no ando de 2011. Desta forma, as informações apresentadas nos resultados deste trabalho (item 4) foram referenciais ao ano de implementação (referência: indicador 2011 = 100\%), respeitando desta forma a abordagem sigilosa das informações.

c.2) Entrevista com Clientes: visando qualificar a efetividade do processo S\&OP perante os clientes, foi realizada uma seleção dos 3 clientes mais importantes comercialmente para empresa (período: 2015) para a participação de um questionário de satisfação quanto ao atendimento dos serviços entregues pela empresa. Para cada um destes clientes foi realizada uma ligação telefônica, no período de 29/11/2015 até 12/01/2016, em que foram questionados com a seguinte pergunta: "Qual a sua percepção a qualidade no atendimento das peças de reposição no período de 2011 até 2015?».

A abordagem utilizada referenciou-se no trabalho de Feichheld (2003), com o objetivo de mensurar o grau de satisfação e fidelidade dos clientes. A utilização desta abordagem foi motivada pela simplicidade, flexibilidade e confiabilidade da metodologia. 


\section{RESULTADOS E DISCUSSÕES}

O foco do estudo esteve concentrado em analisar a evolução de dois indicadores (nível de estoque e nível de atendimento ao cliente) no setor de planejamento de peças de reposição após a implementação do processo S\&OP. Nos departamentos de peças de reposição há sempre o desafio de alcançar um alto nível de disponibilidade das peças de reposição e, por outro lado, imobilizar a menor quantidade possível de capital.

A demanda por peças de reposição era realizada por um sistema ERP (Enterprise Resource Planning), que incluía todo o planejamento de inventario, compra de material e estocagem. A empresa utilizava o método de projeção histórica para as previsões de demanda, incluindo algumas vezes variáveis de mercado, econômicas, geopolíticas, clima, entre outros, em suas previsões.

Em 2011 iniciou-se a implementação do processo de S\&OP na empresa, que perdurou até o ano de 2013. O projeto incluía em seu escopo a atualização da versão do ERP utilizado pela unidade. Todos os níveis hierárquicos foram envolvidos no projeto. A Figura 2 ilustra de uma forma holística o processo de S\&OP da empresa avaliado, o qual enfatizava os pilares de conhecimento do mercado e o entendimento ao cliente, passando pelos subprocessos de operação, planejamento, marketing e vendas.
Figura 2 - Ilustração do processo S\&OP na empresa estudada em 2014.

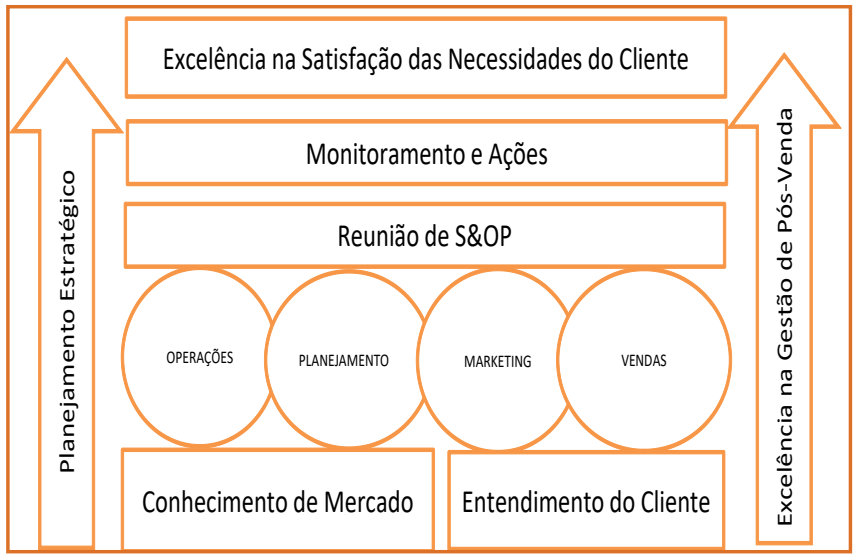

Fonte: Adaptado de Corrêa et al. (2001)

Com a implementação do processo S\&OP foi possível observar melhorias sistêmicas significativas nos processos de reposição de peças, os quais refletiram diretamente nos indicadores monitorados pela empresa. A seguir são apresentadas as melhorias alcançadas com a implementação do processo S\&OP.

a) Valor em Estoque Total (VeT): A empresa acompanhava criteriosamente os estoques de reposição, uma vez que fazia parte da composição dos custos do produto ao cliente. Assim, havia uma estrutura dentro da empresa que tinha como objetivo alcançar a otimização deste indicador. Durante o período pesquisado os valores de estoque total apresentaram uma redução acumulada de 14,0 \% do valor total e de $14,5 \%$ em quantidade de peças. A redução financeira do estoque imobilizado foi extremamente significativa. A Figura 3 apresenta a redução deste indicador (referência: indicador $2011=$ 100\%) no período de 2011 a 2015. 
Figura 3 - Redução do Valor em Estoque Total da empresa após implementação do processo S\&OP

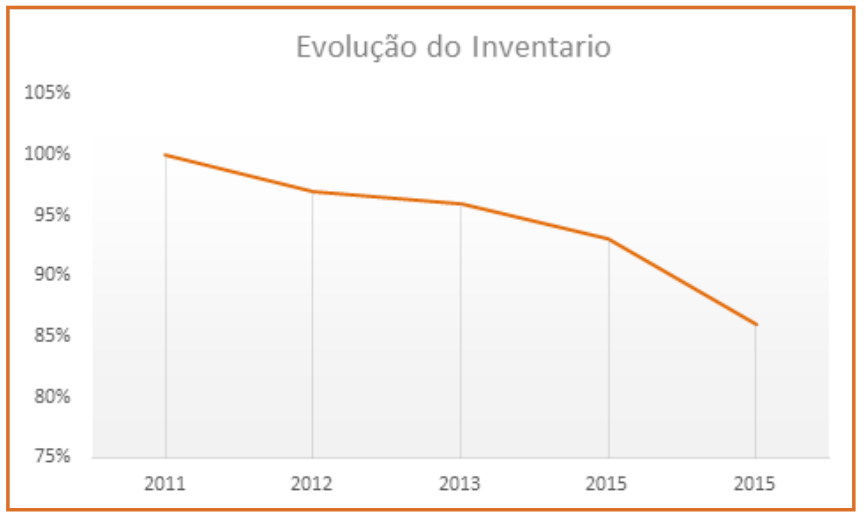

Os estoques têm como objetivo melhorar o nível de serviços, gerar maior economia na produção, proteger a empresa de incertezas de demanda e servir como segurança em caso de contingências. A redução do nível de estoques sem prejudicar o nível de atendimento ao cliente é extremamente interessante em qualquer tipo de negócio.

b) Índice de Atendimento ao Cliente (x\%): Uma vez reduzido os níveis de estoques, poder-se-ia esperar alguma redução no índice de atendimento ao cliente. No entanto, com a implementação do processo de S\&OP verificou-se um crescimento de $29 \%$ neste índice, o que significou ganhos significativos para a organização. A Figura 4 apresenta o aumento deste indicador (referência: indicador $2011=100 \%$ ) no período de 2011 a 2015.
Figura 4 - Aumento do Índice de Atendimento ao Cliente da empresa após implementação do processo S\&OP

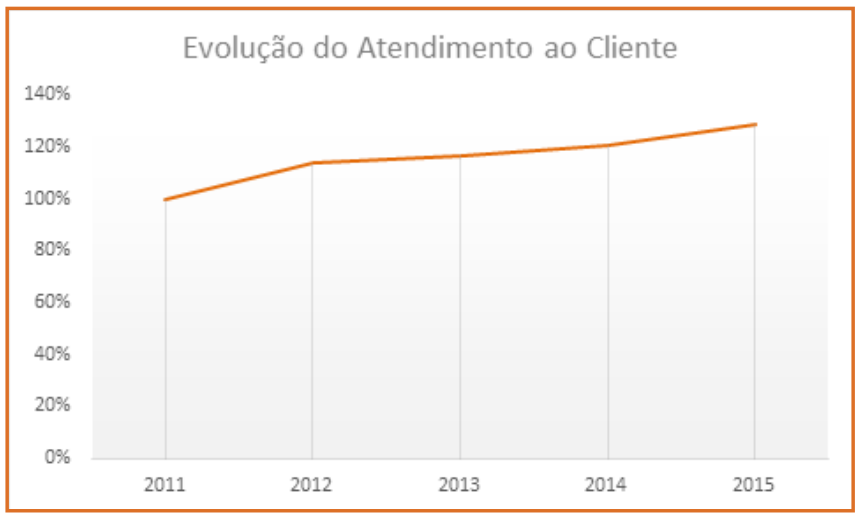

Uma vez que a empresa analisada trabalha com equipamentos agrícolas, em que aplicações são normalmente sujeitas a esforços intensos, é fundamental para esta uma alta disponibilidade das peças de reposição, levando consequentemente aos altos Índices de Atendimento ao Cliente. Desta forma, assim como foi para a redução do Valor em Estoque Total, o processo de S\&OP novamente mostrouse eficaz quanto o aprimoramento do Índice de Atendimento ao Cliente.

c) Entrevista com Clientes: A Figura 5 a seguir apresenta as respostas obtidas com a pesquisa de satisfação realizada com os 3 maiores clientes da empresa. Os resultados da pesquisa indicaram que as evoluções alcançadas nos indicadores VeT e x\% realmente foram percebidos pelos clientes, ou seja, estes perceberam melhorias na disponibilidade das peças de reposição. 
Figura 5 - Resultado das pesquisas com clientes.

"Qual a sua percepção a qualidade do atendimento de peças de reposição no período de 2011 até 2015? "

\begin{tabular}{|c|c|c|c|c|}
\hline Cliente & Região & Setor & Resposta & Cargo do Entrevistado \\
\hline 1 & SP & Usina & $\begin{array}{l}\text { Houve uma evoluação na } \\
\text { qualidade do } \\
\text { atendimento dos pedidos } \\
\text { de peças de reposição. } \\
\text { Não temos registro de } \\
\text { reclamações dos times } \\
\text { de operação e agricola } \\
\text { qanto ao desempenho } \\
\text { das colheitadeiras. }\end{array}$ & $\begin{array}{c}\text { Gerete corporativo } \\
\text { de Manutenção }\end{array}$ \\
\hline 2 & SP/PR & Usina & $\begin{array}{l}\text { Sentimos sim uma } \\
\text { melhora significativa na } \\
\text { disponibilidade de peças } \\
\text { de reposição. Além de } \\
\text { notóriamente ver a } \\
\text { redução dos tempos } \\
\text { médios de entrega dos } \\
\text { pedidos. Fizemos nos } \\
\text { últimos anos um estudo } \\
\text { de custo de uma } \\
\text { colheitadeira parada. } \\
\text { Houve uma redução de } \\
67 \% \text { das paradas de } \\
\text { máquinas por fala de } \\
\text { peças de reposição no } \\
\text { período de } 2011 \text { até } \\
2015 \text {. Uma expressiva } \\
\text { melhora }\end{array}$ & Diretor de Operação \\
\hline 3 & $\begin{array}{l}\text { SP/PR/ } \\
\text { GO/MG }\end{array}$ & Usina & $\begin{array}{c}\text { Comecei a trabalhar na } \\
\text { empresa no ano de } 2013 . \\
\text { Mas os dados que temos } \\
\text { para medir a performance } \\
\text { de vocês nos mostram } \\
\text { uma evolução na } \\
\text { disponibilidade de } \\
\text { estoque. Além de um } \\
\text { atendimento mais rápido, } \\
\text { se não houver estoque no } \\
\text { momento. O importante é } \\
\text { que nos últimos anos a } \\
\text { nossa percepção é que } \\
\text { vocês estão cuidando do } \\
\text { cliente como nenhuma } \\
\text { outra empresa tem feito. }\end{array}$ & $\begin{array}{l}\text { Gerente Geral de } \\
\text { Operação Agrícola }\end{array}$ \\
\hline
\end{tabular}




\section{CONCLUSÃO}

O estudo evidenciou a importância do processo de S\&OP na empresa avaliada. Os resultados dentro do departamento de planejamento de peças de reposição foram bastante positivos, o que foi evidenciado pelo acompanhamento dos indicadores do setor e pela percepção dos clientes quanto aos níveis de serviços ofertados.

Mesmo operante por certa de 5 anos, o processo S\&OP da organização estudada ainda é relativamente novo, o que indica que os resultados podem se mostraram ainda mais promissores com a maturidade do sistema.

Foi verificada uma redução no valor dos estoques de aproximadamente 14\%, o que trouxe benefícios significativos à organização, uma vez que reduziu os investimentos em ativos imobilizados. Ainda assim (menor nível de estocagem), pode-se constatar também um aumento de $29 \%$ do nível de atendimento ao cliente, o qual foi percebido pelos clientes, que reconheceram um melhor nível de atendimento quanto ao fornecimento de peças de reposição.

\section{REFERÊNCIAS}

[1] APICS Dictionary. American Production and Inventory Control Society. Falls Church, VA, 1995.

[2] ARROZO, A. Sales and Operations Planning. Uma maneira simples de obter ganhos com integração interna.2006.Disponível em:www.feg.unesp.br/ fmarins/FAl/ S\&OP.ppt; acesso em outubro de 2010.

[3] Bower, P. How the S\&OP Process Creates Value in the Supply Chain. The Journal of Business Forecasting Methods \& Systems. Vol 25. No 2 pag 20-32, 2006.

[4] BALLOU, R. H. Gerenciamento da Cadeia de Suprimentos/Logística Empresarial. Porto Alegre. Bookman, 2006

[5] CARDOSO, A.A. A interface entre vendas e manufatura: uma análise da relação operacional. São Paulo: Dissertação de mestrado - Escola Politécnica da Universidade de São Paulo, 2005.

[6] CORRÊA, H. L.; GIANESI, I.; CAON, M. S\&OPPlanejamento de Vendas e Operações (Sales and Operations Planning), Planejamento Programação e Controle da Produção. Editora Atlas, 2001
[7] DIAS, A. S. Uso de conhecimentos teóricos e de especialista para Previsão de Demanda. São Carlos, SP. Dissertação (Engenharia de Produção) - Universidade Federal de São Carlos, 2004

[8] DWARAKNATH, V.; CHEN, C.; ÇAKANYILDIRIM, M.; ISBULAN, B. Sales and Operations Planning Practices at Semiconductor Companies. Disponível em:https://proxy. utdallas.edu/ metin/Research/ sopsurveyhidden.pdf; acesso em outubro de 2015.

[9] FEICHHELD, F. The One Number You Need to Grow, Harvard Business Review, December 2003

[10] JULIANELLI, L. Análise do processo de planejamento da demanda e S\&OP em empresas brasileiras: parte 2. Niterói: Arte \& Ofício, 1992. Disponível em: <http://www.ilos. com.br/web/index.php?option= com_content\&view=article\& $\mathrm{id}=1752 \% 3 \mathrm{Aartigos}$-analise-do-processo-de-planejamentoda-demanda-e-saop-em-empresas-brasileiras\&catid=4\&lte mid=182\&lang=br>. Acesso em: 3 abril. 2016.

[11] HAMMER, M., CHAMPY J. Reengenharia. São Paulo: Campus, 1994

[12] MACGOUGAN, G. S\&OP for Top management in a small business. International Conference Proceedings, APICS, F-06, p. 1-4, 2003

[13] MOREIRA, C. Marketing Industrial. São Paulo. Atlas, 1989

[14] NAVARRO, J.; LIMA, R. Planejamento de vendas e operações (S\&OP): Um estudo de caso em uma empresa da indústria de telecomunicações. ENEGEP 2006

[15] O'KEEFFE, P. Understanding supply chain risk areas, solutions, and plans - a five-part series. Protiviti Independent Risk Consulting; APICS, 2004

[16] OLIVA, R.; WATSON, N. Cross-functional alignment in supply chain planning: A case of sales and operations planning. Journal of Operations Management, v. 29, n. 5, p. 434-448, 2011.

[17] PELLEGRINI, F. R. Metodologia para implantação de Sistemas de Previsão de Demanda. Porto Alegre, RS. 111 p. Dissertação (Engenharia de Produção) - Universidade Federal do Rio Grande do Sul, 2000

[18] PIRES, S. R. I. Gestão estratégica de produção. Piracicaba: Editora UNIMEP, 1995 


\section{CAPÍTULO 18}

\section{Gestáo de ESTOQUe: ANÁlise da literatura PARA IDENTIFICAÇÃO DE OPORTUNIDADE DE PESQUISAS}

\section{Rayane Carla Scheffer}

Claudilaine Caldas de Oliveira

Rony Peterson da Rocha

Rosimeire E. dos Santos Sehaber

Ederaldo Luiz Beline

Resumo: A gestão de estoques auxilia as organizações atingirem o nível de serviço que o mercado exige, garantindo assim, maior disponibilidade de produtos com o menor nível de estoque possivel, visto que, estoque em excesso, significa custos. Este trabalho teve como objetivo, realizar uma análise de literatura de um conjunto de trabalhos científicos, referentes ao tema gestão e controle de estoques, visando maior conhecimento sobre o tema e identificação de oportunidades de pesquisas. A pesquisa classifica-se, quanto aos fins, como descritiva e, quanto aos meios, como bibliográfica. O método de abordagem foi o quantitativo-qualitativo. Como resultado, obteve-se um portfólio formado por 30 trabalhos científicos alinhados ao tema de pesquisa e a partir destes, foram realizados a análise bibliométrica e revisão sistêmica. Há utilização de diversas metodologias e métodos utilizados em outras áreas, que consideram aspectos e variáveis de acordo com a necessidade da organização, principalmente nos artigos de ámbito internacional. os resultados desta pesquisa proporcionaram conhecimento sobre o tema alem da identificação de lacunas e oportunidades de pesquisa que venham a contribuir cientificamente para esse tema.

Palavras chave: Controle de estoques, Estoques, Classificação ABC. 


\section{INTRODUÇÃO}

Com a exigência do consumidor e o aumento da competitividade, as organizações necessitam se adaptar constantemente às tendências do mercado, melhorar suas performances e agregar valor aos produtos e serviços. Neste contexto, a gestão de estoques auxilia as organizações atingirem o nível de serviço que o mercado exige, garantindo assim, maior disponibilidade de produto com o menor nível de estoque possível, pois, estoque em excesso, significa custos.

Controle de estoques na percepção de Siqueira (2009), refere-se a busca do equilíbrio entre manter o serviço de acordo com o que foi planejado e evitar o excesso de custos, ou seja, deve-se levar em conta que o estoque é um recurso produtivo que é capaz de produzir valor para a empresa e para o cliente, de modo a gerar o menor custo possível.

Nas organizações, as decisões de estocagem e de produção, devem ser consideradas juntas, pois entre as decisões mais importantes do controle de estoque, estão quais itens devem ser repostos, quando está reposição deve ser feita e qual a quantidade necessária de itens para a reposição, até chegar aos níveis de estoques desejados (FREIRE e MESQUITA, 2011; TUBINO, 2009).

As diferenças das demandas nas organizações e os cálculos envolvidos nas decisões de estocagem são aspectos que caracterizam os diferentes modelos utilizados nos sistemas de controle de estoques (FREIRE e MESQUITA, 2011). Antes de montar um sistema de controle de estoque, deve-se especificar alguns fatores, como o tipo de estoque existente na organização, o nível adequado de estoque para atender as necessidades demandas e a relação entre o nível de estoque e o capital envolvido (DIAS, 1993).

As empresas muitas vezes podem encontrar dificuldades para lidar com milhares de itens em estoques, pois além de diversos fornecedores, possui consumidores individuais, o que torna o controle de estoques complexo, então surge à necessidade de utilizar um sistema de controle (SLACK et al., 2009).

Para que não haja excesso de itens em estoque, deve-se gerenciá-lo para obter a redução de custos e manter apenas a quantidade de itens necessários, para atender o desejo do cliente, visando permanecer no mercado competitivo. Portanto, os itens devem ser adquiridos de acordo com a demanda, pois o excesso, pode comprometer o capital de giro, proporcionando problemas de desempenho na organização e, consequentemente, diminuindo os lucros, sendo assim, é indispensável que as organizações tenham um controle de estoques bem definido.

Diante destes pressupostos, este artigo teve por objetivo, realizar uma análise de literatura, de um conjunto de trabalhos científicos, referentes ao tema gestão e controle de estoques, visando maior conhecimento sobre o tema e identificação de oportunidades de pesquisa futuras.

O trabalho está estruturado em seis seções. $\mathrm{Na}$ primeira, apresenta-se o contexto e objetivo, a segunda, é composta pela fundamentação, contendo as principais características que envolve a gestão de estoque. A terceira é composta pela metodologia de pesquisa. Na quarta seção, apresenta-se os resultados encontrados, ou seja, uma análise da literatura referentes à gestão e controle de estoques, na quinta, as considerações finais e por fim, listam-se as referências.

\section{GESTÃO DE ESTOQUES}

Com a função de compras, as empresas perceberam a importância de relacionar o fluxo de materiais e as funções de apoio, afim de fornecer os produtos aos clientes no prazo determinado, então, surgiu a gestão de estoques (SLACK et al., 2009).

O gerenciamento dos estoques visa a redução dos custos relacionado à aquisição e gestão dos itens e engloba o planejamento, controle e a retroalimentação do planejamento. $O$ planejamento consiste em determinar valores do estoque, datas de entrada e saídas de itens de estoque e pontos de pedidos. 0 controle é o registro dos dados, que correspondem ao que foi planejado. A retroalimentação é a comparação dos dados do controle com o planejamento para identificar desvios, afim de corrigi-los para não obter 
aumento de custos (CHING, 2001).

A gestão de estoques tem se tornando essencial para o gerenciamento da cadeia de suprimentos, pois permite que os gestores analisem se os estoques estão sendo bem utilizados, se a localização está adequada e se os itens estão sendo bem manuseados e controlados, não havendo assim, falta ou excesso de itens (MARTINS e ALT, 2000; WANKE, 2008).

\subsection{ESTOQUES}

Para a gestão é necessário entender o que são os estoques. Os estoques são "quantidades de bens físicos que sejam conservados na forma improdutiva, por algum intervalo de tempo" (FRANCISCHINI e GURGEL, 2004, p. 81), para Slack et al. (2009, p. 356) os "estoques são a acumulação armazenada de recursos materiais em um sistema de transformação" e para Ballou (2010) os estoques são acúmulos de materiais (matérias-primas, insumos, componentes, produtos) que estão presentes em todos os canais logísticos e de produção.

Os estoques auxiliam no fluxo de negócio, pois como a frequência de recebimento de mercadorias normalmente é diferente da frequência com que são utilizados há a necessidade de um controle de estoque como um mecanismo de segurança (MARTINS e ALT, 2000).

Segundo Moreira (2009), os estoques proporcionam algumas vantagens, como cobrir mudanças previstas no suprimento e na demanda, proteger contra incertezas e permitir produção ou compra econômica.

Atender os clientes na quantidade e nos prazos certos tem sido os objetivos das organizações, devido a isso, a rapidez e a distribuição desempenham papel de destaque nas empresas, visando obter vantagens competitivas (MARTINS e ALT, 2000).

Os estoques são responsáveis por uma considerável quantidade de ativos de uma empresa, "eles recebem um tratamento contábil minucioso, sendo classificados em cinco grandes categorias" (MARTINS e ALT, 2000, p. 136). De acordo com Slack et al. (2009), em manufaturas há basicamente cinco tipos de estoques, os quais podem ser visualizados no Quadro 1.

Quadro 1- Tipos de estoques

\begin{tabular}{|l|l|}
\hline $\begin{array}{l}\text { TIPOS DE } \\
\text { ESTOQUES }\end{array}$ & CARACTERÍSTICAS \\
\hline $\begin{array}{l}\text { Estoque de } \\
\text { matéria-prima }\end{array}$ & $\begin{array}{l}\text { Corresponde aos itens utilizados para o } \\
\text { processo de fabricação para produtos } \\
\text { acabados. São todos os materiais utilizados } \\
\text { pela empresa para utilizar no processo } \\
\text { produtivo, sendo diretos (que incorporam } \\
\text { o produto final) ou indiretos (materiais } \\
\text { auxiliares). }\end{array}$ \\
\hline $\begin{array}{l}\text { Estoque de } \\
\text { produto em } \\
\text { processo }\end{array}$ & $\begin{array}{l}\text { Corresponde aos itens que já passaram } \\
\text { pelo processo produtivo, mas que ainda } \\
\text { não é o produto acabado. São matérias } \\
\text { que já sofreram transformações, mas não } \\
\text { estão finalizados. }\end{array}$ \\
\hline $\begin{array}{l}\text { Estoque de } \\
\text { produto acabado }\end{array}$ & $\begin{array}{l}\text { Corresponde aos itens que já passaram } \\
\text { pelo processo produtivo e estão acabados. } \\
\text { São os produtos prontos para serem } \\
\text { entregues ao consumidor final. }\end{array}$ \\
\hline $\begin{array}{l}\text { Estoque em } \\
\text { trânsito }\end{array}$ & $\begin{array}{l}\text { Corresponde aos itens que já estão } \\
\text { acabados e que já foram enviados de uma } \\
\text { unidade para a outra, porém não chegou } \\
\text { ainda ao consumidor final. }\end{array}$ \\
\hline $\begin{array}{l}\text { Estoque em } \\
\text { consignação }\end{array}$ & $\begin{array}{l}\text { Corresponde aos itens que ainda são } \\
\text { pertencentes aos fornecedores, até } \\
\text { que sejam vendidos, caso contrário são } \\
\text { devolvidos. }\end{array}$ \\
\hline
\end{tabular}

Fonte: Martins e Alt (2000, p. 136)

\subsection{CLASSIFICAÇÃO ABC}

A classificação $A B C$ permite a identificação dos itens em estoque que necessitam de mais ou menos atenção (DIAS, 1993). A classificação ABC se baseia no raciocínio do Diagrama de Pareto, realizado por Vilfredo Pareto, em que nem todos os itens têm a mesma importância e apenas uma pequena quantidade de itens domina os resultados atingidos e deve ser dada mais atenção (ARNOLD, 1999, CHING, 2001).

De acordo com Dias (1993), Arnold (1999) e Moreira (2009), quando aplicada à administração de estoques, apresenta-se uma relação de porcentagens de itens e a utilização anual em valores monetários, sendo:

a) Classe A: grupo de itens mais importantes, que devem ser tratados com mais atenção e correspondem a $20 \%$ dos itens totais em estoque e $80 \%$ da utilização em valores monetários; 
b) Classe B: grupo de itens em situação intermediária entre a classe A e C e correspondem a $30 \%$ dos itens totais do estoque e a $15 \%$ da utilização em valores monetários; e

c) Classe C: grupo de itens menos importantes que justificam pouca atenção e correspondem a 50\% dos itens totais do estoque e a 5\% da utilização em valores monetários.

As porcentagens são aproximadas e podem variar de acordo com cada tipo de estoque (ARNOLD, 1999).

Não existe uma fórmula definida para se classificar os itens, deve-se ter como base a importância relativa das três classes em relação ao investimento (MOREIRA, 2009).

\subsection{CONTROLE DE ESTOQUES}

Controle é definido como um fluxo de informações em que é possível fazer comparação do resultado real com o planejado, e para que seja eficiente, é necessário que as informações sejam adequadas e o resultado esperado seja parecido com o comportamento real (FRANCISCHINI e GURGEL, 2002). O controle de estoque é a relação das atividades de coordenação de fornecedores, estruturas, armazenagem, distribuição e registros de materiais (GURGEL, 2000).

O objetivo do controle do estoque é que o estoque contenha os itens alocados em locais de fácil acesso, de acordo com suas necessidades e que não seja tão alto de modo que não comprometa o lucro da empresa, pois os estoques influenciam significativamente no lucro, devido a utilização do capital que poderia ser investido para potencializar a organização (CHING, 2001).

Neste contexto, deve-se encontrar um nível de estoque adequado para que possa atender adequadamente as necessidades, determinar os lotes de compras, classificar os itens em estoques, para obter maior controle dos itens e utilizar um sistema de controle para facilitar a administração do estoque.

\subsubsection{NÍVEIS DE ESTOQUES}

Os estoques podem ser representados pela utilização de diversas ferramentas, que se usadas juntas proporcionam uma eficiente análise dos níveis de estoque (DIAS, 1993). As ferramentas utilizadas para determinar os níveis de estoque podem ser: curva dente de serra, tempo de reposição, estoque de segurança, ponto de pedido, estoque médio e giro de estoque, entre outras.

\subsubsection{SISTEMAS DE CONTROLE DE ESTOQUES}

As organizações muitas vezes podem encontrar dificuldades para lidar com milhares de itens em estoques que são fornecidos por diversos fornecedores e possuir vários consumidores individuais, isso torna a tarefa de controlar os estoques complexa, sendo assim, para realizar esse controle as empresas necessitam investir em sistemas de controle de estoque para administrar os estoques (SLACK et al., 2009). Há diversos sistemas de controle de estoques, como o sistema de reposição contínua, sistema das revisões periódicas, sistema duas gavetas, sistemas dos máximos e mínimos, sistema just in time e sistema de planejamento das necessidades de materiais (Manufacturing resource planning - MRP) (DIAS, 1993).

\section{METODOLOGIA}

A pesquisa aqui relatada classifica-se, quanto aos fins, como descritiva e, quanto aos meios, como bibliográfica. O método de abordagem adotado foi o quantitativo-qualitativo.

Assim, realizou-se uma pesquisa, com o objetivo de identificar nos trabalhos publicados, quais os principais conteúdos abordados sobre gestão de estoques, a metodologia utilizada, durante o período de 2005 à 2015.

Para as buscas dos trabalhos foram realizadas no Google Scholar, nas bases de dados da Coordenação de Aperfeiçoamento de Pessoal de Nível Superior (CAPES), Scielo, Science Direct, Scopus, Web of Science e Wiley Online Library. A pesquisa limitouse às palavras-chave: gestão de estoque, controle 
de estoque, estoque, sistema de controle de estoque e classificação ABC, e a para a análise de artigos internacionais, foram utilizadas as mesmas palavraschave, em inglês: inventory management, inventory control, inventory, inventory control system e $A B C$ classification.

Foram selecionados 30 trabalhos alinhados com o tema desse estudo, tratado aqui como portfólio. Destes, 10 são trabalhos de conclusão de curso de graduação, 10 artigos nacionais, 6 artigos internacionais e 4 dissertações.

A análise de conteúdo dos trabalhos encontrados foi estruturada em bibliométrica sistêmica baseado na percepção dos pesquisadores.

\section{RESULTADOS E DISCUSSÕES \\ 4.1 ANÁLISE BIBLIOMÉTRICA}

Para a análise bibliométrica, identificou-se: (i) palavraschave mais utilizadas, e (ii) reconhecimento científico dos trabalhos.

Um dos pontos mais importantes a serem pesquisados e que evidencia a efetividade do processo de mapeamento de um tema é o conjunto de palavraschave mais citados. Analisando as palavras-chave dos trabalhos que compõe o portfólio, foi elaborado um gráfico (Figura 1) em que são apresentadas as principais utilizas pelos autores.

Figura 1 - Relevância das palavras-chave do portfólio

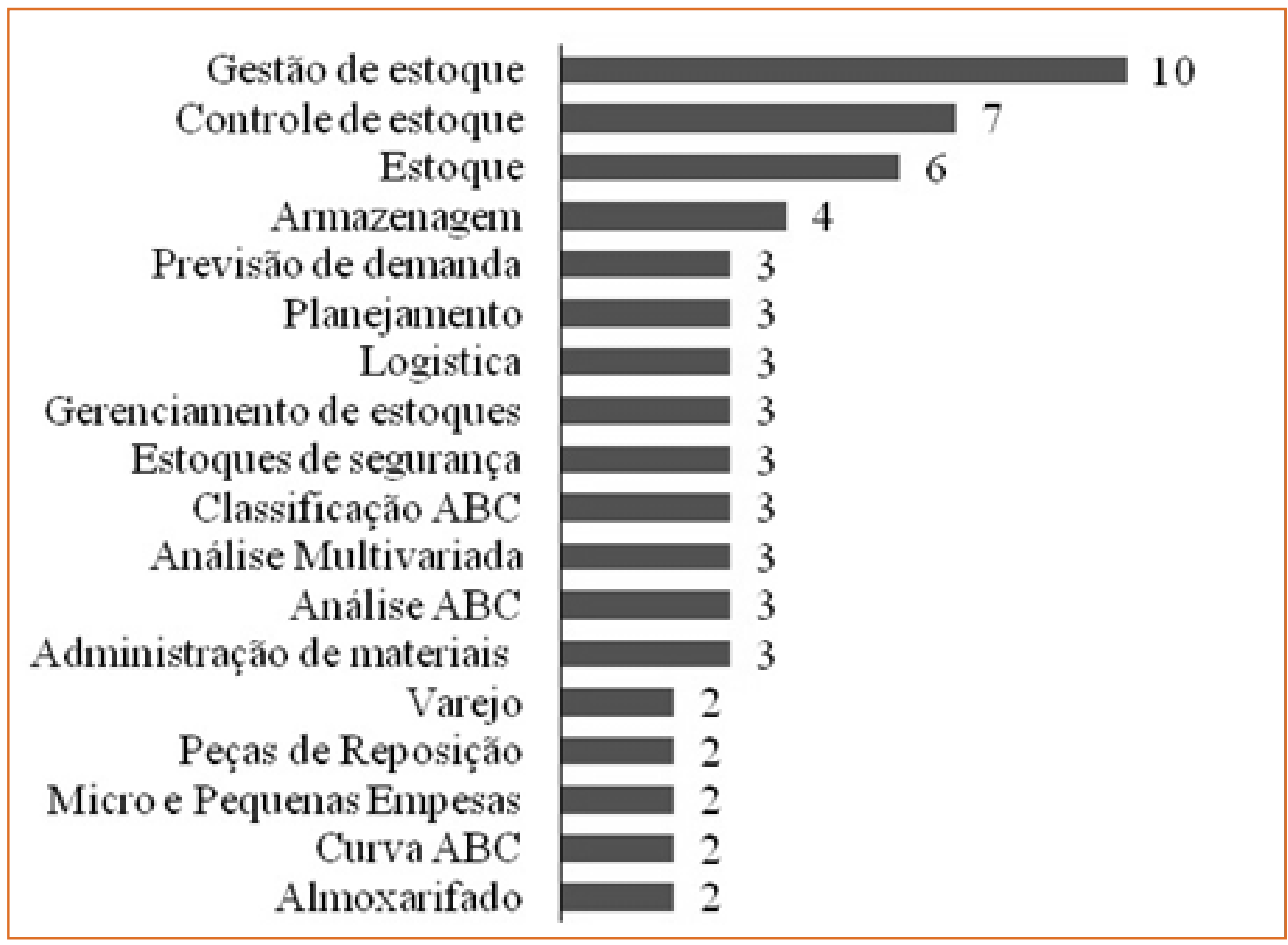


análise foram consideradas apenas as palavras que apareceram mais de uma vez. Observando a Figura 1, nota-se que as palavras-chave que mais apareceram foram: Gestão de estoque, com 10 aparições, controle de estoque, com sete e estoque com quatro. Diante desta observação, nota-se que as palavras-chave utilizadas para a elaboração da revisão de literatura, foram efetivas, pois abrangeram as palavras-chave que foram mais utilizadas nos trabalhos.

Para o reconhecimento científico de cada trabalho do portfólio, mediante a identificação do número de vezes que o trabalho foi citado, por outros estudos científicos, foi utilizado o Google Scholar, os trabalhos que compõe o portfólio, podem ser observados no Quadro 2, com seus respectivos códigos.

Quadro 2 - Trabalhos que compõe o portfólio (fim)

\begin{tabular}{|c|c|}
\hline Código & Trabalho que compõe o portfólio \\
\hline 1 & $\begin{array}{l}\text { ALVES, JUNIOR, P. N. Gestão de estoque no setor de varejo calçadista: abordagem dia análise multivariada e teoria do controle } \\
\text { ótimo. 2014. 105f. Dissertação (Mestrado) - Faculdade de Engenharia de Bauru. Universidade Estadual Paulista, Bauru, } 2014 .\end{array}$ \\
\hline 2 & $\begin{array}{l}\text { AMARAL, J. L. S.; OLIVEIRA, M. de. Gestão de estoques e sua contribuição para os objetivos de desempenho numa fábrica } \\
\text { têxtil de pequeno porte. Revista Produção e Engenharia. Vol. 07, n.01, p. 600-612, } 2015 .\end{array}$ \\
\hline 3 & $\begin{array}{l}\text { BALAJI, K.; V.S. SENTHIL KUMAR, V. S. Multicriteria Inventory ABC Classification in an Automobile Rubber Components } \\
\text { Manufacturing Industry. 47th CIRP Conference on Manufacturing Systems. Vol. 17, p. 463-468, } 2014 .\end{array}$ \\
\hline 4 & $\begin{array}{l}\text { BORGES, F. A. Gerenciamento de estoque como diferencial na empresa revenderia peças e acessórios LTDA. 2014. 51f. } \\
\text { Monografia (Graduação). Universidade Federal do Maranhão, São Luiz, } 2014 .\end{array}$ \\
\hline 5 & $\begin{array}{l}\text { BOSSONI, C. A. A gestão de estoques no almoxarifado de uma empresa pública de transporte ferroviário. 2009. } 101 \text { f. } \\
\text { Monografia (Tecnólogo em logística). Faculdade de Tecnologia da Zona Leste. Centro Paula Souza, São Paulo, } 2009 .\end{array}$ \\
\hline 6 & $\begin{array}{l}\text { BRAGA, L. M.; PIMENTA, C. M.; VIEIRA, J. G. V. Gestão de armazenagem em um supermercado de pequeno porte. Pesquisa \& } \\
\text { Desenvolvimento Engenharia de Produção, n.9, p. 57-77, } 2008 .\end{array}$ \\
\hline 7 & $\begin{array}{l}\text { BRITO, T. L. de. Aplicação de modelos de gestão de estoques para controle de ressuprimento em uma pequena empresa } \\
\text { industrial: um estudo de caso. 2010. 57f. Monografia (Gradução). Universidade Federal de Juiz de Fora, Juiz de Fora, } 2010 .\end{array}$ \\
\hline 8 & $\begin{array}{l}\text { CALLEGARO, C. G.; QUACLIATO, L. F. Gestão de estoques e sua importância para as organizações. 24f. Monografia } \\
\text { (Graduação) Faculdade Cenetista de Capivari. Capivari, } 2010 .\end{array}$ \\
\hline 9 & $\begin{array}{l}\text { CUNHA, A. C. S. et al. Modelo de gestão de estoques em uma empresa de ferragens e produtos metalúrgicos de pequeno } \\
\text { porte. In: Encontro Nacional de Engenharia de Produção, 32, 2013. Salvador/BA. Anais... Salvador/BA: } 2013 .\end{array}$ \\
\hline 10 & $\begin{array}{l}\text { De FELICE, F. et al. Inventory management using both quantitative and qualitative criteria in manufacturing system. 19th IFAC } \\
\text { World Congress Cape Town. p. 24-29, } 2014 .\end{array}$ \\
\hline 11 & $\begin{array}{l}\text { HADI-VENCHEH, A. An improvement to multiple criteria ABC inventory classification. European Journal of Operational Research. } \\
\text { Vol. 201, p. 962-965, } 2010 .\end{array}$ \\
\hline 12 & $\begin{array}{l}\text { IWANO, K. L.; JOHO, P. H. Sistema integrado no gerenciamento de estoques. 59f. Monografia (conclusão de curso). Centro } \\
\text { Universitário da Fundação Educacional de Barretos (UNIFEB), Barretos, } 2013 .\end{array}$ \\
\hline 13 & $\begin{array}{l}\text { KUNIGAMI, F. J.; OSÓRIO, W. R. Gestão no controle de Estoque: estudo de caso em montadora automobilística. Revista Gestão } \\
\text { Industrial. Vol. 05, n. 04. p. 24-41, } 2009 .\end{array}$ \\
\hline 14 & $\begin{array}{l}\text { MEDEIROS, S. da B. Gestão de estoque no comércio varejista de materiais de construção. 2007. 87f. Monografia (Graduação). } \\
\text { Universidade do Extremo Sul Catarinense. Criciúma, } 2007 .\end{array}$ \\
\hline 15 & $\begin{array}{l}\text { MILLSTEIN, M. A.; YANG, L.; LI, H. Optimizing ABC inventory groping decisions. International Journal of Production Economics. } \\
\text { Vol. 148, p.71-80, } 2014 .\end{array}$ \\
\hline 16 & $\begin{array}{l}\text { MORAIS, M. M. Planejamento da Produção e Gestão de Estoques de uma indústria madeireira de pequeno porte. 2014. } 72 f . \\
\text { Monografia (Conclusão de curso). Universidade Federal de São João Del-Rei. São João Del-Rei, 2014. }\end{array}$ \\
\hline 17 & $\begin{array}{l}\text { NG, W. L. A simple classifier for multiple criteria ABC Analysis. European Journal of Operational Research. Vol. 11, ed. 1. p. 344- } \\
353,2007 .\end{array}$ \\
\hline 18 & $\begin{array}{l}\text { PAULINO, JR.; NETO, A. A. Gerenciamento de estoques em uma indústria de lubrificantes norte-americana. In: Simpósio de } \\
\text { Engenharia de Produção, 22, 2015. Bauru/SP. Anais... Bauru/SP: } 2015 .\end{array}$ \\
\hline 19 & $\begin{array}{l}\text { RAMALHO, A. da S.; BELTRAME, J. N.; VILLELA, J. M. V. A importância de gestão de estoque no supermercado central de } \\
\text { compra Santo Antônio. 2012. 48f. Monografia (Conclusão de curso). Faculdade Norte Capixaba de São Mateus. São Mateus, } \\
\text { 2012. }\end{array}$ \\
\hline 20 & $\begin{array}{l}\text { REGO, J. R. do. Gestão de estoques de peças de reposição: simulação e análise de modelos com dados empíricos. 2014. 122f. } \\
\text { Tese (Doutorado) - Escola Politécnica da Universidade de São Paulo. Universidade de São Paulo. São Paulo, } 2014 .\end{array}$ \\
\hline
\end{tabular}




\begin{tabular}{|c|c|}
\hline Código & Trabalho que compõe o portfólio \\
\hline 21 & $\begin{array}{l}\text { ROCHA, A. Gerenciamento dos estoques de produto acabado em uma empresa metalúrgica. 2007. 94f. Monografia (Trabalho } \\
\text { de conclusão de curso). Centro Universitário Univates. Lajeado, } 2007 .\end{array}$ \\
\hline 22 & $\begin{array}{l}\text { RODRIGUES, P. C. C. A gestão de estoques em sistemas produtivos engineering-to-order e make-to-order: estudo de casos em } \\
\text { empresas do setor gráfico. } 97 \text { f. Dissertação (Mestrado) - Faculdade de Engenharia de Bauru. Universidade Estadual Paulista, } \\
\text { Bauru, 2008. }\end{array}$ \\
\hline 23 & $\begin{array}{l}\text { SANTOS, A. M.; RODRIGUES, I. A. Controle de estoque de materiais com diferentes padrões de demanda: estudo de caso em } \\
\text { uma indústria química. Revista Gestão e Produção, São Carlos, Vol. 13, n.02, p. 223-231, } 2006 .\end{array}$ \\
\hline 24 & $\begin{array}{l}\text { TOLEDO, L. G. C. de. Aplicação dos modelos clássicos de estoques em uma rede de varejo supermercadista. 2011. 100f. } \\
\text { Dissertação (mestrado) - Faculdade de Engenharia de Bauru. Universidade Estadual Paulista. Bauru, } 2011 .\end{array}$ \\
\hline 25 & $\begin{array}{l}\text { TORABI, S. A.; HATEFI, S.M.; SALECK PAY, S. A. ABC Inventory classification in the presence of both quantitative and qualitative } \\
\text { criteria. Computers \& Industrial Engineering. Vol. } 63 \text {, ed. 2. p. 530-537, } 2012 .\end{array}$ \\
\hline 26 & $\begin{array}{l}\text { VAGO, F. R. M. et al. A importância do gerenciamento de estoque por meio da ferramenta curva ABC. Revista Sociais e } \\
\text { humanas. Vol. } 26, \text { n.03, p. 638-655, } 2013 \text {. }\end{array}$ \\
\hline 27 & $\begin{array}{l}\text { VASCONCELOS, A. P. dos S.; DA SILVA, M. C. P. Reestruturação da gestão de estoques em uma empresa de pequeno porte. } \\
\text { 2013. 68f. Monografia (Trabalho de conclusão de curso). Universidade da Amazônia. Belém, } 2013 .\end{array}$ \\
\hline 28 & $\begin{array}{l}\text { VASCONCELOS, J. I. C.; BARROSO, A. C.; ASSUNÇÃO, S. G. dos S. Análise ABC como ferramenta de gestão de estoque: } \\
\text { estudo de caso em uma loja de materiais de construção. In: Congresso Brasileiro de Engenharia de produção, 5, 2015. Ponta } \\
\text { Grossa/PR. Anais... Ponta Grossa/PR: } 2015 .\end{array}$ \\
\hline 29 & $\begin{array}{l}\text { WANKE, P. Metodologia para gestão de estoques de peças de reposição: um estudo de caso em empresa brasileira. Revista } \\
\text { Tecnologística. Rio de Janeiro, } 121 \text { ed, p.60-65, } 2005 \text {. }\end{array}$ \\
\hline 20 & ão e Produção. Vol. 12, n.1, p. 1-9, 2005. \\
\hline
\end{tabular}

A partir deste portfólio, foi elaborado um gráfico para apresentar os trabalhos que foram citados, representados por suas codificações. Esse gráfico pode ser visualizado na Figura 2.

Figura 2 - Relevância dos trabalhos que compõe o portfólio

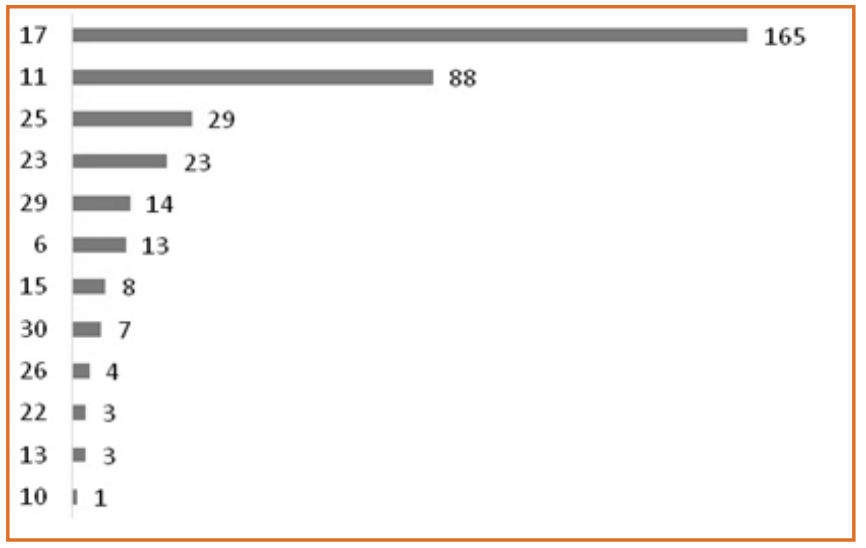

Para essa análise, foram considerados apenas os trabalhos que possuem uma ou mais citações. Pode-se observar na Figura 2, que dos 30 trabalhos analisados, apenas 12 foram referenciados. Destes, o trabalho mais relevante com 165 citações foi o artigo internacional publicado no periódico European Journal of Operational Research, intitulado A simple classifier for multiple criteria ABC Analysis. O segundo mais referenciado, com 88 citações, foi o artigo internacional publicado no mesmo periódico, European Journal of Operational Research, intitulado An improvement to multiple criteria $A B C$ inventory classification e o terceiro trabalho mais referenciado, com 29 citações, foi o artigo publicado no periódico, Computers \& Industrial Engineering, intitulado Inventory classification in the presence of both quantitative and qualitative criteria.

\subsection{ANÁLISE SISTÊMICA}

Foi realizada uma análise sistêmica para identificar, baseado em abordagens definidas pelos pesquisadores, evidenciar perspectivas sobre o assunto. As abordagens foram: (i) trabalhos que utilizaram a curva $A B C$; (ii) trabalhos que utilizaram níveis de estoque; (iii) objetivo dos trabalhos; (iv) resultados, e; (v) lacunas e oportunidades em comum dos trabalhos.

Assim, foram analisados se os trabalhos utilizaram a curva $\mathrm{ABC}$ e os níveis de estoque. O Quadro 3 apresenta esses trabalhos. 
Quadro 3 - Trabalhos que utilizaram a curva ABC para a classificação os itens

\begin{tabular}{|l|l|}
\hline & BALAJI et al. (2014); BORGES \\
& (2014); BOSSONI (2009); BRAGA \\
& et al. (2009); BRITO (2010); \\
& CUNHA et al. (2013); DE FELICE \\
& et al. (2014); MILLSTEIN et \\
al. (2014); MEDEIROS (2007); & MORAIS (2014); NG (2005); \\
TRABALHOS QUE & PAULINO; AFFONSO NETO \\
CLILIZARAM A & (2015); ROCHA (2007); SANTOS; \\
& RODRIGUES (2006); TORABI et \\
& al. (2012); VAGO et al. (2013); \\
& VASCONCELOS et al. (2015); \\
& VASCONCELOS; SILVA (2013). \\
\hline
\end{tabular}

Dos 30 trabalhos analisados, 60\% (18 trabalhos) utilizaram a curva ABC para a classificação dos itens (Quadro 3).

Com relação aos trabalhos que aplicaram os níveis de estoque em seus estudos, podem ser observados no Quadro 4.

Quadro 4 - Trabalhos que utilizaram os níveis de estoque

\begin{tabular}{|l|l|}
\hline & ALVES JR (2014); BRITO (2010); \\
& CUNHA et al. (2013); HADI- \\
& VENCHEH (2010); KUNIGAMI; \\
& OSÓRIO (2009); MEDEIROS \\
& (2007); MORAIS (2014); NG \\
TRABALHOS QUE & (2005); PAULINO; AFFONSO \\
UTILIZARAM OS NIVEIS DE & NETO (2015); RAMALHO et al. \\
ESTOQUE & (2012); REGO (2014); ROCHA \\
& (2007); SANTOS; RODRIGUES \\
& (2006); TOLEDO (2011); TORABI \\
& et al. (2012); VAGO et al. (2013); \\
& VASCONCELOS et al. (2015); \\
& VASCONCELOS; SILVA (2013); e \\
& WANKE (2005). \\
\hline
\end{tabular}

Dos 30 trabalhos analisados, 63,33\% (19 trabalhos) utilizaram um ou mais níveis de estoque para o cálculo e análise dos estoques.

Para a descrição dos objetivos, resultados e lacunas e oportunidade foram considerados os mais relevantes para esta pesquisa.

Observou-se que os objetivos pretendidos nos trabalhos se resumem basicamente a aplicar a análise da curva $A B C$ e analisar sua contribuição para a organização; analisar a gestão de estoques e como o gerenciamento pode contribuir para os resultados da empresa; identificar as estratégias de gestão de estoques utilizadas; realizar análise multicritérios de classificação de estoques; apresentar um comparativo de modelos propostos por diferentes autores; e propor modelo de gestão de estoques e a utilização de um sistema de controle de estoques.

Como resultados, os trabalhos obtiveram a reutilização do espaço do armazém, a proposta de um novo layout e de um sistema de controle de estoque, a redução de custos e desperdícios, ganhos em eficiência operacional, melhoria dos processos, maximização da rentabilidade da empresa, identificação das diferenças com a comparação de modelos. Também foram identificados estoques que estavam excessivos, constataram que a utilização do sistema MRP auxilia no desenvolvimento de toda a empresa, proporcionando benefícios, apresentaram as vantagens do uso de um sistema de controle, determinaram os níveis de estoque e também obtiveram um melhor gerenciamento $e$ controle das entradas e saídas de produtos.

Em relação as lacunas e oportunidades de pesquisas, dentre elas estão: a continuação dos cálculos dos níveis de estoque para determinada classe de itens; estudos para visualização de produtos através de imagens (fotos) vinculadas no cadastro de cada item, visando agilizar o atendimento ao cliente e identificação detalhada dos produtos; pesquisa sobre a análise dos custos de estocagem e sobre aplicação de diferentes distribuições de probabilidade na gestão de estoques; implementar sistemas de controle de estoques na empresa em que foi realizado o estudo e em empresas do mesmo ou de outros setores produtivos; explorar melhor o potencial do estoque; verificar a rentabilidade e/ou materiais com longo prazo de armazenamento; analisar a viabilidade da realização de promoções a fim de liquidar estoques parados; avaliar o arranjo físico proposto e se as sugestões foram válidas; sugeriuse também a implantação do MRP; a criação de um modelo multivariado teórico de controle de estoque; e utilizar o modelo apresentado e o modelo proposto em uma situação real.

\section{CONSIDERAÇÕES FINAIS}

Com o desenvolvimento deste trabalho, pode-se observar que as palavras-chave utilizadas para a 
elaboração da revisão de literatura, foram efetivas, pois abrangeram as palavras que foram mais utilizadas nos trabalhos.

Observou-se que o gerenciamento de estoques influencia muito no desempenho da organização, pois com uma boa administração reduz muito custos. O controle de estoque também está diretamente relacionado com a demanda e pode estar relacionado com os objetivos de desempenho das organizações.

Há utilização de diversas metodologias e métodos utilizados em outras áreas, principalmente nos artigos de âmbito internacional, que consideram aspectos e variáveis de acordo com a necessidade da organização.

Com a realização desta pesquisa, pode observar que os trabalhos que utilizaram técnicas de gestão de estoque obtiveram a redução de custo. Observou-se que $63,33 \%$ dos trabalhos utilizaram um ou mais níveis de estoque para o cálculo e análise de estoques, mas não realizam a aplicação de um sistema de controle de estoque, alguns apenas sugere.

A partir dos resultados desta pesquisa, verifica-se a importância de realizar uma análise de literatura do tema a ser estudado, uma vez que proporcionou conhecimento sobre o tema de interesse e identificou lacunas e oportunidades de pesquisa que venha a contribuir cientificamente para esse tema. Também, ficou claro que ainda existe um vasto campo para pesquisas em gestão de estoque, em especial, a nível de Brasil.

Sugere-se para trabalhos futuros, uma revisão de literatura, visando a identificação da relação entre a Logística e a Programação e Controle da Produção (PCP), em relação à gestão de estoques. Identificar em qual área/subárea da Abepro os trabalhos de gestão de estoques estão sendo publicados e realizar o levantamento das diferenças em abordar o trabalho de gestão de estoques na subárea de PCP e na área de Logística.

\section{REFERÊNCIAS}

[1] ALVES, JUNIOR, P. N. Gestão de estoque no setor de varejo calçadista: abordagem dia análise multivariada e teoria do controle ótimo. 2014. 105f. Dissertação (Mestrado) - Faculdade de Engenharia de Bauru. Universidade Estadual Paulista, Bauru, 2014

[2] AMARAL, J. L. S.; OLIVEIRA, M. de. Gestão de estoques e sua contribuição para os objetivos de desempenho numa fábrica têxtil de pequeno porte. Revista Produção e Engenharia. Vol. 07, n.01, p.600-612, 2015.

[3] ARNOLD; J. R. T. Administração de materiais: uma introdução. 3. ed. São Paulo, Atlas, 1999.

[4] BALAJI, K.; SENTHIL KUMAR, V. S. Multicriteria Inventory $\mathrm{ABC}$ Classification in an Automobile Rubber Components Manufacturing Industry. 47th CIRP Conference on Manufacturing Systems. Vol. 17, p. 463-468, 2014.

[5] BALLOU, R. H. Gerenciamento da Cadeia de Suprimentos: logística empresarial. Porto Alegre: Bookman, 2010.

[6] BORGES, F. A. Gerenciamento de estoque como diferencial na empresa revenderia peças e acessórios LTDA. 2014. 51f. Monografia (Graduação). Universidade Federal do Maranhão, São Luiz, 2014

[7] BOssoni, C. A. A gestão de estoques no almoxarifado de uma empresa pública de transporte ferroviário. 2009. 101 f. Monografia (Tecnólogo em logística). Faculdade de Tecnologia da Zona Leste. Centro Paula Souza, São Paulo, 2009

[8] BRAGA, L. M.; PIMINTA, C. M.; VIEIRA, J. G. V. Gestão de armazenagem em um supermercado de pequeno porte. Pesquisa \& Desenvolvimento Engenharia de Produção. n.9, p. 57-77, 2008.

[9] BRITO, T. L. de. Aplicação de modelos de gestão de estoques para controle de ressuprimento em uma pequena empresa industrial: um estudo de caso. 2010. 57f. Monografia (Gradução). Universidade Federal de Juiz de Fora, Juiz de Fora, 2010.

[10] CAlleGARO, C. G.; QuACliATO, L. F. Gestão de estoques e sua importância para as organizações. $24 f$. Monografia (Graduaç) Faculdade Cenetista de Capivari. Capivari, 2010.

[11] CHING, H. Y. Gestão de estoques na cadeia logística integrada: supply chain. 2. ed. São Paulo: Atlas, 2001.

[12] CREMONEZI, G. O. G. Administração básica. 1. ed. Campo Grande: Life editora, 2015.

[13] CUNHA, A. C. S. et al. Modelo de gestão de estoques em uma empresa de ferragens e produtos metalúrgicos de pequeno porte. In: Encontro Nacional de Engenharia de Produção, 32, 2013. Salvador/BA. Anais... Salvador/BA: 2013 
[14] De FELICE, F. et al. Inventory management using both quantitative and qualitative criteria in manufacturing system. 19 th IFAC World Congress Cape Town. p.24-29, 2014.

[15] DIAS, M. A. P. Administração de materiais: uma abordagem logística. 4. ed. São Paulo: Atlas, 1993.

[16] DIAS, M. A. P. Administração de materiais: uma abordagem logística. 4. ed. São Paulo, Atlas, 1993.

[17] FRANCISCHINI; P. G; GURGEL, F. do A. Administração de materiais e do patrimônio. São Paulo: Pioneira Thomson Learning, 2004.

[18] FREIRE, G.; MESQUITA, M. A. Gestão de estoques. In: FERREIRA, G. et al. Planejamento e controle da produção. Rio de Janeiro: Elsevier, 2011.

[19] GURGEL, F. do A. Logística industrial. 1. ed. São Paulo: Atlas, 2000.

[20] HADI-VENCHEH, A. An improvement to multiple criteria ABC inventory classification. European Journal of Operational Research. Vol. 201, p. 962-965, 2010

[21] IWANO, K. L.; JOHO, P. H. Sistema integrado no gerenciamento de estoques. 59f. Monografia (conclusão de curso). Centro Universitário da Fundação Educacional de Barretos (UNIFEB), Barretos, 2013.

[22] KUNIGAMI, F. J.; OSÓRIO, W. R. Gestão no controle de estoque: estudo de caso em montadora automobilística. Revista Gestão Industrial, Vol. 05, n. 04. p. 24-41, 2009.

[23] MARTINS, P. G.; ALT, P. R. C. Administração de materiais e recursos patrimoniais. São Paulo: Saraiva, 2000.

[24] MEDEIROS, S. da B. Gestão de estoque no comércio varejista de materiais de construção. 2007. 87f. Monografia (Graduação). Universidade do Extremo Sul Catarinense. Criciúma, 2007.

[25] MILLSTEIN, M. A.; YANG, L.; LI, H. Optimizing ABC inventory groping decisions. International Journal of Production Economics. Vol. 148, p. 71-80, 2014.

[26] MORAIS, M. M. Planejamento da Produção e Gestão de Estoques de uma indústria madeireira de pequeno porte. 2014. 72f. Monografia (Conclusão de curso). Universidade Federal de São João Del-Rei. São João Del-Rei, 2014.

[27] MOREIRA, D. A. Administração da produção e operações. 2. ed. São Paulo: Cengage Learning, 2009.

[28] NG, W. L. A simple classifier for multiple criteria ABC Analysis. European Journal of Operational Research. Vol. 11, ed. 1. p.344-353, 2007.

[29] PAULINO, JR.; NETO, A. A. Gerenciamento de estoques em uma indústria de lubrificantes norte-americana. In: Simpósio de Engenharia de Produção, 22, 2015. Bauru/SP. Anais... Bauru/SP: 2015
[30] RAMALHO, A. da S.; BELTRAME, J. N.; VILLELA, J. M. V. A importância de gestão de estoque no supermercado central de compra Santo Antônio. 2012. 48f. Monografia (Conclusão de curso). Faculdade Norte Capixaba de São Mateus. São Mateus, 2012.

[31] REGO, J. R. do. Gestão de estoques de peças de reposição: simulação e análise de modelos com dados empíricos. 2014. 122f. Tese (Doutorado) - Escola Politécnica da Universidade de São Paulo. Universidade de São Paulo. São Paulo, 2014

[32] ROCHA, A. Gerenciamento dos estoques de produto acabado em uma empresa metalúrgica. 2007. $94 f$. Monografia (Trabalho de conclusão de curso). Centro Universitário Univates. Lajeado, 2007.

[33] RODRIGUES, P. C. C. A gestão de estoques em sistemas produtivos engineering-to-order e make-toorder: estudo de casos em empresas do setor gráfico. 97 f. Dissertação (Mestrado) - Faculdade de Engenharia de Bauru. Universidade Estadual Paulista, Bauru, 2008.

[34] SANTOS, A. M.; RODRIGUES, I. A. Controle de estoque de materiais com diferentes padrões de demanda: estudo de caso em uma indústria química. Revista Gestão e Produção. Vol. 13, n. 02, p. 223-231, 2006.

[35] SIQUEIRA, J. P. L. de. Gestão de produção e operações. Curitiba: IESDE Brasil S. A., 2009.

[36] SLACK, N. et al. Administração da produção. 3. ed. São Paulo, Atlas, 2009

[37] TOLEDO, L. G. C. de. Aplicação dos modelos clássicos de estoques em uma rede de varejo supermercadista. 100f. Dissertação (mestrado) - Faculdade de Engenharia de Bauru. Universidade Estadual Paulista. Bauru, 2011.

[38] TORABI, S. A.; HATEFI, S.M.; SALECK PAY, S. A. ABC Inventory classification in the presence of both quantitative and qualitative criteria. Computers \& Industrial Engineering. Vol. 63, ed. 2. p. 530-537, 2012.

[39] TUBINO, D. F. Planejamento e controle da produção: teoria e prática. 2. ed. São Paulo: Atlas, 2009.

[40] VAGO, F. R. M. et al. A importância do gerenciamento de estoque por meio da ferramenta curva $A B C$. Revista Sociais e humanas. Vol. 26, n.03, p. 638-655, 2013.

[41] VASCONCELOS, A. P. dos S.; DA SILVA, M. C. P. Reestruturação da gestão de estoques em uma empresa de pequeno porte. 2013. 68f. Monografia (Trabalho de conclusão de curso). Universidade da Amazônia. Belém, 2013

[42] VASCONCELOS, J. I. C.; BARROSO, A. C.; ASSUNÇÃO, S. G. dos S. Análise ABC como ferramenta de gestão de estoque: estudo de caso em uma loja de materiais de construção. In: Congresso Brasileiro de Engenharia de produção, 5, 2015. Ponta Grossa/PR. Anais... Ponta Grossa/ PR: 2015. 
[43] VENDRAME, F. C. Administração de recursos materiais e patrimoniais. (Apostila da Disciplina de Administração) Lins: Faculdades Salesianas de Lins, 2008.

[44] VERGARA, S. C. Projetos e relatórios em administração. 4. ed. São Paulo: Atlas, 2003.

[45] WANKE, P. Gestão de estoques na cadeia de suprimentos: decisões e modelos quantitativos. 2. ed. São Paulo: Atlas, 2008.
[46] WANKE, P. Metodologia para gestão de estoques de peças de reposição: um estudo de caso em empresa brasileira. Revista Tecnologística. Ed. 121, p. 60-65, 2005.

[47] WANKE, P.; SALIBY, E. Proposta para a gestão de estoques de novos produtos: solução do modelo $(Q, r)$ para a distribuição uniforme da demanda e do lead-time de suprimento. Revista Gestão e Produção. Vol. 12, n. 1, p. 1-9, 2005. 


\section{CAPÍTULO 19}

\section{ANÁLISE DO SISTEMA DE FILAS DA ESTAÇÃO TRENSURB EM NOVO HAMBURGO, RS, UTILIZANDO A FERRAMENTA ARENA}

\section{Andrey Eduardo Gomes}

Guilherme Mendes Fernandes

Yan Henning

Christiane Wenck Nogueira Fernandes

Silvia Lopes de Sena Taglialenha

Resumo: A implantaçáol de um transporte metroviário deve ser inteiramente planejada por meio de estudos de viabilidade econômica e socioeconômica a curto e longo prazo, de modo a disponibilizar um melhor atendimento aos usuários da categoria deste tipo de transporte. Para isso, estima-se uma demanda futura de passageiros do empreendimento conforme o historico de crescimento da população local, para partir de então realizar os cálculos necessarios para a construção de seu layout. Este estudo visa estimar o nível de serviço que a estação irá oferecer aos usuários ao analisar o tempo médio de espera nas bilheterias da estação metroviária, após a análise de um conjunto de informações e características a respeito do fluxo de passageiros da estação de metró de superfície na cidade de Novo Hamburgo - RS, o TRENSURB. Com a união dos conceitos de pesquisa operacional, que envolve a teoria de filas e a sua aplicabilidade a partir da utilização do software ARENA realiza-se uma análise no que se refere às filas da bilheteria da estaçáo junto às taxas de chegada dos passageiros. Conclui-se que somente duas bitheterias sáo necessárias para deixar o fluxo de pessoas na área da bilheteria economicamente viável.

Palavras chave: TRENSURB, ARENA, Nível de serviço, Bilheterias, Filas. 


\section{INTRODUÇÃO}

O maior empecilho para se locomover nos grandes centros urbanos é o congestionamento. Eles podem ser causados pela quantidade exorbitante de automóveis que circula nas cidades todos os dias. Eles causam quilômetros de trânsito lento ou parado, principalmente nos horários de rush.

Um dos objetivos da Política Nacional de Mobilidade Urbana, Lei 12.587/12, é proporcionar melhoria nas condições urbanas de acessibilidade e mobilidade da população e priorizar o uso do transporte coletivo (BRASIL, 2012).

O transporte sobre trilhos é um importante modal de transporte público que contribui muito na mobilidade urbana, pois afeta grande de forma significativa parte das pessoas que necessitam de médios ou grandes deslocamentos para exercerem suas atividades promovendo vantagens por conta da sua rapidez na locomoção por dentro das grandes cidades. Sua praticidade, velocidade e baixo custo em relação ao transporte individual, faz com que milhões de pessoas usem esse tipo de transporte diariamente.

A implantação de um sistema de transporte metroviário deve ser inteiramente planejada por meio de estudos de viabilidade econômica e socioeconômica a curta e longo prazo, de modo a disponibilizar um melhor atendimento aos usuários da categoria deste tipo de transporte. Para isso é importante uma estimativa da demanda futura de passageiros do empreendimento conforme o histórico de crescimento da população local, para partir de então realizar os cálculos necessários para a construção de seu layout (GUAZZELLI, 2011, DAAMEN, 2004).

De modo a efetuar constantes melhoras e estabelecer um padrão de qualidade satisfatória aos usuários, diminuir o tempo de espera dos clientes na bilheteria é parte fundamental para fortalecer o nível de serviço da estação metroviária, já que a satisfação proposta pelo serviço ofertada ao consumidor deve ao menos cobrir expectativas básicas, o que muitas vezes não acontece na prática.

Segundo pesquisas comportamentais efetuadas por especialistas no assunto, quanto mais próximo de ser atendido, maior a sensação de demora por parte dos clientes (UCG, 2009). Uma pesquisa publicada no New York Times, o principal motivo das pessoas se desesperarem nas filas é representado pela desocupação nesse intervalo de tempo (STONE, 2012).

Hillier (2013) também cita a importância de um sistema de filas eficiente, no qual em estudos realizados nos Estados Unidos, a espera em filas está estimada em 37.000.000.000 horas por ano e se este tempo fosse gasto produtivamente, resultaria em aproximadamente 20 milhões de pessoas-ano de trabalho útil por ano.

Esse desempenho total em termos de nível de serviço proveniente do fluxo de pessoas que passam por um determinado local pode ser analisado conforme o tempo de espera do usuário para realizar certa atividade. Segundo Taha (2008), se trata da quantificação do processo de espera, seja representando conforme comprimento ou tempo.

Este artigo, através da Teoria das Filas, visa estimar o nível de serviço que a estação irá oferecer aos usuários ao analisar o tempo médio de espera nas bilheterias da estação metroviária, após a análise de um conjunto de informações e características a respeito do fluxo de passageiros da estação de metrô de superfície na cidade de Novo Hamburgo - RS. E com o auxílio do software de simulação ARENA, utiliza-se de análises a partir de simulações feitas com os dados coletados pela própria companhia a fim de obter-se o número de bilheterias necessárias para atender a demanda atual de clientes, de modo que o tempo de espera seja minimizado.

\section{TEORIA DAS FILAS}

As filas fazem parte do cotidiano das pessoas, todos acabam esperando em alguma fila por um momento para: comprar um ingresso para uma sessão no cinema, na fila do supermercado ou remeter um pacote no correio. Assim, as pessoas acabaram se acostumando de certa maneira com esse processo. Entretanto, este tempo perdido não está sujeito a apenas transtornos pessoas, mas também, representando o mau 
funcionamento desse sistema (ANDRADE, 2004; BORGES, 2010; HILLIER, 2013).

A formação do sistema de fila ocorre quando a demanda por um eventual serviço é superior à oferta proporcionada. Com isso, se utiliza métodos e fórmulas matemáticas para encontrar o equilíbrio entre a satisfação do cliente e economicamente viável ao prestador do serviço.

A Teoria das Filas é uma das áreas da Pesquisa Operacional na qual se utiliza conceitos de processos estocásticos tratando os estudos de filas matematicamente. Sendo modelos úteis para se definir as medidas de desempenho de filas, considerando o tempo médio de espera e o tempo de atendimento, assim pode-se determinar como operar estas filas de uma forma mais eficiente. Permitindo encontrar o equilíbrio apropriado entre o custo de serviço e o tempo de espera. (TAHA, 2008; LEAL, 2012; HILLIER, 2013).

A Figura 1 representa a definição feita por Martins (2011), no qual seu é composto por população, processo de chegadas de clientes e a sua organização na fila, seguida da disciplina de atendimento, definida pelo sistema a ser implantado e o processo de atendimento aos clientes.

Figura 1: Estrutura de um sistema de filas

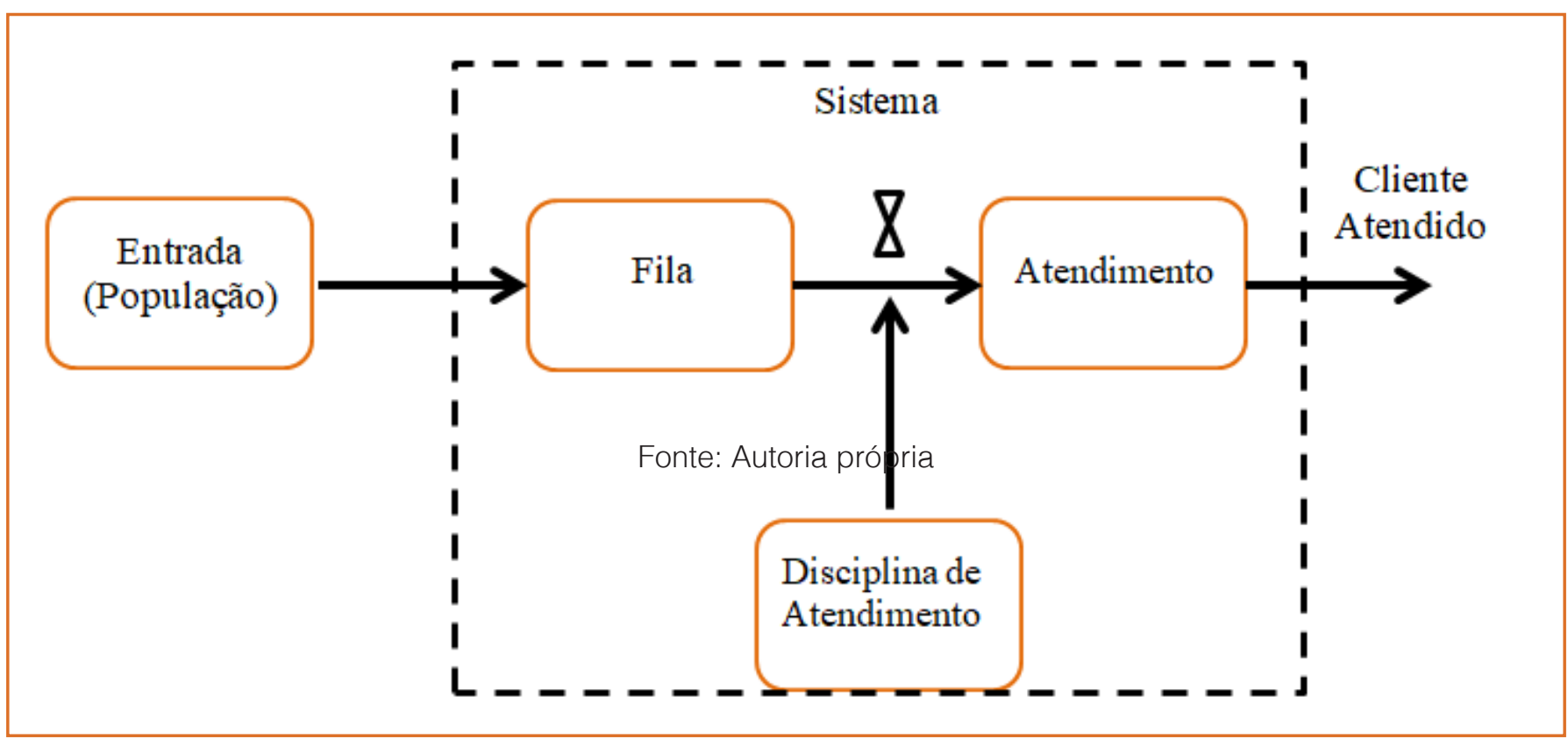

O sistema de filas consiste no processo de chegada de clientes, o processo de atendimento a disciplina das

filas. No qual o processo de chegada é definido pelo número de indivíduos que solicitaram o serviço do sistema no intervalo de $(0, t)$, sendo $t>0$. Sendo assim, um processo de contagem que pode ser denotado através da distribuição dos intervalos de tempo entre chegadas sucessivas, ou através da distribuição do número de chegadas em intervalos disjuntos. Com isso, o número de chegadas tem distribuição de Poisson com média . Nesta situação particular pode-ser fazer o intervalo de tempo entre chegadas sucessivas sendo $1 /$.
Essas variáveis são aleatórias que variam com o tempo, porém elas são consideradas independentes e identicamente distribuídas, para casos mais avançados estes indivíduos podem chegar em grupos.

Assim como o processo de chegadas, Hillier (2013) relata que o atendimento aos clientes pode ocorrer individualmente ou em grupo. Sua principal característica é o tempo de atendimento, ou duração de atendimento, ou ainda pode ser o número de atendimentos. A duração de atendimento pode ser constante, ou é uma variável aleatória com uma 
distribuição conhecida. Nos modelos mais comuns, pode-se assumir que o número de atendimentos é uma distribuição de Poisson com média $\mu$ e o tempo de atendimento é uma distribuição de Poisson negativa $1 / \mu$.

Para se realizar o atendimento é necessário ter uma disciplina das filas, que segundo Taha (2008) esta relacionada na maneira segundo a qual os indivíduos receberão o atendimento, podendo ser o primeiro a chegar é o primeiro a sair (em inglês a sigla FIFO) que é o mais comum, podendo ser até o último a entrar o primeiro a sair (sendo LIFO a sigla em inglês) isso acaba ocorrendo em elevadores muito lotados e alguns sistemas de estoque. A disciplina também pode ser aleatória, tudo depende de cada sistema.

\subsection{CAPACIDADE DO SISTEMA}

Em diversos modelos de fila, existe uma limitação física para o número de clientes que podem fazer parte do sistema. Enquanto a capacidade não for excedida, o sistema irá operar normalmente, se os indivíduos chegarem e a capacidade tiver excedido, então eles são recusados.

Uma notação de modelos de fila foi proposta por Kendall e é universalmente adotada. Segundo Kendall (apud MARINS 2011) um modelo de filas é descrito por sucessão de símbolos, colocados em campos delimitados por barras inclinadas.

Para Kendall, o primeiro campo fornece informações da distribuição de intervalos entre chegadas, o segundo se refere à distribuição dos atendimentos, 0 terceiro é a quantidade de atendentes disponíveis, o quarto indica a restrição da capacidade do sistema, o quinto tem informações sobre o tamanho da população e finalmente o sexto informa sobre a disciplina de atendimento.

Para os casos em que a capacidade é ilimitada, a população é muito grande tende a ser infinita, e a disciplina é FIFO, os três últimos símbolos podem ser omitidos, sendo alguns símbolos muito usados: a. M: Para o processo de chegadas com distribuição de Poisson e atendimentos com probabilidades exponenciais para os tempos de serviço;

b. Gl: Para o processo de chegadas independentes sendo assim diferente do de Poisson;

c. D: Para tempo de serviço constante, usado em casos determinísticos;

d. Ek: Utilizado para a distribuição de probabilidades de Erlang de ordem k;

e. G: Utilizado para a distribuição geral de tempos de atendimento.

Sendo assim uma fila $M / M / 1$ é uma fila com um processo de chegadas com distribuição de Poisson, atendimentos com probabilidades exponenciais para os tempos de serviço e apenas um guichê de atendimento, este é o tipo de fila mais simples que se consta na literatura, como os últimos três termos estão omitidos, a fila também tem capacidade ilimitada, a população é muito grande e a sua disciplina é FIFO.

Em (XIN-YUE et a., 2014 ) aparece uma descrição de conceitos de capacidade de estação de metrô.

Os autores (LI G.; XI M.; NI L., 2016) apresentam resultados de simulações que sugerem a quantidade adequada de equipamentos de cobrança na estação de Longshouyuan.

\subsection{MODELOS DE FILAS MARKOVIANAS}

A seguir serão expostos alguns dos principais modelos de filas Markovianas, que são os modelos que têm as chegadas e atendimentos seguindo a distribuição de Poisson e exponencial.

\subsubsection{FILA M/M/1}

Como podemos observar o primeiro parâmetro está preenchido com a letra $\mathrm{M}$, sendo assim é uma fila com um processo de chegadas de acordo com a distribuição de Poisson e taxa média de, assim da mesma maneira o segundo parâmetro também contém a letra, podemos observar que a fila passa por um processo de tempo de serviço exponencial, 
com parâmetro médio de atendimento $\mu$ n, já o número 1 no terceiro parâmetro denota que o sistema possui apenas 1 guichê de atendimento.

\subsubsection{FILA M/M/S}

Este caso é análogo ao anterior, com a chegada sendo pela distribuição de Poisson com média e a de atendimentos sendo a exponencial com taxa de , porém com canais de atendimento em paralelo.

\subsubsection{FILA M/M/S/N}

Para a fila $M / M / S / N$ é o mesmo caso da fila $M / M / S$, porém sendo a capacidade do sistema igual a $\mathrm{N}$.

\section{ESTUDO DE CASO}

O presente artigo visa à aplicabilidade dos conceitos em teorias das filas no estudo das filas correspondentes ao sistema de bilheteria da estação de metrô da cidade de Novo Hamburgo, Rio Grande do Sul. Inaugurada em 2014, a estação foi projetada com intuito de atender uma demanda futura, no qual de acordo com a empresa de Trens Urbano e Ônibus Urbano de Porto Alegre, TRENSURB (2015), possui na sua infraestrutura um mezanino e plataforma de embarque e desembarque tipo ilha central, com acesso por meio de prédios de apoio leste/oeste, possuindo cinco pontos comerciais, três elevadores, duas escadas rolantes e quatro escadas fixas. Além de possuir áreas para o setor administrativo, setor operacional, setor de comércio e serviços público.

A estação é controlada pela empresa TRENSURB, uma empresa de sociedade mista vinculada ao Ministério das Cidades e Governo Federal, que tem por acionistas a União (99,8558\%), o estado do Rio Grande do Sul (RS) (0,1116\%) e o município de Porto Alegre (0,0326\%) (TRENSURB, 2015). O que torna o preço da passagem baixo devida o financiamento de quase cem por cento da União.

\subsection{METODOLOGIA}

A partir dos dados obtidos com a empresa TRENSURB, foi realizado o diagnóstico detalhado da real situação da estação e poder prever mudanças de acordo com a necessidade da operação utilizando o software de simulação ARENA.

\subsubsection{SOFTWARE ARENA}

O ARENA é um ambiente gráfico integrado de simulação, não há necessidade de programar em nenhuma linguagem para que se consiga modelar e simular algum processo desejado pelo analista. $O$ software foi desenvolvido pela empresa Rockwell Automation.

O software possui diversas versões, como a profissional, acadêmica e estudante e a versão utilizada para este estudo de caso é a versão estudante, que possui limitação na criação de entidades, não pode ser usada para fins comerciais e com o objetivo de ampliar o conhecimento dos estudantes utilizando destes conhecimentos. Mais detalhes de ferramentas e funcionamento do ARENA serão abordados no desenvolvimento do estudo.

\subsubsection{COLETA DE DADOS}

A coleta de dados foi realizada pela empresa TRENSURB no dia 17 de setembro de 2014, em um período compreendido entre 06h00min e 09h00min. Então, para esse artigo, a fim de obter um uma análise detalhada do horário que possui maior movimento na estação, foram pegos os dados do fluxo da hora pico, considerado das 06h45min as 07h45min da manhã.

\subsection{ANÁLISE DO CENÁRIO}

De acordo com a Figura 2, possuímos a real situação do fluxo de entrada dos passageiros na estação. Onde temos duas bilheterias que operam de acordo com a situação do dia, 6 bloqueios de entradas, sendo um para deficientes e também 4 bloqueios de saídas. 
Figura 2: caracterização da situação atual

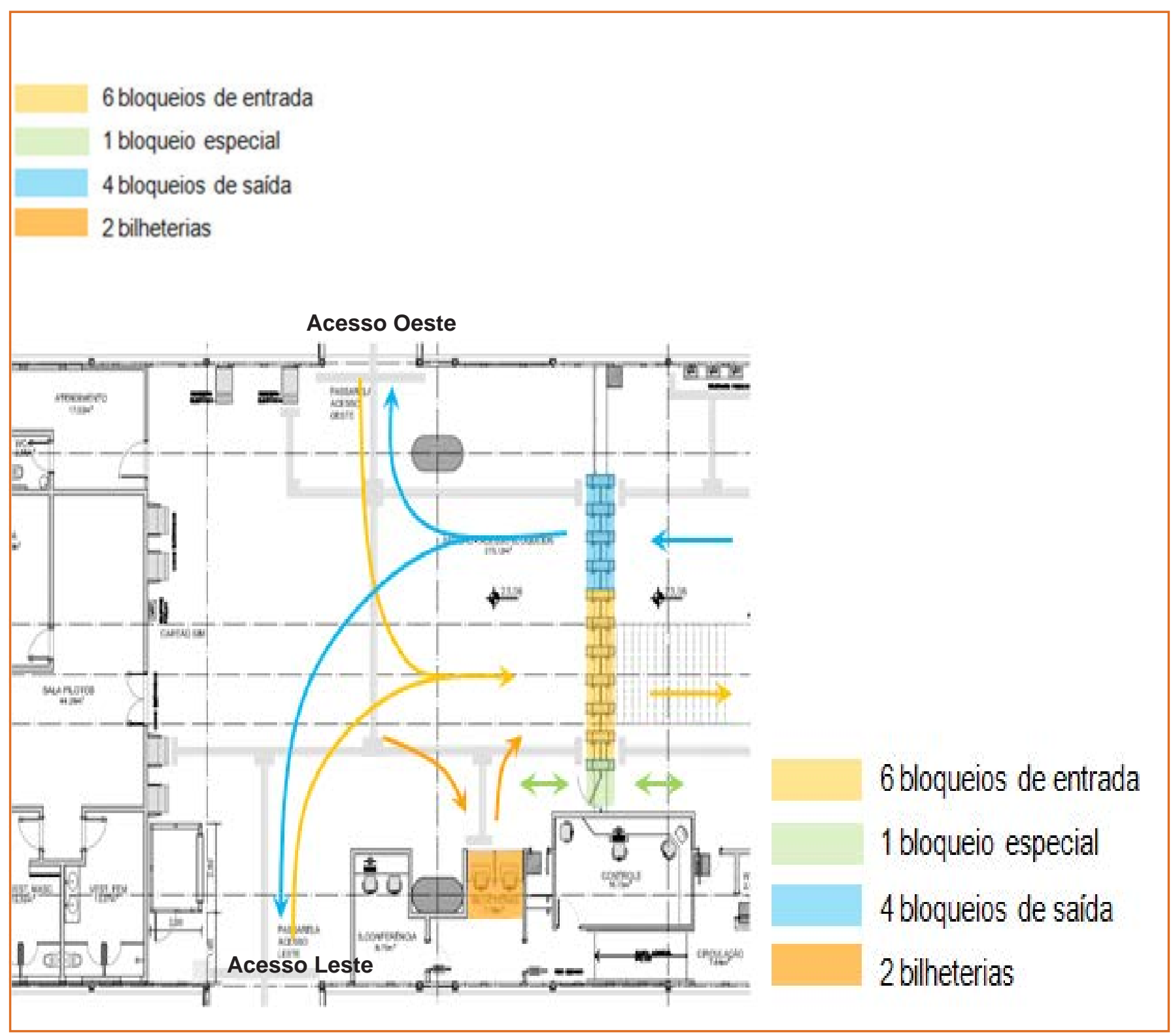

Fonte: Autoria própria

\subsubsection{MOVIMENTAÇÃO DE PASSAGEIROS}

Através da Tabela 1 podemos verificar a demanda de passageiros que passam pela estação na hora de maior movimento, considerada das $06 \mathrm{~h} 45 \mathrm{~min}$ as 07h45min da manhã, na qual se verifica que o fluxo de passageiros que acessaram a estação nessa hora de pico, valor de 986, sendo que 107 passaram nos 5 minutos mais carregados.

A Tabela 1 mostra também que há diferentes fluxos para algumas catracas de entrada, isso se dá devido ao metrô possuir diferentes tipos de passagens que são usadas para entrar na estação, sendo nessa ocasião dividida pelo cartão SIM, que funciona integrado ao sistema de bilhetagem eletrônica de Porto Alegre, sendo que através deste bilhete é possível utilizar o metrô e ônibus da capital, e o cartão TEU, utilizado apenas para o uso do metrô. Suas porcentagens de utilização no metrô são de 86 e 14, respectivamente (TRENSURB, 2014). 
Tabela 1 - Fluxo de passageiros na hora de maior movimento

\begin{tabular}{|c|c|c|c|c|c|c|c|c|c|}
\hline \multirow{2}{*}{\multicolumn{2}{|c|}{ Hora }} & \multirow{3}{*}{$\begin{array}{l}\text { SIM } \\
\text { BL1 }\end{array}$} & \multirow{3}{*}{$\begin{array}{l}\text { TEU } \\
\text { BL2 }\end{array}$} & \multirow{3}{*}{$\begin{array}{l}\text { TEU } \\
\text { BL3 }\end{array}$} & \multirow{3}{*}{$\begin{array}{l}\text { SIM } \\
\text { BL4 }\end{array}$} & \multirow{3}{*}{$\begin{array}{l}\text { SIM } \\
\text { BL5 }\end{array}$} & \multirow{3}{*}{$\begin{array}{l}\text { SIM } \\
\text { BL6 }\end{array}$} & \multirow[b]{2}{*}{ SIM } & \multirow[b]{3}{*}{ Total } \\
\hline & & & & & & & & & \\
\hline Início & Fim & & & & & & & BL7 & \\
\hline 06h45min & 06h50min & 6 & 8 & 5 & 13 & 16 & 21 & 3 & 72 \\
\hline 06h50min & 06h55min & 11 & 3 & 4 & 10 & 13 & 21 & 0 & 62 \\
\hline 06h55min & $07 \mathrm{~h} 00 \mathrm{~min}$ & 11 & 7 & 7 & 10 & 13 & 22 & 1 & 71 \\
\hline 07h00min & 07h05min & 16 & 10 & 7 & 16 & 24 & 34 & 0 & 107 \\
\hline 07h05min & $07 \mathrm{~h} 10 \mathrm{~min}$ & 18 & 5 & 5 & 12 & 16 & 24 & 1 & 81 \\
\hline 07h10min & 07h15min & 14 & 8 & 9 & 19 & 17 & 23 & 1 & 91 \\
\hline 07h15min & $07 \mathrm{~h} 20 \mathrm{~min}$ & 4 & 7 & 7 & 20 & 20 & 26 & 1 & 85 \\
\hline $07 \mathrm{~h} 20 \mathrm{~min}$ & $07 \mathrm{~h} 25 \mathrm{~min}$ & 13 & 7 & 8 & 15 & 22 & 25 & 0 & 90 \\
\hline $07 \mathrm{~h} 25 \mathrm{~min}$ & $07 \mathrm{~h} 30 \mathrm{~min}$ & 16 & 5 & 10 & 17 & 16 & 22 & 0 & 86 \\
\hline $07 \mathrm{~h} 30 \mathrm{~min}$ & 07h35min & 11 & 9 & 6 & 13 & 14 & 25 & 0 & 78 \\
\hline 07h35min & 07h40min & 11 & 6 & 4 & 20 & 22 & 24 & 0 & 87 \\
\hline $07 \mathrm{~h} 40 \mathrm{~min}$ & 07h45min & 10 & 6 & 5 & 18 & 14 & 22 & 1 & 76 \\
\hline \multicolumn{2}{|c|}{ Total $14 \%$} & 141 & 81 & 77 & 183 & 207 & 289 & 8 & 986 \\
\hline & & $8 \%$ & $8 \%$ & $19 \%$ & $21 \%$ & $29 \%$ & $1 \%$ & $100 \%$ & \\
\hline
\end{tabular}

Fonte: Adaptado Trensurb (2014)

\section{MATERIAL E MÉTODO}

Com a entrada de pessoas fixada em 986 na hora pico, foi então analisada, a partir dos dados de fluxo de entrada por minuto a melhor distribuição que poderia ser representada. Foram, então, analisados com o auxilio da ferramenta input analyser, (analisador de dados de entrada) do software ARENA. Que segundo Freitas Filho (2008, p.200) "[...] uma ferramenta independente da ferramenta de modelagem", no qual o principal propósito é a "[...] identificação da distribuição teórica de probabilidades por meio de testes de aderência".
Feita a analise inicial para os dados de taxas de chegadas por minuto dos passageiros, a melhor distribuição correspondente foi uma Normal, com expressão de 0.0618 e 0.00909. Já para os passageiros especiais a taxa de chegada considerada foi uma distribuição exponencial de 7.5 minutos, calculada a partir do numero de chegadas em uma hora.

A simulação de todo o processo da estação foi realizado com o auxilio do software ARENA. No qual sua estruturação esta representada na Figura 3.

Figura 3: Fluxograma do processo desenvolvido no ARENA

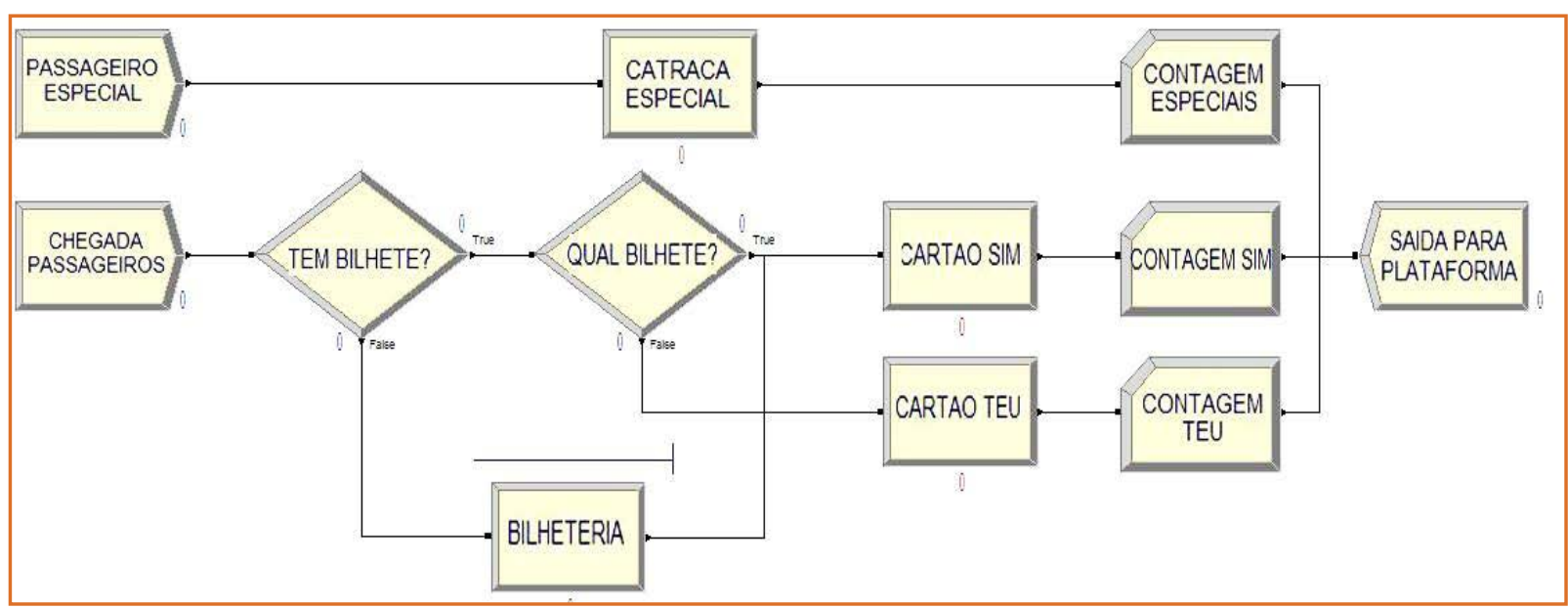


A partir disto serão feitas as análises de acordo com os relatórios publicados pelo software. Ao final da operação do modelo, com os devidos fatores considerados, obteve-se, seguido de diferentes cenários, a representação do sistema de atendimento e fluxo de pessoas da estação de metrô.

\subsection{ESTRUTURAÇÃO DO PROBLEMA}

A figura 2 representa como é o fluxo de passageiros na estação, no qual segue os seguintes passos:

a. Os passageiros especiais, no qual podemos considerar pessoas portadoras de alguma necessidade especial, chegam à estação e passam direto para a plataforma, havendo apenas o seu lead time até chegar no destino.

b. Já os outros passageiros que chegam, temse que alguns deles não possuem o bilhete que tem acesso a plataforma de embarque. Então, de acordo com os dados coletados, essa porcentagem de abstinência é de 39\%, ou seja, dos 986 passageiros, 388 não possuem a passagem (TRENSURB, 2015).

Após esse processo de decisão os clientes que já possuem o bilhete escolhem qual o tipo de cartão, se o SIM ou TEU, para que tenham entrada para a plataforma de embarque.

\subsubsection{BILHETERIA}

Quando os passageiros não possuem bilhete é necessária a compra do mesmo, então se vai em uma bilheteria. A estação de Novo Hamburgo possui duas bilheterias, que funcionam em termos de aplicação da teoria FIFO, no qual o primeiro a chegar é o primeiro a ser atendido, na forma de uma exponencial.

\section{RESULTADOS E DISCUSSÕES}

Realizaram-se observações, simulações e comparações para o devido estudo das possíveis situações e cenários a ser considerada como eventual solução para o problema de filas nas bilheterias. Com isso, através dos relatórios do ARENA, foram considerado três cenários.

No primeiro cenário consideramos uma bilheteria aberta. Então, conforme os dados obtidos, a média do tempo de atendimento dos passageiros foi de 8,27 segundos, apresentado por uma distribuição exponencial. A partir disso, obtemos seus relatórios, que serviram como para a operação, que são:

Tabela 2: Relatório do ARENA com uma bilheteria

\begin{tabular}{|l|l|}
\hline Tempo médio na fila & 29,7833 segundos \\
\hline Tempo máximo na fila & 2,36 minutos \\
\hline Tamanho médio das filas & 3,22 passageiros \\
\hline No. máximo de passageiros na fila & 21 \\
\hline Taxa de utilização & $82,68 \%$ \\
\hline Passageiros atendidos & 364 \\
\hline
\end{tabular}

Fonte: Autoria própria

Com os resultados obtidos na Tabela 2, podemos ver um numero expressivo de pessoas e o tempo máximo que foi esperado na fila nessa hora pico, 21 pessoas e $2.36 \mathrm{~min}$, respectivamente. Fato que pode afetar o nível de serviço da estação, refletindo em uma diminuição gradativa dos clientes por questões preferenciais. Outra questão seria a taxa que a bilheteria esteve trabalhando, com um percentual de $82,68 \%$. Essa porcentagem considera que $\mathrm{o}$ atendente quase não obteve descanso, o que pode provocar problemas de estresse excessivo, na qual a chance de dar algo errado na emissão do bilhete é maior.

Outro cenário a ser considerado seria a abertura de uma segunda bilheteria na hora pico. Que em relação a anterior apresentou um tempo médio de atendimento um valor de 11,51 segundos, esse aumento pode ser considerado devido a questão de não possuir muitas pessoas esperando na fila, no qual apresentou uma taxa de utilização de 58\%, sendo assim, não há pressões psicológicas para obter mais agilidade nesse processo, no qual evita erros na emissão do bilhete. A Tabela 3 a seguir mostra mais claramente os resultados obtidos da análise. 
Tabela 3: Relatório do ARENA com duas bilheterias

\begin{tabular}{|l|l|}
\hline Tempo médio na fila & 3,24 segundos \\
\hline Tempo máximo na fila (min) & 34,664 minutos \\
\hline Tamanho médio das filas & 0,3336 passageiros \\
\hline No. máximo de passageiros na fila & 5 \\
\hline Taxa de utilização & $58 \%$ \\
\hline Passageiros atendidos & 368 \\
\hline
\end{tabular}

Fonte: Autoria própria

Com essa abertura, se vê um maior fluxo de pessoas que saíram no processo. Comparando com o cenário 1, na qual saíram para plataforma cerca de 968 passageiros, o cenário 2 , teve como saída 10 pessoas a mais, fato que se da pelo menor tempo nas filas da bilheteria, aumentando seu nível de serviço. Outro fato que comprova, são a diminuição no tempo médio da fila, de 3,24 segundos e o número máximo de passageiros na fila, cinco passageiros.

No último cenário se considerou três bilheterias abertas na hora em estudo. Como resultado obtido pelo software, percebe-se que todos os quesitos foram abaixados ainda mais, o que levou uma taxa elevada de ociosidade das bilheterias, no qual a taxa de utilização apresentou porcentagem de $41 \%$. Não houve mudanças significativas em relação ao cenário 2. A Tabela 4 mostra com mais detalhes os dados obtidos.

Tabela 4: Relatório do ARENA com três bilheterias

\begin{tabular}{|l|l|}
\hline Tempo médio na fila & 0,334 segundos \\
\hline Tempo máximo na fila & 13,64 minutos \\
\hline Tamanho médio das filas & 0,0348 passageiros \\
\hline No. máximo de passageiros na fila & 3 \\
\hline Taxa de utilização & $41 \%$ \\
\hline Passageiros atendidos & 373 \\
\hline
\end{tabular}

Fonte: Adaptado ARENA

\subsection{SUGESTÃO}

Observando-se os resultados obtidos verifica-se a necessidade de mudanças no sistema de bilheterias da estação na qual deve haver um equilíbrio entre os clientes e passageiros visando uma melhoria no sistema geral, que seria tanto em recursos humanos, como nível de serviço adequado.

Na hora pico, a abertura de uma segunda bilheteria seria ideal para o sistema, o que reduziria o tempo de espera, aumentando seu nível de serviço, possibilitando também a melhora no atendimento por meio dos funcionários e redução do tempo ocioso.

\subsubsection{INFRAESTRUTURA}

Segundo a TRENSURB (2014), para haver uma melhora no acesso e atendimento, foram identificados alguns problemas que eventualmente deveriam ser solucionados, como:

a. Dificuldade no acesso de Deficientes Visuais: Cones posicionados em cima do piso podo tátil;

b. Fila significativa na bilheteria;

c. Dificuldade de entrada e saída da estação, por causa da fila da bilheteria;

d. Dificuldade de visualização da bilheteria próxima aos bloqueios.

\section{CONSIDERAÇÕES FINAIS}

Com os resultados obtidos, após a aplicação da Teoria das Filas junto à simulação no software ARENA, puderam-se comparar os resultados apresentados pela empresa a partir do levantamento de dados reais, aos resultados simulados no estudo de caso. Tornando possível apresentar os conhecimentos adquiridos na teoria e a prática.

Constatou-se que a estação ferroviária de Novo Hamburgo da TRENSURB, oferece um nível de serviço muito satisfatório aos usuários. Isso se dá, devido a ser uma estação nova em nível tecnológico, com elevadores, centro comercial, sistema com sete catracas de entrada, rampas de acesso, escadas, a fim de, tornar a acessibilidade do local de fácil acesso. Através dos cenários propostos, o que torna o sistema operacional mais adequado foi a implementação das duas bilheterias na hora pico, visto que esse é o mais eficiente em termos de atendimento e operação. 
Apesar dos resultados obtidos serem satisfatórios em relação a análise real feita pela TRENSURB, um fato que não foi considerado no estudo foi o tempo de deslocamento das pessoas, visto que para esse diagnóstico foi considerado apenas a taxa de chegada dos passageiros e a média do tempo de atendimento nas bilheterias. Essa análise de deslocamento só é possível por meio de estudos mais avançados dentro da estação e também com o uso de outras ferramentas do software ARENA, no entanto, para este trabalho foi usado o modelo mais simples para o desenvolvimento do problema.

Outro fato que torna os resultados bons é o alto investimento da estação e a ampliação da estrutura ferroviária como um todo. Analisando de forma qualitativa uma previsão de cenários, a tendência é aumentar a demanda atual.

\section{AGRADECIMENTOS}

Os autores agradecem a disponibilidade e apoio da TRENSURB na realização deste trabalho.

\section{REFERÊNCIAS}

[1] ANDRADE, E. L. Introdução à Pesquisa Operacional Métodos e Modelos para Análise de Decisões. 4aㅡ edição. LTC, 2009. Vital Book file.

[2] BATISTA D. Psicólogos explicam as atitudes das pessoas nas filas <http://www.ucg.br/ucg/agencia/home/ secao.asp?id_secao=2425 >. Acesso em: 16 abr. 2016.

[3] BORGES, RENATA MASSOLI et al. Teoria das filas e da simulação aplicada ao embarque de minério de ferro e manganês no terminal marítimo de ponta da madeira. XXX Encontro Nacional de Engenharia De Produção, São Carlos/ SP, 2010.

[4] BRASIL. Lei 12.587, de 03 de janeiro de 2012. Publicada no Diário Oficial da União em 04 de janeiro de 2012.

[5] DAAMEN, W. Modelling passenger flows in public transport facilities. 2004. 377 f. Tese (Doutorado em engenharia civil) - Curso de Engenharia Civil, Delft University, Leidschendam, 2004.
[6] FREITAS FILHO, P. J. Introdução À Modelagem e Simulação de Sistemas: com Aplicações ARENA. 2. ed. Florianópolis: Visual Books, 2008. 372 p.

[7] GUAZZELLI, C. S. Contribuição ao dimensionamento e à avaliação operacional de terminais urbanos de passageiros metroviários e ferroviários. Dissertação de mestrado, USP, São Paulo, 2011

[8] HILLIER, F.; LIEBERMAN, G. J. Introdução à Pesquisa Operacional. 9a Edição. AMGH, 2013. VitalBook file.

[9] LEAL, J. E. O uso da teoria das filas no acesso rodoviário aos terminais de contêiner. 2012. Tese de Doutorado. PUCRio.

[10] LI G.; XI M.; NI L. A Queuing Simulation Research of Fare Collection Equipments in Xi'an Subway Longshouyuan Station. In: Qin Y., Jia L., Feng J., An M., Diao L. (eds) Proceedings of the 2015 International Conference on Electrical and Information Technologies for Rail Transportation. Lecture Notes in Electrical Engineering, vol 378. Springer, Berlin, Heidelberg, 2016.

[11] MARINS, F. A. S. Introdução à pesquisa operacional. São Paulo: Cultura Acadêmica, 2011. 1 v.

[12] STONE A.. Why waiting is torture. <http://www.nytimes. com/2012/08/19/opinion/sunday/why-waiting-in-line-istorture.html?_r=3\& >. Acesso em: 02 jun. 2016.

[13] NOVO HAMBURGO. <http://censo2010.ibge.gov.br/ pt/>. Acesso em: 22 nov.2015.

[14] SZTRIK, J. Basic queueing theory. University of Debrecen, Faculty of Informatics, v. 193, 2012.

[15] TAHA, H.A.; MARQUES, A. S.; SCARPEL, R. A. Pesquisa operacional. Pearson Education do Brasil, 2008.

[16] TRENSURB. < http://www.trensurb.gov.br. > Acesso em: 23 nov. 2015

[17] TRENSURB. Análise de Fluxos e Proposição de medidas: Estação Novo Hamburgo. Novo Hamburgo. Nov. 2014. 20 slides. Apresentação de Power Point.

[18] XIN-YUEX.; JUNL.; HAI-YING L.; JIAN-QIANG H. Analysis of subway station capacity with the use of queueing theory. Transportation Research Part C: Emerging Technologies, Volume 38, 2014. Disponível em <http://www.sciencedirect. com/science/article/pii/S096809 0X13002258>. Acesso em novembro de 2017. 


\section{CAPÍTULO 20}

\section{ESTRATÉGIAS RELAX-AND-FIX NA SOLUÇÃO DE UM PROBLEMA DE ROTEAMENTO PERIÓdICO EM ARCOS CAPACITADOS (PCARP)}

Jailson Domingos de Oliveira

Cassius Tadeu Scarpin

Resumo: Nesse trabalho. aplicou-se uma estratégia baseada na heurística relax-and-fix como método de soluçáo para o Problema de Roteamento Periódico em Arcos Capacitados (PCARR-Periodic Capacitated Arc Routing Problem). Considerou-se o caso especial em que os veículos não têm a necessidade de voltar ao depósito no final de um período e, ainda, têm a possibilidade de folgar em qualquer dia do horizonte de tempo. O PCARP é um problema pouco explorado na literatura. Configura-se como um problema NP-hard, sendo comumente aplicado em coleta de resíduos urbano, inspeção de linhas de força, despejo de sal em vias com neves, entrega de correspondéncia entre outros. Desenvolveu-se 4 estratégias diferentes para heurística relax-and-fix e avaliando-se seus desempenhos. Os testes computacionais realizados indicaram que as estratégias propostas para heurística são rápidas na determinação de soluções iniciais para o problema. Destaca-se que das 23 instâncias testadas em nenhum caso se esgotou a memória do computador, fato que ocorre com frequência na tentativa de resolver o problema por métodos exatos.

Palavras chave: Relax-and-fix, Problema de Roteamento Periódico em Arcos Capacitados, Heurística. 


\section{INTRODUÇÃO}

A literatura traz estudos em três grandes problemas logísticos: gerenciamento de armazéns, localização de facilidades e roteamento de veículos. Nesse último, em especial, a literatura sugere dois objetivos explorados: a redução do número de veículos utilizados e/ou a redução da distância total percorrida (DOULABI; SEIFE, 2013). O Problema de Roteamento de Veículos (PRV) ou Vehicle Routing Problems (VRP) é considerado um problema clássico da literatura (DANTZIG; RAMSER, 1959). Para Franco e Oliveira (2012) entende-se por roteamento de veículos, um conjunto de problemas que tem por objetivo determinar as melhores rotas para uma frota de veículos atenderem um conjunto de usuários finais (arcos ou nós).

Problemas de Roteamento de Veículos tem recebido a atenção de muitos pesquisadores no decorrer dos anos, seja com o surgimento de novos modelos e abordagens, ou pelo número elevado de aplicações práticas comparados a outros problemas clássicos. Destaca-se: distribuições de jornais, alimentos, bebidas, produtos diversos, transporte escolar, recolhimento de lixo, entrega de correspondência, serviço de emergência entre outros (GOLDBARG, 2005).

Para Goldbarg (2005) os problemas de roteamento de veículos estão entre os mais complexos da área de otimização combinatória. Isto deve-se pelo grande número de variáveis, diversidade de restrição e objetivos, pertencendo a classe de problemas NPHard em que, não há algoritmos em tempo polinomial para encontrar soluções ótimas.

Segundo Goldbarg (2005) problemas de roteamento de veículos podem ser classificados em duas classes: Problema de Roteamento em Nós (associado aos ciclos Hamiltonianos) e Problemas de Roteamento em Arcos (associados aos ciclos Eulerianos). Problemas de roteamento em nós consistem em determinar uma ou mais rotas que passe por todos os nós ou vértices de um grafo enquanto que o roteamento em arcos tem por objetivo determinar uma ou mais rotas que atenda todos os arcos ou arestas de um grafo (MONROY; AMAYA; LANGEVIN, 2013). roteamento em arcos. Mais especificamente, o Problema de Roteamento Periódico em Arcos Capacitados (PCARP), baseando-se na formulação matemática proposta por Batista (2013). Como abordagem de solução, foi proposto uma heurística do tipo relax-and-fix descrita em Wolsey (1998) que decompõem o modelo original em submodelos que podem ser resolvidos de modo exato, sem, entretabto, garantir o ótimo do problema original. Além de propor diferentes estratégias para heurística, esse trabalho procurou contribuir com a literatura verificando a viabilidade e desempenho da heurística quando aplicada no PCARP.

\section{PROBLEMAS DE ROTEAMENTO EM ARCOS}

O Problema de Roteamento em Arcos (Arc Routing Problems - ARP) é um dos mais antigos problemas relacionados a grafos, sendo a primeira referência advinda do problema das pontes de Königsberg (1736) resolvido pelo famoso matemático suíço Euler. O termo "percurso em arco" foi estabelecido mais claramente em 1995 por Eiselt et al. (1995).

O problema de roteamento em arcos, refere-se a problemas de roteamento onde a atividade principal é cobrir os arcos e suas demandas. Enquanto que problemas de roteamento em nós, a atividade é servilos e os arcos são de interesse apenas como caminhos que conectam os nós (EISEL et al., 1995i). Segundo Eisel et al. (1995i) o principal objetivo dos ARPs é determinar o menor custo para atravessar um conjunto de arcos de um grafo, com ou sem restrições.

De acordo com Corberán e Prins (2010) os ARPs tem sido menos estudados do que os problemas de roteamento em nós, mas, tem ganhado destaque nas últimas décadas e desenvolvimentos impressionantes foram alcançados. Existem um grande número de situações reais que podem ser modelados por esse tipo de problema tais como: a coleta de lixo urbano, a inspeção de linhas de forças, o despejo de sal em vias com neves, entrega de correspondências, entre outros (CORBERÁN; PRINS, 2010).

Diversos são os problemas que se encaixam na classificação ARPs, entre os quais, destaca-se: o 
problema das pontes de Königsberg, Problema do Carteiro Chinês, o Problema do Carteiro Rural, Problema de Roteamento em Arcos Capacitados e Problema de Roteamento Periódico em Arcos Capacitados.

\subsection{PROBLEMAS DE ROTEAMENTO PERIÓDICO EM ARCOS CAPACITADOS}

O Problema de Roteamento em Arcos Capacitado (Capacitated Arc Routing Problem - CARP), foi proposto por Golden e Wong (1981) e envolve a "capacidade" dos veículos. Essa capacidade, muitas vezes pode estar associada à carga máxima ou a um tempo máximo de trabalho ou, também, a uma distância percorrida. Os ARPs capacitados são mais difíceis de serem resolvidos e seu estudo é mais recente (CORBERÁN; PRINS, 2010).

Como o CARP envolve restrições operacionais que limitam a capacidade de atendimento, sua resolução de maneira exata é conciderada difícil. Golden e Wong (1981) apresentam a primeira formulação matemática para o CARP propondo um algoritmo para solucionar o modelo e demonstrar que o problema é NP-hard. Devido sua complexidade, diversos métodos heurísticos têm sido desenvolvidos para a resolução do CARP. Eiselt et al. (1995ii) classificam esses métodos em três categorias: 1) os construtivos simples; (2) os construtivos de duas fases; e 3) os de melhoria.

O CARP é frequentemente utilizado para resolver problemas de coleta de resíduos urbanos que necessitam de tomadas de decisões de níveis operacionais, onde rotas são definidas num prazo curto, diariamente, em geral. Todavia, em alguns problemas é necessário tomadas de decisões de nível tático, com horizontes de tempo maior e que ainda envolvam restrições de periodicidades. Nesse caso, destaca-se o Problema de Roteamento Periódico em Arcos Capacitados (BATISTA; SCARPIN, 2015).

O Problema de Roteamento Periódico em Arcos Capacitados (Periodic Capacitated Arc Routing Problem - PCARP) é uma extensão do CARP. Ao invés do problema ser resolvido para tomada de decisões de nível operacional são utilizados para decisões de nível tático, para horizontes de tempo maiores do que um período e com restrições de frequência (LACOMME; PRINS; RAMDANE-CHÉRIF, 2002i).

Em muitos problemas, alguns arcos possuem uma necessidade de serem atendidos com maior frequência. Por exemplo, no caso da coleta de resíduos urbanos que em grandes centros a produção é maior do que em bairros. Logo, essas regiões demandam uma frequência maior de coleta, em que se faz necessário um planejamento baseado em múltiplos períodos. Portanto, resolver PCARP implica a determinação simultânea de decisões táticas: determinando para cada rua um número de tratamento de acordo com sua frequência; e operacionais: determinando uma rota, de forma que, para cada período, as ruas sejam atendidas. O custo total depende da combinação das decisões de designação e roteamento (LACOMME; PRINS; RAMDANE-CHÉRIF, 2005).

Um dos primeiros modelos matemáticos foram propostos por Chu, Labadi e Prins (2004) que utilizaram softwares comerciais para resolução do problema e conseguiram soluções apenas para instâncias pequenas com 5 períodos e 10 arestas. Chu, Labadi e Prins (2006) descrevem o PCARP como extensão do CARP e aplicam dois algoritmos para resolução. O primeiro é uma heurística gulosa e o segundo é o algoritmo Scatter Serch (SS) baseado em busca local, utilizados para avaliar dois conjuntos de casos.

Lacome, Prins e Ramdame-Chérif (2005) afirmam que pesquisas sobre o PCARP são ainda embrionários e muito recentes. Utilizaram um Algoritmo Genético híbrido cujos objetivos eram minimizar tanto a frota de veículos quanto os custos das viagens (LACOMME, PRINS e RAMDAME-CHERÉF, 2002ii).

Kansou e Yassine (2009) trabalharam com o PCARP de forma que cada serviço ocorresse de acordo com uma combinação de dias que satisfizessem as frequências, nomeado Problema de Roteamento Periódico Misto em Arcos Capacitados. Para resolução combinram uma heurística de inserção e a meta-heurística de Colônia de Formigas. 
Batista (2014) apresentou um modelo com características diferenciadas das já propostas na literatura, como: não necessitar voltar a um depósito ao final de um dia e a possibilidade de um veículo folgar em um determinado dia. Seu modelo foi aplicado na manutenção preditiva e preventiva de linhas férreas. Utilizou um software comercial para resolver, conseguindo chegar na solução ótima em apenas uma das 23 instâncias proposta pelo autor.

O PCARP é um problema NP-hard uma vez que inclui CARP como caso particular e, quanto mais restrições, mais difícil é encontrar uma solução (LACOMME; PRINS; CHÉRIF, 2002). Logo, métodos exatos para sua solução são, até o momento na literatura, ineficientes quando trabalhado com problemas reais devido sua complexidade. O que leva ao desenvolvimento e proposta de novos métodos para determinar soluções viáveis.

\section{FORMULAÇÃO MATEMÁTICA}

O modelo proposto em Batista (2014), parte de um grafo não direcionado $G=(X, E)$ com $n$ nós, $X=\left\{x_{1}, x_{2}, \ldots, x_{n}\right\}$, e $m$ arestas com $E=\left\{e_{1}, e_{2}, e_{3}, \ldots, e_{m}\right\}$ que devem ser percorridos por $n k$ carros definidos pelo conjunto $K=\{1,2, \ldots, n k\}$. Cada aresta $e$ é formada por um par de nós chamado de $x_{i j}=\left(x_{i}, x_{j}\right)$, os quais são associado a um custo $\mathrm{C}_{\mathrm{ij}}$.

Batista (2014) considerou a capacidade dos veículos usados, como sendo a máxima distância que estes podem se deslocar, ou seja, 1 aresta por dia.

O horizonte de tempo $H$ é formado por np períodos $H=\{1,2, \ldots \mid, n p\}$, onde cada período é representado por $p$. A demanda nesse modelo é considerado a periodicidade de cada aresta que é expressa na quantidade máxima de períodos em que uma aresta deve ser atendido ao menos uma vez $M P\left(x_{i j}\right)$.

O modelo é baseado em Programação Linear Binária, com três variáveis descritas abaixo:

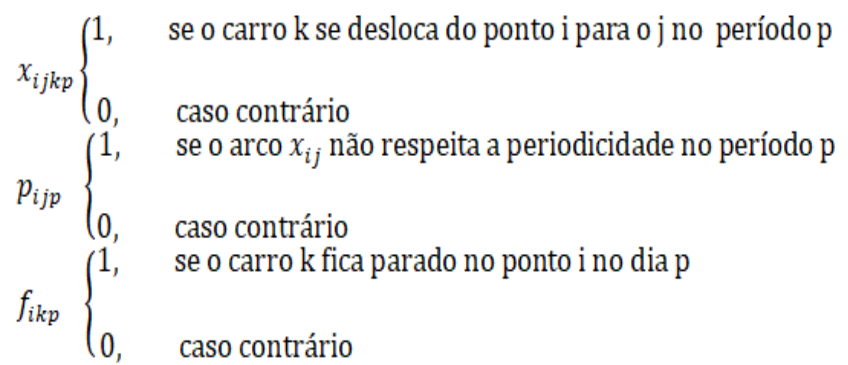

As variáveis $p_{\mathrm{ijp}}$ ef $\mathrm{f}_{\mathrm{ikp}}$ são propostas para que o modelo tenha viabilidade. Cada variável $\mathrm{p}_{\mathrm{ijp}}$ está associada a uma punição $P \cup_{i j}$, caso uma aresta não tenha sua periodicidade atendida o que permite que haja atrasos no atendimento de algumas aresta.

Já a variável $\mathrm{f}_{\mathrm{ikp}}$ permite que um carro folgue em um determinado dia, permitindo em algumas vezes obter uma solução com menor quantidade de deslocamentos.

Modelo:

$$
\min Z=\sum_{[i, j] \in E} \sum_{k=1}^{n k} \sum_{p=1}^{n p} c_{i j} * x_{i j k p}+\sum_{[i, j] \in E}^{n p} \sum_{p=1}^{n p} P U_{i j} * p_{i j p}
$$

Sujeito à:

$\sum_{[i, j] \in E} x_{i j k p}+f_{j k p}-\sum_{[i, j] \in E} x_{j i k, p+1}-f_{j k, p+1}=0 \quad \forall j \in X, \forall k \in K, \forall p \in H$

$\sum_{[i, j] \in E} x_{i j k p}+\sum_{[i, j] \in E} x_{j i k p}+\sum_{i=1}^{n} f_{i k p}=1 \forall p \in H, \forall k \in K$

$\sum_{k=1}^{n k}\left(\begin{array}{c}x_{i j k p+} x_{j i k p}+x_{i j k, p+1}+x_{j i k, p+1}+\cdots \\ +x_{i j k, p+M P\left(x_{i j}\right)-1}+x_{j i k, p+M P\left(x_{i j}\right)-1}\end{array}\right)+p_{i j p} \geq 1 \forall[i, j] \in E, \forall p \in H$

$x_{i j k p}, p_{i j p}, f_{i k p} \in\{0,1\} \quad \forall[i, j] \in E, \forall k \in K, \forall p \in H$

O objetivo do modelo (1) é a minimização dos custos de deslocamentos e atrasos. A restrição (2) garante o fluxo diário dos carros permitindo folgar. Pode ser observado nessa restrição que se um carro chega em um ponto em um determinado dia somando a possibilidade do veículo já estar no ponto, deve ser igual ao movimento no dia seguinte ou permanência no mesmo. A restrição (3) garante que todos os carros terão uma designação para cada dia $p$, isto é, que 
cada veículo no dia $p$ pode se deslocar de ipara $j$, ou de $j$ para $i$, ou ainda permanecer parado em um ponto i. A restrição (4) se refere à periodicidade que deve ser atendida em cada aresta. Observa-se que se as variáveis $p_{\mathrm{ijp}}$ assumam valor 1 , indica que a aresta $e_{i}$ teve sua periodicidade atrasada em um dia implicando em uma punição $P \cup_{i j}$ na função objetivo. Por fim, a restrição (5) determina que todas as variáveis do modelo sejam binárias.

\section{HEURÍSTICA RELAX-AND-FIX}

A heurística relax-and-fix tem sido aplicada nas últimas décadas para solucionar problemas de otimização combinatória, em especial, problemas de dimensionamento de lotes como mostram os trabalhos desenvolvidos por Dastidar e Nagi (2004), Ferreira et al (2009) e Ferreira et al (2010). A heurística foi desenvolvida por Wolsey (1998) e consiste em um método de decomposição de um modelo de programação inteira mista em submodelos menores disjuntos, que podem ser resolvidos rapidamente, porém sem a garantia de resolução do problema original de forma ótima.

A heurística baseia-se na partição das variáveis inteiras ou binárias do modelo criando $n$ conjuntos distintos, $P_{i}, i=1, \ldots n$. Observa-se que o conjunto de variáveis originais são divididos em três grupos: um contendo variáveis inteiras e binárias, um segundo contendo as variáveis relaxadas, e o último com variáveis fixadas. O número $n$ indica o número de iterações da heurística.

Em uma iteração $i$, as variáveis do conjunto $\mathrm{P}_{1}$ são definidas como inteiras e binárias, as variáveis $(1, \ldots, i-1)$ são fixadas e as demais variáveis $(i+$ $1, \ldots, n)$ são relaxadas. O submodelo resultante é resolvido. Caso o submodelo seja infactível, então se para a metodologia, pois não pode ser encontrado uma solução viável para o modelo original com as variáveis $(1, \ldots, i-1)$ fixadas. Caso contrário, as variáveis do conjunto $P_{i}$ são fixadas, repete-se o processo para os demais conjuntos até que todas as variáveis $(i, \ldots, n-1)$ sejam todas fixadas e as variáveis da partição sejam inteiras ou binárias. Assim, obtém-se uma solução inicial para o modelo original.
Segundo a literatura a heurística relax-and-fix tem demonstrado bom desempenho para determinar soluções iniciais para modelos de dimensionamento de lotes, esses resultados são posteriormente melhorados com a aplicação de uma heurística de melhoramento, como a heurística fix-and-optimize, estratégias utilizadas pelos autores Dastidar e Nagi (2005) e Ferreira et al. (2009).

Os processos de escolha das partições das variáveis do problema afetam o desempenho da heurística, uma vez que seu objetivo é resolver submodelos inteiros mistos menores (MORAES; SANTOS, 2012).

Nesse trabalho foram implementadas quatro estratégias diferentes para a heurística relax-and-fix e aplicadas ao PCARP proposto por Batista (2014). Nas três primeiras estratégias foram realizadas decomposição por período, na quarta foi proposto uma decomposição por adjacência de nós. Descrevese cada estratégia a seguir:

Relax-and-Fix Forward (RFF) - Nessa estratégia o problema original foi dividido em $\mathrm{P}$ subproblemas a serem resolvidos de modo que cada subproblema corresponda a um dia $p$ do horizonte de tempo. A ordem da resolução é a -cronológica, isto é, iniciando a resolução no subproblema correspondente ao primeiro período do horizonte de tempo e finalizando no subproblema correspondente ao último período.

A figura 1 (a) ilustra o funcionamento dessa estratégia. Para o primeiro subproblema, primeira iteração da heurística, as variáveis binárias referentes a $p=1$ foram mantidas e as variáveis para os demais períodos foram relaxadas (valores no intervalo $[0,1]$ ). Após a resolução do primeiro subproblema, as variáveis binárias do primeiro período são fixadas, tornam-se parâmetros, as variáveis do segundo período $(p=2)$ são mantidas binárias, e as demais dos período ( $3, \ldots$, p) são relaxadas. O processo se repete até que o último subproblema, seja resolvido. 
Figura 1 - Representação da heurística Relax-and-fix

a)

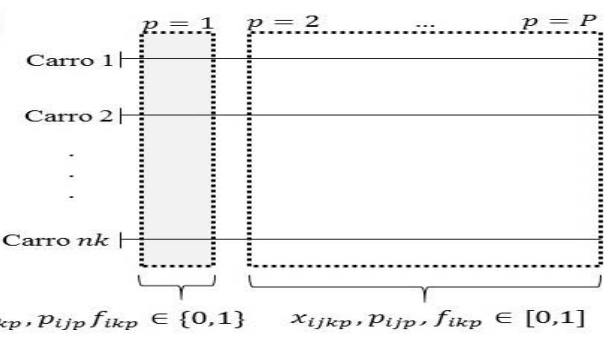

b)

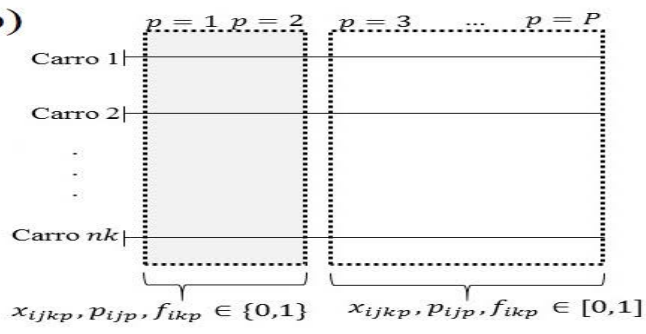

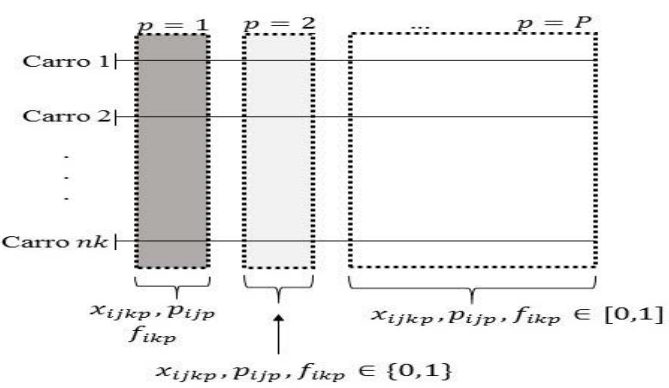

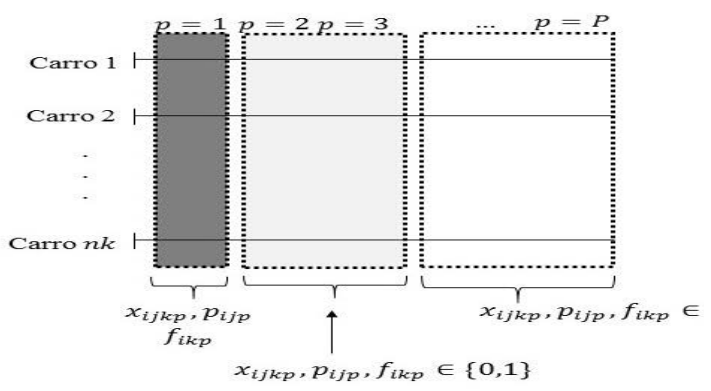

Relax-and-fix com Overlapping 1 (RFO1) - Essa estratégia, se baseia na partição do problema original em P períodos com sobreposição de partições. Seja uma partição as variáveis correspondente aos subproblemas $p$ e $p$-1 e são mantidas binárias e as demais variáveis subsequentes a esses períodos p-1 são relaxadas. Na próxima iteração, as variáveis do período são fixadas, as variáveis dos períodos $p$ e $p+1$ e mantidas binárias e as demais variáveis são relaxadas. O processo ocorre até que o último subproblema seja resolvido.

A figura 1 (b) ilustra essa estratégia. Para o primeiro subproblema temos as variáveis correspondente ao primeiro e segundo período $(p=1$ e $p=2)$ do horizonte de tempo, mantidas binárias e para os demais períodos foram relaxadas. Após a resolução desse primeiro subproblema, as variáveis binárias do primeiro período são fixadas (tornando-se parâmetro), as variáveis referentes ao segundo e terceiro período ( $p=2$ e $p=3$ ) são mantidas binárias, e as demais variáveis são relaxadas. O processo ocorre da mesma forma até a resolução do último subproblema correspondente ao último período.

Relax-and-fix com Overloping 2 (RFO2) - Essa estratégia, baseia-se na sobreposição de partições, semelhante a estratégia anterior RFO1. Nessa proposta cada subproblema é resolvido mantendo as variáveis binárias correspondentes aos períodos $p-3, p-2$, e $p$ - 1 e $p$, sendo as demais variáveis dos períodos subsequentes relaxadas. No próximo subproblema, as variáveis correspondentes aos períodos $p-3$ e $p$ e são fixadas, as variáveis dos períodos $p-1, p+1$ e $p+2$ são mantidas binárias e as demais variáveis subsequentes relaxadas, assim sucessivamente até o último subproblema ser resolvido.

Relax-and-fix nós Adjacentes (RFNA) - Nessa estratégia as partições foram baseadas em adjacências dos nós. Escolhe-se um nó para ser o nó raiz. A relaxação ocorre a partir desse nó, isto é, criamos um subconjunto que é formado pelo nó raiz e seus respectivos nós adjacentes, todas as variáveis referentes a esse conjunto de nós são mantidas binárias e as demais variáveis são relaxadas. Na segunda iteração as variáveis correspondentes ao nó raiz e seus adjacentes são fixadas as variáveis correspondentes aos nós adjacentes dos adjacentes do nó raiz são mantidas binárias e as demais relaxadas. Finalizando o processo quando todas as variáveis referentes aos nós do grafo $\mathrm{G}$ sejam fixas ou binárias.

A figura 2 descreve o funcionamento dessa estratégia, consideremos um grafo $\mathrm{G}=(\mathrm{X}, \mathrm{A})$ formado por 8 nós e 10 arestas. Inicia-se, neste exemplo, pelo nó raiz 6, para esse primeiro subproblema todas as variáveis 
correspondentes aos nós adjacentes a 6 são mantidas binárias e as demais relaxadas. Na segunda iteração, as variáveis referentes aos nós adjacentes de 6 são fixadas, as adjacentes ao nó 1 são mantidas binárias e as demais relaxadas. Na terceira e última iteração as variáveis referentes aos nós adjacentes a 1 e 6 são fixadas e as adjacentes aos nós 2, 4 e 5 são binárias.

Figura 2 - Representação da heurística Relax-and-fix RFNA

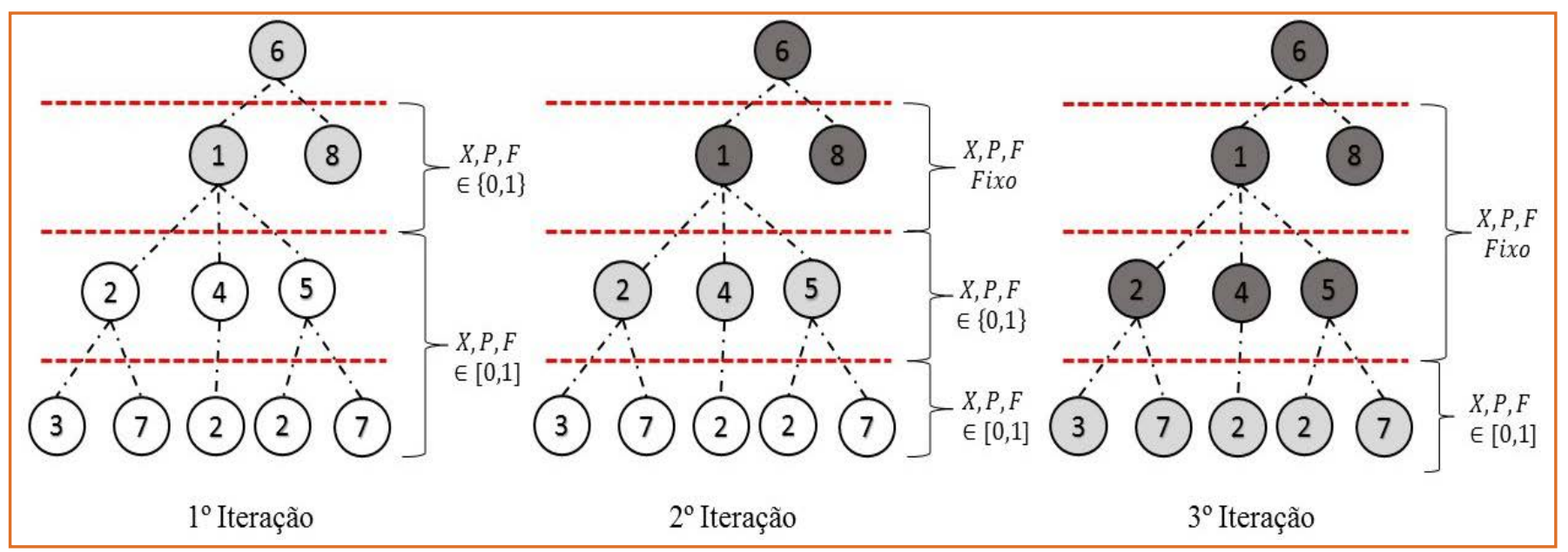

Tabela 1- Características dos 23 problemas

\section{EXPERIMENTOS COMPUTACIONAIS}

As estratégias propostas para a heurística relax-andfix para a resolução do PCARP, foram implementadas no Microsoft Visual Studio 2015 utilizando pacote de otimização IBM ILOG CPLEX 12.4. Os testes foram realizados utilizando um computador com processador Intel Core i7-5500U com velocidade de $2.4 \mathrm{GHz}$, memória de RAM de 8GB sob o sistema operacional Windows 10.

Foram utilizadas 23 instâncias proposta no trabalho de Batista (2014), para verificar o desempenho das estratégias sugeridas nesse trabalho. As características para cada uma das instâncias, como número de nós, número arestas, quantidade de carros e o horizonte de tempo (Dias) estão dispostos na Tabela 1. Percebese que as instâncias propostas dependendo do número de dias, carros e arestas tornam os problemas complexos de serem resolvidos, fato esperado devido a natureza do problema NP-hard.

\begin{tabular}{|l|l|l|l|l|l|l|}
\hline Problema & Nós & Arestas & Período & Carros & Neces. & Dias \\
\hline gdb1 & 12 & 22 & 2 & 1 & 32 & 38 \\
\hline gdb2 & 12 & 26 & 3 & 1 & 44 & 53 \\
\hline gdb3 & 12 & 22 & 2 & 2 & 31 & 19 \\
\hline gdb4 & 11 & 19 & 3 & 2 & 34 & 21 \\
\hline gdb5 & 13 & 26 & 4 & 2 & 53 & 32 \\
\hline gdb6 & 12 & 22 & 2 & 3 & 32 & 14 \\
\hline gdb7 & 12 & 22 & 3 & 3 & 37 & 45 \\
\hline gdb8 & 27 & 46 & 4 & 3 & 67 & 27 \\
\hline gdb9 & 27 & 51 & 3 & 4 & 78 & 24 \\
\hline gdb10 & 12 & 25 & 4 & 4 & 70 & 21 \\
\hline gdb11 & 22 & 45 & 2 & 1 & 50 & 60 \\
\hline gdb12 & 13 & 23 & 3 & 1 & 33 & 40 \\
\hline gdb13 & 10 & 28 & 2 & 2 & 33 & 20 \\
\hline gdb14 & 7 & 21 & 3 & 2 & 32 & 20 \\
\hline gdb15 & 7 & 21 & 4 & 2 & 48 & 29 \\
\hline gdb16 & 8 & 28 & 2 & 3 & 40 & 24 \\
\hline gdb17 & 8 & 28 & 3 & 3 & 52 & 21 \\
\hline gdb18 & 9 & 36 & 4 & 3 & 81 & 33 \\
\hline gdb19 & 8 & 11 & 3 & 4 & 29 & 12 \\
\hline gdb20 & 11 & 22 & 4 & 4 & 53 & 16 \\
\hline gdb21 & 11 & 33 & 2 & 5 & 46 & 12 \\
\hline gdb22 & 11 & 44 & 4 & 5 & 88 & 22 \\
\hline gdb23 & 11 & 55 & 2 & 6 & 82 & 17 \\
\hline
\end{tabular}


A Tabela 2 mostra o valor da função objetivo e o tempo gasto em segundos na execução de cada heurística proposta, para cada uma das 23 instâncias. Foi estipulado um tempo limite de 1 hora ou 3600 segundos para as três primeiras heurísticas propostas (RFF, RFO1, RFO2) e de 300 segundos por iteração para a quarta heurística proposta (RFNA). Os símbolos "--" indicam que a estratégia gerou subproblemas infactíveis, enquanto que os símbolos "*" que a heurística utilizou o tempo limite e não chegou em uma solução.

A última coluna da tabela refere-se aos valores da função objetivo de cada instância do trabalho de Batista (2014), os quais foram resolvidas pelo software CPLEX 12.4 utilizando a configuração default do solver, com um tempo limite para obtenção de uma solução de 24 horas ou 86400 segundos. Os símbolos "**" indicam que os problemas esgotaram a memória do computador antes de chegar a uma solução ótima ou atingir o tempo limite.

A estratégia RFF apresentou o pior desempenho em relação as demais, das 23 instâncias 19 dessas foram infactíveis. A infactibilidade ocorreu com grande frequência nas três primeiras estratégias propostas. Esse fato é devido ao funcionamento da heurística relax-and-fix, pois o modelo exige que os veículos retornem ao nó onde iniciaram a rota, em muitos casos um determinado veículo encontra-se em um nó muito longe do nó onde iniciou sua rota, não havendo dias suficientes no horizonte de tempo para seu retorno ao nó inicial, o que torna infactível o problema.

Tabela 2 - Resultados das estratégias propostas para heurísticas relax-and-fix

\begin{tabular}{|c|c|c|c|c|c|c|c|c|c|c|}
\hline \multirow[b]{2}{*}{ Problema } & \multicolumn{2}{|l|}{ RFF } & \multicolumn{2}{|c|}{ RFO1 } & \multicolumn{2}{|l|}{ RFO2 } & \multicolumn{2}{|l|}{ RFNA } & \multicolumn{2}{|c|}{$\begin{array}{l}\text { EXATO } \\
\text { (Batista, 2014) }\end{array}$} \\
\hline & Solu. & Tempo & Solu. & Tempo & Solu. & Tempo & Solu & Temp & Solu. & Tempo \\
\hline gdb1 & -- & -- & -- & -- & -- & -- & 53426 & 358 & 4450 & $39000^{* *}$ \\
\hline gdb2 & -- & -- & -- & -- & -- & -- & 7620 & 360 & 11622 & $70423^{\star *}$ \\
\hline gdb3 & -- & -- & -- & -- & -- & -- & 344 & 349 & 340 & $36906^{* *}$ \\
\hline gdb4 & -- & -- & -- & -- & 14503 & 105 & 10479 & 387 & 3555 & $49595^{\star \star}$ \\
\hline gdb5 & -- & -- & -- & & -- & -- & 22699 & 657 & 1750 & $86400^{*}$ \\
\hline gdb6 & -- & -- & 4478 & 260 & 459 & 180 & 456 & 109 & 456 & $86400^{*}$ \\
\hline gdb7 & -- & -- & -- & -- & 15520 & 270 & 3550 & 649 & 518 & $55767^{\star *}$ \\
\hline gdb8 & -- & -- & -- & -- & -- & -- & -- & -- & 12395 & $86400^{*}$ \\
\hline gdb9 & & * & & * & & * & -- & -- & 13454 & $86400^{*}$ \\
\hline gdb10 & & * & & * & & * & -- & -- & 734 & $86400^{*}$ \\
\hline gdb11 & -- & -- & -- & -- & -- & -- & -- & -- & 64437 & $31510^{\star *}$ \\
\hline gdb12 & -- & -- & -- & -- & -- & -- & 12558 & 129 & 536 & $86400^{*}$ \\
\hline gdb13 & -- & -- & 620 & 111 & 620 & 111 & 620 & 51 & 620 & $86400^{*}$ \\
\hline gdb14 & -- & -- & -- & -- & 145 & 105 & 145 & 31 & 145 & 261 \\
\hline gdb15 & -- & -- & -- & -- & 3144 & 1681 & 142 & 156 & 140 & $63135^{* *}$ \\
\hline gdb16 & -- & -- & 185 & 182 & 184 & 145 & 182 & 175 & 182 & $35301^{\star *}$ \\
\hline gdb17 & -- & -- & 3180 & 305 & -- & -- & 168 & 174 & 168 & $77693^{\star *}$ \\
\hline gdb18 & -- & -- & -- & -- & & * & 404 & 737 & 415 & $86400^{*}$ \\
\hline gdb19 & 2135 & 122 & 129 & 145 & 135 & 125 & 125 & 53 & 125 & $47566^{\star *}$ \\
\hline gdb20 & -- & -- & -- & -- & 6258 & 137 & -- & -- & 2280 & $67903^{* *}$ \\
\hline gdb21 & -- & -- & -- & -- & 212 & 122 & 212 & 123 & 212 & $38181^{* *}$ \\
\hline gdb22 & & * & & * & & * & 470 & 746 & 433 & $86400^{*}$ \\
\hline gdb23 & -- & -- & -- & -- & 336 & 1432 & 345 & 423 & 336 & $86400^{*}$ \\
\hline
\end{tabular}


A estratégia RFO1 apresentou desempenho superior a primeira estratégia. Conseguiu resolver 5 das 23 instâncias, chegando ao mesmo valor para a função objetivo que Batista (2014) para o problema gdb13, com um tempo inferior, enquanto que o método exato levou 24 horas a heurística levou 111 segundos (1 minuto e 51 segundos).

A estratégia RFO2, obteve melhor desempenho que RFO1 e RFF, chegou em uma solução viável para 11 dos 23 problemas, sendo que para as instâncias gdb13, gdb14, gdb21 e gdb23 obteve o mesmo valor que o método exato executado por 24 horas para a função objetivo, em um tempo de execução muito inferior. É possível observar ainda que para as instâncias gdb6, gdb16 e gdb19 a heurística teve bom desempenho chegando em um valor para função objetivo próxima do método exato e, novamente, com um tempo muito inferior a esse. Esses valores podem posteriormente ser melhorados com a aplicação de uma heurística de melhoria como, por exemplo, a heurística fix-andoptimize.

A última estratégia proposta nesse trabalho RFNA, obteve os melhores desempenho. Alcançou uma solução viável para 18 das 23 instâncias propostas em Batista (2014). A estratégia obteve os mesmos valores que o método exato para os problemas gdb6, gdb13, gdb14, gdb16, gdb17, gdb19 e gdb21, com um tempo de execução inferior. Para os problemas gdb2 e gdb18 teve desempenho superior, encontrando soluções com valores menores que o exato executado por 24 horas, e com tempos de execução menores.

Para as instâncias gdb3, gdb15, gdb22 e gdb23 a estratégia RFNA, obteve soluções próximas do método exato e com tempos muito inferior a esse, destacamos a possibilidade da utilização de uma heurística de melhoria para esses casos.

Pode-se destacar que, para as quatro estratégias propostas, em nenhum caso esgotou-se a memória do computador, algo que ocorreu com frequência na execução do método exato.

\section{CONSIDERAÇÕES FINAIS}

Nesse trabalho estudou-se o Problema de Roteamento Periódico em Arcos Capacitados (PCARP). Utilizouse a heurística relax-and-fix como método de solução para o modelo proposto por Batista (2014). Foram desenvolvidas quatro estratégias de decomposição das variáveis binárias do problema e realizado testes com 23 instâncias propostas na literatura.

A heurística relax-and-fix mostrou-se uma boa estratégia para determinar uma solução inicial para o modelo PCARP estudado nesse trabalho. Houve ganho em tempo computacional e em nenhum caso houve estouro de memória do computador. Em alguns casos, os valores da função objetivo podem ficar distantes da solução ótima, o que pode ser futuramente melhorada com uma heurística de melhoria.

De acordo com os testes realizados, verificou-se que a melhor heurística proposta foi a Relax-andFix Nós Adjacentes, que apresentou maior número de soluções quando comparada com as demais. Esta obteve solução viável para 18 instâncias das 23 propostas, sendo que, para duas dessas obteve soluções melhores que o método exato executado por 24 horas e interrompido por este tempo.

Futuramente, pode-se implementar novas estratégias para heurística relax-and-fix, baseando-se em outros particionamento do modelo e implementar uma heurística de melhoria do tipo fix-and-optimizie, com o objetivo de melhorar as soluções encontradas pelo heurística relax-and-fix.

\section{REFERÊNCIAS}

[1] BATISTA, G. V. Proposta de Um Modelo Matemático para o Problema de Roteamento em Arcos Capacitado e Periódico. Dissertação de Mestrado. UFPR. 2014. Disponível em: $\quad$ http://dspace.c3sl.ufpr.br/dspace/bitstream/ handle/1884/35767/R\%20-\%20D\%20 \%20GUILHERME\%20 VINICYUS\%20BATISTA. pdf?sequence=1>.

[2] BATISTA, G. V.; SCARPIN, C. T. Problema de Roteamento em Arcos Capacitado e Periódico Aplicado a um Contexto Real. Revista Produção Online. Vol. 15, n. 3, p. 1080-1098, 2015. 
[3] CHU, F.; LABADI, N.; PRINS, C. The Periodic Capacitated Arc Routing Problem Linear Programming Model, Metaheuristic and Lower Bounds. Journal of Systems Science and Systems Engineering, v. 13, n. 4, p. 423-435, 2004.

[4] CHU, F.; LABADI, N.; PRINS, C. A Scatter Search for the Periodic Capacitated Arc Routing Problem. European Journa of Operational Research. Vol. 169, p. 586-605, 2006.

CORBERÁN, A.; PRINS, C. Recent Results on Arc Routing Problems: An Annotated Bibliography. Networks, p. 50-69, 2010.

[5] DASTIDAR, S. G.; NAGI, R. Scheduling injection molding operations with multiple resource constraints and sequence dependent setup times and costs. Computers \& Operations Research. Vol. 32, p. 2987-3005, 2005

[6] DANTZIG, G. B.; RAMSER, J. H. The Truck Dispatching Problem. Management Science. Vol. 6, n. 1, p.80-91, 1959.

[7] DOULABI, S. H. H.; SEIFE, A. Lower and upper bounds for location-arc routing problems with vehicle capacity constraints. European Journal of Operational Research. Vol. 224, n. 1, p.189-208, 2013

[8] EISELT, H. A.; GeNDREAU, M.; LAPORTE, G. Arc Routing Problems, Part I: The Chinese Postman Problem. Operations Research. Vol. 43, n. 2, p. 231-242, $1995 \mathrm{i}$. Disponível em: <http://or.journal.informs.org/cgi/doi/10.1287/ opre.43.2.231>

[9] EISELT, H. A.; GENDREAU, M.; LAPORTE, G. Arc Routing Problems, Part II : The Rural Postman Problem. Operations Research. Vol. 43, n. 3, p. 399-414, 1995ii. Disponível em: $<$ http://or.journal.informs.org/content/43/3/399.full.pdf>

[10] FERREIRA, D.; MORABITO, R.; RANGEL, S. Solution Approaches for the Soft Drink lintegrated Production Lot Sizing and Scheduling Problem. European Journal of Operational Research. Vol. 196, p. 697-706, 2009.

[11] FERREIRA, D.; MORABITO, R.; RANGEL, S. Relax and Fix Heuristics to Solve One-Stage Onemachine Lot-Scheduling Models for Small-Scale soft Drink Plants. Computers \& Operations Research. Vol.37, p. 684-691, 2010.

[12] FRANCO, E. F. J.; OLIVEIRA, H. C. B. Adaptação da Meta-Heurística GRASP na resolução do problema de Roteamento de Veículos com Janela de Tempo. Rio de Janeiro. Vol. 4, n. 3, p. 271-287, 2012.
[13] GOLDEN, B. L.; WONG, R. T. Capacitated Arc Routing Problem. Networks. Vol. 11, p. 305-315, 1981.

[14] GOLDBARG, M. C. Otimização Combinatória e Programação Linear: Modelos e Algoritmos. 2. ed. Rio de Janeiro: Elsevier, 2005.

[15] KANSOU, A.; YASSINE, A. Ant Colony System for the Periodic Capacitated Arc Routing Problem. Proc. 2009 International Network Optimization Conference. Anais... p.17, 2009

[15] LACOMME, P.; PRINS, C.; RAMDANE-CHÉRIF, W. Evolutionary Algorithms for Multiperiod Arc Routing Problems. In: IPMU 2002 (Ed.); 9th Int. Conf. on Information Processing and Management of Uncertainty in Knowledge-Based systems. Anais. p.1-8, 2002i

[16] LACOMME, P.; $\quad$ PRINS, $\quad$ C.; $\quad$ RAMDANECHÉRIF, W. Planning Problems in Arc Routing. In: F. U.-E. de Valencia (Ed.); Actes de PMS 2002 (EURO Working Group on Project Management and Scheduling). Anais... p.232-235, 2002ii.

[17] LACOMME, P.; PRINS, C.; RAMDANE-CHÉRIF, W. Evolutionary Algorithms for Periodic Arc Routing Problems. European Journal of Operational Research. Vol. 165, p. 535553,2005

[18] MONROY, I. M.; AMAYA, C. A.; LANGEVIN, A. The periodic capacitated arc routing problem with irregular services. Discrete Applied Mathematics. Vol. 161, p. 691701,2013

[19] MORAES, L. C. C.; SANTOS, M. O. Heurística Relaxand-Fix para o Problema de Dimensionamento de Lotes com Janela de Tempo de Produção. 2012. Disponível em: <http:// www.din.uem.br/sbpo/sbpo2012/pdf/arq0479.pdf>.

[20] NEGREIROS, M.; COELHO JUNIOR, W. R.; PALHANO, A. W. D. C.; et al. O Problema do Carteiro Chinês, Algoritmos Exatos e um Ambiente MVI para Análise de suas Instâncias: Sistema XNÊS. Pesquisa Operacional. Vol. 29, n. 2, p. 323363, 2009.

[21] WOLSEY, L. A. Wiley-Interscience Series in Discrete Mathematics and Optimization: Integer Programming. Wiley. 1998. 


\section{CAPÍTULO 21}

\section{O USO DE FERRAMENTAS TECNOLÓGICAS NA GESTÃO DO CONHECIMENTO}

Danieli Pinto

Gisele Caroline Urbano Lourenço

Flávio Bortolozzi

Mariana Santos de Oliveira

Velson Tenório

Resumo: As tecnologias da informação e comunicação (TIC) elevaram o conhecimento e a informação para a centro dos processos organizacionais. Com isso, surgiu a necessidade de controlar o fluxo de conhecimento e informação gerados nas organizações buscando tornar os conhecimentos individuais em coletivos. Nesse cenário, as TIC se destacaram como grandes atiadas da gestão do conhecimento, assegurando hovas relações de trabalho e novos comportamentos, bem como, a sustentação, armazenamento e distribuição das informações coletadas.

Palavras chave: Conhecimento; Informação; Controle do fluxo de informações. 


\section{INTRODUÇÃO}

De acordo com Castells (1999), as tecnologias da informação e comunicação (TICs) possibilitaram o surgimento de uma sociedade alicerçada em informação e conhecimento. Hargreaves (2003) enfatiza que a consequência direta disso foi um mundo imerso em um grande fluxo de informações com o conhecimento como um recurso flexível, fluido e que está sempre em expansão e mudança. Nesse sentido, Carvalho (2003) destaca que as mudanças impactaram diretamente as empresas que passaram a considerar o conhecimento como um de seus principais ativos, agregando, consequentemente, valor aos produtos e serviços. No entanto, para fazer diferença na organização e, possivelmente, gerar inovação e vantagem competitiva o conhecimento precisa estar disponível no ambiente organizacional e aliado ao modelo de gestão da organização.

Para Floriano, Santos e Schroeder (2009), as organizações que conseguem compreender a importância do conhecimento, bem como ele pode ser utilizado para benefício próprio, são capazes de produzir novos conhecimentos, determinantes de novas competências, habilidades, produtos ou serviços, levando ao aperfeiçoamento dos processos internos e ao alcance dos objetivos préestabelecidos. No entanto, Nascimento et al. (2016, p.37) salienta que, o conhecimento gerado no ambiente organizacional só poderá ser utilizado se ele for "objeto da gestão do conhecimento, caso contrário será perdido e/ou disperso". É nesse contexto que Sousa (2014), destaca que a gestão do conhecimento (GC) se alinha aos processos organizacionais, funcionando como uma ferramenta que ajuda a empresa a compreender como o conhecimento é criado, onde está armazenado, como pode ser recuperado e compartilhado.

Nascimento et al. (2016, p. 41) salientam que a sociedade do conhecimento exige que a informação e conhecimento sejam valorizados, pois os ambientes organizacionais são "mutáveis, dinâmicos e complexos". Enfatizam ainda que os dados, informações e conhecimentos presentes no ambiente organizacional podem, se utilizados de maneira correta, garantir inovação e vantagem competitiva frente aos concorrentes.

A gestão do conhecimento pode ser definida, segundo Dalkir (2011), como a coordenação deliberada e sistêmica das pessoas, tecnologias, processos e estrutura organizacional de forma a agregar valor por meio da reutilização e inovação. Essa coordenação é alcançada por meio da criação, compartilhamento e aplicação do conhecimento, assim como, por meio da alimentação de valiosas lições aprendidas e melhores práticas na memória organizacional de forma a promover aprendizagem organizacional contínua.
Segundo Gaspar et al. (2014), atividades relacionadas à GC buscam a transformação do conhecimento em ativos direcionados para um crescimento contínuo e sustentável da organização. No entanto, Gonçalves, Vasconcelos (2011) destaca que para que isso aconteça é necessária a utilização de algumas ferramentas capazes de identificar e atualizar os conhecimentos nas práticas individuais e coletivas da organização.

Sousa (2014) destaca que as ferramentas fundamentadas nas TICS fornecem subsídios às práticas de GC proporcionando às organizações a captura, compartilhamento e armazenamento do conhecimento. Gonçalves, Vasconcelos (2011) destacam que essas ferramentas ajudam a identificar e atualizar os conhecimentos nas práticas individuais e coletivas da organização.

Portanto, com o objetivo de alcançar o melhor resultado possível por meio da criação de novos conhecimentos baseados na renovação e atualização das informações as organizações adotaram ferramentas baseadas nas TICs para apoiarem seus processos de GC. Nesse sentido, Schiuma, Carlucci e Lerro (2012) afirmam que o uso de ferramentas tecnológicas nos processos de GC permitiram a criação, organização e compartilhamento do conhecimento disponível em documentos, planilhas, anotações, relatórios, entre outros.

Felipe, Fell e Dornelas (2013) destacam que o uso de ferramentas tecnológicas no ambiente organizacional também pode desencadear uma nova dinâmica de competitividade e produtividade, proporcionando aos gestores informações dos mais variados setores, tornando a tomada de decisão estratégica, tática e operacional mais eficaz, minimizando, dessa forma, a incerteza, imprecisão e o improviso. A proposta deste capítulo é, portanto, por meio de uma revisão bibliográfica mostrar a importância das ferramentas de TI como apoiadoras da GC nas organizações. Porém, para entender essa relação, é estabelecida uma introdução com mais quatro sessões. A sessão subsequente traz uma abordagem sobre as mudanças geradas pela TI nos ambientes organizacionais como um todo. A terceira sessão contempla a importância da GC nos ambientes organizacionais. A quarta sessão relaciona o uso das ferramentas de TI e a GC e a quinta, e última sessão, traz as considerações finais.

\section{A TI NO CENÁRIO DAS ORGANIZAÇÕES}

Segundo Albino et al. (2013), o desenvolvimento e expansão das TICs no cenário mundial aumentou as opções e demandas tecnológicas, desencadeando mudanças nos processos e atividades organizacionais. Esse cenário exigiu uma nova postura das organizações. 
Ribeiro Neto (1999) no final da década de 90 já afirmava que a introdução da TI no ambiente organizacional havia provocado mudanças profundas na estrutura organizacional, nas relações de trabalho, no perfil do trabalhador e na cultura da organização. Hoje, 18 anos depois, verificamos que a TI realmente alterou os processos organizacionais, fornecendo inúmeras ferramentas de gestão, automatizando processos e facilitando a comunicação entre os indivíduos. A automação desse processo pode ser relatada pela permuta de manuais e documentos impressos á documentos eletrônicos nas organizações atuais.

Pode-se dizer que a TI desencadeou novas possibilidades de comunicação e de negócios e modificou a maioria dos processos. Difícil encontrar uma organização que não utilize pelo menos um computador para elaborar suas tarefas mais simples, tais como a elaboração de relatórios e planilhas, acessar a internet ou o e-mail para se comunicar com clientes e fornecedores ou, ainda, o uso de sistemas, por exemplo, para controle de estoques e o uso de um banco de dados para armazenar seus documentos.

Ribeiro Neto (1999) chegou a conclusão com sua pesquisa de que o uso das tecnologias no ambiente organizacional gerava uma certa resistência, pois elas eram vistas como ameaças a posições estabelecidas. No entanto, Carvalho (2010) sugere que hoje o uso da TI se tornaram útil e necessário, contribuindo para eficácia, eficiência e sustentabilidade dos processos organizacionais.

Neste contexto, Feel e Dornelas (2015) afirmam que a $\mathrm{TI}$ desencadeou nas organizações uma nova dinâmica de competitividade e produtividade, possibilitando aos gestores a disponibilização e utilização de informações para a tomada de decisão estratégica, tática e operacional, promovendo uma integração maior entre os fatores organizacionais e minimizando a incerteza, imprecisão e o improviso.

Castells (1999, p.2) observa que as ferramentas da TI "não são apenas ferramentas para se aplicar, mas processos para desenvolver". Destaca ainda que a mente humana, pela primeira vez na história "é uma força produtiva direta, não apenas um elemento decisivo do sistema de produção". O que está em evidência agora, segundo Carvalho (2010), são as capacidades cognitivas dos homens e não mais a força bruta. De acordo com o autor, o "conhecimento" é o ativo direcionador das organizações, e este precisa ser "gerenciado" minuciosamente, de forma que, não se perca. Fenton (1996) reitera que o uso da GC como suporte aos processos da organização é fundamental devido ao conhecimento dos indivíduos estar diretamente relacionado ao produto final (software). Klein (1998) e Stewart (1998) reforçam que o conhecimento dos indivíduos neste contexto diz respeito a soma dos saberes individuais que formam a cultura e o capital intelectual da organização, preservando-se os saberes com o passar to tempo.

Nesse âmbito, a próxima sessão mostra a importância da GC para as organizações e o seu papel em relação ao conhecimento.

\section{A GC PARA AS ORGANIZAÇÕES}

Nickols (2001) destaca que o objetivo da GC é alavancar $O$ conhecimento para a vantagem competitiva da organização. Segundo Aurum; Daneshgar; Ward (2008), a GC passa a ser o facilitador da aprendizagem organizacional a fim de aumentar a capacidade da organização em aprender com o seu ambiente e incorporar conhecimento em seus processos. Nesse sentido, Nonaka e Takeuchi (2008) propõem a aplicação de uma abordagem sistemática à captura, estruturação, gerenciamento e disseminação de conhecimento em toda a organização. Consequentemente, é possível trabalhar-se mais, em menos tempo, reutilizando as melhores práticas, e assim, reduzindo o retrabalho.

$\mathrm{Na}$ indústria de software, gerenciar o conhecimento tem se tornado crucial. Diante disso, Nawinna (2011) evidencia que por se tratarem de organizações dinâmicas e complexas, utilizar os processos alinhados com o suporte de ferramentas adequados torna o processo cíclico e dinâmico. Nesse sentido, Schiuma, Carlucci e Lerro (2012) enfatizam que o conhecimento passou a ser gerenciado nas organizações para que estas conseguissem um lugar de destaque no mercado, melhorando o seu desempenho, maximizando as suas oportunidades de negócios e minimizando os seus riscos de perda de oportunidades. Desta maneira, adotando estes processos podemos obter, de acordo com Sveiby (1998) um desempenho organizacional que esteja atrelado à eficácia das pessoas em criar novo conhecimento, compartilhá-lo no âmbito da organização, e utilizá-lo para melhoria contínua da empresa e das pessoas envolvidas. Contudo, o conhecimento só é válido a partir dos indivíduos que o compartilham. Portanto, Klein e Stewart (1998) focalizam a soma dos saberes dos indivíduos, juntamente com o know-how, know why e experiência que formam o capital intelectual da organização, que é o mais importante ativo de uma organização, sendo também custoso recriar este conhecimento que já tenha sido inserido no âmbito organizacional.

Todo o conhecimento gerado pelo capital intelectual deve ser armazenado de maneira a facilitar sua recuperação para que todos da empresa consigam acessá-lo e utilizá-lo. Nascimento et al. (2016) destacam que as organizações estão inseridas em um cenário de constante mudança e precisam de modelos e processos que possibilitem aos indivíduos 
o acesso à informação.

Ao discutirem sobre a torca de informações Cisne, Kaneoya e Santos (2015) salientam que essa troca garante a manutenção das atividades diárias e a resolução de problemas que venham a surgir. Consequentemente, Brito, Oliveira e Castro (2012) salientam que essa interação está baseada em um ciclo contínuo, onde o indíviduo é o criador, o grupo o sintetizador e a organização a amplificadora do conhecimento. King (2009) afirma que é tarefa da GC assegurar que 0 conhecimento individual (conhecimento tácito) seja explicitado de alguma forma dentro da organização, por meio, por exemplo, de documentos, relatórios, patentes, manuais, repositórios eletrônicos, entre outros. Nesse sentido King (2009, p. 4), ainda caracteriza a GC como "o planejamento, organização, motivação e controle das pessoas, processos e sistemas".

No que diz respeito ao gerenciamento do conhecimento, Nascimento et al. (2016), afirma que a GC propicia o fluxo das informações e recursos, apoiando as diferentes ações desempenhadas pelos indivíduos no ambiente organizacional, como por exemplo, a tomada de decisão que, a partir das informações disponíveis, gera resultados mais assertivos.

Para Wiig (1997), é papel da GC buscar compreender, focar e gerenciar a criação do conhecimento de forma sistemática, explícita e deliberada, com foco na eficácia e no retorno de seus ativos de conhecimento, possibilitando assim, a renovação permanente. Nascimento et al. (2016, p.34) salientam que o conhecimento gerado no ambiente organizacional "precisa ser gerenciado de modo que possa ser preservado para posterior uso, a fim de subsidiar ações futuras desempenhadas nos diferentes níveis organizacionais".

Contudo, Shinyashiki, Trevizan e Mendes (2003), complementam que a GC fundamenta-se em organizar as informações dos indivíduos em cada processo, tornando-as comuns a todos, de forma que elas possam ser utilizadas na resolução de problemas com a finalidade de atingir os objetivos da organização.

Ré et al. (2007) abordam que a implantação da GC são importantes por disseminarem conhecimento no ambiente organizacional e gerar uma diversidade de produtos, serviços ou melhorias, interferindo, consequentemente, no desempenho da organização. King (2009) afirma que isso só é possível graças às metodologias e sistemas desenvolvidos para suportar o conhecimento organizacional. Para Singhal e Tomar (2016), o incentivo da organização na incorporação e implementação da GC, estimulam o compartilhamento de conhecimentos tácitos e a documentação dos conhecimentos explícitos. Freire et al. (2012) completam que a passagem da informação para o conhecimento requer um contexto organizado e cabível de gerenciamento e que possibilita o compartilhamento das tarefas de trabalho, das experiências e das habilidades pessoais entre o grupo. De acordo com Sousa (2014), a GC é vista nas organizações como uma ferramenta essencial e necessária, mostrando como o conhecimento é criado, onde está armazenado e como pode ser recuperado e compartilhado. Nesse sentido, Kebede (2010) apresenta inúmeros benefícios, tais como, a potencialização das atividades desenvolvidas, o fornecimento de informações para a tomada de decisão e resolução de problemas, o incentivo a inovação e a criatividade, a melhoria contínua dos processos, o compartilhamento do conhecimento tácito, a disseminação das melhores práticas, o aumento de resposta aos clientes, a redução do retrabalho e a criação de novos produtos e serviços.

\section{O USO DE FERRAMENTAS TECNOLÓGICAS NA GC}

Para Natale, Neves, Carvalho (2016), as TICS quando relacionadas à GC funcionam como um suporte, fornecendo às organizações, as ferramentas necessárias para captura, compartilhamento e armazenamento do conhecimento. Com isso, Gaspar et al. (2016) afirmam que estas ferramentas podem aumentar tais atividades e melhorar, consequentemente, o resultado final da organização.

De acordo com Werner (2004), as tecnologias podem apoiar a inteligência, equipamentos compartilhados, ferramentas, gerenciamento de documentos, expansão de linhas horizontais e verticais dentro das empresas, que utilizam destas para apoiar, gerir e obter maior produtividade em seus produtos e serviços, constituindo-se uma espiral de obtenção e geração de recursos, ou seja, adicionando valor aos processos organizacionais. Ao conceituar as ferramentas de GC, Tyndale (2002) destaca que ao suportar a performance das aplicações, atividades ou ações relacionadas com a criação, codificação e transferência do conhecimento a implementação dos processos do conhecimento é facilitada nas organizações. Para Osinski e Trindade (2015) as ferramentas de GC criam novos conhecimentos baseados na renovação e atualização das informações. No entanto, Damiani (2003) afirma que o uso de ferramentas baseadas em tecnologias nos ambientes organizacionais não garante a efetiva GC, porém reduzem os custos e a velocidade da transferência das melhores práticas e das informações.

De acordo com Gonçalves, Vasconcelos (2011) ferramentas baseadas em TI facilitam o acesso a informação e possibilitam que os colaboradores busquem e descubram com maior rapidez a 
informação de que precisam, melhorando a comunicação externa e promovendo o uso do conhecimento e informação presentes na organização. Além disso, Bhagyalaxmi e Surve, (2015) destacam que as ferramentas de GC também proporcionam a redução de custos e a captura do conhecimento coletivo, gerando inovação e, possivelmente, vantagem competitiva. As ferramentas utilizadas para subsidiarem a GC são classificadas em dezesseis categorias, conforme apresentado no quadro 1.

Um processo de GC ao ser implementado em uma organização deve contemplar essas categorias apresentadas e os gestores devem considerar estas tão importantes quanto o conhecimento é para as organizações. Quanto mais ferramentas utilizadas, maior a integração entre as várias fontes de informação e maior a base de conhecimento organizacional.

Nascimento et al. (2016, p.42) abordam que o fluxo de informações desencadeado pela GC "propriciam - acesso e a disseminação de informações e conhecimentos projetivos e retrospectivos como um mecanismo de análise das condições atuais em relação às situações vivenciadas no passado" podendo atuar também como uma ferramenta de "análise das condições atuais em relação às situações do futuro".

É evidente que o apoio das ferramentas de TI facilitam a GC. Porém, Re et al. (2007) abordam que os colaboradores ao compartilhar seu conhecimento devem fazê-lo por meio de um ato voluntário. Para Davenport e Prusak (1998), o uso da tecnologia isoladamente não fará com que a pessoa possuidora do conhecimento o compartilhe com as outras, ou seja, a mera presença de tencologia não criará uma organização de aprendizado contínuo nem uma empresa criadora do conhecimento.

Quadro 1 - Classificação das ferramentas que subsidiam a gestão do conhecimento

\begin{tabular}{|c|c|}
\hline ogias & \\
\hline Internet & $\begin{array}{l}\text { Constitui o sistema de distribuição de informação da empresa, } \\
\text { proporcionando aos colaboradores acesso aos documentos da } \\
\text { empresa }\end{array}$ \\
\hline Portais Webs & $\begin{array}{l}\text { São os web sites. Podem fornecer links para diversos outros } \\
\text { sites }\end{array}$ \\
\hline Gerenciamento de conteúdo & $\begin{array}{l}\text { Engloba banco de dados, servidores e sistema de gestão de } \\
\text { documentos e categoriza as informações para facilitar o acesso }\end{array}$ \\
\hline $\begin{array}{l}\text { Sistemas de gestão de } \\
\text { documentos }\end{array}$ & $\begin{array}{l}\text { Utilizados, principalmente, na coleta, armazenamento e } \\
\text { distribuição das informações }\end{array}$ \\
\hline $\begin{array}{l}\text { Sistemas de busca da } \\
\text { informação }\end{array}$ & $\begin{array}{l}\text { Usados para indexar e procurar dados, principalmente, textos } \\
\text { ou formas desestruturadas }\end{array}$ \\
\hline Banco de dados relacionais & $\begin{array}{l}\text { Oferecem soluções simples para aplicações que envolvem } \\
\text { objetos e o relacionamento entre eles }\end{array}$ \\
\hline $\begin{array}{l}\text { Sistemas de publicação } \\
\text { eletrônica }\end{array}$ & $\begin{array}{l}\text { Permitem a distribuição da informação e entretenimento em } \\
\text { formato digital }\end{array}$ \\
\hline $\begin{array}{l}\text { Sistemas de groupware e de } \\
\text { fluxo de trabalho }\end{array}$ & $\begin{array}{l}\text { É uma tecnologia que facilita o trabalho em grupos. Ajuda a gerir } \\
\text { melhor os processos e, consequentemente, os resultados, sejam } \\
\text { eles produtos ou serviços }\end{array}$ \\
\hline Tecnologias de envio & e informações para os clientes \\
\hline Agentes & $\begin{array}{l}\text { É uma entidade computacional autônoma, colaborativa e } \\
\text { adaptativa. Ela permite a coleta de informações e acessa } \\
\text { informações de várias fontes }\end{array}$ \\
\hline Aplicações de hesp-desk & $\begin{array}{l}\text { m que as organizações ofereçam suporte aos clientes } \\
\text { e externo }\end{array}$ \\
\hline $\begin{array}{l}\text { Gestão de relacionamento } \\
\text { com o cliente }\end{array}$ & $\begin{array}{l}\text { Visa manter um dos ativos mais importante das empresas - o } \\
\text { cliente }\end{array}$ \\
\hline enamento de dados & ositório central de dados comuns para a organização \\
\hline Mineração de dados & SS \\
\hline $\begin{array}{ll}\text { Re-engenharia } & \text { dos } \\
\text { processos empresarial } & \end{array}$ & Análise dos fluxos de trabalho dentro e entre as organizações \\
\hline $\begin{array}{l}\text { Aplicativos de criação do } \\
\text { conhecimento }\end{array}$ & $\begin{array}{l}\text { Incluem aplicações de brainstroming, mapas conceituais, mapas } \\
\text { mentais e aplicações de apoio à decisão }\end{array}$ \\
\hline Gerenciamento de conteúdo & $\begin{array}{l}\text { Engloba banco de dados, servidores, sistema de gestão de } \\
\text { documentos. Categoriza as informações para facilitar o acesso }\end{array}$ \\
\hline
\end{tabular}


Dessa forma, é necessário a definição de políticas de gestão de pessoal que estimulem as pessoas a se conectarem entre elas e a realizarem trocas de conhecimento. Além disso, é preciso que as ferramentas facilitem o contato e a troca de idéias entre as pessoas, sem obrigá-las, necessariamente, a disponibilizar suas informações e conhecimento e uma cultura organizacional que valorize o processo de socializar a experiência e o conhecimento adquiridos (partilhar informações; colaboração de pessoas com diferentes habilidades na solução de um problema) (RÉ et al., 2007).

Terra (2005) afirma que a GC e a TI visam desenvolver e implementar programas que proporcionem integração e difusão do conhecimento. Assim, as organizações podem adotar como ferramentas tecnológicas de apoio chats, blogs, fóruns virtuais, listas de discussão, comunidades de prática, redes sociais, entre outros, propiciando aos colaboradores a troca e aquisição do conhecimento. Dessa forma, a tecnologia pode ser vista como uma importante aliada da GC no que tange em assegurar as novas relações e comportamentos na geração de novos conhecimentos aos envolvidos.

\section{CONSIDERAÇÕES FINAIS}

O presente capítulo apresentou um estudo bibliográfico sobre o uso das ferramentas de $\mathrm{TI}$ e a relação dessas com a GC. Verifica-se que a ascensão das TICs desencadeou mudanças nos processos e atividades organizacionais, bem como no resultado final dos produtos e serviços, que passaram a incorporar o conhecimento como fonte de valor e vantagem competitiva. Nesse cenário, a informação passou a ser uma das principais matérias-prima das organizações.

As novas relações de trabalho foram criadas

\section{REFERÊNCIAS}

[1] ALBINO, J.; RIBEIRO, C.; TEIXEIRA, A.; CAMPANA, E. Gestão do conhecimento e comunidades de prática: um enfoque a partir das TICs. RETEC. v. 6, n.1, p. 53-61, 2013

[2] BHAGYALAXMI, M.; SURVE, A. Knowledge Management Tools: Recognition for the Support. To Healthcare Practitioners. n. 12, p. 923-927, 2015.

[3] AURUM, A.; DANESHGAR, F.; WARD, J. Investigating Knowledge Management practices in software development organisations - An Australian experience. Information and Software Technology, v. 50, n. 6, p. 511533,2008

[4] BRITO, L.; OLIVEIRA, P.; CASTRO, A. Gestão do conhecimento numa instituição pública de assistência técnica e extensão rural do nordeste do Brasil. Revista de Administração Pública. v. 46, n. 5, 2012. oportunizando novas formas de interação entre os indivíduos, como por exemplo, o uso de web conferências e a venda de produtos online. Isso desencadeou um fluxo de informação e conhecimento intenso nas organizações, elevando, consequentemente, a necessidade de se "organizar" e "gerenciar" os conhecimentos criados e compartilhados.

Nesse sentido, tornou-se função da GC intermediar a captura, o armazenamento, a transferência e a aplicação do conhecimento individual para o âmbito organizacional, a fim de que nenhuma informação se perca e de que todos os colaboradores tenham acesso ao que necessitam, podendo criar através dessas informações, novos conhecimentos. Além disso, as ferramentas podem auxiliar no fluxo do conhecimento, onde todos colaboradores podem ter acesso ao conhecimento, sem que o mesmo fique restrito a uma pessoa ou em um grupo.

No entanto, a GC somente serão possíveis se forem subsidiados pelas ferramentas de TI. Essas ferramentas permeiam a maioria dos processos organizacionais e proporcionam a interação entre os colaboradores, facilitando a troca de ideias e experiências. Em um cenário organizacional altamente competitivo as ferramentas tecnológicas quando utilizadas para manter $e$ incorporar o conhecimento no ambiente organizacional podem tornar as organizações mais inovadoras e sustentáveis, além de trazer mais lucros e produtividade para a organização. Dessa forma, é possível promover o alcance dos objetivos organizacionais. Conclui-se que os processos de GC embasados pelas ferramentas de TI permitem uma dinamicidade no fluxo de informações entre os departamentos das organizações, possibilitando, dessa forma, a busca por melhores resultados.

[5] CARVALHO, J. A. Tecnologias e sistemas de informação: uma área científica orientada às necessidades de conhecimento dos profissionais envolvidos na contínua transformação das organizações através da tecnologia da informação. Revista Eletrônica de Biblioteconomia e Ciência da Informação, número especial, 2010.

[6] CARVALHO, R. Tecnologia da Informação aplicada à Gestão do Conhecimento. Belo Horizonte: Comarte, 2003.

[7] CASTELLS, M. A sociedade em rede. São Paulo: Paz e Terra, 1999.

[8] CISNE, C.; KANEOYA, P.; SANTOS, L. Compartilhamento e registro de conhecimento: um estudo de caso na empresa Knowtec. Revista ACB: Biblioteconomia em Santa Catarina, v. 20, n. 1, p. 98-111, 2015.

[9] DALKIR, K. Knowledge Management in Theory and Practice. $2^{\underline{a}}$ ed. Massachusetts: MIT Press, 2011. 
[10] DAMIANI, W. B. Gestão do conhecimento: uma comparação entre empresas brasileiras e norteamericanas. Rio de Janeiro: Fundação Getúlio Vargas, 2003.

[11] DAVENPORT, T.; PRUSAK, L. Conhecimento empresarial: como as organizações gerenciam o seu capital intelectual. Rio de Janeiro: Campus, 1998.

[12] FELIPE, A.; FELL, DE A.; DORNELAS, J. S. Obstáculos ao uso da tecnologia da informação para a gestão do conhecimento : um estudo de casos múltiplos. Revista Gestão Organizacional, v. 11, n. 3, p. 463-474, 2013.

[13] FENTON, N. Lawrence, S. Software metrics: a rigorous and practical approach. 2 ed. International Thomson Computer Press, 1996.

[14] FELL, A.; DORNELAS, J. Obstáculos ao uso da Tecnologia da Informação para a Gestão do Conhecimento: um estudo de caso múltiplos. Gestão e Organização, v. 11, n.3, p. 463-474, 2015

[15] FLORIANO, J.; SANTOS, L.; SCHROEDER, U. Aplicação do modelo proposto por Bukowitz e Willians no diagnóstico da gestão do conhecimento de uma indústria de móveis em Timbó - SC, Florianópolis. In: XXIX Encontro Nacional de Engenharia de Produção, 2009.

[16] FREIRE, P.; TOSTA, K.; HELOU FILHO, E.; SILVA, G. Memória organizacional e seu papel na gestão do conhecimento. Revista de Ciência e Administração. v. 14, n.33, p. 41-51, 2012

[17] GASPAR, M.; SANTOS, S.; DONAIRE, D.; KUNIYOSLU, M.; PREARO, L. Gestão do conhecimento em empresas atuantes na indústria de software no Brasil um estudo das práticas e ferramentas utilizadas. Informação e Sociedade. v. 26, n.1, 2016.

[18] GASPAR, M.; SANTOS, S.; KUNIYOSHI, M.; PREARO, L. Gestão do Conhecimento em Ambientes de Teletrabalho. Revista de Administração FACES. v. 13, n. 2 , p. 46-66, 2014

[19] GONÇALVES, S.; VASCONCELOS, M. Práticas e Ferramentas de Gestão do Conhecimento no Âmbito da Administração Tributária de Minas Gerais: Oportunidade para uma Política Institucional. In: Encontro Nacional da ANPAD - EnANPAD, p. 1-16, 2011.

[20] HARGREAVES, A. O Ensino na Sociedade do Conhecimento: a educação na era da insegurança. Colecção Currículo, Políticas e Práticas. Porto: Porto Editora.

[21] KEBEDE, Gashaw. Knowledge management: an information science perspective. International Journal of Information Management, v.30, p. 416-424, 2010.

[22] KING, W. Knowledge management and organizational learning. In: KING, W. Knowledge Management and Organizational Learning. v. 4, Springer, New York, NY, p. 3-13, 2009.

[23] KLEIN, D. The strategic management of intellectual capital: an introduction. In: KLEIN, D. (Ed.). The strategic management of intellectual capital. Woburn, MA : Butterworth-Heinemann, 1998, p. 1-7.
[24] MENDONCA, C.; GUERRA, L.; SOUZA NETO, M.; ARAÚJO, A. Governança de tecnologia da informação: um estudo do processo decisório em organizações públicas e privadas. Revista de Administração Pública, v. 47, n. 2, p. 443-468, 2013

[25] NASCIMENTO, N.; SOUZA, J.; VALENTIM, M.; CABERO, M. Gerenciamento dos fluxos de informação como requisito para a preservação da memória organizacional: um diferencial competitivo. Perspectivas em Gestão \& Conhecimento, v. 6, p. 29-44, 2016.

[26] NATALE, C. H. C.; NEVES, J. T. R.; CARVALHO, R. B. Maturidade em gestão do conhecimento: análise das percepções dos gestores de uma grande empresa de construção civil. Informação \& Informação, v. 21, n. 1, p. 375-406, 2016

[27] NAWINNA, D. P. A model of knowledge management: delivering competitive advantage to small \& medium scale software industry in Sri Lanka. In: 6th Internacional Conference on Industrial and Information Systems. pp. 414-419, 2011.

[28] NICKOLS, F. W. The knowledge management yearbook 2000-2001. Routledge: 2001.

[29] TAKEUCHI, H.; NONAKA, I. Gestão do Conhecimento. Porto Alegre: Bookman, 2008.

[30] RÉ, C.; LIMBERGER, S.; VIANNA, W.; CUNHA, C. O impacto da cultura organizacional no processo de gestão do conhecimento. In: XXVII Encontro Nacional de Engenharia de Produção. Anais... Foz do Iguaçu, PR. XXVII Encontro Nacional de Engenharia de Produção, 2007.

[31] RIBEIRO NETO, L. Os impactos da tecnologia de informação nas organizações: uma visão política. Alfenas. Vol.5, p. 95-101, 1999

[32] TRINDADE, E. P.: OSINSKI, M.; SELIG, P. M.; GAUTHIER, F. A. O. Análise do processo de gestão do conhecimento em uma empresa de base tecnológica da cidade de Joinville - SC. NAVUS - Revista de Gestão e Tecnologia, v.5, n.3, p. 102-111, 2015.

[33] SCHIUMA, G.; CARLUCCI, D.; LERRO, A. Managing knowledge processes for value creation. Vine, $v$. 42, n. 1, p. 4-14, 2012.

[34] SINGHAL, J.; TOMAR, R. Knowledge management in nonprofit organizations: concept and opportunities. Global Journal for Research Analysis. v. 5, n. 3, 2016.

[35] SOUSA, M. A. B. Gestão do conhecimento: uma Contribuição ao seu entendimento. Revista de Administração e Negócios da Amazônia. v. 6, n. 3, p. 3847, 2014.

[36] SVEIBY, K. E. A nova riqueza das organizações. Rio de Janeiro: Campus, 1998.

[37] TERRA, J. Reflexões sobre a evolução da gestão do conhecimento no Brasil. Produto \& Produção, v. 8, n.2, p. 05-09, 2005.

[38] TYNDALE, P. A taxonomy of knowledge management software tools: Origins and applications. Evaluation and Program Planning, v. 25, n. 2, 183-190, 2002 
[39] WERNER, W.; WERNER, I. A. Gestão do conhecimento: Ferramentas tecnológicas e portais do conhecimento para empresas desenvolvedoras de tecnologias de médio e pequeno porte. Terra e Cultura, ano XX, n`38 p.182-232 janeiro a junho de 2004.
[40] WIIG, K. Knowledge management: where did it come from and where it will go? Expert Systems With Applications. v. 13, n.1, p. 1-14, 1997. 


$$
\text { Alutary }
$$




\section{Hélcio Martins Tristão (Organizador)}

Possui graduação em Cîencias Êconômicas pelo Centro Universitário de Franca (1985), especialização em gestão, contabilidade e recursos humanos, mestrado em Administração pelo Centro Universitário de Franca (2000), doutorado em Engenharia de Produção pelo Programa de Pós-graduação do Departamento de Engenharia da Universidade Federal de São Carlos - UFSCAR (2013), membro do Grupo de Pesquisas em Qualidade -GEPEQUFSCAR. É professor titular do Centro Universitário de Franca. Tem experiência na área de Administração, com ênfase em Administração Geral atuando principalmente nos temas: teorias administrativas, cluster, cadeia produtiva, cooperação, estratégia empresarial, inovação e aprendizagem organizacional.

\section{Adriana Carvalho Pinto Vieira}

Possui graduação em Direito pela Universidade Estadual de Ponta Grossa (1993), mestrado em Direito pela Universidade Metodista de Piracicaba (1999) e doutorado em Desenvolvimento Econômico pela Universidade Estadual de Campinas (2009). Professor disciplinas (Pesquisa, Desenvolvimento e Inovação - PDI e Informações e Conhecimento nas Organizações - ICO/PPGDS), Direito Comercial Comparado (Curso Administração/COMEX) da UNESC. Líder do Grupo de Pesquisa: Propriedade Intelectual, Desenvolvimento e Inovação (PIDI). Atualmente é pesquisador colaborador da Universidade Federal do Estado do Rio de Janeiro, colaborador da Universidade do Contestado e professor titular da Universidade do Extremo Sul Catarinense. Tem experiência na área de Direito e Administração, com ênfase em Sistema de Propriedade Intelectual, atuando principalmente nos seguintes temas: sistema de propriedade intelectual, indicação geográfica, estudos jurídicos (direito consumidor), gestão da inovação, agronegócio, cadeias alimentares e biotecnologia, comércio exterior e negócios internacionais.

\section{Alessandro Aguilera Silva}

Graduado em Engenharia de Produção pela Universidade do Estado de Mato Grosso (2012). Pós - Graduado em Engenharia de Segurança do Trabalho pela Universidade de Cuiabá (2014). Atualmente é Professor e Coordenador do Curso de Engenharia de Produção Campus de Cacoal da Fundação Universidade Federal de Rondônia. Tem experiência na área de Engenharia de Produção, atuando principalmente nos seguintes temas: Engenharia de Operações e Processos da Produção, Engenharia da Sustentabilidade e Engenharia do Trabalho.

\section{Alexandre Possa}

Graduado em Engenharia de Produção pela ULBRA Carazinho. Possui experiência em Sistemas de Produção como analista de processos e como desenhista na engenharia de produto. Trabalha em uma grande indústria de implementos agrícolas. 


\section{Amanda Almeida de Araújo}

Paulista que reside na Paraíba. Cursando Administração na Universidade Estadual da Paraíba, UEPB, Campus VII, Patos-PB

\section{Amaury Paulo de Souza}

Possui graduação em Engenharia Florestal - Universidade Federal de Viçosa (1972), mestrado em Ciência Florestal - University of Washington (1976) e doutorado em Ciência Florestal/Exploração Florestal/Ergonomia - University of British Columbia (1984). Possui especialização em Engenharia de Segurança do Trabalho - FUMEC (2001) e o titulo de Ergonomista Certificado - ABERGO. Atualmente é professor titular da Universidade Federal de Viçosa e coordenador do Laboratório de Ergonomia - LABERGO.

\section{André Grecco Carvallho}

Graduado em Engenharia Química pela Universidade Estadual de Maringá (UEM-2006), Mestre em Biologia Experimental pela Universidade Federal de Rondônia (2015). Trabalhou como Coordenador de Produção em empresas Sucroalcooleiras, Montagens e de Gases Industriais. Atualmente é Docente no curso de Engenharia de Produção na Universidade Federal de Rondônia.

\section{André Luis Almeidla Bastos}

É Engenheiro Mecânico, com especialização em Engenharia do Produto e Processo (UFSC), mestre e doutor em Engenharia de Produção (UFSC). É professor universitário de cursos de graduação e pós-graduação nos cursos de Engenharia de Produção e Administração. É pesquisador líder do grupo vinculado ao CNPq denominado Núcleo de Estudos em Gestão e Desenvolvimento de Produtos e Processos. Atuou em diversos setores da organizações produtivas, tais como: PPCP, Engenharia de Produto, Qualidade, Marketing, Suprimentos e Produção. Autor de dezenas de artigos publicados em congressos nacionais e internacionais.

\section{Andreia Gura}

Mestranda em Engenharia de Produção pela Universidade Tecnológica Federal do Paraná (UTFPR). Possui graduação em Ciências Contábeis pela Universidade Estadual do CentroOeste (2008) e Especialização em Gestão Financeira de Negócios pela Universidade Estadual do Centro Oeste (2014). Foi professora substituta do Instituto Federal do Paraná nos anos de 2015 e 2016. Tem experiência na área de Administração, com ênfase em Ciências Contábeis. Possui experiência como Auditora Interna do Sistema de Gestão Integrado - ISO 9001 e 14001.

\section{Andrey Eduardo Gomes}

Engenheiro de Transportes e Logística formado na Universidade Federal de Santa Catarina/UFSC - Centro de Engenharias da Mobilidade/CEM em Joinville/SC. Desenvolvendo projetos junto a faculdade e orgão público na área de planejamento urbano, com ênfase em mobilidade corporativa e experiência profissional em logística industrial. 


\section{Angelo Palmisano}

Doutor em Ciências Sociais (2003), Mestre em Administração (1999), Graduado em Administração de Empresas (1981), todos cursados na Pontifícia Universidade Católica de São Paulo - PUC/SP. Atuou como Pró-Reitor Acadêmico e Pró-Reitor de Pós-Graduação, Pesquisa e Extensão do Complexo Educacional FMU. Coordenou o Programa e atuou como Professor do Mestrado Profissional de Administração em Governança Corporativa do Centro Universitário das Faculdades Metropolitanas Unidas - FMU até outubro de 2015. Possui experiência nas áreas de administração empresarial e educacional, sobretudo como professor e gestor acadêmico no ensino superior (graduação e pós-graduação), ensino a distância, educação continuada, avaliação institucional, gestão do conhecimento, gestão da qualidade, gestão da tecnologia da informação, inovação tecnológica, gestão de pessoas e governança corporativa. É sócio diretor da Pereira e Palmisano Consultoria e Treinamentos nas áreas de gestão empresarial e educação superior. Atua como pesquisador em grupos de pesquisa nas áreas de gestão, estratégia empresarial, qualidade, engenharia, sustentabilidade e governança corporativa. Atua em reestruturação acadêmica e administrativa de instituições de ensino superior desde 1997.

\section{Antonio Cecílio Silvério}

Possui graduação em Ciências Contábeis pelo Centro Pastoral Educacional e Assistência Dom Carlos (1991), Especilalização em Gerência Contábil (1994) e mestrado em Ciências Sociais Aplicadas, área de concentração Contabilidade, pelo Centro Pastoral Educacional e Assistência Dom Carlos (1999). Atualmente é professor ebtt do Instituto Federal do Paraná. Tem experiência na área de Administração, com ênfase em Ciências Contábeis, atuando principalmente nos seguintes disciplinas: Contabilidade Geral; Contabilidade de Custos; Análise de Custos; Perícia Contábil; Análise Demonstrações Contábeis; Controladoria. Foi Professor de Ensino Superior no UNICS por 13, anos, Coordenador de Curso de Ciências Contábeis do UNICS por 4 anos. Professor Ensino Superior e Coordenador do Curso de Ciências Contábeis na UTFPR, por 4 anos. Atuou como Profissional Liberal/Contador em empresas privadas por 15 anos.

\section{Augusto Faber Flôres}

Possui graduação em Ciências Econômicas (2004) e Pós Graduação em Planejamento e Gestão de Negócios (2006). Mestrando Programa de Pós-Graduação em Desenvolvimento Regional, da UTFPR, Linha de Pesquisa Regionalidade e Desenvolvimento. Atua desde 2005 como professor universitário, também com experiência de docência na Pós-Graduação. Experiência como tutor em EaD na UTFPR. Professor do Instituto Federal do Paraná, campus Palmas, no regime de 40 horas com Dedicação Exclusiva.

\section{Bruno Ricioli de Andrade}

Graduando em Gestão Portuária pela Faculdade de Tecnologia da Baixada Santista - Rubens Lara (FATEC - RL).

\section{Carolina Carvallhaes Cauduro Orlandi}

Graduada em Direito pela Universidade Católica de Santos (UNISANTOS) e Pós-Graduada em Direito Tributário pela Pontifícia Universidade Católica de São Paulo (PUC-SP). Atualmente, é graduanda de Gestão Portuária pela Faculdade de Tecnologia da Baixada Santista - Rubens Lara (FATEC - RL). 


\section{Cassius Tadeu Scarpins}

Doutor (2012) e Mestre (2007) em Pesquisa Operacional pelo Programa de Pós-Graduação em Métodos Numéricos em Engenharia, área de concentração: Programação Matemática, na Universidade Federal do Paraná. Engenheiro de Produção (2010) e Licenciado em Matemática (2002) pela mesma universidade. Atualmente ocupa o cargo de Professor Adjunto no Departamento Administração Geral e Aplicada (DAGA) da Universidade Federal do Paraná (UFPR). Atua em dois programas de pós-graduação Stricto Sensu: Programa de PósGraduação em Métodos Numéricos em Engenharia (PPGMNE) e o Programa de PósGraduação em Engenharia de Produção (PPGEP). Possui experiência na área de Engenharia de Produção, Gestão de Operações e Logística, com particular interesse em Pesquisa Operacional e Logística, atuando principalmente nos seguintes temas: Sistema de Reposição de Estoques, Engenharia da Qualidade, Mapeamento e Análise de Processos, Hierarquia/Regionalização, Carregamento e Roteamento de Veículos, Otimização em fluxo de Pessoas, Previsão de Séries Temporais, Metaheurísticas, Math-Heurísticas e Otimização na Separação de Produtos.

\section{Christiane Wenck Nogueira Fernandes}

Possui Graduação em Matemática pela Universidade Federal de Santa Catarina (1999), Mestrado em Engenharia de Produção pela Universidade Federal de Santa Catarina (2002), Doutorado em Engenharia de Produção pela Universidade Federal de Santa Catarina(2010). Atualmente é Professora Adjunto IV do Departamento de Engenharias da Mobilidade da Universidade Federal de Santa Catarina. Tem experiência na área de Engenharia de Transportes, Pesquisa Operacional e Logística. Participante do Grupo de Pesquisa GIT Grupo de Infraestrutura e Transportes.

\section{Claiton Emilio do Amaral}

Graduado em Eng. Mecânica e Civil, Especialização em Matemática Aplicada, Mestrado e Doutorado em Eng. de Produção. Pesquisador da área de desenvolvimento de novos produtos. Professor universitário das áreas das Engenharias. Experiência nacional e internacional no desenvolvimento e implementação de projetos de produtos em empresa líder mundial na fabricação de eletrodomésticos. Atualmente, na Universidade da Região de Joinville, ocupa a posição de Pró-reitor de Infraestrutura.

\section{Claudilaine Caldas de Oliveira}

Doutoranda em Engenharia de Produção pela Universidade Federal de Santa Catarina (UFSC). Mestrado em Engenharia de Produção pela Universidade Tecnológica Federal do Paraná (UTFPR). Especialização em Vigilância Sanitária em Alimentos pela Universidade Tecnológica Federal do Paraná (UTFPR). Graduação em Engenharia de Produção Agroindustrial pela Faculdade Estadual de Ciências e Letras de Campo Mourão/PR. Atualmente Professora colaboradora do Curso de Graduação em Engenharia de Produção Agroindustrial da Universidade Estadual do Paraná - UNESPAR, campus de Campo Mourão/PR

\section{Danieli Pinto}

Aluna do mestrado em Gestão do Conhecimento nas Organizações do Centro Universitário Cesumar, UniCesumar, Maringá - Paraná 


\section{Délvio Venanzi}

Possui Doutorado em Educação - Universidade de Sorocaba (2016), graduação em Engenharia Elétrica pela Universidade de Mogi das Cruzes (1986),Mestrado em Administração de Empresas pelo Centro Universitário Santana (SP) (2000) e Mestrado em Engenharia de Produção pela Universidade Estadual Paulista Júlio de Mesquita Filho (2008). Atualmente é professor titular da Universidade de Sorocaba e Coordenador do Curso de Engenharia de Produção. Professor de Logística e Supply Chain da Faculdade de Tecnologia de Sorocaba (FATEC). Professor de MBA do IAT/FACENS, Professor Convidado na Especialização em Engenharia de Produção UNESP-Sorocaba

\section{Ederaldo Luiz Beline}

Graduado em Engenharia Civil pela Universidade Estadual de Maringá (1992). Mestre em Geografia pela Universidade Estadual de Maringá (2007). Atualmente é Professor Assistente D da Universidade Estadual do Paraná, Campus Campo Mourão. Tem experiência na área de Engenharia Civil, com ênfase em estruturas, atuando principalmente nos seguintes temas: resíduos sólidos, resíduos sólidos da construção civil, ensaios de compressão simples, reutilização de entulho, processamento e acidente de trabalho.

\section{Evaldo Toniolo Kubaski}

Bolsista de Produtividade Desen. Tec. e Extensão Inovadora do CNPq - Nível 1D - CA 87 Programa de Nanotecnologia e Novos Materiais (vigência de 1\%/03/2016 a 29/02/2020). Possui graduação em Engenharia de Materiais pela Universidade Estadual de Ponta Grossa (2003), mestrado em Engenharia e Ciência de Materiais pela Universidade Estadual de Ponta Grossa (2005) e doutorado em Engenharia e Metalúrgica e de Materiais pela Escola Politécnica da Universidade de São Paulo (2010). Atualmente atua na síntese e caracterização de pigmentos inorgânicos, espumas de vidro e filmes finos. Pesquisador da Nanoita Projetos e Consultoria Industrial e em conjunto com empresas parceiras, participa do desenvolvimento de produtos e processos inovadores.

\section{Everaldo Veres Zahaikevitch}

Doutorando em Engenharia da Produção pela UTFPR - Campus de Ponta Grossa - PR. Mestrado em Engenharia da Produção pela UTFPR - Campus de Ponta Grossa - PR. (2014) Especialização em Gestão Industrial na UTFPR - Ponta Grossa - PR (2011). Especialização em MBA em GERÊNCIA CONTÁBIL, PERÍCIA, AUDITORIA E CONTROLADORIA, pela Faculdade Internacional de Curitiba, Facinter, Curitiba, Brasil (2008), Graduação em CIÊNCIAS CONTÁBEIS pela Universidade Estadual do Centro-Oeste (2005). Atualmente sou Professor EBTT do curso de Ciências Contábeis - no Instituto Federal do Paraná - IFPR, Campus Palmas -PR. Com experiência na área de Administração, com ênfase em Ciências Contábeis nas seguintes áreas: Contabilidade Geral, Contabilidade Empresarial, Contabilidade Gerencial, Análise das Demonstrações Contábeis, Contabilidade Aplicada ao terceiro setor, Contabilidade Avançada, Contabilidade Aplicada ao Agronegócio, Pericia, Sistemas Contábeis e Teoria da Contabilidade. 


\section{Fagner José Coutinho de Melo}

Doutorando do Programa de Pós-graduação em Engenharia da Produção - PPGEP da UFPE (2016) e Pesquisador, Membro do Grupo de Pesquisa Planejamento e Análise de Sistema de Produção de Bens e Serviços - PLANASP (2014). Possui graduação em Administração pela Universidade Federal de Pernambuco (2012), pós-graduação em Gestão da Qualidade e produtividade pela Faculdade dos Guararapes (2014) e Mestrado Acadêmico em Engenharia da Produção pela UFPE.

\section{Flávio Bortolozzi}

França. Pró-Reitor da Pesquisa, Pós-Graduação e Extensão do Centro Universitário Cesumar, UniCesumar. Coordenador e professor do Mestrado em Gestão do Conhecimento nas Organizações do Centro Universitário Cesumar, UniCesumar e professor do Mestrado em Promoção da Saúde no UniCesumar

\section{Francisco Ignácio Giocondo Cesar}

Formação Acadêmica ? Engenheiro Mecânico (UNESP) com Mestrado e Doutorado em Engenharia de Produção pela Universidade Metodista de Piracicaba ? UNIMEP. Atualmente cursa post-doc em Engenharia de produção na FCA - UNICAMP. Possui certificado de qualificação me Project Management (PMI) e Green Belt. Atividades Atuais ? Atualmente é Professor no Departamento Industrial do Instituto Federal de Educação, Ciências e Tecnologia de São Paulo (IFSP - Campus Piracicaba) desde 2011. Também é Professor Pesquisador Colaborador no Programa de Pós Graduação da Engenharia de Produção da Universidade Estadual de Campinas (FCA ? UNICAMP ? Campus Limeira) desde 2016. Coordenado do SBLab (Sustainable Business Lab ? Laboratório de Negócios Sustentáveis http://sblaboratory.wixsite.com/sblabteste). Possui experiência profissional de 23 anos como Gerente de Projetos Internacionais na TRW e Caterpillar Brasil.

\section{Gillson João dos Santos}

Possui graduação em Engenharia de Produção Mecânica pela Universidade Federal de Santa Catarina (1984) e mestrado em Engenharia de Produção (1987), área de concentração: Projeto de Produto, pela mesma universidade. Atualmente é Professor e Coordenador dos cursos de Engenharia de Produção e Pós Graduação em Engenharia de Produção: ênfase em Qualidade e Produtividade da Universidade da Região de Joinville (UNIVILLE). Tem experiência na área de Engenharia de Produção e Mecânica, com ênfase em Engenharia de Projeto de Produto. Está atualmente como Conselheiro Estadual do CREA-SC, participando da Câmara Especializada em Engenharia Mecânica e Metalurgia (CEEMM).

\section{Gisele Caroline Urbano Lourenço}

Aluna do curso superior em Engenharia de Software do Centro Universitário Cesumar, UniCesumar, Maringá - Paraná

\section{Glycia de Araújo Izidro}

Faz graduação em Administração na Universidade Estadual da Paraíba, UEPB, Campus VII, Patos-PB 


\section{Graziela Luiz Franco Martinez}

Graduada em Ciências Econômicas pela Universidade Federal de Viçosa (UFV). Mestre em Teoria Econômica pela Universidade Estadual de Maringá(UEM). Atualmente é Docente no Departamento Acadêmico de Engenharia de Produção da Fundação Universidade Federal de Rondônia (UNIR/Campus Cacoal) com atuação e pesquisa nas áreas da Engenharia Econômica e Economia Industrial.

\section{Guillherme César Silva Mendes}

É Engenheiro de Produção com especialização em Engenharia de Segurança do Trabalho. Possui passagem em empresas multinacionais em diversos setores, dedica-se a projetos de melhoria contínua através da filosofia lean six sigma e atua como Consultor em Projeto de Implementação de Métodos Ágeis na Indústria.

\section{Guilherme Mendes Fernandes}

Carreira em desenvolvimento na área de Engenharia de Transportes e Logística, com formação acadêmica na Universidade Federal de Santa Catarina - Joinville e competência para atuar com análise de mercado, gestão logística, planejamento estratégico e análise de projetos. Foco em ampliar conhecimentos na área de negócios e gestão de pessoas. Vivência de mercado nacional e internacional adquirida ao longo de experiências profissionais, conhecimento o qual é fundamental para tomada de decisão a nível empresarial.

\section{Ieda Kanashiro Makiya}

Docente da Faculdade de Ciências Aplicadas da Universidade Estadual de Campinas - FCAUNICAMP. Líder de Grupo de Pesquisa SB-LAB - Sustainable Business Laboratory / Laboratório de Negócios Sustentáveis na base CNPq. Docente credenciada no Programa de Pós-Graduação em Engenharia de Produção e Manufatura (FCA-UNICAMP). Integrante do Laboratório de Agronegócio (LAG), Laboratório de Estudos de Gestão de Operações Sustentáveis (LEGOS) vinculados ao Centro de Pesquisas em Administração (CEPAD) da Faculdade de Ciências Aplicadas - UNICAMP. Ênfase nos seguintes temas: Sustentabilidade, Qualidade \& Produtividade, Smart Cities, Indústria 4.0, Economia Criativa. Possui PósDoutorado em indicadores de sustentabilidade pelo Climate Change Laboratory - Agricultural and Biological Engineering - University of Florida (2014). Desenvolvimento de pesquisas junto ao Instituto de Pesquisas Tecnológicas do Estado de São Paulo - IPT (2004-2005-2006). Doutorado em Gestão da Qualidade pelo Departamento de Engenharia de Produção da Escola Politécnica da Universidade de São Paulo, EPUSP (2002). Mestrado em Tecnologia de Processos pela Faculdade de Engenharia de Alimentos pela Universidade Estadual de Campinas FEA-UNICAMP (1996). Graduação em Engenharia de Alimentos pela Universidade Estadual Paulista Júlio de Mesquita Filho - UNESP (1989).

\section{Itamar Braga Lemes}

Especialista em Engenharia de Produção, Bacharel em Ciências Contábeis 


\section{Jailson Domingos de Oliveira}

Possui graduação em Matemática pela Universidade Estadual do Centro-Oeste (2009), Mestrando em Métodos Numéricos na Universidade Federal do Paraná (2017) e Doutorando em Métodos Numérico na Universidade Federal do Paraná. Atualmente é professor no ensino superior da Universidade Estadual do Centro-Oeste (UNICENTRO).

\section{João Luiz Kovaleski}

Possui graduação em Engenharia Industrial Eletrônica pela Universidade Tecnológica Federal do Paraná (1986), graduação em Técnologo em Automação Industrial - Universite de Grenoble I (Scientifique Et Medicale - Joseph Fourier) (1985), mestrado em Informática Industrial pela Universidade Tecnológica Federal do Paraná (1988), DEA em Sistemas Eletrônicos no Institut Polithnique de Grenoble (INPG) e doutorado em Instrumentação Industrial - Universite de Grenoble I (Scientifique Et Medicale - Joseph Fourier) (1992). Atualmente é professor Titular da Universidade Tecnológica Federal do Parana - campus Ponta Grossa, editor das Revistas Gestão Industrial (Online) e Revista Innovare, e revisor das revistas RAI da PGT/USP.

\section{Joás Tomaz de Aquino}

Mestre em Administração pelo Programa de Pós-Graduação em Administração (Finanças) da UFPE (2016). Bacharel em Administração pela Universidade Federal de Pernambuco (2013). Tem interesse nas áreas de Finanças, Gestão da Produção e Métodos Quantitativos

\section{Jordana Dorca dos Santos}

Graduada em Engenharia Ambiental pela Universidade Tecnológica Federal do Paraná. Especialista em Engenharia de Segurança do Trabalho pela Universidade Estadual de Maringá. Mestre pelo programa de pós-graduação em Engenharia Química pela UNIOESTEToledo. Tem experiência na área de tratamento de efluentes industriais, Gestão Ambiental e de qualidade. Atualmente é professora colaboradora no Departamento de Engenharia de Produção-UNESPAR.

\section{Juander Antonio de Oliveira Souza}

Possui graduação em Engenharia de Produção Agroindustrial pela Universidade do Estado de Mato Grosso (2008). Especialista em Engenharia de Segurança do Trabalho. Mestrado em Geografia pela Universidade Federal de Rondônia (2013). Docente do Departamento de Engenharia de Produção da Universidade Federal de Rondônia, Campus de Cacoal. Tem experiência na área de Engenharia de Produção, com ênfase em "agroindústria"

\section{Juliana Valença de Sousa}

Professora universitária nas áreas de Administração e em Engenharia de Produção, é mestre em Engenharia da Produção pelo PPGEP/UFPE, possui MBA em Gestão da Produção pelo PPGEP/UFPE, e bacharel em Administração pelo FCHPE. Foi professora adjunta nas instituições de ensino IESP e IPESU, e professora assistente da UFPE nos departamentos de Administração, Engenharia de Produção e Hotelaria e Turismo. Participante do comitê científico do Congresso Nacional em Excelência e Gestão (CNEG) e do Congresso Brasileiro de Engenharia de Produção (CONBREPRO). Principais áreas de interesse: Lean System, Lean Manufacturing, Just in Time, Gestão da Qualidade, Gestão da Produção, Gestão do Conhecimento Organizacional, Logística, e Suape. 


\section{Juliana Vitoria Messias Bittencourt}

Possui graduação em Engenharia Agronômica pela Universidade Estadual de Ponta Grossa (1997), mestrado em Agronomia (Produção Vegetal) pela Universidade Federal do Paraná (2000) e doutorado em Genética Molecular - University of Reading (2007). Atualmente é professor da Universidade Tecnológica Federal do Paraná. Tem experiência na área de Genética, atuando principalmente nos seguintes temas: estratégias de conservação, caracterização da biodiversidade molecular, recursos genéticos, marcadores moleculares, e biotecnologia.

\section{Júlio Cesar Raymundo}

Graduado em Administração de Empresas com ênfase em Comércio Exterior (UNISANTA), Pós graduado em Educação à Distância pela UNIP, Pós graduado em Formação de Orientadores para EAD (PUC-SP), Pós graduado em Gestão Empresarial (IPEN-USP), Pós graduado em Logística ITA (in-company Embraer), Programa Especial de Formação Pedagógica de Docentes, Professor de Ensino superior (FAAP/FATEC/UNIP/FECAP). Possui experiência na área de Gestão Empresarial: (Cadeia de Suprimento, Logística Internacional, Produção, Comércio Exterior e Portos). Coordenador do Curso de Gestão Portuária - FATEC Baixada Santista Rubens Lara. Coordenador de projetos CETECap - Centro Paula Souza . Mestre em Engenharia de Produção (UNIP). Doutorando em Engenharia de Produção (UNIP).

\section{Jullio Cesar Zilli}

Mestre em Desenvolvimento Socioeconômico (2015), MBA em Gestão Empresarial (2003), Especialização para o Magistério Superior (2007) pela Universidade do Extremo Sul Catarinense (UNESC) e Graduado em Ciências Contábeis (1997) pela Universidade do Vale do Itajaí (UNIVALI). Autor de capítulos de livro, artigos científicos publicados em revistas e anais de congressos/seminários/simpósios nacionais e internacionais. Como professor, experiência nos Cursos de Graduação em Administração e Comércio Exterior da UNESC e Escola Superior de Criciúma (ESUCRI) envolvendo as disciplinas de Legislação Aduaneira, Logística Internacional, Transportes e Seguros Internacionais, Práticas Gerenciais de Exportação e Importação, Negociações Internacionais, Administração Estratégica, Introdução ao Comércio Exterior, Projeto de Pesquisa e Trabalho de Curso (TCC).

\section{Leandro Valkinir Kester}

Graduado em Engenharia de Produção pela Fundação Universidade Federal de Rondônia (2015). Pós-Graduado em Engenharia de Segurança do Trabalho pela Faculdade de Santo André (2016). Atualmente é Especialista em MPT - Manutenção Produtiva Total em uma indústria de grande porte do segmento de bebidas. Responsável pelo acompanhamento e desenvolvimento de projetos que envolvem processos e estratégias da empresa, atuando ainda efetivamente para os resultados e desenvolvimento da metodologia de MPT na indústria. Atua ainda como Docente em cursos de magistério superior em nível pós-graduação lato sensu e graduação nas áreas de Engenharia de Produção, Engenharia de Segurança do Trabalho, Administração e áreas afins. 


\section{Luani Back}

Doutorado em andamento em Engenharia de Produção, pela Universidade Tecnológica Federal do Paraná, Campus Ponta Grossa. Mestre em Engenharia de Produção - Stricto Sensu, pela Universidade Tecnológica Federal do Paraná (UTFPR), Campus Ponta Grossa, na área de concentração de Gestão Industrial e linha de pesquisa Transferência de Tecnologia. Bacharel em Engenharia de Produção pela Universidade Tecnológica Federal do Paraná (UTFPR), Campus Medianeira. Atualmente é professora na UDC Medianeira, nos cursos de Administração e Tecnologia em Gestão Comercial.

\section{Luciano José Minette}

Possui graduação em Engenharia Florestal pela Universidade Federal de Viçosa (1984), mestrado em Ciência Florestal pela Universidade Federal de Viçosa (1987) e doutorado em Ciência Florestal pela Universidade Federal de Viçosa (1995). Possui especialização em Engenharia de Segurança do Trabalho - FUMEC (2002). Atualmente, é professor associado IV da Universidade Federal de Viçosa, integrante da Universidade Federal do Espírito Santo. Coordenador do curso de Especialização, Lato Sensu, em Engenharia de Segurança do Trabalho, da Universidade Federal de Viçosa.

\section{Lucyanno Moreira Cardoso de Holandla}

Possui graduação em Administração pela Universidade Federal de Campina Grande (2006) e mestrado em Engenharia de Produção pela Universidade Tecnológica Federal do Paraná (2010). Tem experiência na área de Administração, com ênfase em Administração da produção, atuando principalmente nos seguintes temas: Logística e logística reversa, cadeia de suprimento, produção limpa. Também atua nas disciplinas de gestão do conhecimento e empreendedorismo

\section{Luiz Carlos da Silva Junior}

\section{Bacharel}

Profissão : em Engenharia de

Mecânica; Especialista em processos e produção de eletrodomésticos de linha branca; Auditor líder de SGI (Sistema de gestão Integrada nas normas ISO 9001, 14001 e OHSAS 18001); Disseminador de Lean Manufacturing.

\section{Marcelo Gorri Mazzali}

Possui formação técnica em Química Industrial pela ETECAP(1995), Graduação em Ciências Farmacêuticas pela USF(1999), Especializado em Bioquímica e Indústria Farmacêutica pela USF(2000); Pós graduado em Farmacologia Clínica pela UNIMEP(2002), Pós graduado em Farmácia Clínica pela USP(2003), Pós graduado em Gestão da Qualidade e Garantia da Qualidade pelo Bureau Veritas Brasil(2005), Pós graduado em Gestão Empresarial Transporte pela ADUANEIRAS(2006), Pós graduado em logística empresarial pela Mackenzie(2008), Pós graduado em Licenciatura plena em Biologia e Química pela CLARETIANO(2009). Especialista em gestão da qualidade, qualidade em logística farmacêutica, sistema da qualidade para transportadoras, implantação do sistema de certificação da CEIV PHARMA IATA. Experiência de 17 anos em área da qualidade, garantia da qualidade, gestão da qualidade, especialista em cold chain, supply chain farmacêutico, gerenciamento de projetos na área de cold chain e supply chain farmacêutico. Professor de Pós graduação pela RACINE 


\section{Marcelo Rosseto Ludwig}

Graduado em Engenharia de Produção pela ULBRA Carazinho. Possui experiência em Sistemas e Produção e Planejamento e Controle da Produção.

\section{Marcos Francisco Ietka}

Engenheiro mecânico , UDESC 1984 e Mestre em Engenharia, UFSC , 2010; Especialista Senior em processos industriais, Embraco - 1985 a 2010 .Empresario em Automação Industrial , Prisa - 2012 até o momento; Professor Processos de Fabricação, Robótica e Automação Industrial, 2012 até o momento; Idiomas : Inglês e Italiano fluentes

\section{Maria Cristina Martins}

Doutora em Ciência Florestal pela Universidade Federal de Viçosa. Mestrado em Ciência Florestal pela Universidade Federal de Viçosa (UFV) - MG, 2009, com ênfase em ecoturismo, recursos florestais e engenharia florestal / Subárea: Conservação da Natureza. Bolsista CNPq 2007 - 2009, FAPEMIG 2010 - 2011. Especialização em Gestão Empresarial pela Fundação Getúlio Vargas (FGV), 2005. Graduada em Turismo pela Faculdade Evolutivo - Fortaleza - CE (2003).

\section{Mariana Santos de Oliveira}

Aluna do curso superior em Engenharia de Software do Centro Universitário Cesumar, UniCesumar, Maringá - Paraná

\section{Mario Fernando de Mello}

Professor Universitário na Universidade Federal de Santa Maria - UFSM e na ULBRA, nos cursos de Engenharia de Produção, Engenharia Química, Engenharia Civil, Administração e Arquitetura. Professor de Pós-Graduação em diversas IES como FGV, UNIFRA, IMED, URI. Graduado em Engenharia Mecânica e Ciências Contábeis, Especialista em finanças pela FGV e Mestre em Engenharia de Produção. Possui ainda, Curso de Gestão de Negócios Internacionais pela Universidade da Califórnia-EUA. Possui larga experiência em implantação de Sistemas de Gestão da Qualidade e Produtividade em diversas empresas.

\section{Mauricio Dutra}

Advogado. Graduado em Direito pela Universidade Católica de Santos (UNISANTOS). PósGraduado em Direito do Trabalho pela Universidade Católica de Santos (UNISANTOS), Professor de Direito do Trabalho do curso de Direito da Escola Superior de Administração, Marketing e Comunicação (ESAMC). 


\section{Michele Domingos Schneider}

Possui graduação em Administração de empresas pela Universidade do Extremo Sul Catarinense (2003) e mestrado em DESENVOLVIMENTO SOCIOECONÔMICO pela Universidade do Extremo Sul Catarinense (2016). Atualmente é professor titular da Universidade do Extremo Sul Catarinense. Tem experiência na área de Administração, com ênfase em Logística empresarial, atuando principalmente nos seguintes temas: educação a distância, logística, educação, gestão e competitividade.

\section{Naiara Faiad Sebba Calife}

Possui graduação em Engenharia Elétrica ênfase Eletrônica pela UFU (Universidade Federal de Uberlândia - 2003). Mestrado em Engenharia de Produção pela UFSCar ( Universidade Federal de São Carlos - 2008). Professora Assistente do curso de Engenharia de Produção da Universidade Federal de Goiás - Regional Catalão, atuando principalmente nas seguintes áreas: Logística, Armazenagem, Gestão da Cadeia de Suprimentos e Logística hospitalar. Possui experiência na área hospitalar atuando em gestão hospitalar e gestão financeira.

\section{Natália Francisca Madi}

Graduada em Informática com ênfase em Gestão de Negócios pela Faculdade de Tecnologia da Baixada Santista - Rubens Lara (FATEC - RL). Atualmente, é graduanda em Gestão Portuária pela mesma instituição.

\section{Nelson Tenório}

Doutor em ciência da computação pela Pontifícia Universidade Católica do Rio Grande do Sul com pós-doutorado IT University de Copenhague, na Dinamarca. Mestre em ciências da computação pela Universidade Federal de Santa Catarina. É pesquisador e bolsista produtividade do Instituto Cesumar de Ciência, Tecnologia e Inovação (ICETI), docente do Programa de Mestrado em Gestão do Conhecimento Centro Universitário Cesumar, UniCesumar e pesquisador visitante na Universidade de Copenhague na Dinamarca.

\section{Nilson José Fernandes}

Possui mestrado e doutorado em Engenharia Química pela Universidade Federal de Uberlândia, além de especializações pelas instituições Fundação Getúlio Vargas e Fundação Dom Cabral. Possui sólida experiência em operações industriais. Atuou como consultor de processos químicos. Atualmente é professor do magistério superior na Faculdade de Engenharia da Universidade Federal de Goiás, na cidade de Catalão.

\section{Orlando Roque da Silva}

Professor Titular de Inovação Tecnológica no Centro Universitário das Faculdades Metropolitanas Unidas e professor de Engenharia de Produção na Faccamp. Graduado em Administração pelo Centro Universitário SantAnna, mestre em Administração pela Pontifícia Universidade Católica de São Paulo e doutor em Engenharia de Produção pela Universidade Metodista de Piracicaba. Foi professor do programa de mestrado e doutorado em engenharia de produção da Unimep, atualmente é coordenador do Programa de Mestrado Acadêmico em Administração no Centro Universitário das Faculdades Metropolitanas Unidas. 


\section{Rafael Bonades da Silva}

Possui graduação em Administração de Empresas pelo Instituto de Ensino Superior de Indaiatuba (2011). MBA em Gestão de Marketing e Vendas pela Fundação Getulio Vargas (2013) e uma Especialização em Engenharia de Produção pela UFG (2014). Tem experiência de mais de 10 anos na área de Administração de Materiais e Gestão de Demanda.

\section{Rayane Carla Scheffer}

Formada em Engenharia de Produção Agroindustrial, pela Universidade Estadual do Paraná UNESPAR (2012-2016). Analista de PCP Jr na empresa GTFoods Group (2017).

\section{Renan Cittadin Perito}

Graduado em Administração de Empresas pela Universidade do Extremo Sul Catarinense. Trabalho de Conclusão de Curso: Análise da aplicação de métodos para o melhoramento da gestão de estoque de uma unidade fabril de esquadrias de alumínio. 2015. Experiência profissional em Gestão de Estoques, Gestão de Armazém e controles de estoques.

\section{Renato Cristofolini}

Bacharel em Engenharia Mecânica pela Universidade do Estado de Santa Catarina (1982), Mestre em Ciência e Engenharia de Materiais pela Universidade do Estado de Santa Catarina (1997) e Doutor em Engenharia Mecânica pela UNICAMP (2009). Foi Instrutor com Mestrado no SENAI e atualmente é professor Adjunto I (Doutor) da Universidade da Região de Joinville. Tem experiência na área de Engenharia Mecânica, Engenharia de Produção, atuando principalmente nos seguintes temas: compósitos, reofundição, conformação mecânica de metais, mecânica dos sólidos, resistência dos materiais, vibrações, tixoconformação, usinagem convencional e CNC. Experiência em: simulação computacional dinâmica e em estruturas metálicas; consultorias; A RTs ; perícias; cálculo estrutural. Ampla Experiência Industrial.

\section{Ricardo Santin}

Bacharel em Ciências Contabeis

\section{Robson Couto da Silva}

Possui graduação em Engenharia de Materiais pela Universidade Estadual de Ponta Grossa (2000) e mestrado em Engenharia e Ciência de Materiais pela Universidade Estadual de Ponta Grossa (2004). Foi professor colaborador da Universidade Estadual de Ponta Grossa em 2005. Tem experiência na área de Engenharia de Materiais e Metalúrgica, com ênfase em Engenharia de Materiais, Planejamento e Controle de Processos, Metalurgia e Materiais Cerâmicos. Atualmente é doutorando no programa de pós-graduação em Engenharia de Produção da Universidade Tecnológica Federal do Paraná. 


\section{Rogério Santana Peruchi}

Professor Adjunto do Departamento de Engenharia de Produção, Centro de Tecnologia Universidade Federal da Paraíba. Atuou como Professor Adjunto da Faculdade de Engenharia da Universidade Federal de Goiás - Regional Catalão (2016). Pós-Doutor em Engenharia de Produção pela Universidade Federal de Itajubá (2015). Doutor em Engenharia de Produção pela Universidade Federal de Itajubá (2014) com período sanduíche na University of Tennessee at Knoxville (2013). Possui graduação em Engenharia de Produção Mecânica (2009) e mestrado em Engenharia de Produção (2011) pela Universidade Federal de Itajubá. Possui experiência em Engenharia de Processos no setor automotivo. Tem atuado com pesquisa científica nas áreas de Seis Sigma, Gestão da Qualidade, Controle Estatístico da Qualidade, Modelagem Estatística de Processos e Otimização Multiobjetivo.

\section{Rony Peterson da Rocha}

Doutor e Mestre em Engenharia Química - Modelagem e Otimização de Processos, pelo Programa de Pós Graduação em Engenharia Química, Universidade Estadual de Maringá (UEM) (2015-2011). Especialista em MBA em Gestão Empresarial e em Gestão Ambiental pela FECILCAM - Faculdade Estadual de Ciências e Letras de Campo Mourão (2012-2007). Graduado em Engenheiro de Produção Agroindustrial, pela Universidade Estadual do Paraná - Campus de Campo Mourão (2004). Professor Adjunto do Colegiado de Engenharia de Produção, Universidade Estadual do Paraná - Campus de Campo Mourão, Campo Mourão/PR. Pesquisador do Grupo de Estudos e Pesquisas em Processos e Gestão de Operações (GEPPGO). Coordenador do Curso de Engenharia de Produção Agroindustrial (2016-2017).

\section{Rosimeire E. dos Santos Sehaber}

Graduada em Engenharia de Produção Agroindustrial pela Universidade Estadual do Paraná Campus de Campo Mourão (2011), possui especialização em MBA Executiva Gestão Empresarial pela Faculdade Integrado de Campo Mourão (2014) e mestrado em Engenharia Urbana pela Universidade Estadual de Maringá (2015). Trabalhou como Professora Colaboradora do Departamento de Engenharia de Produção da Universidade Estadual do Paraná Campus de Campo Mourão no ano de 2016, atualmente atua como Micro Empreendedora Individual.

\section{Samila Valdegleycia de Oliveira Costa}

Graduanda em Administração na Universidade Estadual da Paraíba - UEPB, Campus VII Centro de Ciências Exatas e Sociais Aplicadas - CCEA, Patos-PB. Colabora como voluntária na ONG Operação Resgate. Na instituição que estuda, está vinculada a trabalhos e pesquisas acadêmicas voltadas a produção e publicação de artigos científicos.

\section{Sergio Mazurek Tebcherani}

É Licenciado em Química pela Universidade Estadual de Ponta Grossa (UEPG-PR 1987) e doutorado em Química pela Universidade Estadual Paulista Júlio de Mesquita Filho (UNESP-IQ Araraquara SP 2001). Na área de ensino, é professor associado da UEPG, membro permanente dos programas de Engenharia de Produção (UTFPR-PR) e Engenharia e Ciência de Materiais (UEPG-PR), e coorientador no programa de Doutorado em Química (UNESP IQ Araraquara-SP). Na iniciativa privada, é sócio administrativo da empresa Nanoita Projetos \& Consultoria Industrial Ltda. Através da Nanoita e empresas parceiras, desenvolve produtos e processos inovadores. 


\section{Silvia Lopes De Sena Taglialenha}

Professora Associado I da Universidade Federal de Santa Catarina, Chefe do Departamento de Engenharias da Mobilidade, Centro Tecnológico de Joinville, Coordenadora do Grupo de Pesquisa GIT - Grupo de Infraestrutura e Transportes. Possui Licenciatura em Matemática, com habilitação em Física - UNESP - Faculdade de Ciências e Tecnologia - Júlio de Mesquita Filho, Mestrado em Matemática Pura (Análise) - ICMC-USP Universidade de São Paulo - São Carlos e Doutorado em Engenharia Elétrica (Automação) - UNESP - Faculdade de Engenharia de Ilha Solteira. Atua principalmente nos seguintes temas: Pesquisa Operacional, Problemas Combinatoriais, Problemas em trasportes e logística, Meta Heurísticas, Planejamento da Expansão de Sistemas de Transmissão de Energia Elétrica.

\section{Stanley Schettino}

Professor Adjunto na UFMG - Universidade Federal de Minas Gerais / Instituto de Ciências Agrárias. Engenheiro Florestal (Universidade Federal de Viçosa - 1992), Doutor em Ciências Florestais (Universidade Federal de Viçosa - 2016), MBA em Gestão Empresarial (Fundação Getúlio Vargas - 2002), Engenheiro de Segurança do Trabalho (PUC-PR - 2010).

\section{Taciana de Barros Jerônimo}

Doutora em Engenharia de Produção pelo Programa de Pós-Graduação em Engenharia de Produção da UFPE (2013). Professora de Administração da UFPE/ CCSA e da Pós-graduação em Administração da UFPE. Tem interesse nas áreas: Gestão da qualidade e em decisão.

\section{Thágyda Pryscilla Gonçalves do Rêgo}

Graduanda em Administração na Universidade Estadual da Paraíba - UEPB, Campus VII Centro de Ciências Exatas e Sociais Aplicadas - CCEA, Patos-PB. Atua como voluntária na ONG Operação Resgate. Desempenha na instituição que estuda trabalhos e pesquisas acadêmicas voltadas a produção e publicação de artigos científicos.

\section{Thaís Helena Leite Nogueira}

Formação profissional em Engenharia Ambiental pela Universidade Tecnológica Federal do Paraná (UTFPR) campus Medianeira em andamento. Tem experiências nas áreas temáticas: Geoprocessamento como Ferramenta para a Gestão de Águas Subterrâneas e Gerenciamento de Resíduos Sólidos Municipais. Participou do Grupo de pesquisa em Análise, Modelagem, Simulação e Controle em Engenharia de Processos - SIMCOP, da UTFPR na área de tratamento de efluente têxtil.

\section{Thiago Sequinel}

Possui graduação em Licenciatura em Química pela Universidade Estadual de Ponta Grossa (2006), mestrado em Engenharia e Ciência de Materiais pela Universidade Estadual de Ponta Grossa (2008) e doutorado em Química pela Universidade Estadual Paulista Júlio de Mesquita Filho (2013). Atualmente é Professor Adjunto-A junto à Faculdade de Ciências Exatas e Tecnologia da Universidade Federal da Grande Dourados (UFGD), onde atua principalmente nos seguintes temas: filmes finos, propriedades dielétricas, fotoluminescência, sinterizaçao e síntese de materiais nanoparticulados. 


\section{Vanio Faquin}

Estudante de Engenharia Ambiental e formado em Técnico em Saúde e Segurança no Trabalho (ambos pela UTFPR- Medianeira)

\section{Vitor Hugo Breda Barbosa}

Doutorando em Meteorologia Aplicada (2015-2019), Mestre em Meteorologia Agrícola (2015), Engenharia de Segurança do Trabalho (2015) e Engenheiro Florestal (2012) pela Universidade Federal de Viçosa, UFV. Técnico em Construção Civil pelo Centro Federal de Educação Tecnológica do Espírito Santo, CEFETES, Brasil (2004).

\section{Yan Henning}

Graduando em Engenharia de Transportes e Logística na Universidade Federal de Santa Catarina - Centro Tecnológico de Joinville, projetos realizados na área de roteirização, aplicações para dispositivos móveis. Vivência no mercado de trabalho com análise de indicadores de desempenho utilizando o a linguagem de programação python e software de Business Intelligence. 
Agência Brasileira do ISBN ISBN 978-85-93729-34-8

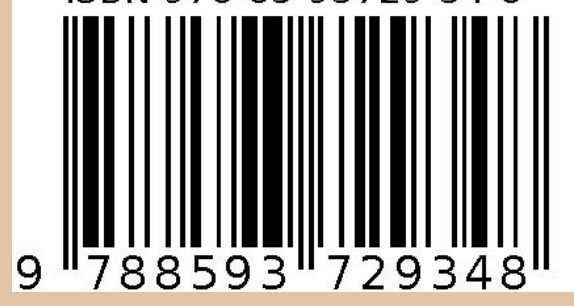

